\title{
Recht en humanisering van de arbeid
}

\author{
Citation for published version (APA):
}

Geers, A. J. C. M. (1988). Recht en humanisering van de arbeid. [Doctoral Thesis, Maastricht University]. Kluwer. https://doi.org/10.26481/dis.19881020ag

Document status and date:

Published: 01/01/1988

DOI:

10.26481/dis.19881020ag

Document Version:

Publisher's PDF, also known as Version of record

\section{Please check the document version of this publication:}

- A submitted manuscript is the version of the article upon submission and before peer-review. There can be important differences between the submitted version and the official published version of record.

People interested in the research are advised to contact the author for the final version of the publication, or visit the DOI to the publisher's website.

- The final author version and the galley proof are versions of the publication after peer review.

- The final published version features the final layout of the paper including the volume, issue and page numbers.

Link to publication

\footnotetext{
General rights rights.

- You may freely distribute the URL identifying the publication in the public portal. please follow below link for the End User Agreement:

www.umlib.nl/taverne-license

Take down policy

If you believe that this document breaches copyright please contact us at:

repository@maastrichtuniversity.nl

providing details and we will investigate your claim.
}

Copyright and moral rights for the publications made accessible in the public portal are retained by the authors and/or other copyright owners and it is a condition of accessing publications that users recognise and abide by the legal requirements associated with these

- Users may download and print one copy of any publication from the public portal for the purpose of private study or research.

- You may not further distribute the material or use it for any profit-making activity or commercial gain

If the publication is distributed under the terms of Article $25 \mathrm{fa}$ of the Dutch Copyright Act, indicated by the "Taverne" license above, 
RECHT EN HUMANISERING

VAN DE ARBEID 
Van dit boek verschijnt ook een handelseditie onder ISBN 9031204927 


\section{Recht en humanisering van de arbeid}

\section{PROEFSCHRIFT}

ter verkrijging van de graad van doctor aan de Rijksuniversiteit Limburg te Maastricht, op gezag van de Rector Magnificus, prof.dr. F.I.M. Bonke, volgens het besluit van het College van Dekanen, in het openbaar te verdedigen op donderdag 20 oktober 1988 om 16.00 uur

\section{DOOR}

Adriaan Jan Cornelis Maria Geers

geboren in 1945 te Steenbergen (N.Br.) 
Promotor: prof.mr. M.G. Rood

Beoordelingscommissie: prof.dr. W. Albeda prof.dr. H.F.M. Crombag mr.dr. J.K.M. Gevers

prof.mr. P.F. van der Heijden 
Graag dank ik iedereen die een bijdrage heeft geleverd aan de totstandkoming van dit boek, dat ik opdraag aan mijn ouders.

De tekst werd afgesloten op 31 mei 1988.

A.J.C.M. Geers

Maastricht, juni 1988 


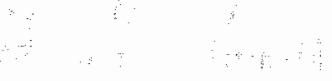




\section{Inhoud}

Hoofdstuk I Inleiding . . . . . . . . . . . . . . . 1

1. Inleiding tot de probleemstelling . . . . . . . . . . . . . 1

2. De probleemstelling . . . . . . . . . . . . . . . . . . . . . 10

3. Enkele begripsbepalingen en afgrenzingen . . . . . . . . . 11

3.1. Humanisering van de arbeid . . . . . . . . . . . . 11

3.2. Arbeidsomstandighedenrecht . . . . . . . . . . 12

3.3. Werknemer . . . . . . . . . . . . . . 13

3.4. Onderneming . . . . . . . . . . . . . . . . 14

4. Opbouw van het boek . . . . . . . . . . . . . . 15

Hoofdstuk II Ontwikkeling . . . . . . . . . . . . . . . . 17

1. Inleiding . . . . . . . . . . . . . . . . . 17

2. De negentiende eeuw tot $1870 \ldots \ldots$

2.1. Economische toestand .............. 19

2.2. Toestand van de arbeiders . . . . . . . . . . . . . . 22

2.3. Rol van de overheid en andere betrokkenen . ...... 26

3. De periode 1870-1919: Van Kinderwet tot Arbeidswet . . . . . 29

3.1. Kinderwet van Houten . . . . . . . . . . . . 33

3.2. Na de Kinderwet 1874 . . . . . . . . . . . . . . . . . 35

3.3. De Arbeidswet 1889 . . . . . . . . . . . . . . . . . . . . . 39

3.4. De Veiligheidswet $1895 \ldots \ldots \ldots$. . . . . . . . 42

3.5. Van de Veiligheidswet 1895 tot de Arbeidswet 1919 . . . . 46

4. Enkele andere wettelijke regelingen in de periode tot $1919 \ldots . .53$

4.1. Enkele specifieke beschermingswetten . . . . . . . . . 54

4.2. De Ongevallenwet 1901 . . . . . . . . . . . . . . . . 57

4.3. Het Burgerlijk Wetboek .............. . . . 59

5. Enkele beschouwingen over de periode tot $1919 \ldots \ldots 2$

6. De periode 1919-1940 . . . . . . . . . . . . . 66

6.1. De Veiligheidswet $1934 \ldots \ldots 6$

6.2. Andere regelingen . . . . . . . . . . . . 71

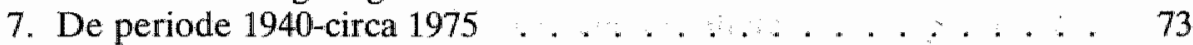

7.1. Aanvullingen op de veiligheidswetgeving . . . . . . . . . 74

7.2. De WOR 1950 en de WOR $1971 \ldots \ldots 77$ 
7.3. De vervanging van de Ongevallenwet in $1967 \ldots . . .279$

7.4. Uitbreiding van de internationale normering ...... 81

8. Van circa $1975-1983 \ldots \ldots . \ldots 2$

8.1. Een omslag in de beleidsontwikkeling . . . . . . . . . 82

8.2. Het Veiligheidsrapport . . . . . . . . . . . 87

8.3. De Arbowet 1980 . . . . . . . . . . . . . . . . . 89

8.4. Wijzigingen van de WOR $1971 \ldots \ldots . \ldots 98$

8.5. De CAO ...................... 100

8.6. Art $1638 \mathrm{x}$ BW ................. 102

8.7. Internationale normen . . . . . . . . . . 103

8.8. De Grondwet . . . . . . . . . . . . . . . . . 104

9. Enkele recente ontwikkelingen ........... . . 105

9.1. Deregulering en fasering van de Arbowet . . . . . . 105

Hoofdstuk III De werkgever, de ondernemingsraad, de deskundigen, de Arbeidsinspectie

en de werknemers- en werkgevers-organisaties . . . . . . . . . . 112

1. Algemene inleiding . . . . . . . . . . . . . . 112

2. De werkgever ..................... 113

2.1. Inleiding . . . . . . . . . . . . . . 113

2.2. De werkgever in de Arbowet . . . . . . . . . . 115

2.2.1. Beleidsopdracht en grondbeginselen . . . . . . 115

2.2.2. Het jaarplan . . . . . . . . . . . . . . 120

2.2.3. Het arbeidsveiligheidsrapport . . . . . . . . . 123

2.2.4. Het jaarverslag . . . . . . . . . . . . . 124

2.2.5. Voorlichting, onderricht en begeleiding. . . . . 127

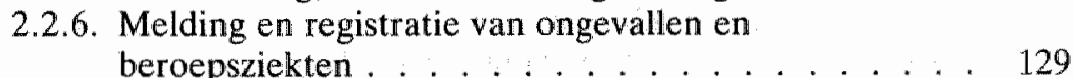

2.2.7. Bescherming van derden . . . . . . . . . . 131

2.2.8. Overige bepalingen ... . . . . . . . . 133

2.2.9. Strafrechtelijke aansprakelijkheid . . . . . . 135

2.3. De werkgever en de WOR . . . . . . . . . . . . 143

2.4. De werkgever in het BW ............ 148

2.4.1. De civielrechtelijke zorgplicht en de relatie met de publiekrechtelijke normen ......... . . 148

2.4.2. (Grove) schuld, medeschuld en schadevergoeding . . 155

2.4.3. Bewijs en causaal verband ............. 158

2.4.4. De werkgever van uitleenkrachten ....... 162

2.4.5. Schadevergoeding uit onrechtmatige daad en art. $1638 \times \mathrm{BW}$

2.4.6. Enkele opmerkingen over artikel $1638 \mathrm{x}$ in de praktijk en de toekomst

3. De ondernemingsraad en de commissies . . . . . . . . . . . 169

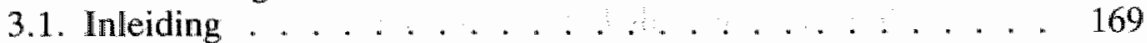

3.2. De ondernemingsraad in de WOR . . . . . . . 171 
3.2.1. Het instemmingsrecht

3.2.2. De naleving van de veiligheids- en gezondheidsvoorschriften

3.2.3. Het informatie- en initiatiefrecht ...... . . 177

3.2.4. Faciliteiten . . . . . . . . . . 178

3.2.5. Commissies van de or ............ 178

3.3. De ondernemingsraad in de Arbowet . . . . . . 181

3.3.1. De Arbocommissie, de gemengde commissie en de or 182

3.3.2. Rechten en faciliteiten ............ 185

3.3.3. Recht op informatie ............ 187

3.3.4. Recht om te adviseren ............ 189

3.3.5. Verplichtingen ............... 189

3.4. Samenloop bepalingen Arbowet en WOR : . . . . . 190

3.4.1. De adviesaanvraag en het advies . . . . . . . 191

3.5. Het werkoverleg in de WOR en in de Arbowet . . . . . 196

3.6. Enkele opmerkingen over de or en de praktijk . . . . . 200

4. De deskundigen ... . . . . . . . . . . . . . 202

4.1. Inleiding ...................... 202

4.2. De bedrijfsgezondheidsdienst (bgd) . . . . . . 204

4.2.1. Instelling, werkingssfeer en erkenning . . . . . 204

4.2.2. Doelstelling en taken . . . . . . . . . . 207

4.2.3. Positie bedrijfsarts . . . . . . . . . . . . . 209

4.2.4. Enkele opmerkingen over de bgd en de praktijk . . 213

4.3. De veiligheidsdienst en de veiligheidskundige . . . . . 216

4.4. De Arbodienst . . . . . . . . . . . . . . . 220

4.5. Arbo-instituten . . . . . . . . . . . . . . . 223

5. De Arbeidsinspectie . . . . . . . . . . . . . . . . . . . . 224

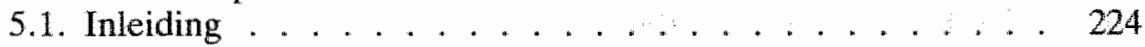

5.2. De taken en de organisatie . . . . . . . . . . . . . . 224

5.3. Beleid, werkwijze en instrumenten . . . . . . . . 228

5.4. Enkele andere bevoegdheden en verplichtingen . . . . . 236

5.5. Enkele opmerkingen over de Arbeidsinspectie en de praktijk 241

6. Werkgevers- en werknemersorganisaties . . . . . . . . 245

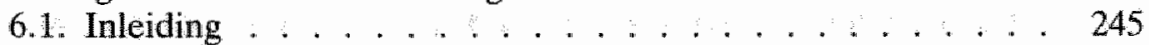

62. De Arboraad en de (districts) commissies . . . . . . . 246

6.3. De werknemersorganisaties in de onderneming . . . . . 252

6.4 . De rol van de CAO . . . . . . . . . . . . 256

6.4.1. Inleiding . . . . . . . . . . . . . 256

6.4.2. Onderzoek naar CAO-bepalingen ... . . . . . 258

6.4.3. Enkele conclusies . . . . . . . . . . . 265

Hoofdstuk IV De werknemer . . . . . . . . . . . . . 267

1. Algemene inleiding . . . . . . . . . . . . . . . 270

2. De werknemer in de Arbowet . . . . . . . . . . . 268

2.1. Inleiding . . . . . . . . . . . . . 268 
2.2. Informatie, voorlichting en onderricht........ 269

2.3. Werkonderbreking . . . . . . . . . . . 271

2.4. Klagen bij de Arbeidsinspectie . . . . . . . . . . . 280

2.5. Enkele andere bepalingen ............. . . . 283

2.5.1. Beleid en grondbeginselen . . . . . . . . . . 283

2.5.2. De deskundigen ............ . . 286

2.6. Belanghebbende werknemers . . . . . . . . 287

2.7. Verplichtingen . . . . . . . . . . . . . 292

3. De werknemer in het BW ... . . . . . . . . . 299

3.1. Inleiding . . . . . . . . . . . . . . . . . 299

3.2. Enkele bepalingen uit het $\mathrm{BW}$ in relatie tot de
arbeidsomstandigheden . . . . . . . . . . 300

4. De werknemer in de CAO . . . . . . . . . . . . 307

5. De werknemer in de WOR ............. 311

6. De werknemer en het klachtrecht . . . . . . . . . . 316

Hoofdstuk V Enkele concluderende beschouwingen . . . . . . . 324

1. Inleiding . . . . . . . . . . . . . . . . . . . 324

2. Ontwikkeling in beleid en wetgeving . . . . . . . . . 324

3. De betrokkenen . . . . . . . . . . . . . . 326

4. De positie van de werknemer nader beschouwd . . . . . . 329

5. Intermezzo uit de praktijk . . . . . . . . . . . . . 337

5.1. De voorgeschiedenis . . . . . . . . . . . . 337

5.2. De procedures . . . . . . . . . . . . . . . . . 339

5.3. Commentaar . . . . . . . . . . . . . . . 342

6. Humanisering en recht . . . . . . . . . . . . . . 349

6.1 . Inleiding .................... 349

6.2. Effectiviteit van de Arbowet ... . . . . . . . 350

6.2.1. Inhoud en vormgeving . . . . . . . . . . . 354

6.2.2. Materiële- en hulpregels . . . . . . . . . . 356

6.2.3. Uitwoerings- en handhavingsvoorzieningen . . . . . 357

6.2.4. Het economisch en sociaal-culturele klimaat . . . . 360

6.2.5. De rechtsconsument/werknemer ... . . . . 363

6.2.6. Betekenis Arbowet en CAO . . . . . . . . . 364

7. Slotconclusie ..................... 366

Summary . . . . . . . . . . . . . . . . . . 369

Lijst van geraadpleegde literatuur . . . . . . . . . . . . 377

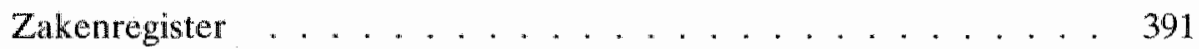

Jurisprudentieregister . . . . . . . . . . . . . 397

Curriculum vitae . . . . . . . . . . . . . . 401 


\section{Inleiding}

\section{Inleiding tot de probleemstelling}

1.1.

Dit boek gaat over recht en humanisering van de arbeid. Vooral de (juridische) positie van de werknemer zal hierbij het uitgangspunt vormen.

Sinds de tweede helft van de jaren zestig is een toenemende belangstelling te constateren voor de humanisering van de arbeid. ${ }^{1}$ Humanisering van de arbeid is een complex begrip, maar de vele definities en omschrijvingen hebben een aantal gemeenschappelijke elementen. Naast een aanvaardbare fysieke werkomgeving (van oudsher een geaccepteerde doelstelling) gaat het sinds die tijd ook om het 'zich welbevinden' tijdens en door het werk, uitgedrukt in termen van mogelijkheden tot zelfontplooiing, zeggenschap, verantwoordelijkheid en autonomie. ${ }^{2}$ Het begrip is bovendien niet statisch, maar voor wat betreft zijn definiëring grotendeels afhankelijk van de heersende opvattingen in een bepaald tijdsbestek. In die zin passen de bovengenoemde welzijnselementen als normatief concept uitstekend in de jaren zestig en zeventig. En hoewel de belangrijke gezichtspunten op het gebied van de arbeid uit die jaren in elk geval in theorie als geaccepteerde normen gekwalificeerd kunnen worden, lijkt in de jaren tachtig mede als gevolg van de werkloosheid het louter hèbben van werk weer sterker te worden benadrukt - ook wanneer dat werk minder aansluit bij de capaciteiten van de werknemer en ook wanneer dat minder ontplooiingsmogelijkheden biedt. ${ }^{3}$

De toegenomen belangstelling en grote mate van consensus op het niveau van de theoretische uitgangspunten betekenen overigens niet dat ook in de praktijk van de ondernemingen overal en met hetzelfde enthousiasme daadwerke-

1 In 1967 noemde van Zuthem 'humaniteit van de arbeid' zelfs het hoofddoel van het personedsbeleid. H.J. van Zuthem, Arbeidsbeleid in de onderneming. Assen 1967, p. 34.

2 Vgl. Van Strien, Wat betekent humanisering van de arbeid?. Humanisering van de arbeid, onder redactie wan D. de Galan, M.R. van Gils, P.J. wan Strien, Assen 1983, (24 druk), p. 15.

A. Koopman-Iwema, S. Wiegersma, Sociate arbeidspsychologie; Hatrlem 1985 (2a druk), p. 147.

3 Vgl ook A. Koopman-Iwema, S. Wiegersma, t.a.p. p. 148. 
lijk gestalte lijkt te zijn gegeven aan de humanisering van de arbeid. De Sitter constateerde in 1982 op basis van een analyse van een aantal onderzoekingen, dat de kwaliteit van de arbeid in kantoren en fabrieken gedurende de afgelopen decennia 'aanzienlijk' is gedaald. ${ }^{4} \mathrm{En}$ in 1986 schreef Fruytier: 'Maakten de jaren zeventig duidelijk dat aanzetten om vanuit een humanitaire visie de kwaliteit van de arbeid te verbeteren falen wanneer er voor de bedrijven geen direct economische voordelen mee te behalen vallen, de jaren tachtig lijken de conclusie te rechtvaardigen dat ook het louter varen op het rendementscompas van het bedrijfsleven een werkelijke humanisering van de arbeid schipbreuk doet lijden."

\section{2 .}

Humanisering van de arbeid als betrekkelijk nieuw begrip is vooral geinspireerd door wetenschappen als die van de arbeidspsychologie en de arbeidssociologie. Toch is een aantal kenmerken en noties die met het begrip geassocieerd worden niet nieuw en met name niet in de (arbeids)rechtswetenschap. Ik doel hierbij niet zozeer op de al veel oudere veiligheids- en gezondheidsdoelstellingen bij het werk, maar vooral op de in de vorige paragraaf genoemde welzijnsdoelstellingen. In 1890 werd ingesteld de zogenaamde 'Staatscommissie Rochussen' die een (voortgezet) onderzoek in moest stellen 'omtrent den arbeid in en omtrent de toestand van fabrieken en werkplaatsen met het oog op de veiligheid, de gezondheid en het welzijn der werklieden'. ${ }^{\text {t}}$

Een van de motieven voor de eerste arbeidswetten was dat een regulering van de arbeids- en rusttijden de betrokken arbeiders de gelegenheid zou geven om een eigen persoonlijk en maatschappelijk leven te leiden, m.a.w. "om waarlijk mens te zijn'. ${ }^{7}$ Of, in de woorden van minister Aalberse tijdens zijn verdediging van de arbeidswet 1919: '... niet de produktie, maar de producerende mens (moet) het uitgangspunt zijn bij de beoordeling van alle sociale wetgeving". Het gaat daarbij immers ook om "het levensgeluk, het geestelijk welzijn'. En in 1931 overwoog de HR: 'dlat de strekking van die wet (bedoeld is eveneens de Arbeidswet $1919, \mathrm{AG}$ ) niet alleen is de arbeider voor overmatige vermoeidheid te behoeden, doch ook om hem de vrije beschikking over een voldoende deel van zijn tijd te geven ten behoeve van eigen ontwikkeling en ontspanning en in het belang van zijn gezin'."

In de oudere, juridische literatuur hebben vooral van Esveld en Molenaar het

4 L.U. de Sitter, Op weg naar nieuwc fabrieken en kantoren, Deventer 1982, p. 74.

5 B. Fruytier, Het einde van de humanisering?, Tijdschrift woor arbeidswraagstukken, 1986, p. 57.

6 De commissic werd ingesteld krachtens Wet van 19 januari 1890 (Stb.1) bij KB van 18 april 1890 , nar: 51 .

7 A.N. Molenaar, Arbeidsrecht, eerste deel, algemeen gedeelte, Zwolle 1953, p. 286.

8 Handelingen TK 1918-1919, p. 2876.

9 HR 16-10-1931, NJ 1932, nr. 413. 
begrip ontplooiing als belangrijk element in het arbeidsrecht verdedigd. ${ }^{10} \mathrm{Van}$ Esveld doet dat in het kader van wat volgens hem de doelstelling van het arbeidsrecht behoort te zijn: "Het arbeidsrecht beoogt dáar in te grijpen waar de sociale afhankelijkheid van sommige bevolkingsgroepen onder bepaalde omstandigheden het gevaar doet ontstaan van aantasting der volkskracht en vermindering der ontplooiingsmogelijkheden' . "Molenaar ziet het belang van ontplooiing vooral in relatie met het zogenaamde autonome arbeidsrecht. Dit is het recht dat primair ontwikkeld wordt in de maatschappij, vooral door wat men nu de sociale partners noemt, en dat in tegenstelling staat tot het heteronoom arbeidsrecht, ontwikkeld door de overheid. Aan dit laatste recht hecht Molenaar minder waarde. Pas als degenen die 'onder het arbeidsrecht vallen' zoveel mogelijk gebracht worden tot ontplooiing van eigen kracht, kunnen zij een zelfstandige bijdrage tot de autonome rechtsvorming leveren. ${ }^{12}$

Het is hier nu niet de plaats om uitvoerig in debat te gaan met beide auteurs. Wel wil ik er kort het volgende over zeggen. Bij beiden lijkt ontplooiing in en door de arbeid geen zelfstandig na te streven doelstelling te zijn, maar eerder een middel om andere doelstellingen van vooral sociaal-politieke aard ("volkskracht', 'autonome rechtsvorming') te bereiken. De auteurs gaan daarbij uit van een normatief maatschappijbeeld dat niet het mijne is. Dat is niet erg, maar het lijkt wel gebaseerd te zijn op een aanvechtbare analyse van de maatschappelijke feiten. Molenaar schrijft bijvoorbeeld in het begin van de jaren vijftig ten aanzien van arbeiders dat "de achterstand op sociaal-economisch gebied is ingehaald' en dat 'andere groepen zich zelfs over bevoorrechting van de arbeiders beklagen". ${ }^{13}$

Enigszins terzijde merk ik nog op dat de doelstelling voor het arbeidsrecht zoals die door Van Esveld is geformuleerd, uiteraard niet exclusief voor dit rechtsgebied geclaimd kan worden. ${ }^{14}$

\section{3.}

Zonder de ideeën, die ten grondslag lagen aan de bestaande arbeidsbeschermende wetgeving, zowel ten aanzien van de doelstelling als ten aanzien van de uitvoering, geheel los te laten zijn veranderde inzichten over zeggenschap,

10 Van Esveld meende zelfs dat de term ontplooing "pas ingang heeft gevonden" nat zijn in noot 11 genoemde boek. N.E.H. van Esveld, Vrijheid en dwang in het arbeidsrecht, SMA 1975 , p. 304 .

11 N.E.H. van Esveld, De ontplooiing van het individu in het arbeidsrecht, 1946, p. 204 en 205. In latere geschriften heeft Van Esveld een dergelijk pleidooi herhaald. Zie bijw. Arbeidsrecht en gerechtigheid, (rede), Rotterdam 1953, Van sociale politiek naar sociaal recht, Alphen a/d Rijn 1966, p. $305-324$.

12 A.M. Molenaar, Bronnen van het arbeidsrecht, Openbare les, Leiden 1927, Van sociale politiek naar sociaal recht, ta.p. p. $72-87$. Later nog eens uitgewerkt in: Arbeidsrecht, tweede deel B, hooldstuk VIII, de ontplooiing van de arbeider, Zwolle 1953, p. 2238-2255.

13 A.N. Molenaar, ta.a.p. p. 2249.

14 Zie ook de bespreking van het in noot 11 genoemde boek van Van Esweld door S. Mok, Arbeidsrecht en individu, Sociaall Maandblad, 1948, vooral p. 20-21. 
inspraak en humanisering van de arbeid steeds explicieter een rol gaan spelen bij het overheidsbeleid en de activiteiten van de wetgever. In de eerste helft van de jaren zeventig is door de toenmalige ministers van Sociale Zaken in de diverse Memories van Toelichting op de departementsbegroting met nadruk gewezen op de grote betekenis van humanisering van de arbeid. ${ }^{15}$ Ook in belangrijke regeringsnota's, uitgebracht ten tijde van het kabinet Den Uyl (1973-1977), zoals de Nota inzake de Werkgelegenheid en de Economische Structuurnota is een dergelijk beleidsuitgangspunt nader uitgewerkt. ${ }^{16}$ Tenslotte werd in 1975 met de vraag aan de SER om te adviseren over een algehele herziening van de bestaande veiligheidswetgeving ${ }^{17}$ een wetgevend proces in gang gezet dat in 1980 leidde tot het unaniem instemmen van de Tweede Kamer met de Arbowet, 'een wan de belangrijkste stukken wetgeving van na de oorlog' ${ }^{18}$ Belangrijk, maar ook in hoge mate nieuw. Immers, nog niet eerder werd humanisering van de arbeid zo expliciet als wettelijk vastgestelde overheidsdoelstelling geformuleerd. In de considerans staat onder meer: '... dat het noodzakelijk is bepalingen vast te stellen ontrent de arbeidsomstandigheden in het algemeen en de veiligheid, de gezondheid en het welzijn in verband met de arbeid in het bijzonder, zulks ter bevordering van menswaardige arbeid'. En in de MvT uitgebreider: "Aan de hoofdlijnen, en in het verlengde daarvan, aan het aangeboden ontwerp ligt een benadering - zo men wil een filosofie - ten grondslag, die niet alleen op de veiligheidswetgeving van toepassing is, doch evenzeer op andere delen van het terrein van de arbeidsbescherming. Deze kan zo worden verstaan dat naast de sterke motieven voortvloeiend uit de wens tot het voortdurend verhogen van de normen van bescherming, die op zichzelf al tot vernieuwing van de wetgeving dringen, vooral. geldt dat behalve aan economische welvaart in toenemende mate belang wordt gehecht aan het zich wel bevinden van de werkende mens met betrekking tot zijn werk. Het zich wel bevinden bij het werk moet geplaatst worden binnen het kader van het tijdsbestek en zal dan ook in overeenstemming moeten zijn met de heersende opvattingen onder werknemers over de beleving van hun arbeid'. ${ }^{19}$

Met deze formulering wordt ook - hoewel nog vaag - een relatie gelegd tussen de inhoud en de organisatie van de arbeid enerzijds en het subjectieve oordeel en de mogelijkheden van de betrokken werknemer anderzijds. Een meer concrete inhoudsduiding werd gegeven in de MvA bij de wet: 'De omstandigheden en verhoudingen waaronder gewerkt wordt en de inhoud van de arbeid die wordt verricht, dienen zo te zijn, dat voldoende ruimte wordt geboden voor ontplooiing en creativiteit. Alleen wanneer de arbeidsomstandighe-

15 Zie bijvoorbeeld TK 1972-1973, 1200, hfdst. XV, nr 2, p. 11; TK 1973-1974, 12600 hfdst. XV, nr. 2 , p. 29 an TK 1974-1975, 13100, hfdst. XV, nr. 2, p. 11.

16 Vgl. TK 1976-1977, 14497, nr. 3, p. 10.

17 Brief van 14 juni 1975, Bijlage I bij Advies inzake vernieuwing van de wetgewing betreffende de gezondheid en de veiligheid bij de arbeid, SER, 1976, nr. 18.

18 Minister Albeda in de Tweede Kamer, Handelingen TK 1979-1980, p. 4673 bij zijn verdediging van de Arbeidsomstandighedenwer, Wet van 8 noventber 1980 , Stb. 664

19 TK $1976-1977,14497$, nr. 3, p. 1 . 
den, de arbeidsorganisatie en de arbeidsinhoud daartoe voldoende mogelijkheden kunnen bieden, kan de arbeid een bijdrage leveren aan het welzijn van de werknemers. Anders gezegd: welzijn in verband met de arbeid heeft te maken met de ruimte, die de arbeidsomstandigheden, de arbeidsorganisatie en de arbeidsinhoud bieden voor eigen verantwoordelijkheid, inbreng en creativiteit van de werknemers'. ${ }^{20}$

Naast de ideële argumenten, die hierboven geformuleerd zijn bij de omschrijving van de doelstelling van de Arbowet, kunnen en worden ook meer praktische, instrumentele argumenten aangevoerd voor het bevorderen van de humanisering van de arbeid van de werknemers. Het gaat dan vooral om het terugdringen van het ziekteverzuim en het aantal bedrijfsongevallen, de vergroting van de motivatie bij het werken en samenhangend daarmee de verhoging van de produktie, en het positief beïnloeden van de innovatie in de onderneming. Als bijkomende argumenten zijn zij ook door de minister genoemd bij de verdediging van de Arbowet. ${ }^{21}$

\section{4 .}

Uit de hierboven aangehaalde citaten kan ook de benadering van de juridische positie van de werknemers op het stuk van de humanisering van de arbeid worden gelezen. In de oudere wetgeving en met name de veiligheidswetten van 1895 en 1934 ging het vooral om de bescherming door de werkgever tegen de gevaren voor de veiligheid en de gezondheid van de werknemers. ${ }^{22} \mathrm{De}$ laatsten waren vooral object van deze zorg. In de Arbowet gaat het niet alleen om het bevorderen van veilig en gezond werken, maar, veel ruimer, om humanisering van de arbeid waarbij de werknemers inplaats van als object van zorg, als zelfstandige dragers van rechten en plichten worden beschouwd; niet alleen instrumenteel, om de humaniseringsdoelstelling te bereiken, maar ook als onderdeel van die doelstelling.

Hierbij moet echter nu al aangetekend worden dat die zelfstandigheid voor een groot deel een relatieve is. Dat komt omdat veel rechten, bevoegdheden en faciliteiten die ten dienste staan van de werknemers zijn toegekend aan hen vertegenwoordigde collectiviteiten en ook moeten worden gerealiseerd en gehandhaafd via de al bestaande collectivistische medezeggenschapsstructuur in de onderneming. In de praktijk betekent dit een cruciale rol voor de ondernemingsraad (or).

Hoewel ook het belang van een - extern - handhavingsapparaat evident is wordt toch algemeen het belang erkend van het inschakelen van direct betrokkenen. ${ }^{23}$ Dit geldt zeker als het de handhaving van regelingen betreft die, zoals

20 TK $1978-1979,14497$, nr. 5 , p. $7 \mathrm{en} 8$.

21 Voor een meer uitgebreide argumentatie van de kant van de minister zie de MvA bij de Arbowet, t.a.p. p. 2 en 3 en Handelingen TK 13 mei 1980 , p. 4674 en 4675.

22 Wet van 20 juli 1895, Stb. 137 resp. Wet van 2 juli 1934 , Stb. 352.

$23 \mathrm{Vgl}$. A.A.G. Peters, Recht als project, Ars Aequi, 1979, p. 881. 
op het onderhavige terrein, zo direct de persoonlijke levenssfeer bij het werk raken, en waarbij het grondwettelijk gegarandeerde grondrecht op de bescherming van de lichamelijke integriteit in het geding kan zijn. ${ }^{24} \mathrm{~V}$ an belang is bovendien nog dat de rol van overheid zowel bij de handhaving van de regelgeving op het gebied van de arbeidsomstandigheden als de nadere invulling ervan een terughoudende is. ${ }^{25}$ Het is een van de uitgangspunten van de Arbowet -en (ook) in dit opzicht is deze wet een afsple geling van een algemene ontwikkeling in het sociaal recht. ${ }^{26}$

De juridische positie van de werknemer wordt niet alleen bepaald door de aan hem al dan niet toegekende rechten en handhavingsmogelijkheden, maar ook door de aan hem opgelegde plichten, bij overtreding waarvan hij eventueel strafrechtelijk aansprakelijk kan worden gesteld. (Naast, uiteraard, de op hem rustende civielrechtelijke verplichtingen en de daarmee corresponderende aansprakelijkheid).

In de eerste Arbeidswet en de eerste Veiligheidswet was van een strafrechtelijke aansprakelijkheid van de werknemer nog geen sprake. Achterliggende gedachte immers was de zorgplicht van de werkgever voor de werknemer. Dit bracht mee dat als er te lang of onder onveilige omstandigheden werd gewerkt, de werkgever werd geacht in zijn zorg te kort geschoten te zijn. Dit tekort schieten in zorg vormde de rechtsgrond voor de strafbaarstelling. Sociaal-psychologisch was het dan ook van belang dat primair de verantwoordelijk gestelde persoon en niet een corporatie strafbaar was gesteld. ${ }^{27}$ Dit uitgangspunt bleef lange tijd de heersende gedachte, hoewel niet altijd onweersproken. ${ }^{28}$ Soms werden trouwens ook uitzonderingen gemaakt. Grond hiervoor vormde de 'gevallen waarin de werkgever al het mogelijke heeft gedaan om de wet na te leven, doch de arbeider nalatig blijft om van de aanwezige beveiligingsmiddelen gebruik te maken of andere in het belang van veiligheid en gezondheid gestelde voorschriften na te leven, met als gevolg gevaar voor zich zelf of voor zijn mede-arbeiders'. Deze formulering werd voor het eerst gebruikt bij de MvT bij de Stuwadoorswet 1931, en herhaald bij de Veiligheidswet $1934 .{ }^{29}$ De Arbowet ziet de zorg voor een veilig, gezond en aangenaam werkmilieu niet meer als een plicht die vrijwel uitsluitend op de werkgever rust. Het tot

24 Art. 11 Grondwet. Ik ga hier niet verder in op kwesties wan het toepassingsgebied en eventuele horizontale werking van dit grondrecht. Voor een algemene bespreking van dit artikel: P.H. Banda, Het recht op onaantastbaarheid van het menselijk lichaam. Grondrechten, Commentaar op hoofdstuk I van de therziene Grondwet (Jeukens-bundel), Nijmegen 1982, p. 249-263. Voor een bespreking van dit artikel in relatie met het arbeidsomstandighedenrecht: J. K.M. Gevers, Zeggenschap van werknemers inzake gezondheid en veiligheid in bedrijven, Deventer 1982, p. 58-p. 61. Deze auteur ontleent onder meer an dit grondrectitt een normatieve grond voor zeggenschap van werknemers op het terrein van veiligheid en gezondheid.

25 Vgl. A.J.C.M. Geers, De inwerkingtreding wan de Arbeidsonnstandighedenwet, NJB, 1983, p. 83 .

26 Vgl. M.G. Rood, Hoofdlijnen in het Sociaal recht, NJB, 1984, p. 998.

Een bevestiging van deze overheidsrol gaf het kabinet nog eens in zijn standpunt ten aanzien van het SER-advies over het sociale beleid in de onderneming. TK 1984-1985, 18711, nr. 1 .

27 M.G. Levenbach, Nederlands bestuursrecht., III, Alphen a/d Rijn 1964, p. 525.

$28 \mathrm{Vgl}$. H.J.A. Nolte, Het Stratrecht in de afzonderlijke wetten, Nijmegen 1949, p. 84.

29 MvT Veiligheidswet 1934, Bijlagen TK $1931,-1932,217,3$, p. 10. 
stand brengen van aanvaardbare werkomstandigheden behoort tot de gezamenlijke taak van werkgever en werknemers. De laatsten dienen dan ook voorlichting en onderricht te ontvangen en krijgen een aantal bevoegdheden om zich van hun nieuwe taak te kwijten. 'Onder deze omstandigheden mag van hen worden verwacht dat zij zich ook van hun verantwoordelijkheid bewust zijn en dat zij in dit verband bereid zijn ook een aantal verplichtingen en de daaruit voortvloeiende aansprakelijkheid te anvaarden, al is deze uiteraard van veel beperktere omvang dan die van de werkgever'.

\section{5 .}

Het recht, en als onderdeel daarvan de wetgeving, is een fenomeen dat is ingebed in een bepaalde politieke, sociale en culturele traditie. Het maakt er deel van uit en kan zich als zodanig ook niet als een autonome eenheid presenteren. Deze relatieve betekenis van het recht geldt ook, of misschien bij uitstek ook, voor díe rechtsregels die betrekking hebben op het reilen en zeilen van ondernemingen: bestaande (machts)verhoudingen zullen de gelding van (nieuw) recht binnen de onderneming in wisselende mate beinvloeden. Het is met name in het licht van deze structurele gegevenheden dat de juridische normeringen op het gebied van de humanisering van de arbeid moeten worden beschouwd.

Ook de Arbowet kan niet als een doorbraak worden beschouwd voor wat betreft het bestaande systeem van geïnstitutionaliseerde arbeidsverhoudingen tussen werkgevers en werknemers.

Over de rol van de or in dit systeem wil ik iets meer zeggen, omdat hij in potentie een gelegaliseerd instrument vormt in de onderneming om de machtsverhoudingen bij te stellen ten faveure van de werknemers. Hierboven is al aangegeven dat rechten, bevoegdheden en faciliteiten die ten dienste staan van werknemers in de Arbowet zoveel mogelijk passend zijn gemaakt binnen de bestaande medezeggenschapsstructuur, waarbij in de onderneming de or centraal staat. Ditzelfde geldt voor de handhavingsmogelijkheden van deze instrumenten. Nu kan er wel begrip worden opgebracht voor deze collectivistische aanpak. Voor veel veiligheids- en gezondheidsproblemen en de oplossingen ervoor geldt dat ze betrekking hebben op grotere groepen werknemers en tot op zeker hoogte objectiveerbaar zijn. Dan ligt een collectieve aanpak voor de hand. Ook is het in grotere arbeidsorganisaties vrijwel onmogelijk om anders dan via een vertegenwoordigende collectiviteit tot besluitvorming te komen. ${ }^{31}$ Bovendien past deze aanpak in de traditioneel gegroeide medezeggenschapsstructuur. ${ }^{32}$ Tenslotte kan een collectieve aanpak onmiskenbare voor-

30 MvT Arbowet, t.a.p. p. 12.

31 Vgl. ook J.K.M. Gewers, t.a.p. p. 72

32 Met name de SER heeft in zijn "Advies inzake vernieuwing van de wetgeving betreffende de gezondheid en de veiligheid bij de arbeid' op dit aspect gewezen. t.a.p. p. 10-13. Zie onk do MvT bij de Arbowet, i.a.p. p. 14. 
delen bieden in termen van machtsvorming en invloed. Maar betekent dit voor de individuele werknemer nu niet dat er een nieuwe afhankelijkheid bij is gekomen? Het vraagstuk is temeer van belang, omdat de wensen van werknemer en or, ook op het terrein van humanisering van de arbeid, niet altijd parallel zullen lopen.

Het gegeven dat de mogelijkheden tot beïnvloeden van humanisering van de arbeid door werknemers rechtens primair zijn toegekend aan de or (of andere al dan niet door de or ingestelde organen - ik kom daar later op terug), doet bovendien de vraag rijzen welke positie de individuele werknemer heeft in die arbeidsorganisaties waar geen or is. Dit kunnen in de eerste plaats arbeidsorganisaties betreffen waar er wettelijk wél een dient te zijn. In 1984 had $84,1 \%$ van de bedrijven met meer dan 100 werknemers een or en van de bedrijven met 35 tot 100 werknemers bezat slechts $32,6 \%$ er een. ${ }^{33}$

In de tweede plaats zijn dat de organisaties met minder dan 35 werknemers. Dit betreft $97,2 \%$ van het totaal aantal vestigingen met $47,5 \%$ van het totaal aantal werknemers. ${ }^{34}$

Waar bij het ontbreken van een formele overlegstructuur in elk geval in de kleine ondernemingen zich bovendien nog de feitelijke omstandigheid voordoet, dat de bezoekfrequentie van de Arbeidsinspectie gemiddeld erg laag ligt $^{35}$, hangt wel erg veel af van de mogelijkheden van de individuele werknemer, evenals trouwens van de (goede) wil van de werkgever en het vakbondswerk in de betreffend ondernemingen. ${ }^{36}$

Het toekennen van in de praktijk eenvoudig en effectief te realliseren individuele rechten en actiemogelijkheden kan bovendien van belang zijn voor de meest kwetsbare groepen deelnemers aan het arbeidsproces: jeugdigen, vrouwen, ouderen en buitenlanders. ${ }^{37}$ Het zijn deze groepen die vaak de laagste scholingsgraad hebben, die nauwelijks (kunnen) participeren in de overleg-en besluitvormingsstructuur van de onderneming, en die vaak werk verrichten waarmee begrippen als welzijn of persoonlijke ontplooiing geen enkele relatie lijken te hebben. ${ }^{38} \mathrm{Ik}$ voeg hier onmiddellijk aan toe, en dit illustreert de bovengenoemde spanning, dat het juist deze groepen zijn die in het algemeen het

33 Resultaten enquête ondernemingsraden, Ministerie van Sociale Zaken en Werkgelegenheid, Den Haag 1985.

34 Vestigingenbestand Directorat-Generall van de arbeid (DGA) in combinatie met gegevens wan de werkgelegenheidsenguête 1981, gepubliceerd als bijlage III wan Arboraad-publicatie, $1984 \mathrm{nr} .1$ Zoetermeer. (N.B.: Het betreft hier volgens de publicatie schattingen incl overherd, provincie $e_{2} d_{n}$ )

35 De relatie met werknemers wan kleine arbeidorganisaties, Nota Arboraad, 1984, nr. 1, Zoetermeer" T.J.M. Reubsaet, P.A.M. de Boer, P.C.J. Sweere, H.J.M. van den Thillaart, De Arbowet in uityoering. Een onderzoek maar ervaringen in de praktijk, Instituut woor Toegepaste Sociale Wetenschappen (ITS), in opdracht van het ministerie van Sociale Zaken en Werkgelegenheid, Den Hag 1988.

$36 \mathrm{Vgl}$. J. Bloemarts, Op weg naar een drie-partijen-model voor het socialal beleid in de onderneming? SMA 1978 , p. 594 .

37 J.P. Kuiper, Een gezondheidskundige kijk op de mens-arbeid relatie, Humanisering van de arbeid, t.a.p. p. 201.

$38 \mathrm{Vgl}$. Wetenschappelijke raad woor het regeringsbeleid, Over sociale ongelijkheid; een beleidsgerichte probleemwerkenning, rapport aan de regering nr. 16, Den Haag 1977, p. 110-113. 
meest gebaat kunnen zijn met collectieve machtsuitoefening.

Een geringe participatie in de beleidsvorming, op welk terrein dan ook van de onderneming, geldt tenslotte nog voor de - groeiende - groep werknemers, die meer in de periferie van de onderneming verkeren zoals degenen met tijdelijke arbeidscontracten, deeltijdwerkers en uitzendkrachten. ${ }^{39}$

1.6.

Omdat een groot deel van de zelfverwerkelijking van mensen die werk hebben, plaats zal vinden in en door dat werk vind ik humanisering van hun arbeid als intrinsieke waarde van het allergrootste belang. Het ant woord op de vraag of en hoe mensen zich kunnen manifesteren als volwaardige en zelfstandige mensen in het arbeidsproces, is een graadmeter voor de kwaliteit van onze samenleving als geheel. Werknemers dienen recht te hebben op een humane arbeidsplaats.

Resultaten op dit vlak kunnen bereikt worden door onderhandelingen tussen werkgevers en werknemers. Maar dat alleen is niet voldoende. Zeker in het licht van de grote betekenis van humanisering van de arbeid mag de vaak zwakkere onderhandelingspositie van werknemers niet van doorslaggevende betekenis zijn. Derhalve ligt er een taak voor de overheid om grenzen te stellen aan de arbeidsprocessen, zodlanig dat een redelijke mate van welzijn van elke werknemer bij zijn arbeid gegarandeerd is. Het jongste - en belangrijkste - product van de wetgever op dit terrein vormt de Arbowet, waarin het welzijn van de werknemer bij zijn arbeid expliciet alls doelstelling is geformuleerd. Deze doelstelling moet gerealiseerd worden in een context van traditioneel bepaalde machtsverhoudingen en structuren, en ongelijksoortige belangen.

De Arbowet sluit ook aan bij de inmiddels al traditionele medezeggenschapsstructuur in de ondernemingen. Dit betekent dat met name veel werknemersinstrumenten gecollectiveerd zijn. Gezien de krachtsinspanning die nodig zal zijn om de nieuwe humaniseringsdoelstellingen en de nieuwe rechten voor werknemers te realiseren, behoeft deze constructie in termen van macht en beïnvloedingsmogelijkheden niet ongunstig uit te pakken. Tegelijkertijd meen ik echter dat er een spanning kan ontstaan tussen de op individuele werknemers afgestemde doelstellingen en rechten en diezelfde constructie. Hoewel de Arbowet dus een belangrijke plaats inneemt in deze studie, zullen, met name ook in het licht van de laatstgenoemde spanningsbron, tevens andere rechtsbronnen onderzocht worden op hun betekenis voor de verbetering

39 Vgl. P.L. Meurs, Heeft de OR de toekomst? M en O, Tijdschrift voor organisatiekunde en sociaal beleid, 1984, p. 499; R.C. van Geuns, J.W.H. Mevissen, J.H. Neve, De andere kant van flexibiliteit, Een onderzoek naar achtergronden, motieven en oondelen van flexibele werknemers, Ministerie van Sociale Zaken en Werkgelegenheid, Den Haag 1987. 


\section{INLEIDING}

van de positie van de werknemer op het gebied van de humanisering van de arbeid.

Met bovenstaande noties zijn de eerste contouren voor dit boek geschetst.

\section{Probleemstelling}

Uit het bovenstaande kan ook de centrale probleemstelling (deels in de vorm van een hypothese) van dit onderzoek al goeddeels gedestilleerd worden. Het gaat om een onderzoek naar de ontwikkelingen en naar de betekenis voor de werknemer van het recht met betrekking tot de humanisering van zijn arbeid. Om deze betekenis reëel te kunnen schetsen is, naast een beschrijving van dit rechtsgebied en de ontwikkeling ervan, een (toetsings)kader nodig. Dit wordt in de eerste plaats gevormd door een (normatief) concept van humanisering van de arbeid. Humanisering van de arbeid is niet alleen een instrument waardoor bepaalde doelstellingen (terugdringen ziekteverzuim e.d.) bereikt kunnen worden, maar vormt vooral een sociaal-ethische doelstelling op zich, heeft een eigen intrinsieke waarde. Van groot belang hierbij zijn aspecten als zeggenschap, ontplooiing en verantwoordelijkheid.

Vervolgens wordt het kader gevormd door de context waarin de humanisering van de arbeid gerealiseerd moet worden. Dit is in het algemeen een arbeidsorganisatie (onderneming), waarin humanisering veelal niet primair als doelstelling van het beleid wordt gezien en waarin bestaande machtsverhoudingen en mede daardoor een ingebakken disharmonie als evenzoveel belemmerende factoren kunnen worden beschouwd.

De vraag naar de betekenis van dit rechtsgebied is dus de vraag naar de mate waarin het 'recht doet' aan de normen en de waarden die inhoud geven aan de humanisering van de arbeid ten behoeve van de werknemers. Niet alleen door de formulering van aspiraties, maar vooral ook door een effectieve juridische instrumentering waardoor factoren die belemmerend zijn voor het bereiken van de doelstelling, kunnen worden geneutraliseerd.

De nauw met elkaar samenhangende vragen die in elk geval beantwoord dienen te worden, zijn de volgende:

- Welke zijn de (juridische) regelingen die de positie van de werknemer bij de humanisering van de arbeid (mede) tot onderwerp hebben?

- Kan op basis van die regelingen gesproken worden van een afdwingbaar subjectief recht op humane arbeid?

- Welke juridische mogelijkheden (in termen van rechten, bevoegdheden, handhavingsmogelijkheden) heeft de werknemer om direct of indirect, invloed uit te oefenen op de humanisering van zijn arbeid?

- Hoe is het anderzijds gesteld met de verplichtingen van de individuele werknemer en de daarmee verbonden strafrechtelijke en civielrechtelijke aansprakelijkheid?

- Hoe dient tenslotte de bijdrage van het recht beoordeeld te worden in het licht van de doelstelling humanisering van de arbeid van werknemers ener- 
zijds en de machtsverhoudingen en divergerende belangen in de onderneming anderzijds?

\section{Enkele begripsbepalingen en afgrenzingen}

In het voorafgaande zijn een aantal malen begrippen gehanteerd die nog niet voldoende zijn omschreven. Een nadere begripsbepaling is temeer noodzakelijk, omdat juist op het onderhavige terrein diverse begrippen vaak door elkaar gehanteerd worden (bijvoorbeeld welzijn, humanisering, zeggenschap), dan wel voor sommige begrippen in de wetgeving en in de juridische literatuur diverse omschrijvingen bestaan (bijvoorbeeld werknemer, werkgever, onderneming), dan wel begrippen in de loop van de tijd van betekenis zijn veranderd (bijvoorbeeld gezag, inrichting). Een aantal begrippen zal ik hieronder verduidelijken.

\subsection{Humanisering van de arbeid}

In plaats van humanisering van de arbeid wordt ook wel gezegd: welzijn in verband met arbeid. Ik gebruik het begrip humanisering omdat het tot de algemeen geaccepteerde terminologie behoort, zonder dat het zijn bruikbaarheid voor deze (voornamelijk juridische) studie verliest. ${ }^{41}$ De Arbowet echter hanteert het begrip welzijn. Minister Albeda in zijn MvA over deze kwestie: 'Weliswaar is de term (bedoeld is humanisering, AG) hier en daar in deskundige kringen aanvaard, doch daarbuiten is de betekenis niet zonder meer duidelijk. Bovendien geef ik de voorkeur aan het woord welzijn boven de aan het Latijn ontleende uitdrukking humanisering." dus onjuist. Voor wat betreft de vermeende onduidelijkheid over de terminologie geldt dat in gelijke mate voor beide begrippen. Impliciet geeft de minister dat elders in zijn MvA ook aan. ${ }^{42} \mathrm{Zijn}$ andere argument is te subjectief om overtuigend te zijn.

Bij humanisering van de arbeid onderscheid ik - in navolging van de meeste auteurs - de volgende aspecten: ${ }^{43}$

- veiligheid, gezondheid en hygiëne

Hiertoe behoren de milieuaspecten van het werk zoals stof, lawaai, temperatuur e.d., maar ook de omgeving van de arbeid en de erbij behorende voorzieningen, zoals de aankleding van de ruimte, toiletten e.d. Het gaat dus vooral om de begrippen veiligheid, gezondheid en hygiëne zoals die in

$40 \mathrm{Zie}$ de in noot 2 genoemde boeken en ook: C. de Galan, Humanisering van de arbeid: betekenis, opbrengsten en kosten, Arbeid, nu en in de toekomst, Nijkerk 1982 p. 43 e.w.

41 MvA, t.a.p. p. 11.

42 Zie noot 19.

$43 \mathrm{Vgl}$. Hoofdstuk VI, Slotbeschouwingen, Humanisering van de arbeid, t.a.p. p. 240-242. 
de oudere veiligheidswetgeving werden omschreven en die vooral dienden ter bestrijding van bedrijfsongevallen en beroepsziekten.

\section{zeggenschap}

Zeggensehap, als doel en als middel, is vooral de laatste jaren een belangrijk element geworden bij de humanisering van de arbeid. Een belangrijk onderscheid is dat tussen directe en indirecte - d.w.z. via vertegenwoordigers te realiseren-zeggenschap. Zeggenschap wordt hier gebruikt in de betekenis van alle mogelijkheden die werknemers kunnen aanwenden om op een of andere wijze de gang van zaken in de onderneming te beïnvloeden. In deze zin is zeggenschap een ruim begrip, dat echter wel kan dienen om het gemeenschappelijk element in allerlei ander gebruikte begrippen, zoals industriële democratie, medezeggenschap, participatie, zelfbestuur e.d., aan te duiden. ${ }^{44}$ Bovenstaande termen zeggen echter nog (te) weinig over de graad, de intensiteit van de zeggenschap. In het algemeen worden hieromtrent vier rechten genoemd: het recht op informatie, het recht op advies, het recht op overleg en het recht op instemming. (Recht op informatie zou ook nog beschouwd kunnen worden als een noodzakelijke voorwaarde voor de volgende 'eigenlijke' zeggenschapsrechten). Alle vier zijn ook terug te vinden in onze medezeggenschapswetgeving. Met name in de literatuur over de arbeidsomstandigheden wordt daar soms nog een vijfde bevoegdheid aan toegevoegd: het recht op controle of inspectie. Tenslotte kan hier in navolging van Gevers, en alleen in het kader van het arbeidsomstandighedenrecht, nog aan toegevoegd worden het recht om bij onmiddellijk dreigend gevaar voor lijf of leden het werk te onderbreken. ${ }^{45}$

- verantwoordelijkheid, ontplooiing en creativiteit

Het gaat hierbij om de mate waarin werknemers zelf kunnen bepalen hoe zij hun werk willen inrichten, om de organisatie en de wijze van leiding geven. Voor wat betreft de inhoud en de aard van het werk ook om de aanpassing van het werk aan de capaciteiten en mogelijkheden van de werknemer. Hierbij kan betrokken worden de mate van de zin van het werk, m.a.w. in hoeverre het werk een bijdrage levert aan het eindresultaat, in hoeverre daar zicht op is en of dat eindresultaat beïnvloed kan worden (het tegengaan wan 'vervreemding'). Tot slot moeten hier genoemd worden de mogelijkheden om contacten te onderhouden met collega-werknemers.

\subsection{Arbeidsomstandighedenrecht}

Arbeidsomstandighedenrecht is een term die pas de laatste jaren - onder invloed van de Arbowet - in zwang is gekomen. Daarvóór werd in het alge-

44 T. de Jong en A.H.C.M. Walravens, Zeggenschap en humanisering, Humanisering van de arbeid, t.a.p. p. 111.

45 J.K.M. Gevers, t.a.p. p. 66. 
meen van arbeidsbescherming gesproken ${ }^{40}$ en nog vroeger van arbeidersbescherming. ${ }^{47}$

Onder arbeidsomstandighedenrecht wordt in het algemeen verstaan het geheel van normen dat gericht is op de bescherming van het lichamelijk en geestelijk welbevinden van de werknemer tegen met het werk samenhangende invloeden die dit welbevinden bedreigen. Deze bescherming kan resulteren in een regeling van de arbeidstijd zowel als in een regeling tegen de gevaren van de arbeid zelf, hetzij door de oorzaken ervan weg te nemen, hetzij door aan de werknemer een bijzondere bescherming te bieden. ${ }^{48}$ Meestal wordt aangenomen dat het daarbij gaat om publiekrechtelijke normen, waarbij de Arbeidswet en de Arbowet centraal staan.

In deze studie wil ik onder arbeidsomstandighedenrecht verstaan: het geheel van regels dat de humanisering van de arbeid normeert. Deze omschrijving is in twee opzichten ruimer dan de bovenstaande. In de eerste plaats omdat zij ook zeggenschapsaspecten omvat zoals die bijv in de WOR geregeld zijn en in de tweede plaats omdat het ook gaat om regels die niet per se met publiekrechtelijke normen behoeven samen te vallen. Ik denk hierbij bijv aan voorschriften op dit terrein in het BW of, buitenwettelijk, bepalingen in CAO's. Daarnaast kunnen internationale afspraken, voorschriften of aanbevelingen een rol spelen.

De omschrijving is anderzijds minder ruim omdat - nog steeds conform mijn begripsbepaling van humanisering van de arbeid in engere zin - de regeling van de arbeidstijd erbuiten valt. (De Arbeidswet komt overigens met name in het volgende - historische - hoofdstuk wel aan de orde, omdat een aantal principiële vragen, die ook betrekking hadden op de wettelijke regeling van de veiligheid en de gezondheid van de werknemers naar aanleiding van de tot standkoming van de Arbeidswet zijn beantwoord).

\subsection{Werknemer}

De juridische terminologie betreffende personen en verhoudingen in het sociaal recht is bepaald niet eenduidig. ${ }^{49}$ Dit geldt zeker voor het begrip werknemer, dat vooral in de recentere wetgeving, zoals de Arbowet, voorkomt. (In de Arbeidswet 1919 en de Veiligheidswet 1934 wordt voor de toepassingsgebieden niet aangeknoopt bij de arbeidende persoon maar bij het begrip arbeid ${ }^{59}$ ). En hoewel aan Koopmans toegegeven moet worden dat het woord werknemer zuiver taalkundig niet fraai is, en dat de reden van het gebruik

$46 \mathrm{Vgl}$. H.L. Bakels en L. Opheikens, Schets van het Nederlandse arbeidsrecht, Deventer 1982 $\left(6^{\mathrm{e}}\right.$ druk $)$, p. 34 .

Vanaf de zevende druk (1986, p. 35) wordt ook in dit bekende leerboek over "arbeidsomstandighedenrecht" gesproken.

47 Bijv. A.N. Molenaar, t.a.p. p. 1175.

48 A.J.C.M. Geers en J.K.M. Gevers, Arbeidsomstandighedenrecht, Deventer 1979, p. II.

49 T. Koopmans, De begrippen werkman, arbeider en werknemer, Alphen a/d Rijn 1962.

50 Uitwoerig aver deze ontwikkeling: T. Koopmans, 1.a.p. p. 13-20. 
waarschijnlijk niet zozeer geweest is het zoeken naar de juridische nuance als wel het gaandeweg in onbruik raken van het woord arbeider in het na-oorlogse sociaal-politieke spraakgebruik, zal ook ik het begrip hanteren ${ }^{51}$ In de eerste plaats is het begrip zowel in als buiten de juridische discipline ingeburgerd. In de tweede plaats wordt het begrip gebruikt in de belangrijkste wet betreffende humanisering van de arbeid, de Arbowet, en in de derde plaats is het ruim genoeg om zowel de werknemer die op basis van een arbeidsovereenkomst werkzaam is (de arbeider van art. 1637a BW) er onder te doen vallen, als degene die zonder arbeidsovereenkomst voor een ander onder diens gezag werkzaam is. $\mathrm{lk}$ moet hierbij een beperking aanbrengen die echter aansluit bij het ingeburgerde spraakgebruik. Onder werknemer versta ik niet degene die met het bestuur of de leiding van of in een onderneming belast is - hoewel er ook dan vaak sprakè zal zijn van een arbeidsovereenkomst.

De positie van de ambtenaar is voor deze studie een problematische. Formeel verschilt zijn positie aanzienlijk van die van de particuliere werknemer. Hij werkt op basis van een éénzijdige vaststelling van de aanstellingsbeschikking, de arbeidswoorwaarden worden éénzijdig vastgesteld en de medezeggenschapsstructuur is anders geregeld. In de praktijk zijn de verschillen inmiddels kleiner geworden: de bonden en de minister van Binnenlandse Zaken discussiëren over een overllegmodel vergelijkbaar met CAO-onderhandelingen, de zeggenschapsstructuur is méer aangepast aan de regelingen in de WOR, bij het denken over organisatievormen wordt het particuliere bedrijfsleven steeds meer als voorbeeld genomen, en de Arbowet geldt in beginsel ook voor alle ambtenaren. Dit laatste betekent dat waar in dit boek gesproken wordt over werknemers in het kader van de Arbowet, in het algemeen tevens gelezen kan worden ambtenaren. In alle andere gevallen wordt de werknemer in de particuliere sector bedoeld; hoewel de verschillen materieel kleiner worden, zijn ze formeel nog wel van dien aard dat telkens afzonderlijke aandacht voor de ambtenaren het bestek van dit boek te buiten gaat.

\subsection{Onderneming}

Wat voor het begrip werknemer geldt, geldt zeker ook voor het begrip onderneming. 'Vrijwel geen begrip wordt in de Nederlandse rechtstaal in zoveel betekenissen gebezigd als het begrip onderneming. ${ }^{52}$ Voor het onderwerp van dit boek is het begrip onderneming zoals dat gedefinieerd wordt in de WOR (art. 1, eerste lid onder c), het meest geschikt. Deze wet omschrijft het begrip onderneming als 'elk in de maatschappij als zelfstandige eenheid optredend organisatorisch verband, waarin krachtens arbeidsovereenkomst arbeid wordt verricht'. Centraal bij deze omschrijving staat de zelfstandige arbeidsorganisatie: de juridische vorm waarin een en ander is gegoten is irrelevant, evenals het

51 T. Koopmans, t.a.p. p. 63.

52 T. Koopmans, t.a. p. p. 303. 
al dan niet beogen van winst. Bijkantoren, filialen e.d. zijn in deze betekenis dus ook ondernemingen. Het is niet vereist dat alle werknemers krachtens arbeidsovereenkomst werkzaam zijn - en in die zin sluit de omschrijving ook aan bij de Arbowet (die in tegenstelling tot de Veiligheidswet 1934 niet uitgaat van 'arbeid in een onderneming', maar van 'werkgever" en 'werknemer").

\section{Opbouw van het boek}

$\mathrm{Na}$ deze inleiding zal het volgende hoofdstuk, telkens in tijdsperioden verdeeld, gewijd zijn aan de historische ontwikkeling van het arbeidsomstandighedenrecht in de betekenis die ik in de vorige paragraaf heb aangegeven. Hoewel de positie van de individuele werknemer, in de vroegste regelingen immers vooral een te beschermen object, dus een weinig geprononceerde is, zal toch geprobeerd worden deze positie enig reliëf te geven. Dat zal gebeuren aan de hand van parlementaire stukken, literatuur (met name ook artikelen in oudere tijdschriften, zoals het Sociaal Weekblad) en verslagen en geschriften van de Arbeidsinspectie. Vervolgens komen de recente ontwikkelingen aan de orde, waarbij eveneens geprobeerd wordt om de juridische regelingen - van velerlei aard - in een sociaal-politieke context te plaatsen.

Het derde hoofdstuk zal handelen over de relatie tussen de werknemers en de andere actoren in en buiten de onderneming. De positie van de eerstgenoemde immers wordt ook, of misschien zelfs vooral, gemarkeerd door de andere betrokkenen in of bij de onderneming. Bovendien kunnen vaak aan de verplichtingen van die anderen de rechten ontleend worden voor de werknemer. Derhalve zullen in afzonderlijke paragrafen aan de orde komen de positie in de diverse juridische regelingen van: dle werkgever, de or, de deskundige diensten (met name de bedrijfsgezondheidsdienst) en het overheidstoezicht (de Arbeidsinspectie). Daarnaast zal aandacht geschonken worden aan de rol van de centrale werkgevers- en werknemersorganisaties. Met name de rol van de $\mathrm{CAO}$ zal hierbij worden betrokken. Vooral van de kant van de vakbeweging wordt steeds meer aangedrongen op het opnemen van arbeidsomstandighedenbepalingen in de $\mathrm{CAO}$, en op het meer concretiseren van de al bestaande bepalingen..$^{53}$

Het vierde hoofdstuk is geheel gewijd aan de positie van de individuele werknemer. Eerst zal geünventariseerd worden - op basis van het vorige hoofdstuk - hoe het gesteld is met zijn rechten, zijn handhavingsmogelijkheden ervan, en zijn plichten in relatie tot de andere actoren. Vervolgens wordt nagegaan hoe het voor het overige staat met zijn juridische positie, in beginsel, en voorzover dat mogelijk is, los van de relatie met bovengenoemden. (Voor wat betreft een juridische mogelijkheid gebaseerd op de Arbowet kan hierbij bij-

$53 \mathrm{Vgl.H} . \mathrm{M}$. de Burlet, Gezondheid en veiligheid op de werkplek, NIPG, Leiden 1978, p. 15; D. Visser, Wat kunnen ondernemingsraden verwachten van de vakbeweging? Arbeidsomstandighedenwet en ondernemingsraad, Industriebond FNV, Amsterdam, mei 1985. 
voorbeeld gedacht worden aan het individuele recht voor elke werknemer om bij dreigend en acuut gevaar het werk neer te leggen). In dit hoofdstuk zal eveneens aandacht worden geschonken aan een door de Arbowet nieuw geïtroduceerd fenomeen: de belanghebbende werknemers of, in een aantal gevallen, een meerderheid van hen.

Met name in de hoofdstukken IIl en IV zal. gebruik worden gemaakt van verschillende (niet-juridische) onderzoeken teneinde ook enig zicht te verkrijgen op de effectiviteit en de praktische betekenis van de juridische regelingen.

Het laatste hoofdstuk zal op basis van de bevindingen uit de vorige hoofdstukken een slotbeschouwing bevatten waarin die bevindingen gewaardeerd worden, mede aan de hand van de noties zoals die in de eerste paragraaf van dit hoofdstuk zijn verwoord. 


\section{Ontwikkeling}

\section{Inleiding}

In dit hoofdstuk wordt de ontwikkeling beschreven van het arbeidsomstandighedenrecht. Een ontwikkeling die begint aan het einde van de negentiende eeuw met enkele wettelijke maatregelen die een summiere bescherming beoogden voor een kleine groep werknemers en die heeft geresulteerd in een complex van regelingen geldend voor vrijwel alle werknemers en betrekking hebbend op het brede terrein van de humanisering van de arbeid. Hoewel de arbeids- en rusttijden in dit boek niet centraal staan, zal er bij de ontstaansgeschiedenis van de eerste arbeidsbeschermende wetgeving wel aandacht aan worden besteed. Immers, de principiële vragen en antwoorden erop die toen een rol speelden, hadden betrekking op zowel de voorgenomen wetgeving ter beperking van de arbeidsduur als op die ter bescherming van de veiligheid en gezondheid. Het veiligheids- en gezondheidsvraagstuk hing - en hangt - ook ten dele samen met de arbeidsduur. Deze vraagstukken betreffen met name de erkenning van de noodzaak van overheidsbemoeienis, de omvang en de samenstelling van de te beschermen groep werknemers en het toezicht op de naleving van de wetgeving.

Bij het ontstaan en de ontwikkeling van de eerste arbeidsbeschermende wetgeving speelt de industrialisatie een belangrijke rol. Dit blijkt ook uit de datum van de totstandkoming van de eerste wetten op dit terrein in West-Europa. In Engeland kwam de eerste wettelijke maatregel tot stand in 1802, in Duitsland in 1839, in Frankrijk in 1842 en in Nederland, dat op dit gebied van de industrialisatie een forse achterstand had op de omringende landen, in $1874 .^{1}$

Deze wetten waren vooral gericht op een beperking van de arbeidsduur voor kinderen en - iets later - ook voor vrouwen: de zgn. personae miserabiles. Soms hadden deze wetten ook al betrekking op enkele beschermingsaspecten tijdens het werk zelf. Pas later trad een verzelfstandiging in van enerzijds de

I Vgl. J.K.M. Gevers, Zeggenschap van werknemers inzake gezondheid en veiligheid in bedrijven. De rechtsontwikkeling in de lid-staten wan de Europese Gemeenschap, Dewenter 1981, p. 29-31.

Over de totstandkoming van de eerste wettelijke maatregelen in Engeland uitgebreid: A.N. Molenaar, Arbeidsrecht I, Zwolle 1953, p. 192 e.w. 
wetgeving op het gebied van de bescherming tijdens de arbeid en anderzijds die op het gebied van de arbeids- en rusttijden.

Het beginpunt van de arbeidsbeschermende wetgeving in Nederland wordt in het algemeen gelegd bij de totstandkoming van de zgn. Kinderwet van Houten in $1874^{2}$. Een voorlopig eindpunt vormt de Arbowet 1980. In de tussenliggende tijd hebben talloze regelingen het licht gezien, die vaak zijn gewijzigd en soms weer zijn ingetrokken. Het betreft niet alleen de publiek-rechtelijke regelgeving op dit terrein (onderdeel van het arbeidsbestuursrecht), maar ook regelingen voortwloeiend uit zulke verschillende bronnen als het $\mathrm{BW}$, internationale afspraken en $\mathrm{CAO}$.

De volgende paragrafen van dit hoofdstuk hebben telkens een bepaalde, min of meer afgeronde, periode tot onderwerp. In elk van die perioden komen eerst de publiekrechtelijke regelingen aan de orde - voor ons onderwerp verreweg de belangrijkste - en vervolgens de overige. Dit geldt overigens niet voor de volgende paragraaf, waarin enkele opmerkingen over de vorige eeuw tot ongeveer 1870 gemaakt worden, om de simpele reden dat er in die tijd nog geen regulering op het gebied van de arbeidsbescherming bestond. Toch wordt aandacht gegeven aan die tijd om de noodzaak van overheidsinterventie op het gebied van de arbeidsverhoudingen te demonstreren, en tevens begrip te creëren voor de wijze waarop dat uiteindelijk, en veel later dan in het buitenland, gebeurt.

Het jaar $1870 \mathrm{kan}$ wellicht in verscheidene opzichten als een breuk beschouwd worden. Niet eens zozeer in juridisch, maar vooral in economisch, sociaal, cultureel en politiek opzicht. ${ }^{3}$ Vooruitlopend op de volgende paragrafen vast een zwart-wit, maar illustratief citaat: 'Wanneer men Nederland na 1870 vergelijkt met Nederland gedurende de eerste helft der negentiende eeuw - de periode 1850-1870 is een overgangsperiode - dan is het alsof men twee verschillende werelden aanschouwt. De achterlijkheid en de rust die vroeger heersten zijn nu verworpen; overal is leven, bedrijvigheid en ook vooruitgang.'4

Vervolgens komt de belangrijke periode tot 1919 aan de orde, het jaar waarin de thans nog vigerende Arbeidswet tot stand wordt gebracht. Belangrijk omdat in deze periode de juridische fundamenten worden gelegd voor de latere

2 De echte eerste beschermende maatregel van de centrale overheid voor ons land was het op de Mijmwet van 1810 gebaseerde decreet van Napoleon wan 13 januari 1813 (Bulletin des Lois, nr. 467). Art. 29 van dit decreet bevatte een verbod op mijnarbeid door kinderen beneden de 10 jalar. Voorts werden in respectievelijk de tweede en derde titel matregelen voorgeschreven ter voorkoming wan ongelukken en maatregelen die moesten worden getroffen als een ongeluk had plaatsgewonden. Vgl. A.N. Molenaar, t.a.p. p. 246.

Volgens Levenbach was deze regeling echter vooral bedoeld ten behoeve van de veiligheid in de mijnen. M.G. Levenbach, Nederlands Bestuursrecht III, Economisch en sociaal bestuur, AIphen a/d Rijn 1964, p. 436.

3 Vgl. I.J. Brugmans, De arbeidende klasse in Nederland in de negentiende eeuw 1813-1870, Utrecht/Antwerpen, tiende druk, 1975, vooral hoofdstuk 6, p. 214-222; 1.J. Brugmans, Paar* denkracht en mensenmacht, sociaal economische geschiedenis van Nederland 1795-1940. Den Haag 1961, p. 286, Th. van "Tijn, Het sociale leven in Nederland 1844-1875, Algemene geschiedenis der Nederlanden, deel 12, Hatrlem 1977. vooral p. 154-165.

4 I.J. Brugmans, Pardenkracht etc. t.a.p. p. 286. 
regellgeving op dit terrein. De ontwikkeling van het arbeidsomstandighedenrecht verloopt nog steeds voor een groot deel langs de in die periode uitgezette lijnen. Zoals uit de betreffende paragraaf blijkt, kan het jaar 1919 ook in andere opzichten als het sluitstuk van een periode - de negentiende eeuw worden gekarakteriseerd. De periode tot 1919 wordt afgesloten met enkele concluderende beschouwingen.

De periode 1919-1940 wordt gekenmerkt door een gestage uitbouw van de arbeidsbeschermende regelgeving, zonder dat van nieuwe inzichten gesproken kan worden, zowel wat betreft de na te streven doelstelling als de te hanteren instrumenten. In deze periode komt onder meer de Veiligheidswet 1934 tot stand, die pas bij de inwerkingtreding van de Arbowet is vervangen.

In de eerste decennia na de Tweede Wereldoorlog kwamen geen ingrijpende nieuwe regelingen tot stand. Zeker in het begin van deze periode stond de wederopbouw van het land centraal. Daarbij paste niet in de eerste plaats een bekommernis om de omstandigheden waaronder de arbeid werd verricht.

In de jaren zeventig verandert dit beeld. Belangrijkste resultaat is de Arbowet. Inmiddels kan geconstateerd worden dat een aantal idealen uit die jaren zeventig, die een belangrijke inspiratiebron vormden voor de Arbowet, op de tocht staan. Dit heeft consequenties voor de juridische producten die het resultaat zijn van die idealen. In een paragraaf over recente ontwikkelingen wordt hieraan aandacht geschonken.

\section{De negentiende eeuw tot 1870}

\subsection{Economische toestand}

De proclamatie bij de totstandkoming van het Koninkrijk der Nederlanden op 17 november 1813 was rijkelijk optimistisch. 'De zee is open, de koophandel herleeft" werd er onder meer in verordonneerd. ${ }^{5}$ De discrepantie tussen dleze wervende tekst en de werkelijkheid bleek echter groot. Berusting en stagnatie lijken nog de meeste vleiende termen om de geest van het tijdperk, zeker tot 1850 , te karakteriseren. ${ }^{6}$ Dit gold ook - of misschien zelfs vooral - voor een aspect van het maatschappelijk leven dat voor dit boek van belang is: de economische ontwikkeling, de industrialisatie en de rol van de arbeid en de arbeiders daarin. ${ }^{7}$

5 I.J. Brugmans, Paardenkracht etc. t.a.p. p. 66.

6 Over de geest van het tijdperk vooral: 1.J. Brugmans, Arbeidende klasse, met name p. 66-83.

7 In de Nederlandse historiografie is er altijd een nauwe band geweest tussen de economische situatie en de industrialisatie. Soms werden economische ontwikkelingen als voorwaarden gezien voor industrialisatie. Soms was de zienswijze juist omgekeerd. Over dit probleem: E.J. Fischer, Fabriqueurs en fabrikanten, Utrecht 1983 , p. 8.

Fischer maakt het volgende onderscheid. Industrialisatie betreft veranderingen op micro-niveau die betrekking hebben op mechanisatie en automatische productie in de afzonderlijke takken van nijverheid, en op macro-niveau die betrekking hebben op thet relatief belangrijker worden van de mijverheid ten opzichte van de overige sectoren van bedrijvigheid, te weten de agrarische en de dienstverlenende sector. 
Eigenlijk kon van een economische ontwikkeling in deze periode - de vroeg-kapitalistische - nauwelijks worden gesproken. Kenmerkend was de uitermate geringe bereidheid om risico's te lopen, nieuwe producten te introduceren, van nieuwe methoden gebruik te maken, kortom een afkeer van nieuwigheden en een daarmee gepaard gaande tevredenheid met geringe groei en winst.

In 1846 klaagde de Maatschappij van Nijverheid: 'De heillooze stelling, dat er tot het opzetten eener industriële onderneming weinig meer behoefd wordt dan een klein beginkapitaal, een geringe arbeidzaamheid en een oudere meesterknecht, deze heillooze stelling is het, die onze Nijverheid heeft in den grond geboord. ${ }^{8}$ Potgieters Jan Salie is nog steeds de belichaming van dit tijdperk. Hildebrand neemt in zijn Camera Obscura 'zijn' oom Stastok als volgt waar: "Mijn oom was iemand, wiens grootvader en vader een zeer bloeiende, en die zelf een vrij bloeiende lintweverij gehad had; om de strikte watheid te zeggen, moet ik bekennen dat hij ze nog had, maar er werd volstrekt niet meer gewerkt, en op de zolders lag nog een aanzienlijke partij oortjesband, die hij liever daar zag verrotten dan haar op de markt te verkopen. Hij behoorde alzo tot die mensen die hun zaken aan kant gedaan hebben en, het uitzicht op verdere winsten opgevende, zich met een vrij aardig inkomen, een onverzettelijke afkeer van stoommachines, en de Haarlemse Courant tevreden stellen. ${ }^{\text {"y }}$ Zeker tot 1850 is van industrialisatie dus nog nauwelijks sprake. ${ }^{\prime \prime}$ Toch was er in de laatste decennia voor 1850 al wel een zekere productietoename, al was het totale aandeel van de industrie in de beroepsbevolking in $1849 \mathrm{nog}$ altijd kleiner dan dat van de landbouw. Bovendien waren vele werklieden direct afhankelijk van de landbouw zoals hoefsmeden, wagenmakers e.d. De Jonge concludeert dat in totaal tenminste de helft van de Nederlandse beroepsbevolking rechtstreeks afhankelijk was van de werkgelegenheid in de landbouw of daarbij nauw betrokken. ${ }^{11}$

Rond 1850 begint zich een zekere verschuiving af te tekenen van een agrarischcommerciële structuur naar een commercieel-industriële. ${ }^{22}$ Niet alleen het

$\rightarrow$

$\overrightarrow{E c o n o m i s c h e ~ o n t w i k k ~ t i n g ~ b e t r e f t ~ e c n ~ v e r a n d e r i n g s p r o c e s ~ i n ~ d e ~ s a m e n l e v i n g ~ d a t ~ l e i d t ~ t o t ~ e x t n ~}$ nielancidentele toename vam de producte van goederen en diensten. (Door bijoorbeeld cen verbetering in do landbouw kan er sprake zjo van economische on wikkeling, zonder dat zich veranderingen voordoen in de mijverheid).

Onder economische groef wordt verstan de niet-incidentele toename van het reele mathomal inkomen per hoofd wan de bevolking. (Economische ontwikketing behoeft dus niet samen te gatan met economisehe groe; bijwoorbeeld als een bevolkingstoename leidt to cen toename van geproduce rde goederen on diensten, zander dat het reele tnkomen per hoofd stijgl). Fischer 1. . . P. p. 9 .

8 Geciteerd bij Brugmans. Arbeidende klasse, t.a.p. p. 69.

9 Hildebrand, Camera Obscura nat de derde uitgave van 1851. Utrecht Amtwerpen, p. 50.

10 Zeen utvoerig over de indust talisatie in dit tijdperk het standaardwerk van I. A. de Jonge. De industrialisatie in Nedertand tussen $1850 \mathrm{en} 1914$, Anmsterdam 1968 (Sun-reprint, Nijmegen $1976)$.

11 de Jonge, ta.p.p. 21.

12 Waren er in 1849 in total 299.000 personen werkzam in de nijwerheid in 1859 waren dat er 326.000 en in 1889482 .000. de Jonge, t. a.p. p. $228-229$. 
aantal personen dat werkzaam was in de nijverheid nam toe, dat gold ook voor het aantal grote bedrijven.

Het industriële groeiproces begon echter pas goed na 1870. Een aanwijzing daarvoor vormt ook de groei van het aantal naamloze vennootschappen. ${ }^{1.7} \mathrm{De}$ N.V. biedt immers een geschikt middel om tot een meer rationele bedrijfsvoering te komen omdat bedrijfskapitaal en privévermogen gescheiden worden. Hierdoor kunnen grotere kapitalen bijeen gebracht worden, wordt de continuiteit van de onderneming verzekerd en kunnen dochterondememingen en onderafdelingen van expanderende ondernemingen verzelfstandigd worden. Deze scheiding was in de eerste helft van de vorige eeuw nog niet gebruikelijk. Omstreeks 1860 waren er niet meer dan 74 naamloze vennootschappen. Tien jaar later was dit aantal al verdubbeld. ${ }^{14}$

Niet alleen kwam het groeiproces van de industrie in Nederland later op gang dan in bijvoorbeeld Engeland en Duitsland, het kwam ook trager op gang. Dit laatste is begrijpelijk: weliswaar kan geleerd worden van elders begane fouten, maar daar staat een forse concurrentie tegenover van al gevestigde industrieën..$^{15}$

Hoe valt nu deze late start en in het algemeen de achterblijvende ontwikkeling in Nederland te verklaren? Hierboven is all gewezen op de bekende 'geest van de tijd' zoals die onder meer tot uitdrukking kwam in de houding van de fabrikanten. Daarnaast speelden echter ook andere, meer objectieve, factoren een belangrijke rol. ${ }^{10}$ In dit verband kunnen genoemd worden het ontbreken van belangrijke grondstoffen en energiebronnen als ijzer en kolen die voor industrialisatie van belang zijn, de gebrekkige transportmiddelen en het volstrekt ontoereikende wegennet. Bovendien konden de buurlanden door het bezit van grondstoffen en voldoende consumptieve vraag een betrekkelijk zelfstandige handelspolitiek voeren. Hierdoor konden de buitenlandse ondernemers wèl op de Nederlandse markt concurreren, terwijl de Nederlandse producten in het buitenland in het algemeen moeilijk afgezet konden worden. De ruime arbeidsmarkt, mede door de economische malaise, noodde bovendien niet tot mechanisatie. Tevens was de aanvoer van grond-en hulpstoffen uit het buitenland gezien de bestaande gebrekkige infrastructuur (te) kostbaar. De slappe bodemgesteldheid maakte verbetering zowel financieel als technisch moeilijk te verwezenlijken. In dit licht moet ook de kapitaalvlucht wan de vermogenden

13 Vgl. J. Valkhoff, Een eeuw rechtsontwikkeling. De vermatschappelijking van het Nederlandse privaatrecht sinds de codificatie (1838-1938), A msterdam 1938, vooral p. 151 469). Valkhoff ziet de toename van de naamloze vennootschappen in die tijo als cen illustratic van de toenemende inperking van de individuele vrijheid. "De individuele wil der rechtssubjecten wordt weer teruggedrongen. Het algemeen belang als objectief belang tegenover de suljectieve partijwil van de oprichters of de atandleelhouders staat woorop. De N.V. is een onderneming, die op een zodanige wijze aan het handelsverkeer deelneernt, dat daarbij veelal de belangen van zeer velen gemoeid zijn'. 1.a.p. p. 155. Zie ook de krithische besproking over Valkhoffs theorie van vermatatschappelijking wan thet recht in: T. wan Peijpe, De on wikkcling van het loonwormingsrecht, Nijmegen 1985, p. $13-25$.

14 de Jonge, t.a.p. p. 235.

15 de Jonge, t.a.p. p. 237.

16 Het navolgende is vooral ontleend aan Fischer, t.a.p. p. 13 en 14. 
gezien worden: Nederland bood simpelweg te weinig emplooi.

In de historiografie van de negentiende eeuw bestaat tussen de verschillende auteurs geen eenstemmigheid over het antwoord op de vraag of de geest van berusting en conservatisme nu een gevolg is geweest van deze ongunstige omstandigheden, of dat beide factoren in gelijke rangorde en gelijke mate verantwoordelijk moeten worden gesteld voor de sociale, culturele en economische toestand in de negentiende eeuw. ${ }^{17}$ Voor het onderwerp van dit boek lijkt het voldoende om vast te stellen dat beide factoren in elk geval van groot belang waren.

Overigens moet gezien recent historisch onderzoek wellicht ook het gangbare beeld van de Nederlandse economie in het begin van de negentiende eeuw gerelativeerd worden. Met geavanceerde statistische technieken kon worden vastgesteld dat het gemiddelde groeipercentage van de productie, daarbij niet alleen de nijverheid betrekkende, de percentuele toename van de bevolking overtrof. Er zou dus wel degelijk sprake zijn van een zekere economische groei. Bovendien zou uit deze onderzoeken blijken dat de toestand in de nijverheidssector, gemeten aan het aandeel in de nationale economie, tot dan toe te somber was voorgesteld. 18

\subsection{Toestand van de arbeiders}

Hierboven is summier en (soms) impressionistisch iets gezegd over de geest van de tijd, de economische structuur en de industrialisatie tot ongeveer 1870. Maar hoe stond het nu met de arbeiders en hun omstandigheden? Het is met name de klassieke studie van I.J. Brugmans over de arbeidende klasse in Nederland in de negentiende eeuw (1813-1870) en een aantal latere publicaties van zijn hand die voor dit onderwerp een rijke bron vormen. ${ }^{19}$

Het Nederland van vóór 1850 vormde een maatschappij die uit slechts twee standen bestond: de armen of het volk aan de ene kant en de gegoeden of deftigen aan de andere kant. Ik schrijf opzettelijk over twee kanten omdat beide groepen volstrekt geïsoleerd van elkaar leefden, zonder dat er sprake was van middengroepen via welke een stijging op de maatschappelijke ladder tot de reële mogelijkheden kon behoren. Brugmans ziet deze situatie zelfs als een van de belangrijkste oorzaken van de Nederlandse lethargie in die tijd. 'Waar die middengroepen ontbreken, daar is dus stijging op de maatschappelijke ladder vrijwell uitgesloten en blijven de hogere standen de onontbeerlijke toestroming van nieuw bloed uit de diepere lagen van de maatschappij missen. En zo kan men zeggen, dat democratie niet slechts een eis van rechtvaardig-

17 Hierover Fischer, Historiografie van de Nederlandse nijverheid in de periode 1815-1930, t.a.p. p. 7-28.

18 Fischer, ta.p. p. 21

19 De arbeidende klasse verscheen woor het eerst als dissertatie in 1925 . Het boek is sindsdien vele malen herdrukt. Ik put uit de tiende druk, Utrecht/Antwerpen 1975. 
heid is, maar evenzeer een eis van economische doelmatigheid. ${ }^{20}$

Tot de grote groep armen ('het volk') behoorden ook degenen die in loondienst werkten. Het loonniveau was immers zo laag, dat zij als het ware vanzelfsprekend tot deze groep werden gerekend. ${ }^{21}$ Het bestaan van een afzonderlijke arbeidende klasse werd tot het midden van de vorige eeuw dan ook niet onderkend. Men kende alleen het vraagstuk van de armoede, van het pauperisme en nauwelijks dat van de arbeidsomstandigheden zoals de arbeidsduur, vrouwen- en kinderarbeid en veiligheid en gezondheid bij het werk. Met andere woorden: de arbeider werd alleen beschouwd als consument en niet als producent. $^{22}$

De toestand van deze bevolkingsgroep was intussen op elk gebied erbarmelijk. De levensduur van de 'behoeftige arbeider' werd omstreeks het midden van de vorige eeuw op 32 jaar gesteld. Zowel voeding, kleding als huisvesting waren inferieur. ${ }^{23}$ Dit gold ook voor de opleiding: één van de redenen waarom, ondanks de grote werkloosheid, hier relatief veel buitenlanders werkzaam waren. ${ }^{24}$ Hoe groot die werkloosheid precies was, is niet bekend. Wel geven de volkstellingsstatistieken grond aan de veronderstelling dat de structurele werkloosheid zeer groot was. Volgens de beroepsstaten van 1859 telde de categorie 'zonder beroep of onbekend' twaalf procent van alle mannen van 23 jaar of ouder - en hiertoe behoorden niet de renteniers en gepensioneerden die apart werden vermeld. ${ }^{25}$

In elk geval kan geconstateerd worden dat massale armoede, vrouwen- en kinderarbeid en structurele werkloosheid ook al vóór het begin van de industriële revolutie kenmerkende verschijnselen waren van de negentiende eeuw. $\mathrm{Na} 1850$ begon de arbeidende klasse zich ook echt als een afzonderlijke klasse te openbaren. Vanaf die tijd zijn ook meer gegevens bekend over arbeidsomstandigheden in de - dan langzaam op gang komende - industrie en de mensen die er werkten.

Om te beginnen waren de arbeidstijden uitermate lang: 16 of nog meer uren waren geen uitzondering, waarbij bedacht moet worden dat het vaak ook van het seizoen afhankelijk was. In het bouwbedrijf was de arbeidsduur in de zomer bijvoorbeeld langer dan in de winter. De klei-industrie sloeg echter het record. In de Franeker 'tichelwerken' werd van 's morgens 2 tot 's avonds 10 uur gewerkt: 20 uren dus. De kinderarbeidsenquête van 1860 geeft voor de

20 I.J. Brugmans, Standen en klassen in Nederland gedurende de negentiende eeuw, Economi sche ontwikkeling en sociale emancipatie, samengesteld door P.A.M. Geurts en F.A.M Messing, Den Haag 1977, p. 128.

21 Tot deze groep werden owerigens in het algemeen ook kleine zelfstandigen gerekend als winkeliers, boeren en kleine patroons, de zgn. ambachtsbazen. Allen hadden tenminste één gemeenschappelijk kenmerk: een uitermate gering inkomen. De inkomsten van de ambachtsbazen bijwoorbeeld verschilden weinig van die van hun knechten. Soms was het verschil slechts enkele tientallen centen per dag; en dan ging het om bedragen van hooguit 1.50 per dag. Vgl. I.J. Brugmans, Standen en klassen, t.a.p. p. 116.

22 Brugmans, Arbeidende klasse, t.a.p. p. 194.

23 Uitgebreid hierover Brugmans, idem, p. 154-193.

24 Brugmans, idem, p. 89.

25 de Jonge, t.a.p. p. 269. 
Franeker steenfabrieken een arbeidsdag van 18 uren, niet slechts voor de volwassenen maar ook voor de jongens tussen 14 en 18 jaar; de vrouwen werktern 12 uren. ${ }^{26}$

Een verschijnsel dat zowel door tijdgenoten als door latere geschiedschrijvers in schrille kleuren is beschreven is dat van de kinderarbeid. De motieven van de ouders om kinderen arbeid te laten verrichten lagen voor de hand "het ging om een-vaak noodzakelijke - aanvilling van het gezinsinkomen. Hoewel dit laatste niet altijd het geval hoefde te zijn. Soms werd het werk als 'leren' gepresenteerd en de verhouding werkgever - werknemer als leraar--leerling. Brugmans constateert over deze situatie, uitzonderingen daargelaten, 'dat ook ten onzent onder het mom van opleiding kinderexploitatie is voorgekomen'. De vrouwen verrichtten haar veelal ongekwalificeerde arbeid meestal in dezelfde (grotere) ondernemingen waarin ook de kinderen werkten. ${ }^{27}$ In sommige ondernemingen gold voor vrouwen (en kinderen) een kortere werktijd dan voor volwassen mannen.

Nog geen aandacht is geschonken aan de omstandigheden in de fabrieken waaronder mannen, vrouwen en kinderen moesten werken. Met inachtneming van alle mogelijke verschillen tussen bijvoorbeeld het werken in grote of in kleine fabrieken (daarvan waren er de meeste), of tussen de verschillende soorten arbeid, leren ook hier zowel de geschriften uit de tijd zelf als de latere, dat de hygiëne en de veiligheid tijdens het arbeidsproces alles te wensen overlieten en dat het werk met recht als ziekmakend gekwalificeerd kon worden. De fabrieksgebouwen waren vaak slecht gebouwd, vervallen, tochtig, in de winter te koud en in de zomer te warm. De verlichting gebrekkig en soms gevaarlijk. Er was geen luchtverversing, en afvoer voor bijvoorbeeld kolendampen ontbrak. Machines hadden geen enkele beveiliging, en vaak waren ze zo dicht bij elkaar geplaatst dat de arbeiders zich nauwelijks konden bewegen. Sommige machines waren bovendien zo ingericht dat ze alleen door kinderen, en dan nog vaak in een onnatuurlijke houding, konden worden bediend. (Dat desondanks het werk in de fabriek voor wat betreft de veiligheid en gezondheid soms nog te prefereren was boven het werk thuis, zegt ook veel over de miserabele woonomstandigheden. ${ }^{2 k}$ )

De toestand van de Nederlandse arbeider in de vorige eeuw tot circa $1870 \mathrm{kan}$ samenvattend gekarakteriseerd worden door twee citaten, én van Brugmans en één van Henriëtte Roland Holst die de eer toekomt als eerste een poging gedaan te hebben om de sociale geschiedenis van Nederland in de vorige eeuw te beschrijuen. ${ }^{29}$

26 Brugmans, Arbeidende klasse, t.a.p. p. 110.

27 Brugmans, idem, t.a.p. p. 108.

28 Brugnans, idem, ta.p. p. 151.

Een buitengewoon expressieve beschrijving van de toestand van de arbeiders in die tijd geeft Henriette Roland Holst in Kapitaal en arbeid in Nederland, deel 1, Amsterdam 1901, (Sunreprint), met name p. $88-114$.

29 In: Kapitaal en Arbeid in Nederland (zie noot 28). Brugmans noemt overigens in zijn Inleiding bij de Arbeidende klasse etc. 'het boekje van Hemriëtte Roland Holst niet meer dan cen verdienstelijke schets." 
Brugmans: 'Beschouwen wij... nog eens de persoonlijkheid van de arbeider in haar geheel, dan zien wij iemand voor ons, die zich in zijn amoedige bestaan in doffe berusting schikt; wie de lichamelijke en geestelijke kracht ontbreekt om zich op te werken; wiens ontwikkeling te gering is om zelfs aan de mogelijkheid van lotsverbetering te denken, in het algemeen: iemand die nog volslagen onmondig was. ${ }^{30}$

En, zeer beeldend, Henriëtte Roland Holst: 'Hun ellende was niet die van den modernen proletariër, voor wien uit wrangste derven het verzet ontstaat dat verheft, de hoop die verzacht, de gemeenschapszin die veredelt. Hun ellende was die van stompzinnige schepselen, zwak van fysieke, nog zwakker van geestelijke krachten, lijden zonder uitzicht en van hun degradatie onbewust. Nòch van den wilde, nòch van den beschaafden mensch bezaten zij de beste eigenschappen of het eigenaardig gebrek, maar van beiden de zwakheden en ondeugden. ${ }^{3} 32$

Hoewel de omstandigheden er alle aanleiding toe gaven, was gezien het bovenstaande, van een (georganiseerd) verzet van de arbeiders, althans van het grootste deel van hen, tegen de toestand waarin ze vaak (nauwelijks) leefden nog geen sprake. Klassebewustzijn - een belangrijke voorwaarde voor hervormende activiteiten - ontbrak vrijwel volledig. Dit kwam onder meer ook door het permanente gebrek aan werk waardoor een werkgever soms eerder beschouwd werd als een filantroop, die werk gaf aan de armen, dan alls een machthebber die zich ten koste van de arbeiders verrijkte. ${ }^{33}$ Bovendien moeten, zeker tot het midden van de vorige eeuw, in de kleine ambachtelijke bedrijfjes, en dat waren de meeste bedrijven, de verhoudingen tussen werkgever en arbeider eerder als partriarchaal en horizontaal gekarakteriseerd worden dan als onderdrukkend of verticaal. ${ }^{32}$ Ook thet buitenland, waar wèl een en ander gebeurde, inspireerde (nog) niet. Henriëtte Roland Holst: 'Rebellie is veerkracht en de veerkracht van dit proletariaat was lang gebroken. Zelfs de

30 Brugmans, Arbeidende klasse, t.a.p. p. 182.

31 Henriette Roland Holst, t.a.p. p. 89.

32 Brugmans, Arbeidende klasse, t.a.p. p. 189.

33 Hofstee karakteriseent deze situatie als volgt: 'Een lange historic heeft de houding, dic in weren stamt uit de agrarisch-ambachtelijke organisatievorm van het economische leven, waarin boer en ambachtsman samenwerken met ển of enkele gezellen of knechten die uit dezelfde sociale en culturele sfeer stammen als de baas, met hem en zijn gezin naw samenle. ven en woor cen groot deel eens zelf de positie zullen gaan innemen, die nu hun baas inneemt. De knecht, de gezel makt deel uit van een patriarchaal gezinsbedrijf, zijn houding is diic wan trouw en afhankelijkheid t.o.v. zijn meester, die enerzijds een-vaderlijk-gezag regenover zijn medewerkers ten toon spreidt en zich verantwoordelijk voelt voor hun welgaan. Behalve een uiterlijke motivering - besttaanszekerheid, mogelijke opklimming tot zelfstandigheid in de toekomsit - ondervond de knecht of gezel een innerlijke motivering in een gevoell wan loyaliteit tegenover het gezin, waarvan hij deel uitmaakte en dat samenviel met het bedrijl watrin hij werkte. Er is geen reden orn verhoudingen zoals ze hierboven werden geschilderd te idealiseren, maar dat ze als een voor de betrokkenen aanvaardbaar sociaal systeen werkten en arbeidskrachten motiveerden tot een zorgvuldige plichtsbetrachting, kon men niet zo lang geleden op de kleine boerenbedrijven op de zandgronden en trouwens hier en dlat in ambachtsbedrijven nog constateren.' $E$.W. Hofstee, Arbeid op de tweesprong, in: Arbeid op de tweesprong, opstellen uitgegeven t.g.v. het vijfenzeventigjarig bestaan der Arbeidsinspectice, Den Haag 1965, p. 115. 
primitieve vormen van individueel verzet, waarvan Engels er in de 'Lage der arbeitenden Klasse' veel aanhaalt, ontbraken: thet eigendom was omstreeks het midden der eeuw nergens veiliger dan in Nederland. Al de bewegingen der veertiger jaren, het Engelsch chartisme, het Fransche socialisme, het Duitse communisme, het ging alles zo hoog en ver boven de Nederlandse arbeiders heen als schoone, stoutgevormde wolken boven een slijmig moeras, dat hen zelfs niet weerspiegelt. De revolutionaire schok, die in ' 48 Europa deed dreunen en daveren tot in Italië en Oostenrijk, wierp hier niets omver dan wat waggelende instellingen van 1813; nooit is een paniek ongegronder geweest, dan die Willem II beving; terwijl studenten, handwerkers en proletariërs te samen streden op de barrikaden in Parijs, in Berlijn en in Weenen, keek de Ned. geld. Bourgeoisie haar effectentrommel na en bestudeerde het rijzen en dalen der fondsen. 34

Dit beeld moet wel enigszins gerelativeerd worden. Acties door middel van stakingen kwamen incidenteel voor bij groepen veenarbeiders, poldergasten en dijk-en wegwerkers, allen dus werkzaam buiten de fabrieken en werkplaatsen. Deze acties richtten zich vooral tegen de lage lonen, maar ook tegen de lange werktijden en barre omstandigheden. Achter deze stakingen stond ook geen organisatie; alleen het werk zelf dwong tot een zekere organisatie. Daarnaast was er steeds sprake van actieleiders, van gestelde eisen en van onderhandelingen. De reactie van de politie en de militairen was in het algemeen gewelddadig en de initiatiefnemers ('raddraaiers') werden op staande voet ontslagen. ${ }^{35}$

Pas omstreeks 1870 beginnen de arbeiders zich te organiseren. Het is duidelijk dat tot die tijd van de arbeiders als stuwende kracht ter verbetering van de arbeidsomstandigheden weinig of niets kon worden verwacht. Hun kracht zou, paradoxaal genoeg, hoogstens kunnen liggen in hun zwakte, die medelijden opriep, of die, economisch gezien, op de langere duur schadelijk zou kunnen worden geacht voor een groeiende productie.

\subsection{Rol van de overheid en andere betrokkenen}

De overheid deed vooralsnog weinig en de activiteiten van de gegoede stand en de kerken beperkten zich tot bedeling en liefdadigheid, niet alleen voor de werklozen maar ook voor de arme werkenden: het onderscheid tussen beide groepen was trouwens niet scherp door het veelvuldig voorkomen van seizoenarbeid, daglonerswerk e.d. Brugmans wijst er terecht op dat het ontbreken van overheidsbemoeienis vóor 1850 niets te maken had met een bepaalde staatsideologie. ${ }^{36}$ Die was er simpelweg niet en Willem I deed wat hem goed-

34 Henriëtte Roland Holst t.a.p. p. 111.

35 Zie over dit oudste "georganiseerde" arbeidersverzet: Ger Harmsen en Rob Reinalda, Voor de bevrijding van de arbeid, Nijmegen 1975, p. 33-36,

36 Brugmans, Arbeidende klasse, t.a.p. p. 193. 
dunkte: vaak resulteerde dat in strakke overheidsreglementering. ${ }^{37}$ Dat deze geen betrekking had op de bescherming van de arbeiders kwam, zoals hierboven al gezegd is, waarschijnlijk omdat deze als zodanig, als klasse, eigenlijk niet erkend waren en dat het bestaan van de verschillende standen nu eenmaal een natuurlijk, van God gegeven, feit was. Iets gebeurde er trouwens wel en dat kwam door de kinderarbeid die al vóor 1850 incidenteel in de belangstelling stond, niet eens zozeer om de arbeid zelf, maar vooral omdat hij leidde tot schoolverzuim en (mede daardoor) als ongewenst ervaren gedrag. Al in 1839 ontving de minister van Binnenlandse Zaken De Kock op zijn verzoek van de Overijsselse gouverneur een wetsontwerp met onder meer een verbod van kinderarbeid beneden de tien jaar. ${ }^{38}$ Dit ontwerp werd niet doorgezet, ondat in 1841 door de regering tot een algemene enquête naar de kinderarbeid werd besloten. Met de resultaten hiervan werd niets gedaan, ze werden opgeborgen, de regering werd er niet over geïnterpelleerd en waarschijnlijk werden ze na verloop van tijd vergeten. ${ }^{39}$ Vast staat wel dat deze overheidsactiviteiten zeker niet steunden op een brede beweging uit de bevolking. ${ }^{40}$

$\mathrm{Na} 1850$ openbaarde zich een grotere belangstelling voor het lot van de arbeiders. Voor het eerst werden zij ook beschouwd als een afzonderlijke klasse, met eigen problemen. Niet langer werden zij alleen maar gerekend tot de armen, wat zij overigens nog steeds waren. Deze belangstelling kwam van verschillende kanten en met name van de kant van de liberalen in en buiten het parlement. Een aantal motieven speelde een rol. Niet alleen was er ongetwijfell sprake van mededogen, maar met de opkomende industriële ontwikkeling ging men ook het belang inzien van een beter opgeleide en fysiek sterkere arbeidersklasse. En ook nu weer was de kinderarbeid niet het enige, maar wel het belangrijkste aanknopingspunt om maatregelen te bepleiten. In dit verband kunnen genoemd worden de Leidse textielondernemer Le Poole die sinds 1859 in artikelen in de Economist (wettelijke) maatregelen bepleitte ter bescherming van arbeidende kinderen èn volwassenen, medici als Coronel en Van Hengel die hun bevindingen in talloze artikelen en rapporten publiceerden en de inspecteur van het stoomwezen De Vries Robbé wiens commentaar op de buitenlandse bepalingen terzake van kinderarbeid wel de Stichtingsbrief van onze sociale wetgeving is genoemd. ${ }^{41}$ In die brief onder meer: '... dat een verordening op het werken der kinderen in de fabrieken vooral bij het gemis van verpligt onderwijs niet alleen volstrekt noodzakelijk is, maar zelfs eene

$37 \mathrm{Vgl}$. ook hoofdstuk 6 Het overheidsbeleid en de belangen der nijverheid bij de Jonge, t.a. p. p. 313-338.

38 Over de kinderarbeid en de pogingen die te reguleren uitgebreid Brugmans, Arbeidende klasse, t.a.p. p. 223-245.

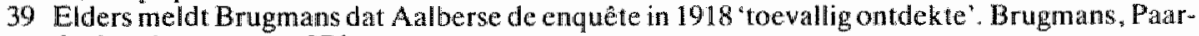
denkracht, t.a.p. p. 276.

40 De belangrijkste reden om te enquêteren kwam ook uit het buitenland: enkele te Stratatsburg uitgegeven brochures, die aan de Franse wet van 1841, "relative au travail des enfants employes dans les manufactures, usines ou ateliers" voorafgingen. Brugmans; Arbeidende klasse, t.a.p. p. 225 .

41 C.W. de Vries in Econ. Hist. Jaarboek VII, 1922, p. 36 geciteerd bij Levenbach, Nederlands Bestuursrecht III, t.a.p. p. 437. 
spoedige voorziening eischt, zullen niet de fabryksarbeiders, zoowel phyziek, intellectueel als moreel, te gronde gaan. ${ }^{42}$ Daarnaast bepleit de rapporteur nog andere maatregelen van wetgevende aard onder meer met betrekking tot de veiligheid, de gezondheid en de ventilatie in de fabrieken en controle en toezicht door een aparte inspecteur. ${ }^{43}$ Het resultaat was - weer - een enquête. In 1860 zond minister Heemstra een aanschrijven hierover naar de commissarissen der provincies. Maar ook nu bleven de resultaten van de enquête uit, al verzetten de commissarissen zich niet tegen eventuele maatregelen. De Limburgse commissaris: "Met volle overtuiging meen ik dan ook te moeten verklaren dat ook hier onbeschaafdheid en zedeloosheid onder de fabrieksarbeiders eensdeels, en verzuim of nalatigheid der particulieren anderdeels het hoogst wenschelijk, ja noodzakelijk maken, dat de Hooge Regeering met beperkende maatregelen tusschen beide trede. Uwer Exc's voornemen daartoe wordt dan ook in de hoogste mate door mij toe gejuicht." ${ }^{44}$

Inmiddels was door de Maatschappij van Nijverheid in 1849 en - met een gewijzigde vraagstelling - in 1853 een prijsvraag uitgeschreven over de vraag naar de toestand van fabriekskinderen en de wenselijkheid van een wettelijke maatregel. (Toen in 1857 eindelijk een antwoord kwam werd dat echter niet bekroond omdat de voordelen van de kinderarbeid te eenzijdig werden benadrukt).

Nà 1860 nam het aantal pamfletten, rekesten, petities e.d. vooral tegen kinderarbeid toe. En opnieuw was het resultaat een enquête. In 1863 stelde Thorbecke mede als antwoord op Cremers brochure over fabriekskinderen een Staatscommissie in onder voorzitterschap van de Vries Robbé. Het ruim duizend pagina's tellende eindverslag verscheen in 1869 en bevatte de onverwachte conclusie dat wettelijke maatregelen ongewenst waren: het kind zou de straat opgejaagd worden, de ouders inkomsten ontberen of hun kinderen thuis laten arbeiden. Beter oordeelde de Commissie het dat de wetgever de leerplicht zou introduceren. De Vries Robbé nam een minderheidsstandpunt in: hij bepleitte "een wettelijke regeling van den duur des arbeids in verhouding tot den leeftijd gepaard aan den schoolpligt'.45

Ook tijdens het werk van de Staatscommissie en na de publicatie van het eindrapport bleef de stroom petities groeien, zonder dat de regering geneigd bleek om op te treden. Zij beriep zich hierbij onder meer op het (verdeelde) eindrapport. ${ }^{46}$ Thorbecke, die zelf nota bene het onderzoek van de Staatscommissie had gelast, antwoordde in 1871 aan het liberale kamerlid Van Houten dat hem aanspoorde tot ingrijpen, dat het de taak van dit kamerlid was "eer zelf het initiatief te nemen, dan een minister, die nog aarzelt, tot het nemen van initiatief aan te moedigen?. ${ }^{47}$

42. Brugmans, idem, p. 232.

43. Vgl. A.N. Molenaar, Arbeidsrecht I, ta.p. p. 250-252; M.G. Levenbach, Nederlands Bestuurstecht III, t.a.p. p. 437.

44 Brugmans, idem, p. 233.

45 Brugmans, idem, p. 238.

46 M.G. Levenbach, Nederlands Bestuursrecht III, t.a.p. p. 438.

47 Handelingen Tweede Kamer, $1871-1872$, p. 357 . 
Maar inmiddels waren de laatste drie decennia van de vorige eeuw aangebroken en de tijden sterk veranderd.

\section{De periode 1870-1919: Van Kinderwet tot Arbeidswet}

Circa 1870 breekt in Nederland de nieuwe tijd aan. ${ }^{48}$ Eén van de belangrijkste kenmerken vormt de dan snel uitbreidende industrialisatie. Het aandeel van de landbouw in het nationale inkomen vermindert, terwijl de bijdrage van de niet-agrarische bedrijven, dienovereenkomstig toeneemt. ${ }^{49}$ De uitvoering van grote, openbare (transport)werken verschaft nieuwe werkgelegenheid vooral voor de vele niet- of half-geschoolde arbeiders. Door het toepassen van nieuwe technische vindingen zoals de stoommachine wordt productie op grotere schaal mogelijk. Er ontstaat een steeds grotere behoefte aan arbeidskrachten en de structurele werkloosheid verdwijnt. ${ }^{50}$ Daarmee samenhangend komt er beweging in het tot dan toe vrijwel volkomen verstardle loonpeil. Op basis van de wijzigingen in de inkomensbesteding is door de Jonge berekend dat het inkomen van de arbeiders ook reëel toeneemt. ${ }^{51}$ De behoefte aan beter opgeleide werknemers doet bovendien de aandacht voor het onderwijs toenemen, wat tevens een impuls vormt bij de bestrijding van de kinderarbeid. ${ }^{52}$

De mogelijkheid van hogere verdiensten en de ruimere werkgelegenheid geeft ook méér kansen op sociale stijging. De oude opvatting over de onwrikbaarheid van de verschillende standen raakt op de achtergrond. Van Tijn: 'Ook nu waren de mogelijkheden tot individuele opklimming natuurlijk niet voor iedereen reëel aanwezig, maar hier trad wat ik het 'loterijeffect' heb genoemd in werking: er zijn veel meer nieten dan prijzen, maar er zijn prijzen, en de hoop daarin te vallen doet velen meespelen. De reactie op de vergrote mogelijkheden kwam snel en op grote schaal. Dat bewijst, dat het conservatieve maatschappijbeeld ('ieder in zijn stand en naar zijn stand, en daarin tevreden*), bij velen slechts een vernisje was, dat snel werd losgelaten toen de loterij geopend werd. ${ }^{53}$

Sinds 1870 kan de 'geest van de tijd' dan ook gekenmerkt worden door een grotere sociale dynamiek deels ten gevolge van het afschaffen van allerlei beperkende maatregelen, deels ten gevolge van het opheffen van verschillende

48 Het spreekt overigens vanzelf dat de historische ontwikkeling in het algeneen te geleidelijk plats vindt, dan dat een bepaald jaar als medogenloze mijlpaal kan worden aangewezen.

49 de Jonge, t.a.p. p. 295.

50 de Jonge, t.a.p. p. 269.

51 de Jonge, t.a.p. p. 290.

52 Met Thorbecke's Onderwi jswet 1863 kwam voor de aanstaande handelsman en industrieel een nieuwe vooropleiding beschikbaar. De nieuwe school was in de eerste plaats bedoeld voor wie '... tot enige tak van handel of nijverheid wensten te worden opgeleid', maar daarnaast zou hij "... voor alle andere matschappelijke betrekkingen' een grondige opleiding kt nnen verschaffen. Geciteerd bij de Jonge, t.a.p. 283 .

53 Th. van Tijn, Het sociale leven in Nederland, 1844-1875, Algemene geschiedenis der Nederlanden, deel 12, Haarlem 1977, p. 154 
stagnerende omstandigheden die in de vorige paragraaf zijn genoemd, en deels door buitenlandse ontwikkelingen. Een belangrijke maatregel was bijvoorbeeld het vrijgeven van Indie door het opheffen van het cultuurstelsel en het uitgeven wan woeste gronden. Een belangrijke buitenlandse impuls was het einde van de Frans-Duitse oorlog waar Duitsland herenigd en vol industrieel élan uit te voorschijn kwam. De oplevende Duitse economie had een positieve invloed op de Nederlandse..$^{54}$

De liberale economische theorie in deze periode onderscheidde voor het eerst ondernemers en arbeiders naar hun functie in het productieproces. De functie van de moderne ondernemer die kapitaal en arbeid in het productieproces bijeen bracht en die door particulier initiatief, winststreven en concurrentie het welvaartspeil zou vergroten, bracht mee dat in dit proces ook de arbeider in zijn, nuttige en nodige, productieve functie werd erkend. ${ }^{55}$ Hoewel dat in de literatuur niet zo duidelijk naar voren komt, lijkt het mij toe dat hiermee ook in beginsel de rechtvaardiging van eventuele overheidsinterventie was gegeven: alle factoren die dit proces konden verstoren, dienden zoveel mogelijk te worden opgeheven, en als dat blijkbaar niet anders kon, door de overheid. Vooralsnog betekende dit overigens niet dat gesproken kon worden van intensief optreden van die kant, zeker niet ten aanzien van een regulering van de arbeidsomstandigheden. Voor zover er op dat front iets gebeurde, moest dat in eerste instantie komen van de fabrikant die sociaal voelde, al dan niet gemengd met eigen belang.

In de vorige paragraaf is Le Poole al genoemd. In zijn spoor volgen fabrikanten als Stork die in 1874 in zijn dagboek schreef: 'Als wij geld genoeg hebben, moeten wij nog wat meer voor de opvoeding der arbeiders doen. Geen mooier en dankbaarder taak dan deze. ${ }^{56}$

Voor wat betreft de activiteiten van de overheid wil ik aan één, betrekkelijk onbekend, fenomeen in dit verband enige aandacht besteden. Het betreft het zogenaamde 'Geneeskundig Staatstoezicht', dat wellicht als een voorloper van de Arbeidsinspectie beschouwd zou kunnen worden, waardoor de laatste bij de instelling ervan toch niet helemaal zo nieuw zou zijn als wel werd en wordt aangenomen. Het Geneeskundig Staatstoezicht kan voor die tijd beschouwd worden als de enige overheidsinstelling die verondersteld werd de belangen van de arbeidende bevolking in de gaten te houden. ${ }^{57} \mathrm{Al}$ in 1851 had de Gemeentewet van Thorbecke de mogelijkheid gecreëerd dat gemeentebesturen plaatselijke gezondheidscommissies in konden stellen om toezicht te houden op woontoestanden, vervuiling, en andere zaken die de gezondheid in gevaar konden brengen. Het gemeentebestuur zou op die punten geadviseerd kunnen worden. In de praktijk kwam er niets van terecht. Of de commissies werden

$54 \mathrm{Vgl}$. Brugmans, Arbeidende klasse, t.a.p., m.n. p. 218-222 en Henriëtte Roland Holst, t.a.p. p. 146 en 147.

55 van Tijn, t.a.p. p. 157.

56. Geciteerd bij Brugmans, Arbeidende klasse, t.a.p. p. 207.

57 Jacques Giele, Nawerk bij de heruitgave van de arbeidsenquête van 1887, Een kwaad lewen, deel 3, Nijmegen 1981, p. 295. 
niet ingesteld of ze werden tegengewerkt. In 1865 besluit Thorbecke, dan weer - minister van binnenlandse zaken, om deze taken onder toezicht van deskundigen te verenigen in het Geneeskundige Staatstoezicht. De inspecteurs en adjunct-inspecteurs werden door de Kroon benoemd en kregen opsporingsbevoegdheid. Zij werden bijgestaan door een Geneeskundige Raad waarin artsen, apothekers en een jurist zitting hadden. Ook deze raad werd door de Kroon benoemd en voorgezeten door de inspecteur. Deze was adviseur zowel van de lagere overheden als van de minister van Binnenlandse Zaken. Volgens de minister was het toezicht vooral bedoeld ten aanzien van woningen, voeding en (kinder)arbeid. ${ }^{58}$ De inspecteurs ontplooiden in de eerste twintig jaar van hun bestaan vele activiteiten, zonder dat dat overigens van grote invloed was op regelgeving ter beteugeling van de wantoestanden bij de arbeid. Rond 1885 verlegden zij bovendien hun werkterrein van de straten en fabrieken naar het eigen kantoor. Daarmee werd het vooral een administratieve functie. ${ }^{59}$ In een volgende paragraaf wordt nog op dit toezicht teruggekomen.

Hoewel intussen de structurele werkloosheid verdween, het inkomen steeg en er (geringe) 'doorstroom' mogelijkheden kwamen, nam dit alles niet weg dat de algemene toestand van de werknemers niet opzienbarend verbeterde. Door de - eindelijk op gang gekomen - industriële revolutie verdween steeds meer het beeld van de kleine ambachtsman. In de plaats daarvan kwamen de grote ondernemingen met massaproductie waarin grote groepen op arbeidscontract werkzaam waren. ${ }^{60}$ Het geschilderde beeld over de werktijden, de vrouwen- en kinderarbeid en de toestanden in de fabrieken en werkplaatsen kwam nog nadrukkelijker naar voren. Bovendien, de structurele werkloosheid mocht dan niet meer bestaan, arbeiders die om welke reden dan ook niet meer konden werken, liepen grote kans aan hun treurige lot te worden overgelaten. Er ontstond een grote toename van het stedelijk proletariaat. Door deze ontwikkelingen werd de tegenstelling tussen kapitaal en arbeid steeds duidelijker. En dit had weer mede tot gevolg dlat de eerste pogingen werden ondernomen om tot een bundeling van krachten van de arbeiders te komen.

Deze eerste pogingen kwamen overigens niet alleen, of zelfs in de eerste plaats van de arbeiders zelf. $\mathrm{Zij}$ kwamen vooral tot stand onder invloed van jongere fabrikanten, technici, economen en politici van liberale huize bij wie de gedachte voorstond van verheffing van de arbeidende klasse, te bereiken door onderlinge verenigingen tot culturele vorming, door het stichten van coöperaties, onderlinge verzekeringen en betere vakscholing. Een deel van hen was

58. De onmiddellijke aanleiding voor Thorbecke om deze maatregel te nemen was de in de zomer van 1865 dreigende cholera epidemie. Deze dreiging gebruikte hij ook om deze overheidsbimoeienis te rechtvaardigen, Jacques Giele, t.a.p. p. 296.

59 Jacques Giele, t.a.p. p. 297.

60 Volgens Levenbach een ontstaansvoorwaarde voor het arbeidsrecht. "Eerst alls de persoonlijke onderschikking meebrengende arbeid tot massaal verschijnsel wordt, kàn de regeling daar. van tot arbeidsrecht groeien.' M.G. Levenbach, Het nieuwe arbeidsrecht, Arbeidsrecht, een bundel opstellen, Alphen a/d Rijn 1951, p. 14. 
ook well voor een vakbeweging, maar dan één, die zorgde voor onderwijs, arbeidswetgeving en minnelijke schikkingen met werkgevers en zich in ellk geval niet bemoeide met communisme, socialisme of klassestrijd. ${ }^{61}$ In 1861 kwam de eerste zelfstandige arbeidersorganisatie tot stand, een in Amsterdam opgerichte typografenvereniging. Amsterdam lijkt niet toevallig. Met nog een aantal andere handelssteden was er het liberalisme sterk vertegenwoordigd en daarmee het monopolie van conservatieve opvattingen doorbroken ${ }^{62}$ In 1865 ondernam deze vereniging een typische vakbondsactiviteit: een verzoek om loonsverhoging. Overigens was van een echte overkoepelende arbeidersbeweging met een eigen ideologie toen nog geen sprake. Wel groeide het aantal zelfstandige vakverenigingen, vaak nog gestimuleerd door progressief-liberale werkgevers.

$\mathrm{Na}$ het politieke strijdgewoel door de kamerontbinding van 1866 (waaruit in 1868 onze 'echte' parlementaire democratie te voorschijn kwam) braken in 1869 in Amsterdam stakingen uit voor loonsverhoging. De meest radicale leden van de verschillende vakverenigingen richtten onder invloed van deze stakingen daarna met onder meer Belgische steun, een afdeling op van het Internationaal Werklieden-Verbond. De afdeling slaagde er overigens niet in een grote aanhang te krijgen onder de Nederlandse arbeiders - al verschilde dat nog wel per vakvereniging. ${ }^{6}{ }^{3}$ Het was mede ter bespreking van de (communistische) denkbeelden van deze eerste Internationale dat een aantal van de hierboven bedoelde progressief-liberalen in 1870 het 'Comité ter bespreking der sociale quaestie' oprichtte. Dit comité ging mede lleiding geven aan het gematigde - grootste-deel der vakbeweging en in hetzelfde jaar 1870 werd in Rotterdam als tegenhanger van de eerste Internationale het (nationale) Algemeen Nederlandsch Werklieden Verbond (ANWV) opgericht. Progressiefliberalen, gereformeerde activisten en gematigde werknemers te zamen tegen de Internationale. ${ }^{64}$ Voorman was de meubelmaker B.H. Heldt. In het begin vielen er successen te noteren zowel voor de Internationale als voor de ANWV. Maar de conjunctuurcrisis van 1873, het tegenoffensief van de werkgevers (bijvoorbeeld door de uitsluiting van leden van de door de Internationale beheerste sigarenmakersbond), deed de snel gewonnen aanhang weer

61 van Tijn, t.a.p. p. 157. Een ander nieuw verschijnsel in die jaren was het opkomend feminisme. In 1871 werd Aletta Jacobs als eerste meisje toegelaten tot de hogere burgerschool. En in 1870 werd besloten tot de oprichting van een Algemeene Nederlandse Vrowwenvereeniging, onder de spreuk 'Arbeid adelt', met als doel de verbetering van het lot 'der onvermogende vroww uit den beschaafden stand door aanmoediging en bevordering van haar kunsi- en arbeidszin.. "Van Tijn wijst erop dat een werschijnsel als 'arbeid adelt' nog geënt kon worden op het oude standsbesef, een verschijnsel dat ook voorkomt bij de prille arbeidersbeweging. Van Tijn, t.a.p. p. 160.

62 van Tijn, ta.p. p. 161.

63 van Tijn, fia.p. p. 162

64. De gematigdheid van het ANWV werd door de 'echte' revolutionairen als vertat aan de klassenstrijd beschouwd. Henriëtte Roland Holst: 'zijn flauwe en bedeesde politick, zijn afschuw van den klassestrijd, zijn geloof aan de mogelijke samenwerking van patroons en arbeiders en aan de eeuwigheid der kap. produktiewijze pasten geheel in de denkwijze van 'de heren' der Ned. arbeiders, ambachtslieden grotendeels, handwerkers; kleinburgerlijk in merg en nieren.' H. Roland Holst, t.a.p. p. 190. 
even snel ineen schrompelen. Vele nieuwe vakwerenigingen verdwenen, andere sloten zich aan bij het ANWV, dat daardoor in 1874 in schijn werd versterkt. In schijn, omdat het vooral ging om gedemoraliseerde restanten en de gehele arbeidersbeweging zelfstandig nauwelijks nog iets kon ondernemen ${ }^{6.5}$ Dat neemt niet weg dat de invloed van de (georganiseerde) werknemers voor verbetering van hun arbeidsomstandigheden voor het eerst gestalte begon te krijgen. Dit gegeven, gevoegd bij de houding van enkele voormannen van liberale thuize, al dan niet uit de industriële wereld, enkele sympatiserende kamerleden, de nog steeds grote nood onder de werknemers èn een staatsideologie die zich niet per definitie tegen overheidsingrijpen verzette, vormden te zamen een voldoende voedingsbodem voor de eerste arbeidsbeschermende overheidsmaatregelen.

\subsection{Kinderwet van Houten}

Toch lieten deze maatregelen nog enige tijd op zich wachten. Het eerste concrete, wettelijke resultaat is de Wet van 19 september 1874 , 'houdende maatregelen tot het tegengaan van overmatigen arbeid en verwaarloozing van kinderen', stbl. 1874, nr. 130: de Kinderwet Van Houten. Voor het zover kwam was de in de vorige paragraaf beschreven druk op de regering om met maatregelen te komen alleen maar gegroeid. Hierbij speelden het Comité ter bespreking van de sociale quaestie en het ANWV eveneens een rol. ${ }^{66}$ Zonder twijfel begon het sociale, culturele en politieke klimaat rijp te worden voor deze daad van wetgeving. Echter nog niet zó dat er een initiatief van de regering kwam. Het was het liberale kamerlid Van Houten, die na uitdrukkelijk door Thorbecke op deze mogelijkheid gewezen te zijn, op 23 februari 1873 met een initiatiefvoorstel kwam. ${ }^{67}$ Het voorstel kwam op het volgende neer. ${ }^{68}$ Verbod van arbeid door kinderen beneden de twaalf jaar, bevoegdheid van gemeentebesturen om tot invoering van de leerplicht voor kinderen van acht tot twaalf jaar over te gaan, de mogelijkheid van dispensatie voor jongens van 10-12 jaar in fabrieken, mits niet 's nachts, niet langer dan 6 uur per dag, en onder verplichting tot het volgen van onderwijs. De toelichting bij het voorstel was summier, en duidelijk bleek dat Van Houten het schoolverzuim belangrijker acht dan het misbruik van de kinderarbeid. ${ }^{69}$

Zowel in als buiten het parlement komen stromen van kritiek. Sommigen vinden het voorstel te ver gaan, anderen juist weer niet. Uiteindelijk verschijnt er een wet in het Staatsblad die het epitheton 'Van Houten' nauwelijks meer

65 van Tijn, t.a.p. p. 164

66 Voor uitvoerige beschrijwingen zie de geschriften van J.C. Vleggeert: de Kinderarbeid, Amsterdam 1951; Kinderarbeid in Nederland 1500-1874, Assen 1964; Kinderarbeid in de negentiende eeuw, Bussum 1967. Eveneens Brugmans, Arbeidende klasse t.a.p. p. 223-245.

67 Zie noot 46

68 Handelingen TK, 1872-1873, bijlage nr. 113.

69 Over de mogelijke - vaak zeer persoonlijke - motieven bij wan Houten: het interessante artikel wan J. Mannoury, Honderd jaar na de Kinderwet van 1874, SMA, 1974, p. 353-369. 
verdient. De leerplicht werd door de confessionelen weggezuiverd, huishoudelijke en veldarbeid werd van het verbod gevrijwaard onder druk van de agrarische-conservatieve vertegenwoordigers (de effectieve lobby van het groene front is niet nieuw) en er kwam een royale overgangsregeling. Het enige dat overeind bleef, was het verbod voor kinderen beneden de twaalf jaar om te werken - met uitzonderingen. ${ }^{70}$ Artikell 1 behelsde dit algemene verbod, art. 2 de uitzondering voor huis- en landarbeid, art. 3 de regeling van de aansprakelijkheid, art. 4 de strafbepaling en art. 5 de overgangsbepaling op grond waarvan gedurende het eerste jaar de wet gold voor kinderen beneden de tien, het volgende voor kinderen beneden de elf jaar en pas na twee jaar voor kinderen beneden de twaalf jaar.

De wet bleek in de praktijk nauwelijks effectief. Dat had een aantal oorzaken. In de eerste plaats was er niet voorzien, zoals in een aantal andere landen al wèl het geval was, in een afzonderlijke inspectie of controle-orgaan. Kennelijk was dat ook niet de bedoeling van Van Houten. Volgens voorstanders van een Arbeidsinspectie hing dat samen met het feit dat het bij hem vooral ging om de opleiding der kinderen, 'zoodat zorg voor de gezondheid van het kind, dat op te vroegen leeftijd tot fabrieksarbeid gedwongen wordt, bij hem slechts op tweede plaats in aanmerking komt' ${ }^{71}$ Het gevolg hiervan was dat de opsporing van overtredingen werd overgelaten aan de 'gewone' politie, die, onder lokaal bevel, al heel weinig voelde voor vervolging van fabrikanten, tot wie de sociale afstand bovendien groot was. Daar kwam nog bij dat de tekst van de wet onzorgvuldige uitdrukkingen bevatte die de animo om te vervolgen niet vergrootte en tot rechtsongelijkheid leidde. Artikel 1 sprak over het verbod om kinderen 'in dienst te hebben' of 'in dienst te nemen'. Over de betekenis hiervan was de jurisprudentie niet eenduidig. In sommige vonnissen werd verwezen naar de juridische kwahificaties uit het BW op grond waarvan een overeenkomst met betrekking tot een kind alleen door de vader van dat kind gesloten kon worden waardoor, bij ontbreken van een dergelijke overeenkomst, niet gesproken kon worden van 'in dienst nemen' of 'hebben' en dus ontslag van rechtsvervolging volgde. In andere werd aangenomen dat, in overeenstemming met de sociale motivatie van de wet 'in dienst nemen en hebben' een feitelijke toestand aanduidt die ontstaat zodra het kind te werk is gesteld en presteert. ${ }^{72}$ Het resultaat was in elk geval dat in het ressort van de rechtbank waar de enge interpretatie werd aangehangen talloze jonge kinderen de school weer verlieten om te gaan werken. ${ }^{73}$

Vervolgens was er de uitzondering van huis- en landarbeid, zodat er voldoen-

70 Voor de parlementaire behandeling, Molenaar, Arbeidsrecht, deel I, t.a.p. p. 260-271.

71 Handelingen TK $1873-1874$, nr. 34 , stuk 1 , p. 3 .

72 Voor een overzicht van de betreffende jurisprudentie: A. Postma, De mislukte pogingen tussen 1874 en 1889 tot verbetering van uitbreiding van de Kinderwet van Houten, Deventer 1977, p. $87-88$.

Vgl. ook over deze terminologie T. Koopmans. De begrippen werkman , arbeider en werknemer, Alphen a/d Rijn 1962, p. 13 en 14.

73 Postma, t.a.p. p. 89. 
de mogelijkheden waren om kinderen tòch te laten werken. ${ }^{74}$ Tot slot werd het verbod niet gekoppeld aan de leerplicht.

Zowel over het bereiken van de doelstelling van de wet als over de betekenis ervan lijkt grote overeenstemming te bestaan. De doelstelling zoals die bleek uit de considerans 'overmatigen arbeid en verwaarloozing van kinderen tegen te gaan', werd stellig niet bereikt. Veeleer moet de betekenis hierin gevonden worden dat voor het eerst wettelijk ingegrepen werd in de tot dan vrije verhouding tussen werkgever en werknemers. ${ }^{75}$ Zo groot als de overeenstemming in het oordeel is over de effectiviteit en de èchte betekenis van de wet, zo gering lijkt die overigens te zijn over de motieven van degenen die tot het uiteindelijke resultaat hebben bijgedragen. Ik kom hier in paragraaf 5 op terug. In elk geval kan geconstateerd worden (maar dat werd ook toen al gedaan) dat de Kinderwet Van Houten voor de humanisering van de arbeid niet van grote betekenis is geweest, ook niet voor die van kinderen. Het lijkt er in een aantal gevallen zelfs op dat door de gebrekkige formulering van wat er wèl staat en door het ontbreken van bijvoorbeeld een regeling over een speciale inspectie, de wet zowel een alibi-functie vervulde en tegelijkertijd (en mede daardoor) de mogelijkheid bood om nog méér dan voorheen kinderen te laten werken. Bovendien trad nog als ongewenst effect op de idee dat vanaf het twaalfde jaar gewerkt mòest worden.

\subsection{Na de Kinderwet 1874}

De volstrekt ontoereikende effectiviteit van de wet zorgde ervoor dat de discussies, de onderzoeken en artikelen doorgingen. Ook het departement van Justitie begon al direct na de publicatie in het Staatsblad zowel met onderzoek naar de naleving van de wet als met het opstellen van een uitgebreider ontwerp.

In 1880 bracht een commissie bestaande uit de Vereeniging tot Bevordering van Fabrieks- en Handwerknijverheid, de Maatschappij ter Bevordering van Nijverheid, de Maatschappij tot nut van het algemeen en het ANWV een rapport uit met als conclusie dat de wet gebrekkig en verbetering dringend noodzakelijk was. 'Men kan ternauwernood een beschaafd land noemen, waar de wetgeving op den kinderarbeicl zoo gebrekkig, zoo verregaand onvolledig is, als in Nederland; geen waar dit hoogst gewichtige onderwerp ten allen tijde met zooveel onverschilligheid van regeeringswege is behandeld. ${ }^{76} \mathrm{De}$ regering bleef niet doof voor deze stemmen. ${ }^{77}$ In 1882 kwam minister Modder-

74 Ook het begrip 'huiselijke en persoonlijke diensten' in artikel 2 was niet duidelijk. Maar de gevolgen van deze onduidelijkheden leken minder groot dan die in artikel 1. Zie Postma, t.a.p. p. 90.

75 Of zoals Valkhoff het in het kader van zijn theorie van steeds verdergaande vermaatschappelijking uitdrukte: 'Dit is een eerste reactie tegen het individualisme', Valkhoff, t.a.p. p. 83.

76 Geciteerd bij Vleggeert, Kinderarbeid in de negentiende eeuw, t.a.p. p. 94.

77 Voor een overzicht van de activiteiten van regeringswege: Postma, t.a.p. p. 19-45. 
man met een wetsontwerp dat alle vormen van arbeid door kinderen beneden de twaalf jaar verbood en waarbij bovendien inspecteurs van den kinderarbeid' werden atngesteld. Het kwam niet tot een openbare behandeling. Al uit het Voorlopig Verslag bleek dat geen meerderheid te vinden zou zijn. Moddermans opvolger, Du Tour van Bellinchave, trok het ontwerp in en diende in 1885 een afgezwakte versie in waarbij met name het ontbreken van een aparte inspectie opviel. Toch was ook dit ontwerp uiteindelijk hetzelfde lot beschoren als zijn voorganger. ${ }^{78}$

De tegenstanders van verdergaande wetgeving kregen bovendien steun uit (onverwachte?) hoek: de christelijke arbeidersbeweging. In 1876 werd het nieuwe Nederlandsche Werklieden-Verbond, genaamd Patrimonium opgericht. Het verbond was uitgesproken conservatief en onder meer tegen alle sociale wetgeving zoals de Kinderwet Van Houten. De Staat nam immers een taak over die door God op de schouders van de ouders was gelegd. ${ }^{79}$ Een bondige samenvatting van de standpunten in die dagen van (uitbreiding van) de kinderwetgeving geeft J. Craandijk in zijn Wandelingen door Nederland in 1885: 'Ook voor vele ouders was de maatregel schadelijk, die hen van de verdiensten hunner kinderen beroofde. Maar van den anderen kant is het betreurenswaardig, als jonge kinderen geheel aan onderwijs en opvoeding worden onttrokken en de ondervinding heeft geleerd, wat er uit een zedelijk en maatschappelijk oogpunt wordt van de jeugd, aldus in den dampkring der fabrieken opgegroeid. Wat anders is te verwachten, dan een bedorven en ontzenuwd geslacht, voor niets anders dan tot den meest werktuigelijken handenarbeid geschikt! Op den duur zal de wet gunstig moeten werken, de fabrieken zullen moeten zien, hoe zij de tijdelijke bezwaren te boven komen; de ouders zullen het moeten leeren, dat zij hun kinderen niet hebben ontvangen, om ze eenvoudig als werkmachines te gebruiken; de menschenvriend zal de middelen moeten zoeken, waardoor de maatregel werkelijk ten zegen der kinderen gedijen kan. ${ }^{\text {so }}$

Het tot stand komen van Patrimonium was illustratief voor een herleving van de georganiseerde arbeidersbeweging op het einde van de jaren zeventig van de vorige eeuw - ook al was Patrimonium vooral een reactie op en gericht tegen het ANWV. Omstreeks die tijd ook trachtten oud-Internationalisten het ANWV in een meer socialistische koers te drijven. Toen dit niet lukte, besloot een aantal van hen in 1878 zelfstandig verder te gaan onder de naam SociaalDemocratische Vereeniging (SDV). Een jaar later sloot de predikant Domela Nieuwenhuis zich bij hen aan waarbij hij zijn weekblad 'Recht voor Allen' ten dienste stelde van de sociaal-democratie. Nadat in verschillende steden plaatselijke SDV's waren opgericht, werd in 1882 een congres belegd waarna de

78. Een uitwoerige beschouwing over de lotgevallen van deze ontwerpen: Postma, t.a.p. p. 46-81.

79 Th. van Tijn, De sociale bewegingen van $1876-1887$. Het sociale leven in Nederland, Algemene Geschiedenis der Nederlanden, Haarlem 1978, deel 13, p. 93.

80 Geciteerd bij Vleggeert, t.a.p. p. 96. 
plaatselijke afdelingen zich beschouwden als afdelingen van de Sociaal Democratische Bond. 81

In het begin van de jaren tachtig van de vorige eeuw waren dus drie richtingen in de arbeidersbeweging te onderscheiden: de socialistische, de algemene of neutrale en de confessionele arbeidersbeweging, respectievelijk vertegenwoordigd door de SDB, het ANWV en Patrimonium. Totaal bedroeg het aantal georganiseerde arbeiders rond 1885 overigens nog maar tien procent. De toen heersende economische crisis en de daarmee gepaard gaande grote werkloosheid deed echter met name de SDB relatief sterk groeien. ${ }^{82}$ De toestand was omstreeks 1885 zeer gespannen door de grote, vooral door de SDB georganiseerde, werklozenmeetings, demonstraties en stakingen. Daar kwam dan nog bij de veroordeling van Domela Nieuwenhuis tot een jaar gevangenisstraf wegens majesteitsschennis. In de zomer van 1886 brak als climax in de gespannen situatie in Amsterdam het palingoproer uit, waarvoor de aanleiding het verbod op het palingtrekken was, maar de oorzaak de economische malaise. Ongetwijfeld was het streven om de arbeidersbeweging de wind uit de zeilen te nemen een belangrijk motief om te komen tot het treffen van arbeidsbeschermende maatregelen eind vorige eeuw. Het zal dan ook geen toeval zijn geweest dat het voorstel tot het houden van een parlementaire enquête naar de naleving van de Kinderwet Van Houten en naar de wenselijkheid van uitbreiding van de arbeidsbeschermende wetgeving werd gedaan binnen drie weken na het palingoproer ${ }^{83}$ Op 12 augustus 1886 diende een aantal kamerleden, onder wie $H$. Goeman Borgesius wiens initiatief het was, het voorstel in om een enquête te houden naar de werking van de Kinderwet Van Houten en naar de toestanden in fabrieken en werkplaatsen in het algemeen. ${ }^{84}$ Het ging dus niet meer alleen om kinderarbeid, maar - voor het eerst - ook om de veiligheid, de gezondheid en het welzijn van de werknemers. ${ }^{85}$ Op 13 oktober van hetzelfde jaar werd het voorstel na een spoedbehandeling aanvaard door de

81 van Tijn, t.a.p. p. 96.

82 Het ledental, eind 1883 geschat op circa 700 , steeg tot circa 4000 aan het eind van 1886 , wan Tijin, t.a.p. p. 99.

83 J. Sevenhuijsen, Historie van de Nederlandse arbeidsbeschermende wetgeving, Universitair onderwijs en onderzoek in veiligheid, Delft 1978, p. 248 . Zie ook: E. Tinga, De geschiedenis wan de Arbeidswet $(1874-1919)$, SMA, 1969, p. 623.

84 Binnen de SDB werd zeer verdeeld gereageerd op het voorstel om een enquête te houden. Met name in 'Recht woor Allen' werd de enquête fel aangevallen. Het dilemma werd verwoord door het verslag van een ledenvergadering wan de SDB afdeling Haarlem: "Enkelen der aan. wezigen meenden dat het toch geen kwaad kon op de gestelde vragen te antwoorclen, alleen masr opdat de werklieden later niet verweten zou kumnen worden, dat zijzelf niet mee hadden willen werken om eene wet op de arbeid tot stand te brengen. Anderen daarentegen meenden dat met zakkenrollers nooit moet onderhandeld worden over middelen tegen zakkenrollerij." Greciteerd bij Giele, De sociaal-democratische bond en de enquête, t.a.p. p. 323.

85 Letterlijk luidde de opdracht:

1. Welke is de werking van de wet van 1874? In hoeverre geven de bestaande toestanden aanleiding tot een aanvulling en uitbreiding van deze wet in overweging te nemen?

2. Welke is de toestand waarin fabrieken en werkplaatsen hier te lande zich bevinden met het oog op de veiligheid, de gezondheid en het welzijn der werklieden? Welke natregelen zouden die toestand kunnen verbeteren?

Geciteerd bij Giele, De parlementaire enquêtecommissie, t.a.p. p. 300. 
Tweede Kamer. In zijn verdediging trachtte Goeman Borgesius het principiele uitgangspunt voor overheidsbemoeienis nog eens duidelijk te maken: 'Zoodra de zelfzucht in de regeling der dienstverhouding alles overheersend wordt en aanleiding geeft tot misbruiken en toestanden, die de harmonische samenleving verstoren en een maatschappelijk gevaar opleveren, kan de tusschenkomst van den Staat tot bescherming der zwakken niet worden gemist. ${ }^{36}$ Met andere woorden: maakten de ondernemers misbruik van het vrije spel der maatschappelijke krachten dan moesten de werknemers deswege wettelijk beschermd worden.

De werkwijze van de commissie is door haarzelf uitvoerig beschreven. ${ }^{87} \mathrm{De}$ buitengewoon zorgvuldige en onpartijdige gang van zaken tijdens het onderzoek, (er werden 146 getuigen gehoord van wie 53 arbeiders), met name van de kant van de voorzitter, H.C. Verniers van der Loeff, overtuigde zelfs de grootste sceptici. ${ }^{88}$ In juli 1887 kwam de commissie met haar eerste verslag. Hoewel het voorgenomen onderzoek nog lang niet was afgerond, was dit in verband met de Kamerontbinding (nodig door de Grondwetsherziening in dat jaar) tevens haar laatste. Maar het rapport bevatte al genoeg materiaal om een zeer diepe indruk te maken - vooral op diegenen, en dat waren bijvoorbeeld niet de lezers van 'Recht voor Allen', die meenden dat het wel niet zo'n vaart liep. Een dergelijk beeld kon inderdaad verkregen zijn, bijvoorbeeld door het eerder genoemde Geneeskundig Staatstoezicht dat over een suikerraffinaderij in Amsterdam in het jaarverslag over 1887 welhaast arcadische kwalificaties gebruikte om de toestand aldaar te schilderen: luchtig, zindelijk, beschermd, geen nadeel voor de gezondheid. ${ }^{89}$ Het rapport van de enquêtecommissie zag het anders. Over de suikerraffinaderijen werd geschreven dat het er zo heet en benauwd was dat arbeiders wel eens in paniek raakten: 'Soms slaat daar een werkman een ruit stuk, om toch maar wat versche lucht te krijgen. ${ }^{90}$ In het algemeen kwam uit het rapport naar voren dat aan de Kinderwet onvoldoende de hand werd gehouden en dat de arbeidstijden, de werkomstandigheden en de arbeidsvoorwaarden miserabel waren. Het is verleidelijk om ter illustratie hiervan uitvoerig te citeren uit het rapport. Laat ik volstaan met één citaat waaruit blijkt welke weerstand tegen overheidsinterventie nog vaak overwonnen moest worden, ook bij de arbeiders, en hoe relatief de betekenis van het recht in dat licht is. Het gaat om het onderhoud met de voorzitter van de afdeling Amsterdam van de ijzer-en metaalbewerkersbond. Nadat hij gezegd had dat sommige ouders de Kinderwet misdadig vonden omdat zij het geld dat hun kinderen verdienden zo goed konden gebruiken, gaat het gesprek als volgt verder: 'Vraag: Dat zijn toch slechte en onverstandige ouders, die voor geld een kind van acht jaar zouden vernielen?

86 Geciteerd bij Giele, De parlementaire enquêtecommissie van 1887, t.a.p. p. 299.

87 Een kwaad leven, Heruitgave van de Arbeidsenquête van 1887, deel 3, eindverslag, Nijmegen 1981, p. 3 - p. 14.

88 Zie noot 84.

89 Giele, Geneeskundig Staatstoezicht, t.a.p. p. 298.

90 De Arbeidsenquête van 1887, deel 1, t.a.p. p. 17. 
Antwoord: Ja, zooals wij hier zitten hebt $U$ volkomen gelijk, maar men moet rekening houden met den honger der menschen. Die doet alles vergeten: menschelijkheid en recht. ${ }^{\text {II }}$

In haar conclusies komt de commissie tot een aantal vèrstrekkende aanbevelingen. Naast een handhaving van het verbod tot kinderarbeid beneden de twaalf jaar wordt gepleit voor een verbod op nachtarbeid voor jongeren onder de achttien jaar, voor beperking van bepaalde typen gevaarlijke arbeid voor jongeren beneden de zestien jaar, voor vier weken verlof na een bevalling, voor wetgeving op het gebied van de veiligheid en gezondheid, voor een voortgezet onderzoek door een Staatscommissie (die meer bevoegdheden zou hebben dan een parlementaire commissie), voor de instelling van een controlerende fabrieksinspectie en voor het creëren van voorzieningen in het belang van de arbeider en zijn gezin bij ongeval, ziekte, ouderdom of overlijden. ${ }^{92} \mathrm{Het}$ zijn evenzoveel voorstellen die in de loop van de tijd gerealiseerd zouden worden. Ongetwijfeld is de enquête en het daarop gebaseerde verslag van 1887 een mijlpaal in de sociale geschiedenis van Nederland, en een uitermate belangrijke bron voor onze kennis over de arbeidsomstandigheden van de arbeiders in de vorige eeuw.

\subsection{De Arbeidswet 1889}

De resultaten van de enquête, gevoegd bij de indruk die de stoeten demonstrerende werklozen gedurende de voorafgaande winters haddlen gemaakt, de angst voor de revolutie (die in het buitenland reëler bleek) zorgden voor een klimaat, waarin aan de noodzaak van overheidsingrijpen in de arbeidsverhoudingen nauwelijks meer werd getwijfeld. ${ }^{93}$ Dit gold ook voor regering en parlement. De hoofdredacteur van het Weekblad van het Recht schreef in 1888 over 'eene wezenlijke verandering in de richting der werkzaamheden van het departement van justitie... De nadruk valt bij dezen minister niet op het burgerlijk-, handels- en procesrecht... maar op de sociale wetgeving in het algemeen, de wetgeving op de regeling van de arbeid in het bijzonder'. De hoofdredacteur constateert dit slechts en wil er verder geen oordeel over geven, immers het Weekblad 'doet niet aan volkshuishoudkunde en gezondheidsleer ${ }^{5} .{ }^{94}$

Deze minister was Ruys van Beerenbroek, voorheen lid van de enquêtecommissie, die in 1888 het ontwerp indiende voor de Arbeidswet 1889. In tegenstelling tot de Kinderwet van Houten ontmoette het ontwerp betrekkelijk weinig weerstand. Het werd in de Kamer aangenomen met slechts de stem van Domela Nieuwenhuis - de enige socialistische afgevaardigde - tegen. Hij vond het ontwerp niet ver genoeg gaan en pleitte onder meer voor een achturi-

91 De Arbeidsenquête van 1887, deel 1, t.a.p. p. 117 .

92 De Arbeidsenquete van 1887 , deel 3, eindwerslag, t,a.p. p. 89 en 90.

93 van Tijn, De sociale bewegingen wan 1876-1887, t.a.p. p. 99.

94 Weekblad van het Recht, 1888 , nr. 5645. 
ge werkdag, ook voor volwassen mannen. Het ontwerp voorzag hij van de bekende karakteristiek: 'een buiteling der kapitalisten ten gevolge van een schop, hun door de socialisten toegediend. ${ }^{25}$ Ter gelegenheid van de parlementaire behandeling werd gelijktijdig een meeting door de SDB georganiseerd waarbij de afwijzing door Domela Nieuwenhuis ook buiten het parlement verwoord werd. ${ }^{\% 6}$

In de wet kwam opnieuw het verbod op arbeid door kinderen beneden twaalf jaar te staan behalve woor de gehele agrarische sector waardoor deze uitzondering verder ging dan de uitzondering van de Kinderwet (art. 3). Voorts bevatte de wet een beperking van de arbeidsduur tot maximaal 11 u ur voor vrouwen en personen beneden dle 16 jaar (art. 5). Voor hen gold ook, behoudens mogelijkheden van ontheffing, een verbod voor zondagsarbeid (art. 7). De wet opende de mogelijkheid dat bij AMvB werd verboden dat vrouwen en jeugdige personen bepaalde soorten arbeid zouden verrichten met het oog op de gevaren voor gezondheid of leven (art. 4). Het werd verboden om vrouwen arbeid te doen verrichten binnen vier weken na haar bevalling (art. 8).

Het ontwerp van Ruys van Beerenbroek voorzag niet in de instelling van een arbeidsinspectie. Dit wekte temeer bevreemding, omdat hij immers lid was van de parlementaire enquêtecommissie die hierop had aangedrongen. Onder sterke druk van de Kamer kwam de minister uiteindelijk aan deze wens (die al in 1860 door De Vries Robbé was geuit!) tegemoet. Volgens art. 12 werd het toezicht op de naleving van de wet opgedragen aan afzonderlijke functionarissen wier werkkring en bevoegdheden bij $\mathrm{AMvB}$ zouden worden vastgesteld. Dat de aanvankelijke huiver voor een dergelijk instituut nog niet geheel overwonnen was, blijkt uit de aanneming van een amendement waarin werd bepaald dat de wet zelf het aantal inspecteurs moest noemen. Het werden er ten hoogste drie. Bij AMvB werd het rijk verdeeld in drie inspecties. ${ }^{97}$ De inspecteurs kregen een drieledige taak, nog steeds de basis voor het huidige takenpakket. In de eerste plaats dienden zij zich op de hoogte te stellen van de toestand van de fabrieken en werkplatatsen en verbeteringen aan te wijzen met het oog op de veiligheid en de gezondheid van de werknemers. In de tweede plaats dienden zij de regering woor te lichten over de bestaande toestanden en haar van advies te dienen inzake de toepassing van de geldende voorschriften en de mogelijke verbetering van de wetgeving. In de derde plaats moesten zij toezien op de naleving van de bestaande wettelijke bepalingen. De Arbeidswet 1889 zelf bepaalde tenslotte in art. 16 dat de inspecteurs jaarlijks een verslag moesten uitbrengen aan de minister, welke verslagen geheel of gedeeltelijk aan de Staten-Generaal zouden worden overlegd. Op 1 maart 1890 startten de drie eerste ambtenaren van de Arbeidsinspectie hun werk, nadat de Arbeidswet op 1 januari 1890 gedeeltelijk in werking was getreden. Met ingang van die datum verviel de Kinderwet Van Houten.

95 Handelingen TK $1888-1889$, p. 843.

96 Voor een overzicht van de parlementaire behandeling: A.N. Molenaar, Arbeidsrecht, deel 1 , t.a.p. p. $279-285$.

$97 \mathrm{~KB}$ van 21 februari 1890, S. 27. 
Dat de effectiviteit van de Arbeidswet groter was dan die van de Kinderwet was zonder twijfel voor een groot deel te danken aan de drie inspecteurs van de arbeid. Dit betekent overigens niet dat hun taak een gemakkelijke was. Met name uit de eerste jaarverslagen bleek grote tegenstand niet alleen van werkgevers, maar ook van werknemers. ${ }^{98}$ Bovendien was de medewerking van de gemeentepolitie niet groot, overigens in tegenstelling tot die van de rijksveldwacht en de koninkliike marechaussee. ${ }^{99}$ Het aantal ontduikingen van de wet verschilde sterk per bedrijfstak: het grootst was deze in de diamantindustrie en de was- en strijkinrichtingen. ${ }^{100}$

Nadat het eerste Arbeidsbesluit op grond van art. 4 van de nieuwe wet betreffende bepalingen omtrent de gezondheid en de hygiëne op de werkplaatsen en in de fabrieken in 1891 tot stand was gekomen, werd het werkterrein van de inspecteurs sterk uitgebreid. ${ }^{101}$

Na enkele jaren lijken zowel werkgevers als werknemers enigszins te "wennen" aan de wet en het daarop gebaseerde optreden van de Arbeidsinspectie. Volgens de inspecteurs begonnen met name de werknemers steeds meer medewerking te verlenen. ${ }^{102}$ Van ontslag aan vrouwen en jeugdige personen door de bepalingen van de Arbeidswet was maar in enkele gevallen sprake. Het effect van de wet was zelfs dat in sommige bedrijven waar veel vrouwen en jeugdigen werkten, de voorgeschreven rusttijd ook voor volwassen mannen ging gelden. ${ }^{103}$

Daarnaast werd ook veel kritiek op de wet en op de handhaving ervan vernomen. In een drietal artikelen in het Sociaal Weekblad van 1898 schrijft H.S. (blijkens zijn artikelen arbeider/letterzetter te Rotterdam) dat zowel de inhoud van 'dat akelige wetje, 't welk men gemeend heeft te moeten betitelen met den naam Arbeidswet', als de controle en inspectie niet deugen. ${ }^{104} \mathrm{Hij}$ merkt op dat de arbeiders wel weten dat de wet bestaat, maar dat zij haar niet serieus nemen en haar alleen zien als een middel, 'om Nederland's fatsoen op

98 Hierover: Een greep uit het vele, 50 jaar Arbeidsinspectie, Den Haag p. 15 .

Voorts vooral over de houding van de werkgever: A.J.C. Snijders, De veiligheid van den werkman bij den arbeid, Vragen des tijds, 1894, vooral p. 178-181.

I.J.M. wan der Ven, Rechtssociologische aantekeningen bij de Arbeidswet 1919, SMA, 1958, p. 290-304, en het verslag van de discussie hierover (oorspronkelijk bestemd voor een bijeenkomst van de Vereniging voor arbeidsrecht) in SMA, 1958, p. 626-634, watrin er onder meer terecht op werd gewezen dat, ondanks de titel, van der Ven's gegevens wooral ontleend waren aan de periode van wón de Arbeidswet 1919. Zie ook de repliek van van der Ven in SMA. 1959, p. 125-128.

99 H.A. Usselsteyn, Vijfentwintig jaren Arbeidsinspectie, 1890-1915 (overdruk uit het central verslag der Arbeidsinspectie over 1915), Den Haag, p. XVII.

100 Jaarverslagen ower 1890 en 1891 , Den Haag, resp. p. 258 en p. 276.

$101 \mathrm{~KB}$ van 15 juli 1891, S. 147.

Gezien de inhoud van de bepalingen is dit besluit eerder te beschouwen als een Veiligheidsbesluit ter bescherming van vrouwen en jeugdige personen dan als een Arbeidsbesluit. Het geeft ook de nauwe band aan die, zeker in die tijd, bestond tussen de Arbeidswet en de komende - Veiligheidswet. Vgl. ook A.N. Molenaar, Arbeidsrecht I, t.a.p. p. 292.

102 Jaarverslag over 1894 , t.a.p. p. 275.

103 Th. van Tijn, Het sociale leven in Nederland, tat.p. p. 89.

104 H.S. Over kindlerarbeid en Arbeidswet, Social Weekblad, 1898 , p. 256 en 257; p. 264 en $265 ;$ p. 272-274. 
te houden tegenover de andere naties, omdat de regering, en over het algemeen de handhavers der wetten juist bij deze wet, waarvan immers zoo luid werd uitgeroepen dat ze was ten gerieve en tot heil van den werkman, maar àl te gaarne en met àl te groot gemak een oogje toeknijpen, eene overtreding voorbijgaan'. ${ }^{105} \mathrm{Hij}$ is van oordeel dat de belangen van de industrie bij de wetgever zwaarder hebben gewogen dan die van het tegengaan van kinderexploitatie (over de bescherming van vrouwen in de Arbeidswet spreekt hij zich niet uit). Nadat hij de handhaving door de rijks- en gemeentepolitie, de marechaussee en de Arbeidsinspectie aan de hand van voorbeelden als onvoldoende heeft geschetst, pleit hij, zoals in die tijd meer gebeurde, voor het inschakelen van de arbeiders zelf bij de inspectie. 'Langzamerhand moet toch de moderne wetgever zich met de idee vertrouwd maken, dat de wetten op den arbeid geen beter opzichters en uitvoerders vinden dan de belanghebbenden, dat zijn de arbeiders. ${ }^{106}$

Naar aanleiding van deze artikelen komt er een ingezonden brief waarin gepleit wordt voor het aanstellen van arbeiders als onbezoldigd rijksveldwachters ten aanzien van de Arbeidswetgeving. De redactie van het Sociaal Weekblad relativeert vervolgens de betekenis van een dergelijk instituut. ${ }^{107}$ Het denkbeeld om arbeiders in te schakelen bij de handhaving van, en controle op de Arbeidswet was overigens al eerder geopperd door A. Kerkdijk eveneens in het Sociaal Weekblad. ${ }^{108}$ (Zie hierover verder paragraaf 3.5.).

Tot slot kan nog gewezen worden op het door de SDAP en het NVV gehouden onderzoek in 1908 'Arbeidersleven in Nederland' waaruit bleek dat, met name in bepaalde bedrijfstakken, de Arbeidswet nog steeds veelvuldig werd overtreden. (zie hierover verder paragraaf 3.5.).

\subsection{De Veiligheidswet 1895}

Vrij snel na de Arbeidswet $1889 \mathrm{kwam}$ de regering tot nieuwe wetgevende activiteiten. In 1893 diende minister Lely een ontwerp voor een Veiligheidswet in. ${ }^{109}$ Een aantal stimulansen voor dit initiatief kan genoemd worden. In de eerste plaats waren dat nog steeds de resultaten en aanbevelingen van de parlementaire enquêtecommissie van 1887 . In de tweede plaats waren dat de nieuwe gegevens die de in 1890 ingestelde Staatscommissie, onder voorzitterschap van W.F. Rochussen opleverde, en die als taak had verzameling van

105 H.S. t.a.p. p. 257.

106 H.S. t.a.p. p. 274.

107 Ingezonden brief van C.J.D., Overtreding der Arbeidswet en reactie van de redactie, Sociaal Weekblad, 1898 , p. 299 .

108 A. Kerdijk, Noodige medewerking, Sociaal Weekblad 1896, p. 241 en p. 242 en (vervolg) p. 249-250. Zic ook de daaropvolgende discussie in hetzelfde jaar in het Sociaal Weekblad, p. 277,278 en 279 .

109 In 1892 werd bij KB wan 29 november 1892, (S. 257), de bemoeienis met de arbeidsbeschermende wetgeving gelegd bij het ministerie van Waterstaat, Handel en Nijverheid, dat in 1893 de afzonderlijke afdeling "Arbeid en fabriekswezen" instelde. 
gegevens voor de kennis van de maatschappelijke toestanden der arbeiders, zulks ter aanvulling van de arbeid van de parlementaire enquêtecommissie, van de verhouding tussen werkgevers en arbeiders in de verschillende bedrijven en van de toestand van fabrieken en werkplaatsen met het oog op de veiligheid en de gezondheid der arbeiders. ${ }^{110}$ In 1894 kwam de commissie met haar rapport waarin onder meer werd aanbevolen om de werktijden van het spoorwegpersoneel te regelen, om te overwegen om maatregelen te nemen inzake werktijden èn de veiligheid en gezondheid van bepaalde categorieën werknemers (bakkers, havenarbeiders) en om werkgevers te verplichten hun werknemers te verzekeren tegen de financiële gevolgen van een bedrijfsongeval. Er werd dus ook, en voor het eerst door een 'officiële instantie' gepleit voor de bescherming van (sommige) volwassen mannen. Een derde stimulans voor de totstandkoming van de eerste Veiligheidswet vormde ongetwijfeld de verslagen van de Arbeidsinspectie. De ambtenaren van deze dienst troffen bij hun bezoeken aan de fabrieken en werkplaatsen nog steeds verschrikkelijke misstanden aan, waarbij duidelijk bleek dat, vaak in tegenstelling tot het naleven van de werk- en rusttijden voor vrouwen en jeugdigen en het verbod van kinderarbeid, veel werkgevers onwil vertoonden ook maar iets meer te doen. ${ }^{111}$ 'Waar dan ook het meerendeel onzer werkgevers zeker nooit uit eigen beweging tot het invoeren van veiligheidsmaatregelen zal overgaan, verdient het waardering, dat de thans afgetreden regeering het initiatief tot regeling dezer zaak heeft genomen. ${ }^{112}$ In de vierde plaats kan gewezen worden op de aandrang van minder gouvernementele instanties en personen zoals de vakbeweging, onafhankelijke auteurs en de invloed van bijvoorbeeld de in 1890 in Amsterdam gehouden 'Eerste Nederlandsche Tentoonstelling tot bevordering van veiligheid en gezondheid in fabrieken en werkplaatsen'. Aansluitend vond een congres plaats met werkgevers, werknemers, kamerleden, technici en juristen. Het congres, ingeleid door de minister van Justitie Ruys van Beerenbroek, gaf een gedetailleerd beeld van de veranderde opvattingen over staatsbemoeienis, oorzaken van ongevallen en voorgestelde maatregelen. "13 In datzelfde jaar werd opgericht de 'Vereeniging tot Voorkoming van Ongelukken in Fabrieken en Werkplaatsen' met als doel 'de gezondheid en de veiligheid van werklieden bij het verrichten van arbeid in of voor eenig bedrijf bevorderen'. Aan de Vereeniging werd deelgenomen zowel door werkgevers als door werknemers. ${ }^{114}$

110 Wet van 19 januari 1890 , (S.1), waarbij de Kroon werd gemachtigd een dergelijke staatscommissie in te stellen. Dit gebeurde bij KB van 18 april 1890 , nr. 51 en opnieuw bij $\mathrm{KB}$ van 21 september 1892 , nr. 50 (op 1 januari 1892 liep het door de wet verleende mandaat af). Over de parlementaire behandeling van de instelling van de staatscommissie, Molenaar, Arbeidsrecht I, t.a.p. p. $287-291$.

111 N.C. Winkel, De taak van de Arbeidsinspectie, t.a.p. p. 16; zie ook noot 98.

112 A.J.C. Snijders, De veiligheid van den werkman bij den arbeid, t.a.p. p. 181.

113 Uitvoerig over tentoonstelling en congres en de betekenis ervan: John Stoop, Geschiedenis van veiligheid en gezondheid in arbeidsomstandigheden in Nederland Delft, 1982, p. 39-44.

114 Hierover: W. de Vries Wzn., De totstandkoming van de Ongewallenwet 1901, Dewenter 1970, p. 25-28. Niet alle industrielen dachten nu echter positief ower (wettelijke) matregelen ter woorkoming van bedrijfsongevallen. Uit het verslag van een vergadering van de Vereeni- 
Ondanks bovengenoemde stimulansen verliep de parlementaire behandeling van het, in 1894 opnieuw door Lely's ambtsopvolger Van der Sleyden ingediende wetsontwerp, niet zonder haken en ogen. ${ }^{115}$

Het belangrijkste principiële punt van discussie vormde de in het ontwerp opgenomen bepalingen ter bescherming van alle werknemers, dus inclusief de volwassen mannelijke, tegen gevaren die hun veiligheid en gezondheid bedreigden. Weliswaar was geaccepteerd dat de overheid zich bemoeide met de arbeid van de personae miserabiles (kinderen en vrouwen), maar dat betekende niet dat de zorg van de overheid zich óók zou moeten uitstrekken tot de arbeid van de volwassen mannen. Volgens Molenaar is de regering in zoverre met deze gedachte meegegaan dat gekozen is voor een aparte Veiligheidswet en niet voor incorporatie van de betreffende bepalingen in de bestaande Arbeidswet. Zou dat laatste wèl gebeuren, dan was men bevreesd dat daarin een begin zou kunnen worden gezien van overheidsbemoeienis ook met de arbeidsduur van volwassen mannen. ${ }^{116}$ Deze achtergrond blijkt echter niet uit de wetsgeschiedenis. ${ }^{117}$ Een illustratief citaat uit het Voorlopig Verslag geeft zowel de bedenkingen aan ten aanzien van de interventiemogelijkheden van ambtenaren (die onder meer tot uitdrukking kwamen via een verregaande delegatiemogelijkheid) als het oordeel over de houding van de werknemers. ${ }^{\text {118 }}$ 'Er waren leden, die zich tegen de geheele strekking verklaarden. Huns inziens is thet een uiting van ziekelijke philanthropie de volwassen arbeiders te willen behoeden voor de gevaren, die hun arbeid noodzakelijk met zich brengt. Het particuliere initiatief moge in dit opzicht trachten verbeteringen aan te brengen, de wetgever onthoude er zich van, een algemeene voogdij over de ingezetenen te willen uitoefenen. Alleen over de personae miserabiles is de Staat geroepen zijne beschermende hand uit te strekken; in zooverre is de Wet van 5 mei 1889 (Staatsblad no. 48), die alleen vrouwen en jeugdige personen betreft te verdedigen. Maar door verder te gaan, doet men te kort aan de

ging van en voor Nederlandse Industriëlen in 1890, naar aanleiding van de tentoonstelling in dat jaar: "Een der oudste industriëlen wil dierbij nog eens herhalen, wat hij zoostraks in het voorbijgatn heeft hooren zeggen, dat men wel moet in aanmerking nemen den dard van het Nederlandsche werkvolk. De meesten willen niet geraden, niet gewarschuwd zijin, doen juist niet wat men hen aanbeveelt en juist dat waarvoor men hen waarschuwt. Spr. heldert dit beweren met woorbeelden op die door andere heeren worden bevestigd. De slotsom is: De Nederlandsche werkman is in den regel onhandelbaar." Geciteerd bij W. de Vries Wzn., t.a.p. p. 28.

115 Nog vóo het ontwerp Lely in de afdelingen was onderzocht, trad thet toenmalige kabinet Tak van Poortvliet af.

116 A.N. Molentar, Arbeidsrecht, Tweede deel B, Het geldend recht, Zwolle 1958, p. 13761377.

117 Thans wordt weer overwogen om-enigszins omgekeerd-- de Arbeidswet 1919 te incorporeren in de Arbowet 1980. Zie: TK 1978-1979, 14.497, nr. 5, p. 37 waaruit het beleidswoornemen blijkt en TK 1983-1984, 17.931, nr. 45, p. 3 watarin de noodzaak weer wordt betwijfeld.

118 Uitwoerig over de problemen van delegatie in het arbeidsomstandighedenrecht zowel aan de Kroon als aan de ambtenaren van de Arbeidsinspectie in het algemeen: A.N. Molenaar, Arbeidsrecht I, t.a.p. p. 518-585; voorts: M.G. Levenbach, Nederlands Bestuursrecht III, t.a.p. p. $501-502 ;$ A.J.C.M. Geers, J.K.M. Gevers, Arbeidsomstandighedenrecht, Dewenter 1979, p. 35-41. Met name over delegatie in de Veiligheidswet 1895: A.N. Molenaar, t.a.p. p. 527-529. 
vrijheid van arbeid, waarbij ten slotte de werklieden evenveel belang hebben als de industriëlen. Tal van belemmeringen zullen uit deze wet voortvloeien en de industriëlen zullen geheel afhankelijk worden van de ambtenaren met het toezicht op de uitvoering der wet belast, terwijl het nog twijfelachtig is, of inderdaad doeltreffende voorschriften voor het voorkomen van ongevallen en ziekten te geven zijn, daar verreweg het grootste gedeelte van de ongelukken voortspruit uit roekeloosheid en zorgeloosheid van de arbeiders. "119

Een meerderheid echter kon instemmen met de strekking van het ontwerp en was mèt de regering van oordeel dat alleen de wetgever in staat was om voor een behoorlijke bescherming tegen de gevaren bij de arbeid te zorgen. Uiteindelijk werd het - inmiddels op onderdelen gewijzigde - ontwerp in de Tweede Kamer aanvaard op 21 juni 1895 met drie stemmen tegen. De Veiligheidswet 1895 trad in werking op 1 januari $1897 .{ }^{120}$

De wet strekt zich volgens art. 1 uit over de arbeid verricht in 'fabrieken en werkplaatsen'. Hieronder worden verstaan alle open of besloten ruimten, waarin 'enig bedrijf' wordt uitgeoefend, voorzover aldaar een krachtwerktuig of een oven wordt gebezigd of tien of meer personen plegen te verblijven. ${ }^{121}$ De artt. 6 en 7 van de wet openen de mogelijkheid dat bij AMvB voorschriften worden gegeven betreffende hetzij de inrichting, hetzij de arbeid in alle of in bepaalde nader te noemen fabrieken of werkplaatsen. Al in deze eerste Veiligheidswet is er de voorkeur aan gegeven dergelijke concrete voorschriften niet in de wet zelf op te nemen, maar in een $\mathrm{AMvB}$ om zo snellere aanpassingen te kunnen realiseren in verband met veranderde omstandigheden en inzichten. Art. 6, over de inrichting van fabrieken of werkplaatsen, noemt als onderwerpen die nader geregeld kunnen worden: de hoogte van de werklokalen, de verlichting, brandveiligheid, kleedkamers, schaftlokalen en privaten. Volgens art. 7 kunnen 0. a. voorschriften gegeven worden betreffende hygiëne, temperatuur, luchtverversing, bescherming tegen schadelijke of hinderlijke dampen, gassen of stoffen en het voorkomen van ongevallen door werktuigen en van vergiftiging, besmetting of beroepsziekten. Ten alanzien van de in dit artikel genoemde onderwerpen kan de Arbeidsinspectie nadere eisen stellen betreffende de wijze van uitvoering van de in de $\mathrm{AMvB}$ vervatte voorschriften.

119 Bijlage bij Handelingen TK 1894-1895, nr. 15 (voorlopig verslag), p. 2.

120 Wet van 20 juli 1895 (S. 137); inwerkingtreding bij KB van 7 december 1896 (S. 216).

121 Bij wijzigingswet van 19 juni 1915 (S. 245) is deze laatste bepaling veranderd in 'vijf of meer personen".

Over de uitleg van de begrippen fabriek, werkplaats en bedrijf was enige jurisprudentie noodzakelijk. In 1901 oordeelde do. HR dat 'bedrijf' de betekenis heeft die het in het datgelijkse leven heeft. (HR 2-12-1901, W. 7700). In 1904 besliste de HR dat het voor de toepassing van de Veiligheidswet irrelevant is of de fabriek of werkplaats in privaatrechtelijk dan wel in publiekrechtelijk beheer is (HR 9-6-1904, W. 8076). In 1917 oordeelde de HR dat onder art. 1 ook ruimten vallen waarin voorwerpen of stoffen die al enige verkoopwaarde bezaten, bewerkt worden. waardoor die waarde nog wordt verhoogd (HR 5-2-1917; vermeld bij Molenaar, IIB p. 1380, overigens niet gepubliceerd). In 1913 vond de HR dat 'fabriek' en "werkplaats' dezelfde betekenis hebben (HR 24-4-1933, W. 12620 ).

Zie ook: Koopmans, begrippen t.a.p. p. 13-20. 
Deze AMvB werd het Veiligheidsbesluit 1896. ${ }^{122}$ Voorts regelt de wet het toezicht op de naleving van de voorschriften (artt. $9 \mathrm{t} / \mathrm{m} \mathrm{15}$ ), het beroep tegen eisen van de Arbeidsinspectie (art. $16 \mathrm{t} / \mathrm{m} \mathrm{18}$ ) en de strafbaarstelling (art. 19 t/m 24).

\subsection{Van de Veiligheidswet 1895 tot de Arbeidswet 1919}

De naleving van de Veiligheidswet verliep niet probleemloos. ${ }^{123}$ Dit lag zowel aan de houding van de werkgevers en de werknemers als aan de geringe bezetting van de Arbeidsinspectie. Gegevens hierover verschaffen de jaarverslagen van de Arbeidsinspectie. In het jaarverslag over 1897 en 1898 worden 99 ongevallen vermeld, waarvan 49 met dodelijke afloop. Oorzaken zijn struikelen, vallen, getroffen worden door losschietende riemen, voorwerpen, lasten, bewegende machinedelen, in aanraking komen met hete vloeistoffen en beklemd raken. Hoewel de ambtenaren actief zijn ('verneem ik bij gerucht of door nieuwsbladen, dat ergens een ongeval heeft plaatsgehad, waarvan de kennisgeving niet tijdig inkwam, dan wordt spoedig nader bericht ingewonnen'. ${ }^{124}$ ), wordt natuurlijk lang niet alles bekend. Dit geldt met name voor (beroeps)ziekten. 'Het is echter zeer moeilijk, zooals mij reeds bij het onderzoek naar nekrosegevallen was gebleken, veel meer dan aanwijzingen te verkrijgen, daar de patiënten uit vrees of verkeerd begrip zwijgen, de doctoren zich meestal niet geroepen gevoelen mededeelingen te doen en de fabrikanten uit den aard der zaak niet de aandacht op ziektegevallen vestigen. Wenselijk zou het zijn, bij de wet de verplichting op te krijgen tot het kennisgeven van die ziektegevallen.' 125

Nog na de eeuwwisseling is er weerstand bij werkgever en werknemer tegen het nemen van veiligheidsmaatregelen. Met sommige werkgevers viel hierover ook nauwelijks te praten. 'De vingers moeten eerst maar eens tusschen de raderen geknepen worden, daarna is beveiliging niet meer noodig', of 'men heeft met die nieuwerwetsigheden liever niets te maken". ${ }^{126}$ Ook de werknemers toonden zich niet echt enthousiast. Beveiligingen werden onklaar gemaakt of beschermingsmiddelen niet gedragen. Dit was echter niet onverklaarbaar. In die tijd was de beveiligingstechniek nog niet zover dat voldoende rekening werd gehouden met de eisen van het werk. Als het werk door

122 Deze AMvB werd vastgesteld bij KB van 7 december 1896 (S. 215) en trad tegelijk met de Veiligheidswet in werking. Het Veiligheidsbeshit is nadien vervangen door dat van 1913 , vastgesteld bij KB van 17 juni 1913 (S.317), in werking getreden 1 juli 1914 en dat van 1916, vastgesteld bij $\mathrm{KB}$ van 21 augustus 1916 (S. 418), en in werking getreden op 1 oktober 1916 .

123 Hierbij moet bovendien bedacht worden dat van de werknemers in de industrie volgens een berekening van een kamerlid tijdens de parlementaire behandeling wan de wijziging wan de Veiligheidswet in 1915, een derde deel niet onder de bescherming wan de Veiligheidswet viel. Handelingen TK 1915-1916, p. 1417.

124 Jaarverslag 1897 en 1898 , t.a.p. p. 56.

125 Jaarverslag 1897 en 1898 , t.a.p. p. 57.

126 Geciterd uit Jaarverslagen van de Arbeidsinspectie door A.H.W. Hacke (destijds Directeur-General van de arbeid), Veiligheid bij den Arbeid, Een greep uit het vele, t.a.p. p. 43. 
de beveiliging vertraagd werd, verminderde dat de inkomsten van degene die op tariefloon werkte. Bovendien: 'Het stond veel flinker geheel onbeschut te werken, dan de vereischte maatregelen te nemen... zelfs arbeiders, die bij den slijparbeid één oog verloren hadden, werden bij controle zonder bril aangetroffen.' ${ }^{127}$

Inmiddels was de Arbeidsinspectie uitgebreid. Dat moest ook wel gezien de uitbreiding van haar werkzaamheden op grond van de Veiligheidswet 1895. Daarom werd de wettelijke beperking tot drie inspecteurs in de Arbeidswet 1889 tegelijk met de aanneming van de Veiligheidswet geschrapt. ${ }^{128}$ In 1896 werd het land verdeeld in zes inspecties. ${ }^{129}$ Vanaf die tijd breidde de dienst zich - onder meer gerelateerd aan nieuwe wettelijke maatregelen - gestaag uit zowel in kwantitatief als in kwalitatief opzicht. ${ }^{130}$

Aan één aspect hiervan wil ik nog enige aandacht besteden. Vanaf 1909 konden ook arbeiders optreden als 'controleur van den arbeid'. ${ }^{131}$ Tijdens de behandeling van de Arbeidswet 1889 was hier al voor gepleit door Domela Nieuwenhuis. Hij vond toen ook dat de inspecteurs niet door de Kroon maar door de arbeiders zelf moesten worden benoemd. Voor een andere vorm van betrokkenheid van arbeiders bij de controle en inspectie werd al eerder gepleit door A. Kerdijk, vooraanstaand progressief liberaal kamerlid. In het Sociaal Weekblad drong hij aan op de instelling van 'Commissiën uit werklieden-verenigingen' met als taak het controleren van de uitvoering der Arbeidswet, het in ontvangst nemen van klachten, en het naar aanleiding daarvan overleggen met de Arbeidsinspectie. ${ }^{132}$ Het gaat er hem vooral om condities te creëren waaronder arbeiders eerder geneigd zijn om zich met klachten, informatie etc. tot de Arbeidsinspectie te wenden. Immers: 'Waar de broodwinning in gevaar kan komen, deinst de overgroote meerderheid er voor terug, zich bloot te stellen aan wraakneming door den patroon, die immers juist reeds door zijn niet-gehoorzamen aan de wet blijk heeft gegeven van een ruim geweten. Zoo beveelt de tusschenkomst van commissiën - bestaande uit mannen, door de werklieden zelven uit hun midden aangewezen - in tweeërlei opzicht zich aan. Enerzijds kunnen zij in arbeidskringen onverschilligheid bestrijden, het besef van den plicht tot medewerking wakker roepen of versterken, en aansporen om feiten, strijdig met de wet, niet te verzwijgen. Anderzijds bieden zij verhoogden waarborg, dat de herkomst der klachten, die zij overbrengen, ver-

127 Hacke, t.a.p. 44

128 Wet van 20 juli 1985 (S. 138).

$129 \mathrm{~KB}$ van 2 april 1896 (S. 63).

130 Over de (vroegste) geschiedenis en de uitbouw van de Arbeidsinspectie: N.C. Winkel, t.a.p. p. 7-36; H.A. wan IJsselsteijn, t.a.p. p. VIII-XX; Gedenkboek 1909-1934, naar annleiding van het feit dat 25 jaar geleden de Arbeidsinspectie ingesteld werd onder leiding van den Directeur-Generaal van den Arbeid, Groningen/Den Haag/Batavia 1934; I. P. de Vooys, Arbeidsinspectie, Vragen des Tijds, 1901, p. 131-164: A.N. Molenaar, IIB, t.a.p. p. 1448-1454.

131 In de betreffende $A M v B$, vastgesteld bij $K B$ van 10 augustus 1909 ( $\$$. 289), werd onder meer de centrale dienst van de Arbeidsinspectie ingesteld onder leiding van een Directeur-Generaal.

132 A. Kerdijk, Noodige medewerking, Sociaal Weekblad, 1896, p. 241-242 en 249-250. 
borgen zal blijven. ${ }^{\text {.133 }} \mathrm{De}$ 'Amsterdamsche Bestuurdersbond' reageert in beginsel positief, maar 'daar deze heeren (bedoeld zijn de ambtenaren van de Arbeidsinspectie, AG) zijn aangesteld om overtredingen op te sporen en niet te ontvangen', wil de bond dat 'de voorgestelde voorlichting en samenwerking niet worden gezocht door werklieden, maar door de heeren inspecteurs door aan de verschillende bonden een uitnoodiging tot samenwerking te richten". ${ }^{34}$ Het gaat hier dus niet on de aanstelling van arbeiders bij de Arbeidsinspectie, maar om een vorm van samenwerking.

Nadat het instituut van controleurs wel was gerealiseerd, schreef Winkel, indertijd hoofdinspecteur van de arbeid: 'Deze ambtenaren werden uit de arbeiders benoemd en in de districten werkzaam gesteld. Men verwachtte, dat personen van voldoende ontwikkeling, die als arbeider het bedrijfsleven grondig hebben leeren kennen, niet zelden beter dan eenig ander in staat zouden zijn om inlichtingen te geven omtrent de in het belang van den arbeid gegeven voorschriften. Hun ervaring zou er veelal toe kunnen bijdragen dat de maatregelen genomen werden, die bij de minste opoffering van de zijde van den werkgever het meest nuttige effect voor den arbeider opleveren... De bezwaren tegen de aanstelling van deze ambtenaren in de Tweede Kamer geuit, dat het moeilijk zou zijn de geschikte personen te vinden, dat deze ambtenaren in een moeilijke verhouding tusschen arbeiders en werkgevers zouden staan en òf het vertrouwen der arbeiders moesten verliezen òf bijzonder scherp moesten optreden, zijn sindsdien gebleken niet in ernstige mate aanwezig te zijn. ${ }^{135}$ Er werd overigens zorgvuldig gelet op de beoogde neutraliteit. 'Ook al werd prijs gesteld op behoud van regelmatig contact met de kringen, waaruit zij waren voortgekomen, toch werd er zorgvuldig tegen gewaakt, dat de titularissen zich min of meer als vertegenwoordigers van een bepaalde groep zouden beschouwen: politicke bestuursfuncties moesten zij neerleggen. "136 Ik meen dat aan de andere functionarissen van de dienst een dergelijke aanste llingsbeperking nooit is gesteld. En tot slot J.J. Camminga, zelf zo'n controleur: 'Met zekerheid kan gezegd worden, dat er een voortdurend contact tusschen inspectie en arbeiders is tot stand gekomen. Als bewijs kan gelden het groot aantal mededeelingen en klachten over vermeende wetsovertredingen, welke jaarlijks van vakvereenigingen en arbeiders zelve bij de inspectie inkomen. Vooral in de groote steden, centra van vakorganisaties, is dit belangrijk. Deze klachten komen zoowel mondeling van de controleurs als schriftelijk op de bureaux. ${ }^{137}$

Rond de eeuwwisseling spelen ook de vakbonden nog een belangrijke rol bij de discussies over verdergaande arbeidsbescherming. Vooral het, in 1906 op-

133 A. Kerdijk, t.a.p. p. 241.

134 H. Heijdenrijk (namens het bestuur van de bond), Arbeidsinspectie, Sociaal Weekblad, 1896, p. 278 .

135 N.C. Winkel, t.a.p. p. 29.

136 Th.C. Geudeker (Hoofd administratie ter Directie van den Arbeid), Een kwart eeuw 'Centrale Dienst", Gedenkboek 1909-1934, t.a.p. p. 74.

137 J.J. Camminga, lets over de taak van de controleurs van den Arbeid, Gedenkboek, t.a.p. p. 59 . 
gerichte NVV richt zich sterk op de sociale wetgeving en de rol die het parlement daarbij kan spelen. ${ }^{138}$ Het in 1893 opgerichte NAS (Nationaal Arbeiders Sekretariaat) richtte zich meer op de directe acties in de bedrijven en op werkstakingen. ${ }^{139}$

Hoewel in 1898 door de regering al een poging was gedaan om de werking van de Arbeidswet uit te breiden tot volwassen mannelijke arbeiders, een poging die door de Kamer werd afgewezen als een ongeoorloofde beperking van de vrijheid tot het sluiten van overeenkomsten, ging het streven naar een algemene beperking van de arbeidsduur in en buiten het parlement onverminderd door ${ }^{140}$ Buiten het parlement werd de strijd voor een algemene arbeidsverkorting gestreden door de vakbeweging. Al sinds 1 mei 1890 werd jaarlijks gedemonstreerd voor een achturige werkdag. Omdat de werkelijke arbeidstijden zoveel langer waren, besloten de SDAP en het NVV eerst te streven naar een tienurige werkdag. ${ }^{141}$ In dat kader publiceerden SDAP en NVV in 1908 een eigen onderzoek naar de arbeidsomstandigheden onder de titel: 'Arbeidersleven in Nederland". ${ }^{142}$ Hieruit kwam geen rooskleurig beeld naar woren. Arbeiders werkten vak veel langer dan 11 uren, met uitschieters in bijvoorbeeld bakkerijen, de strokartonindustrie en in winkels en magazijnen. Volgens het verslag werd bovendien nog een gunstig beeld gegeven omdat de informatie niet afkomstig is "van de slechtst gestelde arbeiders, integendeel het zijn de georganiseerden of in elk geval degenen, in wier midden de organisatie haar zegenbrengend werk heeft verricht". ${ }^{143}$

Omdat de eis van de 10-urige werkdag voor de meeste arbeiders tevens een flinke loonkorting zou betekenen en de Nederlandse industrie geen kostenverhoging kon hebben, pleit het rapport voor arbeidsintensivering, waardoor in kortere tijd hetzelfde wordt gepresteerd. 'De verkorting van arbeidsduur oefent op de lichamelijke kracht en de intelligentie van den arbeider een bij uitstek gunstigen invloed; hij kan nu in een beperkter tijd meer presteerenhij wordt genoodzaakt dit te doen, hetzij onder de onmiddellijke pressie van den werkgever of cliens gemachtigde, hetzij bloot uit hoofde van de afhankelijke positie waarin hij als bezitlooze verkeert. De Hollandsche arbeider weet, dat verhoogde intensiteit van den arbeid het onvermijdelijke gevolg is van verkorting van den arbeidsduur. Toch greep de eisch van den wettelijken 10-

138 Over de oprichting van het NVV, Harmsen/Reinalda, t.a.p. p. 88-95.

139 Over de oprichting en ideeën van het NAS: Harmsen/Reinalda, t.a.p. p. 66-74.

140 Over de poging van de regering in 1898: Molenaar IIB, p. 1175-1178.

141. Het NAS sprak van verraad aan het beginsel van de acht-uren dag. Harmsen/Reinaldat ta.p. 133. De SDAP was in 1894 ontstaan als afsplitsing van de SDB. In 1897 werden hun cerste vertegenwoordigers in de Kamer gekozen. De socialisten in het NVV gingen uit varn een duidelijke taakverdeling: de partij was voor de politiek, de vakorganisatie behartigde de economische belangen - waaronder ook de sociale wetgeving viel. Harmsen/Reinalda, ta.p. p. 113-114.

142 Arbeidersleven in Nederland. Resultaten der enquête, ingesteld door het NVV in het najaar van 1907 naar de wenschelijkheid en mogelijkheid van beperking van den arbeidsdutur voor volwassenen tot 10 uren per etmaal en afschaffing, respectievelijk beperking van nachtwen kinderarbeid, 1908, uitg. SDAP en NVV

143 Arbeidersleven, t.a.p. p. 148. 
urendagen onzen arbeiders dadelijk in het hart. Dit stelt eerst recht in het licht, aan welke praatjesmakerij de Inspecteur van den Arbeid zich schuldig maakte, die den indruk wilde vestigen, dat de Hollander verkiest kalm aan lang te arbeiden, boven zich meer in te spannen gedurende korteren werktijd." 144

Ook aan de veiligheid en gezondheid werd door het NVV gedacht. In 1910 pleitte J. van den Tempel, bestuurslid van het NVV "mede in verband met de toeneming van den fabrieksmatigen arbeid en het onophoudelijk invoeren van nieuwe procédés' voor nieuwe bepalingen of aanscherping van de bestaande 'ter beveiliging van den arbeid bij machines' en de bescherming van 'de gezondheid en het leven van groote groepen arbeiders'. Hij noemde daarbij talrijke onderwerpen, zoals verlichting, lucht, dampen, kleed- en schaftlokalen, temperatuur. ${ }^{145}$

In het parlement diende in 1906 de SDAP afgevaardigde Schaper een motie in waarin onder meer de wenselijkheid van de 10-urige werkdag was neergelegd. Schaper betoogde dat dit wenselijk was in verband met de ontplooiing van de arbeiders en dat deze dan ook meer tijd zouden hebben om naar een betere inrichting van de maatschappij te streven. ${ }^{146}$ Waarschijnlijk met name om dit laatste argument werd de motie verworpen. In 1910 diende Talma een ontwerp in tot wijziging van de Arbeidswet 1889, waarin echter een regeling van de arbeidstijd van volwassen mannen niet voorkwam. Hij kreeg hiervoor steun van Aalberse die er op wees dat, nu voorgesteld werd om de arbeidsduur voor vrouwen en jeugdige personen te beperken tot tien uur dit als het ware vanzelf ook voor de volwassen mannen zou gaan gelden omdat deze nu eenmaal bij veel industrieën, zoals in de textiel, afhankelijk waren van het werk van vrouwen en kinderen. ${ }^{147}$ Hoewel dit argument al niet erg overtuigend is, is het curieus dat dit komt van de man die, bij gelegenheid van de bespreking van de motie van Schaper, zelf een (aangenomen) motie indiende, slechts op een ondergeschikt punt verschillend van die van Schaper, waarin ook werd gepleit voor een wettelijke beperking van de arbeidsduur voor volwassen mannelijke arbeiders tot tien uur. Talma zelf vond de tijd voor een dergelijke regeling nog niet rijp. Schaper diende vervolgens een initiatief-voorstel in, dat echter niet tot behandeling kwam. ${ }^{148}$

In 1911 werd de Arbeidswet Talma, die uitbreiding, maar geen principiële wijzigingen bracht, aangenomen. ${ }^{149}$ Kinderarbeid beneden 13 jaar werd verboden, de leeftijdsgrens van jeugdige personen kwam op 17 jaar en de arbeidsdag voor vrouwen en jeugdige personen werd gebracht op minimaal 10 uur. Nog was er geen regeling voor volwassen mannelijke arbeiders. Blijkbaar wa-

144 Arbeidersleven, t.a.p. p. 153.

$145 \sqrt{ }$. van den Tempel, in De Nederlandsche vakbeweging en haar toekomst, 1910, p. 116, geciteerd bij Stoop, t.a.p. p. 73. In 1915 (S. 282) werd de Veiligheidswet in haar werking op enkele ondergeschikte punten uitgebreid (zie ook noot 121).

146 Handelingen TK 1906-1907, p. 1380.

147 Handelingen TK $1910-1911$, p. 1785.

148 Molenaar II B, t.a.p. 1179-1182.

149 Wet van 7 oktober 1911 (S. 314). 
ren daar ingrijpender maatschappelijke ontwikkelingen voor nodig.

En die kwamen er. Vooral door de Eerste Wereldoorlog was de toestand voor veel arbeiders uitermate slecht geworden. De werkloosheid groeide en tegelijkertijd de onrust zoals die zich bijvoorbeeld manifesteerde in het 'aardappeloproer' in 1917 toen er wel aardappelen waren woor de export, maar niet voor de bevolking. De arbeiders - al dan niet georganiseerd - stelden zich steeds militanter en radicaler op. Stakingen namen toe: in de textielindustrie in Tilburg, in de mijnen in Limburg (door het NVV ontraden met een beroep op het algemeen belang: de noodzaak van kolen), in de havens in Rotterdam. ${ }^{150}$ Ook internationaal steeg de spanning. In 1917 brak in Rusland de revolutie uit en in november 1918 in Duitsland. Ook in andere Europese landen werden regeringen en gegoede burgerij nerveus, terwijl (delen van) de arbeiders hooggespannen verwachtingen koesterden van de blijkbaar aanstaande maatschappelijke omwentelingen. Het is in deze dagen van de 'bibberbourgeoisie', dat Troelstra zijn 'vergissing' maakte door in november 1918 aan te kondigen dat de arbeidersklasse in Nederland de politieke macht zou grijpen. Gematigde leiders van NVV en SDAP zagen minder heil in dit avontuur, en ook voor de meer radicale organisaties kwam de proclamatie van Troelstra tè onverwacht. Zo werd in Nederland de revolutie afgelast, echter niet dan nadat de regering al maatregelen genomen had door onder meer de meest vertrouwde troepen naar Amsterdam, Rotterdam en Den Haag te sturen. Tijdens de kamerdebatten later in die maand erkenden de socialisten bij monde van de (gematigde) Schaper de politieke realiteit. Wel werd nog, eveneens in november, een gezamenlijk congres van NVV en SDAP gehouden waarbij een program van eisen werd geformuleerd, met als een van de belangrijkste de eis voor invoering van de achturige werkdag (naast eisen als bijvoorbeeld het vrouwenkiesrecht en ouderdomspensioen). Na november 1918 werd de acht-uren dag steeds meer een hoofdthema voor de arbeidersbeweging. Nadat SDAP en NVV een comité hadden gevormd om hiervoor te ijveren, werd in een aantal (grote) bedrijven de acht-uren dag afgedwongen. Philips en de Gist- en spiritusfabriek behoorden tot de eerste. Vrij snel daarna volgden rijk en gemeenten. ${ }^{\text {t51 }}$

Op 11 april 1919 diende minister Aalberse zijn ontwerp voor een nieuwe Arbeidswet in, waarin voor het eerst een regeling was opgenomen voor een voor iedere werknemer geldende achturige werkdag. Hoewel de minister van oordeel was dat de indiening niet door de voorafgaande gebeurtenissen in het land was afgedwongen (ten aanzien van hen die dat wél vonden: "dan rest de ondergetekende niets anders dan ook hier in te berusten. $\mathrm{Zij}$ het onder protest tegen de wijze, waarop men de evenbedoelde verklaringen bejegent. ${ }^{152}$ ), lijdt het geen twijfel dat de november-gebeurtenissen de zaak in elk geval hebben bespoedigd: ' ... doordat de dreigende revolutie het verzet uit kringen, die zich

150 Harmsen/Reinalda, t.a.p. p. 128.

151 Over de novembergebeurtenissen: Tinga, t.a.p. p. 631-632, Harmsen/Reinalda, t.a.p. p. 130-132 en Sevenhuisen, t.a.p. p. 254.

152 Handelingen TK 1918-1919 nr. 408 (MvA), p. 8. 
anders tegen een dergelijke maatregel zouden hebben gekant, totaal verlamde en de tegenstanders daarvan zelfs tijdelijk in voorstanders veranderde. ${ }^{15 \%}$ Aan het ontwerp lagen enkele nieuwe uitgangspunten ten grondslag. ${ }^{154}$ In de eerste plaats wordt de Arbeidswet, doordat zij in beginsel geldt voor alle werknemers en het gehele bedrijfsleven, van uitzonderingswetgeving tot normale wetgeving.

In de tweede plaats wordt niet meer gezocht naar het strikte bewijs dat in concrete situaties de werktijden zo overmatig lang zijn dat wettelijk wel moet worden ingegrepen. De acht-uren dag wordt nu als norm genomen, tenzij zulks op economische gronden onmogelijk is.

In de derde plaats speelt het sociale, het ethische motief, het idee om de werknemers de gelegenheid te geven zich te ontplooien een zeer belangrijke rol. Aalberse met name over de twee laatstgenoemde motieven: 'Men zegt: gij, die verkorting van den arbeidsduur wilt, moet eerst bewijzen, met cijfers, met feiten, met statistieken, dat de industrie niet zal worden geschaad. Daarop antwoord ik: zelfs. wanneer ik dat bewijs niet kan leveren, dan nog hebt gij het pleit niet gewonnen, omdat gij een nog veel voornamer factor, het levensgeluk, het geestelijk welzijn, het gezinsleven van den arbeider geheel of te veel buiten rekening laat, en waar dit het zwaarst is, moet dit ook het zwaarst wegen." "ss

Tijdens de kamerbehandeling stond het principe van overheidsbemoeienis ook met volwassen mannelijke werknemers niet meer centraal. Belangrijker argumenten tegen de voorstellen werden gevonden in de internationale concurrentiepositie. Uiteindelijk nam de Tweede Kamer het ontwerp aan met slechts drie stemmen (van de communisten) tegen. ${ }^{156}$ In 1920 traden de eerste bepalingen van de Arbeidswet 1919 in werking. ${ }^{157}$

Naast de acht-urige werkdag (behoudens uitzonderingen), gekoppeld aan de 45-urige werkweek ${ }^{158}$ werd de vrije zaterdagmiddag, de zondagsrust, het verbod van nachtarbeid, van kinderarbeid (tot veertien jaar), en de bijzondere bescherming van jeugdige personen (tot achttien jaar) en van vrouwen in de nieuwe Arbeidswet geregeld. Deze bijzondere bescherming was gebaseerd op art. 10 (in de Arbeidswet 1889 was dat al ter sprake gekomen in art. 4) en

$153 \mathrm{~J}$. Westhoff, Arbeidsbescherming in engeren zin, in: A.L.. Scholtens c.a. , Het Departement van Arbeid, Handel en Nijverheid onder minister Aalberse 1918-1925, Alphen a/d Rijn 1926, p. 12 .

$154 \mathrm{Vgl}$. H.F. Beenhakker, De Arbeidswet 1919, hatar grondslag, inhoud en betekenis, SMA, 1969 , p. 643-662, m.n. p. 644 en 645.

155 Handelingen TK $1918-1919$, p. 2877.

156 Over de parlementaire behandeling: A.N. Molenaar IIB, t.a.p. p. 11.82-1187.

157 Arbeidswet 1919: Wet van 1 november 1919(S. 624). In art. 101 werd bepaald dat de verschillende bepalingen op verschillende tijdstippen in werking konden treden. $\mathrm{Bij} \mathrm{KB}$ van 27 september 1920 (S. 756) is bepaald dat het eerste gedeelte op 24 oktober 1920 in werking zou treden.

158 Bunnen twee jaar werd de achturige werkdag en de 45 -urige werk week al gewijzigd in respectievelijk de acht en een half-urige werkdag en de 48 -urige werkweek in verband met alanwarding wan deze werktijden door de Arbeidsconferentie van Washington in oktober 1919 èn onder druk van de verslechterde economische toestand. Wet van 20 mei 1922 (S. 364). 
was in hoofdzaak bedoeld om bij AMvB voorschriften te geven in de vorm van verboden in gevallen waarin dat niet of niet op de gewenste wijze zou kunnen gebeuren op grond van de Veiligheidswet. ${ }^{159}$ Met name bezorgdheid over de gevolgen van de dan opkomende rationalisering en structurering van het arbeidsproces, het zogeheten Taylorsysteem, speelden daarbij een rol. Met de totstandkoming van de Arbeidswet 1919 is de principiele, ideologische en politieke strijd omtrent wettelijke maatregelen ter bescherming van de werknemers gestreden. "Typerend voor de bijzondere sfeer die bij de behandeling van het ontwerp Arbeidswet 1919 in de Tweede Kamer heerschte, is het feit, dat de uitslag der stemming een twintigtal afgevaardigden aanleiding gaf de Internationale aan te heffen, die door een nog grotere groep Kamerleden met het Wilhelmus werd beantwoord. " 160

\section{Enkele andere wettelijke regelingen in de periode tot 1919}

In de vorige paragraaf is voor wat betreft de regelgeving tot 1919 aandacht geschonken aan de twee belangrijkste algemene wetten op het gebied van enerzijds de arbeidsduur en anderzijds de bescherming tegen gevaren voor de gezondheid en veiligheid bij de arbeid: de Arbeidswet 1919 (met als voorloopster de Kinderwet) en de Veiligheidswet 1895.

Het is ook aan de hand van de ontstaansgeschiedenis van deze wetten dat de ontwikkeling van het arbeidsomstandighedenrecht het beste gelezen kan worden. Maar er was in deze periode sprake van méér regelingen op het terrein van de arbeidsomstandigheden. De belangrijkste hiervan zullen in deze paragraaf in het kort aan de orde komen.

In de eerste plaats is dat een aantal specifieke beschermingswetten, tot stand gekomen voor bepaalde soorten werkzaamheden of bedrijfstakken: de Phosphorluciferwet (1901), de Mijnwet (1903), de Caissonwet (1905), de Steenhouwerswet (1911) en de Stuwadoorswet (1914).

In de tweede plaats is dat de Ongevallenwet (1901). Ging het bij de vorige wetten vooral om bescherming, bij de Ongevallenwet staat centraal een regeling die compensatie biedt voor de financiële gevolgen die ontstaan als zich, ondanks de beschermende maatregelen, tòch een bedrijfsongeval voordoet. In de derde plaats had (en heeft) het slachtoffer van een bedrijfsongeval de mogelijkheid om zich, ter verkrijging van schadevergoeding te beroepen op het BW, met name op art. 1401 en, vanaf 1909 , speciaal op art. $1638 \mathrm{x}$ - al maakte het zgn. 'pacificatieartikel' in de Ongevallenwet deze laatste mogelijkheid (tot 1967) in de meeste gevallen slechts theoretisch.

159 Beenhakker, t.a.p. p. 651. De in art. 1.0 bedoelde AMvB is het Arbeidsbesluit 1920 , vastgesteld bij KB van 10 augustus 1920 ( $\mathrm{S}$. 694).

160 Westhof, t.a.p. p. 14. Volgens andere auteurs werd niet de Internationale, mar de achturen-mars gezonden. (Dat de rechterzijde het Wilhelmus zong, lijkt vast te staan). Tinga, ti.a.p. p. 633 , Harmsen/ Reinalda, t.a.p. p. 134. 


\subsection{Enkele specifieke beschermingswetten}

Gemeenschappelijk kenmerk van deze wetten is, behalve dat zij bedoeld zijn voor specifieke werkzaamheden of bedrijfstakken, dat zij hun ontstaan mede, en in sommige gevallen vooral, danken aan door de Arbeidsinspectie op de betreffende terreinen gesignaleerde misstanden. Waarschijnlijk is ook hierdoor de totstandkoming in het algemeen zonder problemen - in en buiten het parlement - verlopen. Voor wat betreft hun inhoud regelen zij meestal zowel arbeidstijden als veiligheids- en gezondheidsaspecten.

\section{- De Phosphorluciferwet $1901^{161}$}

Aan het eind van de vorige eeuw werden lucifers vervaardigd met behulp van witte (of gele) fosfor. Deze fosforsoort is giftig en meer dan $10 \%$ van de werknemers in de luciferfabrieken leed aan de zeer schadelijke beroepsziekte fosfornecrose. Rode (onschadelijke) fosfor was wel bekend, maar duurder. ${ }^{162} \mathrm{Na}$ uitvoerige en herhaalde rapportages van de Arbeidsinspectie terzake werd eerst in 1898 geprobeerd via een op de Arbeidswet gebaseerd KB het euvel te bestrijden. ${ }^{163}$ Toen dit niet hielp kwam de Phosphorluciferwet in 1901 tot stand. ${ }^{164}$ De wet verbood het gebruik, het vervoer, de invoer en het ten verkoop voorhanden hebben van deze lucifers. Het - door zijn absoluut verbod vèrgaande - wetsontwerp werd in het parlement algemeen gesteund. ${ }^{165}$ De wet is te beschouwen als de eerste die zich expliciet richtte op de bescherming tegen een beroepsziekte. ${ }^{166}$

\section{- De Mijnwet $1903^{167}$}

Naast de regeling van de concessieverlening was de doelstelling van de wet zowel de bescherming van de veiligheid en gezondheid van de mijnwerkers als een regeling van hun werk- en rusttijden en het toezicht daarop. De wet stelde ook bedrijfsgeneeskundige diensten in - lang voor dat een dergelijke regeling in de Veiligheidswet terecht kwam (in 1959). Een aspect in deze wet verdient extra aandacht. Dat betreft de instelling van arbeiderscommissies en arbeiderscontroleurs. Het is historisch belangrijk omdat het hier de eerste wettelijke regeling betreft van een vorm van zeggenschap van werkne-

161 Wet van 28 mei 1901 (S. 133).

162 Sevenhuisen, t.a.p. p. 252 .

$163 \mathrm{~KB}$ wan 24 juni 1898 (S. 148), ex art. 4 Arbeidswet.

164 Wet van 28 mei 1901 (S. 133).

165 Voor de wetsgeschiedenis: A.N. Molenaar, Arbeidsrecht I, ta.p. p. 308; idem, Arbeidsrecht IIB, P. 1410; M.G. Levenbach, Nederlands Bestuursrecht III, t.a. p. p. 444.

166 Naast het verbod van nachtarbeid voor vrouwen in de industrie is het verbod van witte fosfor ook de eerste maatregel die international werd bepleit. De in 1901 opgerichte Internationale Vereniging voor wettelijke bescherming der arbeiders gaf de stoot tot een internationale conferentie over beide voorgestelde maatregelen die in 1905 te Bern werd gehouden. Dit leidde onder meer tot een verdrag betreffende het verbod van witte fosfor dat op 11 juli 1908 (S. 224) werd geratificeerd. Zie hierover A.N. Molenaar, Arbeidsrecht I, t.a.p. p. 426-427.

167 Wet van 27 april 1904 (S. 73). 
mers in zaken van veiligheid en gezondheid. ${ }^{168}$ In het op de Mijnwet gebaseerde Mijnreglement van 1906 werd in mijnen met meer dan 100 werknemers de oprichting verplicht gesteld van arbeiderscommissies. ${ }^{169}$ Deze commissies bestonden uit zes, door de mijnwerkers uit hun midden gekozen, leden. Zij fungeerden als "doorgeefluik" voor de klachten, wensen e.d. van de werknemers naar de directie. Ten minste een maal per maand moest hierover met de bedrijfsleiding worden gesproken. Zowel de uit dit gesprek eventueel voortvloeiende maatregelen als de betreffende klachten moesten worden geregistreerd.

In 1916 werden de arbeiderscontroleurs geïntroduceerd in het Mijnreglement. $\mathrm{Zij}$ werden benoemd door de minister uit een lijst van kandidaten die werd samengesteld door de arbeiderscommissies. Zij waren bevoegd om ondergrondse inspecties te houden en om ongevallen te onderzoeken. $\mathrm{Zij}$ hadden echter niet de bevoegdheid om proces-verbaal op te maken hoewel vooral de vakbeweging daarop wel had aangedrongen. ${ }^{171} \mathrm{Zij}$ waren ondergeschikt aan de Inspecteur-Generaal der Mijnen. ${ }^{172}$

\section{- De Caissonwet $1905^{173}$}

Rond de eeuwwisseling begon men gebruik te maken van het werken in caissons, bijvoorbeeld bij de bouw van spoorwegviaducten, of tunnels onder rivieren. Een caisson is een omgekeerde bak in de vorm van een duikerklok tot het maken van funderingen onder water. Hierin wordt lucht geperst onder een druk, afhankelijk van de diepte onder water, zodat het water uit de caisson wordt weggedrukt en er in de caisson kan worden gewerkt. Naar het oordeel van de Arbeidsinspectie was een wettelijke regelling nodig in verband met de tijd gedurende welke onder hogere dan de atmosferische luchtdruk werd gearbeid en in de tweede plaats in verband met het komen in, respectievelijk het verlaten van de caisson. Zonder maatregelen op dit gebied liepen de werknemers de kans om de - soms dodelijke caissonziekte op te lopen. ${ }^{174}$ Nadere regelingen betreffende zowel de veillig-

168 In de praktijk kwam participatie van werknemers bij het veiligheidsbeleid van het bedrijf al wel voor. Een bekend voorbeeld vormden de veiligheidscommissies in de gist- en spiritusfabriek te Delft. W. de Witte, De organisatie van het veiligheidsoverleg in de onderneming; historische ontwikkeling veiligheidscommissies bij Gist-Brocades, De Veiligheid, $53(1977)$, p. 169-171.

Vgl. ook de door Kerdijk bepleite 'Commissièn uit werkliedenverenigingen', besproken in paragraaf 3.4 van dit hoofdstuk.

169 Hoofdstuk XV van het mijnreglement wan 22 september 1906 (S. 248).

$170 \mathrm{~KB}$ van 13 oktober 1916 (S. 474).

171 A.N. Molenaar, Arbeidsrecht IIB, p. 1311.

172 Het hoofdstuk over de arbeiderscommissies in het mijnreglement is (omdat het in 1.945 al buiten toepassing was verklaard) ingetrokken bij KB van 6 december 1946 (S.349). In datzelfde besluit werd bepaald dat de voordracht voor de arbeiders-controleurs voortaan werd gedaan door de erkende vakorganisaties. De aanwijzing vindt, telkens voor vijf jaar, platats door de Mijnindustrieraad.

173 Wet wan 22 mei 1905 (S. 143).

174 Over de Caissonwet en haar toepassing: A.N. Molenaar, Arbeidsrecht IIB, t. a.p. p. 1313 1316. 
heid en de gezondheid als de arbeidsduur werden neergelegd in een in 1907 vastgesteld $\mathrm{AMvB} .{ }^{175}$

\section{- De Steenhouwerswet $1911^{176}$}

Onderzoekingen van de Arbeidsinspectie rond de eeuwwisseling toonden aan dat voor de beroepsgroep die zich bezig hield met de "fabricage van marmerwaren, marmerslijpers, molensteenscherpers, steenhouwers en steenkloppers (bikkers)', het sterftecijfer per 1000 bedroeg: voor de leeftijdsklasse $23-35$ jaar 14,57 en voor de leeftijdsklasse $36-50$ jaar 21,51 . Het eerste cijfer was het hoogste, het laatste op twee na het hoogste van 96 onderzochte beroepsgroepen. ${ }^{177}$ Voornaamste oorzaak van deze hoge sterfte was de silicose (in die tijd nog tuberculose genaamd). Daarbij kwam nog een sterk verminderde weerstand tegen allerlei ziekten door het uitermate zware werk. ${ }^{178}$ De op de bescherming van deze beroepsgroep gerichte wet regelde zowel de werk- en rusttijden als de veiligheids- en gezondheidsaspecten. Alleen voor wat betreft dit laatste konden nadere voorschriften worden gegeven bij AMvB. Dit is gebeurd in 1923. ${ }^{179}$ Hoewel ook de zakelijke inhoud van deze wet weinig weerstand ondervond in het parlement is over éen bepaling in de Tweede Kamer uitvoerig gesproken. Dat betrof de verplichting van de werkgever om ook nadere schriftelijke voorschriften van het districtshoofd van de Arbeidsinspectie na te leven. Na uitvoerige debatten hierover stemde een aantal leden van de Tweede Kamer tegen de gehele wet omdat in de bovengenoemde bepaling een ongeoorloofde delegatie werd gezien en derhalve in strijd is met de Grondwet. ${ }^{180}$

\section{- Stuwadoorswet $1914^{181}$}

De commissie Rochussen had al geconstateerd dat bij het laden en lossen van schepen (stuwadoorsarbeid) te lange werktijden voorkwamen. ${ }^{182}$ In 1905 verscheen het pamflet 'een noodkreet' van de Algemene Havenarbeidersvereniging 'Streven naar verbetering.' In het pamflet werd onder meer gewezen op wantoestanden als geknoei bij de uitbetaling van lonen, te lange

175 Vastgesteld bij KB wan 26 jantari 1907 (S. 20).

176 Wet van 7 oktober 1911 (S. 315).

177 De Mv'T bij de ontwerp-Steenhouwerswet heeft deze gegevens overgenomen uit de "Statistiek van de sterfte onder de mannen, met onderscheiding naar het beroep en in verband met leeftijd en doodsoorzaken in de jaren 1896-1900", geciteerd bij Molenaar, Arbeidsrecht IIB, t.a.p. p. 1317.

178 Bedacht moet worden dat de Veiligheidswet 1895 in deze tijd nog weinig soelaas kon bieden, omdat zij alleen betrekking had op fabrieken of werkplaatsen met een krachtwerktuig of oven en war 10 of meer personen werkten. Hierdoor vielen de kleine steenhouwerijen, en dat waren de meesten, er buiten.

$179 \mathrm{~KB}$ van 23 juni 1923 ( $\$ .297$ ).

180 Over problemen van delegatie in het arbeidsomstandighedenrecht: zie noot 118. Met name over delegatie in de Steenhouwerswet, Molenaar I, p. 529-551.

181 Wet van 16 oktober 1914 (S. 486).

182 Zie noot 110. Op basis van de Arbeidswet kon niet worden opgetreden, omdat die immers toen (nog) niet voor volwassen mannelijke werknemers gold. 
werktijden en gebrek aan concrete veiligheidsvoorschriften. ${ }^{183} \mathrm{Naar}$ aanleiding van dit pamflet werden door de minister twee controleurs benoemd die een onderzoek terzake moesten instellen. Hiermee werd de basis gelegd voor de latere Inspectie van de Havenarbeid, ingesteld bij art. 17 van de stuwadoorswet. Hun rapportage bevestigde de al eerder openbaar gemaakte schokkende misstanden in de havenbedrijven. De in 1914 tot stand gekomen wet regelt zowel de veiligheidsaspecten als de arbeidsduur. Op deze punten zijn AMvB's uitgevaardigd inhoudende nadere voorschriften.

\subsection{De Ongevallenwet $1901^{184}$}

Al in 1894 pleitte de commissie Rochussen voor een wettelijke regeling ter voorziening in de financiële gevolgen van een aan de werknemer overkomen bedrijfsongeval. En ook over dit onderwerp werd in de troonrede van 1891, vooruitlopend op de resultaten van de bovengenoemde commissie gezegd: 'Maatregelen... tot verzekering van het lot van oude of verminkte werklieden zullen, naarmate het door de wetgever bevolen onderzoek vordert, worden ontworpen. ${ }^{185}$ In 1897 werd het eerste wetsontwerp ter zake van een verplichte ongevallenverzekering ingediend. En hoewel tussen alle belanghebbenden principiële overeenstemming bestond over een wettelijke regeling omdat het langer uitblijven ervan in strijd zou zijn met het rechtsbewustzijn, zoals de MvT het uitdrukte, duurde het toch tot 1901 voor de wet tot stand kwam. ${ }^{186}$ Dit kwam vooral door de heftige meningsverschillen over de wenselijkheid om de uitvoering over te laten aan de Rijksverzekeringsbank tussen werknemers en regering enerzijds en werkgevers anderzijds. "Van de regering: dat het particulier initiatief was tekort geschoten in het treffen van adequate maatregelen en dat deze omstandigheid haar deswege wel gedwongen had de uitvoering van de wet bij de Rijksverzekeringsbank te concentreren. Van de werkgevers: dat dit standpunt van de overheid getuigde van onjuiste, althans onwoldoende erkenning en waardering van hetgeen door de industrie eigener beweging in samenwerking met het verzekeringswezen reeds tot stand was gebracht, meer nog, doorbreking betekende van een positieve ontwikkeling, verstoring van de onontbeerlijke samenwerking van werkgevers en werknemers ten gevolge

183 A.N. Molenaar, Arbeidsrecht IIB, t.a.p. p. 1327.

184 Wet wan 2 januari 1901 (S. 1 ).

185 Geciteerd bij Levenbach, Nederlands Bestuursrecht III, t.a.p. p. 543.

186 Zeer uitwoerig over deze totstandkoming, met name over de rol van werkgevers en werknemers: W. de Vries, Wzn. De totstandkoming van de Ongevallenwet 1901, De inwloed wan werkgevers en werknemers op de eerste sociale werzekeringswet in Nederland, Deventer. 1970, voorts A.N. Molenaar, Arbeidsrecht IIB, t.a.p. p. 1524-1599, M. G. Levenbech, Nederlands Bestuursrecht III, t.a.p. p. 543-544, T. Koopmans, t.a.p. p. 20-26, A.J.C.M. Geers, J.K.M. Gevers, t.a.p. p. 136-140. 
zou hebben en de industrie op kosten zou jagen die haar concurrentiepositie op de internationale markt in gevaar zou brengen. ${ }^{.187}$

Op basis van de uiteindelijk in 1901 tot stand gekomen Ongevallenwet kregen de werknemers in de meest gevaarlijke industrieën bij een ongeval in verband met hun dienstbetrekking een vordering op de Rijksverzekeringsbank. De uitkering bedroeg hoofdzakelijk een gedeelte van het gederfde loon, met een maximum van $80 \%$. De werkgever verzekerde en betaalde de premie aan de genoemde bank. Om er zeker van te zijn dat de werkgevers inderdaad zouden betalen en om te voorkomen dat zij daardoor in een ongunstigere concurrentiepositie zouden komen, werd de verzekering bij de wet verplicht gesteld. Dit leerstuk van het bedrijfsrisico of 'risque professionel' werd de rechtsgrond van de Ongevallenwet. Weijel merkt op dat de discussie over het 'risque professionel" als rechtsgrond geheel ontdaan was van politieke tegenstellingen, van opvattingen over de verhouding van kapitaal en arbeid, en dat het niets meer te maken had met klassenstrijd of socialisatie. 'Integendeel, men zag het geheel als een juridisch probleem en wel van de verplichtingen van werkgever tegenover werknemer in hun arbeidsovereenkomst. Men kan stellen... dat de heftige emoties over de klassenstrijd gekanaliseerd werden in een veel abstractere discussie over wat nu de juridische fundamenten moesten zijn van een klein stukje sociale wetgeving. Het sociale leerstuk van de klassetegenstelling was impliciet aanvaard, maar men sprak daar niet meer over; waar men over sprak was een verschoven probleem, psychologisch was de conflictstof afgevoerd. '188 Mij dunkt dat deze opmerkingen in een aantal opzichten ook van toepassing zouden kunnen zijn op de totstandkoming van sommige arbeidsbeschermende wetten. Zie in dit verband bijvoorbeeld de heftige reactie van minister Aalberse op de suggestie dat de totstandkoming van de Arbeidswet 1919 mede veroorzaakt zou kunnen zijn door de tot klassentegenstellingen terug te voeren onlusten in die tijd (paragraaf 3.5 van dit hoofdstuk).

In ruil voor zijn aanspraak op een uitkering van de Rijksverzekeringsbank moest de werknemer echter zijn civielrechtelijke aanspraken - behoudens enkele uitzonderingen - krachtens art. 87 van de Ongevallenwet laten vervallen. Weliswaar was de werknemer in bepaalde industrieën nu zeker van een schadevergoeding bij een bedrijfsongeval, aan de andere kant beliep deze met name bij ernstige ongevallen slechts een deel van de totale schade. Deze korting op de rechten van de werknemers was door minister Cort van der Linden verdedigd met het argument dat, naast een omvattende publiekrechtelijke regeling, voor een privalatrechtelijke regeling geen plaats was en dat men naast de zware last die de nieuwe wet op het bedrijfsleven legde, niet ook nog de last die er ingevolge het privaatrecht op rustte, kon laten liggen. Tenslotte meende hij "dat deze nieuwe wet zal strekken tot pacificatie en de onaangename hate-

187 W. de Vries Wzn., t.a.p. p. 3. Het rumoer rond het uitwoeringsorgaan voor de Ongevallenwet was een belangrijke aanleiding voor de oprichting van de Vereeniging van Nederlandsche Werkgevers in 1899. W. de Vries Wzn., t.a.p. p. 153.

188 J. Weifel, Achtergronden van Sociale Zekerheid, Amsterdam 1973, p. 39. 
lijke processen tussen werkman en werkgever uit de wereld zal helpen'. 189 Geschillen over de Ongevallenwet werden behandeld door een bij de Beroepswet ingestelde nieuwe administratieve rechter. In eerste instantie waren dat de Raden van Beroep, met leken-rechters, in appel de Centrale Raad van Beroep.

\subsection{Het Burgerlijk Wetboek}

Vóór de Kinderwet Van Houten (1874) bestond er nauwelijks enige wettelijke regeling met betrekking tot de arbeidsverhoudingen. Het Burgerlijk Wetboek van 1838 kende slechts drie artikelen die handelden over de arbeid die in afhankelijkheid werd verricht. Illustratief voor hun betekenis waren zij te vinden in de zevende titel van boek II dat handelde over de huurovereenkomst. De schrielheid van de wetgever is te verklaren doordat de industriële loonarbeid in Nederland nog niet tot ontwikkeling was gekomen en omdat ook de Code Napoléon (het grote voorbeeld) slechts een uiterst magere regeling inhield. En dat kwam weer omdat in het Romeinse recht vrijwel niets te vinden was over afhankelijke arbeid. ${ }^{190}$ Behalve door schrielheid werd de regeling ook gekenmerkt door de (processuele) voordelen die aan 'de meester' werden geboden. Een en ander betekende dat het slachtoffer van een bedrijfsongeval tegen een werkgever geen andere aanspraken had dan op grond van de algemene onrechtmatige daadsartikelen 1401-1403 BW. ${ }^{191}$ Als men zich realiseert dat het begrip onrechtmatig toen nog zeer beperkt werd uitgelegd, dat de bewijslast geheel op het slachtoffer rustte en dat 'de weg naar het recht' voor de minder bedeelden zo goed als onbegaanbaar was, dan is duidelijk dat vóór de totstandkoming van de Ongevallenwet de lasten van ziekte, invaliditeit en dood in de praktijk vaak geheel op de werknemer en diens nabestaanden rustten. De werknemer had zich bij overeenkomst nu eenmaal verbonden tot het verrichten van het werk, inclusief het daaraan verbonden risico. In het loon waren die risico's als het ware verdisconteerd. Was het werk gevaarlijk dan moest de werknemer maar een hoger loon bedingen. ${ }^{192}$ Het kwam er op neer

189 B. Clausing, Aansprakelijkheid van werkgever en derden, in het bijzonder tegen de ongevalsgetroffene in de Ongevallenwet en in het ontwerp WAO, SMA, 1964, p. 407-408.

190 VgI J. Valkhoff, t.a.p. p. 84-85, T. Koopmans t.a.p. p. 5.

191 Ten aanzien van schepelingen gold een afzonderlijke regeling. Krachtens art. $423 \mathrm{WvK}$ behielden zij als zij gedurende de reis ziek of gewond raakten hun huur en waren zij "gerechtigd tot oppassing en genezing en, ingeval van verminking, tot schadeloosstelling op zodanige voet en op zodanige wijze als de rechter, in geval wan verschil, zou beoordelen te behoren". Voorts gold nog een speciale regeling in de Spoorwetgeving (Wetten van 21 augustus 1859 ( $S$. 98) en van 9 april 1875 (S. 67)), op grond waarvan ondernemers van spoorwegdiensten verantwoordelijk waren woor de schade, door personen (bedoeld was: reizigers) of goederen bij de uitaefening van de dienst geleden, tenzij de schade buiten hun schuld of die van thun ondergeschikten was ontstaan.

192 Ten aanzien van beroepsziekten is dit nog in de $20 \mathrm{e}$ eeuw in de jurisprudentie terug te vinden. Ktg. Amsterdam, 27-11-1922 (Recht. Besl. Arb. ovk. XI, nr. 3 en 4): 'Schadelijke gevolgen die voor de arbeider voortvloeien uit een gevaarlijk bedrijf of beroep komen in het algemeen 
dat de werknemer alleen in geval van ondubbelzinnige schuld van de werkgever of een collega-werknemer vergoeding voor de geleden schade kon krijgen, gesteld althans dat hij alle bovengenoemde barrières wist te overwinnen. ${ }^{193}$

In 1891 kreeg H.L. Drucker de opdracht om een nieuwe wettelijke regeling voor de arbeidsovereenkomst te maken. In 1894 was hij hiermee gereed en in 1907 kwam de nieuwe wettelijke regeling tot stand. ${ }^{194}$ Valkhoff: 'Deze wettelijke regeling was, voor een groot deel althans, de juridische formulering van de nieuwe sociale verhoudingen, zoals die door de veranderingen in de wijze van produceren reeds in het maatschappelijk leven ontstaan waren. Zij was voor een deel een neerslag van hetgeen er in ons land na 1870, in de $19^{\circ}$ eeuw derhalve, reeds gegroeid was.' 195

Overigens betekende dit niet dat de regeling van de arbeidsovereenkomst geen weerstand ontmoette. Deze kwam zowel van de kant van de werkgevers als van de werknemers. Beiden zagen hun vrijheid van handelen bedreigd. In 1904 kwam zelfs een 'Comité van Actie tegen het Arbeidscontract' tot stand, waarvan SDAP, ANWV en de moderne vakbonden deel uitmaakten. ${ }^{196}$ De mening van de werkgevers werd door de Maastrichtse industrieel Regout in de Eerste Kamer als volgt verwoord: 'Dit wetsontwerp met zijn vele onpractische, plaagzieke, wantrouwen kwekende bepalingen die doorkneed zijn met een geest van een eenzijdigheid tegen alles wat werkgever heet, moet ongetwijfeld belemmerend werken op het initiatief en den ondernemingsgeest, niet van onverschillige, maar juist van goedgezinde werkgevers. ${ }^{197}$

Een van de nieuwe verplichtingen voor de werkgevers had betrekking op de veiligheid en de gezondheid van de werknemers. Het betrof het huidige art. $1638 \mathrm{x}$ dat spreekt over de verplichting van de werkgever om de werknemer te beschermen tegen gevaar voor lijf, eerbaarheid en goed. Zijn die verplichtingen niet nagekomen dan is de werkgever gehouden de schade te vergoeden die de werknemer deswege tijdens zijn werk is overkomen. De bepaling is van dwingend recht. Oorspronkelijk wilde minister Loeff art. 1638x niet in het BW opnemen omdat het hier zaken zou betreffen van "publiekrechtelijk karakter" en van 'burgerzin en naastenliefde'. Later nam hij de bepaling alsnog in het ontwerp op omdat, zo luidde zijn argumentatie, het BW nu eenmaal wel meer publiekrechtelijke zaken regelde. ${ }^{198}$

Ook bij de behandeling in de Tweede Kamer was een van de voornaamste

$\rightarrow$

te zijnen laste. De zogenaamde beroepsziekten zijn een risico voor het bedrijf dat geen grond geeft tot een burgelijke vordering tot schadevergoeding van den arbeider tegenover den ondernemer.

193 In de praktijk werd door de werknemer die getroffen was door een bedrijfsongeval, dan ook nawelijks gebruik genaakt van de mogelijkheid om een civiele actie in te stellen tegen zijn werkgever. Vgl. Hacke, Veiligheid bij den arbeid, t.a.p. p. 41, W. de Vries Wzn, de totstandkoming van de Ongevallenwet 1901 , t.a.p. p. 12.

194 Wet van 13 juli 1907 (S. 193).

195 Valkhoff, t.a.p. p. 86-87.

196 Hierover: Harmsen/Reinalda, t.a.p. p. 105-107 en Valkhof, t.a.p. p. 87-88.

197 Geciteerd bij A.E. Bles, De Wet op de Arbeidsovereenkonst, Den Haag 1907-1909, deel I, p. 70 .

198 A.E. Bles, deel III, t.a.p. p. 283-294. 
bezwaren dat het hier een regeling betrof die eigenlijk in het publiekrecht thuishoorde en daar - in de Veiligheidswet -- dan ook al geregeld was. De Savornin Lohman in de Tweede Kamer: 'Men heeft m.i. terecht aangenomen dat de wetgever of, krachtens de wet, de openbare macht beslissen moet welke eischen voor de veilugheid gesteld moeten worden. Wanneer aan die eischen niet voldaan wordt, moet de strafrechter tusschen beiden komen. Om nu daarnaast, alsmede om voor een geheel andere groep een geheel andere verantwoordelijkheid op dien werkgever te leggen, schijnt mij niet gerechtvaardigd, ${ }^{1999}$ Minister Van Raalte en het overgrote deel van de Kamer meenden echter dat, waar het hier de burgerrechtelijke verhouding tussen partijen betrof, het artikel wel degelijk een plaats diende te hebben in de regeling van de arbeidsovereenkomst.

Een tweede bezwaar betrof de overbodigheid van de bepaling omdat deze verplichting immers al uit het 'gemene' burgerlijk recht zou voortvloeien (art. 1375) of in elk geval uit art. $1638 \mathrm{z}$ (het goede werkgeversartikel). Drucker, die de minister terzijde stond tijdens de behandeling, gaf als argument waarom, naast de andere bepalingen in het $\mathrm{BW}, 1638 \mathrm{x}$ toch een plaats verdiende, het volgende voorbeeld. ' $\mathrm{Er}$ is in Nederland een rechtscollege geweest, een van de aanzienlijkste, wel niet in hiërarchischen zin, maar toch een rechtscollege van grooten invloed, waarvoor veel geprocedeerd wordt en waarvan de samenstelling zorgvuldig pleegt te worden overwogen. Dat college had een werkman voor zich, die een patroon in rechte aansprak wegens het niet nakomen van een beweerde verplichting. Men kan de zaak vinden in het Weekblad van het Recht nr. 5546. Dat rechtscollege heeft toen zeer in het algemeen beslist, dat over al dergelijke beweringen van den arbeider niet behoeft gepraat te worden, want zegt die rechtbank, het staat er letterlijk, 'de eenige praestatie, waartoe de huurder van diensten gehouden is, bestaat in de uitbetaling van het overeengekomen loon'. En toen stond art. 1375 ook al in het BW!'200 Enige onduidelijkheid bestond er in de Kamer over de vraag of de beperking van de civielrechtelijke aanspraken ten gevolge van de Ongevallenwet nu ook zou gelden ten aanzien van art. 1638x. Hierover was minister Van Raalte duidelijk. Om elke twijfel op dit punt weg te nemen werd aan art. $1638 \mathrm{x}$ toegevoegd. . 'alles behoudens de bepalingen van Hoofdstuk XII der Ongevallenwet $1901,20 !$

199 A.E. Bles, deel III, t.a.p. p. 297.

200 A.E. Bles, deel III, t.a.p. p. 309.

Ook van der Grinten twijfelt om dezelfde als in de tekst genoemde redenen aan het nut van art. $1638 \mathrm{x}$. Een uitzondering lijkt hij te willen maken woor het derde lid, dat bepaalt dat de aansprakelijkheid wan de werkgever door partijen niet kan worden uitgesloten. Volgens het gemene recht zou een dergelijke uitsluiting niet in zich ongeoorloofd zijn. W.C.L. van der Grinten, De goede werkgever en de goede arbeider, in Hedendarags Aibeidsrecht (Levenbach-bundel), Alphen a/d Rijn 1966, p. 141 .

201 De minister zelf gaf aan hoe men tot de conclusie zou kunnen komen, dat art. 1638x wèl in alle gevallen toepassing zou kunnen vinden: 'De Wet op het Arbeidscontract is van latere datum dan de Ongevallenwet; an de Ongevallenwet zal dus door eerstgenoemde wet worden gederogeerd, voor zoover betreft de toepassing van art. 1638x... maar: De Ongevallenwet moet blijven primeeren.' A.E. Bles, deel III, t.a.p. p. 303. 
Omdat hierdoor art. $1638 \mathrm{x}$ een sluimerend bestaan heeft geleid tot 1967 toen de Ongevallenwet vervangen werd door de WAO, heeft de rechtsontwikkeling van dit artikel in tegenstelling tot vele andere bepalingen over de arbeidsovereenkomst, tot het genoemde jaar vrijwel stil gestaan. (In het volgende hoofdstuk wordt uitvoeriger ingegaan op de betekenis voor de werknemer van dit artikel na 1967).

Tot slot dient gememoreerd te worden dat art. $1637 \mathrm{n}$ een eerste summiere, wettelijke basis gaf voor de sinds circa 1900 voorkomende CAO, waarin soms ook bepalingen ten aanzien van de arbeidsomstandigheden waren opgenomen. ${ }^{202}$

\section{Enkele beschouwingen over de periode tot 1919}

Met het vredesverdrag van Versailles na de eerste wereldoorlog trad ook Nederland definitief de twintigste eeuw binnen. Maar het jaar 1919 kan ook in andere opzichten als de afsluiting van een periode worden beschouwd. Niet alleen had de introductie van de sociale wetgeving de overheid van gezicht doen veranderen, maar ook was het algemeen kiesrecht ingevoerd, was de financiële gelijkstelling van het bijzonder en het openbaar onderwijs tot stand gekomen en was de sociale politiek geïnstitutionaliseerd in een departement van Arbeid, Handel en Nijverheid met als eerste minister de katholiek P.J.M. Aalberse..$^{203}$ In 1.91 .9 stelde hij het eerste formele samenwerkingsorgaan tussen werkgevers en werknemers in: de Hooge Raad van Arbeid, die de regering op haar verzoek moest adviseren over aangelegenheden de arbeid betreffende. ${ }^{204}$ Bovendien was Nederland geïndustrialiseerd en de verzuiling leek al definitief te zijn geworteld. Dit gold bijvoorbeeld ook voor de in de voorafgaande jaren van de grond gekomen arbeidsbeweging. Sociale hervormingen waren gekomen, de revolutie, misschien juist daardoor, niet. In elk geval waren bij de eerste verkiezingen met algemeen kiesrecht in 1918 niet de socialisten de winnaars, in tegenstelling tot de verwachtingen, maar de katholieken. Ook in dat opzicht was het optreden van de eerste katholieke minister-president Ch. Ruys de Beerenbrouck jr. de afsluiting van een periode, en tevens het begin van een nieuwe, waarvan de kenmerken tot op heden een grote continuïteit vertonen - en niet alleen voor wat betreft de politieke kleur van de ministerpresident.

Terugziende op de besproken periode, met vooral het oog gericht op de relatie maatschappelijke en economische ontwikkeling, overheidsoptreden en de positie van de te beschermen werknemers valt het moeilijk om juist hierover

202 Over de CAO vóór 1919: T, van Peype, t.a.p. p. 97-99. In 1910 waren er 46 CAO's, in 1914 en in 1918 923, Van Peype, t.a.p. p. 99. Brugmans noemt echter voor 1914 een aantal van 290. Brugmans, Paardenikracht, t.a.p. p. 418.

203 Vgl. A.L. Scholtens e.a., Het Departement van Arbeid, Handel en Nijverheid onder minister Aalberse, 1918-1925, Alphen a/d Rijn 1926.

204. KB van 4 oktober 1919 (S. 591). 
eenduidige uitspraken te doen. Dit geldt al in de eerste plaats bij een poging om te analyseren welke factoren nu hebben bijgedragen tot de totstandkoming van de arbeidsbeschermende wetgeving. Vast staat dat die moet worden gezien tegen de achtergrond van de toenemende industrialisatie. Maar hieruit kan bijvoorbeeld niet afgeleid worden dat vóór de periode van industrialisatie de noodzaak hiervoor niet aanwezig was: ook vóór 1870 kwam uitbuiting en vrouwen- en kinderarbeid voor.

Wanneer in de literatuur gesproken wordt over de factoren die een rol hebben gespeeld bij de totstandkoming van de eerste arbeidsbeschermende wetgeving lijken de standpunten nogal eens eenzijdig te zijn ingekleurd, waarschijnlijk mede afhankelijk van de professie van de schrijvers (zo ligt het voor de hand dat juristen in het algemeen méer de nadruk leggen op het formele proces van wetgeving en de rol van kabinet en parlement daarin dan historici) en wellicht ook van hun visie op wat zij wenselijk of geboden achtten. Een voorbeeld van twee uitersten. A.N. Molenaar benadrukt zeer sterk de rol van de overheid, met name van de liberale parlements- en kabinetsleden en minimaliseert de rol van de arbeiders en de socialistische voormannen. De stem van het geweten van deze liberale voormannen was hun belangrijkste drijfveer ${ }^{205}$ Henriëtte Roland Holst ziet dit geheel anders. Weliswaar was het de 'bourgeoisie' die zich verwaardigde een 'schijnstoot' te doen, maar 'de uitbreiding der Internationale door Europa, haar korte verschijning in Nederland, de donderslag der Parijsche Kommune, en ... de agitatie van het Alg. Ned. Werklieden-Verbond waren noodig om de paskwillige wet van Houten tot stand te brengen... 206 Vier groepen kunnen in elk geval onderscheiden worden die een rol hebben gespeeld. Vooral in de eerste fase waren dat de progressieve liberalen en het (vooral ook: hun) Comité ter bespreking van de Sociale Quaestie. Het kamerlid van Houten speelde hierbij een belangrijke rol. De invloed van deze liberale stroming werd overigens niet in hoofdzaak bepaald door de fractie in het parlement, maar door een aantal - vooral grotere-ondernemers. Zij werden ongetwijfeld gedreven door medeleven met de slachtoffers van de industriële ontwikkeling, maar even ongetwijfeld ook door de angst dat radicale stromingen (de Internationale) vaste voet zouden krijgen. Bovendien bood een zwakke (fabrieks)bevolking weinig perspectief bij de nog steeds toenemende industrialisatie. De slechte arbeidsomstandigheden vormden dus een bedreiging van de toekomstige welvaart. ${ }^{207}$ Het waren derhalve zowel politiek/maatschappelijke, ethische en economische motieven die bij deze groep een rol speelden. Het is duidelijk dat het vrijwel onmogelijk is om te zeggen in welke relatie deze motieven tot elkaar stonden en wat uiteindelijk van doorslaggevende betekenis is geweest. Dat verscheidene motieven tegelijkertijd een rol kunnen spelen, ook bij een persoon, lijkt daarnaast niet onwaarschijnlijk. Zo

205 A.N. Molenaar, Arbeidsrecht I. t.a.p. vooral p. 277-279 en p. 317-320.

206 Henriëtte Roland Holst, Kapitaal en Arbeid, t.a.p. p. 188.

207 Hierover ook: E. Tinga, in een verslag van de discussie over J. J.M. van der Ven's Rechtssociologische Aantekeningen bij de Arbeidswet 1919, SMA, 1958, p. 629. 
heeft J. Mannoury zeer aannemelijk gemaakt dat bij Van Houten zijn inspanningen voor de Kinderwet voor een groot deel ingegeven waren door publicitaire overwegingen: zijn kamerzetell stond op het spel. ${ }^{208}$

Een tweede groep werd gevormd door diverse individuele personen die soms, maar vaak ook niet bij de eerste groep hoorden. Gemeenschappelijke kenmerken van de leden van deze groep vormden vooral hun publicitaire activiteiten. Het ging om medici, literatoren, journalisten, onderwijzers, en anderen. $\mathrm{Bij}$ hen stond mededogen en verontwaardiging op de eerste plaats.

Een derde groep werd gevormd - maar later - door de werknemers zelf. Ten tijde van de opkomst van de industrie waren zij nog nauwelijks georganiseerd. De eerste arbeidersorganisatie (ANWV) opereerde feitelijk onder de vleugels van de liberalen. Met de groei van het klassebewustzijn, de organisatiegraad en de verruiming van het kiesrecht kon hun stem ook beter doorklinken in het parlement. Zij wilden ook verder gaan dan de liberalen. Naast bescherming werd door hen vanaf het begin een wetgeving beoogd die ook kansen moest bieden voor ontplooiing.

Een vierde groep, maar nog later, vormde de overheid, vooral via de ambtenaren die met het toezicht waren belast. Nadat de eerste ambtenaren van de Arbeidsinspectie eenmaal waren begonnen, gaf hun rapportage over de wantoestanden en de weigerachtige reacties van de werkgevers om er iets aan te doen vaak de nodige impulsen om tot wetgeving te komen, vooral op specifieke terreinen.

Er waren natuurlijk ook tegenkrachten. In de eerste plaats waren dat die ondernemers die, vooral op korte termijn redenerend, meenden dat de arbeidsbescherming méér kosten met zich meebracht. Veiligheidsmaatregelen kostten geld en kinderen waren goedkoper dan volwassenen.

Daarnaast waren er de algemeen levende opvattingen over de arbeidsverhoudingen die sterk in het teken stonden van het formele gelijkheidsbeginsel en de angst voor staatsbevoogding. De arbeidsovereenkomst tussen werkgever en werknemer was in deze opvatting een vrijwillig gesloten overeenkomst tussen twee gelijkwaardige partners. De overheid diende zich hier niet mee te bemoeien. Dat remde zowel de ontplooiling van de onderneming als van de werknemers. Deze argumenten speelden ook in het parlement een rol. Later ging het niet meer zozeer over de principiële vraag of, maar over de meer praktische vraag hóe ver de overheid zou mogen gaan bij interveniërend optreden in de arbeidsverhoudingen. ${ }^{209}$

Tot slot waren daar de opvattingen van de confessionelen die vonden dat overheidsingrijpen pas dan geboden was als de zedelijke krachten in de maatschap-

208 J. Mannoury, Honderd jaar na de Kinderwet 1874, SMA, 1974, p. 353-369.

209 In twee artikelen in het Sociaal Weekblad in 1911 onderzoekt H.J. Tasman of daar een leidend beginsel, althans voor het gebied van de sociale wetgeving, voor is te formulteren. Uiteindelijk moet volgens hem toch de weg van een bepaalde worm van opportunisme gekozen worden, "opdat niet in de praktijk voor theoretische beginselvastheid practische beginselloosheid in de plaats trede. "H.J. Tasman, De grenzen der sociale wetgeving, Sociaal Weekblad, 1911, p. 169-171 en p. 185-187, citaat op p. 171 . 
pij te kort zouden schieten. (In katholieke kring werd dat overigens eerder gevonden dan in protestants-christelijke kringen, met name onder invloed van en na de encycliek Rerum Novarum van Leo XIII van 1891).

Het moge duidelijk zijn dat uit deze - weliswaar kort weergegeven - mélange van tegenstrijdige opvattingen, divergerende motieven en verschillen en verschuivingen in politieke en maatschappelijke machtsverhoudingen geen heldere en eenduidige regelgeving geïndiceerd is. En dat was dan ook niet het geval. Vooral de eerste maatregelen moesten bevochten worden op principiële geheelonthouders. Het resultaat was wetgeving met, zeker in verhouding tot het beoogde doel, veel voorbehouden, uitzonderingen en onduidelijke bepalingen. Weliswaar werden de werkgevers enigszins beperkt in hun feitelijk beslissingsbevoegdheid over wie ze in dienst konden nemen en over de voorwaarden waaronder dan gewerkt moest worden, maar van een wezenlijke aantasting van deze bevoegheid ten faveure van gehumaniseerde werkomstandigheden kon op basis van deze wetgeving nog geen sprake zijn.

De wetgeving was bovendien uitsluitend gericht op de bescherming van de fysieke arbeidsomstandigheden van de werknemers. Aan de context, de sociaal-culturele infrastructuur waarbinnen dat gerealiseerd zou moeten worden, werd door de wetgever nauwelijks aandacht geschonken. De werknemer speelde in dit soort wetgeving, behalve als een te beschermen object, dan ook nauwelijks enige rol. (Een uitzondering moet gemaakt worden voor de hierboven beschreven rol van werknemers als controleurs van de arbeid (Arbeidswet) of als betrokkenen bij de controle op de naleving van de Mijnwet). De werkgever was de adressant en hij was in beginsel aansprakelijk woor de overtreding van de regels. Een aansprakelijkheid die voor de meesten slechts theoretisch was. Dit gold zowel de strafrechtelijke aansprakelijkheid wegens de gebrekkige handhaving van de voorschriften door de overheid, als de civielrechtelijke wegens de praktische en juridische barrières die werknemers moesten nemen bij een eventuele procedure.

Niet alleen had de werknemer geen verplichtingen, er was ook nauwelijks sprake van rechten, bijvoorbeeld op zeggenschap, op invloed, of zelfs maar op informatie. De enige rechten waarvan eventueel sprake zou kunnen zijn, vloeiden voort uit hetzij de arbeidsovereenkomst (vooral na 1909 met name genormeerd door het $\mathrm{BW}$ ) of de $\mathrm{CAO}$. Gezien de overigens uiterst afhankelijke positie van de meeste werknemers waren ook deze moeilijk tot gelding te brengen.

Het oordeel over effectiviteit van de eerste arbeidsbeschermende wetgeving althans gemeten aan de doelstelling ervan moet negatief luiden. De inhoud van de wetgeving, de gebrekkige handhaving ervan, de houding van veel werkgevers en de onmacht - en soms onwil - van de werknemers hebben ertoe bijgedragen dat de erbarmelijke arbeidsomstandigheden - zeker in het begin - niet veranderd werden, en later hooguit gemitigeerd. De betekenis van deze eerste wetten was vooral gelegen in het feit dàt de overheid ging ingrijpen. ${ }^{210}$ 
Zij veroorzaakten niet een ingrijpende verandering in de vigerende machtspatronen binnen de onderneming waardoor de werknemer een zelfstandig, in de praktijk ook waar te maken recht verkeeg op humane arbeidsomstandigheden. In het licht van die tijd en van de toen bestaande maatschappelijke verhoudingen zou dat overigens ook een te hooggespannen verwachting zijn.

\section{De periode $1919-1940$}

De periode tussen de beide wereldoorlogen wordt voor wat betreft wetgevende activiteiten op het gebied van de arbeidsomstandigheden gekenmerkt door een zekere pas op de plaats. De belangrijkste wet bleef de Veiligheidswet 1895 , die pas in 1939 vervangen werd door de inwerkingtreding van de Veiligheidswet 1934. ${ }^{211}$ Tot de inwerkingtreding van (een groot deel van) de Arbowet in 1983 bleef deze wet de belangrijkste op het gebied van de veiligheid en gezondheid van de werknemers. In deze paragraaf zal eerst aan de Veiligheidswet 1934 aandacht worden geschonken en vervolgens aan enkele andere relevante regelingen.

\subsection{De Veiligheidswet 1934}

De Veiligheidswet 1895 beoogde alleen de beveiliging bij het verblijf in fabrieken en werkplaatsen. Volgens de MvT bij het in 1931 ingediende ontwerp voor een nieuwe Veiligheidswet waren de gevaren voor bedrijfsongevallen en beroepsziekten bij de arbeid buiten de fabrieken of werkplaatsen echter, door de sterk toegenomen toepassingen van de techniek, veelvuldig aanwezig. Nu zou de beveiliging tegen deze nieuwe gevaren, verbonden aan bepaalde soorten van arbeid, telkens bij afzonderlijke wet kunnen worden geregeld, maar die methode werd in de MvT 'tijdrovend' en in de toepassing 'omslachtig' genoemd. ${ }^{212}$ Het ontwerp beoogde dus in hoofdzaak uitbreiding van de werkingssfeer van de veiligheidswetgeving; de herziening van de bestaande bepalingen van de Veiligheidswet 1985 nam een ondergeschikte plaats in. In art. 1 wordt het begrip 'arbeid' geïntroduceerd. Arbeid heeft betrekking op alle werkzaamheden in een onderneming, behalve die welke verricht worden door

210 J.J.M. van der Ven, mede als reactie op het in de tekst genoemde citaat van Henriëtte Roland Holst: 'Inderdaad had het (de Kinderwet Van Houten, AG) kwantitatief heel weinig te betekenen, maar tegelijk was het kwalitatief de verdringing van strikt individualistisch-liberalistisch denken op het ganse terrein van arbeid-kapitaal-staat door sociale bewogenheid en door medeverantwoordelijkheid wan de staatsoverheid. Het was immers het startschot woor wat wel geen edele wedloop, maar dan toch een markante beweging naar de hedendaagse arbeidswetgeving is geworden.' J.J.M. van der Ven, Voortgang en Stilstand van het arbeidsrecht, in: Hedendaags Arbeidsrecht (Levenbach-bundel), Alphen a/d Rijn 1966, p. 349.

211 Wet van 2 juli 1934 (S. 352). Voor een groot deel in werking getreden met ingang van 1 januari 1939 bij $\mathrm{KB}$ van november 1938 ( $\mathrm{S}$. 886).

212 Bijlage bij de Handelingen TK 1931-1932, 217, nr. 3 (Memorie van Toelichting), p. 7. 
het hoofd of de bestuurder of diens echtgenote. In de wet worden afzonderlijke paragrafen gewijd aan de beveiliging van de arbeid in de landbouw, bij het vervoer te water met binnenschepen en bij het laden en lossen daarvan, aan boord van boten in de zeevisserij en bij het gebruik van loodhoudende stoffen bij het schilderwerk. In art. 9 wordt bovendien bepaald dat bij AMvB veiligheidsvoorschriften kunnen worden gegeven bij arbeid die niet wordt verricht in fabrieken of werkplaatsen of die niet genoemd wordt in de hierboven bedoelde paragrafen, en wel over dezelfde onderwerpen als aangegeven in art. 7 met betrekking tot fabrieken en werkplaatsen. Hierdoor kan dus telkens wanneer dat nodig is regelend worden opgetreden, zonder dat daarvoor een nieuwe wettelijke regeling nodig is.

Enige nadere aandacht verdient de positie van de werknemers. Op drie manieren is deze positie in het kader van de Veiligheidswet 1934 expliciet aan de orde. In de eerste plaats betreft dat zijn strafrechtelijke aansprakelijkheid, in de tweede plaats zijn deelname aan de veiligheidscommissies en in de derde plaats zijn eventuele rol bij de controle van de wettelijke voorschriften.

In de artt. 7 zesde lid, 9 zesde lid, 12 vijfde lid, 13 vijfde lid en 17 vijfde lid van de Veiligheidswet 1934 komen vrijwel eensluidende bepalingen voor die in het kort hierop neerkomen dat een arbeider die arbeid verricht, waarop een nader aangeduid voorschrift of eis betrekking heeft, verplicht is dat voorschrift of die eis na te leven, voor zover hij redelijkerwijze kan worden geacht met dat voorschrift of die eis bekend te zijn. Bij het niet nakomen van die verplichting kan de betreffende werknemer strafrechtelijk vervolgd worden (art. 31 eerste lid). Dergelijke bepalingen waren niet helemaal nieuw. De strafbaarstelling van de werknemer was voor het eerst opgenomen in de (in 1931 herziene) Stuwadoorswet, ten aanzien van een overtreding van een eis of voorschrift door een havenarbeider (art. 12 zevende lid, art. 20 tweede lid). ${ }^{213}$

Volgens de MvT bij de Stuwadoorswet 1931, later herhaald in de MvT bij de Veiligheidswet 1934, leek het 'helaas' nodig om sommige arbeiders in hun eigen belang en dat van hun mede-arbeiders te dwingen de te hunner beschikking gestelde veiligheidsmiddelen te gebruiken en andere in het belang van hun veiligheid en gezondheid gestelde voorschriften na te leven. De voorgestelde voorziening was alleen bedoeld voor die gevallen, waarin de werkgever al het mogelijke had gedaan om de wet na te leven, maar de werknemer nalatig bleef om de daartoe onmisbare medewerking te verlenen. Voor zijn strafbaarheid was echter wel nodig dat hij redelijkerwijze kon geacht worden met het voorschrift of de eis, waarvan overtreding plaats had, bekend te zijn. Ook wanneer de werknemer aansprakelijk kon worden gesteld bleef op de werkgever (of het toezichthoudend personeel) de plicht rusten om alles te doen, wat in redelijkheid gevorderd kon worden om de naleving der voorschriften en eisen in het belang van de veiligheid en de gezondheid te verzekeren. ${ }^{214} \mathrm{Bij}$ de behandeling in de Tweede Kamer werd erop gewezen dat, hoewel de arbei- 
dersorganisaties die de Hooge Raad van Arbeid terzake hadden geadviseerd, accoord waren, deze bepaling toch zeer voorzichtig moest worden gehanteerd. Immers: 'In den tegenwoordigen tijd, met zijn stukloonsysteem en zijn rationalisatie, waarin van den arbeider dikwijls het uiterste wordt verlangd, komt de arbeider, om aan een redelijk loon te komen of om de taak te vervullen, die de werkgever van hem wenscht, wel eens in de verleiding bepaalde veiligheidsmaatregelen, die op zichzelf goed zijn, niet in acht te nemen, omdat hij anders misschien tot een te geringe productie komt." De toenmalige minister van sociale zaken Slotemaker de Bruine, was het daar 'natuurlijk' mee eens. ${ }^{215}$

Ruim tien jaar eerder werd over een eventuele strafbaarstelling van de werknemer nog volstrekt anders gedacht. Nadat volgens het Voorlopig Verslag bij het ontwerp Arbeidswet 1919 deze zaak aan de orde was gesteld, wees minister Aalberse deze strafbaarstelling in de MvA resoluut van de hand in verband met de economisch zwakkere en afhankelijke positie van de werknemer. Ondanks de toenemende kracht der vakbewegingen vond hij dat 'het aanhangige wetvoorstel zijns inziens historisch en feitelijk nog staat in het teeken van de bescherming der economisch zwakken'. Enigszins in strijd hiermee wees hij ook op het doel van de wet: 'Hier, door strafbepalingen die met de persoonlijke eigenschappen geen rekening kunnen houden, een voogdij te scheppen over ieder die gedwongen is een deel van zijn tijd in loondienst te werken, zou eerder tot verlamming van de volkskracht dan tot verhoging daarvan leiden. ${ }^{216}$ Nolte, die meent dat het ontbreken van een strafbaarstelling ten aanzien van degene die een tot hem gerichte norm overtreedt, te ver gaat (hij spreekt van een 'anomalie voor het Nederlandse strafrecht') legt de bedoelingen van de wetgever als volgt uit. Enerzijds kan men stellen dat de wetgever is uitgegaan van de gedachte dat het conflict tussen het belang van de arbeider en diens rechtsplicht ongewenst verscherpt zou worden door strafbaarstelling van zijn gedraging. Met andere woorden, men zou kunnen aannemen, dat de werknemer geacht wordt in een overmachtspositie te verkeren, dit wil zeggen hij kan een wetsovertreding plegen, maar hij handelt niet wederrechtelijk, omdat wan hem onder geen enkele omstandigheid naleving van de wet (Nolte heeft het over de Arbeidswet) gevergd kan worden. Anderzijds kan de straffeloosheid hierin gezocht worden, dat de strafbaarstelling van de werknemer overbodig moet worden geacht, omdat de wet juist in zijn belang gegeven is. ${ }^{217}$ Dit laatste moge waar zijn, ook Nolte merkt op dat juist straf kan meewerken tot het dienen van het eigen belang door haar preventieve werking. In elk geval wormde dit laatste een belangrijk argument om tot strafbaarstelling over te gaan, temeer daar nogal eens de mening werd (en wordt) verkondigd dat de werknemers vaak een loopje nemen met het beschermen van de veiligheid van

21.5 Handelingen TK 1934, p. 1203-1204.

216 Resp. Bijlagen bij de Handelingen TK 1918-1919, 408, nr. 4 (voorllopig verslag), p. 43 en MvA, t.a.p. p. 14

217 H.J.A. Nolte, Het strafrecht in de afzonderlijke wetten, Utrecht 1949 , p. 83-84. 
henzelf of van hun mede-werknemers. ${ }^{218}$ Welnu: eigen schuld, dikke bult. Blijkbaar werden de werknemers ten tijde van de behandeling van de Stuwadoorswet 1931 en de Veiligheidswet 1934 'rijp' geacht voor deze strafbaarstelling. Molenaar oordeelt dat deze mogelijk was geworden door een zekere "volwassenheid' der werknemers, en ook in de arbeidswereld werd aanvaard als 'een eigen stuk verantwoordelijkheid waaraan men zich in de gewijzigde verhoudingen niet mag onttrekken'. ${ }^{219}$ 'Tak sluit hier op aan: 'Het opnemen van strafbaarstellingen van de werknemer voor het niet naleven van voorschriften gericht op eigen veiligheid en gezondheid kan het resultaat zijn van een emancipatieproces waarin de werknemer groeide van een te beschermen afhankelijke naar een volwassen, voor het arbeidsklimaat mede verantwoordelijke nevengeschikte. ${ }^{220}$

Hoe dit ook zij, als de zelfstandigheid van de 'volwassen en geëmancipeerde' werknemer alleen daardoor juridisch reliëf $\mathrm{krijgt}$ dat hem verplichtingen worden opgelegd die strafrechtelijk gesanctioneerd zijn, dan lijkt dat wel erg eenzijdig. Dienen tegenover deze dwingende verplichtingen niet ook bepaalde rechten (voorlichting, zeggenschap) te staan? Het is in het verlengde van deze vraag dat de Hooge Raad van de Arbeid bij de bespreking van het voorontwerp van de Veiligheidwet 1934 in verband met de beoogde aansprakelijkheid van de werknemers voorstelde om de instelling van veiligheidscommissies wettelijk te regelen. Dit verliep niet zonder discussie. Er lagen twee voorstellen bij de Hooge Raad van Arbeid. Eén van de commissie die over het voorontwerp van wet een prae-advies had uitgebracht aan de Raad, en én behelzende een accoord tussen het Nederlandsch Verbond van Vakvereenigingen, het R.K. Werkliedenverbond, het Christelijk Nationaal Vakverbond en het Verbond van Nederlandsche werkgevers. ${ }^{221}$ In hoofdzaak is aansluiting gezocht bij het laatste voorstel. Het (toenmalige) art. 21 opende de mogelijkheid dat veiligheidscommissies werden ingesteld of erkend met een adviserende taak. Ambtelijke bevoegdheden kregen zij niet. 'Doch ook met de hier gestelde beperking zullen zij nuttig werkzaam kunnen zijn door de directie der onderneming, de arbeiders en de Arbeidsinspectie desgevraagd of uit eigen beweging van voorlichting te dienen. ${ }^{222} \mathrm{Bij} \mathrm{AMvB}$ zouden ten aanzien van de ondernemingen die aangewezen waren om een commissie te hebben, reglementen worden gegeven met nadere voorschriften over samenstelling, bevoegdheid en werkwijze. Aan vrijwillig ingestelde commissies werd de voorkeur gegeven; later konden die erkend worden. Op deze commissies was het regle-

218 Vel. bijvoorbeeld de radio-overdracht wan de Controleur van de Arbeid H.A. Korst jens op 6 juli 1934 over: Het aandeel van de werknemers in de veiligheidswoorzorg, gepubliceerd in Veiligheid, 1934, p. 74-78; Handelingen TK 1934 (behandeling Veiligheidswet, 1934), p. 1203; A.D. Kuiper, Beursbericht, SMA, 1957, p. 236; recenter de MvT bij de Arbowet, TK 1976-1977, nr. 14497, nr. p. 28.

219 A.N. Molenaar, Arbeidsrecht, IIB, ta.p. p. 1346.

220 P.J.P. Tak, Leven en laten leven, over paternalistische strafwetgeving, Rede, Zwolle 1978 p. 24.

221 MvT Veiligheidswet 1934 , t.a.p. p. 14

222 MvT Veiligheidswet 1934 , t.a.p. p. 14. 
ment niet van toepassing (art. 21 leden 6 en 7 ). De minister wilde als regel de taak van een veiligheidscommissie tot één onderneming beperken, maar wilde het instellen van een commissie voor een groep ondernemingen niet uitsluiten (art. 21 lid 1). De minister koos hiermee partij voor de werknemers in een geschil op dit punt met de werkgevers. ${ }^{223}$

De regeling liet uiteindelijk nog veel vragen open, en ook bij het - overigens summiere - debat in de Tweede Kamer werd weinig helderheid verschaft over wat de wetgever zich nu eigenlijk voorstelde bij deze commissies. Het werd als 'een experiment' gekwalificeerd en met het oog daarop werd de wens uitgesproken dat de Arbeidsinspectie een oog in het zeil zou houden. ${ }^{224}$ Een aanwijzing voor het antwoord op de vraag hoe deze laatste dacht over de concrete invulling van art. 21 werd gegeven in een voordracht in 1936 voor het Kon. Instituut van ingenieurs door ir. Winkel, inspecteur van de arbeid. ${ }^{225}$ Als doel formuleerde hij het bevorderen van een goede sfeer in de fabriek en het vestigen van de aandacht op allerlei op zich zelf weinig belangrijke gebeurtenissen en omstandigheden die echter aanleiding zouden kunnen zijn voor een ongeval. Als belangrijke conditie is echter een 'ambitieuze leiding' nodig. Voor wat betreft de samenstelling dacht de inspecteur aan hogere en lagere leidinggevende personen voor de doorvoering van de ontworpen maatregelen; voor het doen behandelen van suggesties van werknemers echter aan leden, gekozen uit werknemers en lagere leidinggevende personen. Hij zou de leden een recht willen toekennen om ongevallen te onderzoeken en om periodieke inspecties te houden. Maar hij waarschuwde er wel voor 'dat het bevorderen van een veilige sfeer door de commissies niet in botsing mag komen met de onmisbare zelfde taak welke rust op de bazen. Openlijke of heimelijke conflicten tusschen deze twee groepen: veiligheidscommissies en bazen moeten worden vermeden. ${ }^{226}$

Echte participatie in het veiligheidsbeleid zou in elk geval op deze manier niet verkregen worden. De regeling is echter nooit in werking getreden omdat zij te ver afstond van de inmiddels gegroeide praktijk ${ }^{227}$ Deze praktijk was - en isoverigens zeer divers, zowel voor wat betreft de aanwezigheid van een commissie en haar samenstelling, als voor wat betreft taken en bevoegdheden. De leden werden (en worden) meestal door de werkgever, soms na overleg met (vertegenwoordigers van) de werknemers, aangewezen. Veellal hebben in een dergelijke commissie ook deskundigen zitting, zoals de veiligheidsfunctionaris. Soms is een directielid, een leidinggevend functionaris of de personeels-

223 MvT Veiligheidswet 1934 , t.a.p. p. 15.

224 Handelingen TK 1934, p. 1203.

225 N.C. Winkel, Beginselen voor de beveiliging bij den arbeid in fabrieken, gedeelten uit een voordracht voor de afdeeling Gezondheidstechniek van het Kon. Int. v. ingenieurs op 10 juli 1936, gepubliceerd in De Veiligheid, 1936, p. 114-123 en 129-134. Over de Veiligheidscommissies: p. 133.

226 N.C. Winkel. t.a.p. p. 133.

227 Vgl. de adviesaanvraag van de minister van sociale zaken aan de SER van 19 juni 1975 inzake de vernieuwing van de wetgeving betreffende de gezondheid en de veiligheid bij de arbeid, bijlage $\mathbb{I}$ bij SER-advies terzake, $1976, \mathrm{nr} .18$, p. 13. 
chef voorzitter. Bevoegdheden, verkregen van de werkgever kunnen bijwoorbeeld zijn: een direct adviesrecht, opdracht om ongevallen te analyseren, mogelijkheid tot zelfstandig inspecteren, mogelijkheid om veiligheidsprogramma's en veiligheidswoorschriften op te stellen of te doen opstellen, etc. ${ }^{228}$

Juridisch is echter de mogelijkheid van werknemers om zich te bemoeien met de arbeidsomstandigheden in de onderneming als compensatie, of althans in relatie met de hun opgelegde strafrechtlijk aansprakelijkheid in de Veiligheidswet 1934 niet gerealiseerd.

Tot slot is bij de behandeling van de Veiligheidswet nog aan de orde geweest de mogelijkheid voor werknemersorganisaties om controle uit te oefenen op naleving van de veiligheidsvoorschriften. Dit punt werd met name naar voren gebracht in verband met de mededeling van de minister dat voorlopig niet gedacht kon worden aan uitbreiding van de Arbeidsinspectie, terwijl aan de wetgeving met name aan de Arbeidswet, juist wèl uitbreiding was gegeven. ${ }^{229}$ De minister voelde echter niet voor deze suggestie in verband met de uitermate delicate taak van de Arbeidsinspectie en om het feit dat er alles aan gelegen moet zijn 'dat in ons gansche bedrijfsleven, ook bij de patroons en ook bij de arbeiders, het als een paal boven water staat, dat de Arbeidsinspectie onpartijdig is, boven de partijen de zaken behandelt'. ${ }^{230}$

\subsection{Andere regelingen}

In deze periode kwamen ook weer enkele specifieke regelingen tot stand. In 1921 werd de Steenhouwerswet uit 1911 vervangen. ${ }^{231}$ Belangrijke verschillen betroffen de leeftijd van steenhouwers die voor verplicht geneeskundig onderzoek in aanmerking kwamen (in 1911 alleen beneden de 21 jaar; in 1921 alle leeftijden) en de verruiming van de rusttijden en vrije dagen ten opzichte van de Steenhouwerswet van 1911. Eveneens werd de Stuwadoorswet 1916 vervangen door die van $1931 .{ }^{232}$ Het werkingsgebied werd uitgebreid evenals de rusttijden en het aantal vrije dagen. In 1933 kwam de Huisarbeidswet tot stand. ${ }^{233}$ De wet heeft tot doel 'het bestrijden van misstanden in de huisindustrie: . De meeste artikelen betreffen overigens de vaststelling van het loon bij

228 H.J. van Zwam, Veiligheidscommissies en de Wet op de Ondernemingstaden, De Veiligheid, 1976 , p. 266 .

229 Een van de problemen bij de inwerkingtreding van de Arbowet is nog steeds dat deze wet ecn uitbreiding geeft van de taken van de Arbeidsinspectie, therwijl deze dienst tegelijkertijd onderhevig is aan de zgn. twee procent-operatie, op grond waarvan het aantal ambtentren met twee procent dient te worden teruggebracht. Niets nieuws dus onder de zon. De relatie tussen de inwerkingtreding van de Arbowet en het personeelsbestand is herhaaldelijk aan de orde geweest in het parlement en bij de verantwoordelijke bewindslieden. Vgl. bijvoorbeeld: TK 1979-1981 14.497, nr. 172 (motie B. Bakker en Weyers); TK 1983-1984, 18.100, hfdst. XV, nr. 2, p. 67; idem, nr. 39 (motie Poppe en Spieker); Handelingen TK 1983, p. 4970; Handelingen TK 1984, p. 2514.

230 Handelingen TK 1934, p. 1204.

231 Wet van 11 november 1921 (S. 1167 ).

232 Wet van 27 juli 1931 (S. 331).

233 Wet wan 17 november 1933 (S. 597). 
huisarbeid. De Ongevallenwet 1901 werd vervangen door de Ongevallenwet 1921. ${ }^{234} \mathrm{Zij}$ ging nu alle bedrijven omvatten behalve die in de landbouw en de zeevaart. (Voor die sectoren golden respectievelijk de Land- en tuinbouwongevallenwet 1922 en de Zeeongevallenwet 1919). Bovendien werd de leer van het zuivere 'risque professionel' enigszins losgelaten omdat de verzekering werd verruimd tot die van 'ongevallen in verband met de dienstbestrekking", waardoor bijvoorbeeld ook de ongevallen tussen werk en huis verzekerd waren. In 1928 werd de wet opnieuw aangevuld doordat bedrijven nu ook eigen, erkende geneeskundige diensten bij de uitwoering van de wet konden inschakelen en doordat diverse beroepsziekten en letsel, in betrekkelijk korte tijd ontstaan, met ongevallen gelijk werden gesteld. 235

De civielrechtelijke bepalingen, en vooral $1638 \mathrm{x}$ BW, verdwenen, door de uitbreiding van de werkingssfeer van de Ongevallenwet zo mogelijk nog meer naar de achtergrond. Het 'pacificatieartikel' immers (art. 93 in de Ongevallenwet 1921) bleef onverkort gehandhaafd. Daarom ook had de ruime uitleg van het begrip 'onrechtmatig' door de Hoge Raad in 1919 voor civiele acties in verband met bedrijfsongevallen of beroepsziekten nauwelijks betekenis.

$\mathrm{Na}$ de uiterst summiere regeling van de CAO in art. 1637n BW kwam in 1927 de Wet op de Collectieve Arbeidsovereenkomst tot stand en in 1937 de Wet op het algemeen verbindend en onverbindend verklaren van bepalingen van collectieve arbeidsovereenkomsten. ${ }^{236}$ Overigens was de belangstelling van de vakbeweging in dit tijdvak voor de arbeidsomstandigheden (in tegenstelling tot de tijd rond de eeuwwisseling en de eerste jaren daarna) gering, en daarmee samenhangend ook het aantal en de reikwijdte van bepalingen op dit punt in de CAO's. ${ }^{237}$

Voor het eerst vormden ook internationale regelingen en aanbevelingen een factor bij de ontwikkeling van het arbeidsomstandighedenrecht. In deze periode gaat het daarbij om de aanbevelingen en verdragen van de International Labour Organization (ILO), die in 1919 werd opgericht en waarvan de Constitutie als hoofdstuk XIII van het Vredesverdrag van Versailles werd ingevoegd. Veel van de eerste verdragen en aanbevelingen hebben betrekking op de veiligheid en gezondheid. ${ }^{238}$ Een verdrag dat geratificeerd wordt, verplicht de lidstaat om de erin neergelegde bepalingen toe te passen, onder meer door de nationale wetgeving ermee in overeenstemming te brengen. Over de uitvoering van die bepalingen moet dan regelmatig aan de ILO gerapporteerd wor-

234 Wet van 2 mei 1921 (S. 700 ).

235 Wet van 12 mei 1928 (S. 166) resp. Wet wan 2 juli 1928 (S. 223)

236 Wet van 24 december 1927 (S. 415) resp. Wet wan 25 mei 1937 (S. 801). Zeer uitwoerig over de totstandkoming van beide wetten: T. van Peype, t.a.p. p. 177-213 en p. 246-269 (met verdere literatuur).

237 H.M. de Burlet, Gezondheid en Veiligheid op de werkplek, Leiden 1978, p. 5.

238 Van de 128 verdragen en 132 aanbevelingen die de ILO tussen 1919 en 1968 aanvaardde, hadden er 54 , resp. 52 betrekking op arbeidsomstandigheden. M. Robert en $L$. Parmeggiani, Fifty yestrs of international collaboration in occupational safety and health, Intermational Labour Review, 1969, p. 4.

Een volledige lijst is te vinden in de jaarlijkse ILO-uitgave Publications on occupational safety and health. 
den. Deze rapportages worden beoordeeld door een onafhankelijke commissie van deskundigen die haar bevindingen publiceert en voorlegt op de jaarlijkse zitting van de Arbeidsconferentie te Genève. Een aanbeveling is niet bindend, maar bedoeld als leidraad bij het moderniseren van wetgeving en praktijk. De betekenis van de verdragen bleek onder meer uit de rol die zij speelden bij de herziening van de Ongevallenwet 1901: zo was de hierboven besproken uitbreiding in de toepasselijkheid van de wet tot een aantal beroepsziekten in 1928 een gevolg van het ILO-verdrag betreffende schadeloosstelling voor beroepsziekten in 1925 . Toch moet de betekenis niet overschat worden: veel onderwerpen waren al in de door de conventies en aanbevelingen bedoelde zin in Nederland geregeld en voor zover dat niet zo was, ratificeerde ons land niet, totdat het Nederlandse recht in overeenstemming was gebracht met de inhoud van het verdrag. ${ }^{23 \%}$

\section{De periode 1940 - circa 1975}

Tijdens de oorlog kwamen geen regelingen op het gebied van de arbeidsomstandigheden tot stand. De periode vlak na de oorlog stond vooral in het teken van de gezamenlijke wederopbouw, en werd gekenmerkt door een verzuilde samenleving waarin de respectievelijke elites zoveel mogelijk probeerden samen te werken om een harmonieuze ontwikkeling van de samenleving te bevorderen. De eerste Wet op de Ondernemingsraden (WOR) van 1950 kan op ondernemingsniveau beschouwd worden als een produkt van deze vreedzame politiek onder leiding van een, zoals Lijpart dat noemt, 'accomoderende' elite. ${ }^{240}$ In deze eerste WOR werd ook aandacht geschonken aan enkele mogelijkheden van beïnvloeding door een ondernemingsraad (or) van aspecten van het arbeidsomstandighedenbeleid in de onderneming. In 1971 werd de WOR 1950 vervangen. Aan beide wetten zal hieronder kort aandacht worden geschonken. Daarnaast komt in deze paragraaf aan de orde de vervanging van de Ongevallenwet door de Wet op de Arbeidsongeschiktheidsverzekering in 1967 en de invloed daarvan op de civielrechtelijke mogelijkheden voor de werknemer die door een bedrijfsongeval of beroepsziekte is getroffen. Ook de zich uitbreidende internationale normstelling krijgt enige aandacht. Maar eerst wordt begonnen met enkele belangrijke wijzigingen van de Veiligheidswet 1934.

239 Over de Nederlandse opstelling in de beginperiode van de ILO: A.M. Joekes, De internationale arbeidswetgeving 1919-1925, A.L. Scholtens e.a., Het Departement van Arbeid Handel en Nijverheid onder minister Aalberse 1918-1925, Alphen a/d Rijn 1926, p. 263-279; A.N. Molenaar, Arbeidsrecht I, t.a.p. p. 501.

240 A. Lijphart, The politics of accommodation, Berkley 1968, p. 103-104. Over de rol van de politiek en de wetgeving bij de medezeggenschap in ondernemingen in die tijd: $G$. van den Heuvel, Industrieel burgerschap als uitnodiging, Deventer 1983, p. 53-71. 


\subsection{Aanvullingen op de veiligheidswetgeving}

In deze periode vonden in de Veiligheidswet 1934 (weer) een aantal veranderingen plaats. De belangrijkste zijn de volgende. In 1951 is aan het districtshoofd (of aan een ander door de minister aangewezen ambtenaar) de bevoegdheild gegeven om te bevelen dat personen niet mogen verblijven in door hem aangewezen ruimten, of dat door hem aangewezen werkzaamheden moeten worden gestaakt, indien dat verblijf of die werkzaamheden ernstig gevaar voor personen opleveren. ${ }^{241}$ Dit wordt de bevoegdheid tot 'parate executie' genoemd. Een bellangrijke waarborg voor een juiste hantering van deze vergaande bevoegdheid is hierin gellegen, dat, als het werk langer dan zeven dagen wordt stilgelegd, het bevel door de president van de terzake bevoegde rechtbank moet worden bekrachtigd. Op deze beschikking van de president is geen beroep mogelijk, behalve cassatie in het belang der wet (art. 26 bis lid 3). Deze bevoegdheid is mede in de wet gekomen door het in 1947 door de ILO aanvaarde verdrag nr. 81 inzake de Arbeidsinspectie, waarin een dergelijke bevoegdheid uitdrukkelijk was neergelegd. ${ }^{242}$ In 1971 is de beperking in het betreffende artikel 26 bis dat het ingrijpen slechts geoorloofd was als de gevaarlijke toestand een gevolg was van overtreding van het bij of krachtens de Veiligheids-wet bepaalde, geschrapt. ${ }^{243}$ Hierdoor kan ook worden ingegrepen in notoire gevaarssituaties, zonder dat er sprake is van overtreding van een wettelijk voorschrift. Wanneer zich een dergelijke situatie voordoet kan deze bevoegdheid van de Arbeidsinspectie voor de werknemer van belang zijn in de gevallen dat de werkgever de situatie minder ernstig inschat en door wil laten werken: immers voor het mogen stoppen met het werk is medewerking van de werkgever niet nodig.

In hetzelfde jaar 1971, bij dezelfde wetswijziging, zijn nog een aantal zaken toegevoegd. In de eerste plaats werd het werkingsgebied verruimd, door de mogelijkheid voor de minister om ter uitvoering van de door de Kroon vastgestelde veiligheidsvoorschriften ten aanzien van nog meer onderwerpen nadere regelingen te treffen. In de tweede plaats betrof dat de uitbreiding van de mogelijkheden om werknemers die bepaalde werkzaamheden verrichten aan een keuring te onderwerpen en het feit dat toestemming voor het verrichten van bepaalde werkzaamheden van een keuring of een onderzoek naar de bekwaamheden van de betrokken werknemer afhankelijk kon worden gesteld. Dit was een belangrijke ingreep in de verhouding werkgever-werknemer. Voor het eerst (behoudens een dergelijke bepaling in de Steenhouwerswet 1921) konden bepaalde werkzaamheden aan werknemers worden verboden. Bovendien werd uit de aard van de wijzigingen duidelijk dat de begrippen 'veiligheid en gezondheid' ruimer werden gedefinieerd. Steeds minder ging

241 Wet van 25 april 1951 (S. 136).

242 Bij Wet van 9 september 1949 ( $\mathrm{S} 424$ ), werd de bevoegdheid tot toetreding tot het werdrag aan de Kroon voorbehouden. Het verdrag werd door Nederland geratificeerd op 15 september 1951 (Tractatenblad 1951, nr. 140).

243 Wet van 25 maart 1971 (S. 225); slechts gedeeltelijk in werking getreden. 
het alleen om de fysieke veiligheid en steeds meer om de psychische aspecten van veiligheid en gezondheid. Dit komt onder meer tot uitdrukking door het opnemen in de wet van begrippen als 'uitzicht naar buiten' ( art. 6 lid 1 onder b) of het opnemen van 'hinderlijk' geluid, naast 'schadelijk' geluid (art. 7 lid 1 onder i) of door de introductie van 'draaglijke' temperatuur (art. 11 lid 1 onder g).

De belangrijkste wijziging van de Veiligheidswet betrof ongetwijfeld de invoering van een nieuwe paragraaf betreffende de bedrijfsgeneeskundige diensten in 1959. Sterk gestimuleerd door de Arbeidsinpectie deed de bedrijfsgeneeskunde feitelijk haar intrede in de twintiger jaren: in 1928 werd bij Philips Eindhoven de eerste dienst opgericht. ${ }^{244}$ Maar pas na de Tweede Wereldoorlog kwam de ontwikkeling goed op gang. De overtuiging dat een doeltreffend georganiseerde preventieve gezondheidszorg in bedrijven van belang is, zowel voor het lichamelijk en geestelijk welbevinden van de werknemers, als voor het rendement van de ondernemingen, leidde in diezelfde periode tot de wens om een wettelijke regeling tot stand te brengen, waarmee aan de groei van de bedrijfsgeneeskunde stimulans en richting gegeven zou kunnen worden. Een dergelijke regeling zou er tevens toe kunnen dienen het verzorgingsveld nader te omgrenzen, richtlijnen te geven voor de opzet van de bedrijfsgeneeskundige diensten, en de onafhankelijkheid van de bedrijfsarts in de onderneming te waarborgen. ${ }^{245} \mathrm{Na}$ het verschijnen van het rapport van de staatscommissie 'Ontwikkeling van de bedrijfskunde in Nederland' in 1952 werd in 1954 een ontwerp-wet ingediend, dat in 1959 na enkele wijzigingen werd aanvaard. ${ }^{246}$ Deze 'Wet op de bedrijfsgeneeskunde' werd ingevoegd in de Veiligheidswet 1934 en vormde daarin een afzonderlijke paragraaf $2 a$. Hoewel de materie mede betrekking heeft op het algemene terrein van de volksgezondheid en tegelijkertijd kan worden beschouwd als een medische beroepsregeling, is er toch de voorkeur aan gegeven om haar niet in een afzonderlijke wet op te nemen. Dit werd gemotiveerd met de overweging, dat het bedrijfsgeneeskundig werk zijn primaire taak vindt in de onderneming en dat een regeling terzake derhalve aan moet sluiten bij andere, het interne ondernemingsgebeuren rakende, regels. Bovendien zou het toezicht op de bedrijfsgeneeskundige diensten toevallen aan de Arbeidsinspectie. ${ }^{247}$

244 Niet alleen humanitaire overwegingen speelden bij Philips een rol, maar ook het economisch rendement. In 1939, ter gelegenheid van de 100.000 ste röntgendoorlichting door de dienst, hield A. Philips een toespraak waarin hij de kosten van de bedrijfsgeneeskundige zorg afzette tegen de terugloop van het ziekteverzuim. Tewreden kon hij constateren: 'De kleine kost gaat de grote baat vooruit.' F. Huysmans e.a. (red.), Gezondheidszorg in Nederland, Nijmegen 1973 , p. 195.

245 Voor een uitwoerig overzicht van de geschiedenis van de bedrijfsgeneeskunde: G.C.E. Burger, De ontwikkeling van de arbeids- en bedrijfsgeneeskunde, Leiden 1974, wooral hoofdstuk 1 .

246 Wet van 19 februari 1959 (S. 56).

247 Over de totstandkoming en plaatsing van de bepalingen in de Veiligheidswet: H.F. Beenhakker, De Betekenis van de Wet op de Bedrijfsgeneeskunde voor de volksgezondheid, Tijdschrift voor Sociale Geneeskunde, 1971, p. 736-742.

Leenen meent dat de bedrijfsgeneeskunde, samen met andere vormen van medische be- 
Kort samengevat was de inhoud van de Wet van 1959 als volgt: fabrieken of werkplaatsen waarin een bij AMvB nader te bepalen aantal werknemers werkzaam is, moeten een eigen bedrijfsgeneeskundige dienst instellen, dan wel zich aansluiten bij een gezamenlijke, voor meer ondlernemingen werkzame dienst. De bedoelde AMvB stelde het aantal werknemers op $750 .^{248}$ Als doelstelling werd genoemd het stimuleren van matregelen welke een doeltreffende preventieve gezondheidszorg in de onderneming bevorderen. Deze doelstelling wordt vervolgens in een uitvoerige - overigens niet limitatieve opsomming van taken, variërend van aanstellingskeuringen tot spreekuur houden, geconcretiseerd. Uitdrukkelijk wordt bepaald dat de bedrijfsarts zich moet onthouden van adviezen en behandelingen die treden in de verhouding van de patiënt tot zijn huisarts.

Met deze regeling wordt een nieuw element in de Veiligheidswet geïntroduceerd: het gaat niet meer alleen om technische, op bepaalde duidelijke gevaren gerichte maatregelen, maar om organisatorische, op een meer algemeen doel, namelijk preventie, gerichte. Uit de regeling kan overigens geen ondubbelzinnig recht voor de werknemer op preventieve gezondheidszorg worden afgeleid. Wel kan hij feitelijk gedwongen worden om mee te werken of zich te onderwerpen aan activiteiten van de bedrijfsarts, zonder dat hij zich daartegen in het algemeen effectief kan verzetten. ${ }^{249}$

Een nieuwe richting in het arbeidsomstandighedenrecht wordt in deze periade eveneens ingeslagen met de totstandkoming van twee specifieke veiligheidswetten: de Silicosewet 1951 en de Wet Gevaarlijke Werktuigen 1952.250 De Silicosewet beoogt bescherming tegen longziekten, met name asbestose en sillicose. De nieuwe elementen worden vooral gevormd door het feit dat de regeling zich richt op preventie, op de bestrijding van gevaren bij de bron (en dus op de werkzaamheden die samenhangen met het ontstaan van de gevaarlijke stof, vooral de bewerking van zandsteen en asbest), en dat de bescherming zich ook uitstrekt tot zelfstandigen en werkgevers. Vooral in het licht van dit laatste aspect is het opmerkelijk dat de wet zonder beraadslaging en hoofdelijke stemming door beide Kamers werd aanvaard.

Soortgelijke overwegingen als hierboven vermeld leidden tot de Wet Gevaarlijke Werktuigen 1952. Deze wet geeft de mogelijkheid om voor bepaalde

$\rightarrow$

roepsuitoeleningen in een nieuwe Wet op de uitoefening der geneeskunde een platsts zou noeten krijgen. Dit zou uit het oogpunt van juridische systematick de voorkeur verdienen. $H_{n}$ J.J. Leenen, Tijdschrift voor Sociale Geneeskunde, 1968, p. 461. Ook: G.H. van Urk, Aanstellingskeuring, ziekteverzuim en karakter der sociale geneeskunde, Medisch Contact, 1969 , p. 847 .

248 Beslluit aanwijzing ondernemingen bedrijfsgeneeskundige diensten wan 20 juli 1961 ( $S$. 236). Pas zeer onlangs is deze grens verllagd naar 500 (zie hoofdstuk III). En dat terwijl in de MvT bij het oorspronkelujke wetsontwerp de grens werd gelegd bij 250 werknemers. "Ts eenmat een bepaald cijfer van het aantal arbeiders vastgesteld, dan zal dit geleidelijk kunnen worden verlaagd naar gelang meer bedrijfsartsen beschikbaar komen. "Bijlage bij Handelingen. TK 1954-1955, 3834, nr. 3 (MvT) p. 5.

249 A.J.C.M. Geers, J.K.M. Gevers, Bedrijfsarts en werknemer, Ars Aequi, 1976 (Themanummer Gezondheidsrecht), p. 624.

250 Resp. Wet van 2 april 1951 (S. 134) en Wet van 5 maart 1952 (S. 104). 
gevaarlijke werktuigen of beveiligingsmiddelen te eisen dat ze van een certifcaat of merk van goedkeuring zijn voorzien, alvorens ze gebruikt mogen worden. Ook deze wet werd zonder slag of stoot door de Kamers aanvaard.

Tot slot verdient nog vermelding dat de Caissonwet 1905 in 1968 geheel werd herzien, waarbij de citeertitel gewijzigd werd in Wet op werken onder overdruk. ${ }^{251}$ De werkingssfeer van de wet werd verruimd tot alle situaties, waarin arbeid (en zelfs verblijf) onder hogere dan atmosferische druk plaatsvindt.

\subsection{De WOR 1950 en de WOR 1971}

In 1950 werd voor de eerste keer aan de betrokken werkgevers de verplichting opgelegd om een or in te stellen. ${ }^{252}$ (De wet van 1950 spreekt in navolging van de Veiligheidswet van 'hoofd of bestuurder', de wet van 1971 over 'ondernemer' als degene die een onderneming in stand houdt en die er voor moet zorgen dat er een or komt en over 'bestuurder' als degene die rechtstreeks de hoogste zeggenschap uitoefent en de ondernemer vertegenwoordigt in overleg met de or. Wanneer de ondememer een natuurlijk persoon is zal hij vaak ook bestuurder zijn). ${ }^{253}$ De ondernemingraden kregen tot taak 'onder erkenning van de zelfstandige functie van de ondernemer naar vermogen bij te dragen tot een zo goed mogelijk functioneren der onderneming" (art. 6 lid 1). Om hiertoe in staat te zijn kreeg de or een aantal bevoegdheden, die echter niet ver gingen en geheel pasten bij de ideeën van een bedrijfsgemeenschap waarin samenwerking en een harmonie van belangen leidende beginselen zijn. Eén bevoegdheid betrof de arbeidsomstandigheden. Krachtens art. 6, tweede lid onder $d$ kreeg de or de bevoegdheid om toezicht te houden op de naleving van de wettelijke voorschriften ter bescherming van de werknemers in de onderneming, alsmede op de inrichting in het belang van de veiligheid, de gezondheid en de hygiëne en op de schaft- en kleedgelegenheden. Evenals dat met de andere bepalingen uit de WOR 1950 het geval was, was de praktische betekenis nagenoeg nihil. Het nieuwe van de wet moest veel meer gezocht worden in het feit dat de wetgever het overleg in de onderneming erkende en in een ruimer publiekrechtelijk kader plaatste dan dat het enige verandering bracht in de verhoudingen en het overleg in de onderneming. ${ }^{254} \mathrm{Op}$ het gebied van de zeggenschap consolideerde de wet eerder dan dat zij innoveerde. Intussen evolueerde het denken over medezeggenschap. Meer dan voorheen werd het belang benadrukt van de aparte, vertegenwoordigende functie van de or,

251 Wet van 20 juli 1968 (S. 44).

252 Wet wan 4 mei 1950 (S K. 174 ).

253 Over deze terminologie: Duk, Fase, van der Heijden, Masschaupt, De ondernemingsraad, losbladig, Deventer, art. 1, aant. 8 en $9 ;$ M.G. Rood, Wet op de ondernemingsraden, losbladig, Arnhem, art. 1, p. 28-29. Beiden met literatuturverwijzing.

Over de ontwikkelingen van ondernemingsraden, met name over de relatie tot de zgn. kernen: F. Koning, Omtrent de ondermemingsraad deel I en deel II in SMA. 1975, resp. p. 85 102 en p. $174-182$.

254 Vgl. F. Koning i.a.p. p. 88. 
wiens belangen niet altijd parallel liepen met de belangen van de ondernemer. In het licht hiervan werd aangedrongen op een uitbreiding van de bevoegdheden van de or. Na veel studies, voorstellen tot verbetering en discussies kwam in 1971 een nieuwe WOR tot stand. ${ }^{255}$

In vergelijking met de wet van 1950 is een groot aantal verschillen te constateren. Voor wat betreft de arbeidsomstandigheden is het volgende van belang. Volgens art. 27 lid 1 onder $\mathrm{d}$ behoeft de ondernemer de instemming van de or voor een door hem of door een andere bij de onderneming betrokken persoon te nemen besluit met betrekking tot de vaststelling of wijziging van een maatregel op het gebied van de veiligheid, de gezondheid of de hygiëne. ${ }^{256} \mathrm{Lid} 2$ stipuleert echter dat de or het instemmingsrecht ontbeert als het betreffende onderwerp voor de onderneming geregeld is in een CAO. Dit primaat voor de vakbeweging boven de or zou dus kunnen betekenen dat de vakbeweging de mogelijkheid heeft om via uitgebreide $\mathrm{CAO}$-bepalingen de beleidsruimte van de or te verkleinen.

Art. 28 sluit aan op art. 6 lid 2 onder d van de Wet 1950 . Het bepaalt dat de or zoveel als in zijn vermogen ligt de naleving bevordert van onder meer de wettelijke voorschriften ter bescherming van de werknemers. Het artikel verschilt met het vergelijkbare artikel uit 1950: het 'houden van toezicht' is vervangen door het "bevorderen' van de naleving.

Tot slot is er nog een aantal bepalingen die meer indirect invloed kunnen hebben op de arbeidsomstandigheden in de onderneming. Van deze bepalingen kan genoemd worden de bevoegdheid van de or om commissies in te stellen op grond van art. 15 , die geheel of gedeeltelijk de bevoegdheden van de or kunnen overnemen. Hierdoor kan de or bijvoorbeeld een veiligheidscommissie instellen die zijn taken zoals die geformuleerd zijn in de artt. 27 en 28 geheel of gedeeltelijk zou kunnen overnemen. Als het gaat om een vaste commissie (lid 1) moeten de leden uit zijn midden worden gekozen. Lid 3 opent de mogelijkheid om commissies in te stellen met een beleidsvoorbereidende taak ten aanzien van bepaalde onderwerpen, waarin ook niet-or-leden zitting kunnen hebben. Maar in beide gevallen gaat het om commissies van de or, en niet om de door de werkgever ingestelde veiligheidscommissies. ${ }^{257}$

Was nu de WOR 1971 van grote betekenis voor de werknemer op het gebied van zijn arbeidsomstandigheden? Uit een uitgebreid onderzoek, gepubliceerd in 1976, is gebleken dat aan arbeidsomstandigheden - ook wanneer men dit begrip zeer ruim neemt - door de onderzochte ondernemingsraden relatief weinig aandacht werd geschonken. ${ }^{258}$ De meeste vergadertijd werd uitgetrok-

255 Wet van 2 januari 1971 (S. 54).

256 De formulering is in de wet gekomen via een amendement Boersma (later als minister de indiener van de Arbowet) c.s. TK 1969-1970, 10.355, nr. 22.

$257 \mathrm{Vgl}$. W. de Witte, De organisatie van het veiligheidsoverleg in de onderneming; de historische ontwikkeling veiligheidscommissie bij Gist-Brocades, De Veiligheid, p. 169-171; H.J. van Zwam, Veiligheidscommissies en de Wet op de Ondernemingraden, De Veiligheid, 1976 , p. $265-270$.

258 B. Hövels, P. Nas, Ondernemingsraden en medezeggenschap, Alphen a/d Rijn 1976. 
ken voor problemen die het functioneren van de or zelf betroffen en voor arbeidsvoorwaarden. Aan arbeidsomstandigheden werd slechts $17 \%$ van de tijd besteed; bijna de helft daarvan werd weer gevuld met louter informatieve activiteiten. ${ }^{259}$ Uit bovenstaande gegevens zou afgeleid kunnen worden dat de WOR 1971 aan medezeggenschap in veiligheids- en gezondheidszaken in elk geval slechts beperkt heeft bijgedragen. ${ }^{260}$

\subsection{De vervanging van de Ongevallenwet in 1967}

De 'pacificatie' tengevolge van art. 93 van de Ongevallenwet heeft lang geduurd. Pas in $1967 \mathrm{kwam}$ er een eind aan toen de Ongevallenwet werd vervangen door de Wet op de Arbeidsongeschiktheidsverzekering. ${ }^{261}$ De rechtsgrond van deze laatste wet is beduidend ruimer dan die van de Ongevallenwet. Beoogde deze laatste wet een verzekering tegen het direct met de arbeid samenhangende risico van arbeidsongeschiktheid, de WAO verzekert het algemene, ook buiten het werk bestaande risico van arbeidsongeschiktheid. De rechtsgrond 'risque professional' is vervangen door 'risque social': recht op zelfontplooiing en gelijke kansen en daardoor in economische zin een bestaansminimum voor alle werknemers, ongeacht de oorzaak van de arbeidsongeschiktheid. ${ }^{262}$ In deze opzet past niet een verval van de civiele rechten. Bij de discussie over het ontwerp WAO is het argument van de arbeidsvrede nog wel ter sprake gekomen, naar aanleiding van een advies van de Sociale Verzekeringsraad waarin een minderheid zich kantte tegen het herstel van de aansprakelijkheid van de werkgever. Minister Veldkamp echter ging niet mee met het argument dat dit zou kunnen leiden tot "het ontstaan van tal van procedures tussen bedrijfsgenoten onderling'. Hij stelde dat het laten vervallen van civiele rechten een oneigenlijk middel was om de arbeidsrust te handhaven en dat bovendien de procedures zich meer in het zakelijke vlak zouden afspelen, omdat de meeste werkgevers voldoende verzekerd waren. ${ }^{265}$

Bij de overgang van het systeem van de Ongevallenwet naar dat van de WAO moest een belangrijke vraag van overgangsrecht worden opgelost. In de liquidatiewet Ongevallenwetten was in art. 38a lid 1 als grondregel opgenomen dat er op de werkgever geen burgerlijke aansprakelijkheid rustte voor schade welke het gevolg is van ongevallen die plaats vonden vóór de dag waarop de

259 B. Hövels, P. Nas, t.a.p. p. 181.

260 Daar komt natuurijk bij dat in die tijd het grootste gedeelte van de beroepsbevolking werkte in instellingen waarop de WOR niet van toepassing was. En waar dat wèl zo was, functioneerde er soms geen. 'In 1975 waren volgens de WOR 3907 ondernemingen tot het instellen van een OR verplicht. Volgens een enquête door de Arbeidsinspectie in dat jaar gehouden, had $85 \%$ daarvan inderdaad een $O R .7 \%$ had een ander overlegorgaan, terwijl $8 \%$ in het geheel geen overlegorgaan kende (...). $\circ$, Sociaal-Cuitureell Rapport van het Sociaal en Cultureel Plan-bureau, Den Haag 1978.

261 Wet van 18 februari 1966 (S. 84).

262 J.A. Weijel, t.a.p. p. 62.

$263 \mathrm{P}$. Clausing, Aansprakelijkheid van werkgever en derden, in het bijzonder tegen de ongevalsgetroffene in de Ongevallenwet 1921 en in thet ontwerp WAO, SMA, 1964, p. 416. 
Ongevallenwet werd ingetrokken. Hoe moet dit nu geïnterpreteerd worden indien slechte arbeidsomstandigheden vóór 1967 leiden tot het uitbreken van een beroepsziekte nà die datum? Dit probleem speelt vooral een rol bij beroepsziekten met een lange incubatietijd, zoals asbestose. Het antwoord op de vraag of de betreffende werknemer civielrechtelijke aanspraken heeft op de (voormalige) werkgever, zal dan weer afhangen van de vraag of men zich richt op het tijdstip waarop de beroepsziekte ontstond, of op het tijdstip waarop deze zich manifesteerde. In 1980 koos de HR voor de laatste interpretatie. ${ }^{264}$ De belangrijkste overweging was dat art. $87 \mathrm{~d}$ Ongevallenwet bepaalde dat bij toepassing van de artikelen van die wet met betrekking tot de in de wet bedoelde ziekte voor 'ongeval' wordt gelezen: 'ziekte', en voor 'dag wan het ongeval': 'de dag waarop de ziekte is uitgebroken'.

Het herstel van de mogelijkheid voor door een bedrijfsongeval getroffen werknemers om een civiele schadevergoedingsactie tegen de werkgever in te stellen heeft niet geleid tot een sterke toename van het aantal procedures. In elk geval is de angst voor verstoring van harmonieuze arbeidsverhoudingen om déze reden niet reëel gebleken. (In de volgende paragraaf kom ik hier uitvoeriger op terug).

De invoering van de WAO heeft ook een nadeel gehad. Dat betreft de sterk verminderde mogelijkheid om het aantal bedrijfsongevallen te registreren en te controleren en op basis daarvan een preventief belleid te voeren. Onder de Ongevallenwet bestond een duidelijke regeling voor de aangifte en registratie van bedrijfsongevallen. ${ }^{265}$ Volgens art. 25 Veiligheidswet moesten de uitslagen van de ongevalsonderzoeken die op grond van de Ongevallenwet 1921 of de Land- en Tuinbouwongevallenwet 1922 werden ingesteld 'ten spoedigste' gemeld worden aan het districtshoofd van de Arbeidsinspectie door de toenmalige Rijksverzekeringsbank. In verband met het directe belang erbij - de uitbetaling was immers afhankelijk van de oorzaak van de arbeidsongeschiktheidwerd deze regeling goed nageleefd. Voor het ontlenen van rechten aan de WAO is de oorzaak van de arbeidsongeschik theid echter niet van belang. Hetzelfde geldt voor de aanspraken op uitkering krachtens de Ziektewet gedurende het eerste jaar van de arbeidsongeschiktheid. Wel moet de werkgever op grond van de op art. 58 Ziektewet gebaseerde beschikking Melding ongevallen en beroepsziekten (Stcr. 124) aangifte doen bij de bedrijfsvereniging. Deze dient de melding door te zenden aan het Directoraat-Generaal van de Arbeid. Vervolgens worden de meldingen aan het betreffende districtshoofd gezonden. Maar duidelijk is geworden dat dit systeem in de praktijk niet functioneert. In 1966 werd onder het regime van de Ongevallenwet van 3823 gevallen

264 HR 7 matart 1980, NJ 1980, 365.

265 Volledigheidshalve moet nog vermeld worden dat de Arbeidswet 1919 in art. 82 bepaalde, dat iedere geneeskundige verplicht was on bij het Directoraat-Generaal van de Arbeid aangifte te doen van aan zijn behandeling onderworpen gevallen van nader bij $\mathrm{AMvB}$ (het Be. roepsziektenbesluit van 4 ok tober 1920, S. 773) aangewezen ziek ten. Bij Wet van 25 maart 1971 ( $\mathrm{S} .224$ ) is art. 82 vervallen. De melding van beroepsziekten, op grond van dit voorschrift is echter altijd zeer gebrekkig geweest. Vgl. J.P. Kuiper, Melding van beroepsziekten, probleem van een probleem, Medisch Contact, 1971, p. 1151-1156. 
van beroepsziekten aangifte gedaan bij de Arbeidsinspectie via de Sociale Verzekeringsbank. In 1968, onder de vigueur van de WAO, was dit aantal teruggelopen tot $2320 .{ }^{266}$ Ook de ongevallencijfers in de jaarverslagen van de Arbeidsinspectie liepen plotseling sterk terug na 1967. ${ }^{267}$ Deze terugval kan slechts verklaard worden door de vervanging van de Ongevallenwet door de WAO. De oorzaken zijn waarschijnlijk onder meer hierin te vinden dat de meldingsplicht op grond van de ziektewet niet gesanctioneerd is en dat ook de economische prikkel tot melding is weggevallen. (De Ongevallenwet kende betere voorzieningen voor het slachtoffer dan de vroegere Ziektewet). Toch is melding en registratie van ongevallen en beroepsziekten van groot belang in verband met de mogelijkheden om een behoorlijk inzicht te krijgen in frequentie van vóórkomen en in eventuele oorzaken, waardoor een op preventie gericht beleid beter gevoerd zou kunnen worden.

\subsection{Uitbreiding van de internationale normering}

Naast de ILO werd in deze periode ook door de Europese Gemeenschappen in toenemende mate aandacht besteed aan arbeidsomstandigheden. ${ }^{268}$ De juridische grondslag hiervoor ligt in de artikelen 117 en 118 E.E.G.-verdrag dat in 1957 door Nederland werd ondertekend. In art. 117 gaat het om de noodzaak van de "verbetering van de levensstandaard en van de arbeidsvoorwaarden van de werknemers." Deze dient mede bereikt te worden door het "nader tot elkaar brengen van wettelijke en bestuursrechtelijke bepalingen.' Ook op thet gebied van de arbeidsomstandigheden worden door de Raad van de E.G. richtlijnen uitgevaardigd, waarmee harmonisatie en verbetering van nationale wetgeving wordt beoogd. De richtlijnen zijn wel bindend met betrekking tot het resultaat door iedere lidstaat te bereiken, maar vorm en methode worden aan de nationale wetgever overgelaten. Voorbeeld van een dergelijke richtlijn is de Richtlijn uit 1959 betreffende de vaststelling van basisnormen voor de gezondheidsbescherming van bevolking en werknemers tegen de gevaren van ioniserende stralen. ${ }^{269}$

Art. 118 E.E.G.-verdrag geeft aan de Commissie de taak tussen de lidstaten nauwe samenwerking op sociaal gebied te bevorderen; terreinen die hierbij met name worden genoemd zijn de bescherming tegen arbeidsongevallen en beroepsziekten en de arbeidshygiëne. Op grond van deze bepaling jo. art. 155 van het verdrag, heeft de commissie in de jaren ' 60 een reeks belangrijke aanbevelingen het licht doen zien. Hoewel deze strikt genomen niet bindend

266 J.P. Kuiper, t.a.p. p. 1154-1155.

267 Zo werd bijwoorbeeld in 1970 door het Directorat-Generad wan de Arbeidl het antal niet gennelde bedriffsongevallen geschat op 15 a $20 \%$. H. van Oostrum, Arbeidsrechtelijke en strafrechtelijke aspecten van bedrijisongevallen. Ars Aequi, 1974, p. 139

268 Uitwoerig over de rechtsontwikkeling inzake arbeidsomstandigheden in de E.G., J.K.M. Gevers, Zeggenschap wan werknemers inzake gezondheid en veiligheid in bedrijven, Deventer 1982, p. $271-299$.

269 Richthijn van 2 rebruari 1959, Publicatieblad 1959, nr. 221. 
zijn, worden ze in het algemeen wel opgevolgd, omdat ze eerst tot stand komen - conform art. 118 - na intensieve raadpleging van de lidstaten. ${ }^{270}$

Deze aanbevelingen betreffen:

- de bedrijfsgeneeskundige diensten,

- de vaststelling van een Europese lijst van beroepsziekten,

- de medische controle van werknemers die aan bijzondere risico's blootstaan,

- de schadeloosstelling van door beroepsziekten getroffenen,

- de arbeidsbescherming van jeugdige personen. ${ }^{271}$

Op grond van art. 122 E.E.G.-verdrag moet de Commissie jaarlijks verslag doen van de ontwikkeling van de sociale toestand in de Gemeenschap. Deze verslagen bevatten tevens cijfermateriaal over arbeidsongevallen in de lidstaten en de bedragen die op grond van de nationale ongevallenwetten aan slachtoffers worden uitgekeerd. ${ }^{272}$

Naar aanleiding van een resolutie van de Raad van 21-1-1974, waarin een sociaal actieprogramma voor de jaren 1974-1976 werd aangekondigd, mede gericht op het menswaardig maken van de arbeidsomstandigheden, zijn de inspanningen van de E.G. op het terrein van de arbeidsbescherming verbreed. In 1974 werd een Raadgevend Comité voor de veiligheid, hygiëne en gezondheidsbescherming op de arbeidsplaats ingesteld, en in 1975 een Europese Stichting tot verbetering van de levens- en arbeidsomstandigheden. ${ }^{273}$ In hetzelfde jaar publiceerde de commissie beleidslijnen voor een communautair programma betreffende de veiligheid, de hygiëne en de gezondheidsbescherming op de arbeidsplaats.

\section{Van circa $1975-1983$}

\subsection{Een omslag in de beleidsontwikkeling}

Vanaf het begin van de jaren zeventig valt - in tegenstelling tot de periode ervoor - in toenemende mate onvrede met de bestaande arbeidsbeschermende wetgeving te constateren. Als redenen hiervoor zijn zowel veranderde opvattingen als meer praktische problemen aan te voeren. Zo is er sprake van een algemene accentverschuiving van dwingende wetgeving naar vrijwillige samenwerking tussen de sociale partners en de ontwikkeling van een eigen beleid ten aanzien van de arbeidsomstandigheden in de individuele onderne-

270 P.J.G. Kapteyn en P. Verloren van Themaet, Inleiding tot het recht van de Europese Gemeenschappen, Deventer 1980 , p. 295.

271 Resp.: 20 juli 1962, Publ.blad, 1962, nr. $80 ; 23$ juli 1962, Publ.blad, 1962, nr. $80 ; 27$ juli 1966 , Publ.blad, 1966, p. 2753; 20 juli 1966, Publ.blad, 1966, mr. 147; 31 januari 1967, Publ.blad, 1967 , nt. 25.

272 In 1975 is onder E.G. werknemers een uitgebreide enquête gehouden over hun arbeidsomstandigheden. Zie: Arbeidsvoorwatrden in de landen van de Gemeenschap 1975, Bureau van de Statistiek der Europese Gemeenschappen. 1977.

273 Publ.blad L185, 1974, p. 15. 
mingen. De taak van de wetgever wordt dan primair het scheppen van juridische garanties en institutionele kaders voor deze zelfwerkzaamheid van het bedrijfsleven. Daarnaast kan gewezen worden op de ontwikkeling van traditionele arbeidsbescherming, vooral gericht op de fysieke omstandigheden, naar het bevorderen van het veel ruimere begrip humanisering van de arbeid en de zich wijzigende denkbeelden met betrekking tot de werktijdpatronen. Bovendien laat ook de vanaf de tweede helft van de jaren zestig gegroeide inspraak- en medezeggenschapscultuur haar sporen na in de wetgeving. Markante voorbeelden van de uit het bovengenoemde klimaat voortgekomen wetgevingsproducten zijn de herziening van de WOR in 1979 en de totstandkoming van de Arbowet in 1980.

$\mathrm{Op}$ het einde van de zeventiger jaren tekent zich onder invloed van de economische crisis een duidelijke omslag af in het politiek-maatschappelijk denken, die, zeer kort samengevat, erop neerkomt dat aan het bevorderen van waarden zoals studiebeurzen, goedkope woningbouw, subsidies voor kunst, bouw van crèches en dergelijke door de bevolking beduidend minder waarde wordt gehecht. Dat blijkt althans uit de Sociale en Culturele Verkenningen 1986 waarin de veranderingen in het opinieklimaat zijn vastgelegd over de periode van 1970-1985. ${ }^{274}$ In het algemeen geldt deze verandering in het denken ook de inspraak. Zo wenste in 1970 nog $64,5 \%$ de inspraak van studenten op het bestuur van de universiteit veel of een beetje groter. In 1975 was dat $31,8 \%$ en in 1980 èn in $198525,6 \% .{ }^{275}$ Ook de wens tot vergroting van de medezeggenschap van werknemers in de ondernemingen is voordurend gedaald. In 1970 wenste $67,6 \%$ vergroting van deze vorm van medezeggenschap, in 1975 : $59,9 \%$, in $1980: 57,7 \%$ en in 1985: $51,2 \%$. Hierbij moet echter wel aangetekend worden dat de verandering in de ideeën over dit laatste, gerelateerd aan de overige gevonden data, tamelijk gering is.

Een weerspiegeling van het denken over arbeidsomstandigheden en de rol van werknemers hierbij vanaf het begin van de jaren zeventig tot $1985 \mathrm{kan}$ ook verkregen worden uit de in die tijd verschenen toelichtingen bij de begrotingen van het ministerie van Sociale Zaken en Werkgelegenheid. In de begrotingstoelichting voor het jaar 1973 wordt het begrip 'sociaal welzijn met betrekking tot de arbeid' geïntroduceerd. Dit veronderstelt een actief sociaal beleid dat gedragen dient te worden door het inzicht dat naast en in evenwicht met economische en technische doelstellingen het sociaal aspect van de ondernemingsactiviteiten een waarde in zich heeft. De overheid dient te zorgen voor een wettelijk kader dat de hoofdlijnen aangeeft. ${ }^{276}$ Voor 1974 - het kabinet den Uyl is inmiddels aangetreden - wordt gewezen op onder meer het belang dat werknemers hebben om zich te kunnen ontplooien en dat voldoende informatie daar een belangrijke voorwaarde voor is. Voorts wordt in deze toelichting opgemerkt dat het van belang is te overwegen in hoeverre maatregelen

274 Sociale en Culturele Verkenningen 1986, Sociaal en Cultureel Planbureau, SCP-cahier 48, Rijswijk 1986.

275 SCP-cahier 48 , t.a.p. p. 13.

276 TK 1972-1973, hfdst. XV, nr. 2, p. 27-28. 
mogelijk en gewenst zijn om de werknemer zelf te betrekken bij de problematiek rondom zijn arbeidsweiligheid, waarbij niet alleen aan inspraak dient te worden gedacht, maar ook aan het scheppen van meer verplichtingen dan de huidige wet (bedoeld is de Veiligheidswet 1934) kent. ${ }^{277}$

Voor het begrotingsjaar 1975 wordt ten aanzien van het sociaal beleid in de onderneming opgemerkt dat dat beleid in toenemende mate geconfronteerd wordt met het feit dat de werknemers zich van hun eigenwaarde meer bewust worden, onder meer door een stijging van het opleidings- en ontwikkelingspeil. Aangekondigd worden onder meer: een adviesaanvraag aan de SER over het treffen van voorzieningen die de basis vormen voor het sociaal beleid in de onderneming; de voorbereiding voor een wettelijke regeling van het klachtrecht van werknemers; vernieuwing van de arbeidswetgeving; een meer onderling samenhangende wettelijke regeling van arbeid, arbeidsomstandigheden en arbeidsverhoudingen in de onderneming; de voorbereiding van een wetsontwerp, dat het kader zal vastleggen voor het te voeren sociaal beleid in de onderneming. ${ }^{278}$

Voor het jaar 1977 begint de omslag zich af te tekenen. Nadat opgemerkt is dat bestaande inspraakstructuren nog verbeterd kunnen worden vervolgt de MvT: 'Terwijl ten aanzien van de kwaliteit van de arbeid steeds hogere eisen worden gesteld, bieden economische en technologische ontwikkelingen slechts beperkte mogelijkheden om aan deze eisen tegemoet te komen. Soms bedreigen deze ontwikkelingen opnieuw de veiligheid, de gezondheid en het psychisch welzijn van de betrokken werknemers. ${ }^{279}$ Gewezen wordt op het mogelijke proces van vervreemding, maar: "Van overheidswege wordt gedaan wat mogelijke is... Voor het proces zelf kan de overheid geen verantwoordelijkheid nemen. Dat moet het bedrijfsleven zelf doen en daarbij hebben zowel werkgevers als werknemers een taak en een verantwoordelijkheid. ${ }^{250}$ Voor de begrotingsjaren 1978 en 1979 - het kabinet den Uyl is inmiddels opgewolgd door het (eerste) kabinet van Agt - wordt het belang van humanisering van de arbeid, de medezeggenschap van de werknemers en de rol die de Arbowet daarbij kan spelen, benadrukt. Maar tegelijkertijd wordt er weer op gewezen dat de overheid een terughoudende rol dient te spelen en dat de doelstellingen van de Arbowet gestalte moeten krijgen op het niveau van de onderneming. ${ }^{281}$

Voor 1980 wordt tevreden geconstateerd dat met de inwerkingtreding van de WOR op 1 september 1979 een belangrijke stap is gezet op het pad van de bedrijfsdemocratisering. Ook de Arbowet wordt in dit verband genoemd. Maar het arbeidsomstandighedenbeleid kan niet los worden gezien van het sociaal-economisch beleid in engere zin. 'Enerzijds zijn gelet op de moeilijke financieel-economische situatie van dit moment de mogelijkheden voor het op

277 TK 1973-1974, hfdst. XV, nr. 2, p. 8 en p. 29.

278 TK $1974-1975,13.100$, hfdst. XV, nr. 2, p. 8-12 en p. 18.

279 TK 1976-1977, 14.100, hfdst. XV, nr. 2, p. 12

280 iden, t.a.p. p. 13.

281 resp. "TK $1977-1978,14.800$, hfdst. XV, nr. 2 p. $54-55$ en TK $1978-1979,15.300$, hfdst. XV, nr. 2. p. 71 . 
dit terrein te voeren beleid beperkt. Anderzijds hebben het terugdringen van factoren die de veiligheid en de gezondheid bedreigen en het vergroten van de betrokkenheid van de mens tot zijn arbeid een gunstige invloed op de kostenontwikkeling van de sociale verzekering door een vermindering van het arbeidsverzuim en de arbeidsongeschiktheid. Ook is naar mijn mening een grote betrokkenheid van de werker tot zijn arbeid een randvoorwaarde voor de zo noodzakelijke innovatie in het bedrijfsleven. ${ }^{2} 2 z$

In hoofdstuk 1 (algemeen beleid) van de toelichting op het begrotingsjaar 1981 wordt een uitvoerige beschouwing gegeven omtrent de verzorgingsmaatschappij: onder meer haar geschiedenis en vraagstukken van betaalbaarheid, bestuurbaarheid en legitimiteit. In par. 6 (beleidsreacties in grote lijnen) wordt de problematiek van de betaalbaarheid in relatie gebracht met de humanisering van de arbeid. Dit wordt geplatst in het kader van een toenemende twijfel over de legitimiteit van een maatschappij die wel materiële bestaanszekerheid biedt, maar nog onvoldoende voorziet in menswaardige arbeid en arbeidsomstandigheden. Onder meer tegen deze achtergrond is de Arbowet tot stand gekomen. En optimistisch: 'Met deze kaderwet... is een flexibel instrument geschapen dat is toegesneden op de maatschappelijke dynamiek van de komende jaren. '283

De toelichting voor 1982 staat vooral in het teken van de dynamische relatie tussen economische en sociale doelmatigheid. Dit thema brengt de betrokken bewindsman op een originele gedachte: de verslechterde economische toestand kan ten voordele van de medezeggenschap werken. Immers, de historische samenloop van de noodzaak om de economische malaise te keren en van de opgave om de medezeggenschap van werknemers op te bouwen, kan de betrokken partijen er toe brengen de problemen gezamenlijk aan te pakken. ${ }^{284}$ Samen de handen uit de mouwen om de crisis te keren kortom. De bewindsman benadrukt bovendien dat van kwalitatieve verbeteringen in arbeid en arbeidsomstandigheden onder meer positieve impulsen kunnen uitgaan op de werkgelegenheid, op vermindering van het ziekteverzuim en de arbeidsongeschiktheid. 'Daarom is het van belang, dat zowel de sociale partners als de overheid in de komende jaren een systematische beleidsontwikkeling op het gebied van de humanisering van de arbeid en de sociale innovatie onderkennen als een koerskeuze van betekenis. 285

Voor het jaar 1983 is het pessimisme echter weer gegroeid. Hoewel volgens de MvT de noodzaak van verbetering van de arbeidsomstandigheden wordt onderstreept, zijn de mogelijkheden om verbetering aan te brengen steeds verder onder druk komen te staan. Dit geldt zowel voor het bedrijfsleven, waar een teruglopende investeringsbereidheid ook effect kan hebben op het kwaliteitsniveau van de arbeid, als voor de overheid. ${ }^{286}$

282 TK 1979-1980, 15.800, hfdst. XV, nr. 2, p. 80.

283 TKK 1980-1981, 16.400, hfdst. XV, nr. 2, p. 27

284 TK 1981-1982, 17.100, hfdst. XV, ni, 2 , p. 13.

285 idem, t.a.p. p. 27

286 TK $1982-1983,17,600$, hifdst. XV, nr. 2, p. 76. 
In dit decennium toelichtingen is wel een globale lijn te ontdekken. In het begin wan de jaren zeventig wordt vooral de intrinsieke waarde benadrukt van humanisering van arbeid en de zelfstandige rol van de werknemers daarbij. Het "welzijnsdenken" uit deze periode is duidelijk van invloed op de ideeën van de overheid (of nauwkeuriger: van het dan zittende kabinet en met name de betrokken bewindslieden) over de arbeidsomstandigheden in de onderneming. De overheid wil dit belang in wettelijke maatregellen gestalte geven. Vanaf circa 1976 worden de bedreigingen wan de economische crisis steeds manifester, ó́k ten aanzien van het arbeidsomstandighedenbeleid. Tegelijkertijd wordt de terughoudende rol van de overheid sterker benadrukt. Werkgevers en werknemers moeten het in eerste plaats voorall zelf proberen op te knappen. En dat het de moeite waard is om dat te doen geeft de overheid aan, door naast de intrinsieke waarde die humanisering van de arbeid heeft te beklemtonen, kort samengevat, dat het ook goed is voor het bedrijfsleven en de werkgelegenheid. Humanisering van de arbeid mede als een economisch antwoord op een economische crisis.

De veranderde rol van de overheid komt ook op een zeer verwant gebied duidelijk aan de orde. In 1974 verzocht de toenmalige minister aan de SER advies over het sociaal beleid in de onderneming. In $1981 \mathrm{kwam}$ dat advies en in 1984 het standpunt van de betrokken bewindslieden. In de adviesaanvraag werd wetgeving nog gezien als een belangrijk instrument van de overheid. De SER dacht daar anders over; en het nieuwe kabinetsstandpunt: 'Geconstateerd kan worden, dat door het verlopen van een tamelijk lange periode tussen het vragen van een advies, het ontvangen van dat advies en het formuleren van deze standpuntbepaling gewijzigde maatschappelijke opvattingen voor een groot deel bepalen dat wij ons voor wat betreft de hoofdlijnen van het beleid, meer herkennen in het SER-advies dan in de daaraan ten grondslag liggende adviesaanvraag. ${ }^{287}$

In het vervolg van deze paragraaf zal eerst aandacht worden geschonken aan een belangrijke wijziging in de Veiligheidswet 1934 die al preludeert op de Arbowet 1980: het Veiligheidsrapport. ${ }^{288}$ Vervolgens komt de belangrijkste wet in het kader van dit onderzoek aan de orde: de Arbowet 1980. Daarna wordt enige aandacht besteed aan de wijziging van de WOR 1971, de ontwik-

287 Brief van de minister en de staatssecretaris van Sociale Zaken en Werkgelegenheid aan de Voorzitter wan de Tweede Kamer, TK 1984-1985, 18.711, nr. 1, p. 3.

288 Naast maatregelen die direct betrekking hadden op (een wijziging van) de Veiligheidswet 1934, werden ook andere voorzieningen getroffen, die voorwitliepen op de ideeen die later in de Arbowet werden gepositiweerd. Een sprekend woorbeeld hiervan is de subsidieregeling. arbeidsplaatsenverbetering, waardoor de overheid een actieve inbreng kon hebben in de zorg woor een gezonde en veilige werkplek. Nadat de eerste subsidieregeling in 1976 gebleken had niet te voldoen in verband met onder meer de uitgangspunten, de criteria en de vaststelling ervan (onderzoek van de Nederlandse Organisatiekring, Nota betreffende bouwstenen voor de nieuwe subsidieregeling voor de verbetering van arbeidsplaatsen, Utrecht 1976), kwam in 1977 een mieuwe tot stand. De minister: 'Een wezenlijk punt van verschil ligt in de grotere inbreng die van de kant van de betrokken werknemers wordt verwacht" (Subsidieregeling 1977 arbeidsplaatsenwerbetering; tekst, toelichting en bijlagen, Den Haag, ministerie van Sociale Zaken, 1977, p. 21). 
keling van de $\mathrm{CAO}$, art. $1638 \times \mathrm{BW}$, internationale normen en de wijziging van de Grondwet in 1983. Omdat het hier meestal vigerend recht betreft komen de meeste van deze onderwerpen in de volgende hoofdstukken uitvoeriger aan de orde.

\subsection{Het Veiligheidsrapport}

In 1977 werd, na een relatief korte parlementaire behandeling, de regeling over het veiligheidsrapport in de Veiligheidswet 1934 opgenomen. ${ }^{289}$ Met deze regeling werd al vooruit gelopen op de algehele herziening van de veiligheidswetgeving. De haast om het veiligheidsrapport nog in de bestaande Veiligheidswet te regelen, kwam voort uit de behoefte om vooral in de proces-industrie, waar reacties met gevaarlijke stoffen, brandbare of giftige gassen onder verhoogde druk voorkomen, op korte termijn tot een grotere beheersing van gevaren en tot voorkoming van calamiteiten te komen. Het doel van het rapport is derhalve de leiding van de onderneming zich meer bewust te doen zijn van de gevaren die zich voor de werknemers kunnen voordoen en van haar verantwoordelijkheid daarbij. Daarnaast moet het rapport voor een beter inzicht van de Arbeidsinspectie zorgen in de ondernemingssituatie. 'Het veiligheidsrapport dient een gekwantificeerde schatting van maximaal te verwachten effecten te geven voor die storingen die kunnen leiden tot directe gevaren voor de veiligheid en de gezondheid van de werknemers. Daarnaast moet in het veiligheidsrapport ruime aandacht worden geschonken aan aspecten van organisatorische aard. ${ }^{2}{ }^{290}$ De regeling bestond uit vier artikelen: $20 \mathrm{u} \mathrm{t} / \mathrm{m} 20 \mathrm{x}$. Volgens art. $20 \mathrm{v}$ dient het rapport een beschrijving te bevatten van de situatie van de betreffende inrichting, de potentiële gevaren die zich bij het productieproces kunnen voordoen en de voorzieningen die getroffen zijn om storingen en de gevolgen daarvan zoveel mogelijk te beperken. Het rapport moet de actuele stand van het productieproces geven en volgens art. $20 \mathrm{w}$ zo nodig aan veranderingen worden aangepast. Eveneens volgens art. $20 \mathrm{w}$ moet het rapport worden toegezonden aan het districtshoofd van de Arbeidsinspectie die dan wel eventueel kan eisen dat aan hem aanvullende gegevens worden verstrekt, dan wel dat andere of aanvullende voorzieningen worden getroffen. Ingevolge art. $20 \mathrm{x}$ zendt het districtshoofd het rapport naar enkele andere instanties voor wie het rapport van belang kan zijn, zoals aan de districtsinspecteur voor het brandweerwezen.

De verplichting tot het opstellen van een veiligheidsrapport kan slechts worden opgelegd aan ondernemingen of delen daarvan waarbinnen zich bijzonde-

289) Wet van 23 november 1977 (S. 689). De regeling is later met enkele wijzigingen integraal opgenomen in de Arbowet. De categorale aanwijzing voor de verplichtstelling is vastgelegd in het Besluit verplichtstelling Veiligheidsrapport van 12 augustus 1981 ( $(S .556$ ). De wetsartikellen en het voornoemde besluit zijn per Besluit van 30 december 1981 (S. 826) op I febrali 1982 in werking getreden.

290 TKK 1976-1977, 13.914, nr. 5 (MvA), p. 5. 
re gevaren kunnen voordoen voor de gezondheid of de veiligheid van de werknemers. De verplichtstelling van groepen bedrijven wordt opgelegd via een $A M v B$ en van een individueel bedrijf door de Directeur-Generaal van de Arbeid (art. 20u).

De regeling van het veiligheidsrapport is een duidelijke exponent van de nieuwe filosofie die in de ongeveer in dezelfde tijd ter discusie komende Arbowet nog meer zichtbaar wordt: het zwaartepunt van het arbeidsomstandighedenbeleid in de onderneming wordt verschoven naar de onderneming zelf en moet daar voorwerp zijn van overleg tussen de bedrijfsgenoten.

Deze aanpak heeft aanleiding gegeven tot tenminste twee relevante discussiepunten: welke is de rol van de overheid hierbij, en met name die van de Arbeidsinspectie en hoe moet de participatie van de werknemers gestalte krijgen. Voor wat betreft de rol van het overheidstoezicht is gekozen voor een gedistantieerde opstelling. De overheid houdt in beginsel de handen vrij, keurt het rapport dus ook niet goed, maar heeft de mogelijkheid om in te grijpen als er onmiskenbare tekortkomingen in het rapport worden gesignaleerd. De consequentie van deze terughoudende opstelling is dat de verantwoordelijkheid duidelijker blijft waar zij volgens de wetgever ook primair hoort, namelijk bij de onderneming zelf. Ook het juridische probleem van het disculperende of strafverminderde effect van een nagevolgd deskundigen-advies is daarmee omzeild. ${ }^{291}$ Een nadeel zou echter kunnen zijn dat de stimulans tot scherp toezicht van de Arbeidsinspectie bij afwezigheid van de goedkeuringseis minder is. Anderzijds: de arbeidsomstandigheden zouden ook slechter kunnen worden als de werkgever niet meer verantwoordlelijk geacht kan worden en zich derhalve de risico's minder realiseert. In elk geval erkent de Directeur-Generaal van de Arbeid een dergelijk gevaar: 'In de bedrijven zou men de indruk kunnen krijgen dat de Overheid zorgt voor de veilligheid en de gezondheid. Men zou zelfs binnen het bedrijf 'laks' kunnen worden omdat ze (de overheid) er wel voor zorgen. ${ }^{292}$ Voor wat betreft de inschakeling van de bedrijfsgenoten bij het veiligheidsrapport werd in de Kamer gevraagd om in de wet uitdrukkelijk op te nemen dat de or bij de beoordeling en goedkeuring van het rapport moest worden betrokken. De minister meende echter dat de regeling voor de procedure van dit overleg niet thuishoorde in de veiligheidswetgeving maar in de WOR. ${ }^{293}$ Uiteindelijk is in de Veiligheidswet (in art. $20 \mathrm{w}$ lid 2) alleen de bepaling opgenomen dat ook aan de or een afschrift van het veiligheidsrapport moet worden toegezonden.

291 Algemeen over deskundigen-advies als disculpatiegrond:

HR 3 mei 1949 , NJ 1949, 538 en UR 22 november 1949 , NJ $1973,446$.

Over disculpatie resp. aansprakelijkheidsvermindering naar aamle iding van adwiezen en controle door de Arbeidsinspectie:

Rb. Maastricht, 4 nowember 1969, NJ 1971, 166 en Rb. Assen, 8 december 1971, NJ 1973, 446.

292 A.J. de Roos, De ontwikkelingen in het werk van de Arbeidsinspectie, Maatschappijbelangen, $1976, \mathrm{p} .453$.

293 MvA, ta.p. p. 4. 


\subsection{De Arbowet $1980^{294}$}

In 1975 vroeg de minister van Sociale Zaken advies aan de SER over een aantal bij de adviesaanvrage gevoegde hoofdlijnen voor de vernieuwing van de veiligheidswetgeving. Ruim een jaar later adviseerde de SER vrijwel conform de hoofdlijnen in de aanvraag. Op de valreep van 1980 verscheen de Arbowet in het Staatsblad. ${ }^{295}$ De wet trad in de plaats van de Veiligheidswet 1934, de Silicosewet, de Wet op werken onder overdruk en de Stuwadoorswet, behalve voor wat betreft de regeling van de arbeidsduur in deze laatste wet. De belangrijkste uitgangspunten van de nieuwe wet zijn enerzijds geïnspireerd door de onvolkomenheden die aan de tot dan geldende. Veiligheidswet kleefden en anderzijds door de in de vorige paragraaf gememoreerde ideeën over arbeid en de rol van de overheid en van de bedrijfsgenoten daarbij. Voor wat betreft de technische onvolkomenheden werd onder meer gewezen op de versnipperde wetgeving (deelwetgeving voor bepaalde sectoren of ter voorkoming van specifieke gevaren), en de trage aanpassingsmogelijkheden van de detailwetgeving aan veranderde technische mogelijkheden waardoor de wetgeving niet meer bij de tijd was. ${ }^{296}$ De veranderde ideeën over de rol van de arbeid, de bedrijfsgenoten en de overheid werden in de MvT als volgt verwoord: Het gaat om 'een benadering, zo men wil een filosofie, die niet alleen op de veiligheidswetgeving van toepassing is, doch evenzeer op andere delen van het terrein van de arbeidsbescherming. Deze kan zo worden verstaan dat naast de sterke motieven voortvloeiende uit de wens tot het voordurend verhogen van de normen van bescherming, die op zichzelf al tot vernieuwing van de wetgeving dwingen, vooral geldt dat behalve aan economische welvaart in toenemende mate belang wordt gehecht aan het zich welbevinden van de werkende mens met betrekking tôt zijn werk. Het zich welbevinden bij het werk moet geplaatst worden bimnen het kader van het tijdsbestek en zal dan ook in overeenstemming moeten zijn met de heersende opvattingen onder de werknemers over de beleving van hun arbeid'. ${ }^{297}$ Humanisering van de arbeid wordt een wettelijk vastgelegde doelstelling. De considerans: '... zulks ter bevordering van menswaardige arbeid.' Geheel in overeenstemming met de in de vorige paragraaf beschreven tendens benadrukte minister Albeda vier jaar later tijdens het plenaire debat in de Tweede Kamer ook nog de bedrijfseconomische overwegingen die moesten leiden tot een positief oordeel over de wet. "Alhoewel het niet altijd even zinvol is om kosten en baten van een bepaald sociaal beleid naast elkaar te zetten en gegeven het feit dat gehumaniseerde arbeidsomstandigheden een doel op zichzelf vormen en men dus niet in

294 Gedeetten uit deze paragraaf zijn eerder gepubliceerd in mijn artikel: De inwerkingtreding vam die arbeidsomstandighedenwet, NJB, 1983, p. 83-87.

295 Wet van 8 november 1980 (S. 664). De adviesaanvraag van de minister is opgenomen als bijlage $I$ in het advies inzake de vernieuwing van de wetgeving betreffende de gezondheid en de velligheid bij de arbeid, uitgave SER, 1976, nr. 18 .

296 SER adviesaanvraag, t.a.p. p. I/2.

297 TK 1976-1977, 14.497, nr. 3 (MvT), p. 1. 
laatste instantie het daaraan werken kan laten bepalen door het batige saldo in bedrijfseconomische zin, meen ik dat er toch kan worden gewezen op een aantal positieve effecten van een goed sociaal beleid op de bedrijfsvoering. In de eerste plaats mag worden verwacht dat door een verbetering van de mogelijkheden om zich in zijn werk te ontplooien de motivatie en zeker ook de creativiteit van de werkende mens toeneemt. Dat kan een positieve invloed hebben op de innovatie in het bedrijfsleven. Van een verhoogde aandacht voor veiligheid, gezondheid en welzijn mag in de tweede plaats een verlaging van het aantal ongevallen, al dan niet gepaard gaande met vaak niet geringe materiële schade en beroepsziekten worden verwacht. Van hoeveel belang beperking van het ziekteverzuim is, behoef ik hier niet verder uiteen te zetten. In de derde plaats kan verbetering van de arbeidsomstandigheden leiden tot beperking van uittreden uit het arbeidsproces - van verschillende zijden is gewezen op de problematiek van de WAO - terwijl herintreden wordt bevorderd. In de vierde plaats wil ik er nog op wijzen dat een verbetering van arbeidsplaats en kan bijdragen tot het oplossen van een aantal knelpunten op de arbeidsmarkt en ook daar is van verschillende kanten op gewezen, met name waar het gaat om beperking van het aantal moeilijk vervulbare vacatures. ${ }^{2998}$

Uiteindelijk werd de wet na een aantal wijzigingen, maar zonder in essentie de doelstelling en de uitwerking aan te tasten, door de beide kamers unaniem aanvaard. De belangrijkste bepalingen zijn de volgende. De doelstelling van de wet heeft vergeleken met de Veiligheidswet van 1934 een belangrijke verbreding ondergaan. Het gaat niet meer alleen of voornamelijk om veiligheid en gezondheid, maar om het welzijn bij de arbeid. Bij dit laatste begrip werden overigens zowel in de beide kamers als daarbuiten, met name door de sociale partners, vraagtekens gezet. ${ }^{299}$ In zijn MvA moest de minister toegeven dat het begrip 'inderdaad abstract en moeilijk afgrensbaar' is, maar hij probeerde toch een verduidelijking aan te brengen. 'De omstandigheden en verhoudingen waaronder gewerkt wordt en de inhoud van de arbeid die wordt verricht dienen zo te zijn, dat voldoende ruimte wordt geboden voor ontplooiing en creativiteit. Alleen wanneer de arbeidsomstandigheden, de arbeidsorganisatie en de arbeidsinhoud daartoe voldoende mogelijkheden kunnen bieden, kan de arbeid een bijdrage leveren aan het welzijn van de werknemers. Anders gezegd: welzijn in verband met de arbeid heeft te maken met de ruimte die de arbeidsomstandigheden, de arbeidsorganisatie en de arbeidsinhoud bieden voor eigen verantwoordelijkheid, inbreng en creativiteit van de werknemers. ${ }^{.300}$ Het werkingsgebied van de wet wordt uigebreid tot in beginsel alle

298 Handelingen TK 1979-1980, p. 4674. Al eerder was een soort kosten-baten-analyse gemaakt in de MvA, p. 2 en 3, TK 1978-1979, 14.497, nr. 5.

299 Voor het werkgewersstandpunt: $\mathrm{C}$. de Meester, Ontwerp Arbeidsomstandighedenwet laat veel ter invulling ower, de werkgeversvisic, SMA, 1978, p. 604-616. Voor het werknemersstandpunt: J. Bloemarts, Op weg naar een drie-partijen-model voor het sociaal beleid in de onderneming?, SMA, 1978 , p. 590-603.

300 MvA, t.a.p. p. $7-8$. 
arbeid die verricht wordt op grond van een arbeidsovereenkomst, krachtens een publiekrechtelijke aanstelling, of die verricht wordt onder gezag van een ander. Daarnaast kunnen ook zelfstandigen onder de werking van de wet worden gebracht. Het uitgangspunt van de terughoudende overheid leidt onder meer tot de in art. 4 vervatte beleidsopdracht aan de werkgever om zijn totale ondernemingsbeleid 'mede te richten' op een zo groot mogelijke veiligheid, zo goed mogelijke bescherming van de gezondheid en het bevorderen van het welzijn van de werknemers. De betekenis hiervan is niet gering. De werkgever wordt immers verplicht om deze doelstelling van sociaal beleid te realiseren in dezelfde mate als waarin hij dat tracht te doen ten aanzien van de traditionele, vooral economisch gerichte, bedrijfsdoelstellingen. Dat beleid dient volgens art. 4 de instrumenten te bevatten om de doelstelling te bereiken evenals een duidelijke afbakening van taken en bevoegdheden op dit gebied. Regelmatige toetsing van dit beleid aan de praktijk is eveneens voorgeschreven. Nader aan te wijzen bedrijven moeten een en ander schriftelijk in een jaarplan vastleggen. Bovendien verplicht art. 4 de werkgever om over dat beleid vooraf overleg te plegen met de or of de betreffende commissie, of, als deze beiden ontbreken, met de belanghebbende werkmemers.

Maar de wet gaat verder. In art. 3 worden grondbeginselen opgesomd die moeten dienen als richtsnoer, als toetsingskader voor het op grond van art. 4 te voeren beleid. $\mathrm{Zij}$ liggen op het gebied van de inhoud en organisatie van het werk, de inrichting van de arbeidsplaatsen ('fitting the job to the worker'), de produktie- en werkmethoden en het gebruik van materialen. In het algemeen wordt geëist dat op deze terreinen de grondbeginselen worden nagestreefd voorzover dat in redelijkheid gevergd kan worden. Er moet dus een afweging plaatsvinden. Maar expliciet vermeldt art. 3 dat daarbij wèl betrokken moeten worden 'de best bestaande regelen der techniek', 'de stand van de bedrijfsgezondheidszorg', 'de stand van de wetenschap op het gebied van de ergonomie alsmede de arbeids-en bedrijfskunde'. Beleidsvrijheid dus voor de bedrijven, maar wèl binnen de indicatieve normeringen van de overheid.

De verplichting in art. 4 voor de werkgever om overleg te voeren met de werknemers is een logisch gevolg van de in art. 13 algemeen geformuleerde verplichting voor werkgever en werknemers om samen te werken. ${ }^{301}$ Dit hangt nauw samen met een ander belangrijk uitgangspunt van de Arbowet: de werknemer is niet langer passief object van zorg maar actief betrokkene bij de arbeidsomstandigheden in de onderneming. Hij krijgt daarvoor ook een aantal instrumenten in de vorm van informatie- en medezeggenschapsrechten. Om een goede samenhang met de WOR te verzekeren zijn de rechten en bevoegdheden van de werknemers voor een belangrijk deel gecollectiveerd

301 Volgens Directeur-Generaal van de Arbeid de Roos kunnen de artikelen 3,4 en 13 beschouwd worden als de 'kern van de structumr van de Arbowet', A.J. de Roos, de Arbeidsomstandighedenwet, SMA, 1982, p. 308 . 
dat wil zeggen toegekend aan de or of een Commissie. ${ }^{302}$

De samenwerking en het overleg tussen sociale partners en overheid krijgen op centraal niveau gestalte in de Arboraad. (In afwachting van de definitieve instelling hiervan op 1 januari 1983, functioneerde tot die tijd de Voorlopige Arbeidsraad (VAR) met als belangrijke taak het voorbereiden van de inwerkingtreding van de Arbowet). In de Arboraad zijn werkgevers en werknemers gelijkelijk vertegenwoordigd; ambtenaren zijn lid zonder stemrecht.

Hoewel het zwaartepunt van het arbeidsomstandighedenbeleid in de onderneming zelf ligt, heeft de wet ingrijpen van de overheid, de Arbeidsinspectie, niet uitgesloten. De Arbeidsinspectie krijgt daartoe, met behoud van de andere taken en bevoegdheden, een nieuwe mogelijkheid tot ingrijpen erbij: de aanwijzing tot naleving. Via dit instrument wordt, nà het horen van de bedrijfsgenoten, voorgeschreven hoe algemeen geformuleerde bepalingen in concrete situaties dienen te worden nageleefd. Daarnaast kan de Arbeidsinspectie beslissen of, en zo ja, welke maatregelen genomen moeten worden bij onenigheid tussen werkgever en werknemers (or), wanneer een der partijen daarom vraagt. ${ }^{303}$

Bevordering van de deskundigheid binnen de onderneming is een ander uitgangspunt. Daarbij wordt aangeknoopt bij de regeling in de Veiligheidswet over de bedrijfsgeneeskundige dienst. De bepalingen over de bedrijfsgezondheidsdienst (de nieuwe naam) zijn dan ook voor een groot deel overgenomen, met een aanscherping op het gebied van de functionele onafhankelijkheid en de verplichting tot samenwerking met en informatie verstrekking aan de werknemers c.q. de or c.q. de Commissie. Een soortgelijke regeling is opgenomen ten aanzien van veiligheidsdiensten en veiligheidskundigen. Tenslotte voorziet de wet in de mogelijkheid tot het oprichten van geïntegreerde diensten: de Arbodiensten. Minister Albeda kwalificeerde deze laatste mogelijkheid echter als 'toekomstperspectief'. ${ }^{304}$

Op 1 januari 1983 trad een gedeelte van de Arbowet in werking: de eerste fase. ${ }^{315} \mathrm{Ik}$ zal hier iets dieper op ingaan. In de eerste plaats omdat op die

302 Dit kan een commissie zijn op grond wan de Arbowet ex art. 14, de zgn. Arbocommissie, of een (vaste) commissie op grond van art. 15 lid 1 WOR, de $z \mathrm{gn}$. VGW-commissie. Alleen als un een onderneming geen or is, kan zo"n onderneming aangewezen worden om aan Arbocommissie te hebben. In de praktijk zal het dus vooral gaan om de - niet verplichte - commissic van de or. In de Arbowet wordt onder Commissie (met een hoofdletter) verstaan: de Arbocommissie van art. 14.

303 Dit is het verzoek on wetstoepassing (art. 40). Er kan dan worden gewraagd om een aanwijzing tot naleving (art. 35), een eis (die al mogelijk was op grond van de Veiligheidswet; in de Arbowet art. 36) of een bevel tot stillegging van het werk (de zgn. parate executie, ook all mogelijk op grond van de Veiligheidswet art. 37). Beroep staat open bij de minister van Sociale Zaken en Werkgelegentheid (art. 42).

304 Handelingen t.a.p. p. 46.181 en 46.182 .

305 Besluit van 15 november 1982 (S. 673). Hoewel minister Albeda aan de Kamer toezegde om hoge prioriteit te geven aan de inwerkingtreding wan de wet, had hij al eerder verklaard dat dit onder meer zou afhangen van de mate waarin de Arbeidsinspectie op sterkte zou zijn. Hij noemde een periode van acht jaar. Daarop nam de Kamer een motie aan walarin werd uitgesproken dat de wet zo spoedig mogelijk in werking zou moeten treden, en dat over de gefaseerde invoering telkens een jaarverslag gepubliceerd zou moeten worden (motie B. Bakker en Weyers, TK 1979-1980, 14.497, nr. 172). 
manier kennis kan worden gemaakt met een aantal andere artikelen uit de wet en in de tweede plaats omdat zich rondom de inwerkingtreding tussen werkgevers- en werknemersvertegenwoordigers in de VAR (Arboraad) de eerste schermutselingen manifesteerden die nog steeds voortduren, grotendeels over dezelfde onderwerpen en met dezelfde argumenten en die van invloed zijn, of geweest zijn, op de verdere inwerkingtreding van de Arbowet. Het ging bij die eerste fase om twee groepen artikelen.

De eerste groep betreft artikelen - of delen daarvan - die nodig zijn opdat de geldende regelingen op grond van de Veiligheidswet 1934, de Silicosewet, de Wet op het werken onder overdruk en de Stuwadoorswet, voorzover het tenminste de veiligheids- en gezondheidsaspecten betreft, behouden blijven. Dit zijn de 'status quo'-artikelen. Terecht constateerde de VAR in zijn advies, dat de inwerkingtreding van deze artikelen per 1 januari 1983 - nodig om handhaving van de bestaande situatie te verzekeren - toch nog een viertal materiële wijzigingen inhoudt. ${ }^{306}$ De VAR doelde hierbij op het van toepassing worden van de Wet op de Economische Delicten (WED), het feit dat degene die werknemers leent ten opzichte van het aan hem uitgeleende personeel beschouwd wordt als werkgever, de omzetting van de VAR in de Arboraad en de omzetting van het College van bijstand en advies voor de bedrijfsgeneeskunde in een vaste commissie van de Arboraad.

De tweede groep artikelen brengt nieuws. Over de wenselijkheid tot invoering van een aantal bepalingen uit deze groep bestond unanimiteit in de VAR. De belangrijkste hiervan zijn, in het kort, de volgende:

- de verplichting voor de werkgever van daartoe aangewezen (onderdelen van) potentieel gevaarlijke bedrijven om een arbeidsveiligheidsrapport te maken. Hierover moet vooraf overleg gevoerd worden met de or c.q. de Commissie (art. 5; zie ook de vorige paragraaf).

- de verplichting voor de werkgever om doeltreffende maatregelen te nemen ter voorkoming van gevaar voor anderen dan werknemers (bijvoorbeeld bezoekers; art. 11).

- het hierboven al besproken art. 13 waarin de samenwerking tussen werkgever en werknemers verplicht wordt gesteld;

- de rechten, bevoegdheden en faciliteiten van de Arbocommissie: scholing en vorming; informatie van werkgever, bedrijfsarts, veiligheidskundige en Arbeidsinspectie; beraad met en raadpleging van al dan niet in de onderneming werkzame personen; kennisneming van de arbeidsomstandigheden in de onderneming; vertrouwelijke gesprekken met de Arbeidsinspectie; vergezellen van de Arbeidsinspectie tijdens bezoeken aan de onderneming; alle verdere faciliteiten die nodig zijn voor een goede taakuitoefening en

306 Advies inzake de eerste fase van invoering van de Arbeidsomstandighedenwet, Voorlopige Arbeidsraad, 1982, nr. 2, p. 9. 
waarover de werkgever kan beschikken (art. 14 lid 10). ${ }^{307}$

- art. 15 waarin art. 14 lid 10 van overeenkomstige toepassing wordt verklaard op leden van de or en waarin de eventuele overdracht van (een deel van) de rechten en bevoegdheden van de or aan een commissie van de or wordt geregeld;

- gedeelten van de artt. 18, 20, 22 en 23 die handelen over het verplicht hebben van een (gezamenlijke) bedrijfsgezondheidsdienst, en de bevoegdheden en verplichtingen van zo'n dienst;

- de artt. $32 \mathrm{t} / \mathrm{m} 37$, geheel of gedeeltelijk, over de Arbeidsinspectie, waaronder de nieuwe bevoegdheid om een aanwijzing te geven, na het horen van de betrokken partijen;

- het recht voor elke werknemer om het werk te onderbreken bij dreigend en acuut gevaar. Bij meningswerschillen achteraf over de redelijkheid hiervan berust de bewijslast bij degene die stelt dat de werknemer het werk ten onrechte heeft neergelegd (art. 38).

- de bevoegdheid van de werkgever en van de or c.q. de Commissie, c.q. een meerderheid van de belanghebbende werknemers om tot de Arbeidsinspectie een verzoek om wetstoepassing te richten (art. 40) en van de beslissing eventueel in beroep te gaan bij de minister (art. 42).

Over de inwerkingtreding van een aantal artikelen bestond onenigheid in de VAR tussen de werkgeversvertegenwoordigers en de werknemersvertegenwoordigers. Sommige van deze artikelen zijn wèl ingevoerd per 1 januari 1983, andere werden dat in het vervolg van de eerste fase op $\mathbb{1}$ juni 1985 en weer andere zijn in latere fasen aan de beurt (hierover uitgebreider de volgende paragraaf). Het gaat om de volgende:

- In tegenstelling tot wat de werkgevers wilden, is besloten om ook de bepaling waarin de ontslagbescherming van de bedrijfsartsen is geregeld per 1 januari 1983 in te voeren (art. 18 lid 5). Bij deze beslissing heeft zwaar gewogen het belang van de onafhankelijke positie van de bedrijfsarts, vooral nu hij ook wettelijke taken krijgt ten aanzien van de or ${ }^{308}$

- Een probleem vormde de mogelijke samenloop van beroepsprocedures bij de beslechting van geschillen krachtens art. 15 juncto art. 14 lid 10 (de faciliteitenregeling voor or c.q. commissie, zie hierboven) op grond van respectievelijk de WOR en de Arbowet. ${ }^{309}$ In het eerste geval is de bedrijfscommissie de aangewezen instantie, in het tweede geval de Arbeidsinspectie. In beide gevallen is de minister van Sociale Zaken en Werkgelegenheid de

307 Art. 14 is niet per 1 januari 1983 in werking getreden. Wel wordt aangenomen dat lid 10 door de inwerkingtreding van art. 15 kennelijk geacht wordt ook 'te gelden'. De inwerkingtreding van art. 15 zou anders zonder betekenis zijn, omdat in dit artikel bevoegdheden toegekend worden aan de or resp. de commissie van de or die genoemd worden in art. 14 lid 10.

308 Ten aanzien van art. 18 lid 5 speelt een soortgelijke problematiek als ten aanzien van art. 15 , zoals die in de vorige noot is geschetst. Het in werking getreden artikel 18 lid 5 verwijst naar het nog niet in werking getreden artikel 8 lid 5 , dat overigens op zijn beurt weer verwijst naar art. 21 lid $3 \mathrm{t} / \mathrm{m} 5$ WOR.

309 I. de Meester en H. van de Kamp, Het spanningsveld tussen Arbowet en Wet OR, SMA, 1982 , p. $726-735$. 
aangewezen beroepsinstantie. Dàt deze samenloop een probleem kan zijn, daarover waren werkgevers en werknemers het wel eens. Zij verschilden echter van mening over de oplossing. De werkgevers vonden dat éérst een wetswijziging moest plaatsvinden, of althans de aankondiging daartoe, bijvoorbeeld door een adviesaanvraag aan de SER. De werknemers achtten wetswijziging ook wenselijk, maar de inwerkingtreding zou door kunnen gaan door in die tussentijd via een interne instructie aan de Arbeidsinspectie vast te leggen dat de procedure bij de bedrijfscommissie prevaleert boven die bij de Arbeidsinspectie.

Deze laatste visie is gevolgd. In afwachting van een SER-advies en een eventueel daarop gebaseerde wetswijziging hebben de districtshoofden geen bevoegheid gekregen om aanwijzingen te geven ten aanzien van de faciliteiten die de or ook al heeft op grond van de WOR. Geschillen hierover horen dus exclusief bij de bedrijfscommissie.

- De werknemers hebben hun zin gekregen met het besluit dat de bepaling in werking is getreden dat ook de vakbeweging, bij het ontbreken van een or c.q. Commissie, een verzoek om wetstoepassing kan doen en naar aanleiding van de beslissing van de Arbeidsinspectie in beroep kan gaan bij de minister (art. 40 respectievelijk art. 42). De werkgevers wilden invoering van dit gedeelte van de artikelen uitstellen tot mei 1984, twee jaar na de inwerkingtreding van de '100-min wet'. Het oprichten van een or in deze kleinere bedrijven zou dan achter de rug zijn en tijdens de oprichtingsfase zou dan het interne overleg niet doorkruist kunnen worden door 'externe invloeden' (de vakbeweging dus).

- Onenigheid ook over de inwerkingtreding van de verplichting voor de werkgever tot het geven van voorlichting en onderricht (art. 6). De werknemersleden van de VAR wilden invoering in de eerste fase, de werkgeversleden wilden eerst nagaan hoe aan deze bepaling inhoud zou kunnen worden gegeven. De beslissing is een meedogenloos compromis: wèl invoering in de eerste fase, maar het tijdstip van inwerkingtreding zou afhangen van ontvangst en verwerking van het te vragen VAR-advies over dit artikel. (Het artikel is per 1 juni 1985 ingevoerd).

- Ditzelfde geldt ook voor art. 10: het voor daartoe aangewezen bedrijven verplicht maken van een jaarverslag. Het (versnelde) advies hierover was al gevraagd door staatsecretaris d'Ancona in het kader van de ziektewetplannen van het toenmalige kabinet. ${ }^{310}$ De werkgevers voelden niets voor invoering in de eerste fase, omdat het in hun ogen alleen mar een stuk gelegenheidswetgeving betrof. Hoewel ook de werknemersvertegenwoordigers dit laatste erkenden, meenden zij dat het jaarverslag een nuttige bijdrage zou kunnen leveren aan de verbetering van de arbeidsomstandigheden. Dit standpunt is overgenomen, waardoor ook art. 10 op 1 juni 1985 werd ingevoerd.

310 Ministerie van Sociale Zaken en Werkgelegenheid, brief van 1 maart 1982 aan de VAR (DGA, nr. 232180 ). 
Het belangrijkste verschil van mening in de VAR ging over de invoering van de artt. 3 en 4 . Hierboven heb ik al aangegeven dat deze artikelen beschouwd moeten worden als uitermate belangrijke peilers van de Arbowet. In art. 3 zijn de grondbeginselen voor het te voeren arbeidsomstandighedenbeleid geformuleerd. De werknemers in de VAR vonden invoering van dit artikel in de eerste fase noodzakelijk. Zij zien in de grondbeginselen 'een agenda of toetssteen voor het overleg tussien werkgever en or c.q. bellanghebbende werknemers, welke niet gemist kan worden naast de in te voeren bepalingen die de medezeggenschapspositie van de werknemers regelen'. ${ }^{311}$ De werknemers meenden verder 'dat de interpretatie van de grondbeginselen - mede gelet op de daarin vervatte noodzaak van afweging van belangen - het beste kan geschieden aan de hand van concrete aan de praktijk ontleende casus-posities". Bovendien kan art. 3 van betekenis zijn voor die arbeidsorganisaties waarop (nog) geen concrete uitvoeringsvoorschriften van toepassing zijn zoals die welke in het Veiligheidsbesluit fabrieken of werkplaatsen staan. Het gaat hierbij om een aanzienlijke restgroep waaronder kantoren, winkels, ziekenhuizen e.d. Door invoering van art. 3 kan de Arbeidsinspectie via haar aanwijzingsbevoegdheid in elk geval op die manier verbeteringen afdwingen binnen die arbeidsorganisaties.

De werkgevers vonden het "uiterst ongewenst op basis van concrete casusposities een uitvoeringsbesluit te ontwikkelen en zo te gaan experimenteren met grondbeginselen en begrippen, alvorens over de draagwijdte daarvan degelijk overleg heeft plaatsgevonden". ${ }^{312}$ Voor wat betreft de door de werknemers genoemde groep arbeidsorganisaties waarop geen uitvoeringsbesluiten van toepassing zijn vonden de werkgevers dat de ontwikkeling van deze normen (in het toekomstige Veiligheidsbesluit restgroepen) niet moest worden doorkruist door vast met een uitvoeringsbeleid op grond van art. 3 te starten. Op grond van goeddeels dezelfde argumenten als die van werkgeverskant zijn aangevoerd, is besloten om art. 3 niet op te nemen in de eerste fase. Dat is jammer en teleurstellend. Het betekent dat het artikel waarin bij uitstek daadwerkelijk gestalte wordt gegeven aan de nieuwe manier van denken over arbeid, arbeidsomstandigheden en de rol van de werknemer daarbij, nu juist niet van kracht wordt. Los nog van het feit dat de argumenten van de werknemers in de VAR mij sterker lijken dan de argumenten van werkgeverskant is het psychologisch onjuist om een (gedeelte van de) wet waarvan het belang en het vernieuwende karakter door met name de overheid zo benadrukt wordt, in werking te laten treden zònder het artikel dat dat belang en het vernieuwende karakter voor een groot deel bepaalt. Bovendien kunnen de wèl ingevoerde artikelen in de praktijk beduidend minder betekenis hebben zoals de verplichte samenwerking tussen werkgever en or. Ook de aanwijzingsbevoegdheid van de Arbeidsinspectie kan sterk aan betekenis inboeten zonder de mogelijkheden van art. 3 .

311 VAR-advies, ta.p. p. 37.

312 VAR-advies, t.a.p. p. 38 
Uiteraard bestaat er een directe band tussen dit artikel en art. 4 . Immers art. 3 bevat de bouwstenen voor het arbeidsomstandighedenbeleid dat de werkgever op grond van art. 4 verplicht is te voeren. Om dezelfde redenen als boven bij art. 3 vermeld, verzetten de werkgevers zich tegen invoering van deze verplichte beleidsvoering. En voor het verplichte overleg vooraf met de or over dit te voeren beleid (lid 4 van art. 4), meenden zij, schept de WOR al voldoende garanties. Dit laatste argument is overgenomen. Wèl is in de eerste fase de verplichtstelling om een beleid te voeren dat mede is gericht op veiligheid, gezondheid en welzijn opgenomen (art. 4 leden 1 en 2), weliswaar eveneens gefaseerd binnen de eerste fase (dus op 1 juni 1985 in werking getreden), maar de overige leden van art. 4 treden niet in werking. Dit is dus met name van belang voor het in lid 4 verplicht gestelde overleg vooraf met de or, de Commissie (of, bij het ontbreken van beide colleges, met de belanghebbende werknemers) over dat beleid. Volgens de werknemersleden in de VAR biedt de overlegbepaling in dit vierde lid een concretisering van de samenwerking tussen werkgevers en werknemers en een wezenlijke aanvulling op het initiatiefen instemmingsrecht van de or op grond van de WOR. De werkgevers meenden echter dat juist deze rechten van de or nu al voldoende basis bieden voor het met de werkgever te voeren overleg. De verantwoordelijke bewindslieden hebben zich daar dus bij aangesloten. ${ }^{313}$ Dit lijkt niet juist. Door het niet invoeren van de overlegbepalingen krijgt art. 4 een tè vrijblijvend karakter en de WOR maakt dat niet goed. Immers, de verplichting voor de werkgever om vooraf overleg te voeren is iets geheel anders dan het recht van de or om op grond van de WOR zaken op de agenda voor het overleg te zetten. Ook het instemmingsrecht van de or op grond van art. 27 lid 1 onder e WOR ten aanzien van een voorgenomen besluit tot vaststellen of wijzigen van een 'regeling op het gebied van de veiligheid, de gezondheid of het welzijn in verband met: de arbeid' biedt hier onvoldoende soelaas. Het gaat daarbij immers feitelijk, althans in eerste instantie, om een veto-recht voor de or en bovendien: een regeling behoeft niet gelijk te zijn aan een beleid. Mijn belangrijste bezwaar is echter hetzelfde als bij art. 3: door dit gedeelte van art. 4 niet in werking te laten treden verliest het in werking getreden gedeelte van de wet een groot gedeelte van haar karakter en daarmee van haar vernieuwende dimensie.

313 In zijn brief van 16 september 1982 aan de VAR inzake de inwerkingtreding cerste fase (DGA, Hoofdafd. Wetgevingsbeleid, nr. 242 763) noemt de staatssecretanis op p. 2 als basis voor dit overleg met name de art. 23,31 en 356 van de WOR. Opneming vatn dit laatste artikel is kennelijk een wergissing. Bedoeld is ongetwijfeld art. $31 \mathrm{~b}$. 


\subsection{Wijzigingen van de WOR 1971}

Al vrij snel na de totstandkoming wan de WOR 1971 werd begonnen met de voorbereidingen van een grondige herziening. ${ }^{3.4}$ De minister-president van het in 1973 aangetreden kabinet Den Uyl, zei hierover in zijn bekende Nijmeegse rede tot de christelijke werkgevers onder meer dat wetgeving vaak het product is van een jarenlange ontwikkeling en dat voor wat betreft de WOR moest worden erkend dat ze het resultaat was van het denken in de jaren vijftig en zestig. Na gewezen te hebben op diverse verouderde rapporten vervolgde hij: 'Ondertussen is er ook in de onderneming een nieuwe generatie met - zeg ik erbij - meer onderwijs, meer opleiding aan bod gekomen, is de gedachte omtrent selectieve groei vrij algemeen aanvaard, heeft de behoefte aan nieuwe zeggenschaps-structuren zich op een breed maatschappelijk veld gemanifesteerd, ligt er bijvoorbeeld sinds dit voorjaar in Duitsland een voorstel op tafel tot paritaire samenstelling van de Raden van Commissarissen, half factor arbeid, half factor kapitaal voor het hele bedrijfsleven. Het is een illusie te menen, dat ons ondernemingsrecht, hoe zeer ook betrekkelijk kort geleden in nieuwe wetgevende omhulsels gestoken, aan deze ontwikkeling voorbij zou kunnen gaan. En daarom is het niet redelijk om te klagen dat wetgeving zo betrekkelijk kort na de totstandkoming opnieuw aan herbezinning wordt onderworpen. "315

In de adviesaanvraag aan de SER in oktober 1973 werd, naast op den Uyls verhaal aansluitende overwegingen dat in de onderneming een zo groot mogelijke democratisering tot stand moest worden gebracht en dat van verschillende kanten gepleit werd voor een verdere uitbreiding van de bevoegdheden van de or, gewezen op de 'aanmerkelijke meningsverschillen' tussen or en vakbeweging, met name "op kritieke momenten' bij stakingen. ${ }^{316}$ Het twee jaar later uitgekomen advies van de SER was sterk verdeeld vooral rondom het vraagstuk van de zelfstandigheid van de or en het voorzitterschap. Het kabinet koos in beginsel voor het standpunt van de minderheid: de bestuurder werd geen voorzitter van een betrekkelijk zelfstandige or. Nadat de gewijzigde WOR bijna een kabinetscrisis had opgeleverd, struikelde het kabinet den Uyl tenslotte over een ander 'hervormingsvoorstel', de grondpolitiek. ${ }^{317}$ Het daarop

314 Uitvoerig over de wijziging van 1979: Duk, Fase, van der Heijden; Maschhaupt, t.a.p.; M.G. Rood, t.a.p.; G. van den Heuvel, t.a.p. Alle met verdere literatuurwerwijzingen.

In 1974 en 1976 werd de WOR - niet ingrijpend - gewijzigd. Het ging resp. om heffingen ter bevordering van scholing en vorming en om de mogelijkheid om groepsondernemingsraden in te stellen (Wet van 23-8-1974, S. 538 en Wet van 24-3-1976, S. 225).

315 J.M. den Uyl, Socialisme en vrije ondernemingsgewijze produktie, in: Inzicht en witzicht, opstellen over economie en politiek, Amsterdam, 1978, p. 190.

316 Adviesaanvraag aan de SER van 4 oktober 1973 , bijlage I bij SER-advies van 17 oktober 1975, SER 1975, nr. 14.

317 Tijdens de debatten over de WOR was al bekend dat het kabinet het niet eens kon worden over de grondpolitiek. De PSP-afgevaardigde: 'Is dit wetsontwerp (de WOR, AG) dan hellemaal onschuldig? Of moet je zeggen dat werknemers minder gevreesde kiezers zijn dan grondeigenaren? Of heeft men het idee dat ondernemers beter en vrijwel zeker hun zin kumnen doordrijven?' Handelingen TK 1976-1977, p. 3873. 
volgende (eerste) kabinet van Agt bracht echter slechts kleine wijzigingen aan in het wetsontwerp en uiteindelijk werd de ingrijpende herziening van de WOR 1971 in 1979 door beide kamers aanvaard. ${ }^{318}$ De belangrijkste veranderingen betroffen de samenstelling van de raad (alleen gekozen leden en de bestuurder geen voorzitter), de uitbreiding van het adviesrecht met een beroepsmogelijkheid bij de ondernemingskamer en de uitbreiding van het instemmingsrecht.

Voor wat betreft de mogelijkheden van de or op het gebied van de arbeidsomstandigheden in de onderneming, is er weinig veranderd bij de wetswijziging in 1979. Het instemmingsrecht van de or voor "een maatregel op het gebied van de veiligheid, gezondheid of de hygiëne" werd veranderd in een instemmingsrecht ten aanzien van 'een regeling op het gebied van de veiligheid, de gezondheid of het welzijn in verband met de arbeid'. Het begrip hygiëne is verdwenen omdat het "thans onder de gezondheid (wordt) begrepen". ${ }^{31}$ "Over het onderwerp 'welzijn in verband met arbeid' (oorspronkelijk: welzijn bij of in verband met de arbeid) werd door de grote christelijke partijen gevraagd of het wel verstandig was dit onderdeel op te nemen, omdat het tot eindeloze discussies aanleiding zou kunnen geven. De minister meende dat dit niet hoefde te gebeuren. Het begrip is volgens hem 'ontleend aan en dient te worden geïnterpreteerd binnen het kader van de in voorbereiding zijnde Arbeidsomstandighedenwet... ${ }^{320}$ Een daarna door enkele fractieleden van de VVD ingediend amendement om 'welzijn in verband met de arbeid' weer te vervangen door 'hygiëne' in verband met de vaagheid van de eerstgenoemde term, die niet zou passen in een limitatieve opsomming van verplichtingen, werd niet aanvaard ${ }^{321}$ (Zie over het begrip welzijn in verband met de arbeid in het kader van de Arbowet de vorige paragraaf). Het prevaleren van een $\mathrm{CAO}$ terzake (in 1971 lid 2; in 1979 lid 3) geldt alleen als het betrokken onderwerp daarin 'inhoudelijk' is geregeld. Deze bepaling kan voor de or van belang zijn in het licht van de vanaf deze tijd weer toenemende belangstelling voor het opnemen van arbeidsomstandigheden-bepalingen in een CAO (zie de volgende paragraaf). In 1971 prevaleerde de CAO gezien de formulering - het ging louter om een regeling - dus 'minder'. In art. 28 is het bevorderen van 'de wettelijke voorschriften ter bescherming' vervangen door het bevorderen van 'de voorschriften ter bescherming van de veiligheid en de gezondheid'. De taak van de or behoeft zich dus niet meer te beperken tot wettelijke voorschriften, maar kan mede omvatten interne reglementen, $\mathrm{CAO}$-bepalingen, aanwijzingen van de Arbeidsinspectie e.d. Een amendement van een PSP-fractielid om in plaats van 'bevordert zoveel als in zijn vermogen ligt' te lezen: 'controleert', in verband met de suggestie dat de or anders een soort uitvoerend orgaan van de ondernemingsleiding zou zijn, werd verworpen. ${ }^{322}$ Het is overigens vreemd dat

319 TK 1976-1977, 13.954, nr. 7 (Toelichting bij nota van wijzigingen), p. 13.

320 TK 1976-1977, 13.954, nr. 12 (Nota n.a.v. het eindverslag), p. 14.

321 TK 1976-1977, 13.954, nr. 31 (amendement Rietkerk c.s.).

322 TK 1976-1977, 13.954, nr. 45 (amendement van der Lek). 
aan de formulering van art. 28 het begrip welzijn niet is toegevoegd zoals dat wèl is gebeurd bij art. 27. Maar een redelijke uitleg brengt met zich mee dat de stimulerende taak van de or zich uitstrekt tot het hele gebied dat door de Arbowet wordt bestreken. ${ }^{323}$ In verband met de mogelijkheid om voor het arbeidsomstandighedenbeleid in de onderneming een vaste commissie van de or in te stellen is het van belang te vermelden dat sinds de wijziging van de WOR in 1979 deze commissie niet meer behoeft te bestaan uit louter or-leden. Wel moet een meerderheid van de commissie nog uit or-leden bestaan (art. 15 lid 1). Nieuw is de bepaling (art. 31b) dat de ondernemer ten behoeve van de bespreking van de algemene gang van zaken van de onderneming ten minste éénmaal per jaar aan de or onder meer schriftelijke gegevens moet verstrekken over het gevoerde èn het jaar daarop te voeren, (dit laatste mag ook mondeling) sociale beleid, in het bijzonder met betrekking tot de aangelegenheden die bedoeld worden in de artt. 27, 28 en 29. De gegevens over de arbeidsomstandigheden in de onderneming die de or op deze manier verkrijgt, kunnen een belangrijke rol spelen in het overleg met de ondernemer hierover. Eventueel kunnen zij aanleiding zijn voor de or om zelf het initiatief te nemen om deze aangelegenheid bij de ondernemer aan de orde te stellen (art. 23). Tot slot is in 1981 de WOR aangevuld met twee artikelen (artt. 35a en 35b) die de medezeggenschap in kleine ondernemingen regelen. ${ }^{324}$ Voor ondernemingen met meer dan 35 maar met minder dan 100 werknemers geldt een aangepast regime, dat voor de medezeggenschap inzake arbeidsomstandigheden echter geen afwijkende bepalingen bevat, behalve dat de informatie van 31b niet schriftelijk behoeft te worden gegeven en dat de or de toestemming van de ondernemer nodig heeft voor het instellen van commissies en het uitnodigen van deskundigen (art. 35a lid 1 onder e en idem onder i).

In de nog kleinere ondernemingen waar in de regel tenminste 10 mensen werken, maar minder dan 35 voor meer dan een derde van de normale werktijden gelden slechts enkele globale medezeggenschapsregels - en geen enkele specifiek voor het arbeidsomstandighedenbeleid. Echter wel met dien verstande dat de ondernemer de in de onderneming werkzame personen in de gelegenheid moet stellen een advies uit te brengen over een voorgenomen besluit dat kan leiden tot een belangrijke verandering van onder meer de arbeidsomstandigheden van tenminste een vierde van de in de onderneming werkzame personen (art. 35b lid 5).

\subsection{De CAO}

Vanaf circa 1975 groeit de belangstelling van de vakbeweging - vooral van de Industriebond NVV - voor de gevaren die de gezondheid en de veiligheid 
van de werknemers bedreigen. ${ }^{325}$ Deze belangstelling kan onder meer vertaald worden door het opnemen van bepalingen op dit terrein in CAO's. Het kan hierbij zowel om bedrijfstakgewijze als om ondernemingsgewijze CAO's gaan. (Een tendens om steeds meer en gedetailleerdere regelingen in de CAO op te nemen heeft overigens wel consequenties voor de or. Ingevolge art. 27 lid 2 WOR zal, naarmate meer inhoudelijk op dit gebied in de CAO geregeld wordt, de instemmingsbevoegcheid van de or evenredig afnemen).

Een indruk van de CAO bepalingen terzake in het midden wan de jaren zeventig kan verkregen worden door een onderzoek van het Loonbureau (tegenwoordig de Dienst Collectieve Arbeidsvoorwaarden) uit 1977. ${ }^{327}$ In deze publicatie werd een samenvatting gegeven van de CAO-bepalingen in de bedrijfstakken over het contractjaar 1975-1976. De per onderneming afgesloten CAO's waren dus niet bij het onderzoek betrokken. Van de 184 bij het Loonbureau geregistreerde CAO's (2.014.000 werknemers) waren in 107 ( 1.500 .500 werknemers) bepalingen op het gebied van veiligheid, gezondheid, hygiëne en milieu opgenomen. Voor ongeveer $75 \%$ van de betreffende werknemers gold dus een of meer van dergelijke bepalingen. Het minst kwamen zij voor in de bedrijfstakken handel en horeca en in het bank-en verzekeringswezen. Voor wat betreft de inhoud van de CAO valt het op dat de bepalingen grotendeels overeenkwamen met de bestaande wetten en besluiten en zich vooral richtten op algemene en organisatorische zaken en minder op technische veiligheidsvoorzieningen. Zo werd bijvoorbeeld in de metaal-CAO (225.000 werknemers) aanbevolen om onder meer aan de volgende punten aandacht te schenken: de veiligheidsopleiding, de verdeling van de verantwoordelijkheid voor de veiligheid tussen leiding, werknemers en gespecialiseerde functionarissen, de taak van de or en het overnemen van die taak door een commmissie, het betrekken van de overige werknemers bij het veiligheidsbeleid en het opstellen van een veiligheidsprogramma.

In 28 bedrijfstak-CAO's (geldend voor 790.238 werknemers) was de werkgever verplicht de te nemen maatregelen te bespreken met de or of met een representatief deel van de werknemers in zijn onderneming. Voorts waren in verscheidene bedrijfstak-CAO's bepatingen opgenomen inzake geneeskundig onderzoek en arbeid door jeugdigen. Allerlei overige bepalingen hadden bijvoorbeeld betrekking op een rook- en alcoholverbod, schaftgelegenheden en slaapdiensten.

Geconcludeerd kan worden dat in het midden van de jaren zeventig weliswaar op ruime schaal gebruik werd gemaakt van de mogelijkheden die de $\mathrm{CAO}$ biedt, maar dat de praktische meerwaarde in verhouding tot de bestaande

325 H.M. de Burlet, t.a.p. p. 15

326 Illustratief voor de vasthoudendheid van de vakbond om in de CAO bepalingen op te willen nemen op het gebied van de arbeidsomstandigheden waren bijvoorbeeld de geruchtmakende onderhandelingen hierover bij Shell-Pernis in 1975, L. Reijnders e.a., Veilig op je werk, Amsterdam 1976, p. 101.

327 Loonbureau, Veiligheid, gezondheid, hygiëne en miliew; bepalingen terzake woorkomend in de collectieve arbeidsovereenkomsten voor bedrijfstakken. Den Haag 1977. 
wetgeving niet erg groot was. Waarschijnlijk moet het belang toch vooral gezocht worden in een symbolische betekenis: partijen, maar vooral de werkgevers, worden ook zelf verantwoordelijk geacht voor behoorlijke arbeidsomstandigheden in de onderneming.

\subsection{Art. $1638 \times \mathrm{BW}$}

Heeft in deze periode de praktische herleving in 1967 van de aansprakelijkheid van de werkgever voor schade tengevolge van bedrijfsongevallen en beroepsziekten nu tot een toename geleid van het aantal schadevergoedingsprocedures ex $1638 \times \mathrm{BW}$, aangespannen door getroffen werknemers? Exacte gegevens zijn hierover niet voorhanden. Wel is in 1976 een beperkt onderzoek gedaan waaruit voorzichtig enkele conclusies kunnen worden getrokken. ${ }^{328}$ Het onderzoek richtte zich vooral op de bureaus voor arbeidsrecht van het NVV. Het ligt immers voor de hand dat deze rechtshulpverleners bij uitstek geconfronteerd word met dergelijke gevallen. Uit het onderzoek is gebleken dat de bureaus tesamen in die tijd omstreeks 100 gevallen per jaar kregen voorgelegd. Maar de overgrote meerderheid daarvan werd buiten proces in overleg met de verzekeraar van de werkgever tot een oplossing gebracht. In een enkel geval met name wanneer de werkgever niet verzekerd was) kwam het tot een rechtszaak, waarbij zelden geprocedeerd werd op grond van art. 1401. (Dit viel overigens ook daarom niet te verwachten omdat dan geprocedeerd zou moeten worden bij de Rechtbank in plaats van bij de Kantonrechter. En alleen bij de laatste kunnen niet-procureurs voor de rechter een rol spelen).

Tentatief zouden wel enige oorzaken genoemd kunnen worden waarom toch nog betrekkelijk weinig werknemers hun civiele rechten in die tijd geldend maakten - zeker ook gezien het grote aantal bedrijfsongevallen. ${ }^{329}$ In de eerste plaats zal dat samenhangen met angst voor verstoring van de relatie met de werkgever, schuldgevoelens en soms zelfs psychische druk. ${ }^{330}$ In de tweede plaats zal de onvoldoende bekendheid met de civiele mogelijkheden op dit gebied een rol gespeeld hebben, nog versterkt door het feit dat men in het algemeen tòch al een uitkering kreeg, meestal aangevuld tot $100 \%$ van het laatst genoten loon. ${ }^{331}$ In de derde plaats hadden met name grotere bedrijven zoals Philips en Hoogovens vaak een eigen interne regeling waardoor de werknemer zijn eventuele schadeclaim rechtstreeks ten gelde kon maken. Hierdoor konden processen met werknemers, die als bedreigend voor de goede sfeer in de onderneming werden ervaren, worden voorkomen. De schadever-

328 A.J.C.M. Geers, J.K.M. Gevers, Schadeloosstelling van slachtoffers van bedrijfsongevallen en beroepsziekten, NJB, 1977, p. 951-959.

329 In 1975 bedroeg het aantal geregistreerde bedrijfsongevallen $92.924 \mathrm{en}$ in 197698.426 , CBS, Statistisch Zakboek, resp. 1976 en 1977.

$330 \mathrm{Vgll}$. ook A.J. Hoekema, Rechtssociologische antekeningen bij het schadevergoedingsrecht, Schade lijden en schade dragen, Zwolle 1980, p. 186.

331 Dit blijkt bijwoorbeeld uit gegewens van de 'Stichting de Ombudsman', H.M. de Burlet, t.a.p. p. 25 en enkele persoonlijke ervaringen. 
goeding werd dan bijvoorbeeld vastgesteld overeenkomstig de normen van de ANWB voor verkeersongevallen. ${ }^{332}$ In de vierde plaats was in de beschreven tijd het verkrijgen van de nodige informatie over het bedrijfongeval van de Arbeidsinspectie soms een belangrijk knelpunt. Omdat op het slachtoffer in beginsel de bewijslast rustte, was voor hem het rapport over het bedrijfsongeval van de Arbeidsinspectie van grote betekenis. Wanneer hij hierover niet kon beschikken was hij voor zijn relevante informatie vrijwel uitsluitend aangewezen op informatie van de werkgever ${ }^{333}$ Het ontbreken van medewerking van de Arbeidsinspectie zal getroffenen er ongetwijfeld mede toe aangezet hebben om niet met een tijdrovende en vaak met emoties beladen civiele procedure te starten. Tot slot waren, zeker in het begin van de jaren zeventig, diverse rechtsvragen in verband met art. $1638 \mathrm{x}$ nog onbeantwoord. Deze onduidelijkheid zal ook een factor zijn geweest bij de afweging om te gaan procederen of niet. In de loop van de jaren is voor een aantal problemen door de groeiende jurisprudentie echter een oplossing gevonden. In het volgende hoofdstuk ga ik daar uitvoeriger op in.

Het was overigens de verwachting van enkele bureaus dat met name de toenemende bewustwording van de rechten die men als werknemer heeft, in de toekomst voor meer schadeclaims zou kunnen gaan zorgen. In het vervolg van dit boek zal worden onderzocht of deze voorspelling ook is uitgekomen.

\subsection{Internationale normen}

Naast de zich uitbreidende activiteiten van de ILO (recentelijk bijvoorbeeld het verdrag en de aanbeveling inzake veiligheid en gezondheid bij de arbeid in 1981 respectievelijk nr. 155 en 164) en die van de EG (bijvoorbeeld de resolutie van de raad voor een actieprogramma in 1978 Publ. blad C 165, op het gebied van onder meer onderzoek naar ongevallen en ziekten bij het werk, inspectie en voorlichting) dient voor deze periode het in 1961 in Turijn tot stand gekomen Europees Sociaal Handvest genoemd te worden. Eerst in 1978 is Nederland toegetreden tot het ESH. ${ }^{334}$ Art. 3 met name heeft betrekking op de arbeidssituatie. Het verplicht de aangesloten landen om, teneinde het recht op een veilige arbeidsplaats te garanderen, voorschriften terzake wit te vaardigen, de naleving van de voorschriften te controleren en zo nodig overleg te plegen met de sociale partners omtrent maatregelen die de bedrijfsveiligheid en de hygiëne kunnen verhogen. Arbeidsbeschermende bepalingen zijn bij-

332 H.M. de Burlet, t.a.p. p. 26.

333 H. van Oostrum, t.a.p. p. 136. De toenmalige hoofdinspecteur van Dodeweerd meende echter, dat je "over je eigen ongeval altijd het nodige te weten kon komen". J.J. van Dodeweerd, Over je eigen ongeval kun je altijd het nodige te weten komen!, De Veiligheid, 1977, p. 45-47. Belanghebbenden verzekerden echter dat het vaak zeer moeiijk, zo niet onmogelijk was. A.J.C.M. Geers, J.K.M. Gevers, NJB, 1977, t.a.p. p. 956

334 Het Handvest werd goedgekeurd bij Rijkswet van 2 november 1978 (behoudens o.a. art. 6 lid 4 voor wat betreft het stakingsrecht van ambtenaren), geratificeerd op 22 april 1980 en trad een maand later in werking. 
voorbeeld ook te vinden in art. 7 (het recht van kinderen en jeugdige personen op bescherming), art. 8 (het recht van vrouwelijke werknemers op bescherming) en art. 20 (verplichting om een Arbeidsinspectie te hebben).

Het toezicht op de naleving van de bepalingen is te vergelijken met dat van de ILO. Rapportages, onderzoek en daarop gebaseerde confrontatie zijn de belangrijkste instrumenten.

\subsection{De Grondwet}

Volledigheidshalve wil ik nog wijzen op de sociale grondrechten die in 1983 in de Grondwet zijn opgenomen. Het nieuwe art. 19 lid 2 luidt: "De wet stelt regels omtrent de rechtspositie van hen die arbeid verrichten en omtrent hun bescherming daarbij, alsmede omtrent medezeggenschap.' Terecht merkt de MvT op dat deze opdracht aan de wetgever een bevestiging is van hetgeen al in de wetgeving is gerealiseerd. ${ }^{335}$ Tijdens de parlementaire behandeling is het oorspronkelijk in de tekst opgenomen woord 'werknemers' vervangen door 'hen die arbeid verrichten', opdat hier niet a contrario geredeneerd zou kunnen worden dat zelfstandigen geen bescherming zouden behoeven. Dit betekent volgens de regering nu echter weer niet dat de eventuele maatregelen ten aanzien van zelfstandigen dezelfde zullen zijn als die ten aanzien van werknemers. ${ }^{336}$ Door deze wijziging komt echter het woord 'medezeggenschap', immers niet wel denkbaar bij zelfstandigen, er wat raar en geïsoleerd bij te hangen. In de MvA wordt voorts ingegaan op het vraagstuk of de betreffende instructienorm voor de overheid ook een subjectief recht aan de burgers, de werknemers garandeert. 'Wij hebben niet gezegd dat de burger ten overstaan van de rechter een subjectief recht geldend zou kunnen maken.' Hoewel dit volgens de MvA 'wellicht mooier' zou zijn geweest, laten zowel de materie als de mogelijkheden van de overheid dit niet toe. ${ }^{337}$ Iets verder merkt de regering op dat wel enkele bepalingen kunnen worden aangewezen waarbij de horizontale werking aanwezig is. Onder meer zou dit gelden voor art. 19 lid 2, 'waarbij wetgeving en bestuur ter uitvoering van deze bepalingen kunnen leiden tot garanties voor wat betreft rechtspositie, arbeidsbescherming, medezeggenschap en leefbaar milieu ook in de verhoudingen tussen burgers onderling'. ${ }^{338}$ Een ander aspect verdient nog enige aandacht. Dat betreft de nota die enige PvdA fractieleden hadden opgesteld teneinde in de Grondwet te komen tot de opneming van grondrechten voor individuele werknemers. ${ }^{339}$ ' $\mathrm{Hem}$ (de werknemer, AG) dient de positie te worden verschaft van gelijkwaardige deelne-

335 TK 1975-1976, 13.873, nrs. 1-4, (MvT) p. 10.

336 TK $1976-1977,13.873$, nr. 8 (Nota van wijziging

337 TK 1976-1977, 13.873, nr. 3 (MvA) p. 3.

338 MvA, t.a.p. p. 4.

339 TK 1975-1976, 13.873, nrs. 5-6 (Nota van de leden Franssen, Roethof en van Thijn), p. 21 28. Hierover ook: Riet Kronenberg, Werknemersrechten: een discussienota, Socialisme en Democratie, 1975 , p. 258-270. 
mer aan het werk van de bedrijfsgemeenschap voor de samenleving. Daarbij zullen dusdanige arbeidsomstandigheden moeten worden geschapen, dat deze deelnemer in zijn werk de mogelijkheid heeft tot maximale zelfontplooing en zelfrealisatie in verantwoordelijkheid. ${ }^{340}$ Deze werknemersrechten zouden onder meer moeten zijn: het recht op informatie, vrijheid van meningsuiting, recht op educatief verlof en stakingsrecht.

Hoewel de regering meende dat voor een afgewogen oordeel over de voorstellen nadere analyse, studie en overleg nodig was, is daar in dat kader nauwelijks meer iets van vernomen. ${ }^{341}$ In de Arbowet is in elk geval op een aantal punten iets van de voorstellen terug te vinden.

\section{Enkele recente onwikkelingen}

De belangrijkste ontwikkelingen die van betekenis zijn voor de Arbowet na haar totstandkoming, zijn de wetswijzigingen ten gevolge van de dereguleringsoperatie, de verdere fasering van inwerkingtreding en de gevolgen van de ongelukkige samenloop van een aantal bepalingen in de Arbowet en de WOR. Omdat dit laatste onderwerp direkt raakt aan de juridische bevoegdheden en mogelijkheden van de OR op het gebied van de arbeidsomstandigheden, wordt het in het volgende hoofdstuk behandeld. Over deregulering en fasering gaat het volgende.

\subsection{Deregulering en fasering van de Arbowet}

De Arbowet was koud aangenomen en nog niet (gedeeltelijk) in werking getreden, of het dereguleringsvirus sloeg onverbiddelijk toe. Geheel onverwacht kwam dat echter niet. In het thema-nummer over derugeleren van het tijdschrift Beleid en Maatschappij in 1982 werd de Arbowet opvallend vaak aangehaald als voorbeeld van een wet die een belemmerende rol zou vervullen bij het nastreven van het primaire doel van het bedrijfsleven: het winstgevend produceren van goederen en diensten. ${ }^{342}$ De econoom van Duijn schreef bijvoorbeeld hoopvol over de Arbowet: "Gezien de verwachte verborgen beleidskosten van deze wet zou het goed zijn om te bezien of hier al niet gedereguleerd zou kunnen worden al voor de regulering een feit is. ${ }^{343}$ Staatssecretaris van Zeil wilde kennelijk niet achterblijven. Drie maanden vóór de eerste fase van de wet op 1 januari 1983 eindelijk in werking zou treden, vroeg hij aan de VAR om 'zo spoedig mogelijk' (!) aan te geven 'waar de knelpunten of

340 Nota Franssen c.s., t.a.p.p. 26.

341 MvA t.a.p. p. 14. Een jaar later is er door minister Boersma op teruggekomen tijdens een Commissievergadering. Hij deelde toen mede de Kamer graag te informeren 'over het resultaat van de verdergaande interne studie'. OCV, 15 maart 1976, p. 660.

342 Belleid en Maatschappij, 1982, p. 177-227.

343 J.J. van Duijn, Macro-economische gevolgen van deregulering, Beleid en Maatschappij, 1982 , p. 218. 
belemmeringen worden ervaren in de wet- en regelgeving, of in de uitvoering daarvan, met betrekking tot de arbeidsomstandigheden', teneindle 'te werken aan vereenvoudiging en opschorting van wet-en regelgeving met het oog op een structureel herstel van de werkgelegenheid. ${ }^{344}$

Voor het zware geschut bogen zich tenslotte achtereenvolgens twee commissies over de Arbowet: de commissie deregulering in verband met de economische ontwikkeling (Commissie van der Grinten) en de commissie vermindering en vereenvoudiging wan overheidsregels (Commissie Geelhoed). De Commissie van der Grinten kwam onder meer met het vèrstrekkende voorstel om het bevorderen van het welzijn van werknemers niet meer als een zelfstandig bestanddeel te zien, maar als een van veiligheid en gezondheid afgeleide en derhalve secundaire doelstelling. Zij meende dat het begrip welzijn aanleiding zou geven tot te grote verschillen van inzicht. Het in de Arbowet voorziene proces van beleidsafweging zou daardoor worden verstoord, terwijl geen maatstaven aanwezig zouden zijn voor de bevoegdheden van de or en de Arbeidsinspectie. Omdat het bevorderen van het welzijn slechts een ondersteunende functie zou kunnen hebben voor het bereiken van doelstellingen op het gebied van de veiligheid en de gezondheid, zou met name art. 3 in die zin geherformuleerd dienen te worden. ${ }^{345}$

Het kabinet hield zijn beslissing over het advies van de Commissie van der Grinten aan en gaf de Commissie Geelhoed vervolgens opdracht om de Arbowet nader te toetsen aan ruimere maatstaven, namelijk doorzichtigheid en overzichtelijkheid van normstellingen, externe beleidslasten, interne beleidslasten, en lasten, voortvloeiend uit controle, handhaving en rechtsbescherming. Het advies van de Commissie Geelhoed ging minder ver in de dereguleringsrichting, maar bevatte toch nog een aantal fors in de Arbowet ingrijpende voorstellen. ${ }^{346}$ Hoewel (ook) de Commissie Geelhoed meende, dat het begrip welzijn een vage streefnorm was, een overmaat aan beleidslasten met zich mee zou brengen en aanleiding kon geven tot rechtsonzekerheid en verregaande rechtsaanspraken dan wel verplichtingen, wilde zij welzijn als zelfstandige doelstelling echter niet uit de wet schrappen. Wel moest het begrip voorzichtig gehanteerd worden. Dit zou bereikt kunnen worden door - met vermijding van het welzijnsbegrip als zodanig in de wettekst - welzijnselementen in de wettekst te concretiseren en te limiteren. Het in dit licht uitermate belangrijke art. 3 zou derhalve stevig moeten worden aangepast (maar overigens ook de andere artikelen waarin welzijn voorkomt: de artt. 4, 6, 10, 13, 14, 16, 17, 21 en 24). Een van de belangrijkste consequenties voor art. 3 zou het geheel schrappen zijn van het eerste lid onder $h$ en $\mathrm{i}$. Lid 1 onder $\mathrm{h}$ handelt over de verplichting voor de werkgever om de arbeid zo te organiseren, dat daarvan geen nadelige invloed uitgaat op de lichamelijke en geestelijke gezondheid van de werknemer. Lid 1 onder $i$ over het bijdragen van de arbeid tot zelf-

344 Brief van de staatssecretaris van Sociale Zaken en Werkgelegenheid aan de VAR d.d. 7 oktober 1982, kenmerk nr. 240221 AAZ, p. 3.

345 TK $1982-1983,17.931$, nr. 5 , p. 3 en p. 30.

346 TK $1983-1984,17.931$, nr. 9 , p. $165-176$. 
ontplooiing en vermeerdering van vakbekwaamheid, en over voldoende mogelijkheid om het werk naar eigen inzicht in te richten, contact te onderhouden met collega's en het zich op de hoogte kunnen stellen van doel en resultaten van de arbeid. Beide opdrachten worden gerelativeerd door een redelijkerwijs-clausule.

Ondanks de vrome belijdenis van de commissie dat welzijn als aparte doelstelling gehandhaafd zou dienen te blijven, zou schrapping van bovengenoemde bepalingen het hart van de Arbowet treffen. Uitvoerig is nu juist over de betekenis hiervan in het parlement gesproken. Tijdens de plenaire behandeling in de Tweede Kamer kon de toenmalige minister Albeda dan ook terecht concluderen: 'Over de introductie van het begrip 'welzijn' hebben wij intensief van gedachten gewisseld vanaf het moment dat het wetsontwerp was ingediend. $\mathbb{k}$ meen nu te mogen constateren dat alle partijen, ieder vanuit haar eigen specifieke grondslagen en dus met een eigen perspectief, het opnemen van welzijnsartikelen in dit wetsontwerp toejuichen. ${ }^{347}$

Deze uitvoerige gedachtenwisseling heeft er bovendien toe geleid, dat het begrip welzijn in de wet helemaal niet zo vaag is, maar dat het in art. 3 afgebakend en beperkt is tot een aantal functionele en objectieve aspecten, die, rechtstreeks voortvloeiend uit de te verrichten arbeid, vooral betrekking hebben op de arbeidsinhoud en de arbeidsorganisatie.

Voorts wenste de Commissie onder meer over te gaan tot het schrappen van de volgende verplichtingen: het op grote schaal verspreiden van het arbeidsveiligheidsrapport (art. 5), het aanstellen van een mentor voor jeugdige werknemers (art. 8), het registreren van bijna-ongevallen (art. 9), het oprichten of zich aansluiten bij een Arbodienst (art. 17), het oprichten of zich aansluiten bij een Arbo-instituut (art. 21) en het stellen van voorwaarden, indien de werkgever al dan niet gedeeltelijk zijn taken overdraagt aan werknemers (art. 31). Bovendien wilde de Commissie een flexibele formulering van de overlegbepalingen (art. 14), een limitatief karakter toekennen aan de opsomming van het aantal onderwerpen waarover bij AMvB nadere regels kunnen worden gesteld (art. 24), een heroverweging van de ontslagbescherming van de deskundigen in de onderneming (artt. $17 \mathrm{t} / \mathrm{m} \mathrm{19}$ ), en het schrappen van de districtcommissies (art. 45).

De destijds verantwoordelijke staatssecretaris Kappeijne van de Coppello liet er echter geen enkel misverstand over bestaan, dat de voorstellen haar te ver gingen: 'In ieder geval staat het voor mij vast, dat het begrip welzijn niet uit de Arbowet zal verdwijnen. ${ }^{348}$ En in de vaste Kamercommissie voor het emancipatiebeleid (bijeen ter bespreking van de ergonomische aspecten van vrouwenarbeid) merkte zij manhaftig op: “De invoering van de artikelen van deze wet gaat gewoon door. ${ }^{349} \mathrm{Zij}$ deed deze laatste uitspraak enkele dagen voordat de minister van Justitie het kabinetsstandpunt aan de Tweede Kamer aan-

349 TK $1983-1984,18,100$, hfdst. XV, nr. 79 (verslag mondeling overleg d.d. 20 juni 1984), p. 7. 
bood. Dit standpunt was ten aanzien van de Arbowet inhoudsloos. Na een vrijblijvend compliment aan de commissie, dat "het dereguleringsonderzoek een aantal waardevolle voorstellen tot vereenvoudiging heeft opgeleverd' wordt cryptisch vervolgd: 'Het kabinet onthoudt zich echter thans van een standpunt over deze voorstellen, omdat het de consequenties van de Arbowet nog eens in een ruimer verband wil bezien'. ${ }^{350}$ Wat dat 'ruimer verband' nu precies betekende, bleef duister. Ook na het, enkele maanden later aangeboden, definitieve en inhoudelijke kabinetsstandpunt. ${ }^{351}$ Dit hield een gedeeltelijke tegemoetkoming aan het ferme standpunt van de staatssecretaris in, zodat niet alle commissievoorstellen werden gevolgd. Het kabinet kwam tot een aantal voorstellen, die, nadat zowel Arboraad als SER medegedeeld hadden af te willen zien van advisering (in verband met het belang van de problematiek volstrekt ten onrechte, lijkt me), ruim een jaar later op 29 december 1986 als wetsontwerp werden aangeboden aan de Tweede Kamer. ${ }^{352}$ Het kabinetsstandpunt en het daarop gebaseerde wetsontwerp kwamen in het kort hierop neer:

- Welzijn als afzonderlijke doelstelling wordt gehandhaafd maar wordt in de tekst wel gelimiteerd. Dit betekent onder meer dat art. 3, inclusief her eerste lid onder h en i (in de oorspronkelijke wettekst), weliswaar gewijzigd, blijft bestaan. Belangrijke wijzigingen betreffen een nieuwe formulering van lid 1 onder $i$, waardoor de opdracht aan de werkgever dat de arbeid moet bijdragen tot zelfontplooiing verdwijnt en waardoor eveneens vervalt de bepaling dat de arbeid moet bijdragen aan een vermeerdering van de vakbekwaamheid van de werknemer; in de nieuwe tekst moet de arbeid alleen bijdragen tot de vakbekwaamheid. Daarnaast wordt de in art. 3 gehanteerde toetsingsnorm 'best bestaande regelen der techniek' (via een amendement in de wet gekomen) vervangen door de oorspronkelijke tekst in het wetsontwerp 'algemeen erkende regelen der techniek'.

- De mogelijkheid om het verspreidingsgebied van het arbeidsveiligheidsrapport te beperken (art. 5) zal nader worden bestudeerd. Voorlopig zal dit nog niet tot wetswijziging leiden.

- Alleen als initiatieven uit het bedrijfsleven tekort schieten kan het mentorschap voor jeugdige werknemers bij $\mathrm{AMvB}$ verplicht worden gesteld (art. 8 ).

- De registratieplicht voor bijna-ongevallen komt te vervallen (art. 9).

- Hoewel de verplichting tot het oprichten van, of aansluiten bij een Arbodienst vervalt, blijven de in art. 17 genoemde materiële taken gehandhaafd.

- De ontslagbescherming van bedrijfsartsen en veiligheidskundigen (art. 19) blijft gehandhaafd. Later zal dit onderwerp opnieuw worden bekeken naar aanleiding van het SER-advies over het ontslagrecht in algemene zin (Dit advies is er, zomer 1988 , nog niet).

350 TK 1983-1984, 17.931, nr. 38, p. 13.

351 TK $1983-1984,17.931$, nr. 45 (brief van de minister van Justitie d.d. 11 september 1984 aan de voorzitter van de Tweede Kamer).

352 TK 1986-1987, 19.824, nrs. $1-2$. 
- De bepaling inzake een centraal instituut (Arbo-instituut, art. 21) blijft gehandhaafd in afwachting van een advies van de Arboraad terzake. (Dit advies bleek ten aanzien van een dergelijk instituut in beginsel positief te zijn; zie het volgende hoofdstuk, paragraaf 4.4.).

- De opsomming van nader bij AMvB te regelen onderwerpen in art. 24 zal limitatief worden geformulleerd.

- De tekst van art. 31 wordt opnieuw geformuleerd, opdat beter tot uitdrukking komt dat het bij het overdragen van Arbowet-taken door de werkgever aan de werknemer(s) gaat om toezichthoudende taken en opdat rekening wordt gehouden met de positie van bestuurders van een rechtspersoon (die in deze zin niet als werknemer worden beschouwd).

- De districtscommissies (art. 45) zullen in beginsel op een later tijdstip komen te vervallen. Rekening zal daarbij worden gehouden met de uitkomsten van het (nog steeds) lopende beraad over functionele decentralisatie van taken binnen het departement van Sociale Zaken en Werkgelegenheid. De parlementaire behandeling zorgde weliswaar voor enkele wijzigingen in het ontwerp, maar zij waren niet fundamenteel. Het belangrijkste was de terugkeer van de Arbodienst. Met alleen de stemmen van de VVD tegen werd een amendement aangenomen waardoor aan art. 20 de mogelijkheid werd toegevoegd, dat de werkgever aan zijn verplichtingen ten aanzien van een bedrijfsgezondheidsdienst en een veiligheidsdienst c.q. veiligheidskundige kan voldoen door een Arbodienst in te stellen of er zich bij aan te sluiten ${ }^{353}$ De PvdA diende een aantal amendementen in over onder meer de handhaving van de registratieplicht voor bijna-ongevallen, de handhaving van de algemene verplichting tot aanstelling van een mentor voor jeugdige werknemers, de vervanging in art. 3 van 'de algemeen erkende regelen der techniek' door: de best bestaande regelen der techniek, en de vervanging eveneens in art. 3 van 'moet de arbeid bijdragen tot de vakbekwaamheid van de werknemer' door: moet de arbeid bijdragen tot vermeerdering van de vakbekwaamheid van de werknemer. ${ }^{354}$ Van de aanneming ervan zou de PvdA het laten afhangen of ze uiteindelijk voor of tegen de gehele wetswijziging zou stemmen. Alle hierboven genoemde amendementen werden verworpen. Anders dan in 1980, toen de Arbowet kamerbreed werd aangenomen, werd het wetsvoorstel tot wijziging aangenomen met de stemmen van de PvdA, de PPR en de PSP tegen.

De behandeling in de Eerste Kamer was kort en summier en in november 1987 verscheen de wijziging van de Arbowet in het Staatsblad. ${ }^{355}$

Hoewel de wijziging van de wet beduidend minder ingrijpend is geworden dan de Commissies van der Grinten en Geelhoed beoogden, kan toch ook niet zonder meer gesproken worden van alleen een face-lift van deze jeugdige dame.

353 TK 1986-1987, 19.824, nr. 18 (amendement van de Leeuw en Leijnse).

354 TK $1986-1987,19.824$, resp de nrs. $13,14,15$ en 16 (amendementer van Leinse)

355 Stbl. 1987,535 
Maar wooraf dienen vraagtekens gezet te worden bij het fenomeen dat een wet, die nog kort tevoren eensgezind omarmd werd zowel in als buiten het parlement, nog vóór zij goed en well in werking is getreden al onderwerp is van deregulering. Getuigt het immers niet van kortzichtigheid om tot dereguleren over te gaan zonder dat eerst een gedegen onderzoek is ingesteld naar motieven en doelstellingen van de regulering in relatie tot haar effecten en kosten? ${ }^{356}$ Daar komt bij dat de toetsingsnormen voor de deregulering niet alle even objectiveerbaar zijn. Terecht wees de PvdA-woordvoerder in het plenaire Tweede Kamer debat over de deregulering van de Arbowet erop dat als externe beleidslasten en organisatielasten in de beoordeling worden betrokken, er altijd sprake is van een afweging tussen aan de ene kant het dereguleringsmotief en aan de andere kant het doel waarop de regelgeving oorspronkelijk was gericht. ${ }^{357}$ De grens tussen wetswijziging op dereguleringsgronden en wetswijziging op andere gronden, te maken hebbend met het gewicht dat aan de doelstellingen van de wet wordt toegekend, is dan zeker niet haarscherp. Het lijkt erop dat het kabinet van de vlag van het dereguleringsmotief gebruik heeft gemaakt om onderdelen van de Arbowet te schrappen die het bedrijfsleven niet welgevallig zijn. Deze verdenking laadt het kabinet bijvoorbeeld op zich ten aanzien van de vervanging van het criterium 'best bestaande regelen der techniek' door: algemeen erkende regelen der techniek in art. 3 . In de eerste plaats is de oorspronkelijke formulering doelbewust via een aangenomen amendement in de wet opgenomen en nog niet in de praktijk getoetst. In de tweede plaats is het gebruik van 'best bestaande' innovatief en passend in het concept van de Arbowet dat gestreefd moet worden naar zo goed mogelijke arbeidsomstandigheden; het gebruik van 'algemeen erkend' is conservatief, niet vernieuwend en nauwelijks aspiratief. In de derde plaats wordt het begrip 'algemeen erkend' in de Westduitse wetgeving gehanteerd en de ervaring daar leert dat het begrip nogal eens aanleiding geeft tot verschillen van opvatting - en in dat opzicht zal de term niet verschillen van het begrip 'best bestaande regelen der techniek'. 358

Op twee andere verslechteringen in art. 3 wil ik nog wijzen. In de eerste plaats is dat het vervallen van de verplichting dat, zoveel als redelijkerwijs kan worden gevergd, de arbeid bijdraagt tot de zelfontplooiing van de werknemer. Deze doelstelling zou te ambitieus zijn. Wat nu? Juist dit soort begrippen en doelstellingen bepalen in vergelijking met de oude Veiligheidswet toch grotendeels het nieuwe karakter van de Arbowet? Bovendien is het streven nog bescheiden geformuleerd: 'zoveel als redelijkerwijs kan worden gevergd"...'bijdraagt aan.' Heeft welzijn in verband met de arbeid trouwens niet een direkte relatie met, verdedigd zou zelfs kunnen worden is identiek met, zelfontplooiing? Hoewel het schrappen van dit doel voor de praktijk misschien niet eens zoveel uit zal maken gezien de overige bepalingen in art. 3 , is het in elk geval psychologisch fout om een dergelijk begrip als te ambitieus te schrap-

356 Vgl. D.J. Kraan, Deregulering: een begripsbepaling, Beleid en Maatschappij, 1982, p. 179.

357 Handelingen TK 1987-1988 (17 juni 1987), p. 4452.

358 TK 1986-1987, 19.824, nr. 7 (eindverslag), p. 4. 
pen. Het is bovendien een onterechte steun in de rug van degenen die menen dat de Arbowet eigenlijk geheel ontdaan zou moeten worden van welzijnsbepalingen.

Een tweede af te keuren verandering betreft het schrappen van de bepaling dat de arbeid moet bijdragen tot een vermeerdering van de vakbekwaamheid van de werknemer. Gebleven is dus alleen dat de arbeid moet bijdragen tot de vakbekwaamheid. Dat is daarom te betreuren omdat de snelle verandering van funktie-eisen als gevolg van de technologische ontwikkeling voor de werknemer die zijn vakbekwaamheid niet vermeerdert, een groeiend risico oplevert werkloos te worden.

Tijdens de parlementaire behandeling van de dereguleringsvoorstellen werd ook uitvoerig gesproken over de verdere fasering van de invoering van de Arbowet. Op dit punt is onoverzichtelijkheid troef. De wet zou in vier fasen in werking treden, afhankelijk van de beleidsmatige prioriteiten, het tempo waarmee de beleidsvoorbereiding en besluitvorming tot stand kunnen komen, het organisatorisch opnamevermogen wan werkgevers en werknemers en de kosten die de invoering met zich meebrengt. Op 1 januari 1983 is de eerste fase in werking getreden - echter nog niet voor de overheid - en op 1 juni 1985 het tweede gedeelte van de eerste fase -en de gehele eerste fase ook voor de overheid. Op 1 januari 1988 is de tweede fase - tegelijk met de wijzigingen ten gevolge van de deregulering - in werking getreden. Herhaaldelijk is door de verantwoordelijke bewindslieden betoogd dat de hele inwerkingtreding in 1990 een feit moet zijn. In dit verband is de gedachte geopperd en door de staatssecretaris overgenomen om de derde en de vierde fase te combineren. ${ }^{35 \%}$ Eind 1987 adviseerde de Arboraad positief over dit voornemen. ${ }^{36}($ Uit de adviesaanvraag blijkt dat de invoering van de Arbowet voor onderwijsinrichtingen, middelen van vervoer en justitiële inrichtingen losgekoppeld wordt van de invoering van de gecombineerde derde en vierde fase. De bedoelde bepalingen (art. 2 leden 1, 3 en 4) komen voor tussentijdse invoering in aanmerking. Dit geldt ook voor de bepalingen over het opmaken van een onderzoeksrapport door de Arbeidsinspectie en het machtigen van bepaalde ambtenaren van de Arbeidsinspectie tot het stellen van eisen (resp, art. 32 lid 5 en art. 36 lid 2). Het is de bedoeling om de uitvoeringsbesluiten voor de onderwijs-en justitiele inrichtingen in 1988 in werking te laten treden. Het streven is deze voor de vervoerssector (art. 2 lid 3) in 1989 in te voeren. De Arboraad heeft hiermee ingestemd. Ook de uitwoeringsmaatregelen zijn op verschillende momenten van kracht geworden en zullen dat ook in de toekomst doen. Het ligt in elk geval in de bedoeling om het Veiligheidsbesluit restgroepen eind 1988 in te voeren. Pas dan kan volgens de staatssecretaris - ten onrechte, heb ik al betoogd - ook art. 3 (in 1990) ingevoerd worden. ${ }^{361}$

359 Vgl. bijw. TK 1986-1987, 19.824 , nr. 5 (MWA), p. 2.

360 Arboraad, Advies inzake invoering volgende fasen Arbowet, Zoetermeer, 22 december 1987.

361 Vgl. ook TK 1986-1987, 19.700, hfdst. XV (MWT bij de begroting 1987, ministerie wan Sociale Zaken en Werkgelegenheid), p. 71 


\section{De werkgever, de ondernemingsraad, de deskundigen, de Arbeidsinspectie en de werknemers- en werkgevers- organisaties}

\section{Algemene inleiding}

De juridische positie van de werknemer bij de humanisering van zijn arbeid kan vanuit verschillende invalshoeken beschreven worden. Een mogelijkheid om deze positie te beschrijven is het telkens uitgaan van een van de relevante (wettelijke) regelingen, zoals die in het vorige hoofdstuk de revue zijn gepasseerd. De positie van de werknemer op dit vlak krijgt echter meer reliëf en doet waarschijnlijk méér recht aan de gecompliceerde werkelijkheid wanneer zij beschreven wordt uitgaande van, en in relatie met de andere betrokkenen bij de arbeidsomstandigheden in de onderneming. Immers de rol van deze betrokkenen zal in de praktijk in hoge mate bepalend zijn voor de rol die de werknemer speelt of kan spelen. Bovendien wordt het spiegelbeeld van de (juridische) verplichtingen voor de éen vaak gevormd door de daaruit voortvloeiende rechten voor de ander. Even zo goed kunnen de bevoegdheden van de ene partij een beperking van de handelingswrijheid voor de ander betekenen. In het vervolg van dit hoofdstuk zal dus de rol van andere belangrijke actoren op het gebied van de humanisering van de arbeid in de onderneming beschouwd worden, om mede op die manier inzicht te verkrijgen binnen welk krachtenveld de positie van de werknemer gestalte krijgt. Hierbij zal well per actor telkens de vigerende regelgeving ter sprake komen. Eerst zal aandacht worden geschonken aan de drie partijen die vooral binnen de onderneming zèlf een rol spelen: de werkgever, de or, en de deskundige diensten. Vervolgens komen de actoren aan de orde die meer indirecte invloed van buiten uitoefenen: de Arbeidsinspectie en de werkgevers- en werknemersorganisaties. ${ }^{1}$

1 Uiteraard zijn ook andere diensten en functionarissen betrokken bij de arbeidsomstandigheden in de onderneming, zoals personeelsfunctionarissen. Over hun rol: P.L. Spanjersberg, Inzicht in de Arbowet, Deventer 1983, p. 153-159 


\section{De werkgever}

\subsection{Inleiding}

Ik gebruik het begrip werkgever aansluitend bij de terminologie in de Arbowet en het BW en in overeenstemming met het spraakgebruik waardoor het begrip mede omvat diegene die namens de juridisch werkgever belast is met de feitelijke leiding van de onderneming of delen daarvan: de leiding, de directie, het management etc. In juridische zin zullen zij vaak als werknemer gekwalificeerd dienen te worden en zal de 'echte' werkgever een rechtspersoon zijn. I k begin met de rol van de werkgever omdat hij vroeger de enige en thans in de praktijk nog steeds de belangrijkste vormgever is van de arbeidsomstandigheden in de onderneming. Dat is niet zo vreemd. De werkgever heeft nog steeds de primaire verantwoordelijkheid en beslissingsbevoegdheid (èn de daarmee samenhangende juridische aansprakelijkheid) voor het gehele ondernemingsbeleid en dus ook voor het sociaal beleid, en als onderdeel daarvan weer het arbeidsomstandighedenbeleid. (Uiteraard wordt ook invloed uitgeoefend door bijvoorbeeld de Raad van commissarissen of de aandeelhouders, maar zij zijn, zeker voor het arbeidsomstandighedenbeleid, van beduidend minder betekenis). Als feitelijk gegeven verschillen overheid en sociale partners hierover niet van mening. Dit bleek bijvoorbeeld in het SER-advies over het sociaal beleid in de onderneming en het standpunt van de betrokken bewindslieden datarover: "Met de SER zijn wij van mening, dat in de eerste plaats de ondernemingsleiding verantwoordelijk is voor het sociaal beleid in de onderneming. ${ }^{2}$ Dit laatste neemt niet weg dat de beslissingsbevoegdheid van de werkgever al lang geen absolute meer is. Op verschillende manieren afhankelijk van onder meer de grootte, de rechtsvorm, de cultuur, de producten en de marktpositie van de onderneming wordt hierop ingewerkt. Belangrijke factor hierbij is de mogelijkheid tot zeggenschap door anderen, zowel formeel, met name gebaseerd op de regeling in de WOR, als informeel op grond waarvan, zonder wettelijke basis, werkgeversfuncties zijn gespreid over de werknemers van de onderneming. ${ }^{3}$

Deze spreiding van bevoegdheden heeft onmiskenbaar een machtsverschuiving in de onderneming ten gevolge - en daarmee samenhangend een wijziging in de doelstelling. Deze andere doelstelling is, meer dan de traditionele

2 Brief van de minister en de staatssecretaris van Sociate Zaken en Werkgelegenheid d.d. 2 nowember 1984 aan de woorzitter van de Tweede Kamer, TK 1984-1985, 18.711, nr. 1 p. 2. De SER formuleerde het overigens wel met inachtneming van de positie van de werknemers: "Voorop staat dat werkgevers tezamen met werknemers(vertegenwoordigers) primair zelf verantwoordelijk zijn voor een regeling wan het sociaal beleid in de onderneming." SER-advies inzake thet Social beleid in de onderneming, 1981, nr. 11, p. 23.

3 Vgl. H.L. Bakels, De leiding van de onderneming en de belangen van de werknemers, Vrijheid en Recht, ('s Jacob-bundel), Zwolle 1975, p. 413-424, met name p. 422.

Zie ook G.H.A. Schut, Medezeggenschap en het gezag van de werkgever, Arbeidsrechtelijke geschriften (samenst. H.L. Bakels), Deventer/Alphen a/d Rijn 1977, p. 266-272, met name p. 270. 
ondernemingsdoelstellingen (in het algemeen: continuïteit en winstmaximalisatie) gericht op het sociale, het welzijnsaspect. ${ }^{4}$ Toch blijft het de werkgever die uiteindelijk verantwoordelijk is wanneer een keuze gemaakt moet worden op basis van een afweging van enerzijds bedrijfseconomische doelstellingen en anderzijds van sociale, humaniseringsdoelstellingen.

In dit verband moet opgemerkt worden dat sommigen, zoals bijvoorbeeld de auteurs van het boek 'Gezondheidszorg in Nederland", vinden dat voor deze afweging überhaupt geen plaats kan en mag zijn; in elk geval niet voorzover het gaat om de gezondheid en de veiligheid. ${ }^{5} \mathrm{Het}$ is in deze visie niet toelaatbaar dat zij onderwerp zouden zijn van onderhandelen, van afwegingen en compromissen. In de eerste plaats om de waarden zelf die in het geding zijn en in de tweede plaats, maar dit lijkt al moeilijker te verdedigen, omdat de afweging gezondheid-winst typisch een kwalijke uitwas zou zijn van de kapitalistische productiemaatschappij waarin winst de alles overheersende factor is. Deze visie lijkt mij niet vol te houden: ook in de niet-kapitalistisch georiënteerde landen bestaat een duidelijke spanning tussen winst en gezondheid. ${ }^{6}$ Bovendien behoeft een afweging op zich niet onoirbaar te zijn: het gaat uiteindelijk om het resultaat in een concrete situatie. De vrijheid bij deze afweging is trouwens in hoge mate beperkt door allerlei regelingen die onderling verschillen in afzender, werkingsgebied en status.

I $\mathrm{k}$ zal me vooral richten op wettelijke regelingen, die overigens vaak zèlf het resultaat zijn van een compromis. Soms bevatten die zeer concrete voorschriften - en dan is er ook voor de werkgever geen ruimte voor welke afweging dan ook. In dat geval trouwens evenmin voor zeggenschap van werknemers. Soms nodigen de formuleringen wan de wet zelf uit tot afwegingen en compromissen. Tenslotte schrijft de wet aan de werkgever soms procedures voor om te komen tot bepaalde beslissingen. Naast de normerende en controlerende overheid kunnen bij de regelgeving de sociale partners via de $\mathrm{CAO}$ een belangrijke rol spelen.

4 M.G. Rood, Bedrijfsdemocratie: wlag of lading?, Deventer 1979, p. 7 en 8. Hoewel ook Rood de terminologie 'samenhangend met' gebruikt, bedoelt hij blijkens de context van zijn betoog dat de verschuiving wan doelstelling een gevolg is van medezeggenschap. Oorzaak en gevolg lijken mij echter niet altijd even duidelijk te zijn op dit punt. Een verandering van de doelstellling - of liever een witbreiding van de doelstellingen - kan op meer nanieren tot stand komen, bijwoorbeeld door veranderde inzichten of domweg omdat het opgelegd wordt door wetgeving of aandeellhouders. Zeker wanneer het dan gaat om sociale doelstellingen kan medezeggenschap een uitstekend instrument zijn ter bereiking daarvan.

5 Frans Huysmans e.a. (Aktiegroep medicijnen Nijmegen), Gezondheidszorg in Nederland, Nijmegen 1973, p. 208-209.

Over deze kwestie onder meer: H.M. de Burlet, Gezondheid en veiligheid op de werkplek, Leiden 1978, p. 62-64; J.K.M. Gevers, Zeggenschap van werknemers inzake gezondheid en veiligheid in bedrijven, Deventer 1982, p. 47-52

Bij de behandeling van de Arbowet speelde dit vraagstuk op verschillende momenten een rol. Vgl. bijw. TK 1977-1978, 14.497, nr. 4 (Voorlopig Verslag), met name bij de opmerkingen van algemene aard en de begrippen veiligheid, gezondheid en welzijn, p. 1-11, idem MwA p. 1-55; idem Eindverslagg p. 1-7, idem Nota n.a.v. het Eindverslag p. 1-5.

6 Vgl. J.K.M. Gevers, t.a.p. p. 49. 
De belangrijkste wet die de positie van de werkgever normeert, is de Arbowet. De relevante bepalingen hieruit die van belang zijn voor de positie van de werkgever zullen hieronder worden besproken. Het gaat daarbij vooral om verplichtingen van de werkgever: immers zijn belangrijkste recht, de bevoegdheid om intern de wet te stellen, is gegeven. De inbreuken daarop dienen geformuleerd te worden. Overigens zullen niet alle verplichtingen in de eerstvolgende paragraaf worden besproken. Een aantal komt aan de orde bij de bespreking van de positie van andere actoren.

\subsubsection{Beleiasopdracht en grondbeginselen}

Hoewel de MvT bij de Arbowet nog eens benadrukt dat de werkgever primair bepaalt onder welke omstandigheden het werk wordt verricht, heeft de Arbowet aan de werkgever de in het vorige hoofdstuk al ter sprake gekomen verplichting opgelegd om zijn algemeen ondernemingsbeleid 'mede te richten op een zo groot mogelijke veiligheid, een zo goed mogelijke bescherming van de gezondheid en het bevorderen van het welzijn van de werknemer binnen het bedrijf of de inrichting; dat beleid behelst de middelen waarmee, en de wijze waarop deze doelstelling moet worden bereikt, en legt de onderscheiden bevoegdheden en verantwoordelijkheden vast welke in dit verband op de bij de werkgever werkzame personen rusten.' (art. 4 lid 1). Volgens het tweede lid moet dit beleid regelmatig getoetst worden en op grond daarvan of van gewijzigde werkmethoden of werkomstandigheden worden aangepast. Dit moet eveneens gebeuren wanneer zich op het gebied van de algemeen erkende regelen der techniek of in de stand van de bedrijfsgezondheidszorg dan wel in de stand van de ergonomie en die van de arbeids- of bedrijfskunde belangrijke wijzigingen voordoen. ${ }^{7}$ De MvT vermeldt nog dat het in feite gaat om de publiekrechtelijke uitwerking van datgene waartoe de werkgever reeds op grond van art. $1638 \mathrm{x} \mathrm{BW}$ verplicht is. ${ }^{8}$ Dat moge al twijfelachtig geweest zijn ten aanzien van de oorspronkelijke tekst (toen in art. 3) omdat daarin weliswaar alleen nog een zorgplicht voor de werkgever werd geformuleerd, maar dan wel inclusief de verplichting tot het nemen van welzijnsbevorderende maatregelen die, lijkt mij, ook bij een extensieve interpretatie van de verplichting ex art. 1638x er niet onder vallen, de huidige tekst heeft ongetwijfeld een veel verdere strekking dan art. $1638 x$. Het gaat nu om de verplichting van de werkgever om systematisch een geformaliseerd beleid te formuleren en te voeren op het gebied van de arbeidsomstandigheden. Het artikel spreekt (evenals het hierna te bespreken art. 3) over 'zo groot mogelijke veiligheid' en 'zo goed mogelijke bescherming van de gezondheid' en (slechts?) 'het bevorderen van het welzijn'.

7 Deze beide leden wan art. 4 zijn per 1 juni 1985 in werking getreden. De rest van art. 4 zall waarschijnlijk in 1990 (de laatste fase) in werking treden (zie hoofdstuk II, paragraaf 9).

8. TK 1976-1977, 14.497, nr. 3(MvT), p. 12. 
'En dat houdt in dat bij de bepaling van het beleid en het doen van keuzes alle beleidselementen (waaronder ook de economische randvoorwaarden) in de overwegingen worden betrokken. "Met andere woorden: hoewel een minimale invulling van het beleid in dit opzicht onvoldoende is, is een maximale niet nodig. Het resultaat mag en zal verschillen per onderneming. Het feit echter dat de werkgever een dergelijke ondernemingsdoelstelling dient te formuleren, kan van verstrekkende betekenis zijn, al was het alleen maar omdat het in de praktijk lang niet altijd gebeurt. De SER constateert tenminste in zijn advies over het sociaal beleid 'dat er in de praktijk ook sprake is van een minder systematische benadering en dat beleid - en derhalve ook sociaal beleid eveneens de resultante is van niet altijd bewust als zodanig vastgestelde doelstellingen' "10

Ik schreef dat de onderhavige werkgeversverplichting van vèrstrekkende betekenis kàn zijn. Dat hangt met nog iets anders samen. De bepalingen hebben een algemene en weinig concrete strekking. De Arboraad, gevraagd om een reactie op een ambtelijke nota inzake art. 4 leden 1 en 2 , concludeerde hieruit dat deze bepalingen nauwelijks zelfstandig betekenis hebben, maar voornamelijk van belang zijn als algemeen kader voor de bestaande en toekomstige (wettelijke) voorschriften. ${ }^{11}$ Deze conclusie lijkt mij terecht, maar het betekent wèl, dat zolang die bepalingen die inhoud moeten geven aan deze eerste twee leden van art. 4 niet in werking zijn getreden, de leden 1 en 2 van art. 4 vooral een aspiratieve, symbolische betekenis hebben. Zo zou bijvoorbeeld de invoering van lid 4 van art. 4 al voor wat meer substantie kunnen zorgen: via dit artikellid immers is de werkgever verplicht om alvorens tot vaststelling van het beleid over te gaan voorzover dat van aanwijsbare invloed kan zijn op de arbeidsomstandigheden, overleg te voeren met de or, c.q. de belanghebbende werknemers. In paragraaf 8 van het vorige hoofdstuk heb ik al geschreven dat lid 4 in afwachting van een SER-advies terzake nog niet in werking zou treden. Het inmiddels bekend geworden SER-advies is op dit punt niet unaniem, en geheel conform de verwachting herhalen werkgevers en werknemers de standpunten die zij al eerder in de Arboraad hadden ingenomen ten aanzien van de inwerkingtreding: de werkgevers menen dat de WOR (art. 23, juncto art. 31b) voldoende voorziet in de mogelijkheden tot overleg vooraf over het arbeidsomstandighedenbeleid, de werknemers menen, m.i. terecht, dat art. 4 lid 4 Arbowet zelfstandige betekenis heeft, naast de WOR-bepalingen. ${ }^{12}$ In de Ar-

9 Eerste Kamer, $1980-1981,14.497$, nr. 12 (MvA), p. 5.

10 SER-adwies 1981 , t.a.p. p. 8.

11 Arboraad, Reactie op de ambtelijke nota "Beleidswoering in het kader van de Arbeidsomstandighedenwell' (artikel 4), Zoetermeer 1983, p. 4.

12 SER-advies inzake samenloop van de Wet op de ondernemingstaden en de Arbeidsomstandighedenwet, Den Haag 1986, nr. 6.

De werkgevers woerden ook nog de wetsgeschiedenis aan als argument. In de Nota n.a.v. het eindverslag over het ontwerp-Arbowet merkte de minister nl. op dat art. 4 lid 4 Arbowet 'de tegenhanger' is wan art. 23 juncto art. $31 \mathrm{~b}$ WOR. TK 1979-1980, 14.497, nr. 11, p. 16. Weliswaar heeft de toenmalige bewindsman dit opgemerkt, maar dit betekent niet dat daarom inhoud en strekking van bedoelde bepalingen dezelfde zijn. Uit de wetsgeschiedenis blijkt dit ook nergens. 
bowet gaat het immers - in tegenstelling tot de WOR - om het verplicht nemen van het initiatief tot het overleg door de werkgever.

De hierboven vermelde ambtelijke notilie benadrukt nog eens de eigen verantwoordelijkheid van de bedrijfsgenoten bij bet arbeidsomstandighedenbeleid, met name van de werkgever. Weliswaar kan het districtshoofd van de Arbeidsinspectie terzake van art. 4 leden 1 en 2 een aanwijzing geven maar dat zal eerst denkbaar zijn 'teneinde een minimum normering t.a.v. arbeid en arbeidsomstandigheden te handhaven"."3

De wetgever laat de werkgever niet zitten met een tamelijke abstracte verplichting om een zo goed mogelijk arbeidsomstandighedenbeleid te voeren. In art. 3 worden acht grondbeginselen genoemd, eveneens geformuleerd in de vorm van verplichtingen voor de werkgever, waaraan dat beleid moet voldoen. Ook art. 3 is echter nog niet in werking getreden. (zie voor de betreffende discussie paragraaf 8 van het vorige hoofdstuk). Deze grondbeginselen hebben betrekking op de organisatie en de inhoud van de arbeid, de productie- en werkmethoden en de inrichting van de arbeidsplaatsen. Voor een belangrijk deel betreft het onderwerpen die ook in nadere regels zijn of worden vastgelegd. ${ }^{14}$ Maar: '... voor een andere deel hebben deze grondbeginselen betrekking op onderwerpen welke niet in nadere regels worden vastgelegd. $\mathrm{Bij} \mathrm{de}$ laatste groepen behoren in ieder geval de maatregelen die tot doel hebben de ontplooiingsmogelijkheden van de mens in zijn arbeid en de kwaliteit van de arbeid te verbeteren. ${ }^{15}$

Verderop in de MvA wordt dit welzijnsaspect geconcretiseerd: 'Dit houdt in dat steeds bij de planning en de inrichting van het werk rekening gehouden moet worden met de mogelijkheden voor individuele werknemers om verantwoordelijkheid te dragen en zich in hun werk te ontwikkelen en te ontplooien. In concreto gaat het hierbij om het opheffen van monotonie in het werk door middel van cyclusverlenging en taakverbreding. Werk waarvan inhoud en tempo bepaald worden door de machine of de lopende band dient zoveel mogelijk vermeden te worden. Veeleer moet het werk zo zijn ingericht dat het mogelijkheden biedt voor variatie en contacten tussen de werknemers onderling. Ook vormen van inspraak en overleg zijn daarbij van belang. "is Ook na de dereguleringsoperatie (waarbij wèl het begrip ontplooiing is weggevallen) zijn deze aspecten in art. 3 behouden gebleven.

13 Ambtelijke nota 'Beleidsvorming in het kader van de Arbeidsomstandighedenwet' (artikel 4), gepubliceerd als onderdeel IV van de reactie terzake van de Arboraad, t. at.p. p. 9.

14 Veelal zijn of worden deze nadere regelingen gebaseerd op art. 24 Arbowet. In het eerste lid wordt in bet algemeen gesteld dat bij of krachtens $A M v B$ regels worden gesteld ter verzekering van de veiligheid, ter bescherming van de gezondheid en ten bevordering van het welzijn van de werknemers in verband met de arbeid. In de wolgende leden wordt nader omschreven waarop deze regels betrekking kunnen hebben. Het betreft zowel de 'klassieke' regelingen. zoals het Veiligheidsbesluit fabrieken of werkplaatsen met daarin vooral gezondheids- en veiligheidsaspecten, als de nieuwere welzijusregelingen die bijwoorbeeld betrekking kunnen heb. ben op het werk tempo, de inhoud, de organisatie en de ergonomische aspecten van de arbeid en wan de machines e.d. (art. 24 lid 3 onder a, ben c).

115 MvA, t.a.p. p. 4.

16 MvA, t.a.p.p. 9. 
Het gaat dus in art. 3 om twee groepen maatregelen. De eerste groep richt zich op de veiligheid en gezondheid. Veelal bestaan er al langer AMvB's op dit punt. De betekenis van deze groep maatregelen is in dat geval dat zij verder kunnen gaan dan de in die besluiten geformuleerde minima. Zijn er nog geen besluiten over bepaalde onderwerpen vastgesteld, dan biedt art. 3 de mogelijkheid dat toch maatregelen op het gebied van de veiligheid en gezondheid kunnen worden getroffen. Het nieuwe van art. 3 zit echter met name in de tweede groep: de verplichting om ook welzijnsmaatregelen te treffen. Deze richten zich vooral op de individuele werknemer. Binnen deze groep gaat het om vier soorten wettelijke bepalingen. In de eerste plaats die welke een axanpassing vragen van de arbeidssituatie en -taak aan de eigenschappen van de werknemer, in de tweede plaats die welke van de werkgever verlangt het werk zó in te richten dat de werknemers ruimte hebben om hun werk zoveel mogelijk naar eigen inzicht te verrichten, in de derde plaats die welke verlangt het werk zó in te richten dat de werknemers contacten met andere werknemers kunnen onderhouden, en in de vierde plaats die welke van de werkgever vraagt dat aan de werknemer informatie over doel en resultaten van het werk wordt verstrekt. ${ }^{17}$

Behoudens de maatregelen die genomen moeten worden om het een werknemer mogelijk te maken bij acuut gevaar zich snel in veiligheid te stellen, zijn alle maatregelen vereist "tenzij zulks redelijkerwijs niet kan worden gevergd". Hierdoor wordt aan de werkgever een zekere ruimte verschaft om tot een afweging te komen tussen enerzijds veiligheids- en gezondheidsbelangen en anderzijds andere, met name economische belangen. Een, gezien de formulering objectief en dwingend criterium wordt hierbij gegeven doordat bij de invulling van de grondbeginselen gekeken moet worden naar de 'algemeen erkende regelen der techniek', 'de stand van de bedrijfsgezondheidszorg', en 'de stand van de ergonomie en die van de arbeids- en bedrijfskunde'. Een beroep op de redelijkerwijze-clausule lijkt echter niet al te snel te zullen worden gehonoreerd. Een voorstel van de SER om de formule 'tenzij zulks in de gegeven omstandigheden in redelijkheid niet van de werkgever kan worden gevergd" te gebruiken werd in de MvT verworpen omdat hierdoor de normering te zeer zou worden toegespitst op de individuele omstandigheden van de betrokken werkgever ${ }^{18}$ En de MwA: 'Het criterium redelijkerwijs zal in ieder geval in objectieve zin moeten worden verstaan, dat wil zeggen dat geen rekening mag worden gehouden met de individuele omstandigheden van een werkgever. ${ }^{19}$ Veel meer dan deze, toch nog wat cryptische mededelingen, werd er tijidens de parlementaire behandeling zowell van de Arbowet als van de deregulering ervan, niet gezegd over dit afwegingsaspect. Het gaat dus om een afweging in het algemeen, los van de concrete situatie in de onderneming. Het

17 Zie voor deze (her)groepering van de welzijnsbepalingen in art. 3 de ambtelijke nota De inhoud van het welzijns begrip in artikel 3 van de Arbowet, Directoraat-Generaal van de Arbeid, Voorburg 1985, p. 7 .

18 MvT t.a.p. p. 10 .

19 MWA tial.p. p. 55 
probleem is echter dat de afweging zèlf uiteraard een subjectieve zaak zal zijn. ${ }^{20}$

De adviesaanvraag aan de SER met betrekking tot het voorkomen en beperken van overmatig geluid in fabrieken of werkplaatsen uit 1981 brengt een zekere verduidelijking. Het gaat hierbij om art. 179a van het Veiligheidsbesluit voor fabrieken of werkplaatsen waarin ook sprake is van een redelijkerwijze formulering. Volgens de adviesaanvraag dient de werkgever eerst dàn tot een belangenafweging te komen als resultaat waarvan hij in een aantal gevallen tot een beroep op de redelijkerwijze-clausule zou mogen komen "wanneer daarbij duidelijk is dat nakoming van deze plicht andere zwaarwegende belangen, waarvoor hij ook verantwoordelijk is, te zeer zou schaden'. ${ }^{21}$ Onder het begrip zwaarwegende belangen kunnen dan o.a. gerekend worden belangrijke economische implicaties, waarbij met name gedacht wordt aan verstoring van de concurrentieverhoudingen, ook in relatie tot het buitenland. Maar indien de financièle situatie van een onderneming van dien aard is dat zij meent de technisch in de bedrijfstak gebruikelijke en gewenste voorzieningen niet te kunnen treffen, dan ligt een blijvend beroep op de redelijkerwijzeclausule minder voor de hand. De SER lijkt in zijn advies met deze interpretatie accoord te gaan, verzet er zich althans niet tegen en preciseert nog als volgt: 'De Raad gaat er tenslotte van uit dat een beroep door de werkgever op de redelijkheids-clausule slechts door de Arbeidsinspectie zal worden aanvaard indien de werkgever aannemelijk maakt dat zijn beleid planmatig is ingericht op de verwezenlijking van de gewenste situatie. Het is daarbij tevens niet de bedoeling dat in het verleden opgelopen achterstanden zonder meer met een beroep op de redelijkerwijze-clausule kunnen worden gelegitimeerd. ${ }^{22}$

Geconcludeerd kan in elk geval worden dat het zeker niet de bedoeling is dat de werkgever al te gemakkelijk met een beroep op de redelijkheid onder zijn verplichtingen op het gebied van het te voeren arbeidsomstandighedenbeleid uit kan komen en, doet hij dat toch, dat hij moet kunnen aantonen, dat objectief gezien niet van hem verwacht kan worden bepaalde verplichtingen op dat punt na te komen. Daar komt bij dat, ook al heeft hij de primaire zorg voor de arbeidsomstandigheden in de onderneming, hij er ook de werknemers(vertegenwoordiging) bij dient te betrekken. Voorop staat immers steeds de zelfwerkzaamheid binnen de onderneming. Pas als dat niet tot aanvaardbare resultaten leidt, zal de Arbeidsinspectie kunnen ingrijpen, hetzij op eigen initiatief hetzij op verzoek van de werkgever of de werknemers (-vertegenwoordiging), indien partijen het over de te nemen maatregelen niet eens kunnen worden. Dit gebeurt dan via het zgn. verzoek om wetstoepas-

$20 \mathrm{Vgl}$. ook J. Bloemarts, Op weg nateen drie-partijen-model voor het sociaal beleid in de onderneming?, SMA, 1978 , p. 600 .

21 Adviesaanvragg met betrekking tot hel voorkomen en beperken van overmatig geluid in labrieken of werkplatsen van de minister van Sociale Zaken en Werkgetegenheid aan de SER d.d. 18 juni 1981, opgenomen als bijlage I van het SER-advies Geluid op de arbeidsplants, Publikatie nr.. 1,1984, p. 56.

22 SER-advies Geluid op de arbeidplaats, t.a.p. p. 31. 
sing ex art. 40. Ten aanzien van de naleving van art. 3 kan het districtshoofd dan een aanwijzing tot naleving geven, nadat hij de betrokken partijen heeft gehoord (art. 35). Met betrekking tot art. 3 onder g en $\mathrm{h}$ kan het districtshoofd dat zelfs niet op eigen initiatief, maar slechts nadat een verzoek om wetstoepassing is ingediend. (De betreffende bepalingen handelen over het bijdragen tot de vakbekwaamheid, de mogelijkheid tot contact met anderen, het op de hoogte zijn van doel en resultaten wan het werk en over het vermijden van monotone arbeid). Pas wanneer een aanwijzing niet wordt opgevolgd, kan strafrechtelijk worden ingegrepen. (Het niet volgen van een aanwijzing is een economisch delict; art. 57). Dit past bij het karakter van deze bepalingen, die immers niet beschouwd kunnen worden als concrete voorschriften waaraan een directe strafsanctie kan worden vierbonden, maar die primair dienen als beleidsuitgangspunten voor de onderneming waarbinnen zij gerealiseerd moeten worden. Overheidsingrijpen wordt niet uitgesloten, maar komt pas op de tweede plaats. ${ }^{23}$

\subsubsection{Het jaarplan}

De verplichting voor de werkgever ex art. 4 leden 1 en 2 om een arbeidsomstandighedenbeleid te voeren betekent niet automatisch dat dit beleid ook in een schriftelijk stuk moet worden vastgelegd. In de praktijk zal dit overigens wel vaak gebeuren, zeker wanneer ook lid 4 in werking is getreden, waarin immers de verplichting is opgenomen om over dit te voeren beleid eerst te overleggen met de werknemers(vertegenwoordiging). Het valt niet goed in te zien hoe een dergelijk overleg gevoerd kan worden zonder enig schriftelijk stuk. Toch bepaalt art. 4 lid 3 dat bepaalde bedrijven of inrichtingen bij AMvB aangewezen kunnen worden om een schriftelijk jaarplan op te stellen. Maar ook dit lid zal pas in de laatste fase (in 1990 waarschijnlijk) in werking treden. Volgens de MvT is het nut van een dergelijk geschrift enerzijds dat het voorwerp van bespreking kan zijn tussen werknemers onderling en tussen werkgever en werknemers en anderzijds dat het kan dienen als een soort voorlichtingsmateriaal. ${ }^{24}$

Voor opneming in de betreffende AMvB wordt volgens de MvA gedacht aan de grote en middelgrote ondernemingen. Daarnaast zal rekening worden gehouden met die ondernemingen waar een verhoogd risico aanwezig is. De aanwijzing wordt gericht aan de werkgever, maar heeft betrekking op "bedrijven of inrichtingen'. Dit betekent dat het jaarplan ook beperkt kan zijn tot tot de onderneming behorende onderdelen. Een meerjarenplan wordt niet verplicht gesteld omdat, volgens de minister, het verplichtstellen 'reeds een tamelijk grote stap betekent ${ }^{26}{ }^{26} \mathrm{Nu}$ staat in de wet dat het plan a) jaarlijks moet worden gemaakt en b) tenminste een periode van een jaar moet bestrijken. 
Over de inhoud van het plan geeft de wettekst weinig houvast. Het gaat om de vastlegging van 'het beleid'. De parlementaire behandeling geeft wel enige duidelijkheid. De MvT vermeldt dat het plan bijwoorbeeld betrekking kan hebben op de meer traditionele terreinen van welzijnszorg zoals kantines e.d. of 'om een moderner voorbeeld te noemen' op het invoeren van nieuwere werkmethoden. Een ander voorbeeld vormt het voornemen tot aansluiting bij een bedrijfsgezondheidsdienst of tot wijziging in de organisatie van zo'n dienst. ${ }^{27}$ De MvA noemt voorts beleidsvoornemens ten aanzien van de arbeidsorganisatie en de productie- en werkmethoden. "In het algemeen kan gesteld worden dat de concrete inhoud van het jaarplan in belangrijke mate bepaald wordt door hetgeen in art. 8 (thans art. 10) als minimale inhoud van het jaarverslag wordt voorgeschreven. ${ }^{28}$ (hierover: paragraaf 2.2 .4 . van dit hoofdstuk). Tenslotte zei de minister tijdens de artikelsgewijze behandeling in de openbare vergadering van de vaste commissie voor sociale zaken: 'Het jaarplan behoort een volledig beeld te geven van het door de werkgever te voeren beleid. Het zal niet alleen de niet-wettelijke verplichtingen en regelingen bevatten die onderworpen zijn aan het instemmingsrecht van de ondernemingsraad of commissie, maar ook zal het jaarplan de wel wettelijk verplichte maatregelen bevatten. ${ }^{29}$ Zeker in het licht van de laatste formulering zal het plan dus vrijwel elk beleidsvoornemen op het gebied van de arbeidsomstandigheden van de werkgever dienen te bevatten.

Iedere werknemer moet 'desgewenst' kennis kunnen nemen van het plan. Het plan mag worden opgenomen in de informatie die op grond van art. $31 \mathrm{~b}$ lid 2 van de WOR jaarlijks aan de or moet worden verstrekt over het in het komende jaar te voeren sociale beleid. In dat geval kan de informatie ex art. $31 \mathrm{~b}$ lid 2 dus niet mondeling - wat overigens volgens de WOR wel toegestaan is worden verstrekt. Het plan moet worden toegestuurd, niet ter goedkeuring, maar ter kennisneming aan het districtshoofd van de Arbeidsinspectie, evenals daarvón aan de or of de Arbocommissie. Het oordeel van de laatste wordt meegestuurd aan het districtshoofd. Evenals dat geldt voor het te voeren beleid ex art. 4 leden 1 en 2 dient ook over het jaarplan vooraf overleg gevoerd te worden met de werknemers(vertegenwoordiging).

Een belangrijk onderwerp gedurende vrijwel de gehele parlementaire behandeling werd gevormd door het vraagstuk van het instemmingsrecht van de or ex art. 27 lid 1 onder e WOR ten aanzien van het jaarplan. (Een soortgelijke instemmingsprocedure is in de Arbowet geregeld voor de Arbocommissie in art. 14 lid $6.3^{30}$

In antwoord op vragen hierover in de vaste kamercommissie werd het instemmingsrecht in de MvA afgewezen. 'Het wetsontwerp ziet het jaarplan evenals trouwens ook het arbeidsveiligheidsrapport primair als feitelijke mededelin-

27 MVT t.a.p. p. 13.

28 MvA ti.a.p. p. 35.

29 Handelingen TK 1979-1980, OCV 3 mant $1980, p .1283$

30 Pas later in de wet gekomen bij (de ecrte) Nota wan wijzigingen, TK 1978-1979, 14.497, nr.6. 
gen van de werkgever. Deze mededelingen lenen zich naar hun aard niet voor een instemmingsrecht. Het gaat hierbij immers niet om concrete regelingen.' En verderop wordt gezegd dat het jaarplan "slechts" een beleidsplan zou zijn. ${ }^{31}$ Bij deze opvatting kunnen vraagtekens worden geplaatst. Immers een plan waarin het beleid voor tenminste een jaar wordt vastgelegd, kan toch moeilijk als een feitelijke mededeling beschouwd worden. Ook het argument dat het beleidsplan geen concrete regelingen zou bevatten, en daarom niet voor de instemmingsprocedure in aanmerking zou komen, is zeer discutabel. Dit temeer in het licht van de beoogde inhoud van het plan zoals die hierboven is omschreven In zijn Nota naar aanleiding van het eindverslag komt de minister dan ook terug op zijn aanvankelijk oordeel. Het jaarplan bevat inderdaad méér dan feitelijke mededelingen en het moet op zich mogelijk zijn om beleidsvoornemens aan het instemmingsrecht te onderwerpen. Toch blijft hij het instemmingsrecht ontraden en wel om twee redenen. In de eerste plaats omdat het wel opnemen van het instemmingsrecht ten aanzien van het jaarplan een inbreuk zou betekenen op het systeem wan de WOR. In de tweede plaats omdat bij het eventueel niet verkrijgen van instemming er een mogelijke samenloop van geschillenprocedures ontstaat $\mathrm{nl}$. zowel op basis van de WOR (artt. 27 lid 4 jo. 44 ; verzoek aan de bedrijfscommissie en in beroep aan de minister om vervangende goedkeuring) als op basis van de Arbowet (artt. 40 jo. 35 en 36 jo. 42 ; verzoek aan het districtshoofd om wetstoepassing met eveneens beroepsmogelijkheid op de minister). ${ }^{32}$ Voor wat betreft het eerste argument gaat dat in elk geval op voorzover het jaarplan andere voorgenomen besluiten betreft dan voorgenomen regelingen op het gebied van de veiligheid, de gezondheid en het welzijn bij de arbeid in de zin van art. 27 lid 1 onder e WOR. Gezien de beoogde inhoud van het plan lijkt dat echter slechts een theoretische mogelijk heid te zijn. Het tweede argument ziet vooral op procedurele problemen. Deze zijn niet denkbeeldig. (Inmiddels heeft de SER advies uitgebracht over de samenloop van beide geschillenprocedures bij het instemmingsrecht in het algemeen. Zie daarover 3.4.1.). Hoewel in de Arbowet uiteindelijk geen instemmingsrecht is opgenomen ten aanzien van het jaarplan als zodanig, heeft de minister naar aanleiding van een aanvaarde motie terzake wel toegezegd de kwestie 'in studie te nemen', ${ }^{33}$ Vervolgens is hier niets meer van vernomen. Dat is jammer. Maar mochten we nog iets vernemen op dit punt dan is het te hopen dat in de studie tot de conclusie wordt gekomen dat de argumenten die pleiten vór het verlenen van instemmingsrecht ten aanzien van het jaarplan sterker zijn dan de argumenten tegen.

Hoewel art. 4 lid 3 pas in de laatste fase in werking zal treden, beschikt een aantal ondernemingen al wel over een jaarplan. Uit het begin $1988 \mathrm{gepubli}$ ceerd ITS onderzoek naar de receptie van de Arbowet blijkt, dat van de 30 onderzochte ondernemingen $20 \%$ een dergelijk plan heeft. De grotere onder-

31 MvA t.a.p. p. 35 resp. p. 58.

32 TTK 1979-1980, 14.497, nr. 1. (Nota naar anleiding van het eindverslag), p. 16.

33 TK 1979-1980, 14.497, nr. 175 (motie Hartmeyer c.s.) en TK 1979-1980, 14.497, nr. 186 (brief minister), p. 2. 
nemingen lijken daarbij iets oververtegenwoordigd. Bewust of onbewust wordt dus geanticipeerd op de komende verplichtstelling. De inhoud van de plannen varieert overigens sterk, wan goed doorwrochte programma's tot lijstjes met aandachtspunten. ${ }^{34}$

\subsubsection{Het arbeidsveiligheidsrapport}

De regeling met betrekking tot de verplichting voor de werkgever om er voor te zorgen dat in zijn onderneming of in een of meer delen daarvan, een arbeidsveiligheidsrapport aanwezig moet zijn, is in essentie overgenomen uit de Veiligheidswet 1934, waarin de regeling in 1977, toen onder de naam veiligheidsrapport, werd opgenomen. ${ }^{35}$ In paragraaf 8.2. van het vorige hoofdstuk is deze aanvulling op de Veiligheidswet aan de orde geweest. Toen is ook de discussie over de rol van de or ter sprake gekomen. Uiteindelijk resulteerde deze erin, dat de werkgever alleen verplicht werd om een afschrift van het rapport, of een wijziging daarvan, aan de or te sturen.

In de regeling zoals die thans in art. 5 Arbowet is opgenomen, is de rol van de or (c.q. commissies van de or, c.q. de Arbocommissie) geprononceerder. Volgens het zesde lid van art. 5 moet de werkgever nu vooraf overleg plegen over het arbeidsveiligheidsrapport en de wijziging daarvan met de or. Het is overigens opvallend dat dit punt bij de parlementaire behandeling van de Arbowet nauwelijks een rol heeft gespeeld. Pas tijdens de openbare commissievergadering deelde minister Albeda, naar aanleiding van een terzake ingediend amendement, mede, dat het voorgestelde overleg over het arbeidsveiligheidsrapport tussen werkgever en or helemaal in het wetsontwerp paste. ${ }^{36}$ Het betreffende zesde lid werd ingevoegd bij de vierde Nota van wijzigingen. ${ }^{37}$

34 T.I.M. Reubsaet, P.A.M. de Boer, P.C.J. Sweere, H.J.M. van den Tillaart, De Arbowet in uitvoering, Een onderzoek naar ervaringen in de praktijk, onderzoek door het Instituut voor Toegepaste Sociale Wetenschappen (ITS), in opdracht van het ministerie van Sociale Zaken en Werkgelegenheid, Den Haag 1988, p. 42 (zie ook noot 112).

35 Wet van 23-11-1977 (S. 689); paragraaf $8 \mathrm{~d}$, artt. $20 \mathrm{v} / \mathrm{m}$ 20x. De categorale aanwijzing ten aanzuen van (delen van) ondernemingen waarin gevaarlijke stoffen alanwezig zijn, is vastgesteld in het Besluit verplichtstelling veiligheidsrapport van 12 augustus 1981 (S. 556). Het gast om ongeveer honderd (delen van) onderme mingen vooral in de chemische procesindustrie. Bij besluit van 30 december 1981 (S. 826) zijn zowel de betreffende artikelen in de Veiligheidswet als het Besluit per 1 februari 1982 in werking getreden. Bij Besluit van 18 mei 1982 (S. 408) is met name de terminologie van het besluit aangepast aan die van de Arbowet, krachtens welke het besluit thans geacht wordt te zijn wastgesteld.

Bij brief van 11 augustus 1986 (nF. DGA/HAWB/86/7257) heeft de minister van Sociale Zaken en Werkgelegentheid aan de Arboraad advies gevraagd over een samen met het ministerie van VROM opgestelde AMvB op grond van art. 5 Arbowet en art. $2 a$ Hinderwet. Deze AMvB strekt ter voldoening aan de richtlijn van de EG van 24 juni 1982 (nr. $82 / 501 / \mathrm{EEG}$ ), inzake de risico's zware ongevallen bij industriële activiteiten (Post-Seveso-richtlijn). Op 26 februari 1987 is het advies door de Arboraad wastgesteld. Arborad, Advies inzake Besluiten risico's zware ongevallen en de wijziging van thet Besluit verplichtstelling arbeidsveuligheidsrapport. Zoetermeer 1987 , nr. 21.

36 Handelingen TK 1979-1980, OCV 3 maart 1980, p. 1286. Het amendement was getekend door de PvdA-leden Hartmeyer, Moor en Touseaint, TK 1979-1980, 14497, nr. 34 en kon wegens de toezegging van de minister later worden ingetrokken.

37 TK 1979-1980, 14.497, nr. 138 (vïerde Nota van wijzigingen), p. 1 . 
Het niet nakomen van deze werplichting (en een aantal andere voortvloeiende uit art. 5) door de werkgever, is krachtens art. 5 lid 13 jo. art. 57 een economisch delict.

In juni 1985 zijn de resultaten gepubliceerd van een evaluatie met betrekking tot het arbeidsveiligheidsrapport. ${ }^{38}$ Eén van de conclusies luidde, dat de betrokkenheid van de or bij de start of bij het opstellen van het rapport zeer uiteenlopend is geweest, en dat het rapport in veel gevallen te ingewikkeld en technisch van aard was. Op grond hiervan is door de Arbeidsinspectie besloten om in de ondernemingen meer aandacht te schenken aan de mogelijkheden tot het betrekken van de werknemers via de or bij het arbeidsveiligheidsrapport. ${ }^{39}$ De Arboraad wijst er in zijn commentaar van februari 1987 onder meer op, dat hier niet alleen een taak is weggelegd voor de Arbeidsinspectie, maar evenzeer voor de werkgever die volgens art. 5 lid 6 immers gehouden is vooraf overleg te plegen met de or. ${ }^{40}$ Dat is juist, en deze opmerking benadrukt nog eens dat het niet aangaat dat de werkgever feitelijk onder zijn overlegverplichting uitkomt door niet tevens voldoende en functionele informatie, uitleg en voorlichting te geven - zeker bij zulke ingewikkelde zaken als het arbeidsweiligheidsrapport. Art. 14 lid 10 onder b. $1^{\circ}$ verplicht de werkgever trouwens ook tot het verschaffen van de nodige inlichtingen die de or (Arbocommissie) redelijkerwijs voor de uitoefening van zijn (haar) taak nodig heeft.

\subsubsection{Het jaarverslag}

Art. 10 bevat de verplichting voor de werkgever om een jaarverslag op te maken, indien ten aanzien van zijn bedrijf of inrichting een jaarplan is voorgeschreven, of indien zijn bedrijf of inrichting behoort tot een bij AMvB aangewezen categorie. In de oorspronkelijke tekst van art. 10 was deze verplichting minder scherp geformuleerd: de werkgever moest zorgen dat er een jaarverslag aanwezig was. De CDA-fractie gaf echter de voorkeur aan de voorgestelde tekst van de FNV, zodat de terminologie in overeenstemming zou zijn met die in art. 4, waarin de verplichting voor de werkgever directer geformuleerd was. Om deze reden werd de wijziging overgenomen. ${ }^{41}$ (Dit dus in tegenstelling tot de verplichting met betrekking tot het arbeidsveiligheidsrapport. In dat betreffende artikel staat nog: 'er voor zorgen ... dat aanwezig.')

Het jaarverslag moet ertoe leiden, dat duidelijk wordt in hoeverre het voorgenomen beleicl is gerealiseerd en welke de redenen waren waarom het is bijgesteld of slechts ten dele uitgevoerd. Op deze wijze kan het jaarverslag ertoe bijdragen, dat regelmatig herbezinning plaatsvindt met betrekking tot de zorg

38 De conclusies van het evaluatierapport en voorgestelde acties zijin opgenomen in het Commentaar op de nota: Evaluatie le fase AVR (Arbeidsveiligheidsrapport) en aanpassing van de AVR-regeling, Zoetermeer 1987, nr. 22.

39 Arboraad, 1987, nr. 22, t.a.p. p. 17 .

40 Arboraad, 1987 , nr. 22, t.a.p. p. 9

41 Nota n.a.v. het eindverslag, t.a.p. p. 34; Tweede nota van verbetering, TK 1979-1980, 14.497, nr. 12, p. 2 . 
voor de veiligheid, de gezondheid en het welzijn bij de arbeid. ${ }^{42}$ Het artikel bevat een uitvoerige beschrijving van wat het verslag 'tenminste' moet inhouden. Naast een beschrijving van het gevoerde beleid noemt het tweede lid nog inlichtingen over de samenwerking en het overleg in de onderneming en over de deskundige diensten, inlichtingen over het onderricht, de begeleiding en de voorlichting, een beschrijving van de getroffen maatregelen naar aanleiding van ongevallen, (vermoede) beroepsziekten en gebeurtenissen die grote materiële schade hebben veroorzaakt, een overzicht van de door de werknemers gemelde gevaren, vermelding van de aanwijzigingen en eisen van de Arbeidsinspectie en de manier waarop er aan is voldaan en tot slot een cijfermatig overzicht van ongevallen, ziekten, arbeidsverzuim en het aantal van de daarbij betrokken werknemers. Het verslag mag deel uitmaken van de gegevens die krachtens art. $31 \mathrm{~b}$ lid 1 van de WOR aan de or dienen te worden verstrekt. Het moet, behalve aan de or (of de Arbocommissie) ook worden toegezonden aan het districtshoofd van de Arbeidsinspectie. Bovendien moet de werkgever ervoor zorgen dat iedere werknemer desgewenst kennis kan nemen van het verslag. Volgens de MvA is de betekenis hiervan dat wordt aangenomen, dat er bij voldoende gebleken belangstelling een praktijk zal ontstaan dat de werknemers in het bezit worden gesteld van een kort verslag waarin de belangrijkste punten uit het jaarverslag zijn vermeld. ${ }^{43}$

Over het moment van inwerkingtreding van dit artikel is nogal wat te doen geweest. Oorspronkelijk kwam art. 10 niet voor in de reeks artikelen die in de eerste fase in werking zou treden. Nadat echter in de SER-adviesaanvraag van 4 januari 1982 inzake maatregelen ziekteverzuim een versnelde inwerkingtreding van art. 10 werd aangekondigd als een maatregel die direct of indirect zou kunnen bijdragen tot het terugdringen van het ziekteverzuim en de daarmee samenhangende uitgaven, werd aan de VAR gevraagd om over een versnelde inwerkingtreding advies uit te brengen. ${ }^{44}$ In deze adviesaanvraag zette de toenmalige staatssecretaris nog eens het doel en de betekenis van art. 10 uiteen. In de eerste plaats geeft het de werkgever inzicht in de ontwikkelingen binnen zijn onderneming en zal het hem stimuleren tot het voeren van een beleid gericht op de verbetering van de veiligheid, de gezondheid en het welzijn van zijn werknemers. Daardoor zal het jaarverslag een gunstige invloed hebben op het ziekteverzuim voorzover de oorzaken daarvan in de arbeidssituatie zijn gelegen. In de tweede plaats zal de aan de werkgever opgelegde jaarlijkse verslaglegging teiden tot een vruchtbare discussie met de werknemers. Dit gezamenlijk overleg zal een belangrijke uitwerking kunnen hebben met betrekking tot het terugdringen van ziekte en ongevallen en de daaruit voortvloeiende kosten.

42 MvT. t.a.p. p. 12

43 MvA. t.a.p.p. 63.

44. De adwesacmvriag an de SER (Kenmerk 50059, Directie Soz. Verz./FEV, Hooldafd. W. V.) is als bijlage l opgenomen in de adviesaanvraag a an de $V A R$ over de inwerkingtreding van art. 10 , d.d. 1 maart 1982 (Kenmerk DGA, 232180 ). 
Méer dan voorheen werd dus in deze adviesaanvraag het instrumentele karakter van het verslag benadrukt, vooral gericht op het doen terugbrengen van ziekten en ongevallen en de daarmee verband houdende kosten.

Op 16 september 1982 bracht de VAR zijn advies uit. ${ }^{45}$ Zowel de werknemersals de werkgeverswertegenwoordigers achtten deze plotselinge adviesaanvraag minder gelukkig. Terecht vestigden zij er bovendien de aandacht op, dat de keuze voor eerdere inwerkingtreding van dit art. 10 nogal willekeurig was. Waarom geen andere artikelen genoemd die evenzeer een bijdrage konden leveren aan het beoogde doel? Het advies was uiteindelijk niet unaniem. De werknemersleden waren vóór spoedige inwerkingtreding om de redenen die in de adviesaanvraag waren genoemd. De werkgeversleden waren er tegen, omdat zij bang waren voor extra kosten en omdat deze verplichting voor de werkgever al voldoende tot uitdrukking zou zijn gebracht in art. $31 \mathrm{~b}$. jo. art. $27 \mathrm{lid} \mathbb{1}$ onder e WOR. Dit laatste argument lijkt mij slechts ten dele op te gaan. Immers gelet op het bepaalde in art. 10 ten aanzien van de inhoud van het verslag gaat het om een nadere concretisering en kan het een beduidende méérwaarde betekenen ten opzichte van het bepaalde in art. 31b WOR.

Uiteindelijk is art. 10 bijna in zijn geheel in werking getreden per 1 juni 1985 als onderdeel van het tweede gedeelte van de eerste fase. ${ }^{46}$ De categorale aanwijzing heeft nu betrekking op die bedrijven of inrichtingen waar 100 of meer werknemers in dienst van een werkgever zijn. Het eerste verslag moest het jaar 1986 bestrijken. ${ }^{47} \mathrm{Op}$ grond van art. 10 lid 5 zijn bij ministerieel besluit nadere regels gegeven met betrekking tot de inhoud van het verslag. Met name zijn definities gegeven voor de begrippen ongeval, beroepsziekte, vermoede beroepsziekte, en grote materiële schade en is aangegeven op welke wijze de ongevallen en het verzuim in het jaarverslag moeten worden verwerkt. (zie hierover ook paragraaf 2.2.6.)

$\mathrm{Bij}$ het besluit behoort een bijlage waarin de ziekten en aandoeningen zijn genoemd die een beroepsziekte kunnen zijn in de zin van art. 10 lid 2.48 Over de wijze van naleving van art. 10 kan het districtshoofd van de Arbeidsinspectie, al dan niet op verzoek, een aanwijzing tot naleving geven (art. 35). Nietnaleving van de verplichting ex art. 10 vormt een economisch delict (art. 57). Ondanks de verplichtstelling om - voor het eerst over 1986 - een jaarverslag te produceren, hebben twee onafhankelijk van elkaar uitgevoerde onderzoeken aangetoond, dat dat nog niet in alle gevallen gebeurt. ${ }^{49}$ In de kleinere van de ondernemingen die verplicht over een jaarverslag moeten beschikken (met 100-200 werknemers) gebeurt het slechts in de helft van de gevallen. De beide

45 Vootlopige Arbeidsraad, Advies inzake de inwerkingtreding van art. 10 van de Arbowet, Zoetermeer 1982 , nr. 3.

46 KB 8 maart 1985 (S 212). Alleen het tweede lid onder e (de verplichting tot het opnemen van maatregelen genomen naar aanleiding van gebeurtenissen met grote materiele schade) is per 1 januari 1988 in werking getreden.

47 KB 8 maart 1985 (S. 227)

$48 \mathrm{~KB} 4$ april 1985 (Stcrt. 1985, 84) + bijlage.

49 ITS-onderzoek 1988, t.a.p. p. 43; Guido Bayens, Arbo-jaarverslagen nader bekeken, Maandblad woor arbeidsomstandigheden, 1988, p. 91-95. 
onderzoeken komen in het algemeen ook tot een gelijkluidende conclusie met betrekking tot de inhoud van het verslag: maar in een paar gevallen komt die in de buurt van wat de wet in dit opzicht beleidsmatig verlangt. Meestal beperkt het verslag zich tot een weergave van de ziekteverzuim- en ongevallencijfers, soms met aangekondigde maatregelen in dit verband en opsommingen van praktische aktiviteiten zoals voorlichting, die in het afgelopen jaar hebben plaatsgevonden.

Dat is jammer, want op deze manier kan weinig terecht komen van de functies van het jaarverslag: terugkoppeling naar het beoogde beleid en beleidsdocument in het kader van het overleg binnen de onderneming. Uiteraard wordt het nog droeviger als zowel het ontbreken van het jaarverslag als de lacuneuze inhoud ervan inderdaad een getrouwe weergave bieden van het gevoerde arbeidsomstandighedenbeleid.

\subsubsection{Voorlichting, onderricht en begeleiding}

De verplichting voor de werkgever tot het geven van voorlichting, onderricht en begeleiding is neergelegd in de artt. 6,7 en 8 . Art. 6 gaat over voorlichting en onderricht, art. 7 over voorlichting en onderricht aan jeugdige werknemers, en art. 8 over de begeleiding van jeugdige werknemers. De laatste twee artikelen bevatten een aantal bijzondere verplichtingen ten aanzien van werknemers jonger dan 18 jaar. ${ }^{50}$ Het gaat daarbij vooral om vormings- en opleidingsaspecten. In nader bij AMvB aangewezen categorieën ondernemingen, warin tenminste een bij die maatregel bepaald aantal jeugdige werknemers arbeid pleegt te verrichten, moet de werkgever ervoor zorgen dat zij begeleid worden door één of meer mentoren. Volgens het kabinetsstandpunt over de dereguleringsvoorstellen zal een dergelijke $\mathrm{AMvB}$ uitgevaardigd worden voor zover in de praktijk blijkt, dat initiatieven terzake uit het bedrijfsleven tekort schieten. $^{51}$

In het onderstaande zal ik me verder beperken tot het belangrijkste artikel van het trio: art. 6 . Dit is in werking getreden per 1 juni 1985 , in tegenstelling tot de andere twee: art. 7 is per 1 januari 1988 in werking getreden en art. 8 zal pas in de laatste fase in werking treden. (Een merkwaardige uitzondering moet gemaakt worden voor het vijfde lid van art. 8 , dat handelt over het beëindigen van de dienstbetrekking van de mentor en de bescherming die hij daarbij ontvangt. Dit lid is weliswaar niet in werking getreden, maar 'geldt' wel. ${ }^{52}$ ). Art. 6

50 De artt. 7 en 8 zijn oorspronkelijk afkomstig uit het wetsontwerp tot wijziging van de Arbeidswet 1919 (het zgn. Jongerenstatuut tweede fase; TK 1977-1978, 14.828, nr. 2). Zij zijn bij Tweede Nota van wijzigingen (TK 1979-1980, 14.497, nr. 10) aan het wetsontwerp Arbowct toegevoegd.

51 Brief van de minister van Justitie inzake het kabinetsstandpunt eindbericht commissie Geelhoed, tha.p. p. 2 en 3.

52 Dat komt omdat het vijfde lid van art. 8 van overeenkomstige toepassing wordt werklaard op het wèl in werking getreden art. 18 lid 5 , dat handelt over her einde van de dienstbetrekking van bedrijfsartsen. Derhalve 'geldt' de inhoud van art. 8 lid 5 wèl ten aanzien van de bedrijfsarts. Vgl. de Nota van toelichting bij KB van 15 november 1982 (S.673). Het is owerigens niet 
bevat de verplichting voor de werkgever om ervoor te zorgen, dat alle werknemers bij indiensttreding en voorts zo vaak als nodig is, doeltreffend worden ingelicht over de aard van hun werk, de daaraan verbonden gevaren en de ter voorkoming daarvan genomen maatregelen; dat zij doeltreffend en aan hun taken aangepast, onderricht worden met betrekking tot de arbeidsomstandighedlen bij het werk en dat dit opnieuw moet gebeuren zo vaak als de omstandigheden daar aanleiding toe geven; dat de werknemers op de hoogte zijn van doel, werking en gebruik van hun persoonlijke beschermingsmiddelen en van de angebrachte beveiligingen.

De ratio van deze bepaling is duidelijk. De wet verlangt van de werknemers een actieve inbreng in de arbeidsomstandigheden en het is derhalve van groot belang "dat zij inzicht kunnen verkrijgen in de aard van de gevaren waaraan zij bij de arbeid zijn blootgesteld en de wijze waarop deze het beste kunnen worden bestreden'. ${ }^{53}$ Noch in de wet of de toelichting erop, noch in adviezen van de Arboraad of van de Arbeidsinspectie wordt een duidelijk onderscheid gemaakt tussen voorlichting en onderricht. Voorlichting heeft waarschijnlijk meer betrekking op basisinformatie, onderricht gaat verder, is concreter, meer vaktechnisch. In de praktijk zal het een vaak in het ander overlopen.

De wet gebruikt het woord 'doeltreffend'. Dit betekent dat de voorlichting en het onderricht aangepast dienen te zijn aan opleiding, capaciteit en dergelijke van elke individuele werknemer. Het dient desnoods in een vreemde taal te worden gegeven, aanschouwelijk en niet uitsluitend schriftelijk..$^{54}$

Als de werkgever de opzet van zijn activiteiten op het gebied van de voorlichting en het onderricht neerlegt in wat kan worden aangemerkt als een regeling in de zin wan art. 27 lid 1 onder $e$ WOR, behoeft de regeling de instemming van de or. Dit instemmingsrecht wordt begrensd enerzijds door de wettelijke verplichting voor de werkgever tot het geven van voorlichting en onderricht, anderzijds door hetgeen ten aanzien van voorlichting en onderricht eventueel inhoudelijk in een CAO is geregeld (art. 27 lid 3 WOR). Los hiervan vormt deze verplichting ook voor de werkgever een onderdeel van zijn arbeidsomstandighedenbeleid en zal ook om die reden overleg met de werknemers(vertegenwoordiging) geïndiceerd zijn.

$\mathrm{Bij}$ de parlementaire behandeling is ter sprake gekomen of deze verplichting van de werkgever nu ook beschouwd kon worden als een recht voor de werknemer. Om eventuele onduidelijkheid hierover weg te nemen stelde D'66 voor om het recht op informatie als zodanig duidelijk in de wet vast te leggen. ${ }^{5.5}$ In zijn MvA meende de minister dat dat niet nodig was, omdat door deze verplichting voldoende gewaarborgd was, dat de werknemers alle benodigde

$\rightarrow$

fraai dat deze lechnix van wetgeven, bestaande uit het verwijen naar de inhoud wan voorgande artikelen in plaats wan die inhoud nog een keer herhalen, moet leiden tot een dergelij* ke juridische (?) kunstgreep.

53 MvT t. . P. p. 25.

54 Zie ook Arborand. Advies inzake de wijze van inwerkingtreding van art. 6 wan de Arbowet, Zoetermeer, 21 april 1983.

55 Voorlopig Verslag, t.a.p. p. 42. 
informatie zouden ontvangen. ${ }^{5}$ Later drukte hij zich minder terughoudend uit door te verklaren dat de verplichting van de werkgever om informatie te geven "juridisch het recht op informatie bevat". 5 "

In de ambtelijke nota die de adviesaanvraag aan de VAR over de invoering van art. 6 vergezelde, wordt uitdrukkelijk een stapsgewijze aanpak aanbevolen. Uitgangspunt zou in elk geval moeten zijn dat de werknemers welke in hun werk de grootste risico's voor hun veiligheid en gezondheid lopen, het eerst voor voorlichting en/of onderricht in aammerking komen. ${ }^{58}$ Vervolgens geeft de nota een soort actieprogramma dat tenminste de daar genoemde punten zou moeten bevatten. Overtreding van art. 6 vormt een economisch delict (art. 57). Daarnaast kan de Arbeidsinspectie terzake van de uitvoering van art. 6 aan aanwijzing to naleving geven (art. 35).

Uit het ITS-onderzoek is inmiddels gebleken dat het aantal ondernemingen dat systematisch aandacht besteed aan voorlichting en onderricht voor de zittende werknemers nog betrekkelijk gering is ${ }^{59}$ Meestal gebeurt het ad-hoc en zonder continuiteit. In ongeveer de helft van de onderzochte ondernemingen vinden activiteiten op het gebied van de voorlichting en het onderricht plaats. Zij variëren van voorlichtingsbijeenkomsten voor alle werknemers tot het ophangen van veiligheidsposters.

Wel stellen steeds meer ondernemingen de arbeidsomstandigheden uitvoeriger en systematischer aan de orde bij de introductie van nieuwe werknemers. Dit geldt minder voor ondernemingen met veel tijdelijke werknemers.

\subsubsection{Melding en registratie van ongevallen en beroepsziekten}

In het per 1 januari 1988 in werking getreden art. 9 is de verplichting voor de werkgever opgenomen om, indien een werknemer in verband met het verrichten van arbeid een ongeval overkomt dat ernstig lichamelijk letsel of de dood tot gevolg heeft, dit zo spoedig mogelijk mede te delen aan het districtshoofd van de Arbeidsinspectie. In het oorspronkelijke ontwerp stond 'bij de arbeid'. Bij derde Nota van wijzigingen is dit veranderd in 'in verband met arbeid', zodat ook de in dat lid bedoelde ongevallen die zich hebben voorgedaan buiten de arbeidsplaatsen - bijvoorbeeld in de kantine - onder de meldingsplicht vallen. ${ }^{6 i}$ Uitdrukkelijk worden ongevallen die de werknemer overkomen tijdens het woon-werkverkeer uitgesloten. Het is niet de bedoeling om, naast de bestaande meldingsprocedure aan de organen die belast zịn met de uitvoering van de sociale verzekeringswetgeving, een tweede schriftelijke melding in te

$56 \mathrm{MVT}, \mathrm{ta}, \mathrm{p}, \mathrm{p}, 60$

57 Nota n.a.v. het eindverstag, va.p. p. 33

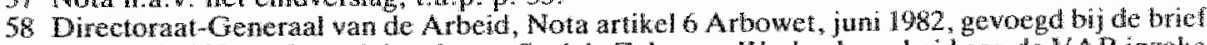
van 1 juli 1982 van het ministerie van Sockale Zaken en Werkgelegenheid ande $Y$ AR inzake

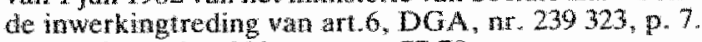

59 TTS-onderzock, 1988, i. a.p. p. 77-78.

60 Derde nota wa wifrigingen, $\mathrm{k}, 1979-1980,4.497, \mathrm{nr} .13, \mathrm{p} .8$. 
voeren. Een telefonische melding, later eventueel schriftelijk bevestigd, volstaat. ${ }^{61}$

De werkgever moet volgens het tweede lid ook gebeurtenissen melden, waarbij grote materiële schade is veroorzaakt en waarbij tevens gevaar voor de veiligheid of de gezondheid van werknemers heeft bestaan. Hoewel de minister meende dat het in de praktijk vrijwel onmogelijk is kwantitatieve normen te geven - immers, schade die voor een groot concern als gering wordt beschouwd, kan voor een kleinere onderneming groot zijn - meende hij toch dat naar een objectief criterium moest worden gezocht. ${ }^{62}$

Een meldingsplicht aan het districtshoofd bestaat volgens het vierde lid ook voor (vermoede) beroepsziekten en de gevallen waarin de gezondheid van een werknemer door de arbeid gevaar loopt.

Op grond van het derde lid moet de werkgever een register bijhouden, waarin de bovenbedoelde ongevallen en gebeurtenissen met grote materiële schade en de overige ongevallen welke enig lichamelijk letsel ten gevolge hebben gehad, worden vermeld. De oorspronkelijke registratieplicht van bijna-ongevallen is door de dereguleringsoperatie uit art. 9 geschrapt.

Volgens het vijfde lid kan de minister met betrekking tot het bepaalde in art. 9 nadere regels stellen. Dat is in 1987 gebeurd ${ }^{63}$ In dit besluit (dat overigens ook geldt ten aanzien van art. 10 over het jaarverslag) worden enkele belangrijke begrippen nader omschreven. Zo dient onder ongeval te worden verstaan: een aan een werknemer in verband met het verrichten van arbeid overkomen plotselinge gebeurtenis, die schade aan de gezondheid of de dood tot vrijwel onmiddellijk gevolg heeft gehad en ertoe heeft geleid, dat de werknemer tijdens de werktijd de arbeid heeft gestaakt en niet meer heeft hervat, dan wel met de arbeid geen aanvang heeft gemaakt. Onder ernstig lichamelijk letsel moet worden verstaan: schade aan de gezondheid die binnen 24 uur na het tijdstip van de gebeurtenis leidt tot opname in een ziekenhuis ter observatie of behandeling, dan wel naar redelijk oordeel blijvend zal zijn. Onder enig lichamelijk letsel dient verstaan te worden de schade aan de gezondheid die noch binnen 24 uur na de gebeurtenis leidt tot ziekenhuisopname noch als blijvend kan worden aangemerkt. Onder grote materiële schade tenslotte wordt verstaan: schade aan gebouwen, materieel, grondstoffen of produkten die een recht-

$61 \mathrm{MvT}$, t.a.p. p. 26. Tot 1967 bestond al een dergelijke verplichting ex art. 25 Veiligheidswet 1934. Deze procedure was echter veel onslachtiger. Volgens genoemd artikel moesten de uitslagen van ongevalsonderzoeken die op grond van de Ongevallenwet 1921. of de Land-en Tuinbouwongevallenwet 1922 werden ingesteld "ten spoedigste" gemeld worden aan het districtshoofd van de Arbeidsinspectie door de toenmalige Rijksverzekeringsbank (thans de Sociale Verzekeringsbank). Door de vervanging van de Ongevallenwet door de WAO (zie hooldstuk II par. 7.2.) in dat jaar verviel het onderscheid tussen arbeidsverzuim wegens een bedrijlsongeval of wegens ziekte. Sindsdien moet de werkgewer op grond wan de op art. 58 Ziektewet gebaseerde bescluikling Melding ongevallen en beroepsziekten ( $S$. 124) aangifte doen bij de bedrijtsvereniging. Deze dient de melding door te zenden aan het DirectoraatGeneraal van de Arbeid te Voorburg. Vervolgens worden de meldingen naar het betreffende districtshoofd gezonden. In de praktijk functioneert dit systeem niet (vgl. ook hooldstuk II, par. 7.3.).

62 MvA, t.a.p. p. 61.

63 Besluit van 22 september 1987, Stcrt. 1987, 197. 
streeks gevolg is van een ongewenste gebeurtenis, ten bedrage van tenminste f 100.000 .

Van belang is het tenslotte dat overtreding door de werkgever van het bepaalde in art. 9 een economisch delict vormt en derhalve direct strafbaar is gesteld. Het districtshoofd kan terzake geen aanwijzingen geven.

Al eerder (in paragraaf 7.3. van het vorige hoofdstuk) heb ik gewezen op de gebrekkige registratie van bedrijfsongevallen en beroepsziekten. Er is sprake van een grote onder-rapportage, vermoedelijk in de orde van grootte van $66 \%{ }^{64}$ Toch is betrouwbare informatie absoluut nodig voor een op preventie gericht beleid. Het is de vraag of het invoeren van de nieuwe meldings- en registratieplicht een verbetering betekent. Dit geldt vooral voor de melding van beroepsziekten. In de eerste plaats rust de verplichting op de werkgever. Als er geen bedrijfsgezondheidszorg in de onderneming is (nog altijd zo"n $50 \%$ ), hoe moet hij dan als niet-medicus vaststellen of er sprake is van een beroepsziekte? (De bijlage bij het ministeriële besluit geeft aan welke ziekten als vermoede beroepsziekten dienen te worden gekwalificeerd). In de tweede plaats is er het gebrek aan kennis over de meldingsplicht van beroepsziekten. Uit onderzoek onder bijna 300 werkgevers in de metaalproduktenindustrie bleek $41 \%$ niet op de hoogte te zijn van een meldingsplicht aan de bedrijfsvereniging op basis van de Ziektewet. ${ }^{65}$ In de derde plaats zal de controle op het niet nakomen van de meldingsplicht uiterst lastig te operationaliseren zijn. Tot slot ontbreekt ook in het nieuwe systeem de financiële prikkel. ${ }^{66}$ Een betere voorlichting aan de ondernemingen over het grote belang van een betrouwbare registratie, hulp bij de wijze van melden en registreren (eenvoudig in te vullen formulieren) èn een (verplichte) rol hierbij van de betreffende werknemers lijken voor de hand liggende manieren om art. 9 in de praktijk zoveel mogelijk effectief te doen zijn.

\subsubsection{Bescherming van derden}

Ingevolge het per 1 januari 1983 in werking getreden art. 11 heeft de werkgever ook verplichtingen met betrekking tot de veiligheid en gezondheid van andere personen dan de eigen werknemers. Ten aanzien van deze derden moet de werkgever doeltreffende maatregelen nemen ter voorkoming van gevaar voor hun gezondheid en veiligheid, indien bij of rechtstreeks in verband met de arbeid die de werkgever door zijn werknemers laat verrichten, dat gevaar kan ontstaan.

Het artikel munt niet uit door helderheid. Uit de parlementaire geschiedenis

$64 \mathrm{Vgl}$. L. van Vliet, Preventie staat of valt met betrouwbare informatie, Maandblad voor arbeidsomstandigheden, 1987, p. $166-177$.

65 Elly Brouwer, Han willems, Hoe staan werkgevers tegenover een verplichte melding van beroepsziekten?, Maandblad voor arbeidsomstandigheden, 1987, p. 100-103.

66 Zie ook E. Brouwer, Melding en registratie van beroepsziekten, Verslag Workshop beroepsziekten, Interfacultaire werkgroep Arbeid en gezondheid, Coronel Laboratorium, 1987, p. $11-18$. 
valt op te maken dat bij derden gedacht wordt zowel aan degenen die in de onderneming verblijven, zoals bezoekers, en werknemers van andere werkgevers die in de onderneming werkzaam zijn tot het verrichten van enkele diensten, als aan onmiddellijk omwonenden. Ten aanzien van de eerste groep zullen veelal dezelfde maatregelen getroffen dienen te worden als ten aanzien van de eigen werknemers. Ten aanzien van de tweede groep ligt dit moeilijker, omdat vaak al speciale wetten met gedetailleerde voorschriften van toepassing zijn (bijvoorbeeld in het kader van Hinderwet, bouwwerordening) ${ }^{67}$

(Direct ingeleende werknemers worden krachtens wetsduiding, art. 1 lid 2, beschouwd als eigen werknemers in de zin van de Arbowet).

Naar aanleiding van de beoogde inwerkingtreding van art. 11 in de eerste fase hebben de werkgeversvertegenwoordigers in de VAR het standpunt ingenomen dat art. 11 eventueel van kracht kon worden, als meer duidelijkheid zou ontstaan over de praktische betekenis van het artikel dan uit de parlementaire geschiedenis kon worden opgemaakt. Als antwoord op deze wens heeft het Directoraat-Generaal van de Arbeid in samenwerking met het Ministerie van Volksgezondheid en Milieuhygiëne een nota opgesteld, met de inhoud waarvan de VAR kon instemmen ${ }^{68}$ Volgens de nota verplicht art. 11 niet om een absolute veiligheid te garanderen. In dit verband wordt verwezen naar de (juridische) literatuur, waarin onder gevaar in het algemeen wordt verstaan: die aanmerkelijke kans - reële mogelijkheid - die een normaal voorzichtig mens (in casu de werkgever) niet zou nemen. Op zich moge dit een verduidelijkende mededeling zijn, deze aan het civiele recht ontleende interpretatie geeft toch nog betrekkelijk weinig houvast bij een eventuele strafrechtelijke vervolging van de werkgever (overtreding van art. 11 vormt een economisch delict).

$\mathrm{Bij}$ de interpretatie van art. 11 wordt er volgens de nota van uit gegaan, dat de werkgever voldaan heeft aan zijn verplichtingen ten aanzien van zijn eigen werknemers. Tevens dat voldaan is aan art. 30 , dat handelt over de verplichte onderlinge samenwerking wanneer meer werkgevers in een onderneming laten arbeiden. (Bijvoorbeeld bij het uitbesteden van werk aan een onderaannemer; zie over dit artikel ook de volgende paragraaf). ${ }^{69}$ Voor wat betreft de gevaren in de onmiddellijke omgeving benadrukt de nota, dat het artikel niet bedoeld is voor gevaarssituaties waarvoor al andere wetten, zoals milieu-wetten, bestaan.

Het bovenstaande in aanmerking nemend lijkt het mij toe dat art. 11 eigenlijk alleen een rol zou kunnen spelen in die enkele gevallen waarin gevaar voor derden is veroorzaakt, zonder dat ten aanzien van omwonenden in strijd is gehandeld met de vigerende specifieke voorschriften, zoals die bijvoorbeeld

67 Vgl. MvT, ta.p. p. 28; MvA, t.a.p. p. 49; Nota n.a.v, het Eindverslag, t.a.p. p. 35.

68 Ministeric van Sociale Zaken en Werkgelegenheid, Directoraat-Generaal van de Arbeid, Nota: toelichting op art. 11 van de Arbowet, verzonden aan de VAR bij brief d.d. 7 juni 1982 , Voorburg, kenmerk 238528; Voorlopige Arbeidsraad, Reactie op de toelichtende nota op art. 11 , d.d. 26 oktober 1982 .

69 Art. 30 is per 1 januari 1988 in werking getreden. Tot die tijd leken dus ook de werknemers werkzaam in een bedrijt of inrichting ten behoeve van meer werkgevers (alleen) onder de bescherming van art. 11 te vallen. 
gebaseerd zijn op de Hinderwet, of ten aanzien van de eigen werknemers in strijd met de arbeidsomstandighedenwetgeving. Immers, al in 1963 heeft de HR (kippenhokarrest) uitgemaakt, dat 'aan het feit dat het treffen van een wettelijke voorziening noodzakelijk is geacht met het oog op de belangen van een bepaalde groep personen, niet de gevolgtrekking mag worden verbonden, dat de gegeven voorschriften uitsluitend dienen ter bescherming van die belangen'. En de HR vervolgt: 'dat het niet naleven van de krachtens art. 10 (van de Veiligheidswet 1934, AG) gegeven voorschriften ook anderen dan de in de onderneming werkende arbeiders in gevaar brengt en de verwezenlijking van het gevaar niet ernstiger of minder ernstig is naargelang van de persoon die daarvan het slachtoffer is'. ${ }^{70}$

\subsubsection{Overige bepalingen}

In de bovenstaande paragrafen is een aantal belangrijke verplichtingen van de werkgever besproken. Zij zijn te vinden in hoofdstuk II van de Arbowet onder de titel 'Algemene verplichtingen van de werkgever'. Verspreid door de wet zijn echter meer verplichtingen voor de werkgever geformuleerd. Veel ervan zullen - evenals dat in de wet zelf gebeurt - aan de orde komen in de volgende paragrafen, waarin andere actoren centraal staan. Vaak zijn het verplichtingen die niet exclusief voor de werkgever gereserveerd zijn, maar ook opgelegd worden aan de werknemers. Belangrijk op dit laatste punt is de verplichting in art. 13 voor de werkgever en de werknemers om samen te werken in het behartigen van de zorg voor de veiligheid, de gezondheid en het welzijn in de onderneming. Nu kan het belang van deze bepaling wel gerelativeerd worden. Immers, zo geformuleerd, is zij louter de expressie van een vooral normatief bepaald uitgangspunt, dat werkgever en werknemers in het algemeen zouden moeten samenwerken. De opdracht krijgt eerst praktische betekenis door de rechten, bevoegdheden, faciliteiten, overige verplichtingen en organisatorische voorzieningen die de tot samenwerking verplichte partners krijgen. Hiermee hangt ook samen dat het woord 'werknemers' in de tekst niet betekent, dat de werkgever moet overleggen en samenwerken met iedere werknemer afzonderlijk, maar met de werknemers als collectiviteit, met name met de or. Dat blijkt uit het volgende artikel, over de Arbocommissie (zie paragraaf 3.3.1.). Met name voor de kleinere ondernemingen zonder formeel overlegorgaan zou het artikel dus betekenis kunnen hebben, ware het niet dat juist in die ondernemingen geen sprake is van allerlei ondersteunende faciliteiten, die bijwoorbeeld toegekend zijn aan de or, juist door het ontbreken van deze laatste.

De verplichting is - overigens voor de hand liggend - niet strafrechtelijk gesanctioneerd. Weliswaar heeft de Arbeidsinspectie een aanwijzingsbevoegdheid ten aanzien van art. 13 (alleen echter als er om is gevraagd; art. 35 lid 7 jo.

70 HR $\mathbb{I}$ maart 1963, NJ 1964, 12. Zie hierower ook: H.J. van Zwam, Veranderingen in het: Arbeidsomstandighedenrecht, Deventer, 1983, p. 141-143. 
art. 40), maar in de VAR is er op aangedrongen dat de Arbeidsinspectie met de grootst mogelijke terughoudendheid van deze bevoegdheid gebruik zou moeten maken. De Arbeidsinspectie zou bovendien een oneigenlijk gebruik maken van haar aanwijzingsbevoegdheid, wanneer zij daardoor zou proberen ofwel om de naleving van de WOR af te dwingen, ofwel de naleving van nog niet in werking getreden artikelen van de Arbowet. De aanbeveling van de VAR om deze opvattingen in de interne dienstinstructies op te nemen is gevolgd. ${ }^{71}$

In het kader van de verplichtingen die zowel voor de werkgever als voor de werknemers gelden, dient hier ook de voor de praktijk uiterst belangrijke verplichting genoemd te worden tot naleving van de voorschriften of verboden, welke bij of krachtens de op art. 24 gebaseerde AMvB's zijn vastgesteld voor zover en op de wijze als bij ieder van deze maatregelen is bepaald (art. 26). Het niet voldoen aan deze verplichting levert een economisch delict op. Eenzelfde verplichting geldt in het algemeen ten aanzien van de eisen en aanwijzingen van de Arbeidsinspectie.

Andere verplichtingen voor de werkgever hebben tot doel dat bepaalde voorzieningen en organen (zoals bijvoorbeeld een bedrijfsgezondheidsdienst) aanwezig zijn en dat deze laatste ook behoorlijk kunnen functioneren.

In hoofdstuk VI 'Bijzondere bepalingen' zijn in de per 1 januari 1988 in werking getreden artt. 30 en 31 enkele specifieke verplichtingen voor de werkgever opgenomen. Volgens art. 30 lid 1 moeten, wanneer in een bedrijf of inrichting verschillende werkgevers arbeid doen verrichten, zij onderling op doelmatige wijze samenwerken teneinde de naleving van de arbeidsomstandighedenwetgeving te verzekeren. Het voorschrift doelt op situaties die in de praktijk vaak voorkomen. ${ }^{72}$ Vooral in de bouwsector zijn dikwijls verschillende ondernemers gelijktijdig of kort na elkaar met éen bepaald object bezig. Omdat de maatregelen die de ene werkgever neemt, van invloed kunnen zijn op de veiligheid en gezondheid van werknemers van een andere werkgever, wordt een verplichting tot coördinatie opgelegd. Volgens het tweede lid moeten de werkgevers er voor zorgen dat, alvorens werkzaambeden behorende tot een bij AMvB aangewezen categorie te beginnen, schriftelijk de coördinerende maatregelen zijn vastgelegd.

Art. 31 verplicht de werkgever om, indien hij werknemers taken opdraagt in het kader van de Arbowet, er voor te zorgen dat aan de betreffende werknemers de bevoegdheden en middelen worden ver]eend, die nodig zijn voor een goede taakuitoefening, slechts één werknemer belast wordt met dezelfde taak en dat de taak schriftelijk, nauwkeurig is vastgesteld met vermelding van de naam van de werknemer. Het artikel hangt samen met art. 4, waarin immers onder meer staat dat 'het beleid' de onderscheiden bevoegdheden en verantwoordelijkheden 'vastlegt', welke in verband met dat beleid op de bij de

71 Voorlopige Arbeidsratad, Advies inzake de eerste fase van invoering van de Arbeidsomstandighedenwet, Zoetermeer 1982 , nr. 2, p. 30.

72 MvT, t.a.p. p. 47; zie ook:. Arboraad, Advies inzake art. 30 van de Arbeidsomstandighedenwet, Zoetermeer 1987, nr. 23. 
werkgever werkzame personen rusten. ${ }^{73}$ Door dit voorschrift worden werknemers beschermd tegen het opdragen van taken en verantwoordelijkheden die ze eigenlijk niet goed kunnen dragen, omdat de bevoegdheden en de middelen onvoldoende zijn of omdat de taakstelling onduidelijk is. Die bescherming is temeer nodig, omdat art. $51 \mathrm{WvS}$ het mogelijk maakt dat werknemers, die taken uitvoeren, welke bij of krachtens de wet door de werkgever (rechtspersoon) moeten worden uitgevoerd, waardoor zij feitelijk leidinggevenden zijn, strafrechtelijk aansprakelijk worden naast, of in plaats van de werkgever. Het feit op zich dàt aan een werknemer die taken zijn opgedragen, houdt niet automatisch in dat hij ook de feitelijke leiding heeft gehad zoals bedoeld in art. 51 WvS, 'doch het kan wel een rol spelen bij de beantwoording van de vraag wie in het concrete geval de feitelijke leiding uitoefenden bij het verboden handelen of nalaten'. ${ }^{74}$ (Zie hierover voorts de volgende paragraaf).

In het voorafgaande zijn belangrijke verplichtingen voor de werkgever in de Arbowet aan de orde geweest. Maar, naast zijn in de inleiding gememoreerde algemene bevoegdheid om uiteindelijk het beleid vast te stellen, kent de Arbowet hem een aantal specifieke rechten en bevoegdheden toe. De meeste ervan zijn ook toegekend aan de werknemers(vertegenwoordiging). Een aantal is alleen bedoeld voor de werkgever. De belangrijkste van de eerste groep zijn het recht op kennisneming (bijvoorbeeld van een rapport van de Arbeidsinspectie, art. 32 lid 5), het recht om gehoord te worden (bijvoorbeeld alvorens het districtshoofd een aanwijzing tot naleving geeft (art. 35 lid 1), het recht om een verzoek tot wetstoepassing te doen aan het districtshoofd (art. 40 ), en het recht om in beroep te gaan van een beslissing wan het districtshoofd (art. 42).

Voorbeelden van de tweede groep zijn het recht om aan het districtshoofd ontheffing te vragen van de voorschriften van de hoofdstukken IV en V (respectievelijk handelend over samenwerking en overleg tussen werkgevers en werknemers en deskundige diensten en over zelfstandigen en derden), en het recht op enkele beroepsmogelijkheden (zoals het recht om aan de President van de rechtbank te verzoeken om de beschikking van het districtshoofd dat een eis geen schorsende werking heeft, buiten werking te stellen, art. 36 lid 8).

\subsubsection{Strafrechtelijke aansprakelijkheid}

De juridische positie van de werkgever wordt mede bepaald door de mogelijkheid van sanctionering bij overtreding van de aan hem gegeven voorschriften. Omdat deze voorschriften vaak gegeven zijn ten faveure van goede arbeidsomstandigheden, heeft ook de werknemer daar belang bij.

Volgens art. 57 van de Arbowet is overtreding van een groot aantal bepalingen van deze wet strafbaar en door toevoeging aan art. 1 onder $4^{\circ}$ WED tot econo-

73 Zie ook: Arboraad, Advies inzake art. 31 van de Arbeidsomstandighedenwet, Zoetermeer 1987 , nr. 24.

74 MvT, t.a.p. p. 48. 
misch delict verklaard. Volgens art. 2 lid 4 van deze wet zijn deze delicten overtredingen. Eén van de bepalingen die art. 57 noemt, is art. 26 Arbowet, waardoor ook de niet-naleving van de voorschriften en verboden die bij of krachtens de op de Arbowet gebaseerd AMvB's zijn vastgesteld, een economisch delict vormt. (Krachtens art. 47 Arbowet worden de daar opgesomde AMvB's - ouder dan de Arbowet en tot dan gebaseerd op de Veiligheidswet 1934 en een aantal verwante wetten - geacht te zijn vastgesteld krachtens de Arbowet) ${ }^{75}$

De argumentatie voor onderbrenging van het strafrechtelijk deel van de Arbowet in de WED is summier. In de adviesaanvraag aan de SER inzake de hoofdlijnen van de nieuwe Arbowet merkt de minister op dat in de praktijk is gebleken dat cle opgelegde straffen dikwijls op gespannen voet staan met de ernst van het begane delict. Teneinde een evenwichtige beoordeling en bestraffing van begane feiten mogelijk te maken is gekozen voor de WED. ${ }^{76} \mathrm{De}$ SER acht dit voornemen aanvaardbaar 'gezien het meer algemene streven om delicten die gepleegd kunnen worden in de sfeer van de onderneming - mede in het belang van een efficiënte rechtspleging - onder de Wet Economische Delicten te brengen' ${ }^{77}$ De raad oordeelde het bovendien zinvol om aansprakelijkheid en strafbaarstelling in de verschillende arbeidsomstandighedenwetten uniform te regelen. ${ }^{78}$ Van dit laatste is thans nog geen sprake. De MvT beperkte zich tot kiet herhalen van bovengenoemde standpunten. ${ }^{79}$ Ook tijdens de parlementaire behandeling is het uitgangspunt om de WED van toepassing te verklaren als zodanig nauwelijks aan de orde geweest. Wel was er discussie over een amenclement van het CDA dat, in navolging van het standpunt van het $\mathrm{CNV}$, beoogde om overtredingen van de Arbowet onder art. 1 onder $2^{\circ}$ van de WED te brengen, waardoor deze overtredingen als misdrijven zouden worden gekwalificeerd, en een hogere strafmaat mogelijk zou worden. ${ }^{80} \mathrm{Na}$ overleg met zijn ambtgenoot van justitie ontraadde de minister het amendement ten sterkste, omdat de delicten onder art. 1 onder $2^{\circ}$ in hoofd-

$75 \mathrm{Vgl}$. hierover J.G.M. Arnold. Arbeidsomstandighedenwet en strafbatrheid van overtreding van veiligheidsbesluiten, SMA, 1985, p. 594-597. Arnold meent dat de Arbowet legitimatie van strafbaarstelling van vór 1 januari 1983 reeds van kracht zijnde bepalingen van Veiligheidsbesluiten niet biedt. Hij beroept zich daarbij vooral op de kennelijke bedoeling van de wetgever. Ik ben het niet met hem eens. Zijn standpunt vindt $\mathrm{m}$.i. geen enkele steun in de wetsgeschiedenis. Vgl. mijn reactic in SMA, $1986, p .2811-284$.

76 Brief van de minister wan Sociale Zaken en Werkgelegenheid d.d. 19 juni 1975 aan de SER. Bijlage I bij het SER-advies inzake de vernieuwing van de wetgeving betreffende de gezondheid en veiligheid bij de arbeid, 1976 , nr. 1.8, p. 8.

77 SER-advies, 1976 , nr. 18, t.a.p. p. 21. Een aantal SER-leden was niet overtuigd van de noodzaak van introductie van de WED, omdat hierdoor mogelijk afbreuk zou kunnen worden gedaan aan de vertrouwensbasis die nodig is om de Arbowet door te voeren. Bovendien vonden zij dat de mogelijkheden van de Veiligheidswet 1934 op dit punt werden miskend.

78 Dit pleidooi werd al eerder gevoerd door J.J. van Dodeweerd, in: Daderschap en strafbarstelling in enkele sociale wetten, SMA, 1963 , p. $414-426$ en p. $584-591$ en in: Recente ontwikkeling der strafbatarstelling in enkele sociale wetten, SMA, 1973, p. 85-p. 89.

79 MvT, t.a.p. p. 63.

80 TK 1979-1980, 14.497, nr. 87 (anendement B. Bakker en Weyers). Voor de discussie: Handelingen TK 1979-1980, OCV van 19 maart 1980, p. 1457-1459 en Handelingen TK 1979-1980, p. $4665 \times 4666$. 
zaak delicten zijn waarbij rechtstreeks essentiële belangen van de staat zijn gemoeid, omdat opzet bij het plegen van misdrijven bewezen moet worden, wat in de praktijk zeer moeilijk is en omdat ook bij overtredingen onder de WED al fikse straffen en maatregelen mogelijk zijn. Het amendement werd daarop ingetrokken. ${ }^{81}$

De Veiligheidswet 1934 kende het systeem van de persoonlijke aansprakelijkheid. Aansprakelijk was in de meeste gevallen 'het hoofd of de bestuurder' van de onderneming. Deze regeling deed echter geen recht aan de gecompliceerde structuur van met name grote ondernemingen. De Arbowet spreekt dan ook van werkgever. Als de werkgever een rechtspersoon is - en in veel gevallen zal dat zo zijn - dan kan volgens art. $51 \mathrm{WvS}$ vervolging worden ingesteld en de straf worden uitgesproken tegen: 1 . de rechtspersoon dan wel tegen: 2 . hen die tot het feit opdracht hebben gegeven, alsmede tegen hen die de feitelijke leiding hebben gegeven aan de verboden gedraging, dan wel tegen 1 en 2 beiden. Wanneer nu uit de organisatie een overtreding voortkomt, zonder dat eigenlijk direct een natuurlijk persoon als dader valt aan te wijzen, dan ligt het voor de hand de rechtspersoon aansprakelijk te stellen en te vervolgen. Volgens vaste jurisprudentie geldt ditzelfde voor de situatie dat wèl een feitelijke dader kan worden aangewezen, maar dat deze functioneel, dat wil zeggen binnen de grenzen van zijn bevoegdheid, handelde. Bij disfunctioneel handelen, dat wil zeggen een handeling buiten de toegekende bevoegdheden om, zal in het algemeen de feitelijke dader zelf vervolgd worden..$^{82}$

Volgens de Veiligheidswet (art. 29 lid 1) kon behalve het hoofd of de bestuurder ook het toezichthoudend personeel aansprakelijk worden gesteld, namelijk indien en voorzover het door het hoofd of de bestuurder met de zorg voor de naleving van de bepalingen werd belast. Ten aanzien van deze opdracht was in de Veiligheidswet geen enkel voorschrift te vinden. Dat bracht in de praktijk nogal eens problemen met zich mee met betrekking tot het antwoord op de vraag of, en zo ja in hoeverre een toezichthoudende functionaris aansprakelijk kan worden gesteld voor een bepaalde overtreding. ${ }^{63}$ Overigens heft deze delegatie de aansprakelijkheid van het hoofd of de bestuurder niet op. ${ }^{84}$ In de Arbowet is mede daarom in art. 31 een regeling opgenomen over de voorwaarden waaronder een werkgever moet delegeren (zie hierover de vorige paragraaf). Maar ook wanneer aan die voorwaarden is voldaan, terwijl er bovendien voldoende toezicht is gehouden door of namens de werkgever, en de betreffende werknemer blijft toch in gebreke, betekent dat nog niet automatisch dat de werkgever vrij uit zal gaan. ${ }^{85}$

Art. 29 lid 2 van de Veiligheidswet gaf aan het hoofd of de bestuurder en het toezichthoudend personeel de mogelijkheid zich te disculperen, "wanneer zij

81. Handelingen t.a.p. p. 4683 en 4689.

82 HR 31 januari 1950 , NJ 1950,286 ; HR 23 februari 1954 , NJ 1954,378 (m.n. B.V.A.R.) en SEW 1954, p. $85-91$ (m.n. A.M.).

$83 \mathrm{Vgl}$ bijw. HR 29 april 1969 , NJ 1970, 46

84 A. onder de Veiligheidswet 1895: Ktg. Zuidbroek, 23 september 1926, NJ 1926, p. 1358.

85 Zie hiervoor ook: Nota n.a.v. het eindverslag, t.a.p. p. 43. 
aantonen dat door hen de nodige bevelen zijn gegeven, de nodige maatregelen zijn genomen, de nodige middelen zijn verschaft en het redelijkerwijze te vorderen toezicht is gehouden, om de naleving te verzekeren van de bepalingen, voor welker naleving zij verplicht waren te zorgen'. Zij werden in dat geval 'geacht aan hun verplichtingen te hebben voldaan'. Het ging hier dus om de voorwaarden waaronder de leiding geacht kon worden aan zijn zorgplicht te hebben voldaan. "Ten genoege van de rechter, die over de feiten oordeelt', moesten het hoofd of de bestuurder of het toezichthoudend personeel aantonen dat zij de maatregelen, die redelijkerwijze wan hen konden worden verwacht, hadden genomen. ${ }^{\$ 6}$ Het is vaste jurisprudentie dat het, om met succes een beroep te kunnen doen op disculpatie, niet voldoende was om maatregelen te nemen, middelen en informatie te verstrekken, maar dat ook gecontroleerd diende te worden of de genomen maatregelen effect hadden, de verstrekte middelen juist gebruikt werden etc. ${ }^{87}$

De disculpatiemogelijkheden van art. 29 lid 2 van de Veiligheidswet zijn in de Arbowet niet teruggekeerd. Volgens de MvT bestond daar ook geen behoefte. aan, omdat deze regeling immers besloten ligt in het beginsel dat bij gebleken afwezigheid van alle schuld (AVAS) geen strafbaarheid wordt aangenomen. ${ }^{88}$ Zo kan het oordeel van de Arbeidsinspectie een bevrijdende omstandigheid vormen. Kàn: het zal telkens van de omstandigheden afhangen of, en zo ja in hoeverre dat het geval is. Zo honoreerde de Rechtbank Maastricht in 1969 het beroep op AVAS, omdat de Arbeidsinspectie geen duidelijke aanwijzingen had gegeven welke maatregelen verdachte moest treffen. In dat geval kon ook van de verdachte niet worden geëist dat hij, nu overheidsinstanties geen oplossing wisten, bij de aanvang van het werk adequate veiligheidsmaatregelen had getroffen. ${ }^{89}$ De Rechtbank Assen oordeelde in 1971 dat controlebezoeken van de Arbeidsinspectie weliswaar niet disculperend, maar wel aansprakelijkheidsverminderend en strafverminderend konden werken ${ }^{90}$ Het Hof Arnhem besliste in 1986, dat een door de Arbeidsinspectie uitgevoerde, algemeen oriënterende en niet specifiek op bijvoorbeeld bepaalde machines gerichte inspectie niet een soort veiligheidsgarantie betekent voor de geïnspecteerde onderneming. ${ }^{91}$ En in 1985 oordeelde de HR dat, wanneer een overheidsorgaan dat zelf niet verantwoordelijk is voor het strafvervolgingsbeleid, uit woorden of daden laat blijken dat het een bepaalde situatie zal gedogen, dat niet betekent dat het O.M. niet zou mogen vervolgen. Het O.M. heeft een eigen verantwoordelijkheid. ${ }^{92}$

Dat over het aantonen en honoreren van AVAS niet te licht moet worden gedacht toont de volgende zaak. Na een ongeval met een deegkneedmachine

86 HR 4 november 1929 , NJ 1929, p. 1662.

87 HR 28 januari 1918, NJ 1918, p. 261.

88 MvT, t.a.p. p. 48. Dit beginsel is door de HR geformuleerd in HR 44 februari 1916 , NI 1916, 681 .

89 Rb. Maastricht, 4 november 1969, NJ 1971, 166.

90 Rb. Assen, \& december 1971, NJ 1973, 446.

91 Hof Arnhem, 11 december 1986, nr. 212/86, gepubliceerd in Arbobulletin, 1987, p. 9.

92 HR 17 december 1985, NJ 1986, 591. 
deed een werkgever een beroep op AVAS, omdat de dagelijkse werkzaamheden werden verricht onder voldoende gekwalificeerde leiding, omdat bij indiensttreding instructies werden gegeven en omdat tijdens de acht jaar, dat verdachte hoofd van de onderneming was, nog nooit een bedrijfsongeval had plaatsgevonden. Bovendien was nog vóór het smeren van de deegkneedmachine medegedeeld, dat het smeerwerk alleen bij stilstand van de draaiende delen mocht worden verricht. De Rechtbank vond dit onvoldoende. De vakbekwaamheid van de leiding, de introductiegesprekken en het karakter van het ongeval aan de machine waren op zichzelf en in onderling verband niet bevrijdend voor de verdachte. De instructie vooraf was dat evenmin, gelet op de bewezen gang van zaken tijdens het smeren van de deegmachine. In 1983 oordeelde de HR dat hiermee het beroep op AVAS voldoende gemotiveerd door de Rechtbank was verworpen..$^{93}$

Met name door van Dodeweerd werd het betreurd, dat de disculpatiegronden van de Veiligheidswet, 'deze waardevolle en beproefde constructie' in de Arbowet geen plaats heeft kunnen vinden ${ }^{94}$ Immers, deze disculpatieregeling vervulde een nuttige functie met betrekking tot de taak van de werkgever op het gebied van de veiligheid door als het ware uit te groeien tot een gedragsregel en tevens een opdracht om op sluitende wijze de veiligheid te organiseren - aldus de argumenten. ${ }^{95}$ Dat moge zo zijn, anderzijds staan in de Arbowet zoveel, zowel algemeen als concreet geformuleerde opdrachten gericht aan de werkgever, dat ook om die reden handhaving van de disculpatiegronden onnodig lijkt.

In zijn MvA ging de minister nog eens in op het verschil in juridisch karakter tussen art. 29, lid 2 Veiligheidswet en art. 31 van de Arbowet. ${ }^{96}$ Art. 29, lid 2 Veiligheidswet stelde het hoofd of de bestuurder geen regels voor omvang, kwaliteit van de bevoegdheden en middelen die hij aan het toezichthoudend personeel moest verlenen. Het ging slechts om een disculpatiebepaling. Dat nam niet weg dat hiervan een stimulans kon uitgaan naar de werkgever en dat het disculpatieartikel in hoge mate ertoe heeft bijgedragen dat er voldoende duidelijkheid bestond over de wijze waarop de verantwoordelijkheid voor de veiligheid diende te worden verleend. Art. 31 Arbowet is echter geen disculpatieartikel, maar het regelt rechtstreeks de modaliteiten waaronder de werkgever de zorg voor naleving aan werknemers mag opdragen; met zoveel woorden wordt gezegd, dat de bevoegdheden en middelen toereikend moeten zijn. Dat in art. 31 Arbowet niet wordt gesproken over het redelijkerwijs te vorderen toezicht, welke bewoordingen wèl in art. 29 , lid 2 Veiligheidswet voorkomen,

93 HR 17 mei 1983, NJ 1983, 690 (m.n. G.E.M.).

94 J.J. van Dodeweerd, Het stelsel wan atansprakelijkheid wolgens de Arbeidsomstandigheden. wet, SMA, 1977 , p. 768 .

95 Vgl. hierover ook: P.J.P. Tak, De strafrechtelijke verantwoordelijkheid voor de naleving wan de technische bouwwoorschriften, Bouwrecht, 1980, p. 543-560, ni.n. p. 551-552. Hij is het uit 'arbeidsomstandighedenpolitieke' overwegingen met van Dodleweerd eens, maar meent bovendien dat het "besloten liggen" van art. 29 lid 2 Veiligheidswet in de AVAS-regeling dogma* tisch onjuist is.

96 MvT, t.a.p. p. 73 en 74. 
wloeit voort uit het geheel andere karakter van het nieuwe artikel. Voor de duidelijkheid over de wijze waarop de verantwoordelijkheid voor de veiligheid dient te worden verleend, is dat element echter niet relevant; als een hoofd of bestuurder in het oude stelsel en een werkgever in het nieuwe stelsel onvoldoende toezicht houdt op de wijze waarop de werknemers hun taak uitoefenen, gaat het hoofd of de bestuurder, respectievelijk de werkgever, niet vrijuit bij het zich voordoen van situaties die in strijd zijn met de wet.

De WED kent een groot en gevarieerd aantal straffen en maatregelen; door sommigen ervan kan ook de onderneming zèlf getroffen worden. De minister in zijn MvA: "Ik hoop intussen dat ... straks in de gevallen dat de Arbeidsinspectie meent tot vervolging van een overtreding van de voorgestelde bepaling te moeten overgaan, de rechter, op basis van de Wet economische delicten, straffen zal opleggen die evenredig zijn aan de ernst van de begane delicten. 97

Toch ziet het er niet naar uit, dat de rechter in de praktijk veel gebruik zal maken van het gevarieerde arsenaal straffen en matregelen dat de WED mogelijk maakt. Dit heeft een aantal oorzaken. In de eerste plaats zijn ook onder de Veiligheidswet de straffen, als het al tot een veroordeling kwam, meestal ver onder de toelaatbare maxima gebleven. In de tweede plaats geven de ervaringen met de wetten die al langer onder de werking van de WED zijn gebracht aan, dat de rechter zich zeer terughoudend betoont met het opleggen van andere dan de traditionele straffen. "Hoe zal ook de strafrechter de consequenties van een gehele of gedeeltelijke stillegging van een onderneming van enige omvang kunnen overzien, wetende bovendien dat hij geen invloed heeft op het opvangen van voor de samenleving nadelige gevolgen?' meer klemmen in een ongunstig economisch klimaat. In de derde plaats gaat het bij de Arbowet, anders dan bij het merendeel van de wetten waarop de WED van toepassing is verklaard, niet zozeer om de marktverhoudingen als wel om de stimulering van goede arbeidsverhoudingen binnen de onderneming. De relatie tussen de overtreding en het behaalde voordeel is daardoor vaak minder zichtbaar. Nog afgezien van de vraag of de WED dan wel het juiste handhavingsinstrument is, zal de rechter hierdoor waarschijnlijk nog voorzichtiger zijn met het opleggen van straffen en maatregelen die direct de onderneming raken. ${ }^{\text {w }}$

Tot slot dienen in deze paragraaf nog enkele problemen van overgangsrecht

97 MVA, t.a.p. p. 25

98 Th. W. van Veen, Door overmacht gedwongen in Recht als instrument van behoud en ver" andering (J.J.M. v/d Ven bundel), Deventer 1972, p. 341 .

99 Wanneer het al twijfelachtig is of de doelstelling van de wet toepassing vart een potenticel streng strafsysteem rechtvaardigt, dan dient extra aandacht te worden geschonken aan de beschermingstunctie die het strafrecht an de (potentiöle) verdachte en veroordeelde óok biedt. En juist deze functie heeft de WED in veel mindere mate dan het commune strafrecht. De warborgen voor de justiabele zijn zowel in het stadium van de opsporing als van de berechting uit doelmatigheidsoverwegingen beduidend mincler. Vgl. ook: Th.J. Buiting, Economische criminaliteit in Recht, macht en manipulatie (red. C. Kelk e.a.), Antwerpen 1976, p. 281. 
aan de orde te worden gesteld. ${ }^{100}$ Problemen die zijn ontstaan door de vervanging per 1 januari 1983 van de Veiligheidswet 1934 door de Arbowet 1980 . Hoe zit het nu met overtredingen begaan vóór 1 januari 1983, maar berecht erná? Deze vraag is vooral aan de orde geweest bij overtredingen van het Veiligheidsbesluit fabrieken of werkplaatsen (VBF) dat immers, zelf nauwelijks veranderd, tot 1 januari 1983 was vastgesteld krachtens de Veiligheidswet en daarna krachtens de Arbowet. Omdat de Arbowet geen overgangsregeling bevat, kwamen al spoedig de volgende, nauw met elkaar samenhangende vragen aan de orde: Kan er sprake zijn van art. 1, lid $2 \mathrm{WvS}$, namelijk dat bij verandering van wetgeving de voor de verdachte meest gunstige bepalingen moeten worden toegepast? Wie is ten aanzien van overtredingen van het VBF, begaan vóór 1 januari 1983, bevoegd, de economische politierechter of de kantonrechter? Hoe zit het met de positie van de eventuele verdachte: onder de Veiligheidswet het 'hoofd of de bestuurder' en onder de Arbowet de 'werkgever' waardoor art. $51 \mathrm{Sr}$. van toepassing is?

In september 1983 oordeelde de economische politierechter te Roermond zich bevoegd ten aanzien van een vór 1 januari 1983 gepleegde overtreding van het VBF. Zijn overzichtelijke redenering: art. 47 Arbowet bepaalt dat voor de toepassing van de Arbowet onder meer het VBF geacht wordt te zijn vastgesteld krachtens de Arbowet. Art. 47 en art. 57 Arbowet (onderbrenging WED) in onderling verband beschouwd, bepalen de bevoegdheid van de economische politierechter vanaf 1 januari 1983. Vervolgens concludeerde hij dat, nu in casu de werkgeefster een rechtspersoon is, het hoofd of de bestuurder onder de. Arbowet nooit in die kwaliteit kan worden bestraft. Omdat de verdachte wel is gedagvaard in zijn kwaliteit van hoofd of bestuurder, moet hij - gelet op art. 1 lid 2 WvS - van rechtsvervolging worden ontslagen. ${ }^{101}$

Eerder meende de kantonrechter Amsterdam echter, dat art. 1 lid 2 hier niet van toepassing was en hij dus bevoegd was, waarna hij het hoofd of de bestuurder veroordeelde. ${ }^{102}$

De kantonrechter in Zevenbergen meende weer dat hij onbevoegd was, omdat de betreffende verdachte onder de Veiligheidswet 1934 inderdaad wel als hoofd of bestuurder terecht zou moeten staan, maar onder de Arbowet niet, omdat hij geen feitelijke leiding had gegeven. ${ }^{10,3}$

In het eerste van een aantal op dezelfde dag gewezen arresten over deze problemen spreekt de HR zich uit over de toepasselijkheid van art. 1 lid 2 Sr en de bevoegdheid van de economische politierechter. ${ }^{104} \mathrm{Na}$ de constatering dat de Arbowet geen overgangsregeling kent, overweegt de HR dat een vergelijking van de regeling in de Veiligheidswet 1934 en de regeling in de Arbowet tot het

100 Hierover eveneens mijn in noot 75 genoemde bijdrage in SMA.

101 Rb. Roermond, 14 september 1983 , NJ 1984, 141.

102 Ktg. Amsterdam, 2 februari 1983, nr. 231.034/2, gepubliceerd in de Veiligheid, 1985, p. 417 in een artikel wan J.J. van Dodeweerd.

$103 \mathrm{Ktg}$. Zevenbergen, 24 oktober 1984, nr. 02.565835/82, gepubliceerd in de Veiligheid, 1985 ,

104 HR 9 april 1985 , NJ 1985, nrs 857.858 en 859 (allen m.n. Th. W.v.V.). 
oordeel leidt 'dat geen sprake is van een - in voor de verdachte gunstige zin veranderd inzicht van de wetgever omtrent de strafwaardigheid van feiten als het te dezen te laste gelegde feit'. (Het ging om een overtreding van de brandvoorschriften in het VBF). Omdat de onderhavige wetswijziging dus niet kan worden aangemerkt als een verandering in wetgeving in de zin van art. 1 lid 2 $\mathrm{Sr}$, zijn de artikelen van de Veiligheidswet van toepassing gebleven. Dit betekent dat er geen sprake is van een economisch delict en dat de economische politierechter dus onbevoegd is.

In het tweede arrest spreekt de HR zich uit over de eventuele gelijkstelling van het hoofd of de bestuurder van de onderneming, zoals bedoeld in de Veiligheildswet en het hoofd of de bestuurder die in de zin van art. 51 lid 2, onder 2 Sr. feitelijke leiding geeft aan de verboden gedragingen. De HR verwerpt deze gelijkstelling uitdrukkelijk, omdat 'het hoofd of de bestuurder van een onderneming die niet voldoet aan de in art. 7 lid 5 Veiligheidswet bedoelde verplichting, reeds door het enkel niet voldoen aan die verplichting een in art. 31 dier wet strafbaar gestelde overtreding begaat, terwijl het hoofd of de bestuurder van een rechtspersoon die als werkgever niet voldoet aan de in art. 26 lid 1 Arbowet vermelde verplichting, ingevolge art. 51 lid 2 onder $2 \mathrm{Sr}$ slechts strafbaar is indien hij 'feitelijke leiding heeft gegeven ' aan het handelen en/of nalaten dat de door de rechtspersoon als werkgever begane overtreding oplevert.' (Op basis van de redenering genoemd in het vorige arrest, had het Hof de economische politierechter terecht onbevoegd verklaard. Omdat deze beslissing een einduitspraak is krachtens art. $138 \mathrm{~Sv}$ had het Hof echter ten onrechte de zaak ter afdoening naar de kantonrechter verwezen).

In het derde arrest besliste de HR, nauw aansluitend bij het vorige dat het, door het hoofd of de bestuurder met de zorg voor de naleving van de artt. 6 lid 3 en 7 lid 5 van de Veiligheidswet belaste, toezichthoudende personeelslid dat de in die bepalingen bedoelde verplichtingen verzaakt om er voor te zorgen dat wordt voldaan aan het VBF, niet gelijk kan worden gesteld met degene die volgens art. 51 lid 2 onder $2 \mathrm{Sr}$ 'feitelijke leiding' geeft aan de verboden gedraging van een rechtspersoon, die als werkgever niet voldoet aan de verplichting in art. 26 lid 1 Arbowet tot naleving van het VBF.

Samenvattend luidt de conclusie van het bovenstaande dus, dat 1) overtreding van de normen in het VBF sinds 1 januari 1983 een economisch delict vormt, 2) dat art. 1 lid $2 \mathrm{Sr}$ niet van toepassing is, 3) dat overtredingen begaan vóór 1 januari 1983 géén economische delicten vormen en dus niet door de economische politierechter kunnen worden afgedaan en 4) dat het hoofd of de bestuurder van de onderneming in de zin van de Veiligheidswet 1934 niet dezelfde persoon behoeft te zijn als de opdracht- of leidinggevende van art. $51 \mathrm{Sr} .{ }^{105}$

105 Impliciet maakte de HR in deze arresten uit dat cle strafbaarstelling van Veiligheidsbesluiten een voldoende juridische basis heeft in de Arbowet. (Vgl noot 75). 


\subsection{De werkgever en de WOR}

De tweede algemene wet die ook voor de werkgever van groot belang is ten aanzien van de arbeidsomstandigheden in de onderneming is de WOR 1971. Zij zal in deze paragraaf slechts kort aan de orde komen, omdat het bij deze wet méér voor de hand ligt om ook de positie van de werkgever te bekijken aan de hand van de rechten en bevoegdheden die de or heeft op basis van deze wet. Dat zal in paragraaf 3 van dit hoofdstuk gebeuren. Daarin zal tevens aandacht worden geschonken aan enige aspecten van de relatie tussen de WOR en de Arbowet.

Hier wil ik aan de orde stellen de juridische verplichting voor de werkgever om een or te hebben en om met hem het overleg over de arbeidsomstandigheden te voeren. Daarnaast zal ik aan de hand van een aantal onderzoeken iets zeggen over de acceptatie en de ideeën van de werkgevers op dit punt.

Volgens art. 2 lid 1 WOR dient iedere ondernemer ervoor te zorgen dat er in zijn onderneming een or is, indien daarin in de regel hetzij tenminste 100 personen werkzaam zijn, hetzij tenminste 35 personen meer dan een derde van de normale arbeidstijd (tegenwoordig dus tussen de 12 en 13 uur per week) werkzaam zijn. De naleving van deze verplichting kan echter niet door de overheid, bijvoorbeeld door de minister van Sociale Zaken en Werkgelegenheid, worden afgedwongen. Dit kan wel door iedere kiesgerechtigde werknemer en door een vakorganisatie die het recht van kandidaatstelling in de betrokken onderneming heeft bij de kantonrechter op grond van art. 36 lid $1 .{ }^{106}$ In geval van bijzondere omstandigheden bij een bepaalde bedrijfstak of een deel daarvan kan de SER bij verordening, goedgekeurd door de minister van Sociale Zaken en Werkgelegenheid een vrijstelling geven van het verplicht hebben van een or. Het verzoek moet worden gedaan door de werkgeversorganisaties of de vakorganisatie(s), die naar het oordeel van de SER voldoende representatief zijn (art. 4 lid 1). Volgens art. 5 lid 1 kan de bedrijfscommissie desgevraagd door de werknemer bij bijzondere omstandigheden aan een afzonderlijke onderneming eveneens ontheffing geven van de verplichting om een or te hebben. (In zijn Advies inzake vereenvoudiging van de Wet op de ondernemingsraden van 24 oktober 1986 , nr. 14 heeft de SER overigens voorgesteld om de ontheffingsbevoegdheid eveneens bij de SER te concentreren. De verplichting voor de werkgever om het overleg en de samenwerking met de werknemers over de arbeidsomstandigheden in beginsel te realiseren via de or kan afgeleid worden uit art. 13. Arbowet (werkgevers en werknemers zijn verplicht om samen te werken 'in het behartigen van de zorg voor de veiligheid, de gezondheid en het welzijn' - zie over deze bepaling 2.2.8.) en art. 14 lid 1 Arbowet (ter bevordering van deze samenwerking kunnen Arbocommissies worden ingesteld 'tenzij het bedrijf of de inrichting behoort tot een onderne-

106 Het vierde lid van art. 36 kwalificeert een dergelijk geschil als een met betrekking tot een arbeidsovereenkomst: de kantonrechter is de bevoegde instantie en de vordering wordt ingesteld bij verzoekschrift. Op straffe van niet-ontwankelijkheid wan het verzoekschrift dient eerst de bemiddeling van de bedriffscommissie te worden ingeroepen (lid 5). 
ming waarwoor een ondernemingsraad is ingesteld'). Ten aanzien van de naleving van art. 13 Arbowet kan de Arbeidsinspectie, alleen nadat daarom is verzocht, een aanwijzing tot naleving geven (art. 35 lid 7 onder b jo. art. 40). Dit kan de Arbeidsinspectie eveneens - in dit geval echter ook ongevraagd ten aanzien van art. 14 lid 1 (art. 35 lid 6 onder j jo. art. 40). Een dergelijk verzoek kan gedaan worden door de or, de Arbocommissie, of bij het ontbreken van beide colleges door een meerderheid van de belanghebbende werknemers èn door de in de betreffende onderneming werkzame vakorganisatie. In theorie $\| j$ kt dit dus de mogelijkheid te openen, niet alleen dat een or via de Arbeidsinspectie effectief overleg over de arbeidsomstandigheden met de werkgever kan afdwingen, maar óók dat, bij het ontbreken van een or, een meerderheid van de belanghebbende werknemers (ik ga hier voorbij aan het probleem wie dat onder welke omstandigheden zijn) en de vakorganisatie via de Arbeidsinspectie de ondernemer kunnen dwingen uitvoering te geven aan art. 2 WOR. Ik schreef: in theorie. Immers, in paragraaf 2.2.8. is al uiteengezet dat de Arbeidsinspectie zich uiterst terughoudend zal opstellen ten aanzien wan de naleving van de artt. 13 en 14 lid 1 . Bovendien zou zij oneigenlijk gebruik maken van haar bevoegdheid om via de Arbowet de naleving van de WOR te bevorderen.

Dit geldt uiteraard ook voor het geval dat er, hoewel volgens art. 2 WOR verplicht, (nog) geen or aanwezig is. Bovendien kent de WOR voor dat geval een aparte procedure, die praktisch door dezelfde belanghebbenden kan worden gestart als in de Arbowet bij het verzoek om wetstoepassing: in beide wetten de vakorganisatie en daarnaast in de WOR iedere kiesgerechtigde werknemer en in de Arbowet een meerderheid van de belanghebbende werknemers. Hoewel de WOR dus een ruimere mogelijkheid biedt ('iedere kiesgerechtigde werknemer') kan elke werknemer natuurlijk ook trachten de vakorganisatie in te schakelen en zo een procedure op grond van de Arbowet te starten.

Over de houding van de werkgever ten opzichte van de or en de taak van de laatste bij het arbeidsomstandighedenbeleid in de onderneming is het moeilijk om dwingende, eenduidige uitspraken te doen. Dat komt natuurlijk in de eerste plaats omdat er grote onderlinge verschillen zijn tussen de werkgevers, die onder meer samenhangen met het karakter en de omvang van de onderneming. Maar in de tweede plaats zijn de uitkomsten van de verschillende onderzoeken over dit onderwerp niet allemaal gelijk. Dit laatste hangt onder meer samen met de verschillen in de gehanteerde onderzoeksmethode, met name op het punt van selectie van ondervraagden en representativiteit.

In 1983 deed het Gemeenschappelijk Begeleidingsinstituut Ondernemingsraden (GBIO) een onderzoek onder or-leden die een cursus volgden bij een van de aangesloten instellingen over arbeidsomstandigheden. ${ }^{107}$ Uit dit onderzoek

107 GBIO, OR-cursussen onderzocht, Arboscholing en -vorming in ontwikkeling, Den Haag. december 1983.

Het onderzoek bestond uit een inventarisatie van gegevens over de aard, de omvang en het 
bleek dat van alle geïnterviewde or-leden $62 \%$ vond dat het er in het algemeen goed voorstond voor wat betreft de arbeidsomstandigheden in hun respectievelijke onderneming. Circa eenderde van deze vond dat het er goed voorstond, omdat 'de onderneming' zich actief bezig hield met de arbeidsomstandigheden door voorlichting, controle e.d. Volgens een even grote groep stond het er goed voor, omdat 'de directie' er serieus aandacht aan besteedde, vooral aan klachten op dat gebied. In hoeverre de or bij een en ander betrokken was, werd uit het onderzoek niet duidelijk. Maar omdat de geinterviewden allen orleden waren met een taak op het gebied van de arbeidsomstandigheden of tenminste belangstelling ervoor, lijkt dat niet onwaarschijnlijk.

In 1985 publiceerde de Industriebond FNV de resultaten van een enquête onder haar kaderleden over de Arbowet en de or. ${ }^{108}$ Hieruit bleek dat in $53 \%$ van de ondernemingen de werkgever vóóraf overleg pleegde met de or over het te voeren arbeidsomstandighedenbeleid. Art 4 lid 4 Arbowet, waarin een dergelijke verplichting is geformuleerd, was en is echter nog niet in werking getreden. Uit het onderzoek kon niet worden opgemaakt of de or van andere juridische middelen gebruik had gemaakt om dit overleg te bevorderen of af te dwingen. Met name kan dan gedacht worden aan het in dit opzicht al ter sprake gekomen initiatiefrecht ex art. 23 WOR, al dan niet in combinatie met art. $31 \mathrm{~b}$ WOR (sociaal jaarverslag en toekomstverwachtingen). In ondernemingen waarin de werkgever overleg voerde met de or, gebeurde dat in $50 \%$ van de gevallen aan de hand van een schriftelijk jaarplan. (Art. 4 lid 3, waarin de verplichting tot een schriftelijk jaarplan is geregeld, was en is evenmin in werking getreden). Concrete regelingen met betrekking tot de arbeidsomstandigheden zijn echter in de jaren 1983 en 1984 in $63 \%$ van de ondernemingen getroffen zonder de vereiste instemming van de or (art. 27 WOR). Het is de vraag wat dit laatste gegeven betekent, vooral in het licht wan het andere gegeven, dat in ruim de helft van de gevallen wèl overleg is gevoerd tussen or en werkgever over het te voeren beleid. Bovendien wijst een recenter onderzoek in een andere richting. Dit betreft het interim-rapport over de praktische uitoefening van wettelijke bevoegdheden door de or, uitgevoerd in opdracht van

bereik wan de scholing en de vorming op basis van programma's wan die (ca. 650 ) cursussen welke in én jaar plaatswonden en een inventarisatie wan de ervaringen met de cursussen door middel van afzonderlijke vraaggesprekken met in total 166 or-leden. Voorts werd middels een schriftelijke enquête onder een landelijke steekproet uit alle or plichtige onderncmingen en instellingen de te verwachten vraag gepeild naar Arboscholing en -vorming en werden de plannen van de instituten geinventariseerd. Uit deze opzet blijkt dus dat het onderzoek zich niet primair richtte op de vragg hoe de werkgever reageerde op de Arbowet en het ruedezeggenschapsaspect daarbij. (Het GBHO coördineert de scholings- en vormingsactiviteiten voor ondermemingsraden en heeft daarioe een overeenkomst gesloten met een groot aantat instellingen dat cursussen voor ondernemingsraden organiseert. In deze cursussen wordt valk aardacht besteed aan de arbeidsomstandigheden en de Arbowet).

108 Industriebond FNV, Vakbondskaderleden beoordelen de Arbeidsonstandighederwet, Amsterdam, aprill 1985. Het onderzok bestond wit een schrifielijke enquête onder de ruimi 500 geformaliseerde bedrijfsledengroepen wan de bond. Kaderleden vit 250 ondernemingen vulden de enquête in. De reacties kwamen overwegend wit middelgrote en grotere ondernemingen, met globaal 150.000 werknemers. 
het ministerie van Sociale Zaken en Werkgelegenheid door het Instituut voor toegepaste sociale wetenschappen. ${ }^{109}$ Uit dit onderzoek valt op te maken, dat in ruim $80 \%$ door de werkgever om instemming is gevraagd aan de or als het ging om regelingen op het gebied van de arbeidsomstandigheden. Het is bovendien in de onderzochte periode het op één na meest woorkomende instemmingsonderwerp. (Het hoogste scoort de werktijd- of vakantieregeling in art. 27 lid 1 onder c). In bijna 95\% van de gevallen handelde de werkgever met betrekking tot het instemmingsrecht in het algemeen conform het standpunt van de or. In $31 \%$ kreeg de werkgever de instemming na wijziging van het voorgenomen besluit. Uit het onderzoek kan niet worden afgeleid of ten aanzien van het specifieke instemmingsonderwerp arbeidsomstandigheden andere percentages gelden. Er is echter geen reden om dat aan te nemen.

Een indruk over de relatie werkgever-or op het gebied van de arbeidsomstandigheden kan ook verkregen worden uit het verslag van de gesprekken die de Arbeidsinspectie heeft gevoerd in bijna alle middelgrote en grote ondernemingen (in het algemeen de ' 100 plus' ondernemingen) over de consequenties van de invoering van de Arbowet. ${ }^{110}$ Over het jaar 1983 wordt geconcludeerd, dat het contact tussen or en 'het bedrijfsleven' in het algemeen nog niet zo soepel verloopt en dat de or en de werkgever nog moeten wennen aan hun gezamenlijke taak en verantwoordelijkheid in het kader van de Arbowet. Benadrukt wordt het wezenlijke belang van betrokkenheid en positieve gezindheid van werkgeverskant bij het realiseren van Arbowet-activiteiten. Over 1984 en het eerste deel van 1985 wordt dit laatste nog eens in andere bewoordingen herhaald, zonder dat teruggekomen wordt op de andere bovengenoemde opmerkingen over het jaar 1983. Wellicht dat hieruit kan worden opgemaakt dat het gewenningsproces tot positieve resultaten heeft geleid.

Hoewel ik hierboven schreef dat het beeld uit de onderzoeken om een aantal redenen niet zonder meer eenduidig is, lijkt deze laatste voorzichtige conclusie ook wel bevestigd te worden door de andere onderzoeken. In deze richting tendeert ook het commentaar van het hoofd arbeidsverhoudingen van de Algemene werkgeversvereniging op het bovengenoemde onderzoek van de In-

109 J.C. Looise, J.L. Heijink, De or en zijn bevoegdheden, Instituut voor toegepaste sociale wetenschappen, Nijmegen 1986.

Het rapport is gebaseerd op de eerste fase van het onderzoek nl. een survey onder een representatieve steekproef van alle ondernemingsraden uit ondernemingen met meer dan 100 werknemers, in de periode december 1984 - december 1985.

Met name omdat de case-studies nog ontbreken (de tweede fase), dienen de uitkomsten wolgens de onderzoekers zelf met het nodige voorbehoud te worden bekeken. Ook op de eerste fase van het onderzoek als zodanig is echter al - vooral methodologisch - kritiek mogelijk. Zie hiervoor P. Lakeman, Functioneert de WOR echt wel zo goed?, Or-informatie, julli/augustus 1986, p. 22 . Het in 1987 verschenen vervolgonderzoek tast de resultaten van het interim-rapport op de hier genoemde punten echter niet aan. F.G.M. de Lange, J.C. Looise, Ondernemingsraden, bestuurders en beshuitvorming, Nijmegen 1987.

110 Zie hiervoor de voortgangsnotitie betreffendle de Arbowet, respectievelijk over 1983 en over de periode januari 1984 tot medio 1985 van het Directoraat-Generaal van de Arbeid, Voorburg, september 1984 en november 1985 . Hierna zijn deze voortgangsnotities gestopt. 
dustriebond FNV, " "Hij benadrukt sterk de verscheidenheid van ondernemingen, waardoor bij de een niet kan wat bij de ander wel kan; zowel uit een oogpunt van kosten als uit een oogpunt van toegepaste technologie. Bovendien is het volgens hem 'ontstellend moeilijk en moeizaam' om in ondernemingen veranderingen teweeg te brengen en niet te verzanden in juridisch gekissebis. "Voorwaarde op ondernemingsniveau is goed overleg tussen management en or over de echte problemen. "En gelukkig "zijn er hoopvolle signalen uit een aantal ondernemingen".

Het meest recente en waarschijnlijk meest uitgebreide onderzoek, het ITSonderzoek dat begin 1988 verscheen, sluit eveneens voor een groot gedeelte aan op de vroegere onderzoeken. ${ }^{112}$ Ook hier wordt geconstateerd dat er betrekkelijk grote verschillen zijn tussen de onderzochte ondernemingen. Hoewel de relatie tussen bedrijfsleiding en or volgens beide partijen in de meeste ondernemingen als goed is te kwalificeren, betekent dat niet dat ze ook allemaal tevreden zijn over de $k$ waliteit van hun wederzijdse inbreng. Over ongeveer $20 \%$ van de ondernemingsraden wordt door de directies naar voren gebracht dat deze weinig inbreng hebben. Van de andere kant wordt ten aanzien van de relatie directie-or soms gesteld dat deze te veel wordt gedomineerd door éénrichtingsverkeer vanuit de directie. Voor zover er hoofdlijnen te trekken zijn over deze relatie is dat eigenlijk de volgende: in een vrij groot aantal ondernemingen zijn de contacten tussen directie en or over de arbeidsomstandigheden zeer beperkt. Dat komt omdat het arbeidsomstandighedenbeleid veelal gedelegeerd is an respectievelijk beleids- of staffunctionarissen en de VGW-commissie. Vooral de or is in een aantal ondernemingen ver terug getreden.

De relatie tussen directie en or kan blijkens het onderzoek de invloed ondergaan van een groot aantal verschillende factoren, waarin geen algemene lijn te onderkennen valt. Met name kunnen in dit verband wisselingen in de samenstelling van de directie en de or genoemd worden.

Hoewel de Arbowet in de meeste ondernemingen geen extra belasting vormt voor de directie, wordt desondanks de tijdsdruk waaronder de directie staat en

111. Gepubliceerd in: Industriebond FNV, Vakbondsheden beoordelen de Arbeidsomstandighedenter, Amsterdam, april 1985 (zie ook noot 108).

112 T.J.M. Reubsaet, P.A.M. de Boer, P.C.J. Sweere, H.J.M. van den Tillacrt De Arbowet in uitvoering, en onderzoek naar ervaringen in de praktijk, ITS, Nijmegen 1988.

Dit onderzoek is verricht in opdracht van helt ministerie van Sociale Zaken en Werkgelegenheid (D. G.A.) en betreft vooral de wijze waarop door de arbeidsorganisaties is gereageerd op de (gedeeltelijke) invoering van de Arbowet. Zie ook: D.G.A. Onderzoeksvoorstel invoering Arbowet, Voorburg, 9 mavart 1984 (bijgestelde versie mei 1985); Instituut voor toegepaste sociologie, Voorstel voor een onderzoek naar de wijze waarop door arbeidsonganisaties is gereageerd op de (gedeeltelijke) inworing van de Arbowet per 1 januari 1985 , Nijmegen, oktober 1985 .

In het onderzoek is bet uitvoeringsproces in 30 onderneminger (cases) afzonderlijk beschre wen. Per onderneming werden betrokkenen geinterviewd. Deze cases zijn verdeeld over verschillende bedrijfssectoren (bouw 6; voedings-en genotmiddelen 10; metaal en metaalprodukten 10 ; chemie 4) en over verschillende grootteklassen. Het onderzoeks rapport bevat een overalli-analyse van de genoemde case-verslagen. 
de organisatorische belasting door de Arbowet soms als reden aangevoerd voor de trage reactie op voorstellen van or en VGW-commissie.

\subsection{De werkgever in het $B W$}

De positie van de werkgever wordt op het gebied van de arbeidsomstandigheden in zijn onderneming niet alleen genormeerd door publiekrechtelijke regels, maar ook door civielrechtelijke. De belangrijkste daarvan is te vinden in art. $1638 \mathrm{x} \mathrm{BW}$. Het verplicht de werkgever om de lokalen, de werktuigen en de gereedschappen waarin of waarmee hij laat werken, zó in te richten en te onderhouden en zodanige regelingen en aanwijzingen te geven dat werknemers, zoveel als redelijkerwijs in verband met de arbeid gevraagd kan worden, beschermd worden tegen gevaren. Is de werkgever in het nakomen van die verplichting tekort geschoten en lijdt de werknemer daardoor schade, dan is de werkgever gehouden die te vergoeden, tenzij hij kan aantonen dat er overmacht in het spel is of dat de schade in belangrijke mate mede te wijten is aan grove schuld van de werknemer. Bij overlijden wan de werknemer door het niet nakomen wan deze werkgeversverplichting ontstaat eenzelfde schadevergoedingsplicht jegens de nagelaten betrekkingen van de overleden werknemer. De regeling is van dwingend recht. Over de geschiedenis van dit artikel en de betekenis van het jaar 1967 in dit verband moge ik verwijzen naar het vorige hoofdstuk, de paragrafen 4.3. en 7.3. Hieronder zal ik aandacht besteden aan de diverse juridische vragen en antwoorden, die het artikel heeft opgeroepen. Daarbij zullen ook enkele andere relevante artikelen uit het BW aan de orde komen. De paragraaf wordt afgesloten met de resultaten van een (beperkt) onderzoek naar het gebruik in de praktijk van art. 1638x.

\subsubsection{De civielrechtelijke zorgplicht en de relatie met de publiekrechtelijke normen}

De werkgever heeft een civielrechtelijke zorgplicht. Bij het tekortschieten daarin wordt hij aansprakelijk. Hoe ver strekt die zorgplicht zich nu uit? Het artikel spreekt over de zorg die 'redelijkerwijs in verband met den aard van den arbeid gevorderd kan worden'. Hij is dus niet gehouden om door $100 \%$ zekere maatregelen de werknemers volledig en afdoende in alle denkbare werksituaties tegen gevaren te beschermen. ${ }^{113}$

Wel dient hij zich te gedragen als 'goede werkgever'. In die zin is art. $1638 \mathrm{x}$ een nadere uitwerking van art. $1638 \mathrm{z}$, dat op zijn beurt de algemene norm herhaalt dat overeenkomsten te goeder trouw ten uitwoer moeten worden gelegd en dat zij mede verbinden tot hetgeen de billijkheid vordert (artt. 1374 en 1375

113 In gelijke zin: W.C.L. van der Gtinten, Arbeidsovereenkomstenrecht, Alphen a/d Rijn 1987. (veertiende druk), p. 106; vgl. ook HR 27 juni 1975, NJ 1976, 81 . 
B.W.). Wat nu redelik en billik is, zal telkens afhangen van de omstandigheden in een concrete situatie, ter beoordeling van de rechter. ${ }^{15}$ Wat ten aanzien van de ene werkgever acceptabel is, behoeft dat niet te zijn ten aanzien van een andere werkgever. Zo zullen aan een werkgever die in zijn onderneming gebruik gaat maken c.q. gebruik makk van nieuwe, relatief onbekende chemische stoffen extra zware eisen gesteld dienen te worden met betrekking tot de bevelliging en de constructie van de installaties die gebruikt (gaan) worden en de opleiding en begeleiding wan de betrokken werknemers. ${ }^{16}$ Ten aanzien van de nalewing van de Arbeidswet 1919 meende de HR zelfs dat de zorgplicht voor de werkgever met zich meebrengt dat ook maatregelen die dermate veel hinder veroorzaken voor de werknemers dat daarvan een werkstaking is te duchten, niet onder alle omstandigheden zijn uitgesloten. ${ }^{17}$ in 1978 bevestigde de HR nog eens de hoofdregel 'dat de zorgverplichting van de werkgever telkens afhangt van de omstandigheden van het concrete geval', "18 Maar hij formuleerde daar een aantal subregels bij. "In het bijzonder kunnen daarbij een rol spelen de kenbaarheid voor de werkgever van de gevaren aan het gebruik van de machine verbonden, mede in het licht van het ervaringsfeit dat de dagelijkse omgang met die machine de gebruiker ervan licht ertoe zal brengen niet alle voorzichtigheid in acht te nemen die ter voorkoming van ongelukken geraden is, en voorts de mate waarin het treffen van die veligheidsmaatregelen reeds vór dat een ongeval zich had voorgedaan, voor de werkgever of de deskundigen waarover hij in zijn bedrijf beschikt, voor de hand lag.'

Kenbaarheid voor de werkgever van de gevaren die aan de machine zijn verbonden, speelt dus een rol. Dat impliceert ook, dat de zorgplicht met zich meebrengt dat de werkgever zich moet laten voorlichten, c.q. een onderzoek moet laten instellen. Dat deze onderzoeksplicht ver kan reiken, blijkt uit een arrest van de HR uit $1983{ }^{119}$ Hierin sanctioneerde de HR een vonnis van de Rechtbank Utrecht die oordeelde, dat het in casu een zo gevarscheppend apparaat en/of proces betrof, dat de zorgplicht ex art. 1638x lid 1 met zich bracht dat de werkgever, alvorens het toestel door zijn werknemers te laten gebruiken, zich had moeten laten voorlichten omtrent alle (!) gevaren die aan

114 Over $1638 \mathrm{z}$ (en 1639d, handelend over de goede werknemer) W.C.L. van der Grinten, De goede werkgever en de goede arbeider, Hedendaags arbeidsrecht (Levenbach-bundel), Alphen a/d Rijn 1966, p. 134-135. Hij concludeert tot schrapping van de bepalingen wegens overbodigheid; M.G. Rood, Over de goede werkgever en de goede werknemer, SMA, 1982, overbodigheid; M. G. Rood, Over de goede werkgever en de goede werkner zij de mogelijkheid bieden 'de sociale en culturele oniwikkelingen harmonisch te volgen'. (1.a.p. p. 507). Hij vindt bovendien niet dat art. $1638 \mathrm{z}$ de normen wan de art. 1374 en 1375 herhath.

In elk gevall blijkt het aantal malen dat bij de (kort-geding)rechter een beroep wordt gedaan op art. $1638 z$ aanzienlijk te zijn toegenomen. R.C. Gisolf, De goede werkgever, Arbeid en kort geding (Borgerhoff Mulder bundel), Deventer 1983, p. 33.

$115 \mathrm{Vgl}$. M.G. Rood, Over vage vormen in het sociaal recht, Gratia Comercii (van Oven-bundel), Zwolle 1981, p. 225-234.

$116 \mathrm{Rb}$ Almelo 5 november 1975, NJ 1977, 532.

$117 \mathrm{HR}$ I februari 1949, NJ $1949,552$.

118 HR 14 april 1978, NJ 1979, 245.

119 HR 29 april 1983, NJ 1984, 19. 
het gebruik van het toestel waren verbonden. Het betrof hier nota bene een stoomtoestel in de zin van de Stoomwet, dat derhalve door de Dienst van het Stoomwezen was gekeurd. De werkgever heeft dus niet aan zijn zorgplicht voldaan wanneer hij alleen de (wettelijk voorgeschreven) keuringen laat verrichten. Hij mag zich niet afwachtend opstellen tot iemand (i.c. een deskundige van het stoomwezen) hem waarschuwt, maar bij een dergelijk gevaarscheppend apparaat moet hij zich actief opstellen en zelf navraag doen naar alle risico's. De Rechtbank overwoog bovendien dat de werkgever niet van de Dienst van het Stoomwezen mocht verwachten dat deze zich zou inlaten met alle chemische aspecten van het proces en de werkomstandigheden in de werkplaats. (In cassatie ging het om de aansprakelijkheid ex art. 1638x. Oorspronkelijk was de vordering echter gebaseerd op de artt. 1401 en $1405 \mathrm{BW}$. Vandaar dat de procedure bij de Rechtbank was gestart. Later werd de vordering gebaseerd op art. 1638x. Nadat deze wijziging bestreden was, besliste het Hof op dit incident en keurde de wijziging van de eis goed).

De werkgever is in beginsel eveneens aansprakelijk voor de gevolgen van een ongeval dat aan de werknemer is overkomen bij het gebruiken - met al dan niet stilzwijgende toestemming - van ondeugdelijk gebleken materiaal van een derde. Dit zou anders zijn, indien de werkgever zijn werknemer duidelijk aanwijzingen geeft om alleen het eigen materiaal van de werkgever te gebruiken. ${ }^{120}$

Hoewel de zorgplicht van de werkgever dus zeer omvattend kan zijn, is zij nog steeds niet absoluut. Eveneens in 1983 overwoog de HR dat art. $1638 \mathrm{x}$ niet beoogt om een absolute waarborg te scheppen voor de bescherming van de werknemer, maar alleen inzoverre dat redelijkerwijze in verband met de aard van de arbeid kan worden gevergd. Tegen de achtergrond hiervan schiet de werkgever niet reeds tekort in zijn verplichting door het enkele feit, dat hij zijn werknemers belast met de bediening van een machine die, indien verkeerd bediend, gevaar oplevert. Voor dit tekortschieten in zorg is méér vereist, bijvoorbeeld dat de werkgever nalatig is in het geven en handhaven van - met het oog op het van verkeerde bediening te duchten gevaar - genoegzame instructies, of dat de werkgever behoort te beseffen dat de door hem met de bediening belaste werknemer de geschiktheid daartoe mist. ${ }^{121}$ Voor een juiste vervulling van zijn zorgverplichting kan dus ook van belang zijn of de werkgever zijn werknemers adequaat heeft geïnstrueerd en toezicht heeft gehouden en bovendien of hij wel de juiste man op de juiste plaats heeft neergezet. Op het belang van behoorlijke instructies had de rechtspraak al eerder gewezen. Behoorlijk betekent vooral: duidelijk, niet mis te verstaan. ${ }^{122}$ Instructies in een taal die een werknemer niet verstaat, zijn uiteraard niet duidelijk. Gebaren-

$1.20 \mathrm{Ktg}$. Utrecht 14 mei 1987, Praktijkgids, 1987, nr. 2710

121 HR 10 juni 1983, NJ 1984, 20 m.n. P.A.S. (ook handelend over NJ 1984, 19). Over dit arrest: H.J. van Zwam, De gehaaste textielarbeider, SMA, 1984 , p. 232-246.

$1.22 \mathrm{Rb}$ Zutphen 23 oktober 1980 , Praktijkgids, 1982, nr. 1821;

HR 15 oktober 1982, NJ 1984, 21 m.nt. F.H.J.M.

Rb 's Hertogenbosch 26 april 1985, Praktijkgids, 1988, nr. 2805. 
taal is in beginsel wel toegestaan, maar wèl moet dan vaststaan dat de werknemer de instructies heeft begrepen. ${ }^{123}$

In 1987 verwierp de HR echter de opvatting dat de werkgever, die zelf goede instructies heeft gegeven, jegens de werknemer aansprakelijk kan zijn op de enkele grond dat hem (achteraf onjuist gebleken) aanwijzingen zijn gegeven door een collega-werknemer van wie de werknemer redelijkerwijze en naar verkeersopvattingen mag aannemen, dat deze de gegeven aanwijzingen mag verstrekken, althans van wiens aanwijzingen de werknemer mag aannemen dat zij vanwege de bedrijfsleiding, althans van hogerhand, zijn verstrekt. Hetgeen de werknemer op dit punt heeft mogen aannemen, kan weliswaar voor de aansprakelijkheid van belang zijn, maar dan slechts als omstandigheid die moet worden betrokken bij de beantwoording van de vraag in hoeverre de gegeven instructies van de werkgever ruimte laten voor misverstand. ${ }^{124}$ Schuld van een leidinggevende kan dus onder omstandigheden de aansprakelijkheid van de werkgever wegnemen.

Zoals ook uit bovengenoemde rechtspraak blijkt, impliciet of expliciet, kunnen ook de publiekrechtelijke normen uit (vroeger) de Veiligheidswet en (nu) de Arbowet c.a. nadere inhoud geven aan het begrip redelijke zorg in het civiel recht. Dit impliceert echter niet automatisch, dat een strafrechtelijke veroordeling wegens overtreding van de veiligheidsvoorschriften schuld in civilibus betekent. ${ }^{125}$ Omgekeerd sluit ontslag van rechtsvervolging bij een overtreding van de veiligheidsvoorschriften niet uit dat er sprake is van civielrechtelijke schuld. ${ }^{126}$ (Een strafrechtelijke veroordeling kan ex art. $1955 \mathrm{BW}$ wèl dienen, behoudens tegenbewijs, als bewijs van de feiten in het civiele proces). In 1983 bevestigde de HR dat met een strafvonnis in elk geval het niet naleven van de veiligheidsvoorschriften vaststaat ex art. $1955 \mathrm{BW}$. Dit tekortschieten rechtvaardigt echter nog niet de conclusie dat dit ook aan de schuld van de bestuurder van de onderneming is te wijten. ${ }^{127}$

De HR gebruikte in dit arrest voorts een belangwekkende overweging. Ervan uitgaande dat op de werkgever in dit geval de last rustte om te stellen en te bewijzen dat hem geen schuld kan worden verweten, wordt de omvang van die plicht bepaald, ook in burgerlijke zaken 'door een sinds de Arbeidswet 191.1 in het arbeidsomstandighedenrecht gebruikelijke en voor de veiligheidswetgeving in art. 29 lid 2 Veiligheidswet 1934 neergelegde formule'. Dit artikel 29 lid 2 geeft aan het hoofd of de bestuurder of aan het toezichthoudende personeel de mogelijkheid om zich te disculperen, indien zij kunnen aantonen dat door hen "de nodige bevelen zijn gegeven, de nodige maatregelen zijn genomen, de

123 HR 14 april 1978, NJ 1979, 245

124 HR 6 maart 1987, NJ 1987, 533 .

125 HR I maart 1963, NJ 1964, 12. Over dit arrest: J.H. de Jong, Nieuwe ontwikkelingen in de Arbeidsomstandighedenwetgeving en de Arbeidsveiligheidswetgeving in de bouw. Bouw. recht, 1977, p. 694. Zie ook: H. van Oostrum, Arbeidsrechtelijke en strafrechtelijke aspectten van bedrijfsongevallen. Ars Aequi, 1974, p. 131-144, met name p. 139 .

$126 \mathrm{Ktg}$. Tilburg, 24 april 1975, NJ 1976, 402 . Vgl, ook J.J. van Dodeweerd en J. Struik, Uitspraken veiligheidswetgeving. Deventer 1979 , p. 57-61.

127 HR 15 oktober 1982 , NJ 1984,21 , m.nt. F.H.J.M. 
nodige middelen zijn verstrekt en het redelijkerwijze te vorderen toezicht is gehouden, om de naleving te verzekeren van de bepalingen, voor welke naleving zij werplicht waren te zorgen'. Om twee redenen is deze overweging belangwekkend. In de eerste plaats was op het moment van het wijzen van dit arrest de Arbowet al vastgesteld en zou enkele maanden later (gedeeltelijk) in werking treden. Een bepaling als art. $29 \mathrm{lid} 2 \mathrm{komt}$ daarin echter - met redenen-niet terug. (Zie paragraaf 2.2.9. van dit hoofdstuk). De letterlijke tekst van art. 29 lid 2 Veiligheidswet is echter wèl opgenomen in art. 7.10.4.2. NBW (het "oude" $1638 \mathrm{x}$ ). In de tweede plaats wordt gesproken over arbeidsomstandighedenrecht. Dit zou dus kunnen betekenen dat deze formule niet haar betekenis heeft verloren met de vervanging van de Veiligheidswet door de Arbowet. ${ }^{128}$

En met name deze laatste wet biedt belangrijke aanknopingspunten voor de invulling van het begrip redelijke zorg. Hierbij kan vooral gedacht worden aan de verplichting om doeltreffend" onderricht te verschaffen en om een eigen arbeidsomstandighedenbelleid te ontwikkelen, dat gebaseerd moet zijn op een aantal in art. 3 van de Arbowet geformuleerde grondbeginselen (zie paragraaf 2.2.1. van dit hoofdstuk). ${ }^{12 y}$ De onderneming dient in een aantal gevallen bovendien de beschikking te hebben over (beleids)documenten zoals een jaarplan, een jaarverslag of een arbeidsveiligheidsrapport. Mede door toetsing aan deze documenten kan de rechter tot een antwoord komen op de vraag of in een concreet geval de nodige zorg is betracht.

De verwevenheid tussen de publiekrechtelijke veiligheidsnormen en de daarop gebaseerde strafrechtelijke aansprakelijkheid en de civielrechtelijke aansprakelijkheid kwam ook aan de orde tijdens de parlementaire behandeling van de Arbowet. Het ging om art. 28 Arbowet, waarin is bepaald dat bij $A M v B$ de verplichting tot naleving van veiligheidsvoorschriften op een ander dan de werkgever kan worden gelegd. In dit verband werd aan de minister gevraagd of het aanwijzen van een ander dan de werkgever, naast of met uitsluiting van deze, als strafrechtelijk aansprakelijk voor de naleving van die voorschriften, consequenties heeft voor de werknemer die na een bedrijfsongeval civielrechtelijk schadevergoeding wil eisen. Terecht wees de minister erop dat het strafrechtelijk aansprakelijkheidsstelsel van de Arbowet geen automatische invloed uitoefent op de civielrechtelijke aansprakelijkheid: ook in geval van schade, veroorzaakt door een bedrijfsongeval dat is te wijten aan een van een derde betrokken werktuig (die daarvoor aansprakelijk is), kan de werknemer op grond van $1638 \mathrm{x}$ BW de eigen werkgever blijven aanspreken.

128 Ook zo: Annotator Mijnssen bij dit arrest, NJ, t.a "p. p. 98.

129 De President van de Rechtbank Breda veroordeelde in 1985 een werkgever om een werk. neemsten onder dazelfde arbeidsomstandigheden als voor hatar (ten onrechte gegeven) ontslag te laten werken en baseerde dat merkwaardigerwigs eveneens op de verplichting van de werkgever ex art. 3 Arbowet. Dit was merkwardig ondat hier bij witstek 16382 van toepassing zou zijn en bovendien omdat art. 3 nog niet in werking is (in elk geval toen: was) getreden en het artikel bowendien gewijzigd zou gaan worden in verband met de dereguleringsoperarie!

President $R$ b Breda, 9 december 1985, $\mathrm{KG}, 1986,28$. 
Ter voorkoming echter bij voorbaat van een ongewenste ontwik keling besloot de minister in zijn Nota naar aanleiding van het eindverslag een bepaling toe te voegen (de derde zin van art. 28 , eerste lid), die buiten twijfel stelt dat een op art. 28 steunende aanwijzing geen wijziging brengt in de burgerrechtelijke aansprakelijkheid van de werkgever. ${ }^{130}$

Hoewel deze laatste toevoeging naar mijn mening volstrekt overbodig is, neemt een en ander natuurlijk niet weg dat het in de praktijk wel degelijk een verschil kan maken voor een voor schadevergoeding procederende werknemer of zijn werkgever al dan niet strafrechtelijk is veroordeeld. Is dat wel het geval, dan stijgt zijn kans op succes in een civielrechtelijke procedure aanmerkelijk. Immers, feiten uit het strafrechtelijk vonnis kunnen aangevoerd worden ten bate van het bewijs in civilibus.

Een ietwat curieuze uitspraak van de kantonrechter Rotterdam uit 1984 verdient nog enige aandacht. ${ }^{131}$ Een door een bedrijfsongeval getroffen werknemer vorderde schadevergoeding van zijn werkgever en baseerde deze vordering op art. 1638x. De kantonrechter stelde vast dat de werkgever voldaan had aan het vereiste van de redlelijke zorg ex art. 1638x. Met andere woorden: art. $1638 \mathrm{x}$ miste toepassing. Vervolgens overwoog de kantonrechter echter, dat dit alles niet behoefde te betekenen dat een dergelijke vordering onder bepaalde omstandigheden zou moeten worden afgewezen. "Zulke omstandigheden zullen zich met name kunnen voordoen indien de werknemer tengevolge van de uitvoering van zijn werk in relatie tot de mate van zijn schuld zó evenredig veel nadeel ondervindt dat, ook al valt zijn werkgever niets of nauwelijks iets te verwijten, het alsdan niet toekennen van een redelijke tegemoetkoming aan de werknemer in strijd met een goed werkgeverschap te achten is.' De kantonrechter beriep zich dus kennelijk op art. $1638 \mathrm{z} \mathrm{BW.} \mathrm{Voorwaarde} \mathrm{is} \mathrm{wel,}$ dat niet gebleken moet zijn dat een werknemer die schade oploopt zonder enig toedoen of nalatigheid van zijn werkgever onder omstandigheden toch een recht op schadevergoeding krijgt. Het lijkt er derhalve op, dat via deze omweg een zekere risico-aansprakelijkheid voor de werkgever gevestigd wordt. En hoe sympathiek men daar ook tegenover moge staan: art. 1638x sluit deze uit, in 1982 nog eens uitdrukkelijk door de HR bevestigd. ${ }^{132}$

Samenvattend kan over de civielrechtelijke zorgplicht voor de werkgever op het gebied van de veiligheid en gezondheid in elk geval geconcludeerd worden dat deze dermate uitgebreid is dat de werkgever gehouden is om, zowel ten opzichte van de te gebruiken of gebruikte machines, stoffen e.d., als ten opzichte van zijn werknemers mér dan alleen de onmiddellijk voor de hand liggende beschermingsmaatregelen te nemen. Datgene wat "redelijkerwijze in verband met de arbeid' van hem verwacht mag worden, is - mede geinspireerd door de publiekrechtelijke normstellingen op dit terrein - behoorlijk opgerekt. En hoewel schuldaansprakelijkheid bij $1638 \mathrm{x}$ nog steeds de regel is, 
komt men aan de hand hiervan soms tot een resultaat dat praktisch veel weg heeft van risico-aansprakelijkheid. Zie bijvoorbeeld, behalve de uitspraak van de kantonrechter Rotterdam, het bovengenoemde arrest van 19 april 1983. waarin de HR de werkgever aansprakelijk houdt voor het feit dat hij zich niet heeft laten voorlichten over de gevaren van de - door de Dienst voor het Stoomwezen goedgekeurde - machine en de daarmee samenhangende maatregelen van preventie. Terecht merkt annotator Stein bij dit arrest echter op, dat het resultaat niet op één lijjn kan worden gesteld met risico-aansprakelijkheid. Immers, als de deskundigen verkeerd zouden adviseren, is de werkgever in het algemeen van zijn aansprakelijkheid ontheven. ${ }^{133}$

I $\mathrm{k}$ ben het van harte eens met de interpretatie dat de zorgplicht van de werkgever voor veilige werkomstandigheden zo groot dient te zijn dat hij zich niet gemakkelijk van de aansprakelijkheid voor een bedrijfsongeval moet kunnen bevrijden. De A.G. Biegman-Hartogh voert in haar conclusie bij HR 15-101982 drie argumenten hiervoor aan. ${ }^{134} \mathrm{Zij}$ zijn overtuigend. In de eerste plaats is deze opvatting in overeenstemming met de strekking van de Veiligheidswet en de Arbowet met alle zo minitieus geregelde uitvoeringsbesluiten op vele terreinen. Niet alleen de strafrechtelijke, maar ook de civiele aansprakelijkheidsstelling is in staat - en behoort hier ook - een normversterkende invloed uit te oefenen, wellicht mede met behulp van door verzekeraars te stellen voorwaarden. In de tweede plaats is dit uitgangspunt niet meer dan redelijk, nu het uitsluitend de werkgever is die de arbeidsomstandigheden in zijn onderneming bepaalt. De werknemer heeft het geboden arbeidsklimaat, als hij werken moet of wil, in beginsel maar voor lief te nemen. Hoogstens kan hij trachten via de or iets te bereiken. Het is dan ook eigenlijk niet duidelijk waarom in dit opzicht niet een soort risico-aansprakelijkheid van de werkgever kan worden aangenomen. In de derde plaats is de bestuurder ook de aangewezen persoon om eventuele gevaren bij het werk te onderkennen en er iets tegen te ondernemen, onder meer door er zich van te vergewissen dat de werknemers niet alleen de veiligheidsvoorschriften kennen en begrijpen, maar er zich ook aan houden. Zeker waar het gaat om bijvoorbeeld buitenlandse werknemers. Letterlijk schrijft zij vervolgens: 'Daarom behoort zo'n bestuurder in beginsel géen baat te hebben bij een beroep op roekeloosheid of verregaande domheid van de arbeider - roekeloos kan men alleen zijn ten aanzien van een gevaar dat men kent en dat men (ook psychologisch gezien) kan vermijden, en als de man het woor het zeggen had, was hij misschien ook liever jurist geworden - en zéker niet in een geval als het onderhavige waar het niet ging om een arbeider die zorgeloos of gemakzuchtig geen gebruik had gemakt van de door de werkgever verstrekte veiligheidsvoorzieningen, maar om een man wiens ijver en haast om "zijn' machine draaiende te houden hem een paar vingers kostte. En het schijnt mij toe, dat men vragen van schuld en

133 Vgl. ook: Th.H.J. Dorrestein, Hernieuwde belangstelling voor art. 1638x, NJB 1972, p. $1141-1151$, m.n. p. 1148.

134 N.J1984, 21, t.a.p. p. 94. 
aansprakelijkheid niet goed kan beantwoorden als men niet ook realiteiten als hier even aangestipt, in zijn overwegingen betrekt.'

\subsection{2. (Grove) schuld, medeschuld en schadevergoeding}

Volgens het tweede lid van art. 1638x is de werkgever van zijn schadevergoedingsplicht bevrijd, indien door hem het bewijs kan worden geleverd, dat er sprake is van overmacht of dat de schade in belangrijke mate mede aan de grove schuld van de werknemer is te wijten. De overmachtsregel spreekt vanzelf: immers, er wordt alleen redelijke zorg vereist. De regeling is derhalve slechts van betekenis voor het bewijs. Wat dient nu te worden verstaan onder grove schuld? In 1975 gaf de HR een definitie van het begrip 'grove schuld' in $1638 \mathrm{x} .{ }^{135}$

Een man raakt met zijn arm beklemd tussen een pers. Al vóór het ongeval bleek een beschermende bladveer te zijn gebroken. De werknemer diende een eis tot schadevergoeding in, omdat de werkgever volgens hem tekort geschoten was in een regelmatige controle op de deugdelijkheid van de bladveer. Kantonrechter en rechtbank oordeelden dat de werknemer, als zijnde de enige bedieningsman van de pers, het breken van de bladveer had moeten merken en de werkgever daarvan op de hoogte had moeten stellen. Nu hij dit niet had gedaan, was er sprake van grove schuld van zijn kant. De HR oordeelde anders met een restrictieve interpretatie van grove schuld. Hiervan kan eerst sprake zijn als - rekening houdend met alle omstandigheden van het geval de schuld van de werknemer zo ernstig is, dat daarentegen de tekortkoming van de werkgewer in de nakoming van zijn verplichtingen in het niet valt. ${ }^{136}$ Volgens de HR moet hierbij rekening worden gehouden met de overweging die de wetgever ertoe gebracht heeft voor niet-aansprakelijkheid van de werkgever meer dan gewone schuld van de werknemer te eisen. Door grove schuld te eisen had de werkgever de bedoeling om de werknemer te beschermen door bij de aan zijn schuld te stellen eisen rekening te houden met het ervaringsfeit dat de dagelijkse omgang met werktuigen of gereedschappen de gebruiker ervan er licht toe zal brengen niet alle voorzichtigheid in acht te nemen, die ter voorkoming van ongelukken geraden is. In het onderhavige geval zou, voor zover de enige aan de werknemer te verwijten fout zou zijn dat hij na het breken van de veer het wegvallen van de tegendruk van de bladveer niet had bemerkt, hoewel hij dit had behoren te bemerken, een dergelijke fout geen grove schuld opleveren. ${ }^{137}$

$\mathrm{Bij}$ dit arrest moet wel opgemerkt worden, dat uit de grove schuld van de

135 HR 27 juli 1975 . NI 1976,81, m.nt. G.J.S.

136 Met deze restrictieve interpretatie makte de HR een einde aan de opvattingen, wooral gebaseerd op de rechtsgeschiedenis, dat grove schuld ruim uitgelegd dient te worden en dat het gelijk gesteld moet worden met de 'merkelijke schuld' uit $294 \mathrm{~K}$. Vgl. Th. H.J. Dorrestein, t.a.p. p. 1150 .

137 Vgl. in dit verband ook: HR 15 oktober 1982, NJ 1984, 21, waarin het oordeel wan cen lagere rechter dat de onvoorzichtigheid van de werknemer zodanig is dat zijn handelen 'roekeloos' was, als onvoldoende gemotiveerd wordt verworpen. 
werknemer niet het ontbreken van schuld bij de werkgever mag worden afgeleid. Grove schuld van de werknemer komt derhalve eerst aan de orde, indien de schuld van de werkgever in welke mate dan ook, vaststaat. Heeft de werkgever zijn in redelijkheid vereiste zorg betracht en dus geen schuld, dan behoeft de schuld van de werknemer niet meer aan de orde te komen. ${ }^{138}$

Met dit arrest was echter nog niet de wraag beslist of, als er geen grove schuld maar wel schuld is bij de werknemer, dit de hoogte van de schadevergoeding kan beïnvloeden. Eenstemmigheid was er wèl ten aanzien van geringe schuld bij de werknemer: de werkgever blijft alsdan gehouden de volledige schade te vergoeden. ${ }^{139}$

De schrijvers en de jurisprudentie bleven echter verdeeld over het antwoord op de vraag hoe het zit met schuld van de werknemer, die in ligt tussen grove schuld en geringe schuld. ${ }^{140}$ Aan de ene kant stond de mening, dat er dan plaats zou moeten zijn voor gedeeltelijke schadevergoeding, gerelateerd aan de mate van wederzijdse schuld; aan de andere kant werd verdedigd, dat het in art. 1638x om het "alles of niets' beginsel zou gaan. Bij de eerste opvatting werd gewezen op het argument dat op deze wijze aansluiting zou worden verkregen bij het gemene recht, met name bij de wordering tot schadevergoeding uit onrechtmatige daad. ${ }^{141}$ De opvatting werd onder meer in 1974 gedeeld door de Rechtbank Utrecht op basis van een wetshistorische interpretatie. ${ }^{142}$ Meer recent meende de Kantonrechter Nijmegen in 1985 zonder enige nadere adstructie dat, nu ook bij het slachtoffer schuld lag die noch gering was, noch een grove was, 'de schade voor een deel ten laste van ieder der partijen dient te komen'. Hij achtte vervolgens de schuld van ieder van de partijen even groot. ${ }^{1.43}$

Voor de andere mening pleit art. 7.10.4.2. NBW, dat grove schuld vervangt door opzet of bewuste roekeloosheid en dat niet voorziet in de mogelijkheid van gedeeltelijke schadevergoeding. Bovendien zijn voor de "alles of niets" opvatting eveneens rechtshistorische argumenten aan te voeren, vooral liggend in de ratio - bescherming van werknemers - van de bepaling. ${ }^{144}$ Ook dit standpunt werd gesteund door jurisprudentie. Volgens de Rechtbank Breda (in 1978) brengt de beschermingsdoelstelling van art. 1638x met zich, dat de werknemer volledig schadeloos gesteld wordt. De bescherming kan alleen worden opgeheven ingeval van grove schuld - waar in casu geen sprake van was. ${ }^{145}$ De Rechtbank Haarlem oordeelde in 1982, dat de in artikel 1638x geregelde aansprakelijkheid van de werkgever naar haar strekking mede berust op

$138 \mathrm{Vgl}$. H.J. van Zwam, t.a.p. p. 239

139 W.C.L. van der Grinten, Arbeidsovereenkomstenrecht, 1983 (dertiende druk), p. 103; C.J.M. de Leede in Asser-Kamphuisen, Bijzondere overeenkomsten III, 1983, p. 208.

140 Voor een overzicht van de opvattingen wan oudere schrijvers: $H$. van Oostrum, ta.p. p. 135.

141 W.C.L. van der Grinten, 1983, t.a.p. p. 103.

$142 \mathrm{Rb}$ Utrecht 29 mei 1974 , NJ $1976,156$.

143 Ktg. Nijmegen 22 februari 1985, Praktijkgids 1986, nr. 2532.

144 G.J. Scholten in zijn noot onder NJ 1976, ta.p. p. 187; Asser Kamphuisen, t.a.p. p. 208; L.J. Fillet, Gedeelde smart, halve smart?, SMA, 1984, p. 350-361.

145 Rb Breda 7 matart 1978, NJ 1981, 10. 
het ervaringsfeit dat de werknemer die dagelijks in gevaarlijke situaties verkeert, niet steeds de nodige voorzichtigheid in acht zal nemen. Het zou dan onbillijk zijn om aan de werknemer 'zijn aan de aard van zijn arbeidssituatie eigen onvoorzichtig gedrag als eigen schuld toe te rekenen en op die grond de schade die hij als gevolg van het ongeval lijdt, gedeeltelijk te zijnen laste te laten'. ${ }^{146}$ In 1984 constateerde de Rechtbank Zwolle eveneens onvoorzichtig gedrag van de werknemer (het betrof hier een 15 -jarige part-time werker) en daarom medeschuld, maar ook deze Rechtbank meende dat de ratio van art. $1638 x$ meebrengt, dat een minder vèrgaande dan grove schuld van de werknemer niet leidt tot gedeeltelijke opheffing van de aansprakelijkheid van de werkgever. ${ }^{147}$

In 1987 beslechtte de HR het pleit ten gunste van de 'alles of niets' opvatting. De HR relativeert daarbij, als het ware teleologisch interpreterend, de wetsgeschiedenis. Na het oordeel dat in overeenstemming met de bewoordingen van art. $1638 \mathrm{x}$ moet worden aangenomen, dat de werkgever tot vergoeding van de gehele schade van de werknemer is gehouden, tenzij door hem het aan het slot van het tweede lid bedoelde tegenbewijs wordt geleverd, vervolgt de HR: 'Daaraan staat niet in de weg dat bij de behandeling in de Eerste Kamer van het wetsontwerp dat tot art. 1638x heeft geleid, van de zijde van de regering naar voren is gebracht diat het tweede lid niet zegt dat in andere gevallen dan daar bedoeld de schade steeds algeheel moet worden vergoed; dat de vraag wat hier geldt moet worden beantwoord aan de hand van algemene beginselen; en dat ten tijde van die behandeling 'vrij algemeen' werd aangenomen dat de eigen schuld van de benadeelde bij het vaststellen van het bedrag van de schadevergoeding in aanmerking moet worden genomen.

Bij deze uitlatingen moet immers worden bedacht dat zij zijn gedaan in een tijd dat het recht met betrekking tot de invloed van eigen schuld van de benadeelde op zijn vordering tot schadevergoeding, zich nog in het begin van zijn ontwikkeling bevond. Uit die uitingen kan daarom niet worden afgeleid dat de regells betreffende eigen schuld als grond tot matiging van schadevergoeding, zoals deze regels zich nadien hebben ontwikkeld met betrekking tot de vaststelling van schadevergoeding in het algemeen, zich met de strekking van art. $1638 x$, tweede lid, laten verenigen. Die strekking komt hierop neer dat deze bepaling de werknemer beoogt te beschermen door bij de aan zijn schuld te stellen eisen rekening te houden met het ervaringsfeit dat de dagelijkse omgang met machines, werktuigen of gereedschappen de werknemer die deze gebruikt, er licht toe zal brengen niet alle voorzichtigheid in acht te nemen die ter voorkoming van ongelukken geraden is, terwijl veel veiligheidsvoorschriften ter bescherming van werknemers bij hun werk juist met het oog op deze menselijke neiging zijn gegeven (HR 27 juni 1975, NJ 1976,81). Deze ge-

146 Rrb Haarlem 4 mei 1982 , NJ 1983, 396.

147 Rb Zwolle 20 juni 1984, Praktijkgids, 1984, nr. 2159.

148 HR 9 januari 1987, NJ 1987,948 m.nt. P.A.S. Over dit arrest eveneens: L.J. Fillet, Geen dikke bult bijeigen schuld ex art. 1638x BW, SMA, 1987, p. 170-175; P. van Schilfgarde Ars Aequi, 1987, p. 477-480. 
dachte is na de totstandkoming van art. 1638x als gevolg van de latere ontwikkeling van de maatschappelijke opvattingen op dit punt nog in belang toegenomen en voorts mede betrokken op de beantwoording van de vraag in welke gevallen de schade die de werknemer door zijn fouten toebrengt aan derden of aan zijn - niet mede-schuldige - werkgever, door deze laatste moet worden gedragen. Met deze ontwikkeling - zoals deze onder meer ten uiting komt in art. 6.3.2.2. lid 3 nieuw BW - strookt niet dat, indien de werkgever jegens zijn werknemers wanprestatie heeft gepleegd doordat hij zijn in art. $1638 \mathrm{x}$ bedoelde, hem met het oog op veiligheid van zijn werknemers opgelegde verplichtingen niet is nagekomen, niettemin de schade niet volledig te zijnen laste zou komen op de grond dat ook de werknemer schuld treft, zonder dat evenwel de in het tweede lid van dat artikel bedoelde grove schuld is bewezen.'

De HR trekt de lijn van de beschermingsgedachte van de werknemer in dit arrest, vooral met een beroep op de maatschappelijke verhoudingen, dus dóor. Hij sluit daarbij nauw aan - voor een groot deel in dezelfde bewoordingen - bij het hierboven genoemde arrest van 27-6-1975 (interpretatie van grove schuld).

Ik ben het in beginsel eens met de HR, zij het met de kanttekening dat het beginsel wel èrg absoluut is geformuleerd. Naar mijn mening dient het niet om een wet van Meden en Perzen te gaan. Met andere woorden: de omstandigheden van het geval zouden met zich mee kunnen brengen, dat zwaardere dan lichte eigen schuld van de werknemer een rol speelt bij de bepaling van de schadevergoeding door de werkgever -al mag dat niet licht gebeuren. Het is de vraag (door de A.G. in beginsel negatief beantwoord), of het nodig is en wellicht zelfs gewenst, dat de werknemer - behoudens grove schuld - geen enkele verantwoordelijkheid meer zou behoeven te dragen. Huidige maatschappelijke opvattingen houden toch ook in dat de werknemer, méér dan vroeger, beschouwd wordt als zelfstandige drager van rechten en bevoegdheden en een daarmee corresponderende aansprakelijkheid? Uitgaande van de beschermingsgedachte van art. $1638 \mathrm{x}$, geëxpliciteerd in de overwegingen zoals die in de vorige paragraaf geformuleerd zijn door de A.G. bij HR 15-1-1982, is de werknemer desalniettemin door de invoering van de Arbowet ook méér dan voorheen 'gewapend", bijvoorbeeld door het 'doeltreffende' onderricht (art. 6), dat de werkgever niet alleen verplicht is om te geven, maar dat de werknemer ook verplicht is actief te volgen (art. 12). ${ }^{149}$

\subsubsection{Bewijs en causaal verband}

De werknemer die op grond van art. 1638x ageert tegen zijn werkgever, moet aantonen dat de laatste tekort is geschoten in zijn zorgverplichting. Zowel een wetshistorische als een grammaticale interpretatie lijken geen andere conclu-

$149 \mathrm{Vgl}$. voor een benadering waarbij van geval tot geval een oordeel wordt gegeven over het 'meetellen' van de eigen schuld van de werknemer: J. van Oostrum, t.a.p. p. 135-136; A.J.C.M. Geers, J.K.M. Gevers, Arbeidsonstandighedenrecht, t.a.p. p. 143. 
sie toe te laten. ${ }^{150} \mathrm{Zo}$ vanzelfsprekend is dat echter niet. Te verdedigen valt zeer wel dat hier een meer teleologische interpretatie voor de hand ligt. Immers de productieprocessen zijn tegenwoordig heel wat gecompliceerder dan in het begin van deze eeuw. Natuurlijk, ook de positie van de werknemer is veranderd in die zin dat hij niet meer zo onwetend en ongeschoold is als in die tijd. Maar toch staat hij nog al te vaak tegenover een voor hem ondoorzichtig complex van technische gegevens, productieplanning, economische overwegingen e.d., die het niet meer dan billijk maken dat de rechter bij de bewijslastverdeling rekening houdt met deze praktische ongelijkheid. Dan wordt ook recht gedaan aan de feitelijke arbeidsverhoudingen. ${ }^{151}$

Ook art. 7.10.4.2. NBW geeft steun aan deze gedachte. In dit artikel, dat $1638 \mathrm{x}$ vervangt, moet niet de werknemer aantonen dat de werkgever tekort is geschoten, maar moet de werknemer aantonen dat hij al het redelijke heeft gedaan om de schade te voorkomen. Dit is uiteraard een essentiële verbetering voor het slachtoffer van een bedrijfsongeval dat een civiele procedure tegen zijn werkgever wil starten. Ook de lagere rechtspraak heeft in een aantal gevallen tot omkering van de bewijslast geconcludeerd. Met name de Rechtbank Rotterdam heeft er betrekkelijk uitvoerige overwegingen over ten beste gegeven. ${ }^{152}$ De Rechtbank onder meer: '... Aan de wetsgeschiedenis kan in deze evenwel geen beslissende betekenis worden toegekend (...). Als gevolg van de omstandigheid dat art. $1638 \mathrm{x}$ tot an 1967 in feite praktisch was uitgeschakeld, hebben rechtspraak en doctrine niet de gelegenheid gehad deze bepaling in het licht van de veranderde technische en maatschappelijke omstandigheden verder te ontwikkelen. Wellicht is dit er de oorzaak van dat in de meeste commentaren ... nog wordt vastgesteld dat de bewijslast bij art. $1638 \mathrm{x}$ op de werknemer rust. (...) In het huidige aansprakelijkheidsrecht past veeleer een omkering van de bewijslast in die zin dat op de werkgever het risico rust voor het bewijs dat hij zijn veiligheidsverplichtingen is nagekomen. Een aanwijzing hiervoor kan worden geput uit art. 7.10.4.2. (voor)ontwerp NBW, dat in het tweede lid de bewijslast voor het nakomen van de veiligheidsverplichtingen op de werkgever legt (zie hieromtrent de Toelichting Meijers blz. 1052-1053).'

In 1982 makkte de HR korte metten met dit standpunt, echter niet zonder enkele belangrijke subregels te geven die de hoofdregel in belangrijke mate relativeren. ${ }^{153}$ Volgens de HR verzetten tekst en structuur van art. $1638 \mathrm{x}$ BW zich tegen de stelling dat 'naar huidig aansprakelijkheidsrecht op de werkgever het risico rust voor het bewijs dat hij zijn veiligheidsverplichtingen is nagekomen'. Op de werknemer rust dus in beginsel de bewijslast. Maar, zo voegt

150 Th.H.J. Dorrestein, t.a.p. p. 1145; W.C.L. van der Grinten, (veertiende druk), t.al.p. p. 106. 151 Voor deze opvatting, Asser-Kamphuisen, ta.p. p. 207; H. van Oostrum, t.a.p. p. 135; A.J.C.M. Geers en J.K.M. Gevers, t.a.p. p. 142.

152 Rb Rotterdam 4 januari 1980 , NJ 1980, 579; zie ook Rb Zutphen 23 oktober 1980, Praktijkgids, 1982, nr. 1821 .

153 HR 25 juni 1982 , NJ 1983, 15॥, m.nt. P.A.S. Zie ook de noot onder dit arrest van D. Christe, SMA, 1982, p. 683-686. 
de HR eraan toe, van de werkgever moet worden verlangd dat hij een ontkenning dat hij zijn voormelde verplichtingen niet is nagekomen, zoveel mogelijk met redenen omkleedt - hetgeen kan meebrengen dat hij heeft aan te geven welke maatregelen hij heeft genomen ter voorkoming van arbeidsongevallen als waarom het in het gegeven geval gaat. Daarnaast kan de rechter aan de omstandigheden van het geval, waaronder de aard van het ongeval, vermoedens ontlenen op grond waarvan de bewijslast geheel of ten dele op de werkgever wordt gelegd. Met deze twee subregels komt de HR in elk geval een flink stuk tegemoet aan de bovengenoemde bezwaren die kleven aan het toepassen van de hoofdregel zonder meer. In zijn noot meent Stein dat de HR met dit arrest een anticiperende werking op het NBW heeft verworpen indien tekst en structuur van het artikel dit niet toelaten, ook al is de regel van het NBW meer in overeenstemming met de rechtsontwikkeling.

Deze mening deel ik niet. Weliswaar geeft de HR grenzen aan, gevormd door tekst en structuur van art. $1638 \mathrm{x}$, maar tegelijkertijd worden deze grenzen als het ware opgeschoven doordat onder omstandigheden een billijke bewijslastverdeling tot stand kan worden gebracht, die met de letterlijke tekst en structuur van art. 1638x BW op gespannen voet staat, maar recht doet aan de maatschappelijke ontwikkeling en tendeert in de richting van art. 7.10.4.2. NBW. Al een paar maanden later kon de HR een illustratie geven van een geval waarin op grond van de omstandigheden de bewijslast op de werkgever rustte. ${ }^{154}$ Uit de strafrechtelijke veroordeling was in casu gebleken, dat de werkgever tekort was geschoten in het nakomen van de veiligheidsnormen. Op hem rustte nu de last om te bewijzen welke duidelijke bevelen en doeltreffende maatregelen hij persoonlijk had gegeven respectievelijk had genomen om te verzekeren dat de leidinggevenden aan het inachtnemen van veiligheidsvoorschriften zorgvuldig aandacht zouden besteden èn op welke wijze en met welke frequentie hij persoonlijk op de naleving van zijn bevelen en maatregelen toezicht had uitgeoefend.

Een probleem kan nog gevormd worden door het moeten aantonen van het verband tussen het ongeval en het handelen of nalaten van de werkgever. De werkgever moet immers de schade vergoeden die de werknemer 'dientengevolge' is overkomen.

In 1974 gaf de HR een arrest over dit probleem van causaliteit. ${ }^{155}$ Een werknemer viel van een trap zonder leuning. Hij eiste schadevergoeding. De rechtbank oordeelde, mede op eigen waarneming gebaseerd, dat het ontbreken van de leuning, in strijd met het VBF, de kans op het aan de werknemer overkomen ongeval in aanmerkelijke mate heeft verhoogd. De HR oordeelde, dat hiermede het vereiste verband tussen het verzuim van de werkgever en het ongeval van de werknemer, is vastgesteld. Het zou op de weg van de werkgever hebben gelegen om aan te tonen, dat het aanwezig zijn van een leuning het

1.54 HR 15 oktober 1982, NJ 1984,21, m.nt. F.H.J.M.; zie ook Rb Alkmaar 27 oktober 1983 en 7 augustus 1986, Praktijkgids, 1988, nr. 2806.

155 HR 21 juni 1974 , NJ 1974, 453, m.nt. C.J.H.B. 
ongevall waarschijnlijk niet zou hebben voorkomen. ${ }^{156}$ "In aanmerking genomen dat het aanwezig zijn van een leuning wettelijk is voorgeschreven ter voorkoming van ongevallen, hetgeen niet anders kan worden begrepen dan als voorkomen dat degenen die van de trap gebruik maken daar af vallen en gewond raken, heeft de rechtbank geen onjuiste maatstaf aangelegd, door na op grond van een eigen waarneming tot het oordeel te zijn gekomen dat het in het algemeen door de wetgever geduchte gevaar zich inderdaad in de onderhavige situatie voordeed, causaal verband tussen het niet nakomen van de verplichting van de werkgever en de aan de werknemer overkomen schade aan te nemen. Dit oordeel is van feitelijke aard en niet onbegrijpelijk.'

Twee zaken uit dit arrest verdienen de aandacht. In de eerste plaats dat causaal verband kan worden aangenomen als door het handelen of nalaten van de werkgever de kans op het aan het slachtoffer overkomen letsel 'in aanmerkelijke mate' is verhoogd. In de tweede plaats dat éerst de onrech tmatigheid van het nalaten moet worden vastgesteld alvorens het vraagstuk van de causaliteit aan de orde komt. In dit geval was dat niet zo problematisch, omdat het nalaten in strijd was met een wettelijke bepaling (het Veiligheidsbesluit fabrieken of werkplaatsen). Zou er in een dergelijk geval geen wettelijk voorschrift zijn, dan zou toch eerst dienen te worden vastgesteld dat het ontbreken van een leuning onrechtmatig is. (Hiervoor is natuurlijk niet nodig dat het wel aanwezig moeten zijn met zoveel woorden in de wet staat).

G.J.S. in zijn noot onder het arrest: 'Want als dat niet zo zou zijn, zou de vraag naar het causalle verband zinloos zijn omdat men een onbepaald aantal afwezige omstandigheden kan bedenken die als zij niet afwezig zouden geweest zijn, het vallen belet zouden hebben. Ook doordat er geen lift was, is het ongeluk gebeurd, en ook doordat niet iemand de man een hand heeft gegeven, enz.' Wat, indien de operatie die een werknemer ten gevolge van een arbeidsongeval moet ondergaan, niet tot succes leidt? Moet de werkgever deze extra schade vergoeden, ook als het uitblijven van herstel mede aan de persoonlijkheidsstructuur van de werknemer te wijten is? De HR beantwoordde deze vraag bevestigend: "Indien in een zodanig geval het in de normale lijn der verwachting liggend herstel uitblijft (...) als gevolg van een tekort schieten door de betrokken artsen, zal het uitblijven van herstel in het algemeen als een gevolg van het ongeval aan de werkgever moeten worden toegerekend, ook wanneer (...) dat medische tekort schieten slechts door en in samenhang met de psychische reactie daarop van de werknemer tot verstoring van het herstelproces heeft kunnen leiden. ${ }^{157}$

156 Hiermee lijkt de HR al te preluderen op het "bewijsarrest" van 25 juni 1982, NJ 1983 (noot 153).

157 HR 8 februari 1985, NJ 1986, 136, m.nt. C.J.H.B. 


\subsubsection{De werkgever van uitleenkrachten}

De aansprakelijkheid van art. $1638 \mathrm{x}$ veronderstelt een arbeidsovereenkomst. Hoe zit het nu in de situatie dat een uitgeleende werknemer een bedrijfsongeval overkomt? Wie kan hij in zo"n geval aanspreken? De HR lijkt, in het voetspoor van de meeste schrijvers, een arbeidsovereenkomst tussen uitzendkracht en uitzendbureau aan te nemen, waarmee de vraag zou zijn opgelost. ${ }^{\text {i58 }}$ In de lagere rechtspraak wordt echter over het antwoord op de vraag wie de aansprakelijke werkgever is in $1638 \mathrm{x}$ verschillend geoordeeld. In 1986 meende de kantonrechter Zutphen dat, op het moment dat de uitzendkracht werk heeft aanvaard, er een arbeidsovereenkomst tot stand is gekomen tussen het uitzendbureau en de uitzendkracht. Hoewel het uitzendbureau geen rechtstreekse invloed kan uitoefenen op de arbeidsomstandigheden en de naleving van de veiligheidsvoorschriften laat de tekst van art. $1638 \mathrm{x}$ nu eenmaal geen uitzonderingen toe: het uitzendbureau is aansprakelijk als aan de uitzendkracht een bedrijfsongeval overkomt. (Ten overvloede werd overwogen dat de gelaedeerde zijn vordering ook tegen de inlenende onderneming had kunnen richten, maar dan op grond van onrechtmatige daad). ${ }^{159}$

Eerder, in 1980, kwam de Rechtbank Rotterdam echter tot de slotsom dat de werknemer zich in casu kon wenden tot hetzij zijn formele werkgever, hetzij tot de onderneming waaraan hij was uitgeleend, omdat 'bij de in het geding zijnde uitleenverhouding de relatie tussen uitlener en leenbedrijf zo nauw is, dat deze gezamenlijk tegenover de werknemer als het ware als één werkgever gelden' " ${ }^{169}$ De kantonrechter Bergen op Zoom stelde in 1982 kort en goed, dat het zo moge zijn 'dat er een arbeidsverhouding bestaat tussen het uitzendbureau en de uitzendkracht $0 . m$. in die zin dat laatstgenoemde verplicht is te gaan werken bij een door dat bureau aangewezen ondernemer, de werkzaamheden dáár verricht hij in opdracht en op aanwijzingen van die ondernemer. Dit moge ook blijken uit de eigen stellingen van gedaagde, dat eiser zich heeft gehouden aan de werkinstructies, waarvan toch moet worden aangenomen, dat ze van gedaagde zijn uitgegaan". "tit Dit was voldoende om de inlener aansprakelijk te stellen ex art. 1638x. In 1983 kwam ook de Rechtbank 's Gravenhage tot de conclusie, dat art. $1638 \mathrm{x}$ van toepassing was in de relatie uitzendkracht-inlener. De rechtbank baseerde dat oordeel mede op grond van het feit dat van een 'zodanig permanente arbeidssituatie' sprake was tussen inlener en

158 HR 23 mei 1980 , N. 1980, 633, m.nt. P.A.S.

Anders. T. Jongbloed, Civielrechtelijke verhoudingen rond uizendarbeid., Ars Aequi, 1982 p. 43; H Naber, Is het gezag van de werkgever overdiragbaar?, NJB, 1984, p. 106-111.

$159 \mathrm{Ktg}$. Zutphen 25 nowember 1986, Praktijkgids, 1987, nr. 2779

$160 \mathrm{Rb}$ Rotterdam 4 jamuari 1980 , NJ 1980, 597. Zic over deze uitspraak ook H. Naber, De arbeidsovereenkomst in Necterland, Deventer 1985, p. 156-157.

Naber wijst op het bijzondere karakter van de relatie tussen uitlener en inlener resp. de Stichting Samenwerkende Havenbedrijven te Rotterdam en Seaport Terminals. De SHB is als het ware het verlengstuk van diverse personeelsafdelingen van aangesloten bedrijven.

161 Ktg. Bergen op Zoom 13 oktober 1982 en 30-3-1983, Praktijkgids, 1984, nr. 2050, m.nt. W. Hesseling. 
uitzendkracht, dat op eerstgenoemde, '- naast de formele wetgever in administratieve zin - de werkgeversaansprakelijkheid rust als bedoeld in art. $1638 \mathrm{x}$ BW' ${ }^{162}$ Bij de kantonrechter Bergen op Zoom speelde dus vooral het aspect van feitelijke zeggenschap een rol; bij de rechtbank 's Gravenhage de permanente arbeidssituatie. In beide zaken is bij verzoekschrift de kantonrechter geadieerd, zonder dat de rechtsgrond van de vordering duidelijk lijkt. Blijkbaar werd een arbeidsovereenkomst tussen verzoeker en inlener aangenomen. Geen van de rechters heeft zich in elk geval onbevoegd verklaard, at wordt nergens gerept van het bestaan van een arbeidsovereenkomst. Dat laatste zou ook, gezien de Wet op het terbeschikkingstellen van arbeidskrachten, contra legem zijn. ${ }^{163}$

In een recent vonnis (19-4-1988, 4293/87, niet gepubliceerd) oordeelde de Rechtbank Breda, anders dan de kantonrechter Tilburg in deze zaak, in hoger beroep dat de aansprakelijkheid uit hoofde van art. 1638x (althans mede) op de inlener berust. De Rechtbank beroept zich op de strekking van art. $1638 \mathrm{x}$, het systeem van de Arbowet, en tenslotte op het feit dat het bij de bescherming van de werknemer niet wel zou passen "dat de uitzendkracht voor het verkrijgen van schadevergoeding uitsluitend op het uitzendbureau zou zijn aangewezen en daardoor het risico van insolventie van het uitzendbureau zou moeten dragen, zulks terwijl vaststaat dat de inlener tekort is geschoten in het treffen van veiligheidsmaatregelen en de inlener in dit soort situaties op grond van de onderlinge rechtsverhouding veelal ook jegens het uitzendbureau weer verplicht is tot vrijwaren of schadevergoeding.'

Nu de rechtsverhouding uitzendkracht-inlener niet wettelijk geregeld is, is deze analoge toepassing van art. $1638 \mathrm{x}$ op deze verhouding bevredigend te noemen. ${ }^{164}$ In de eerste plaats behoeft de werknemer er nu niet de dupe van te worden, dat zowel de 'formele' als 'feitelijke' werkgever elk om een andere reden de boot zullen trachten af te houden. In de tweede plaats sluit deze jurisprudentie aan bij het inzicht dat feitelijke verhoudingen mede-bepalend dienen te zijn voor het antwoord op de vraag wie in een concrete situatie aansprakelijk en schadeplichtig kan worden gesteld. In de Arbowet is juist daarom de feitelijke, materiële werkgever ten opzichte van zijn ingeleend personeel verplicht de bij of krachtens deze wet gegeven voorschriften nate leven (art. 1 lid 2 Arbowet). En ook dit pleit voor een analoge toepassing van art. 1638x op de verhouding inlener-inleenkracht.

\subsubsection{Schadevergoeding uit onrechtmatige daad en art. $1638 \times \mathrm{BW}$}

Theoretisch kan, naast een vordering ex $1638 \mathrm{x}$, de werkgever ook aangesproken worden wit onrechtmatige daad. In de praktijk zal dit weinig voorkomen,

$162 \mathrm{Rb}$ Den Haag 23 movember 1983, Praktijkgids, 1984, nt. 2057.

163 Vgl. L. Bots, Wie van de twee is de aansprakelijke werkgever bedoeld in artikel $1638 \mathrm{xW}$ ?, Blinde vlekken in het sociaal recht (Frenkel-bundel), Deventer 1986, p. 167.

164 Eveneens W. Hesseling in zijn noot ander Ktg. Bergen op Zoom 3 oktober 1982 en 30 juli 1983, Praktijkgids, t.a.p. p. 35. 
ondat de aansprakelijkheid uit onrechtmatige daad niet verder gaat dan die uit wanprestatie. ${ }^{165}$ Art. $1638 \mathrm{x}$ lijkt ook enkele voordelen te bieden aan de getroffen werknemers. In de eerste plaats kan geprocedeerd worden bij de kantonrechter, waardoor werknemers zich bijvoorbeeld kunnen laten vertegenwoordigen door hun vakbond. In de tweede plaats bevrijdt de schuld van de werknemer in beginsel niet de werkgever en speelt deze eventuele (niet grove) schuld geen rol bij de vaststelling van het schadevergoedingsbedrag. In de derde plaats kent art. 1638x (hoogstwaarschijnlijk) niet de beperking van art. 1406 slot en art. 1407 lid 2 (inachtnemen van wederzijdse stand en fortuin). In verband met kwesties van bewijslast lijkt de keuze eveneens in het voordeel van art. $1638 \times$ uit te vallen. ${ }^{i 66}$

Over de processuele relatie tussen $1638 \mathrm{x}$ en een vordering ex delictu oordeelde de HR in 1979. In cassatie was aangevoerd, dat het Hof ambtshalve had behoren te onderzoeken of, nu gevorderd was ex art. 1406, de vordering niet toegewezen had kunnen worden op grond van art. 1638x. De HR oordeelde negatief: "Art. $1638 \mathrm{x}$ kan niet van toepassing zijn dan voor zover de zaak er een is betrekkelijk tot een arbeidovereenkomst... Voor zover de zaak er een is met betrekking tot een arbeidsovereenkomst, was in eerste instantie de kantonrechter bevoegd daarvan kennis te nemen. $B$ heeft de vordering echter in eerste instantie aangebracht bij de rechtbank. Nu (de verweerder) in deze instantie niet de onbevoegdheid van de rechtbank heeft ingeroepen kon de rechtbank ingevolge art. $157 \mathrm{Rv}$ de vordering van $\mathrm{B}$ niet anders dan in hoogste ressort toetsen aan art. $1638 \mathrm{x}$. Aan het Hof stond het daarom niet meer vrij art. $1638 \mathrm{x}$ in het hogere beroep toe te passen.' ${ }^{167}$

In een aantal gevallen kan art. 1638x echter minder of geen soelaas bieden en kunnen de artt. 1401 e.v. deswege van evenredig meer belang zijn. Wanneer bijvoorbeeld het ongeval te wijten is aan de fout van een collega-werknemer, dan kan art. 1638x weliswaar een rol spelen, namelijk in het geval dat de fout van een collega een gevolg was van een verwijtbare tekortkoming van hun beider werkgever, bijvoorbeeld bij gebrekkig onderhoud van een machine, maar meer voor de hand ligt dan een vordering ex art. 1403 lid 3 op de werkgever.

Daarnaast kan de collega-werknemer uiteraard zèlf aangesproken worden op grond van art. 1401, mits hij aan de vereisten van onrechtmatige daad voldoet. Ook wanneer een werkgever zelf een fout maakt bij de bediening van een machine - hij handelt daarmee niet in strijd met art. $1638 \mathrm{x}$ - en hij veroorzaakt daardoor een ongeluk bij zijn werknemer, moet aangenomen worden dat hij aansprakelijk gesteld kan worden ex delictu en ex contractu. ${ }^{168}$

165 Asser-Kamphuisen, III, t.a.p. p 208.

166 Met zoveel woorden: Ktg. Zutphen 25 november 1986, Praktijkgids, 1987, nr. 2779.

167 HR 16 februari 1979 , NI 1979, 453 , m.nt. P.A.S.

168 H.C.F. Schoordijk, Enige aantekeningen naar aanleiding van de aansprakelijkheid van ondernemer en arbeicer voor bedrijtsongevallen na de inwerkingtreding van de WAO mede in verband met de thans geldende W.A.-verzekeringen voor bedrijven, NJB, 1967, p. 341-350, m.n. p. 342. Anders dan in de vorige drukken is dit thans (veertiende druk) ook de mening van van der Grinten, t.a, p. p. 105. 
Bij ongevallen, veroorzaakt door verborgen gebreken, mist art. $1638 \mathrm{x}$ toepassing. Relevant is dan voor wat betreft gebouwen art. 1405: zelfistandige schadetoebrenging door gebouwen. Van belang is hier het antwoord op de vraag wanneer gesproken kan worden van een gebouw. De HR hangt een ruime interpretatie aan. Zo behoort bijvoorbeeld door bestemming tot een gebouw een loopkraan of een lift. ${ }^{169}$ Hetzelfde vond de HR van een olie-opslagtank. ${ }^{170}$ Als het gaat om schade door 'zaken welke men onder zijn opzigt heeft", dan kan art. 1403 lid 1 een rol spelen.

De door de rechtspraak aanvaarde risico-aansprakelijkheid van art. 1405 gaat verder dan die van art. $1638 \mathrm{x}$, waarin van de werkgever slechts een redelijke mate van zorg wordt verlangd. Hoewel sommige schrijvers en de lagere rechtspraak ook tendeerden naar een risico-aansprakelijkheid bij art. 1403, lid 1 is dit in 1979 definitief door de HR afgewezen. ${ }^{171}$

De HR: 'in onderdeel (...) wordt het bestaan van een rechtsregel ingeroepen welke zou inhouden dat degeen die een bijzonder gevaar opleverende zaakin casu vinylacetaat - onder zijn opzicht heeft, aansprakelijk is wanneer dat gevaar zich verwezenlijkt, als ware het verwezenlijken van dat gevaar aan zijn fout te wijten. Het bestaan van een zodanige rechtsregel kan naar huidig Nederlands recht niet worden aangenomen. Ook bij schade, veroorzaakt door bijzonder gevaar opleverende zaken die iemand onder zijn opzicht heeft, moeten onrechtmatigheid en schuld worden vastgesteld, wil aansprakelijkheid worden aangenomen. Ook de minder vergaande regel $(\ldots)$, inhoudende dat degeen die de zaak onder zijn opzicht heeft bewijs zou moeten leveren dat de schade niet door zijn onrechtmatige daad is veroorzaakt opdat hem ter zake geen verwijt treft, kan niet worden aanvaard'.

\subsubsection{Enkele opmerkingen over artikel $1638 x$ in de praktijk en de toekomst}

In het vorige hoofdstuk is melding gemaakt van het in 1976 gepubliceerde onderzoek inzake het gebruik van art. $1638 \mathrm{x}$ in de praktijk. Het bleek dat betrekkelijk weinig werknemers - zeker gezien het grote aantal (geregistreerde) bedrijfsongevallen - hun civiele rechten, althans bij de rechter, geldend maakten. Als er al iets gebeurde, was dit meestal het buiten proces onderhandelen over een mogelijke schadevergoeding met (de verzekeraar van) de werkgever. Een aantal mogelijke oorzaken werd voor dit geringe gebruik genoemd: angst voor de relatie met de werkgever, onbekendheid met de juridische mogelijkheden, uitkeringen tot vaak $100 \%$ van het laatstgenoten loon, interne bedrijfsregelingen, ontbrekende medewerking van de Arbeidsinspectie bij de bewijsplicht en veel nog niet opgeloste rechtsvragen. Wel werd de verwachting uitgesproken, dat in de toekomst meer schadeclaims bij de rechter gedeponeerd zouden worden. Is deze verwachting ook uitgekomen? Vast staat dat er sinds 1976 wel het een en ander veranderd is in verband met art.

169 HR 21 juni 1974 , NJ 1975, 17, m.nt. G.J.S.

170 HR 13 juni 1975 , NJ $1975,509$.

171 HR 22 juni 1979 , NJ 1979,535, m.nt. G.J.S. 
1638x. Veranderingen die tevens, althans gedeeltelijk, betrekking hebben op de (vermeende) oorzaken van het geringe gebruik van het artikel door getroffen werknemers. In de eerste plaats geeft de (gedeeltelijk in werking getreden) Arbowet een zekere invulling aan het begrip redelijke zorg. En in het algemeen is door deze wet en het proces van totstandkoming ervan het belang van goede arbeidsomstandigheden en de waarde die daaraan moet worden toegekend, benadrukt en meer bekend geworden. In de tweede plaats zijn de WAO-uitkeringen in vergelijking met tien jaar geleden procentueel behoorlijk gezakt. De financiële noodzaak tot het voeren van een schadevergoedingsprocedure bij de rechter zou daardoor ook toegenomen kunnen zijn. In de derde plaats lijkt de Arbeidsinspectie, méér dan vroeger, bereid te zijn om de gelaedeerde werknemer terzijde te staan met behulp van onderzoeksrapporten en ander bewijsmateriaal. Tot slot zijn sinds 1975 een aantal rechtsvragen met betrekking tot art. 1638x beantwoord, die grotendeels strekken ten faveure van de getroffen werknemers. Ik denk hierbij onder meer aan de restrictieve interpretatie van het begrip grove schuld en aan de verlichting van de bewijslast voor de werknemer. ${ }^{172}$

Ter beantwoording van bovenstaande vraag is informatie ingewonnen - evenals bij het vorige onderzoek - bij de bureaus van de rechtskundige dienst van de FNV. Uit de verstrekte gegevens lijkt met de nodige voorzichtigheid opgemaakt te kunnen worden, dat de bureaus tesamen thans per jaar (althans in 1985 en in 1986) ruim 200 gevallen krijgen voorgelegd. ${ }^{173}$ Dat is ten opzichte van het vorige onderzoek een verdubbeling. Percentueel komt het echter nog steeds zelden tot een rechtszaak: in slechts $10 \%$ van de gevallen werd voor de kantonrechter geprocedeerd op grond van art. $1638 \mathrm{x}$. Dit percentage komt globaal overeen met dat van 1976. In absolute zin is er dus ook sprake van een verdubbeling van het aantal $1638 \mathrm{x}$-procedures. Dit beeld lijkt te worden bevestigd door het kaartsysteem van de Nederlandse jurisprudentie: in de periode 1967-1976 trof ik zes uitspraken over art. 1638x en in de periode 1976-1985 waren dat er twaalf.

Ook een, overigens zeer beperkt, onderzoek van de Erasmusuniversiteit wijst in dezelfde richting. ${ }^{174}$ Van acht geïnterviewde slachtoffers van een bedrijfsongeval was er slechts één een civiele procedure tot schadevergoeding begonnen; twee anderen onderzochten nog de mogelijkheden. De meeste respondenten hadden echter wel een beroep gedaan op (rechts)hulpverleners. Uit het bovenstaande zou de voorzichtige conclusie kunnen worden getrokken, dat, terwijl het aantal bedrijfsongevallen ongeveer gelijk is gebleven, zich beduidend meer slachtoffers wenden tot rechtshulpverleners teneinde de mo-

172 Resp. HR 27 juli 1975, NJ 1976, 81; HR 25 juni 1982, NJ 1983, 151. Zie voor een bespreking valn deze arresten eerder dit hoofdstuk.

173 Het onderzoekje heeft zich beperkt tot die kantoren van de rechtskundige dienst van de FNV waar een of meer schaderegelaars werkzaam zijn. Zij ontvingen een schriftelijke vragenlijst die in $50 \%$ van de gevallen werd beantwoord. Het beeld werd aangevuld met enkele interviews met andere juristen van de rechtskundige dienst en enkele andere rechtshulpwerleners.

174 Anja Tamminga, Irene Vrijk, Peter de Koning, De lange weg naar schadeloosstelling, Wetenschapswinkel/Erasmusuniversiteit, Rotterdam 1986. 
gelijkheden tot schadevergoeding te onderzoeken. Dit heeft echter niet geleid tot een percentuele toename van het aantal $1638 \mathrm{x}$-zaken bij de kantonrechter, hoewel de toename in absolute zin sinds 1976 verdubbeld is.

Hoe valt dit nu te verklaren? De toename van het aantal gevallen bij de rechtshulpverlening zou erop kunnen wijzen dat de verwachting, die in 1976 werd geformuleerd door een aantal rechtshulpbureaus van de FNV is uitgekomen: een grotere bewustwording van de rechten die de werknemer heeft en met name een grotere bekendheid met de mogelijkheden tot schadevergoeding zal leiden tot een toename van het aantal gevallen. Deze grotere bewustwording en kennis van de mogelijkheden heeft er echter waarschijnlijk ook toe geleid, dat er relatief nog weinig geprocedeerd wordt. Uit het eigen onderzoek is gebleken dat in $14 \%$ van de gevallen de werkgever spontaan een vergoeding betaalt. In alle andere gevallen wordt eerst geprobeerd via onderhandelingen met de werkgever tot een bevredigend resultaat te komen. De overheersende mening bij de rechtshulpverleners is dat op die manier méér bereikt kan worden dan via een civiele procedure. Pas als dat niet lukt, bijwoorbeeld ondat er geen verzekeringsmaatschappij opduikt, of omdat de werkgever niet reageert, wordt serieus overwogen de rechter in te schakelen. En op dat moment pleegt de getroffene zelf nogal eens te retireren uit angst voor zijn positie in de onderneming, omdat de rechterlijke weg naar schadevergoeding langdurig en moeizaam is, of omdat psychische druk wordt uitgeoefend. Hoewel er geen reden is om aan te nemen dat deze laatste factoren in de toekomst géén rol meer zullen spelen, vermoed ik toch dat zich gaandeweg ook percentueel méér slachtoffers tot de rechter zullen wenden. Behalve de hierboven genoemde overwegingen wil ik nog de volgende noemen. In de eerste plaats het hierboven besproken recente arrest waarin de $\mathrm{HR}$ uitmaakte, dat bij niet-nakoming door de werkgever van zijn verplichtingen ex art. $1638 \mathrm{x}$ lid 1 er geen ruimte is voor een weging van de wederzijds mate van schuld. ${ }^{175} \mathrm{Er}$ is dus sprake van een volledige aansprakelijkheid van de werkgever tot op het aan het slot van art. 1638x lid 2 bedoelde tegenbewijs ( $\mathrm{nl}$. dat de niet-nakoming is te wijten aan overmacht, of dat de schade in belangrijke mate mede te wijten is aan grove schuld van de werknemer). Hiermee is uiteindelijk de omstreden rechtsvraag beantwoord of de schuld van de werknemer, inliggend tussen lichte schuld en grove schuld zou moeten leiden tot een evenredige vermindering van de schadevergoedingsplicht door de werkgever. In de tweede plaats nieuwe wetgeving. $1 \mathrm{k}$ denk daarbij met name aan de inwerkingtreding (hoewel pas in 1990) van art. 3 Arbowet dat, door de formulering van de door de werkgever in acht te nemen grondbeginselen bij zijn arbeidsomstandighedenbeleid uitstekende aanknopingspunten biedt voor de invulling van zijn op art. $1638 \mathrm{x}$ BW gebaseerde verplichting tot de nodige zorg, en aan art. 7.10.4.2 NBW dat het huidige art. 
$1638 \mathrm{x}$ zal vervangen. ${ }^{176}$ Een essentieel werschil tussen dit laatste artikel en het overeenkomstige in het NBW betreft de bewijslast. Niet de werknemer moet aantonen dat de werkgever tekort is geschoten in zorg, maar de werkgever moet aantonen dat hij al het redelijke heeft gedaan om de schade te voorkomen. Hoewel de HR inmiddels is afgestapt van een ongeclausuleerde bewijsplicht voor de werknemer, is het principe niet aangetast. ${ }^{177}$ Een van de belangrijkste bezwaren tegen de huidige regeling wordt hierdoor dan ook weggenomen. Een ander punt van verschil betreft de vergoeding van immateriële schade. De toelichting bij het nieuwe artikel zegt ondubbelzinnig dat de term 'alle schade" tot uitdrukking beoogt te brengen dat de werknemer ook aanspraak heeft op vergoeding van nadeel dat niet in vermogensschade bestaat en dat de toekenning - in afwijking van art 6.1.9.11-niet ter discretionaire bevoegdheid van de rechter staat. Hoewel over de datum van inwerkingtreden van het nieuwe arbeidsovereenkomstenrecht in het $\mathrm{BW}$ nog niets vast staat, kan de rechter anticiperend al wèl rekening houden met de nieuwe formulering over de zorgplicht voor de werkgever. Dit lijkt mij zeker te gelden voor de bewijslast. Juist in verband met de problemen hiermee immers heeft de minister van Sociale Zaken en Werkgelegenheid in 1980 toegezegd, dat in overleg met zijn ambtsgenoot van justitie een wijziging van art. 1638x in de geest van art. 7.10.4.2 NBW 'op korte termijn zal worden bevorderd'. ${ }^{178}$ (Overigens blijkt 'korte termijn' een rekbaar begrip. Acht jaar na de toezegging is mij van een voorgenomen wijziging van art. $1638 \mathrm{x}$, vooruitlopend op de algehele wijziging van de arbeidsovereenkomst in het NBW, nog niets gebleken).

Wellicht kan in de toekomst ook nog de plicht tot wedertewerkstelling in aangepaste arbeid, zoals die in beginsel geldt voor de werkgever sinds HR 8-111985 (van Haaren-Cehave) een rol gaan spelen: enerzijds zou die wedertewerkstelling een schadebeperkende factor kunnen opleveren voor een werknemer en dus ook voor een werkgever, maar anderzijds zou een onredelijke weigering van wedertewerkstelling door de werkgever een reden kunnen zijn voor een extra schadevergoedingsplicht. ${ }^{179}$ In hoeverre deze kwestie echter in de praktijk van invloed zal zijn op aantallen en inhoud van de procedures, is voor mij nog ongewis.

In elk geval lijkt de op stapel staande invoering van nieuwe wetgeving, gevoegd bij recente jurisprudentie die al dan niet daarop is geïspireerd, voor een substantiële verbetering te kunnen zorgen van de positie van slachtoffers van bedrijfsongevallen.

Een belangrijke ruggesteun bij het ook feitelijk en zonder al te veel romp-

176 De Haarlemse advocaat T. Boekman, die zich regelmatig oocupeert met schadeclaims ten gevolge van bedrijfsongevallen, spreekt in een interview over 'een explosieve groei' van het aantal te verwachten schadeclaims ten gevolge van de invoering van art. 7.10.4.2. NBW. Hij vermeldt dat de 1 promille vergoedingseisen bij bedrij fsongevallen naar zijn verwachting zal groeien naar 1 procent. Interwiew in Toegepaste Wetenschap, TNO-magazine, 1986, nr. 1, p. $6-19$.

177 HR 25 juni 1982, NJ 1983, 151.

178 TK $1979-1980,14.497, \mathrm{nr} .11$ p. 9.

179 HR 8 november 1985 , NJ 1986, 309, m.nt. P.A.S. 
slomp verkrijgen van een adequate schadevergoeding vormt tenslotte een door de werkgever ten behoeve van zijn werknemers afgesloten collectieve ongevallenverzekering. Deze is echter niet verplicht. Wettelijke verplichtstelling van een verzekering waarvoor de premies betaald worden door de ondernemingen en die, aanvullend op de sociale verzekeringen een dekking bieden van materieel en immaterieel nadleel ontstaan door bedrijfsongevallen en beroepsziekten, zou een fraai sluitstuk kunnen vormen van de versterking van de positie van slachtoffers van bedrijfsongevallen. ${ }^{180}$

\section{De ondernemingsraad en de commissies}

\subsection{Inleiding}

Het orgaan dat door de wetgever bij uitstek bedoeld is om de exclusieve beleidsbevoegdheid van de werkgever binnen de onderneming te beperken, is de or. Een gebruikelijke indeling in de gradaties die zijn (mede)zeggenschap kan aannemen, is die in meeweten, meespreken en meebeslissen. ${ }^{81}$ Ten aanzien van de arbeidsomstandigheden in de onderneming wil ik daar in elk geval bij noemen: toezicht, inspectie of controle. ${ }^{182}$ Van oudsher is dit ook een van de eerste vormen geweest van bemoeienis van werknemers met de arbeidsomstandigheden. (Vgl. de arbeiderscontroleurs in het mijnreglement 1906, hoofdstuk II, par. 4.1:). Het is ook in de vorm van controlerecht dat de WOR aan de or mogelijkheden biedt tot zeggenschap ten aanzien van de arbeidsomstandigheden in de onderneming. ${ }^{183}$

In de adviesaanvraag aan de SER met daarin de hoofdlijnen voor de vernieuwing van de bestaande veiligheidswetgeving die uiteindelijk leidde tot de Arbowet, werd aanvankelijk gebroken met het uitgangspunt dat de or ten aanzien van de arbeidsomstandigheden het belangrijkste medezeggenschapsorgaan is. ${ }^{184}$ Minister Boersma stelde namelijk voor om in de grotere bedrijven

180 Vgl. woor dit woorstel eerder en uitgebreider, A.J C.M. Geers en J.K.M. Gevers, NJB, t.a.p. p. $958-959$.

181 Vgl. W.J. Slagter, Compendium van het ondernemingsrecht, Deventer 1985, p. 26; M.G. Rood, Bedrijfsdemocratie: whag of lading?, Deventer 1979, p. 4.

182 Juist in de arbeidsomstandighedenliteratuur wordt deze vorm van zeggenschap net name genoemd. Vgl. bijv. S. Atherley, R. Booth, M. Kelley, Worker's' involwement in occupational health and safety in Britain, International Labour Review, 1975, p. 470. Zij noemen drie basisbevoegdheden: consultation (i.e. unclusief informatic), participation (deelname in het beslissingsproces) en inspection; vlg. ook J.K.M. Gevers, t.a.p. p. 66.

183 Strikt genomen is het instemmingsrecht geen recht op meebeslisset. Immers alteen de ondernemer kan met een voorstel komen (weliswalr ook op initiatief van de or, matar dat behoeft hij niet te honoreren). Pas aan dat voorstel van de ondernemer kan de or al dan niet zijn instemming geven. H.J. de Bijll Nachenius, Artikel 27, Wet op de ondernemingsraden, Alphen a/d Rijn 1983 , p. 58; 1. wan Haren, Medezeggenschap van werknemers in bedrijven en instellingen., Deventer 1985 , p. 373-374.

184 Brief van de minister van Sociale Zaken en Werkgelegenheid van 19 juni 1975 aan de SER, bijlage I bij Advies vernieuwing van de wetgeving betreffende de gezondheid en de weiligheid bij de arbeid, SER, 1976, nr. 18, p. L/5 en p. I/6. 
veiligheidscommissies te doen instellem en in alle bedrijven - met uitzondering van de zeer kleine - veiligheidsvertegenwoordigers van de werknemers te doen aanwijzen, die wensen of ideeën met betrekking tot de arbeidsomstandigheden tot uiting kunnen brengen. De SER ging vervolgens uitvoerig in op de zijns inziens wel zeer summiere uiteenzetting van de minister op dit punt. ${ }^{185}$ Hij meende dat het veiligheidsoverleg niet los kan worden gezien van het algemene overleg in de onderneming en de structuren die daarvoor ontwikkeld zijn. Naar het oordeel van de SER zijn er voor de or wel goede argumenten voor de instelling van een veiligheidscommissie. In ondernemingen zonder or acht hij een wettelijke verplichting tot instelling van zo'n commissie, indien daar aanleiding toe zou zijn, gewenst. De commissies zouden uit rechtstreeks door de werknemers gekozen leden moeten bestaan. Indien er een or is, dient deze in de commissie vertegenwoordigd te zijn. De commissies zouden rechten en bevoegdheden moeten hebben analoog aan die van de or. Het voorstel inzake de aanwijzing van veiligheidsvertegenwoordigers wees de SER van de hand. Naast de algemene regeling voor overleg op de werkplek zou aan deze specifieke veiligheidsvertegenwoordigers anders dan als lid van een veiligheidscommissie, geen behoefte bestaan. In het wetsontwerp is aangesloten bij dit laatste. In plaats van de veiligheidsvertegenwoordiger wordt voorgeschreven dat in iedere afdeling van de onderneming voor zover de arbeidsomstandigheden dat noodzakelijk maken, daarover overleg moet worden gepleegd tussen de leiding van de afdeling en de daarin werkzame werknemers. Blijkens de MvT is dit zeer globaal geformuleerde artikel vooral bedoeld als stimulans voor de invoering van het werkoverleg in het algemeen. ${ }^{186}$

Voor wat betreft de commissie sloeg het ontwerp oorspronkelijk een wezenlijk andere weg in dan door de SER geadviseerd. Terwijl de raad deze commissie zag als een zelfstandig orgaan, naast of zonder de or, met een eigen medezeggenschapsfunctie, beschouwt het eerste ontwerp de commissie, inmiddels commissie voor veiligheid, gezondheid en welzijn gedoopt (commissie VGW uiteindelijk Arbocommissie), meer als een loutere adviesinstantie zowel in ondernemingen mèt als zonder een or. ${ }^{187}$

In het gewijzigd ontwerp is de minister op dit standpunt teruggekomen en is aansluiting gezocht bij het SER-advies. De commissie krijgt dezelfde instemmings bevoegdheid als de or in zaken betreffende de arbeidsomstandigheden. Om nu te voorkomen dat de functie van de or zou worden uitgehold doordat voor specifieke beleidsterreinen zelfstandige commissies worden ingesteld met gelijke bevoegdheden, is echter bepaald dat de verplichting tot de instelling van een Arbocommissie niet kan gelden, indien er reeds een or aanwezig is. Wanneer de verplichting wèl geldt, wordt bij $\mathrm{AMvB}$ vastgesteld. Daarnaast kan het districtshoofd van de Arbeidsinspectie aan een afzonderlijke onderne- 
ming een dergelijke verplichting opleggen, gehoord de werkgever en werknemers.

In de loop van de parlementaire behandeling is de wettekst voor wat betreft de medezeggenschapsaspecten op nog een aantal punten meer in overeenstemming gebracht met de WOR. Het uiteindelijke resultaat is echter niet een naadloze aansluiting geworden. In 1986 heeft de SER hierover desgevraagd een advies uitgebracht dat hieronder bij de bespreking van de samenloop van bepalingen in de WOR en de Arbowet aan de orde zal komen. Maar eerst zal de positie van de or beschouwd worden zoals die juridisch gestalte krijgt in de WOR. Vervolgens zal aan deze positie aandacht gegeven worden in de Arbowet. Dit onderdeel wordt afgesloten met iets te zeggen over de praktijk van het or-werk ten aanzien van arbeidsomstandigheden.

\subsection{De ondernemingsraad in de WOR}

De or heeft al vanaf de eerste WOR een wettelijke basis gehad om zich te bemoeien met de arbeidsomstandigheden in de onderneming. Voor enkele historische aspecten moge ik verwijzen naar het vorige hoofdstuk, de paragrafen 7.2. en 8.4. Over de verplichting voor de werkgever om ervoor te zorgen dat in zijn onderneming een or aanwezig is en over de mate van zijn acceptatie van de or naar paragraaf 2.3. van dit hoofdstuk. Hieronder zullen de belangrijkste rechten, bevoegdheden, taken en faciliteiten aan de orde komen die de or heeft op het gebied van de arbeidsomstandigheden volgens de WOR. Zij liggen op het terrein van het meeweten, meespreken, meebeslissen en het bevorderen van de naleving. Het voorwaardenscheppende en organisatorische recht om commissies in te stellen komt eveneens aan de orde.

\subsubsection{Het instemmingsrecht}

Volgens art. 27 lid 1 behoeft de ondernemer de instemming van de or voor elk door hem voorgenomen besluit tot vaststelling, wijziging of instelling voor een aantal limitatief opgesomde regelingen, die vooral het sociaal beleid betreffen. Hiertoe behoort volgens lid 1 onder e ook een regeling op het gebied van de veiligheid, de gezondheid of het welzijn in verband met de arbeid. De verplichting geldt volgens lid 3 niet, indien en voor zover de betrokken aangelegenheid inhoudelijk is geregeld in een $\mathrm{CAO}$. Een arbeidsvoorwaardenregeling, vastgesteld door een publiekrechtelijk orgaan wordt met een CAO gelijkgesteld. Geeft de or geen instemming, dan kan de ondernemer zich ingevolge het vierde lid wenden tot de bedrijfscommissie om vervangende instemming. Een zonder instemming (hetzij van de or, de bedrijfscommissie of in beroep de minister) genomen besluit is nietig. Dit geldt echter uitsluitend indien de or er binnen een maand schriftelijk een beroep op heeft gedaan. Indien de ondernemer dit beroep niet terecht acht, kan hij op zijn beurt binnen een maand aan de kantonrechter een beslissing ter zake vragen. Van de beschik- 
king van de kantonrechter staat uitsluitend beroep in cassatie open (vijfde lid). Het artikel heeft verscheidene vragen opgeroepen. Sommige hangen samen met de algemene bepalingen in het artikel. Aan een aantal daarvan zal ik kort aandacht schenken. Andere hangen meer specifiek samen met het bepaalde in art. 27 lid 1 onder e.

Onder de werking van art. 27 vallen alleen die besluiten die een algemene strekking hebben. ${ }^{16 *}$ Dat wil zeggen: regelingen die betrekking hebben op alle in de onderneming werkzame personen of op een of meer groepen daarvan. Het instemmingsrecht gaat dus niet op wanneer het voorgenomen besluiten betreft die slechts gelden ten aanzien van individuele werknemers. ${ }^{189}$ Volgens sommige auteurs dient een regeling in de zin van art. 27 lid 1 ook nog permanent of duurzaam te zijn. ${ }^{190}$ De minister lijkt dat echter niet te vinden: ten aanzien van een werktijdregeling, welke wijziging voor een jaar zou gelden, besliste hij in 1986 dat het instemmingsrecht van toepassing was. ${ }^{191}$ Hieruit blijkt overigens al hoe lastig het criterium permanent is. Want weliswaar is een regeling voor een jaar niet permanent, maar helemaal incidenteel is zij toch ook niet.

Volgens de kantonrechter Amsterdam in 1980 is een notitie, een schets of een standpuntbepaling nog geen besluit in de zin van art. 27. ${ }^{192}$ Op de uitspraak is met name door de onduidelijke motivering en formulering terecht kritiek gekomen. ${ }^{193}$ Ervan uitgaande immers dat voor een besluit nog niet per se uitvoeringshandelingen nodig zijn, kan het onderscheid tussen een standpuntbepaling en een besluit wel zeer mistig worden. Ook om andere reden kan het moeilijk zijn om te bepalen of er sprake is van een besluit. Dat is bijvoorbeeld het geval wanneer feitelijk een regeling tot stand komt en toegepast wordt zonder dat een daar aan ten grondslag liggend besluit met zoveel woorden is geformuleerd. De kantonrechter Rotterdam oordeelde in 1981 dat met een bepaalde procedure feitelijk en niet-incidenteel werd afgeweken van een eerder met instemming van de or tot stand gekomen regeling. Hieraan lag blijkbaar een wijzigingsbesluit van de bestaande regeling ten grondslag waarvoor ten onrechte geen instemming was gevraagd. Dus ook wanneer uit gevoerd beleid een feitelijke regeling afgeleid kan worden, is er sprake van een besluit in de zin van art. $27 . .^{154}$

Het instemmingsrecht komt de or niet toe, indien de betreffende materie al inhoudelijk in een $\mathrm{CAO}$ is geregeld. ${ }^{195}$ Inhoudelijk betekent dit dat de onder-

188 TK 1975-1976, 13.954, nr. 3 (MvT), p. 23.

189 Vgl. MvA, t.a.p. p. 22.

190 H.J. de Bijll Nachenius, t.a.p. p. 21; M.G. Rood, t.a.p. art. 27 12-16. Anders I. van Haren, t.a.p. p. 375 .

191 Beschikking minister van Sociale Zaken en Werkgelegenheid, 30 december 1986. Rechtspraak de ondernemingsraad, (ROR) Deventer 1986 II, nr. 34, m.mt. P. v.d. H.

$192 \mathrm{Ktg}$. Amsterdam 16 oktober 1980, NJ 1981, 167.

193 Vyl. M.G. Rood, TVVS, 1981 , p. 49 en P.F. van der Heijden, OR-informatie, december 1980, p. 10.

$194 \mathrm{Ktg}$. Rotterdam 20 augustus 1981 , NJ $1983,9$.

195 Algemeen wordt hieruit afgeleid dat het dus een subsidiair recht betreft. Anders: $F$. Koning. Art. 27 WOR: Een bron van mogelijke spanningen in het arbeidsvoorwaardenoverleg, Blin- 
nemer geen wrijheid meer heeft om tot een zelfstandige beslissing over de in de CAO geregelde materie te komen. Dit geldt per definitie dus voor de standaardbepalingen in de $\mathrm{CAO}$, waarvan geen afwijking mogelijk is. Maar indien de $\mathrm{CAO}$ aan de ondernemer opdraagt om binnen bepaalde voorwaarden of richtlijnen (uitvoerings)regelingen te treffen, dan behoeft hij de instemming van de or.

Indien de bestaande $\mathrm{CAO}$ expireert en een nieuwe aansluitend van kracht wordt, dan is er uiteraard geen probleem met betrekking tot art. 27 lid 3. Dat is er evenmin indien er geen nieuwe $\mathrm{CAO}$ wordt afgesloten, bijvoorbeeld doordat de onderhandelingen definitief zijn afgebroken. Hoe nu in de periode dat de oude CAO is afgelopen en over de nieuwe wordt onderhandeld? Strikt juridisch heeft de or dan weer onverkort zijn instemmingsrecht: er is immers inhoudelijk niets (meer) geregeld. Toch lijkt het verstandig dat zowel de ondernemer als de or zich terughoudend opstellen op dit punt, zeker wanneer het gaat om onderwerpen walarvan het voor de hand ligt of waarschijnlijk is dat zij opnieuw inhoudelijk geregeld worden in de $\mathrm{CAO}$. In het andere geval zou de or op de stoel van de onderhandelende vakbond gaan zitten, wat in elk geval in potentie het vaak toch al wankele evenwicht in de driehoek ondernemer, or en vakbond ernstig zou kunnen verstoren. ${ }^{196}$

In dit verband dient nog vermeld te worden dat bij $\mathrm{CAO}$ verder strekkende bevoegdheden kunnen worden toegekend aan de or dan de WOR biedt (art. 32a lid 1). ${ }^{197}$ Dit kan ook de ondernemer doen door middel van een schriftelijk besluit. Een dergelijk besluit behoeft eveneens de instemming van de or (art. 32 a lid 2). In dit laatste geval geldt dan ook de restrictie dat het instemmingsrecht vervalt bij inhoudelijke regeling in een $\mathrm{CAO}$ (art. 32b). Ingevolge art. 32

de wllekken in het sociaal recht (Frenkel-tundel), Deventer 1986, p. 258. H.J. de Bijll Nachenius meent dat het woord 'inhoudelijk' beter geschrapt kan worden. De CAO-partijen zijn immers wrij om bepaalde regelingen te treffen. Laten zij echter bewust een zekere ruimte over, dan zow het niet aangaan om bij de invulling daarvan een andere en zwaarde re procedt:re woor te schrijven. T.a.p. p. 36; voorts over de distributic van medezeggenschapsrechten en de problemen van samenloop die zich daarbij kunnen voordoen: M.G. Rood, Over samenloop wan medezeggenschapsrechten, Arbeid in kort geding, Deventer 1983 (Borgerhofr Mulder-bundel), p. 89-107.

196 B. Geersing meent dat in die pre-contractuele fase de ondernemer door de aan de gang zijnde onderhandelingen is gebonden en acht het in strijd met de redelijkheid, te betrachten jegens de vakorganisatie, indien hij instemming vraagt over onderwerpen die tijdens de onderhandelingen aan de orde zijn. Derhalve komt volgens hem aan de or geen instemmingsrecht toe. B. Geersing, Ondernemingsraden, Alphen a/d Rijn 1979, p. 90. Anders: M.G. Rood, t.a.p. art. 27-20-24; Duk, Fase, van der Heijden, Masschaupt, t. a.p. art . 27-35; F. Koning, t.a.p. p. 260 ; van Haren t.a.p. p. 397.

Voor een oplossing van de problematiek suggereren Fase en Koning om in art. 27 lid 3 op te nemen dat het gaat om een aangelegenheid die "gewoonlijk" bij CAO wordt geregeld (KOning) of 'pleegt' te worden geregeld (Fase).

197 Uit cen in 1988 gepubliceerd onderzoek van de. Dienst Collectieve Arbeidsvoorwatarden is gebleken dat in 38 van de 70 onderzochte CAO's bovenwettelijke bevoegdheden aan de or zijn toegekend. Het gart daarbij vooral om de rol wan de or bij de arbeidsduurverkorting en de uitbreiding c.q. nadere invulling van de faciliteiten voor or-leden. Ministerie van Sociale Zaken en Werkgelegenheid, Dienst Collectieve Arbeidswoorwatarden, OR-bevoegdheden in CAO's, Den Haag 1988. 
kan ook de SER verdergaande bevoegdheden toekennen; ook dan is de bepaling van art. $32 \mathrm{~b}$ van toepassing.

Een met instemming van de or genomen besluit behoeft de individuele werknemers nog niet automatisch te binden. Dat is alleen het geval voor zover het gaat om besluiten die vallen onder de wrije beleidssfeer van de ondernemer, bijvoorbeeld bij het geven van regels krachtens het 'directie-recht' van art. $1639 \mathrm{~b}$ BW. Maar een met instemming van de or genomen besluit kan geen inbreuk maken op de inhoud van de arbeidsovereenkomst tussen werkgever en werknemers. De betekenis van zo'n besluit is dan dat aan de ondernemer als het ware een groen licht gegeven is om met werknemers te onderhandelen, teneinde de arbeidsovereenkomst in overeenstemming te brengen met het met instemming van de or genomen besluit. ${ }^{198}$

Wanneer is er nu sprake van regelingen op het gebied van de veiligheid, de gezondheid of het welzijn in verband met de arbeid? Voor het antwoord op deze vraag is betrekkelijk weinig jurisprudentie en literatuur beschikbaar. Ook de toelichting van de wetgever is uiterst karig. Duidelijk is wel dat in beginsel het gehele terrein van de humanisering van de arbeid wordt bestreken, waarbij het dus gaat om zowel de materiële aspecten (veiligheid en gezondheid) als de immateriële (welzijn tot uitdrukking komend in de inhoud en de organisatie van de arbeid). Uiteraard is het in de praktijk vaak moeilijk om een dergelijk onderscheid te maken. Dat is ook niet nodig. Het is wel zaak, juist door de onderlinge verwevenheid en het brede terrein dat bestreken wordt, om erop bedacht te zijn dat het instemmingsrecht niet uitgehold wordt, doordat feitelijk al regelingen getroffen en uitgevoerd zijn, terwijl er voor het betreffende besluit eigenlijk instemming vereist zou zijn. In een aantal gevallen zal het gaan om regelingen die verplicht voortvloeien uit de Arbowet. Indien het gaat om concrete opdrachten waardoor de ondernemer geen eigen beleidsvrijheid meer heeft, dan behoeft hij geen instemming te vragen. Dat is logisch. Bij weigering van de instemming immers en het volgen daarvan door de ondernemer zou hij in strijd met de wet handelen en zich zelfs schuldig kunnen maken aan het plegen van een economisch delict. Wanneer de Arbowet de ondernemer echter nog vrijheid verschaft om tot een eigen toepassing, invulling of interpretatie te komen, dan behoeft hij de instemming van de orindien uiteraard aan de overige vereisten voor een dergelijk besluit zoals die hierboven zijn vermeld, voldaan is. Het gaat om de bescherming en het welzijn van de eigen werknemers. Besluiten op het gebied van beveiliging tegen bijvoorbeeld inbrekers vallen er dus buiten.

Om een indruk te krijgen van de regelingen die bedoeld kunnen worden in art. 27 lid 1 onder e geef ik hieronder enkele voorbeelden. ${ }^{199}$

198 Uitwoerig hierover: Duk, Fase, van der Heijden, Masschaupt, t.a.p. art. 27-35 t.w. art. 27-41 (aant. 9 bij art. 27). Vgl. ook H. L. Bakels, Schets van het Nederlands arbeidsrecht, Deventer 1987 (achiste druk), p. 237.

199 Ontleend aan P. Spanjersberg, Veiligheid, gezondheid en welzijn, Instemmingsrecht, Cahiers OR-informatie, nr. 2, 1986, p. 28-31 (oorspronkelijk gepubliceerd in OR-informatie, mei 1984). 
Op het gebied van de veiligheid: regelingen op het gebied van identificatie en analyse van gevaarsrisico's, van de brandveiligheid, van vluchtroutes, van veiligheidsinspecties, van prioriteitstelling bij voorlichting en onderricht. Dit laatste is een voorbeeld van een regeling die een uitwerking vormt van een opdracht in de Arbowet. Volgens art. 6 moet de werkgever voorlichting en onderricht geven. De Arbowet zegt dat het doeltreffend moet gebeuren, zo vaak als nodig is e.d. Maar hòe dat moet gebeuren (schriftelijk, mondeling?) en wie daar het eerst voor in aanmerking komen (jongeren, buitenlanders?), dat zijn vragen waarvan de beantwoording aan de ondernemer wordt overgelaten. Een dergelijke regeling behoeft dus in beginsel de insternming van de or.

Ten aanzien van de gezondheid kunnen genoemd worden regelingen op het gebied van het verlenen van eerste hulp, van het vermijden van gevaarlijke dampen, stoffen en lawaai, van de controle op de naleving van de Ziektewet, van de beperking van het ziekteverzuim.

Bij het welzijn in verband met de arbeid kan gedacht worden aan regelingen op het gebied van het gebruik c.q. de verbetering van gehanteerde gereedschappen, hulpmiddelen e.d., van de arbeidsinhoud (taakroulatie, werkstructurering), van het vermijden van kort-cyclische, monotone arbeid, van het verbeteren van de arbeidsplaats (bijvoorbeeld door een 'plattere' organisatie). Voor wat betreft het begrip welzijn in verband met de arbeid is, tijdens de parlementaire behandeling die geleid heeft tot de huidige tekst van art. 27 lid 1 onder e, door de minister gezegd dat het begrip 'ontleend is aan en geinterpreteerd dient te worden binnen het kader van de in voorbereiding zijnde Arbeidsomstandighedenwet'. 200 (Zie hierover hoofdstuk II, de paragrafen 8.3. en 8.4.).

Ik schreef al dat de jurisprudentie over dit onderwerp schaars is. Mij zijn drie uitspraken bekend inzake art. 27 lid 1 onder e. (De bovengenoemde uitspraak van de Rotterdamse kantonrechter van 16-10-1981 reken ik hier niet bij. Welliswaar ging het om een besluit tot regeling van de veiligheid, de gezondheid of het welzijn, maar bij de kantonrechter stond de vraag centraal of het hier ging om een besluit in de zin van art. 27. Terecht meent Rood dat het begrip veiligheid in dit geval niet discutabel was (zie noot 192).) In 1982 besliste de kantonrechter Hilversum, dat ook het besluit tot het aangaan van een collectieve reis- en ongevallenverzekering voor de in de onderneming werkzame personen aan het instemmingsrecht onderhevig was. ${ }^{201}$ De uitspraak is discutabel. Het verweer van de ondernemer dat art. 27 lid 1 onder e alleen ziet op regelingen die betrekking hebben op voorzieningen binnen de onderneming lijkt mij, mèt de kantonrechter, zeker ten aanzien van bepaalde ondernemingen waarvoor regelmatig buiten de plaats van de onderneming moet worden gewerkt, een te enge interpretatie. Maar het beschouwen van een besluit om een risicoverzekering af te sluiten als een besluit in de zin van art. 27 lid 1 onder 
e lijkt mij weer een te ruime interpretatie. Het gaat om besluiten die bescherming beogen, die een bijdrage pogen te leveren aan een behoorlijk werkklimaat. Niet om maatregelen die, als er tòch een ongeval gebeurt, het risico bij derden verzekeren. ${ }^{202}$ De tweede uitspraak is van de minister van Socialle Zaken en Werkgelegenheid in 1983. ${ }^{203}$ Kort en goed stelde de minister dat een besluit om de controle bij ziekte van het eigen personeel niet meer zelf te doen, maar over te dragen aan het GAK, een regeling is in de zin van art. 27 lid 1 onder e. In 1986 tenslotte kreeg de kantonrechter te 's Gravenhage de gelegenheid zich uit te spreken over de vraag of een besluit om een beheersreglement in te voeren ten behoeve van een informatie-systeem waarbij onder meer het gebruik van tijdschrijfformulieren werd voorgeschreven, een besluit was als bedoeld in art. 27 lid 1 onder e. ${ }^{204}$ Met een beroep op de betekenis van het begrip welzijn in verband met de arbeid in de Arbowet meende de kantonrechter van niet. De uitspraak lijkt terecht. Een beheersreglement kan toch moeilijk gerekend worden tot een materie die (een negatieve) invloed heeft op de inhoud of de organisatie van het werk. Het reglement brengt ook niets nieuws ten aanzien van de bestaande werkzaamheden. Deze moeten alleen geregistreerd worden. De resultaten hiervan kunnen wèl leiden tot een verandering in de organisatie - en wellicht in de inhoud - van de arbeid. In beginsel is dan een dergelijk besluit onderhevig aan het instemmingsrecht.

\subsubsection{De naleving van de veiligheids-en gezondheidsvoorschriften}

Art. 28 lid 1 geeft aan de or een bijzondere taak op het gebied van de arbeidsomstandigheden. 'Zoveel als in zijn vermogen ligt' dient de or de nalleving te bevorderen van de voorschriften ter bescherming van de veiligheid en de gezondheid van de in de onderneming werkzame personen (eenzelfde taak is in dit lid geformuleerd ten aanzien van de voorschriften op het gebied van de arbeidsvoorwaarden). De or heeft in dit opzicht een stimulerende taak. Toch is de gedachte aan een zekere controlerende taak van de or, in elk geval ten tijde van de vervanging van de woorden "het houden van toezicht' door 'bevordert zoveel als in zijn vermogen ligt de naleving' (de WOR 1971) niet geheel losgelaten. Dat blijkt uit de MvT bij art. 28 waarin wordt gesteld dat de or een speciale veiligheidscommissie zou kunnen instellen, die dan in het kader van haar werk regelmatig bedrijfsinspecties kan houden. ${ }^{20.5}$

Het artikel maakt alleen melding van veiligheid en gezondheid. Aangenomen moet worden dat sinds de Arbowet deze stimulerende taak zich uitstrekt over het gehele arbeidsomstandighedenterrein zoals dat door de Arbowet wordt

202 Zo ook: Duk, Fase, van der Heijden, Masschaupt, ta.p. art. 27-104.

203 Beschikking minister wan Sociale Zaken en Werkgelegentheid, 29 julli 1983, Geersing/vam der Heijden, Rechtspraak medezeggenschapsrecht $1982-1983$, nr. 64 .

$204 \mathrm{Ktg}$. "s Gravenhage 23 maart 1986, ROR, $1986 \mathrm{LI}$, nr. 35 . Vgl ook mijn noof in OR-informatie, juli/augustus $1986, \mathrm{p} .43$.

205 TK $1969-1970,10335$ nr. 3 (MvT), p. 24. 
bestreken. ${ }^{206}$ Dit blijkt ook uit de taakomschrijving van de Arbocommissie in art. 14 lid 5 van de Arbowet: het zich beraden omtrent de zorg voor de veiligheid, de gezondheid en het welzijn van de werknemers, het regelmatig overleg plegen met de werkgever daaromtrent en het hem dienaangaande adviseren. Deze taakomschrijving, die krachtens het systeem van de Arbowet ook voor de or geldt, is overigens in verscheidene opzichten ruimer dan de tekst van art. 28 lid 1 WOR. De inhoud van deze laatste bepaling is, voor zover het de arbeidsomstandigheden betreft, als het ware geabsorbeerd door art. 14 lid 5 van de Arbowet.

Indien het betreft interne voorschriften, vervat in regelingen, dan heeft de or uiteraard ook nog het instemmingsrecht. Om aan zijn taak ex art. 28 lid 1 inhoud te geven kan de or gebruik maken van het hieronder te noemen informatie- en initiatiefrecht. (Eveneens ingevolge art. 28 heeft de or nog de taak om het werkoverleg te bevorderen; ook deze taak komt hierna nog aan de orde).

\subsubsection{Het informatie-en initiatiefrecht}

In de eerste plaats heeft de or een algemeen informatierecht. De ondernemer is volgens art. 31 lid 1 verplicht om, desgevraagd, de or tijdig alle informatie te verstrekken die hij voor de vervulling van zijn taak redelijkerwijze nodig heeft. De or kan vragen om deze informatie schriftelijk te verschaffen. Bij bezwaren van de ondernemer beslist de bedrijfscommissie. In ondernemingen met minder dan 100 werknemers behoeft de ondernemer de informatie niet schriftelijk te geven.

De or moet deze informatie dus nodig hebben voor de vervulling van zijn taak, d.w.z. taken die door of krachtens de WOR aan de or zijn toegekend. ${ }^{217}$ Hiertoe behoort ook het initiatiefrecht met betrekking tot alle aangelegenheden die de onderneming betreffen (art. 23; zie hieronder).

In de tweede plaats heeft de ondernemer op grond van art. $31 \mathrm{~b}$ een specifieke informatieplicht op het gebied van het sociaal beleid, met name ten aanzien van de aangelegenheden als bedoeld in de artt. 27 en 28. Dus ook ten aanzien van het beleid op het gebied van de veiligheid, de gezondheid en het welzijn in verband met de arbeid. In tegenstelling tot de informatie ex art. 31 moet deze informatie tenminste éénmaal per jaar ongevraagd gegeven worden over het beleid van het afgelopen jaar. Deze gegevens moeten zodanig gespecificeerd worden dat daaruit blijkt welke uitwerking de verschillende onderdelen van het sociaal beleid hebben gehad voor de afzonderlijke afdelingen van, en functiegroepen in de onderneming. In de meeste ondernemingen worden deze gegevens verstrekt in de vorm van een sociaal jaarverslag. In het tweede lid van art. $31 \mathrm{~b}$ wordt de ondernemer verplicht om tegelijk met het verstrekken van de gegevens over het afgelopen tijdvak informatie te verstrekken, schrifte- 
lijk of ook mondeling, over zijn verwachtingen voor het komende jaar (tijdvak) ten aanzien van het door hem te voeren beleid op hetzelfde gebied. Volgens het derde lid van art. 23 is de or bevoegd om tijdens de overlegvergadering alle aangelegenheden die op de onderneming betrekking hebben aan de orde te stellen en om over die aangelegenheden voorstellen te doen en standpunten kenbaar te maken. Uiteraard moet onder 'aangelegenheden de onderneming betreffende' ook gerekend worden onderwerpen op het gebied van het arbeidsomstandighedenbeleid.

Volgens art. 23 lid 4 heeft de or ook buiten de overlegvergadering een recht van initiatief ten aanzien van dezelfde aangelegenheden. De or moet dan zijn voorstel schriftelijk en gemotiveerd aan de ondernemer voorleggen. Over dit voorstel moet ten minste éénmaal in een overlegvergadering overlegd worden. Daarna moet de ondernemer zo spoedig mogelijk eveneens schriftelijk en gemotiveerd aan de or laten weten of en in hoeverre hij het voorstel overneemt. Wanneer de ondernemer of de or te kennen geeft daarop prijs te stellen, wordt het besluit in een owerlegvergadering kenbaar gemaakt. Indien de ondernemer het voorstel niet, of slechts gedeeltelijk overneemt, heeft de or geen recht van beroep. Het zal duidelijk zijn dat het informatierecht van betekenis kan zijn voor het initiatiefrecht. De initiatiefvoorstellen dienen immers gemotiveerd te zijn, en naarmate een voorstel beter onderbouwd is, is de kans dat de ondernemer het overneemt groter. Evenzo zijn het informatierecht en het initiatiefrecht in onderlinge samenhang van belang teneinde effectief inhoud te kunnen geven aan de bijzondere taken van art. 28 .

\subsubsection{Faciliteiten}

De WOR heeft aan de or faciliteiten toegekend om - onder meer - bovenstaande bevoegdheden behoorlijk te kunnen uitoefenen. Het gaat daarbij vooral om:

- het kunnen uitnodigen van deskundigen (bijwoorbeeld ambtenaren van de Arbeidsinspectie) ter vergadering (art. 16 lid 1)

- het gebruik kunnen maken van voorzieningen die redelijkerwijze nodig zijn (art. 17 lid 1)

- het kunnen vergaderen tijdens normale werktijd met behoud van loon (art. 17 leden 2 en 3 )

- de mogelijkheid tot onderling beraad en beraad met en raadpleging van al dan niet in de onderneming werkzame personen (art. 18 lid 1)

- het kunnen deelnemen aan scholings- en vormingsactiviteiten (art. 18 lid 2).

\subsubsection{Commissies van de or}

Art. 15 van de WOR biedt de mogelijkheid aan de or om commissies in te stellen. De wet onderscheidt drie soorten commissies: de vaste commissie, de onderdeelcommissie en de voorbereidingscommissie (respectievelijk de leden 1,2 en 3 van art. 15). Vooral ook door de introductie van de Arbowet kan het 
instellen van met name een vaste commissie van de or deze laatste (gedeeltelijk) ontlasten van de uit deze wet voortvloeiende extra belasting. De in veel ondernemingen bestaande veiligheidscommissies e.d. die opereren op basis van door de werkgever toegekende bevoegdheden, ontberen immers de door de Arbowet toegekende en vaak afdwingbare rechten en bevoegdheden. Als de or vervolgens zijn uit de Arbowet voortvloeiende taak in verband met het bestaan van dergelijke organen niet uitoefent, betekent dat in de praktijk vaak minder in plaats van meer zeggenschap terzake van de arbeidsomstandigheden.

Het instellen van commissies op basis van de WOR kan bovendien de participatiegraad van de overige werknemers bij het arbeidsomstandighedenbeleid verhogen. Tot slot noemt de Arbowet (toevallig eveneens in artikel 15) niet voor niets de (vaste) commissie als mogelijkheid om de aan de or in de Arbowet toegekende bevoegdheden geheel of gedeeltelijk over te dragen.

Een vaste commissie van de or ex art. 15 lid 1 WOR die zich bezighoudt met arbeidsomstandigheden, wordt in het algemeen commissie voor veiligheid, gezondheid en welzijn (commissie VGW) genoemd, ter onderscheiding van de Arbocommissie ex art. 14 van de Arbowet, die alleen ingesteld kan worden door de daartoe aangewezen werkgever als er geen or is.

Samenstelling, werkwijze en bevoegdheden van de commissie VGW kunnen uitsluitend worden vastgelegd in het or-reglement. Dit reglement moet ter goedkeuring aan de bedrijfscommissie worden gezonden. De ondernemer moet eerst gehoord worden door de bedrijfscommissie bij welke gelegenheid hij zijn eventuele bezwaren kenbaar kan maken. Hij zou dit bezwaar bijvoorbeeld kunnen maken indien de arbeidsomstandigheden relatief van zo weinig belang zijn dat de or deze taak gemakkelijk zelf kan vervullen. Vaste commissies kunnen worden ingesteld voor de behandeling van bepaalde onderwerpen. De omvang van de vaste commissie wordt door de wet volledig vrij gelaten. Wel bepaalt art. 15 lid 1 dat een meerderheid van de commissie uit orleden dient te bestaan. Ook tegen de samenstelling van de commissie zou de ondernemer bezwaar kunnen maken. Hij zal dit met name doen als hij meent dat de commissie te veel niet-or-leden heeft. Alle leden hebben immers de rechtsbescherming tegen benadeling en ontslag van art. 21 WOR.

Op instigatie van de FNV hebben de PvdA en de PPR tijdens de behandeling van het ontwerp Arbowet een motie ingediend om, teneinde meer werknemers bij de arbeidsomstandigheden te betrekken, de meerderheidsclausule uit art. 15 lid 1 WOR te schrappen. De motie is, met een beroep op het feit dat het betreffende artikel nog pas onlangs zo was geformuleerd en dat er bij aanneming kans zou bestaan op nog meer overlegsituaties en versnippering van het beleid, verworpen. ${ }^{208}$ De niet-or-leden moeten in elk geval wel in de onderneming werkzaam zijn. Dit sluit externe deskundigen als lid van de commissie uit. De manier waarop de or de leden van de commissie benoemt, is geheel vrij.

De bevoegdheden van de or kunnen in het reglement geheel, gedeeltelijk of 
onder voorwaarden aan de commissie worden overgedragen. Kunnen: het hoeft niet. In dat geval heeft de commissie nog wel de bevoegdheden die de wet zelf geeft aan de commissie zoals het recht op informatie, en het recht om deskundigen uit te nodigen. Delegatie van die bevoegdheden die uit andere wetten dan de WOR voortvloeien, is slechts mogelijk voor zover die wetten zelf die mogelijkheid openen. ${ }^{209}$ Dat is uitdrukkelijk het geval met de bevoegdheden van de Arbowet, krachtens art. 15 van die wet. Uiteraard zal de taakstelling van de vaste commissie per onderneming verschillen en daarmee de mate waarin bevoegdheden worden overgedragen.

Al eerder pleitte ik voor het functioneren van een vaste VGW-commissie als adviescommissie van de or, met daarnaast een aantal uitvoerende taken, zoals bijvoorbeeld het verzamelen van gegevens over de arbeidsomstandigheden in de onderneming. De overdracht van bevoegdheden dient aan deze taak gerelateerd te zijn. ${ }^{210}$ De vaststelling van het door de or te voeren beleid op het gebied van de arbeidsomstandigheden, alsmede het overleg daarover met de werkgever - al dan niet op initiatief van de or - en het instemmingsrecht van art. 27 lid 1 onder e blijven dan bij de or. Voor deze taakverdeling is een aantal redenen aan te voeren. In de eerste plaats heeft de or, waarschijnlijk méér dan een commissie, een overzicht van en inzicht in het totale ondernemingsbeleid waarvan het arbeidsomstandighedenbeleid volgens de Arbowet een onderdeel dient te zijn. Hierdoor kan een betere afweging van en coördinatie tussen de verschillende belangen worden gemaakt. In de tweede plaats kan een maximale overdracht van taken en bevoegdheden het gevaar opleveren, dat er in de praktijk als het ware twee ondernemingsraden zijn met uiteenlopende belangen: een voor het meer traditionele, vooral economisch gerichte beleid, en een voor het sociaal beleid. In de derde plaats blijft in de bovengenoemde constructie de directe verantwoordelijkheid berusten bij het centrale medezeggenschapsorgaan in de onderneming. Dat komt de helderheid ten goede en voorkomt eventuele misverstanden.

De procedure voor het instellen van een onderdeelcommissie ex art. 15 lid 2 is dezelfde als die voor het instellen van een vaste commissie. De onderdeelcommissie kan worden ingesteld voor - geografisch - verspreide onderdelen van de onderneming. Een onderdeel van een onderneming is een groep van personen die binnen een onderneming een organisatorisch verband vormt, waarin op basis van een arbeidsovereenkomst arbeid wordt verricht, maar die niet als een zelfstandige eenheid naar buiten optreedt. ${ }^{211}$ In de onderdeelcommissie

209 I. van Haren, t.a.p. p. 208.

210 A. Geers, Veilig en wel, Alphen a/d Rijn 1985 (tweede herziene druk), p. 64-65.

211 'TK 1976-1977, 13.954, nr. 6 (MvA), p. 25 'Verspreid" betekent: in een apart gebouw waarbij de afstand tot het hoofdgebouw irrelevant is. Beschikking minister Sociale Zaken en Werkgelegenheid, 6 september 1982; Geersing/v.d. Heijden, Rechtspraak medezeggenschapsrecht 1982-1983, nr. 26. Nauwelijks een jaar daarvoor nam de minister aan, dat een "kantoorcommissie' een commissie was in de zin van art. 15 lid 2, terwijl niet bleek dat het kantoor als verspreid onderdeel kon worden aangemerkt. Beschikking minister Sociale Zaken en Werkgelegenheid, 3 juli 1981, Geersing/v.d. Heijden, Rechtspraak medezeggenschapsrecht 1981 . 1982, nr. 13 . 
kunnen de in die onderdelen werkzame personen zitting hebben, alsmede leden van de or. Deze laatsten behoeven dus niet in de betreffende afdeling werkzaam te zijn. Indien in het reglement de bevoegdheid wordt toegekend aan deze commissie om het overleg te voeren met de leiding van het betreffende onderdeel, dan gaan de bevoegdheden van de or, ten aanzien van de aangelegenheden van dat onderdeel, over naar de commissie, tenzij de or besluit om een of meer aangelegenheden zelf te behandelen. De rechten en bevoegdheden van de Arbowet kan de or volgens art. 15 lid 2 echter alleen overdragen aan de (vaste) VGW-commissie. Indien de onderdeelcommissie een taak heeft op het gebied van het werkoverleg zoals dat geformuleerd is in art. 16 lid 1 Arbowet, dan is daarmee volgens lid 2 van dit artikel aan de verplichting tot werkoverleg voldaan. Ongetwijfeld kunnen ook de onderdeelcommissies een belangrijke bijdrage leveren, juist ook door hun contacten met 'de werkvloer' aan de voorbereiding van het arbeidsomstandighedenoverleg in or en VGWcommissie. Het nadeel dat eventueel verschillende, relatief los van elkaar opererende organen ontstaan, kan vermeden worden door ervoor te zorgen dat in dergelijke commissies in elk geval de or vertegenwoordigd is.

De voorbereidingscommissie tot slot (art. 15 lid 3) is een adviescommissie voor, en door de or tijdelijk ingesteld, ter voorbereiding van bepaalde door de or te behandelen onderwerpen, bijvoorbeeld op het gebied van de arbeidsomstandigheden. Deze commissies hebben overigens geen wettelijke bevoegdheden. Er moet minimaal één or-lid zitting in hebben. Indien de ondernemer bezwaar maakt tegen een voorbereidingscommissie kan de or zich wenden tot de bedrijfscommissie.

\subsection{De ondernemingsraad in de Arbowet}

In de Arbowet krijgt de or een aantal nieuwe taken en bevoegdheden. Het belangrijkste recht op het terrein van de arbeidsomstandigheden had de or echter al op grond van de WOR: het instemmingsrecht van art. 27 lid 1 onder e. In de WOR heeft de or geen adviesrecht specifiek ten aanzien van dit terrein. Dat is in de Arbowet wèl het geval. In het algemeen wordt dit recht echter niet zo genoemd; dan heet het het recht om gehoord te worden of recht op overleg vooraf. Bij het ontbreken van de or komen deze rechten ook toe aan de Arbocommissie, indien aanwezig. (Indien beide organen afwezig zijn bovendien aan de belanghebbende werknemers of een meerderheid van hen, of, in sommige gevallen aan de vakorganisatie). In de systematiek van de Arbowet staat de Arbocommissie bovendien in die zin centraal dat een aantal faciliteiten van de or ontleend worden aan deze Commissie. Inmiddels heeft de SER voorgesteld om deze opzet te wijzigen (zie hiema paragraaf 3.4.). Hieronder zal eerst aandacht geschonken worden aan deze Arbocommissie, onder meer in relatie tot de or en de commissies van de or. Vervolgens zullen de faciliteiten van de Arbocommissie - en dus ook van de or - aan de orde komen. Daarna de informatierechten van de or, de adviesrechten en enkele verplichtingen. 


\subsubsection{De Arbocommissie, de gemengde commissie en de or}

Nadat in art. 13 aan de werkgever en de werknemers de verplichting tot samenwerking is opgelegd , wordt in het pas in de laatste fase, waarschijnlijk 1990 , in te voeren art. 14 bepaald dat hiertoe één of meer Commissies voor veiligheid, gezondheid en welzijn moeten worden ingesteld. Deze Commissies worden in het algemeen Arbocommissies genoemd, exclusief gebaseerd als deze zijn op de Arbowet en ter onderscheiding van de in de vorige paragraaf genoemde commissie VGW van de or. In de Arbowet wordt het woord Commissie, als een Arbocommissie wordt bedoeld, met een hoofdletter geschreven. ${ }^{212}$ De verplichting tot het instellen van een Arbocommissie geldt alleen voor bedrijven en inrichtingen die behoren tot een onderneming waarvoor geen or is ingesteld. In de praktijk dus (meestal) de kleine ondernemingen met minder dan 35 werknemers. De verplichting geldt bovendien alleen door aanwijzing: voor categorieën bedrijven en instellingen door AMvB en voor afzonderlijke door het districtshoofd van de Arbeidsinspectie (art. 14 leden 2 en 3). De Arbocommissie moet zijn samengesteld uit vertegenwoordigers van de werknemers uit de desbetreffende bedrijven en inrichtingen. De Commissie kan geen groter aantal leden tellen dan een or op grond van de WOR zou tellen, indien voor de betrokken werknemers een or zou zijn ingesteld. In art. 14 lid 4 wordt bepaald dat de bestuurder in de zin van de WOR voor de toepassing van dit artikellid niet als werknemer wordt beschouwd. Dit betekent dus dat werknemers die werkzaam zijn in een functie die vergelijkbaar is met die van een bestuurder in de zin van de WOR niet tot lid van een Arbocommissie kunnen worden gekozen en dat zij niet mogen worden meegeteld als het gaat om de vraag naar de grootte van de in te stellen Arbocommissie.

De in de vorige paragraaf al genoemde taak van de Arbocommissie is het zich beraden over de arbeidsomstandigheden in de onderneming en het adviseren aan en overleggen met de werkgever ten aanzien van dit onderwerp. Hoewel de taak van de or met betrekking tot de arbeidsomstandigheden in de onderneming dezelfde geacht wordt te zijn als die van de Arbocommissie, verschillen de formuleringen in de WOR en in de Arbowet. Aangenomen moet echter worden dat het inhoudelijk om dezelfde taken gaat, met dien verstande dat art. 14 lid 5 Arbowet een verplichting bevat voor de Arbocommissie om de werkgever te adviseren terwijl in het systeem van de WOR een bevoegdheid wordt verleend aan de or (art. 23 leden 3 en 4) om dat te doen. Mede daarom is zowel in het parlement als daarbuiten gepleit voor verplichte aanwijzing van Commissies voor veiligheid, gezondheid en welzijn, ook indien er een or is, of

212. Ten onrechte was in de publicatie van de Arbowet in het Staatsblad $(1980,664)$ in art. 16 lid 1 het woord commissie vermeld. Dit had Commissie moeten zijn, omdat het gaat om de Arbocommissie van art. 14. Bij de dereguleringswetswijziging is dit abuis per ] januari 1988 hersteld (S. 1987, 535). 
voor direct gekozen veiligheidswertegenwoordigers zoals oorspronkelijk de bedoeling was. ${ }^{213}$

In het zesde lid van art. 14 is het instemmingsrecht van de Arbocommissie geregeld. De formulering wijkt in één opzicht af van de omschrijving van hetzelfde recht dat in art. 27 lid 1 onder e WOR aan de or is toegekend. De beperking dat het voorgenomen besluit betrekking heeft 'op alle of een groep van de in de onderneming werkzame personen' staat niet in art. 14 lid 6 Arbowet. Toch is de betekenis hiervan niet dat het instemmingsrecht van de Arbocommissie óók van toepassing is wanneer een voorgenomen besluit aan de orde is dat slechts van toepassing is op één of enkele werknemers die te zamen geen groep vormen. In de eerste plaats is het blijkens de parlementaire behandeling de bedoeling geweest dat inhoud en strekking van het instemmingsrecht van or en Arbocommissie dezelfde zouden zijn. In de tweede plaats gaat het in beide artikelen om regelingen. En in de MvT die leidde tot de wijziging van de WOR in 1979, staat uitdrukkelijk dat het tot dan toe gebruikte woord maatregel wordt vervangen door regeling 'ten einde tot uitdrukking te brengen dat het om een besluit van algemene strekking gaat en niet tevens, hetgeen het woord 'maatregel' insluit, om een op een individuele werknemer gericht besluit'. ${ }^{214}$ (Zie ook paragraaf 3.2.1. van dit hoofdstuk). In het zesde lid van art. 14 wordt het derde lid van art. 27 WOR - handelend over het ontbreken van een instemmingsrecht indien en voor zover de betrokken aangelegenheid inhoudelijk in een $\mathrm{CAO}$ is geregeld - van overeenkomstige toepassing verklaard. Dit geldt eveneens voor het vragen van vervangende instemming aan de bedrijfscommissie (art. 14 lid 7). Tegen een besluit van de bedrijfscommissie kan door een aantal met name genoemde personen en instanties een bezwaarschrift worden ingediend bij de minister (art. 42 lid 5). Dit laatste is in de WOR weer wèl anders geregeld: volgens art. 44 lid 1 WOR kan iedere belanghebbende in beroep bij de minister.

In het tiende lid van art. 14 wordt aan de Arbocommissie een aantal bevoegdheden en faciliteiten toegekend die in de volgende paragraaf worden genoemd. Het belang van art. 14 is nu vooral hierin gelegen dat deze bevoegdheden en faciliteiten ook toekomen aan (leden van) de or. Het wettelijk systeem ziet er immers als volgt uit. Het geïnstitutionaliseerde overleg met de werkgever over de arbeidsomstandigheden dient primair gevoerd te worden door de

213 Zie ook de inlleiding van deze paragraaf en voorts: TK 1979-1980, 14.497, nr. 11 (Nota n.a.v. het eindwerslag), p. 38, waarin de bewindsman op vragen van de CDA-fractie, geinspireerd door de FNV, opmerkte dat de or de wrijheid moest hounden on commissies in te stellen; Openbare Commissievergadering, Handelingen 1979-1980, p. 1295, waarin de PvdA cen (verworpen) amendement verdedigde van Moor c.s. (nr, 41) dat er op neer kwam dat alle ondernemingen met meer dan 25 werknemers een commissie zouden moeten hebben; J Bloemarts, Op weg naar een drie partijen-model woor het sociaal beleid in de onderneming? de FNV over het ontwerp Arbowet, SMA, 1978, p. 590-603, m.n. p. 602; H.G. de Gier, Making work more human. Een beschouwing over betekenis en achtergronden wan hel' wetsontwerp arbeidsomstandigheden, Beleid en matschappij, 1978, p. 263-272; H.G. de Gier, Making work more human. Welzijn en overleg in thet gewijzigde Wetsontwerp arbeidsomstandigheden, Beleid en maatschappij, 1980, p. 101-107, m.n. p. 105.

214 TK 1976-1977, 13.954, nr. 3 (MvT), p. 44. 
or. Pas als die er niet îs, kàn - via aanwijzing - een Arbocommissie verplicht worden gesteld. ${ }^{215}$ Deze laatste heeft, teneinde haar taken behoorlijk te kunnen vervullen, bevoegdheden en faciliteiten gekregen. Om nu te zorgen dat de (leden van de) or niet in een nadelige positie komen te verkeren ten opzichte van de (leden van de) Arbocommissie, worden deze bevoegdheden en faciliteiten op grond van art. 15 lid 1 ook toegekend aan de (leden van de) or. Uit het tweede lid van art. 15 blijkt dat waar in de Arbowet rechten of bevoegdheden worden gegeven aan de (leden van de) or, deze ook toekomen aan (de leden van) een commissie VGW indien en voor zover die rechten en bevoegdheden in het reglement van de or zijn overgedragen. 216

Hoewel art. 14 nog niet in werking is getreden, 'geldt' het tiende lid wel. Immers art. 15 is wèl in werking getreden en daarin staat dat het bepaalde in art. 14 lid 10 met betrekking tot de rechten van de leden van de Arbocommissie van overeenkomstige toepassing is ten aanzien van de leden van de or (zie de noten 307 en 308 van het vorige hoofdstuk).

Tot slot dient hier nog enige aandacht te worden geschonken aan de al in paragraaf 3.2.5. genoemde commissie die elke wettelijke status ontbeert, maar die in een aantal ondernemingen functioneert op het gebied van de arbeidsomstandigheden en vaak veiligheidscommissie, soms ook Arbocommissie wordt genoemd. De samenstelling van een dergelijke gemengde commissie kan verschillen, maar meestal zitten er vertegenwoordigers in van de kant van de werkgever, personeelszaken, de bedrijfsgezondheidsdienst, de veiligheidsdienst en van de or. ${ }^{217}$ Haar taak is meestal het adviseren over veiligheids- en gezondheidsaangelegenheden aan de werkgever en haar bevoegdheden gaan zover als de werkgever toelaat.

$\mathrm{Bij}$ de rol van deskundigen en or-leden in een dergelijke commissie kunnen vraagtekens worden geplaatst. ${ }^{28}$ In de Arbowet wordt uitdrukkelijk bepaald dat de deskundigen (bedrijfsarts, veiligheidsdeskundige) ook verplicht zijn om te adviseren aan, nauw samen te werken met en bijstand te verlenen aan de or en de andere werknemers, in dezelfde mate als waarin dat moet gebeuren ten aanzien van de werkgever - maar dat laatste was altijd al zo. Het deelnemen wan deskundigen in een dergelijk orgaan mag dus niet betekenen dat op die manier de deskundigheid op het gebied van de arbeidsomstandigheden wordt gemonopoliseerd door de werkgever. Ook or-leden kunnen uiteraard participeren in een dergelijk orgaan, maar het gevaar van een loyaliteitsconflict met de eigen or - ervan uitgaande dat die zijn wettelijke taak op het

215 Art. 14 lid 1 spreekt ook over een or die 'is ingesteld'. Met andere woorden: Voor het eventueel verplicht doen instellen van een Arbocommissie is het niet relevant of er een or behoort te zijn, maar of er feitelijk een is.

216 De bepaling lijkt overbodig, omdat in ant. $15 \mathrm{lid} 2$ Arbowet geen nieuwe bevoegdheid wordt gecreèerd: bedoeld is immers de commissie vat art. 15 lid 1 WOR. Er is echter én verschit: in het systeem van de WOR hebben alleen or-leden recht op scholing en vorming; in het systeem van de Arbowet (art. 14 lid 10 jo art. 15 lid 2 ) ook de nietwor-leden in een VGWconmissie.

217 H.J. van Zwam, Veranderingen in het Arbeidsomstandighedenrecht, Deventer 1983, p. 19 25 .

$218 \mathrm{Ik}$ deed dat eerder in: Veilig en wel Alphen a/d Rijn 1985 (tweede druk), p. 67-68. 
gebied van de arbeidsomstandigheden serieus neemt - is dan niet denkbeeldig. In elk geval zou het meedoen van or-leden aan een dergelijke 'informele' commissie geen alibi mogen vormen voor de or om geheel of gedeeltelijk af te zien van de Arbo-wettaken of om geen gebruik te maken van de wettelijke rechten en bevoegdheden. Dat zou geheel in strijd zijn met de bedoeling van de Arbowet. Een mogelijkheid zou kunnen zijn dat de or-leden in een dergelijk orgaan de vaste commissie VGW van de or vormen. De vergaderingen in die andere commissie kunnen dan beschouwd worden als een soort overlegvergaderingen.

Samenvattend: drie soorten commissies op het gebied van de arbeidsomstandigheden zijn mogelijk. In de eerste plaats de Arbocommissie van art. $14 \mathrm{Ar}-$ bowet die alleen na aanwijzing ingesteld kan worden als er geen or is. In de tweede plaats de (vaste) VGW-commissie van de or, gebaseerd op art. 15 lid 1 WOR en bovendien genoemd in art. 15 lid 2 Arbowet. In de derde plaats een (gemengde) commissie die onder verschillende namen opereert zonder wettelijke basis.

\subsubsection{Rechten en faciliteiten}

De rechten en faciliteiten, genoemd in art. 14 lid 10 voor de Arbocommissie, komen dus ook toe aan de leden van de or en aan de leden van de VGWcommissie voor zover deze althans gedelegeerd zijn. In het ver-vervolg zal ik alleen spreken over de or en leden van de or. Het gaat om de volgende rechten en faciliteiten:

- scholing en vorming

Aan or-leden moet in werktijd en met behoud van loon de mogelijkheid worden geboden om de scholing en vorming te ontvangen die zij voor de uitoefening van hun taak redelijkerwijze nodig hebben (art. 14 lid 10 onder a). Een dergelijk recht is ook in de WOR toegekend: art. 18 lid 2. Bij onenigheid tussen werkgever en or over het aantal dagen dat hieraan besteed mag worden, beslist volgens art. 18 lid 3 WOR de bedrijfscommissie, met dien verstande dat het aantal dagen niet lager mag zijn dan vijf per jaar. (Dit minimum geldt niet voor ondernemingen met minder dan 100 werknemers, art. 35a WOR). De Arbowet kent ter zake geen nadere regeling. Bij onenigheid is hier de Arbeidsinspectie de aangewezen beroepsinstantie; door middel van een verzoek om wetstoepassing kan een beslissing gevraagd worden in de vorm van een aanwijzing (art. 40 jo art. 35) ${ }^{219}$ Zowel op de beslissing van de bedrijfscommissie als op die van de Arbeidsinspectie is beroep mogelijk bij de minister van Sociale Zaken en Werkgelegenheid. Over de botsing van de beroepsprocedures heeft de SER inmiddels geadviseerd (paragraaf 3.4.1.).

219 Art. 15 Arbowet (faciliteiten van de Arbocommissie gelden ook voor de or) wordt niet genoemd in art. 35 (aanwijzing van de Arbeidsinspectie). Gezien de samenhang tussen art. 15 en het wel in art. 35 genoemde art. 14 lid 10 moet aangenomen worden dat een aanwijzing ook gegeven kan worden tem aanzien van art. 15. 


\section{- beraad en raadpleging}

Aan de or-leden moet in werktijd en met behoud van loon voldoende tijd en gelegenheid worden geboden voor raadpleging van al dan niet in de onderneming werkende personen, voor onderling beraad en voor kennisnemen van de arbeidsomstandigheden in de onderneming (art. 14 lid 10 onder $\mathrm{c}$ ). Het recht van onderling beraad en beraad met en raadpleging van anderen is ook geregeld in art. 18 lid 1 WOR. Indien or en werkgever het onderling niet eens kunnen worden, beslist de bedrijfscommissie. Het aantal uren voor ondernemingen met meer dan 100 werknemers mag echter niet lager worden gesteld dan 60 per jaar (art. 18 lid 3 WOR). Voor wat betreft dit laatste aspect in de Arbowet gaat op, wat hiervoor is gezegd over scholing en vorming: bij onenigheid is de Arbeidsinspectie de scheidsrechtelijke instantie. Ook over de samenloop van deze procedures op basis van Arbowet en WOR heeft de SER geadviseerd (paragraaf 3.4.1.).

- vergezellen van ambtenaren van de Arbeidsinspectie

Aan or-leden moet de mogelijkheid worden geboden om de ambtenaren van de Arbeidsinspectie tijdens hun bezoek aan de onderneming te vergezellen, tenzij deze ambtenaren daartegen bezwaar maken vanwege een goede uitoefening van hun functie (art. 14 lid 1 onder d). De Arbowet stelt geen grens aan de tijd die aan dit - volstrekt nieuwe - recht mag worden besteed. In elk geval mag deze tijd niet in mindering worden gebracht op de uren die ingevolge art. $18 \mathrm{lid} 1 \mathrm{en}$ art. $35 \mathrm{alid} 1$ onder $\mathrm{f}$ WOR zijn overeengekomen of vastgesteld voor onderling beraad en raadpleging van al dan niet in de onderneming werkzame personen. ${ }^{220}$ Het betreft hier immers een niet van de WOR afgeleid, geheel zelfstandig recht. Bij dit 'vergezelrecht' kan onder meer gedacht worden aan een inspectie in het kader van de controle op de naleving van de wet of een onderzoek naar aanleiding van een ongeval, een klacht, een verzoek om wetstoepassing, of een aanvraag voor een vergunning of een ontheffing. De ambtenaar zou bezwaar kunnen maken in verband met zijn taakuitoefening wanneer het gaat om persoonsgebonden zaken, zoals het horen van getuigen of bij een ongevalsonderzoek. Het recht is evenmin van toepassing wanneer de ambtenaar de onderneming bezoekt voor een onderhoud of bespreking met de werkgever, al dan niet op diens uitnodiging, bijvoorbeeld voor een adviesgesprek. Wel verzoekt de Arbeidsinspectie daarbij altijd de werkgever of hij bij de or melding wil maken van een dergelijk gesprek. In het omgekeerde geval gaat een dergelijk verzoek uit naar de or. Wil hetzij de or, hetzij de werkgever aanwezig zijn bij een gesprek met één van hen, dan moeten or en werkgever dit onderling afspreken. Eventuele schriftelijke adviezen worden dan door de Arbeidsinspectie in afschrift aan de andere partij gezonden. ${ }^{221}$

220 Zo ook: Voorlopige Arbeidsraad, Advies inzake de eerste fase van invoering van de Arbeidsonnstandighedenwet, Zoetermeer, 17 juni 1982, p. 18.

221 Directoraat-Generaal wan de Arbeid, Hoofdafdeling voor Sociaal bedrijfsbeleid, Het uitvoeringsbeleid met betrekking tot het vergezelrecht, Voorburg, juli 1985, p. 3. 
- vertrouwelijk onderhoud met ambtenaren van de Arbeidsinspectie Aan or-leden moet de mogelijkheid worden geboden om zich buiten tegenwoordigheid van anderen met de ambtenaren van de Arbeidsinspectie te onderhouden. Ook dit recht is nieuw en ook hier heeft de Arbowet geen grens gesteld aan de te besteden tijd voor deze activiteit. Uiteraard heeft ook de werkgever - al is dit niet expliciet in de Arbowet vermeld - het recht om vertrouwelijk met de ambtenaren te spreken. Het initiatief voor een vertrouwelijk gesprek kan natuurlijk ook uitgaan van de Arbeidsinspectie zelf.

- gebruik van voorzieningen

De werkgever moet het gebruik toestaan van de voorzieningen waarover hij als zodanig kan beschikken en die de or voor de vervulling van zijn taak nodig heeft (art. 14 lid 10 onder f). Art. 17 lid 1 WOR heeft ondanks enkele redactionele verschillen, eenzelfde strekking. Ook bij onenigheid over deze faciliteit is de voorziening in de WOR de bedrijfscommissie, en in de Arbowet de Arbeidsinspectie. Er is echter één verschil met de eerder genoemde samenloop-procedures: tegen een beslissing van de bedrijfscommissie als bedoeld in art. 17 lid 1 tweede zin staat geen beroep open bij de minister. (Zie ook over deze samenloop het nog te bespreken SER-advies; paragraaf 3.4.1.).

\subsubsection{Recht op informatie}

De or heeft recht op informatie - en in sommige gevallen op bijstand en advies - van een aantal in de Arbowet genoemde personen en instanties. Zij volgen hieronder:

- informatie door de werkgever

In de eerste plaats hebben de leden van de or een algemeen recht op informatie ("het verschaffen van de nodige inlichtingen") van de kant van de werkgever op grond van art. 14 lid 10 , onder $b, 1^{\circ}$. De bepaling is te vergelijken met art. 31 lid 1 WOR. De Arbowet geeft echter geen duidelijkheid over de vraag of de informatie mondeling of schriftelijk moet plaatsvinden en beperkt zich niet tot het verschaffen van inlichtingen op aanvraag. Bovendien gaat het in de Arbowet om een informatieplicht jegens individuele leden en in de WOR om de or als geheel. ${ }^{222}$ Terecht stelde de voorlopige Arbeidsraad dat ondanks de geconstateerde verschillen in formulering, gelet op het algemene karakter van de informatieverplichting, er geen problemen behoeven voort te vloeien uit de vraag of de Arbowet op dit punt al dan niet een aanvulling vormt op de WOR. ${ }^{223}$

Naast deze algemene informatieplicht moet de werkgever de or - onge-

222 Op dit informatierecht voor individuele leden is met name door de SER in zijn advies uitdrukkelijk verzocht. SER-advies inzake vernieuwing van de wetgeving betreffende de gezondheid en de veiligheid bij de arbeid, $1976, \mathrm{nr} .18, \mathrm{p} .10$.

223 Voorllopige Arbeidsraad, \#.a.p. p. 16. 
vraagd - een aantal documenten toezenden, respectievelijk hem informeren over de inhoud daarvan: het vastgestelde jaarplan (art. 4 lid 5; nog niet in werking getreden), het arbeidsveiligheidsrapport en wijzigingen daarvan (art. 5 lid 5), het jaarverslag (art. 10 lid 3), de beschikking (zo spoedig mogelijk) van de president van de rechtbank tot het buiten werking stellen van de onmiddellijke werking van een eis van de Arbeidsinspectie (art. 36 lid 8), het bevel (zo spoedig mogelijk) tot stillegging van het werk alsmede de beschikking van de president van de rechtbank op een verzoek tot bekrachtiging van een dergelijk bevel (art. 37 lid 8), een verzoek (zo spoedig mogelijk) om wetstoepassing (art. 40 lid 1), het verzoek om ontheffing van wettelijke voorschriften (art. 41 lid 7).

- informatie, bijstand en advies door de deskundige diensten

Volgens art. 14 lid 10 onder b $2^{\circ}$ hebben de leden van de or recht op de nodige inlichtingen van de hoofden van de deskundige dliensten (de bedrijfsgezondheidsdienst in art. 18 , de veiligheidsdienst in art. 19 en de gecombineerde of Arbodienst in art. 20) en van de mentor ter begeleidling van jeugdige werknemers (art. 8). De verplichting voor de deskundige diensten gaat echter nog verder: zij zijn verplicht om te adviseren aan, onderscheidenlijk nauw samen te werken met en bijstand te verlenen aan de or, evenals trouwens aan 'de werknemers' en de werkgever (resp. art. 18 lid 3, art. 19 lid 3 en art. 20 lid 4). Bovendien moeten de diensten ongevraagd een afschrift zenden aan de or van de adviezen, uitgebracht aan de werkgever (art. 17 lid 3, art. 18 lid 3, art. 19 lid 3 en art. 20 lid 4). Tot slot dienen zij jaarlijks een verslag uit te brengen aan de or over hun werkzaamheden en bevindingen (art. 18 lid 4, art. 19 lid 4 en art. 20 lid 4). ${ }^{224}$ Het voldoen aan de informatieplicht door de hoofden van de deskundige diensten kan niet rechtstreeks worden afgedwongen, omdat de aanwijzing van de Arbeidsinspectie gericht wordt tot de werkgever. De laatste dient er voor te zorgen dat de hoofden van de deskundige diensten hun verplichtingen ten opzichte van de or nakomen.

- informatie door de Arbeidsinspectie

Ook de Arbeidsinspectie heeft ten opzichte van de leden van de or een algemene informatieplicht en wel op grond van art. 14 lid 10 onder b $3^{\circ}$. Daarnaast moet de Directeur-Generaal van de Arbeid of het districtshoofd en in een enkel geval de minister een aantal documenten - ongevraagd en bij gedagtekend schrijven - ter kennis brengen van de or: de aanwijzing door de Directeur-Generaal van een bedrijf of inrichting om een arbeidsveiligheidsrapport te componeren (art. 5 lid 14), de eis van het districtshoofd tot het verstrekken van gegevens of het treffen van nadere of andere voor-

224 De verplichting tot toezending aan de werkgever is niet expliciet in de wet opgenomen. In de MvA aan de Eerste Kamer wordt - terecht - opgemerkt dat dat ook niet hoeft, omdat de deskundigen geen werknemersvertegenwoordigers zijn, maar functionarissen die hun taak uitoefenen onder verantwoordelijkheid van de werkgever. Derhalve bestaat de verplichting tot verslaglegging aan de werkgever reeds uit dien hoofde. Eerste Kamer, 1980-1981, 14.497, nr. 12 (MvA), p. 5 . 
zieningen dan die al in het arbeidsveiligheidsrapport zijn opgenomen (art. 5 lid 14), de eis van het districtshoofd tot het totstandbrengen van voorzieningen om de gevolgen van een ramp te beperken (art. 5 lid 14), de aanwijzing door de Directeur-Generaal om een bedrijfsgezondheidsdienst, een veiligheidsdienst of veiligheidskundige te hebben ( $a r t .18$ lid 2, art. 19 lid 2), een eis van het districtshoofd betreffende geneeskundig onderzoek (art. 26 lid 3), het onderzoeksrapport van de Arbeidsinspectie (art. 35 lid 2), een aanwijzing tot naleving (art. 35 lid 2), een eis tot nalleving (art. 36 lid 4), een afwijzing op het verzoek om wetstoepassing (art. 40 lid 3), een beschikking tot ontheffing van de naleving van wettelijke voorschriften (art. 41 lid 9), de beslissing van de minister op een bezwaarschrift (art. 42 lid 10). ${ }^{22.5}$

\subsubsection{Recht om te adviseren}

In de navolgende gevallen heeft de or het recht om vooraf gehoord te worden, om zijn mening kenbaar te maken en om voorafgaand overleg te voeren respectievelijk te adviseren.

Het recht om gehoord te worden en zijn mening kenbaar te maken heeft de or bij: de individuele verplichtstelling van een arbeidsveiligheidsrapport (art. 5 lid 2), de individuele verplichtstelling van een bedrijfsgezondheidsdienst, veiligheidsdienst of veiligheidskundige (resp. art. 18 lid 2 en art. 19 lid 2), een aanwijzing door de Arbeidsinspectie (art. 35 lid 1), de schorsing door de president van de Rechtbank van de onmiddellijke werking van een eis van de Arbeidsinspectie tot stillegging van het werk (art. 37 lid 3 ), de beslissing van de Arbeidsinspectie op een verzoek om wetstoepassing (art. 40 lid 2), de beslissing van de Arbeidsinspectie op een verzoek om ontheffing van wettelijke voorschriften (art. 41 lid 8), het advies van de Arboraad aan de minister over een bezwaarschrift tegen een beslissing van de Arbeidsinspectie (art. 42 lid 9). Recht om advies te geven c.q. Overleg te voeren heeft de or over het ondernemingsbeleid, voor zover dat van aanwijsbare invloed kan zijn op de veiligheid, de gezondheid en het welzijn van de werknemers, alsmede over het jaarplan (art. 4 lid 4), het arbeidsveiligheidsrapport en de wijzigingen daarin (art. 5 lid 6), benoeming en ontslag van de mentor (art. 8 lid 5) en van de deskundigen in de bedrijfsgezondheidsdienst en de veiligheidsdienst (de veiligheidskundige) (art. 18 lid 5 en art. 19 lid 5).

\subsubsection{Verplichtingen}

De or heeft in de Arbowet ook enkele verplichtingen. De eerste is de verplichting tot samenwerking met de werkgever (art. 13; zie hiervoor de paragrafen 2.2.8. en 2.3. van dit hoofdstuk).

225 Bij de dereguleringswetswijziging is per 1 januari $1988(\$ .1987,535)$ art. 43 lid 6 vervallen. Hierin stond dat het in ieder geval" tot de taak van de Arboraad behoorde om, onder meer, aan de or desgewenst bijstand en advies te geven ower vraagstukken van veiligheid, gezondheid en welzijn in verband met de arbeid. 
Volgens art. 34 lid 4 hebben de leden van de or een geheimhoudingsplicht van alle zaken- en bedrijfsgeheimen waarvan $\mathrm{zij}$ in hun hoedanigheid kennisnemen, voor zover deze geheimhouding niet in strijd is met wettelijke bepalingen (inclusief uiteraard de bepalingen van de Arbowet). Deze geheimhoudingsplicht is overigens beduidend minder omvattend dan die ten aanzien van de or-leden in art. 20 lid 1 WOR is geformuleerd. Daar strekt de plicht zich uit, behalve ten aanzien van zaken- en bedrijfsgeheimen, tot alle aangelegenheden ten aanzien waarvan de ondernemer dan well de or hun geheimhouding heeft opgelegd of waarvan zij, in verband met de opgelegde geheimhouding het vertrouwelijke karakter moeten begrijpen. Volgens de minister dient het begrip bedrijfsgeheim, althans in de Arbowet, eng te worden opgevat. Het gaat om gegevens die van belang zijn in de concurrentiestrijd en waarvoor de 'bedrijfsspionage' zich interesseert. ${ }^{226}$

Tot slot zijn uiteraard de verplichtingen die gelden voor alle werknemers ook van toepassing op or-leden (zie voor deze individuele verplichtingen hoofdstuk IV).

\subsection{Samenloop bepalingen Arbowet en WOR}

Zoals hierboven is gebleken, is er op een aantal punten sprake van een samenloop van bepalingen van de WOR en de Arbowet. Dit kan in de praktijk problemen opleveren. Hierop werd reeds uitvoerig gewezen door de VAR in het kader van zijn advies inzake de eerste fase van invoering van de Arbowet. ${ }^{227}$ Een belangrijke oorzaak voor deze problematiek is ongetwijfeld te vinden in de ontstaansgeschiedenis van de overlegstructuur van de Arbowet. ${ }^{228}$ Uitgangspunt was immers een betrekkelijk nieuwe overlegstructuur, waarbij nauwelijks rekening werd gehouden met de al bestaande overlegmogelijkheden in de WOR (zie ook paragraaf 3.1.). Logischer ware het geweest indien voor de medezeggenschapsaspecten in de Arbowet was voortgebouwd op de fundamenten in de WOR. Weliswaar is er tijdens de parlementaire behandeling van de Arbowet nog duchtig gesleuteld aan de betreffende bepalingen van de Arbowet, maar dat heeft zeker niet alle problemen opgelost. Deze problemen betreffen de faciliteitenregeling in de Arbowet en de WOR en de daarop gebaseerde verschillende beroepsprocedures in beide wetten, de scholing en vormingsregeling in beide wetten, de mogelijkheden van het instemmingsrecht en de verschillende daarmee verband houdende procedures in beide wetten, de positie van groeps- en centrale ondernemingsraden en de samenloop van overlegverplichtingen in de WOR en de Arbowet. De meeste onderwer-

226 TK 1978-1979, 14.497, nr. 11 (Nota n.a.v. het eindverslag), p. 43.

227 Voorlopige Arbeidsraad, t.a.p. p. 11-21. Over de oplossing van de problematiek verschilden werkgevers en werknemers overigens van mening. Met name de werkgeversvertegenwoordigers drongen aan op wetswijziging.

$228 \mathrm{Vgl}$. I. de Meester en H. van de Kamp, Het spanningsveld tussen Arbowet en Wet $\mathrm{OR}$, SMA, 1982, p. 726-735. 
pen zijn al eerder aan de orde geweest. In het kader van de samenloopproblematiek en voor de nodige overzichtelijkheid hierin komen ze hieronder - kort - opnieuw aan de orde. Nadlat van de kant van de verantwoordelijke bewindslieden naar aanleiding van het VAR-advies was toegezegd om aan de SER ter zake van deze problematiek om advies te vragen, is op 10 augustus 1984 de adviesaanvraag verstuurd ${ }^{229}$ Op 23 mei 1986 werd het advies vastgesteld. ${ }^{230}$

\subsubsection{De adviesaanvraag en het advies}

In de adviesaanvraag werd door de bewindslieden een aantal oplossingen aangedragen waaraan drie uitgangspunten ten grondslag lagen. In de eerste plaats heeft de WOR als doelstelling de medezeggenschap van werknemers ten aanzien van in beginsel alle aangelegenheden van de onderneming, waaronder de arbeidsomstandigheden. De Arbowet heeft als doel het bereiken van een zo hoog mogelijk peil op het gebied van de arbeidsomstandigheden waartoe deze wet onder meer medezeggenschapsregelingen bevat. ${ }^{231}$ Een verschil in doelstelling dus en daarmee samenhangend van instrumentarium. In de tweede plaats dient de afstemmingsproblematiek benaderd te worden vanuit het oogpunt van de praktische consequenties woor de direct betrokkenen. In de derde plaats noemen de bewindslieden het eveneens praktische uitgangspunt dat de Arbowet ook rakkvlakken heeft met andere wettelijke bepalingen, die eigen bepalingen inzake het vertegenwoordigend overleg bevatten. Hoewel uit de adviesaanvraag niet duidelijk wordt welke bepalingen bedoeld worden, begreep de SER dat het gaat om de regelingen voor de overheidssector. Ik zou ook niet weten welke de indieners anders op het oog zouden hebben. Overigens instemmend met deze uitgangspunten wijst de SER ook nog op de uitspraak van de VAR dat bepaalde faciliteiten die de Arbowet aan de or toekent in zoverre zelfstandige betekenis hebben naast de faciliteiten van de WOR, dat zij daaraan een extra dimensie verlenen.

Hieronder komen de vijf problematische onderwerpen aan de orde. ${ }^{232}$ Eerst de faciliteiten. Uiteraard bestaan er alleen problemen ten aanzien van de samenloop van die faciliteiten die zowel in de Arbowet als in de WOR worden toegekend en derhalve ieder een eigen geschillenbeslechtigingsprocedure kennen. Volgens de WOR kunnen de or en de ondernemer zich alsdan wenden tot de bedrijfscommissie en volgens de Arbowet tot het districtshoofd van de Arbeidsinspectie met een verzoek om wetstoepassing. In beide gevallen staat beroep open bij de minister (behalve bij het gebruik van voorzieningen krachtens de WOR; art. 44 lid 1). Eventueel kan een Arob-beroep volgen. Het gaat om de volgende faciliteiten: scholing en vorming, recht op informatie van de werkgever, gebruik van voorzieningen en het recht op onderling beraad en

229 Brief van de staatssecretaris Kappeyne van de Cappello van 10 augustus 1984, opgenomen als bijlage I van het Advies Samenloop Wet or en Arbowet, SER, 1986, nr. 6, p. $27-33$.

$230 \mathrm{SER}$, Advies Samenloop Wet or en Arbowet, Den Haag 1986, nr. 6.

231 Dit uitgangspunt is ontleend a an meergenoemd VAR advies, t.a.p. p. 12.

232 Commentaar op het SER-advies gaf ik eerder in OR-informatie, april 1986, p. 16-19. 
raadpleging van al dan niet in de onderneming werkzame personen..$^{233}$ In de adviesaanvraag wordt voorgesteld om de realisering van deze faciliteiten uitsluitend te doen geschieden in het kader van de WOR. Dit betekent dat de leden van de or de mogelijkheid moet worden ontnomen om bij geschillen over de bedoelde faciliteiten de procedures uit de Arbowet te volgen. Als de juridisch juiste weg om dit te realiseren wilden de bewindslieden een zodanige wijziging van artikel 15 lid 1 van de Arbowet dat het artikel beperkt wordt tot de faciliteiten die alleen in de Arbowet voorkomen. Tevens wilden zij art. 28 lid 1. WOR uitbreiden met het begrip 'welzijn in verband met de arbeid'.

De SER is het eens met de adviesaanvraag om de or-leden de mogelijkheid te ontnemen de beroepsprocedure van de Arbowet te volgen. Wel stelt hij een andere juridische oplossing voor. De SER wil de faciliteitenbepaling in de Arbowet geheel schrappen (uiteraard gaat het nog steeds om de faciliteiten die zowel in de WOR als in de Arbowet staan). Hierdoor is er dus ook maar ến beroepsprocedure mogelijk: die van de WOR. Om ook de leden van de Arbocommissie in staat te stellen om gebruik te maken van die faciliteiten moet in de Arbowet worden verwezen naar de desbetreffende bepalingen in de WOR. Hoewel er, zeker in het licht van de bovengenoemde uitgangspunten, wel iets te zeggen valt voor deze constructie, is er ook wel iets tégen te zeggen. Het is immers evenzeer een belangrijk uitgangspunt dat de Arbowet aan de or aanvullende taken en bevoegdheden toekent. Dit word took door de SER erkend. Dit kan betekenen dat bijvoorbeeld voor scholing en vorming speciaal op het terrein van arbeidsomstandigheden extra tijd nodig is, boven de tijd die de or heeft op basis van bepalingen in de WOR. De erkenning hiervan zal het meest tot zijn recht komen als het 'extra' van die faciliteiten ook op de een of andere manier in de wet tot uitdrukking komt, hetzij in de Arbowet, hetzij in de WOR.

Laat men de faciliteiten in de Arbowet staan, dan kan in die wet ook worden geregeld dat echter de beroepsprocedure van de WOR gevolgd wordt. Juridisch minder fraai, en daarom ook afgewezen als mogelijkheid door de bewindslieden, maar wèl recht doende aan de bedoelingen van de Arbowet.

Kiest men echter voor de oplossing om de 'dubbele' faciliteiten te schrappen in de Arbowet, dan dient, lijkt mij, in ieder geval in de WOR aangegeven te worden dat het bij de faciliteiten op het gebied van de arbeidsomstandigheden gaat om aanvullende, extra faciliteiten. Dit zou kunnen door een aanpassing van de ondergrens van de tijd die minimaal beschikbaar moet zijn voor onderling beraad en raadpleging en voor scholing en vorming, zoals die in artikel 18 lid 3 van de WOR is vastgelegd. (Niet langer dan respectievelijk 60 uren per

233 Volgens de minister omvat het recht op beraad en raadpleging ex art. 18 lid 1 WOR tevens een recht op vrije rondgang voor or-leden ter kennisneming van de arbeidsomstandigheden in het bedrijf. Dit standpunt lijkt mij juist. Derhalve ontstat tevens een samenloop tussen art. 18 lid I WOR en her recht op kennis nemen van de arbeidsornstandigheden ex art. 14 lid 10 onder c Arbowet. Vaste Kanercommissie n.a.w. het rapport "onvolkomenheden, onduidelijkheden en/of omissies in de wet op de ondernemingsraden, TK 1984-1985, 18.980, nr. 4. 
jaar voor beraad en raadpleging en vijf dagen per jaar voor scholing en vorming).

Hierom nadrukkelijk gevraagd, wijst de SER deze mogelijkheid echter af. De SER is van mening dat in het overleg met de ondernemer ook maar afspraken gemaakt moeten worden over de tijd die nodig is in het kader van de Arbowettaken. Bij onenigheid kan dan de bedrijfscommissie worden ingeschakeld. Naar mijn mening miskent de SER met dit standpunt de zelfstandige betekenis van de Arbowet-faciliteiten, ondanks de beleden instemming met dit uitgangspunt. Door een expliciete wettelijke basis aan dit 'extra' te onthouden en de regeling in eerste instantie alleen over te laten aan het overleg tussen ondernemer en or, zou de betekenis van deze faciliteiten in de praktijk wel eens geminimaliseerd kunnen worden. En dat is duidelijk niet de bedoeling van de $\mathrm{Ar}$ bowet. In dit kader geeft de SER nog ter overweging om uit een oogpunt van systematiek wijziging te brengen in de opzet van de artikelen 14 en 15 van de Arbowet. Beter ware het volgens de SER om in de Arbowet uit te gaan van de positie van de or en voor wat betreft de Arbocommissie te refereren aan de or. Dit oordeel van de SER is juist. Het is immers de bedoeling dat de or het eerst aangewezen overlegorgaan is in de onderneming.

Het volgende problematische onderwerp betreft de scholing en vorming van leden van een commissie van de or. Volgens de Arbowet kan onder meer het recht op scholing en vorming door de or gedelegeerd worden aan een (VGW-) commissie (art. 15 lid 2). Indien de or dat doet, dan komt dit recht toe aan alle leden van de commissie, 66 k als zij geen or-lid zijn. Volgens de WOR kan deze bevoegdheid uitsluitend worden overgedragen aan de or-leden van de commissie.

In de adviesaanvraag wordt voorgesteld deze discrepantie op te heffen door ook in de WOR te regelen dat niet-or-leden, die in een vaste commissie VGW zitten, eveneens een recht op scholing en vorming hebben (uiteraard alleen als de or die bevoegdheid heeft overgedragen).

De SER vindt het in de WOR toekennen van een zelfstandig recht op scholing en vorming aan alle leden van een VGW-commissie niet de juiste oplossing. Zoals de SER ook ten aanzien van het vorige onderwerp concludeert, vindt hij dat ook in dit opzicht maar in het overleg tussen ondernemer en or afspraken moeten worden gemaakt over de tijd voor scholing en vorming voor leden van een vaste VGW-commissie, of ze nu lid zijn van de or of niet. Daarom moet in de WOR en in de Arbowet een onderling samenhangende regeling worden getroffen die erin voorziet dat de or, nadat in overleg met de ondernemer de omvang van het recht op scholing en vorming is vastgesteld, kan beslissen dat een deel van de tijd toekomt aan de leden van de VGW-commissie, of ze nu orlid zijn of niet.

In deze oplossing blijft de or dus het orgaan dat bepaalt of, en zo ja hoeveel, tijd voor scholing en vorming toekomt aan de leden van de VGW-commissie, or-lid of niet. Dat lijkt in het licht van de overige bepalingen ten aanzien van een vaste commissie, waaruit blijkt dat de bevoegdheden van de commissie net zo uitgebreid of gering zijn als de or wil, voor de hand liggend. Hierin past ook 
de constructie dat àls de or bevoegdheden wil overdragen, deze ook moeten kunnen gelden ten aanzien van de niet-or-leden in de vaste commissie.

Een derde probleem wordt gevormd door het instemmingsrecht. Het betreft zowel het instemmingsrecht van de or als van de Arbocommissie. Ik beperk me hier tot het eerste. Wanneer de ondernemer een regeling wil treffen op VGWgebied, dan heeft hij daarvoor de instemming nodig van de or op grond van art. 27 lid 1 sub e WOR. Dit kunnen ook regelingen betreffen ter naleving van Arbowetvoorschriften. Hierdoor kunnen samenloopproblemen ontstaan bij de geschillenprocedures, namelijk op grond van de Arbowet en van de WOR.

Als de or geen instemming geeft, kan de ondernemer een verzoek doen om vervangende goedkeuring aan de bedrijfscommissie met eventueel nog beroep op de minister (WOR) of een verzoek tot wetstoepassing aan het districtshoofd van de Arbeidinspectie, met eveneens een beroepsmogelijkheid op de minister (Arbowet). Voert de ondernemer, zonder instemming, tòch een dergelijk besluit uit, dan kan de or zich wenden tot de kantonrechter (WOR), of op basis van de Arbowet, de hierboven genoemde procedure kiezen. Ter oplossing wordt in de adviesaanvraag een wijziging van art. 27 lid 3 voorgesteld. Dit artikellid zou moeten worden uitgebreid met de bepaling dat het instemmingsrecht van de or inzake VGW-regelingen niet van toepassing is indien en voor zover zo'n regeling betrekking heeft op een onderwerp ten aanzien waarvan bij of krachtens de Arbowet voorschriften zijn gesteld. Met andere woorden: het instemmingsrecht van de or wordt hierdoor ten aanzien van deze onderwerpen een subsidiair, ondergeschikt recht, omdat het alleen aan de or toekomt voor zover de ondernemer een VGW-regeling wil treffen die niet onder de Arbowet valt. De adviesaanvraag vermeldt als bedoeling van het voorstel dat, wanneer de regeling geheel betrekking heeft op onderwerpen die bij of krachtens de Arbowet op enigerlei wijze worden genormeerd, die regeling geheel is onttrokken aan het instemmingsrecht. Is dat gedeeltelijk het geval, dan is alleen dat deel van de regeling aan het instemmingsrecht onttrokken. De SER kan zich met de strekking van dit voorstel verenigen.

Ik niet. Het instemmingsrecht is een zelfstandig recht voor de or, dat een grote praktische betekenis kan hebben. Het is het meest vèrgaande recht van de or. Het is duidelijk dat het instemmingsrecht niet kan worden toegepast in die gevallen, waarin op de werkgever duidelijk geformuleerde wettelijke Arbowet-verplichtingen rusten. Daarover kan geen misverstand bestaan. Een parallel zou kunnen worden getrokken met de bepaling in de WOR dat het instemmingsrecht óók niet geldt als de betreffende zaak al inhoudelijk in de $\mathrm{CAO}$ is geregeld. De advies-aanvraag en het advies gaan echter verder. Er is geen instemmingsrecht als het onderwerpen betreft "die bij of krachtens de Arbowet op enigerlei wijze worden genormeerd'. In deze formulering (die ook volledig afwijkt van de formulering in art. 27 lid 3 ten aanzien van de regeling van de betreffende onderwerpen in de $\mathrm{CAO}$ ) blijft er van het instemmingsrecht in de praktijk niets over. Immers, vrijwel alle regelingen die op enigerlei wijze betrekking hebben op VGW-gebied kunnen tenminste onder artikel 3 Arbowet worden gebracht. In dit artikel worden aan de werkgever de 
algemene verplichtingen opgelegd die hij in acht moet nemen bij het organiseren van de arbeid, het bepalen van de produktie- en werkmethoden en het inrichten van de arbeidsplaatsen. Zij hebben in ruime zin zowel betrekking op de veiligheid, de gezondheid als op het welzijn bij de arbeid. Het overleg binnen de onderneming over de arbeidsomstandigheden in de Arbowet staat centraal. Het instemmingsrecht kan hierbij als effectieve stok achter de deur fungeren. Door het praktisch onttrekken van alle VGW-regelingen aan het instemmingsrecht is deze stok achter de deur vervangen door de gang naar de Arbeidsinspectie. Dat kan een uitholling betekenen van de effectiviteit van de inbreng van de or in het arbeidsomstandighedenbeleid in de onderneming. Naar mijn mening dient in artikel 27 WOR opgenomen te worden dat het instemmingsrecht alleen dan niet geldt, indien en voor zover het gaat om onderwerpen die al bij of krachtens de Arbowet inhoudelijk zijn geregeld. Deze formulering sluit aan bij de overeenkomstige bepaling ten aanzien van de $\mathrm{CAO}$ in art. 27 lid 3.

Het vierde onderwerp in het SER-advies betreft de positie van de groeps-en centrale ondernemingsraad (gor en cor). Deze zijn in de Arbowet nergens genoemd. De adviesaanvragers willen deze positie verduidelijken door art. 15 van de Arbowet in die zin aan te passen, dat gor en cor de faciliteiten krijgen die door de Arbowet ook aan de or worden toegekend. De SER is van oordeel dat deze faciliteiten en bevoegdheden naar hun aard in dienst staan van de werknemersvertegenwoordiging in elk afzonderlijk bedrijf. Derhalve behoeft in de WOR of in de Arbowet geen regeling te worden getroffen, die erin zou voorzien dat bedoelde faciliteiten en bevoegdheden onder omstandigheden overgaan op de (leden van de) gor en/of cor.

Dit lijkt mij een redelijk advies.

Tot slot de problemen met betrekking tot de overlegverplichtingen. Volgens art. $31 \mathrm{~b}$ WOR moet de ondernemer, mede ten behoeve van de bespreking van de algemene gang van zaken in de onderneming, ten minste eenmaal per jaar aan de or informatie verstrekken over het gevoerde en te voeren sociaal beleid - dus onder meer over zaken die samenhangen met de op de or rustende taak om de naleving te bevorderen van de voorschriften ter bescherming van de veiligheid en de gezondheid van de in de onderneming werkzame personen. Hieronder vallen ook de desbetreffende Arbowet-voorschriften.

Vervolgens kan de or op basis hiervan het initiatief nemen tot overleg met de ondernemer (art. 23 leden $1 \mathrm{t} / \mathrm{m} \mathrm{4}$ ). Daarnaast bevat (het nog niet in werking getreden) artikell 4 lid 4 Arbowet de verplichting voor de werkgever om zèlf het initiatief te nemen om met de or te overleggen over het ondernemingsbeleid, voor zover dat van aanwijsbare invloed kan zijn op de veiligheid, de gezondheid en het welzijn van de werknemers. Heeft nu art. 4 lid 4 Arbowet zelfstandige betekenis naast de bovengenoemde WOR-bepalingen? De bewindslieden menen van wel. De SER is verdeeld, al wordt deze verdeeldheid enigszins verborgen onder de unanieme mening dat art. 4 lid 4 een zelfstandige betekenis heeft c.q. kan hebben. Oorspronkelijk waren de standpunten (zowel in de VAR, Arboraad, als in het begin van de besprekingen in de SER) 
duidelijker: volgens de werknemers moet art. 4 lid 4 worden beschouwd als een wezenlijke aanvulling op de overlegbepalingen in de WOR. Volgens de werkgevers is art. 4 lid 4 naast de WOR-bepalingen overbodig en dient het dus geschrapt te worden. ${ }^{234}$ In het SER-advies hebben de werknemers (en de Kroonleden) geen behoefte meer om zich in algemene termen uit te spreken over de betekenis wan art. 4 lid 4 , daargelaten of het naast het in de WOR bepaalde een zelfstandige functie vervult, temeer omdat immers reeds in het advies is ingestemd met het doen vervallen van het instemmingsrecht ten aanzien wan arbeidsomstandighedenregelingen. Met andere woorden: het instemmingsvereiste wordt vervangen door een overlegverplichting. De werkgevers zijn het hier weliswaar mee eens, maar wijzen iedere andere zelfstandige betekenis die aan art. 4 lid 4 zou kunnen worden gehecht, af. Zij willen deze eis geconcretiseerd zien in een wijziging van art. 4 lid 4 , zodanig dat dit artikellid uitsluitend beoogt het instemmingsrecht te vervangen door een verplichting van de werkgever om over voorgenomen regelingen tot uitvoering van Arbowet-voorschriften voorafgaand overleg te plegen met de or.

Voor mijn commentaar moge ik in de eerste plaats verwijzen naar datgene dat ik onder het onderwerp instemmingsrecht heb geschreven. Het onverkort onder art. 4 lid 4 brengen van de regelingen waarvoor oorspronkelijk instemming vereist zou zijn, betekent een verschraling van de or-bevoegdheden.

De uiteindelijk terughoudende en betekenisloze opstelling van de werknemers versterkt de indruk dat omwille van het compromis een belangrijk instrument voor de or verloren gaat.

\subsection{Het werkoverleg in de WOR en in de Arbowet}

Het werkoverleg wordt zowel in de WOR als in de Arbowet genoemd. Geen van beide wetten maakt echter duidelijk wat nu precies moet worden verstaan onder werkoverleg. Ook in de literatuur zijn de definities en omsclurijvingen niet eénduidig. ${ }^{235}$ Een aantal elementen keert echter telkens terug. Op basis daarvan kan werkoverleg omschreven worden als het overleg tussen werknemers en de direct leidinggevende over het eigen werk en de werksituatie. Dit overleg is geïnstitutionaliseerd, als zodanig erkend en vindt plaats met een zekere frequentie.

In de WOR wordt het werkoverleg genoemd in art. 27 lid 1 onder j en art. 28 lid 2. In deze laatste bepaling gaat het om de stimulerende rol van de or, net zoals die geldt ten aanzien van de voorschriften op het gebied van de veiligheid en de gezondheid (art. 28 lid 1). In art. 27 lid 1 onder j wordt een regeling op

234. Arboraad, Reactie van 7 oktober 1983 op de ambtelijke nota Beleidswoering in het kader wan de Arbeidsomstandighedenwet, Zoetermeer 1983.

$235 \mathrm{Vgl}$. bijvoorbeeld P.J. de Kleer, Werkoverleg hoeft geen fopspeen te zijn, Alphen a/d Rijn 1.980; NIVE-werkgroep, Ervaringen met werkowerleg in de praktijk, Alphen a/d Rijn 1980; R.J. Pijpers, Hoe floreert en stagneert werkoverleg? Intermediair, nr. 14 (1978), p. 16; J.H. Kuipers, Beleidswoering door werkoverleg, Alphen a/d Rijn/Brussel 1975, p. 8. 
het gebied van het werkoverleg genoemd als een onderwerp ten aanzien waarvan de or instemmingsrecht heeft. In beide artikelen gaat het om het werkoverleg in het algemeen, dus zonder beperking naar onderwerp, met als achterliggend idee dat werkoverleg voor een directe beïnvloeding door de werknemers van hun werk, werkomstandigheden en werkverhoudingen van grote betekenis kan zijn en mede een wezenlijke bijdrage kan leveren aan de democratisering van de onderneming. ${ }^{236}$

In de Arbowet wordt het werkoverleg geintroduceerd in art. 16, dat overigens pas in de laatste fase (1990) in werking zal treden. In die afdelingen van een bedrijf of inrichting die als een werkeenheid kunnen worden beschouwd moet, voor zover de veiligheid, de gezondheid of het welzijn van de betrokken werknemers dat vereist, regelmatig overleg worden gevoerd tussen chef en werknemers. Dit overleg mag ook plaatsvinden met vertegenwoordigers van de betrokken werknemers die uit hun midden zijn gekozen. De verplichting geldt niet indien de werkgever een Arbocommissie heeft ingesteld die uitsluitend werkzaam is ten behoeve van de werknemers van die afdeling. ${ }^{237}$ Volgens het tweede lid van art. 16 is aan de plicht voldaan indien de or voor de afdeling een commissie heeft ingesteld die eenzelfde taak heeft als bedoeld in art. 16 lid 1 . Naast de vragen die dit artikel oproept, zijn ten minste twee verschillen te constateren met het werkoverleg in de WOR. In de eerste plaats gaat het in art. 16 Arbowet alleen om werkoverleg inzake arbeidsomstandigheden en in de tweede plaats betreft het een wettelijke verplichting. Ten aanzien van deze verplichting vermeldt de wet echter geen adressant. Wel wordt in art. 23 onder a de werkgever opgedragen om het werkoverleg te bevorderen, maar niet om thet in te stellen. Indien werkgever en or het oneens zijn over de instelling of organisatie van het werkoverleg, dan kunnen zij de Arbeidsinspectie verzoeken om ter zake een aanwijzing te geven. De werkgever is dan verplicht om te handelen volgens deze aanwijzing (art. 35 lid 1). De Arbeidsinspectie moet in elk geval eerst de werkgever en de or horen, ook indien zij op eigen initiatief een aanwijzing wil geven.

Hoewel er begrip voor kan worden opgebracht dat de verplichting tot het instellen van het werkoverleg - dloor zijn aard moeilijk op te leggen-zich niet direct richt tot de werkgever (of de or), kan dit tot problemen leiden. ${ }^{238}$ Wat moet er immers gebeuren indien de werkgever, daarin gesteund door de or, gestalte wil geven aan zijn wettelijke opdracht om het werkoverleg te bevorderen en de betrokken werknemers willen dat niet? Ambtshalve zal de Arbeidsinspectie in een dergelijk geval geen aanwijzing geven en op verzoek van de werkgever (of de or) zal het ook problematisch worden. Maar wèl wordt dan, geautoriseerd door het toezichthoudend overheidsorgaan contra legem gehandeld. Ook het andere geval kan zich voordoen: de betrokken werknemers

236 TK 1975-1976, 13.954, nr. 3 (MvT), p. 49.

237 Zie noot 212.

238 Vgl. P.L. Spanjersberg, Arbowet, ondernemingsraad en werkoverleg, SMA, 1982, p. 587 597, m.n. p. 595-596; H.J. van Zwam, Veranderingen in het Arbeidsomstandighedenrecht, t.a.p. p. 33 en p. 81 . 
willen werkoverleg maar de werkgever en de or niet. De laatsten kunnen, in tegenstelling tot de werknemers, een aanwijzing aan de Arbeidsinspectie vragen, maar zij zullen het niet doen. De enige mogelijkheid is dan om te bewerkstelligen dat de Arbeidsinspectie op eigen initiatief een aanwijzing verstrekt. Maar ook dat zal zich niet gemakkelijk voordoen, omdat de Arbeidsinspectie gehouden is om, alvorens een aanwijzing te geven, zowel werkgever als or te horen, die dus beiden tegen zijn. (Ik ga hier nog voorbij aan de taak van de or krachtens art. 28 lid 2 WOR om het werkoverleg te stimuleren en het eventueel via art. 36 WOR vorderen van de naleving daarvan door de werkgever). Art. 16 onderscheidt dus twee vormen van werkoverleg: het directe werkoverleg waaraan de chef en alle werknemers meedoen, en het vertegenwoordigend overleg tussen de chef en uit hun midden gekozen vertegenwoordigers van de betrokken werknemers. Het overleg dient plaats te vinden 'indien een bedrijf of inrichting uit afdelingen bestaat, die als een werkeenheid kunnen worden beschouwd'. Wanneer is er nu sprake van een werkeenheid? Volgens de minister is dat afhankelijk van de feitelijke en organisatorische situatie binnen een onderneming en kan dat niet in het algemeen worden vastgesteld. Uitgangspunt is in principe dat er een samenwerkingsverband van werknemers bestaat, waaraan leiding wordt gegeven. ${ }^{239}$

Andere vragen die het artikel oproept, zijn echter onbeantwoord gebleven zoals hoe vaak regelmatig overleg is, in welke gevallen en hoe een vertegenwoordiging tot stand komt, of en zo ja welke faciliteiten de betrokken werknemers hebben en of er wellicht ook waarborgen zouden moeten zijn tegen benadeling en eventueel ontslagbescherming. De vragen zijn overigens bewust onbeantwoord gebleven. Volgens de MvT heeft de minister namelijk het vertrouwen, 'dat de bedrijfsgenoten gezamenlijk voor dit overleg binnen de onderneming geldende regels zullen opstellen' ${ }^{240}$ En later tijdens de parlementaire behandeling nogmaals desgevraagd: 'Men moet dit artikel zien als een eerste aanzet om in Nederland een wettelijke verplichting tot werkoverleg in te voeren. Daarbij kan, gezien de nieuwheid van het terrein, nog niet in bijzonderheden worden getreden. Wellicht is het mogelijk om, wanneer het SER-advies inzake het sociaal beleid in de onderneming is uitgebracht, de thans gegeven globale verplichting verder te detailleren en in te vullen, eventueell langs de weg van het geven van aanwijzingen door de Arbeidsinspectie. ${ }^{\prime 241}$ Het daarna verschenen bedoelde SER-advies laat er echter ook geen misverstand over bestaan dat dit soort zaken binnen de onderneming zelf geregeld behoort te worden. ${ }^{242}$

De verplichting tot werkoverleg vervalt indien de werkgever een Arbocommissie heeft ingesteld die uitsluitend werkzaam is ten behoeve van de werknemers van een afdeling waarin werkoverleg zou behoren plaats te vinden. De bepaling is duidelijk. In de praktijk zal van deze ontsnappingsmogelijkheid

239 Eerste Kamer, 1980-1981, 14.497, nr. 12 (MvA), p. 6.

240 MvT, t.a.p. p. 33.

241 Nota n.a.v. het eindverslag, t.a.p. p. 39.

242. SER-advies inzake sociaal beleid in de onderneming, 1981, nr. 4. 
weinig gebruik kunnen worden gemaakt, omdat een Arbocommissie immers alleen verplicht kan worden gesteld bij het ontbreken van een or en indien daartoe een aanwijzing is verstrekt. Een andere mogelijkheid om de verplichting tot werkoverleg te ontgaan biedt het tweede lid van art. 16: aan het eerste lid wordt geacht te zijn voldaan indien de or voor de afdeling een commissie heeft ingesteld, die een taak heeft zoals in het eerste lid is geformuleerd. Hoewel uit de bewoordingen van dit lid opgemaakt zou kunnen worden, dat hier een onderdeelcommissie wordt bedoeld, is dat niet het geval. ${ }^{243}$ Dat blijkt uit het feit dat oorspronkelijk inderdaad in de tekst van art. 16 (toen nog art. 14) uitdrukkelijk werd verwezen naar art. 15 lid 2 WOR, maar dat deze verwijzing later uit de tekst van het artikel is geschrapt - overigens zonder toelichting. ${ }^{244}$ Een commissie in art. 16 lid $2 \mathrm{kan}$ dus een vaste commissie, een onderdeelcommissie of een voorbereidingscommissie zijn. Terecht is er op gewezen dat in de praktijk elk van de drie commissies in het kader van art. 16 lid 2 specifieke problemen met zich kan brengen. ${ }^{245} \mathrm{Bij}$ een vaste commissie kan het probleem gevormd worden door de wettelijke eis dat een meerderheid uit or-leden moet bestaan. Getalsmatig kan dat in een grote organisatie moeilijkheden opleveren. Ten aanzien van een onderdeelcommissie zou de consequentie zijn dat verspreide onderdelen van grote omvang zonder werkoverleg blijven. Voorbereidingscommissies lijken helemaal niet in aanmerking te komen als substituut voor het werkoverleg, omdat aan deze commissies geen bevoegdheden kunnen worden overgedragen en omdat zij duidelijk bedoeld zijn als tijdelijke ad-hoc commissies.

In het licht van de vragen en onduidelijkheden die art. 16 oproept, kan met recht betwijfeld worden of deze wettelijke opdracht wel een effectief instrument is ter bevordering van de participatie van de werknemers. Dit temeer omdat werkoverleg 'van wezenlijk belang voor de werknemers' wordt geacht en dat 'bij de beraadslagingen in de commissie (bedoeld is de Arbocommissie van art. 14, AG) de leden zich in belangrijke mate zullen laten leiden door hetgeen bij het overleg op de werkplek naar voren is gekomen'. ${ }^{246}$ Uit het laatste citaat blijkt ook dat er een wezenlijke relatie wordt gezien tussen her werkoverleg en de overige overlegvormen in de onderneming. Later werd dit als volgt geformuleerd: 'Ik merk hierbij op, dat het overleg op de werkplek zelf als 'overleg aan de voet' het complement is van het 'geinstitutionaliseerde overleg $^{\circ}$ op hoger niveau in de onderneming... Het directe overleg in de werkeenheid zelf kan niet worden gemist. ${ }^{247}$ (Deze relatie komt ook in de wettekst zelf tot uiting doordat art. 14 lid 4 bepaalt dat, indien werkoverleg in een afdeling plaatsvindt, iedere afdeling eén persoon kiest als haar vertegenwoordiger, en wel in die Arbocommissie die mede ten behoeve van de werknemers van die afdeling is ingesteld).

243 Ten onrechte anders: H.J. van Zwam, t.a.p. p. 81

244 TK 1978-1979, 14.497, nr. 6 (Nota van wijzigingen), p. 7.

245 P.L. Spanjersberg, t.a.p. p. 594.

246 M.T, t.a.p. p. 16 resp. p. 33.

247 MuA, Eerste Kamer, t.a.p. p. 6. 
Nu lijkt het mij van tweeën één te zijn: òf men meent dat werkoverleg onmisbaar is, zowel als intrinsieke doelstelling als ten behoeve van het effectief functioneren van het geïnstitutionaliseerde overleg en dan wordt de regeling ook helder, eenduidig en imperatief geformuleerd in de wet, ò men meent dat het werkoverleg weliswaar een bijdrage kan leveren aan de participatie en het welzijn van de werknemers, maar niet noodzakelijk is en dan kan worden volstaan met meer intentionele formuleringen. In de Arbowet wordt de lacuneuze en de nog veel vragen onbeantwoord latende tekst van art. 16 echter voorafgegaan door doelstellingen en overwegingen die een andere tekst zouden rechtvaardigen.

$\mathrm{Nu}$ is het natuurlijk moeilijk om door wetteksten werkoverleg min of meer af te dwingen. Maar waarschijnlijk is het formuleren van een plicht voor de werkgever of van een ondubbelzinnig recht voor de werknemer, geflankeerd door juridische hulpmiddelen en waarborgen, in de praktijk toch effectiever. ${ }^{248}$ In elk geval kan nu uit onderzoeken geconstateerd worden dat zònder wettelijk instrumentarium het werkoverleg nog niet al te veel om het lijf heeft. ${ }^{249} \mathrm{Ik}$ bedoel dan niet vormen van overleg in de vorm van kwaliteitskringen en MANS: zij komen vooral voort uit door de werkgever gesignaleerde problemen van efficiency, dienstbetoon en kwaliteit. 'Hiermee hebben de ideeën een zekere eenzijdigheid die het beheersingssysteem van het management weerspiegelt... Het gaat om vormen van afhankelijke participatie, waarin van werknemers een zeer grote mate van betrokkenheid wordt verlangd. Men kan zich afvragen of deze op langere duur mogelijk en wenselijk is. ${ }^{2560}$ In elk geval kunnen en mogen zij geen substituut vormen voor het werkoverleg zoals dat kennelijk bedoeld is in de Arbowet.

\subsection{Enkele opmerkingen over de or en de praktijk}

Uit onderzoek is gebleken dat de belangstelling van ondernemingsraden voor het arbeidsomstandighedenbeleid in de onderneming, althans gemeten naar het gebruik wan WOR-instrumenten, betrekkelijk groot is. ${ }^{251}$ Bowendien worden deze instrumenten in het algemeen met succes gehanteerd. Een relatie met de inwerkingtreding van de Arbowet lijkt hierbij wel voor de hand te liggen. Bijna in alle gevallen dat instemming gevraagd moest worden (volgens de mening van zowel de bestuurder als van or-mensen) voor een maatregel ex

248 Tijdens de parlementaire behandeling strekkende tot opneming wan de sociale grondrechten in de Grondwet hebben enkele PwdA-leden voorgesteld, om, náast een aantal andere grondrechten voor individuele werknemers, het werkoverleg op te nemen als (afdwingbaar) recht voor iedere werknemer. TK 1975w1976, 13.873, nr. 6 (Nota individuele werk nemersrechten), p. 26. De regering beloolde een onderzoek waarover niets meer werd vernomen. Zie hierover uitgebreider paragraal 8.8, van het vorige thoofdstuk.

249 Vgl. bijvoorbeeld COB/SER, Medezeggenschap, besluitvorming en organisatie, Eindrapport wan de reeks experimenten medezeggenschap, Den Haag 1985, waarin gesproken wordt over 'teleurstellende resultaten', p. 38.

250 Medezeggenschap, besluitworming en organisatie, t.a.p. p. 244.

251 J.C. Looise, J.Z. Heijink, de or en zijn bevoegdheden, Nijmegen 1986. Zie ook noot 109 
art. 27 lid 1 onder e gebeurde dat ook. Bovendien handelde de ondernemer in bijna $100 \%$ van de gevallen conform de wens van de or. Daarnaast werd opvallend vaak gebruik gemaakt van het initiatiefrecht om onderwerpen op het gebied van de arbeidsomstandigheden aan de orde te stellen. (De meeste initiatiefvoorstellen - ruim $65 \%$ - had betrekking op onderwerpen vallend onder art. 27 WOR; daarvan namen regelingen op Arbogebied met ruim $11 \%$ een derde plaats in).

De belangstelling bleek ook uit de toename van de scholings- en vormingsactiviteiten rondom de inwerkingtreding van de Arbowet. ${ }^{252}$ In de eerste helft van 1983 kwamen de Arbowet of aspecten van arbeidsomstandigheden voor op bijna de helft van alle algemene programma's van or-cursussen. In 1981 bedroeg dit aantal nog maar éénzesde van allle algemene cursussen. Ook het aantal cursussen dat uitsluitend of hoofdzakelijk over arbeidsomstandigheden ging, groeide sterk en bereikte in de eerste helft van 1983 een aantal van 31 , terwijl er in gehéél 1980 nog maar drie cursussen waren. Bovendien bleek uit datzelfde onderzoek dat in méér dan de helft van de 100 plus-ondernemingen commissies bestonden die zich speciaal bezig hielden met de arbeidsomstandigheden. In ruim $70 \%$ van de gevallen was dat een commissie ex art. 15 lid 1 WOR.

Er lijkt dus veel gedaan te worden (te zijn) op het gebied van oriëntatie, scholing, vorming, het formeren van VGW-commissies en het gebruikmaken van de WOR. Ten aanzien van het specifieke Arbowet-terrein lijkt het beeld genuanceerder te zijn. Van een typisch juridisch instrument uit de Arbowet als het verzoek om wetstoepassing (art. 40) wordt betrekkelijk weinig gebruik gemaakt. In april 1983 kon staatssecretaris Kappeyne van de Capello aan de Tweede Kamer schrijven: "Als vermeldenswaardige gebeurtenis uit de afgelopen maanden wil ik nog vermelden, dat er één werkonderbreking heeft plaatsgevonden en één verzoek om wetstoepassing bij de Arbeidsinspectie is binnengekomen. ${ }^{253}$ Uiteindelijk is in heel 1983 tweemaal een verzoek om wetstoepassing binnengekomen, waarvan nog steeds slechts één van de or. ${ }^{254}$ Ook in 1984 is door de or slechts éénmaal gebruik gemaakt van dit recht. ${ }^{255} \mathrm{Nu}$ moeten deze cijfers wel gerelativeerd worden. Een groot aantal artikelen van de Arbowet is nog niet in werking getreden en daartoe behoren betrekkelijk veel bepalingen ten aanzien waarvan, met name na een verzoek om wetstoepassing, een aanwijzing kan worden gegeven.

Van de mogelijkheid om de Arbeidsinspectie te vergezellen (art. 14 lid 10 onder d jo art. 15) werd door leden van de or in de meeste door de Arbeidsinspectue bezochte ondernemingen één of meermalen gebruik gemaakt. (Het

252 GBIO, or-cursussen onderzocht, Arbo-scholing en -vorming in ontwikkeling, Den Haag, december 1983. Zie ook noot 107 .

253 TK $1982-1983,17.600$, hooldstuk XV, nr. 105, p. 24.

254 Voortgangsnotitie Arbowet over 1983, DGA, Voorburg 1984, p. 4

255 Voortgangsnotitie Arbowet over 1984 tot medio 1985, DGA, voorburg, 1985, p. 5. Vanaf 1985 beschik ik niet meer over gegevens omdat de voortgangsnotities una 1985 niet meer zijn verschenen. 
gaat jaarlijks om circa 20.000 bezoeken aan 100 plus-ondernemingen). Van het recht om een afzonderlijk onderhoud te hebben met de ambtenaar van de Arbeidsinspectie werd echter weer nauwelijks gebruik gemaakt. ${ }^{256}$ Dit laatste gold ook voor het recht om hulp te krijgen van deskundigen, en met name de bedrijfsarts. ${ }^{257}$ Omgekeerd is ook slechts de helft van de bedrijfsartsen tevreden over de contacten met de or (en bijna tweederde over die met de directie). 258

Het recente ITS-onderzoek van 1988 bevestigt goeddeels het bovenstaande. ${ }^{259}$ Het informatieniveau van de meeste ondernemingsraden wordt gekenschetst als voldoende tot goed. Ongeveer een kwart van de ondernemingsraden in de onderzochte ondernemingen is zelf actief bezig met de arbeidsomstandigheden. In ongeveer de helft van de ondernemingen is de bemoeienis zeer gering. Ongeveer een kwart van de ondernemingsraden doet niets aan arbeidsomstandigheden. In ondernemingen met een actieve or is relatief vaak eveneens een actieve VGW-commissie. Kennelijk is een dergelijke actieve commissie voor de or geen reden of alibi om geen of weinig bemoeienis te hebben met de arbeidsomstandigheden in de onderneming.

Enkele voorzichtige conclusies kunnen wellicht getrokken worden. Van de Arbowet als juridisch instrument wordt door de or (nog) betrekkelijk weinig gebruik gemaakt, behalve dan in de sfeer van de voorbereiding (cursussen, vorming VGW-commissies), Of dat zal afnemen is de vraag, gezien de regelmatige wisselingen van de wacht in de ondernemingsraden. Dit betekent overigens niet dat er ook aan de arbeidsomstandigheden weinig tot niets wordt gedaan. Dit laatste geldt echter wèl voor kleinere ondernemingen. ${ }^{260}$ Juridisch gezien lijkt de belangstelling voor de Arbowet vooral geresulteerd te hebben in een toename van het gebruikmaken van instrumenten uit de WOR. Het ligt echter voor de hand - en is overigens ook wenselijk - dat, nu de oriëntatiefase achter de rug is, de or meer gebruik gaat maken van de mogelijkheden die de Arbowet biedt. Ongetwijfeld zal een snelle verdere inwerkingtreding vooral van die artikelen die van belang zijn voor de or, hiertoe een bijdrage leveren.

\section{De deskundigen}

\subsection{Inleiding}

Verhoging van de deskundigheid binnen de onderneming is een belangrijk uitgangspunt van de Arbowet. In 1959 werd hiermee al een begin gemaakt door het opnemen van een Wet op de bedrijfsgeneeskunde in de Veiligheids-

256 Voortgangsnotitie 1985 , t.a.p. p. 5.

257 H.N. Plomp. Werknemers en bedrifsgezondheidsdiensten, Amsterdam 1985, p. 119.

258 Nederlands Instituut voor preventieve gezondheidszorg. NIPG/TNO, De bedrijfsarts over zijn werk, Leiden 1984 , p. 160.

259 ITS-onderzoek 1988, t.a.p. p. 61-65.

260 Instituut voor sociaal-wetenschappelijk ondenzoek. IVA, kleine bedrijven en arbeidsomstandighedenbeleid, Tilburg, december 1985. 
wet. ${ }^{261}$ (Zie hoofdstuk II, paragraaf 7.1.). En in 1976 kon in de MvT bij de Arbowet ten aanzien van dit onderwerp tevreden vastgesteld worden dat "de wetgever van 1959 op de goede weg was". ${ }^{262}$

De kern van de huidige regeling is te vinden in de tweede afdeling van hoofdstuk IV van de Arbowet onder het hoofdje 'Adviserende taken en deskundige diensten'. Het gaat om taken op het gebied van het welzijn (art. 17; oorspronkelijk was in dit artikel de Arbodienst geregeld. Als gevolg van de dereguleringsoperatie is per 1 januari 1988 de verplichting tot het oprichten van of het zich aansluiten bij een Arbodienst in art. 17 vervallen, onder handhaving van de materiële taken; de Arbodienst wordt nu genoemd in art. 20), om de bedrijfsgezondheidsdienst (art. 18), om de veiligheidsdienst en de veiligheidskundige (art. 19), om de gezamenlijke dienst, de gecombineerde dienst en de Arbodienst (art. 20), en om Arbo-instituten (art. 21). Artikel 22 handelt over de erkenning. Deskundigen in de Arbowet zijn dus in elk geval de bedrijfsarts en de veiligheidskundige. Daarnaast kan, zo blijkt uit mededelingen van de minister tijdens de parlementaire behandeling van het wetsontwerp, gedacht worden aan arbeidshygiënisten, maatschappelijk werkers, bedrijfspsychologen en ergonomisch geschoolden. Deze laatste groep zou vooral deel uit moeten maken, samen met de bedrijfsarts en de veiligheidskundige, van een geïntegreerde Arbodienst. Om de stoet nog bonter te maken memoreert de minister dat ook personeelsdiensten en 'wellicht andere diensten of afdelingen een rol (kunnen) spelen bij de bescherming van de werknemers'. ${ }^{263}$ Tot slot kunnen onder de deskundigen van de Arbowet ook nog begrepen worden de mentoren ter begeleiding van jonge werknemers in art. 8. Dit laatste artikel is bovendien van verder strekkend belang in verband met de regeling van de ontslagbescherming van mentoren, die van overeenkomstige toepassing is verklaard voor de andere deskundigen (zie ook paragraaf 2.2.5.).

Hieronder zal ik vooral aandacht besteden aan de bedrijfsgezondheidsdienst, omdat deze al sinds 1959 een plaats in de wet heeft gekregen en er dus al iets te zeggen valt over de praktische betekenis van de wettelijk geregelde bedrijfsgezondheidszorg. Bovendien is de huidige regeling ten aanzien van alle deskundige diensten in hoge mate geïnspireerd door de oorspronkelijke regeling in de Veiligheidswet. (De regeling over de bedrijfsgezondheidsdienst in art. 18 is ook als enige van de tweede afdeling van hoofdstuk IV per 1 januari 1983 in werking getreden). 


\subsection{De bedriifsgezondheidsdienst (bgd)}

\subsubsection{Instelling, werkingssfeer en erkenning}

Indien een bedrijf of inrichting behoort tot een bij AMvB aangewezen categorie, dan moet aan dat bedrijf of die inrichting krachtens art. 18 lid 1 een bgd verbonden zijn. Onder de begrippen bedrijf of inrichting dienen ruimtelijk begrensde onderdelen van een onderneming te worden verstaan, zoals bijvoorbeeld fabrieken of werkplaatsen. Ingevolge art. 23 onder b richt de verplichting zich tot de werkgever. Hij heeft ter zake een zorgverplichting. Volgens art. 23 onder c moet hij zodanige maatregelen treffen en de werkzaamheden zodanig inrichten dat de deskundige diensten hun taken op de juiste wijze kunnen vervullen. Overtreding van dit artikel vormt een economisch delict (art. 57).

De hierboven bedoelde $\mathrm{AMvB}$ is het Besluit verplichtstelling van bedrijfsgezondheidsdiensten. ${ }^{264}$ Volgens dit besluit is een bgd verplicht voor bedrijven of inrichtingen waarin 500 of meer werknemers in dienst zijn en waarin tevens uitsluitend of in hoofdzaak arbeid in een fabriek of werkplaats of stuwadoorsarbeid wordt verricht; voor bedrijven en inrichtingen waarin wordt gewerkt met loodpigmenten of loodaccumulatoren en voor werkverbanden in het kader van de Wet Sociale Werkvoorziening. Er wordt dus zowel een getalscriterium gehanteerd als een risicocriterium, al dan niet in combinatie. ${ }^{265}$

Naast deze categorale aanwijzing kan de Directeur-Generaal van de Arbeid krachtens art. 18 lid 2 een afzonderlijk bedrijf of een afzonderlijke inrichting de verplichting opleggen een bgd te hebben. In een dergelijk geval dient hij eerst de betrokken werkgever, de or of de Arbocommissie, of als de beide laatsten ontbreken de belanghebbende werknemers in de gelegenheid te stellen om hun mening ter zake kenbaar te maken. In tegenstelling tot de overeenkomstige regeling in de Veiligheidswet (art. $20 \mathrm{c}$ en art. 20e) behoeven zich in de afzonderlijk aan te wijzen bedrijven geen bijzondere gevaren voor de gezondheid voor te doen. Van deze bevoegdheid wordt overigens spaarzaam gebruik gemaakt. 2060

De werkgever kan eveneens aan zijn verplichting voldoen door gezamenlijk met een of meer werkgevers over te gaan tot de instelling van een bgd of zich bij een zodanige gezamenlijke dienst aan te sluiten (art. 20 lid 1). In dat geval moet zo'n dienst voldoen aan een aantal bij $\mathrm{AMvB}$ nader te stellen regels met betrekking tot het beheer, de rechtsvorm, de bestuurssamenstelling en de

264 Besluit van 13 november 1974 (S.74),

265 Terecht heeft de Arboraad opgemerkt diat de hantering van het getal van 500 werkmemers in samenhang met het criterium dat tevens uitsluitend of in hoofdzak arbeid in een fabriek of werkplaats dan wel stuwadoorsarbeid wordt verricht, in de praktijk problematisch kan zijn. Een bedriff ummers van 500 werknemers, van wie er 300 fabrieksarbeid verrichten, is verplicht bedrijfsgezondheidszorg te hebben, terwijl deze verplichting niet zou gelden voor een bedrijf van 1000 werknemers van wie er 400 fabrieksarbeid verrichten. Arboraad, Advies betreffende deskundige diensten, deel 1, Bedrijfsgezondheidsdiensten en Bedrijfsveiligheidsdiensiten, Zoetermeer 1984, nr. 4, p. 9.

266 Arboraad, 1984, nr. 4. t.a.p. p. 10. 
werknemersvertegenwoordiging in het beheer en het bestuur van de dienst. Deze AMvB is het Besluit nadere eisen gezamenlijke bedrijfsgezondheidsdiensten. ${ }^{267}$ De belangrijkste voorschriften uit deze AMvB (art. 1) houden in dat het beheer van een gezamenlijke dienst moet zijn opgedragen aan een rechtspersoon en dat een of meer van de betrokken werknemers in het bestuur zitting moeten hebben. ${ }^{268}$

Krachtens art. 22 moet de bgd erkend worden door de minister. Bij AMvB worden onder meer nadere regels gegeven inzake de wijze waarop beslist wordt op de aanvraag en de gronden waarop een erkenning (of een verlenging daarvan) kan worden geweigerd. Deze regels zijn te vinden in het Besluit erkenning bedrijfsgezondheidsdiensten. ${ }^{269}$ Een belangrijke weigeringsgrond voor de erkenning is het niet voldoen aan de wettelijke eisen en/of het niet voldoen aan het bepaalde in het Besluit eisen bedrijfsgezondheidsdiensten.

Ingevolge art. 41 lid $1 \mathrm{kan}$ de minister, gehoord de Arboraad (die overigens ook gehoord moet worden bij alle andere hier genoemde uitvoeringsmaatregelen; art. 43 lid 4) voor categorieën van bedrijven of inrichtingen vrijstelling verlenen van de wettelijke voorschriften ten aanzien van de deskundige diensten. Voor individuele bedrijven kan het districtshoofd van de Arbeidsinspectie ontheffing van deze voorschriften geven.

In 1986 heeft de Arboraad een advies uitgebracht inzake de verdere uitbreiding van de bedrijfsgezondheidszorg. ${ }^{270}$ Met betrekking tot de korte termijn besloot de Arboraad het gezondheidsrisico als voornaamste bepalende factor te hanteren voor de urgentie waarmee de verdere verplichtstelling van bedrijfsgezondheidszorg zal moeten worden gerealiseerd. Een verstandige en voor de hand liggende uitspraak. ${ }^{27 l}$ Over het antwoord op de vraag welke concrete conclusies er op basis van de beschikbare gegevens konden worden getrokken om dit uitgangspunt in de praktijk te realiseren, liepen de meningen binnen de Arboraad uiteen. De werkgeversleden meenden dat de wetenschap over de gezondheidsrisico's nog te fragmentarisch is en dat dus nader onderzoek nodig is alvorens tot eventuele verdere verplichtstelling van bedrijfsgezondheidszorg kan worden overgegaan. Dit nader onderzoek zou tevens duidelijk moeten maken in hoeverre wettelijk verplichte bedrijfsgezondheidszorg een toegevoegde waarde heeft. De werknemersleden waren van

267 Besluit van 18 mei 1982 (S. 406).

268 Naast de wettelijk verplichte (en erkende) bedrijfsgezondheidszorg is er in een aantal ondernemingen eveneens sprake van (een worm van) bedrijfsgezondheidszorg die een wettelijke basis ontbeert, en vrijwillig is ingesteld. Een ruwe schatting geeft bijwoorbeeld aan dat in $30 \%$ van de ondernemingen met $100-500$ werknemers bedrijisgezondheidszorg wordt verleend. In ondernemingen met 50-100 werknemers is dat in circa $10 \%$ het geval: Ingangsnota ten behoeve van het College in verband met de instelling van een Commissie lange-termijnplanning ter realisering van de gedachte: 'bedrijfsgezondheidszorg voor iedere werknemer', p. 22, opgenomen als bijlage III bij Arboraad, Advics termijnplanning uitbouw bedrijfsgezondheidszorg, Zoetermeer 1986, nr. 18.

269 Besluit van 18 mei 1982 (S. 407 ).

270 Arboraad, Advies termijnplanning uitbouw bedrijfsgezondheidszorg, Zoetermeer 1986, nr. 18.

271 De Arboraad volgt hiermee eveneens de al tien jaar eerder geventileerde opvatting van de SER. SER-advies 1976 , nr. 18, t.a.p. p. 14. 
oordeel dat de kennis omtrent de gezondheidsbedreigingen uit diverse binnenen buitenlandse onderzoeken aanzienlijk is. Derhalve meenden zij dat een aantal met name genoemde sectoren nu al in aanmerking zou moeten komen voor verplichte bedrijfsgezondheidszorg. ${ }^{272} \mathrm{Zij}$ baseerden zich voor dit standpunt tevens op de vele klachten van werknemers die de vakorganisaties ter zake bereikten.

Ik meen dat het standpunt van de werknemers juist is: naast de vele onderzoeken die, vooral de laatste jaren plaats hebben gevonden, al dan niet in opdracht van vooral het ministerie wan Sociale Zaken en Werkgelegenheid, lijkt het opnieuw nader onderzoeken een vluchtweg om de bedrijfsgezondheidszorg niet te hoeven uitbreiden. ${ }^{273}$ Hoewel de achterliggende gedachte van werkgeverszijde, dat uitbreiding grote consequenties heeft voor de betrokken ondernemingen 'gelet op zowel de voorschriften uit hoofde van de Arbowet als de financiële implicaties' begrijpelijk is, mogen deze argumenten niet zonder meer doorslaggevend zijn wanneer het gaat om de gezondheid van werknemers. Bovendien: het gaat niet om de eventuele meerwaarde van de wettelijke boven de vrijwillige gezondheidszorg of omgekeerd, het gaat erom dat in risicovolle ondernemingen daadwerkelijk gezondheidszorg aanwezig is, terwijl die aanwezigheid niet afhankelijk mag zijn van conjuncturele omstandigheden en het niveau gegarandeerd is. Daar komt bij dat uitbreiding van de bedrijfsgezondheidszorg recht doet aan het al jaren lang onder meer ook door de regering beleden uitgangspunt dat iedere werknemer in beginsel van deze zorg moet kunnen profiteren. Hoewel in 1959 de grens uiteindelijk werd gelegd bij 750 werknemers (pas in 1982 werd dat 500), merkte de toenmalige staatssecretaris in zijn MvT bij de eerste Wet op de bedrijfsgeneeskunde al op "dat de grens voorlopig wordt gelegd bij fabrieken met bijv. 250 of meer arbeiders' en: 'Is eenmaal een bepaald cijfer van het aantal arbeiders vastgesteld, dan zal dit geleidelijk kunnen worden verlaagd naar gelang meer bedrijfsartsen beschikbaar komen. ${ }^{274}$ En bijna 25 jaar later werd tijdens de parlementaire behandeling van het ontwerp Arbowet door de minister opgemerkt dat "iedere werknemer in beginsel aanspraak moet kunnen maken op bedrijfsgezondheidszorg', maar dat 'iedere uitbreiding van de wettelijke verplichtingen in deze echter in hoge mate afhankelijk is van het aantal beschikbare bedrijfsartsen'. ${ }^{275}$ Dit laatste zou inderdaad een praktisch argument betekenen tegen verdere uitbreiding. Ook het College van bijstand en advies voor de bedrijfsgezondheidszorg heeft herhaaldelijk gesteld dat de bedrijfsgezondheidszorg

272 De sectoren zijn de gezondheidszorg (met name ziekenhuizen en verpleeginrichtingen), de agrarische sector en het onderwijs.

273 Zie bijwoorbeeld woor onderzoeken, projecten e.d. op tal van terremen het literatuuroverzicht in bijlage IV bij het advies van de Arboraad, 1986, nu. 18, t.a.p. p. 36 en p. 40 . Een. goede indruk van de problemen op arbeidsomstandighedengebied in de industrie geeft een onderzoek uitgevoerd in opdracht van het DGA door de Stichting CCOZ: Het werkt anders, een overzicht van maatregelen tegen veel voorkomende problemen met de kwaliteit wan arbeidsplatatsen in de industrie, Voorburg 1986.

274 TK 1954-1955, 3848, nr. 3, (MvT), p. 5.

275 Nota n.a.v. het Eindverslag, Arbowet, t.a.p. p. 19. 
zich in principe dient uit te strekken over allen, die beroepsarbeid verrichten. ${ }^{276}$ Bovendien zou een serieus streven om dit uitgangspunt te realiseren tegemoet komen aan de internationale normen hierover. Al in de Aanbeveling uit 1959 van de ILO werd aanbevolen dat bedrijfsgezondheidszorg uiteindelijk voor alle werknemers beschikbaar zou moeten zijn. In 1962 kwam een EG-aanbeveling die de ILO-aanbeveling volgde. ${ }^{277}$ In 1985 aanvaardde de ILO niet alleen een aanbeveling inzake bedrijfsgezondheidszorg, maar voor het eerst ook een verdrag ter zake. ${ }^{278}$ Dit verdrag bepaalt uitdrukkelijk dat lidstaten ervoor moeten zorgen dat voor alle sectoren en ondernemingen (inclusief de publieke sector) geleidelijk bedrijfsgezondheidsdiensten worden ingesteld. De aanbeveling draagt bovendien op dlat stappen ondernomen dienen te worden die ertoe leiden dat ook zelfstandig werkenden een beroep kunnen doen op bedrijfsgezondheidszorg. Zolang de bedrijfsgezondheidszorg nog miet voor alle werkenden is gerealiseerd, moet de overheid volgens het verdrag overleg voeren met de sociale partners over de vraag voor wie de verplichting dan wèl geldt. Met het overleg in de Arboraad wordt in elk geval formeel aan deze verplichting voldaan, maar aan de strekking van het verdrag zou tekort worden gedaan indien de overheid, mèt de werkgevers, uitbreiding zou tegenhouden in afwachting van - telkens weer - nader onderzoek. De intentie van de opeenvolgende bewindslieden, daarin gevolgd, althans niet tegengesproken door het parlement, is trouwens duidelijk.

\subsubsection{Doelstelling en taken}

De taken van de bgd hebben volgens art. 18 lid 3 'in ieder geval' tot doel het beschermen en het bevorderen van de gezondheid van de werknemers voor zover het betreft problemen die samenhangen met de verhouding waarin werknemers staan tot hun arbeid en arbeidsmilieu. Onmiddellijk daarna volgt, dat de dienst met het oog daarop verplicht is om te adviseren aan onderscheidenlijk nauw samen te werken met en bijstand te verlenen aan de werkgever, de werknemers (bedoeld is nu niet alleen een collectief van werknemers, maar ook de individuele werknemer) en de or, respectievelijk de Arbocommissie. Vervolgens worden 21 activiteiten genoemd die 'in ieder geval' tot de taken van de bgd behoren.

Het betreft geen limitatieve opsomming. Tot de taken behoren eveneens het sturen van een afschrift van een advies aan de andere partij en (lid 4) het uitbrengen van een jaarverslag aan de or respectievelijk de Arbocommissie.

276 College van bijstand en advies voor de bedrijfsgeneeskunde, De toekomst van de bedrijfsgezondheidszorg, Den Haag 1979, p. 6. Krachtens art. 44 Arbowet is de naam van het college gewijzigd in College van bijstand en advies voor de bedrijfsgezondheidszorg. Hel college wordt krachtens ditzelfde artikel geacht te zijn ingesteld als een Commissie van de Arboraad).

277 Aanbeveling van 20 juli $1962, \mathrm{~Pb} .31$ augustus $1962, \mathrm{nr} .80$.

278 Verdrag van 26 juni 1985 , nr. 161 en Aanbeveling van 27 juni 1985, nr. 171 . Ower de aanbeveling en het verdrag: J.K.M. Gevers, De nieuwe ILO-normen inzake de bedrijfsgezondheidszorg, SMA, 1986, p. 414-419. 
Uiteraard wordt hier alleen gedoeld op adviezen van algemene strekking en niet op adviezen over individuele werknemers. Indien het advies aan de werkgever wordt uitgebracht is de or resp. de Arbocommissie de 'andere partij', voor wat betreft het verkrijgen van een afschrift, en omgekeerd. ${ }^{279}$ De verplichting tot het verstrekken van alle informatie die de or voor zijn taakvervulling nodig heeft ex art. 14 lid 10 onder b, is al eerder aan de orde geweest.

Oorspronkelijk werd in het vierde lid van art. 18 de mogelijkheid geopend dat bij $\mathrm{AM}$ BB wordt bepaald welke taken, liggend op het gebied van het welzijn in verband met de arbeid, ook door de bgd zouden moeten worden vervuld. Bij de dereguleringswetswijziging is dit lid per 1 januari 1988 vervallen. Art. 17 noemt nu immers de welzijnstaken, zonder dat het voorschriften bevat over de organisatorische plaats van die taken en van hun beofenæars binnen de onderneming. 'In dit verband bestaat niet langer behoefte aan het bestaande artikel 18 , vierde lid, waarvan bovendien toch al te veel de suggestie uitgaat, dat de organisatorische plaats van de besproken taakuitvoering bij de bedrijfsgezondheidsdienst behoort te liggen. ${ }^{2} 280$

De taken die in art. 18 worden genoemd voor de bgd zijn zeer divers wan aard. Veel ervan zijn overgenomen uit de Veiligheidswet. Sommige taken hebben in het algemeen betrekking op de gezondheidsaspecten van de arbeidsomstandigheden in de onderneming. Het gaat om het brede terrein van het zich op de hoogte houden en stellen (het arbeidsplaats-onderzoek) en het doen van aanbevelingen en het verlenen wam bijstand. Andere taken hebben meer direct betrekking op de individuele werknemer. Dan gaat het bijvoorbeeld om aanstellingskeuringen, periodiek geneeskundig onderzoek, en het houden van een spreekuur.

Een aantal taken, althans voor wat betreft de praktische uitwerking ervan in sommige gevallen, is controversieel. Dit betreft met name de werkzaamheden ter beperking van het ziekteverzuim en het optreden als medisch adviseur van sociale fondsen en instellingen. Voor zover hieronder verstaan wordt de bevordering van de revalidatie van de betrokken werknemers en het adviseren over werkhervatting in het belang van het herstel, behoeft hier geen bezwaar tegen te bestaan. Al sinds een onderzoek uit 1972 is echter bekend dat onder de bedoelde taakomschrijving in vele gevallen tevens begrepen wordt de zgn. ziektewetcontrole. ${ }^{281}$ Het komt er dan op neer dat de bedrijfsarts bepaalt of de zieke werknemer terecht of ten onrechte een uitkering ontvangt. Het is duidelijk dat dit niets te maken heeft met de vooral op preventie gerichte taken van de bedrijfsarts. Het gevaar is bovendien niet denkbeeldig dat de bedrijfsarts hierdoor tegenover de werkgever aan onafhankelijkheid en tegenover de werknemers aan vertrouwen inboet. De strekking van de Arbowet is nu juist

279) TK 1979-1980, 14.497, nr. 13 (derde Nota van wijzigingen), p. 8.

280 TK 1986-1987, 19.829, nr. 3, (MvT bij het dereguleringswetsonwerp), p. 8.

281 Ministerie van Sociale Zaken en Werkgelegenheid, Bedrijfsarts en ziektecontrole, Verslagen en rapporten, Den Haag 1972 . Uit dit onderzoek bleek dat $43 \%$ van de bedrijfsartsen zicktewetcontrôle verrichtte bij de onder hun geneeskundige zorg vallende werknemers. Deze artsen besteedden gemiddeld ruim $30 \%$ van hun tijd atan deze activiteiten. 
een omgekeerde. Dergelijke activiteiten zijn bovendien in strijd met de strekking van de EG-aanbeveling van 1962 en het bovengenoemde ILO-verdrag van 1985. (Voor het overige stemmen doelstelling en taken zoals geformuleerd in de Arbowet grotendeels wèl overeen met het recente verdrag).

In de Veiligheidswet was in art. 20b een expliciet verbod voor de bgd opgenomen om werkzaam te zijn op het gebied van de curatieve gezondheidszorg. Dit verbod staat niet meer in de Arbowet. Dit betekent echter niet dat dit nu wel zou zijn toegestaan. Het verbod - overigens een vreemd element in thet kader van de arbeidsomstandighedenwetgeving - is vooral op verzoek van de betrokken beroepsorganisaties niet teruggekomen in de Arbowet. ${ }^{2{ }^{2} 2}$ De taakafbakening is nu uitsluitend geregeld via collegiale afspraken binnen de Koninklijke maatschappij ter bevordering van de geneeskunst. Volgens deze afspraken is er voor de bedrijfsarts wel enige ruimte voor curatieve verrichtingen, zoals eerste hulp, maar de doelstelling en het daaraan gerelateerde takenpakket blijven primair op preventieve gezondheidszorg gericht.

\subsubsection{Positie bedrijfsarts}

In vergelijking met de regeling in de Veiligheidswet is de onafhankelijke positie van de bedrijfsarts zowel ten opzichte van de werkgever als ten opzichte van de werknemers in de Arbowet extra benadrukt. Dit komt onder meer tot uitdrukking in de hierboven besproken verplichting om alle informatie die zich daartoe leent, aan beide partijen ter beschikking te stellen. De leidinggevende van de bgd, die een arts moet zijn, is verantwoordelijk voor de juiste wijze van taakvervulling door de dienst. Dit is een interne verantwoordelijkheid. Extern kan deze verantwoordelijkheid niet leiden tot strafrechtelijke aansprakelijkheid in de zin van de Arbowet. Deze blijft op de werkgever rusten. ${ }^{283} \mathrm{De}$ leidinggevende arts moet rechtstreekse toegang hebben tot 'degene die aan het hoofd staat' van het bedrijf of de inrichting waaraan de dienst is verbonden. De betekenis hiervan is niet dat de leiding van de bgd per se direct moet rapporteren aan de (hoogste) directie of hiërarchisch onder haar ressorteert. In 1981 oordeelde de Ondernemingskamer over een dergelijke kwestie ten aanzien van een veiligheidsdienst. ${ }^{284}$ De werkgever besloot om een wijziging aan te brengen in de organisatie van de afdeling personeelszaken en van de afdelling veiligheid door de twee afdelingen samen te voegen. De or adviseerde om thet besluit te heroverwegen, omdat hij van mening was dat de veiligheidsafdeling volledig zelfstandig zou moeten blijven functioneren en dat de controle op deze afdeling diende te blijven behoren tot de directe verantwoordelijkheid van de directeur. De or beriep zich voor dit standpunt onder meer op de tekst en de toelichting van het toen bij het parlement in behandeling zijnde

282 MvT, t.a.p. p. 34

283 MvT, t.a.p. p. 35.

284 Hof Amsterdam (Ondernemingskamer) 22 januari 1981, NJ 1982, 243 (m.nt. Ma). Hierower eveneens: F. Koning, SMA, 1981, p. 407; H.J. van Zwam, De hièrarchische plats wan de veiligheidskundige, de veiligheid, juni 1982 , p. $37-38$. 
ontwerp Arbowet. Het advies werd niet gevolgd, waarna de or zich tot de Ondernemingskamer wendde. Deze achtte het voorgenomen besluit een besluit als bedoeld in art. 25 lid 1 onder e WOR, en meende dat de aan de directie toekomende beleidsvrijheid terzake, haar grens dààr vindt waar de directie bij de afweging van de betrokken belangen in redelijkheid niet tot het aangevochten besluit had kunnen komen. De Ondernemingskamer achtte deze grens niet overschreden. De door de or aangehaalde woorden van de minister in de MvT bij de Arbowet houden immers in dat op zich zelf geen bezwaar kan worden gemaakt tegen een veiligheidsdienst die hiërarchisch is ondergebracht bij een andere dienst, mits aan bepaalde voorwaarden is voldaan: de adviezen van de veiligheidsfunctionaris moeten onder alle omstandigheden de leiding kunnen bereiken en die functionaris moet de mogelijkheid hebben om zijn voorstellen persoonlijk toe te lichten en aan te dringen op het nemen van maatregelen bij degene bij wie uiteindelijke de beslissingsbevoegdheid berust. Hieraan was in casu kennelijk voldaan. Het is aardig om te constateren dat de laatste overwegingen van de Ondernemingskamer letterlijk ontleend zijn aan, eveneens, de MvT bij het ontwerp Arbowet, maar dan het gedeelte dat handelt over de positie van de (leidinggevende van de) bgd. ${ }^{285}$ De uitspraak lijkt mij in ellk geval bevredigend, omdat op deze manier rekening kan worden gehouden met de complexiteit van de onderneming en tevens met de strekking van de wettelijke regeling, die in gelijke bewoordingen is geformuleerd zowel ten aanzien van de veiligheidsdienst als ten aanzien van de bgd (resp. art. 19 leden 4 en 5 en art. 18 lid 5).

De in de bgd werkzame artsen moeten hun taak uitoefenen 'met behoud van hun onafhankelijkheid ten opzichte van degene die aan het hoofd staat' van het bedrijf of de inrichting. Oorspronkelijk, onder de vigeur van de Veiligheidswet, stond deze bepaling in het Besluit eisen bedrijfsgeneeskundige diensten. Opname in de wet zelf accentueert nog eens het belang dat door de wetgever aan deze onafhankelijke positie wordt gehecht. Bovendien wordt in art. 18 lid 5 nog een extra waarborg gecreëerd door aan de in dienst werkzame artsen en andere deskundigen ontslagbescherming te geven. Minister Albeda tijdens een vergadering van de vaste Kamercommissie: 'Onze conclusie is dat de positie van de bedrijfsarts toch eigenlijk wel kwetsbaar is en dat hij in die zin dezelfde bescherming behoort te hebben als bijvoorbeeld het ondernemingsraadslid. ${ }^{286}$ Voor deze regeling wordt verwezen naar art. 8 lid 5 waar de ontslagbescherming van de mentor is geregeld. ${ }^{287}$ Volgens deze bepaling heeft de or echter niet alleen het recht om te adviseren over het ontslag, maar ook over de benoeming van de mentor. Zonder dat hiervoor uit de parlementaire behandeling een reden kan worden gedestilleerd, geldt deze laatste bevoegd- 
heid echter niet ten aanzien van de bedrijfsarts. ${ }^{288}$

De werkgever moet de or dus in de gelegenheid stellen om advies uit te brengen over het voorgenomen ontslag van de bedrijfsarts. De werkgever behoeft volgens art. 8 lid 5 de or echter geen advies te vragen in twee gevallen. In de eerste plaats indien het ontslag gegeven wordt wegens een dringende aan de mentor (bedrijfsarts) onverwijld medegedeelde reden, het zgn. ontslag op staande voet. De terminologie is ontleend aan art. $1639 \mathrm{o} \mathrm{BW}$. Voor de werkgever worden als dringende redenen beschouwd zodanige eigenschappen of gedragingen van de werknemer (de bedrijfsarts), die ten gevolge hebben dat van eerstgenoemde redelijkerwijze niet kan worden gevergd de dienstbetrekking te laten voortduren (art. $1639 \mathrm{p}$ lid $1 \mathrm{BW}$ ). In de tweede plaats indien de bedrijfsarts uitdrukkelijk toestemt met het ontslag. De toestemming moet weliswaar uitdrukkelijk gegeven worden, maar dat behoeft, in tegenstelling tot de overeenkomstige bepalingen in art. 21 leden 2 en 4 WOR ten aanzien van ondernemingsraadsleden, blijkbaar niet schriftelijk te gebeuren. Het artikel zegt niets over de situatie dat de werkgever niet zelf wil ontslaan, maar de arbeidsovereenkomst wegens gewichtige reden wil laten ontbinden door de kantonrechter op grond van art. 1639w BW. Hoewel art. 1639w duidelijk bepaalt dat de kantonrechter 'te allen tijde' deze bevoegdheid heeft, lijkt een redelijke uitleg van de bedoeling van de wetgever mij echter mee te brengen dat ook in een dergelijk geval de werkgever gehouden is om, alvorens hij zich tot de kantonrechter wendt, toestemming te vragen aan de or ${ }^{289}$ Dit is slechts anders indien de bedrijfsarts zelf zich zou wenden tot de kantonrechter met een dergelijk verzoek.

Behalve de verplichte advisering door de or wordt in art. 8 lid 5 Arbowet op de beëindiging van de dienstbetrekking van de mentor (bedrijfsarts) art. 21 lid 3 $\mathrm{t} / \mathrm{m} 5$ WOR van overeenkomstige toepassing verklaard, met dien verstande dat de derde zin van het derde lid moet worden gelezen zoals in art. 8 lid 5 Arbowet is geformuleerd. Dit betekent dat de kantonrechter toestemming moet geven voor het beëindigen van de dienstbetrekking van de mentor. Dat kan hij alleen in die gevallen dat het hem aannemelijk voorkomt, dat de beëindiging geen verband houdt met feiten of omstandigheden, voortvloeiende uit een juiste taakuitoefening door de mentor (bedrijfsarts). Toestemming van de kantonrechter is niet vereist wanneer de betrokkene schriftelijk instemt met de beëindiging, wanneer het betreft een ontslag op staande voet of wanneer het gaat om beëindiging van de werkzaamheden van de onderneming of van het onderdeel waarin de betrokkene werkzaam was. Dit alles laat de bevoegdheid van de werkgever om zich tot de kantonrechter te wenden met het verzoek om de arbeidsovereenkomst te ontbinden wegens gewichtige reden (art.

288 Voor de benoeming van een bedrijfsarts was oorspronkelijk de voorafgaande goedkeuring wan de Arboraad voorgeschreven krachtens art. 3 van het Besluit eisen bedrijfsgezondheidsdiensten ( $S$. 1974, 741), gebaseerd op art. 43 lid 7 Arbowet. Per 1 januari 1988 is deze bepaling vervallen (zie paragraaf 6.2.).

$289 \mathrm{Vgl}$. woor een gelijk standpunt ten aanzien van art. 30 WOR (benoeming en ontslag bestuurders), Duk, Fase, van der Heijden, Masschaupt, art. 30-3. 
$1639 \mathrm{w} \mathrm{BW}$ ) echter onverlet. Ook in dit geval kan de kantonrechter het verzoek slechts inwilligen, indien het hem aannemelijk voorkomt dat het verzoek geen verband houdt met feiten of omstandigheden, voortvloeiende uit een juiste taakuitoefening door de arts. Het lijkt voor de hand te liggen dat de kantonrechter bij zijn oordeelsworming mede zal betrekken het advies van de or, dat de ondernemer uiteraard niet verplicht is te volgen.

Uit het advies van de VAR inzake de eerste fase van invoering van de Arbowet is nog een, met het bovenstaande samenhangende, kwestie problematisch gebleken. ${ }^{200} \mathrm{Het}$ betreft de vraag of de ontslagbescherming van art. 18 lid 5 jo art. 8 lid 5 ook van toepassing is op artsen werkzaam in een gezamenlijke dienst. De werknemersleden meenden, gelet op de achtergrond van de ontslagbeschermingsregeling, dat dit inderdaad het geval is. De werkgeversleden waren het hier niet mee eens. Volgens hen is de achtergrond van de beschermingsregeling, dat een waarborg gegeven wordt voor de onafhankelijkheid van de arts. Bij een gezamenlijke dienst is nu juist geen sprake van een afhankelijkheidsrelatie tussen de bedrijfsarts en de aangesloten werkgevers. Dit laatste standpunt lijkt mij juist. De onafhankelijkheid bij een gezamenlijke dienst is juist ook daardoor gewaarborgd dat het beheer berust bij een rechtspersoon die een bestuur heeft waarin ook een of meer werknemersvertegenwoordigers zitting moeten hebben (art. 20 lid 3). Bovendien zou, indien de or in een dergelijk geval wèl de plicht had om te adviseren, zich de situatie kunnen voordoen dat de or dat gaat doen aan een 'vreemde' werkgever over een bij cleze in dienst zijnde werknemer. Dat behoort echter niet tot de - wettelijketaak van de or.

Een dergelijke kwestie als hierboven aan de orde is gesteld, doet zich ook voor ten aanzien van de geheimhoudingsplicht van medische en persoonlijke gegevens die de in een bgd werkzame personen ter kennis komen (art. 18 lid 6). Het lijkt mij duidelijk dat deze geheimhoudingsplicht ook moet gelden voor degenen die verbonden zijn aan een gezamenlijke dienst. ${ }^{291}$

Enige verschillen zijn te constateren tussen de regeling in de Arbowet ten aanzien van de positie van deskundigen en die in het ILO-verdrag 1985. In de eerste plaats ligt bij art. 18 Arbowet de nadruk sterk op het medische karakter. Het hoofd van de dienst moet ook een arts zijn. De bepaling strookt niet met het verdrag. In de tweede plaats behoeft volgens het verdrag een bgd ook niet opgericht te worden door een of meer werkgevers. Dit zou ook door de overheid kunnen gebeuren, waardoor de onafhankelijke positie beter verzekerd lijkt. Een dergelijk voorstel is ook tijdens de parlementaire behandeling ter sprake gekomen. Het idee was om de bgd en eventueel de veiligheidsdienst

290 Voorlopige Arbeidsraad, Advies inzake de eerste fase van invoering van de Arbeidsomstandighedenwet, Zoetermeer 1982, nr. 2, p. 30 .

291 Een bedrijfsarts die onzorgvuldig omgaat met vertrouwelijke gegevens kan ook op grond van de Medische Tuchtwet worden aangesproken; Centraal Medisch Tuchtcollege, 29 november 1951. NJ 1952, 669. In 1976 stelde het Medisch Tuchtcollege Den Haag vast dat de bedrijfsarts niet meer dan de strikt noodzakelijke gegevens aan andere functionarissen van de onderneming mag doorgeven. Medisch Tuchtcollege, Den Haag, 10 november 1976, Tijdschrift voor gezondheidsrecht, 1977 , p. 189. 
onder verantwoordelijkheid te brengen van gemeentelijke of districtsgezondheidsdiensten, zodat een algemeen geïntegreerde openbare gezondheidszorg zou ontstaan. ${ }^{292}$ Volgens de minister zou dit echter tevens betekenen een desintegratie van het beleid inzake arbeidsomstandigheden, omdat in ons sociaaleconomisch stelsel de zorg voor de bescherming van de werknemers primair rust op de schouders van de werkgever. ${ }^{293}$ Terecht zijn daar nog de bezwaren aan toegevoegd dat er zo een risico ontstaat van vermenging met de taken van het overheidstoezicht en dat de kans op beinvloeding door ondernemingen en werknemers kleiner is. ${ }^{294}$ In de derde plaats wil het ILO-verdrag de onafhankelijkheid en de daarmee gepaard gaande ontslagbescherming niet alleen garanderen ten aanzien van de bedrijfsartsen en andere deskundigen, maar ook ten aanzien van 'het personeel'.

De Aanbeveling gaat ook verder dan de Arbowet door te bepalen dat werknemers niet alleen zouden moeten participeren in de organisatie van de dienst, maar ook betrokken zouden moeten worden bij de planning van de activiteiten en de aan te trekken deskundigen. Daarnaast zou het personeel van de dienst volgens de Aanbeveling meer bevoegdheden moeten hebben, zoals bijvoorbeeld vrije toegang tot informatie en het recht om monsters te nemen. In de Aanbeveling zijn tevens enkele bepalingen opgenomen ten aanzien van de bescherming van de persoonsgegevens in de gezondheidsdossiers.

\subsubsection{Enkele opmerkingen over de bgd en de praktijk}

Het ideaal dat iedere werknemer een beroep moet kunnen doen op bedrijfsgezondheidszorg, is in de praktijk nog lang niet gerealiseerd. Wel is de bedrijfsgezondheidszorg in de loop der jaren fors toegenomen. In 1973 werden ongeveer één miljoen werknemers bedrijfsgeneeskundig verzorgd. In tien jaar is dit aantal met $70 \%$ toegenomen tot 1,7 miljoen werknemers. Dit betekent dat ongeveer één op de drie werknemers een bedrijfsarts heeft. In diezelfde periode groeide het aantal bedrijfsartsen van 521 tot 899 . De bedrijfsgezondheidszorg wordt voornamelijk uitgevoerd door enkelvoudige en gezamenlijke bgden. Er zijn ook ondernemingen die de bedrijfsgezondheidstaken laten uitvocren door elders werkzame bedrijfsartsen of door artsen die niet als bedrijfsarts geregistreerd zijn. ${ }^{205}$ Hierbij dient well te worden aangetekend dat de zorg vooral is geconcentreerd in de grotere ondernemingen: in nagenoeg alle ondernemingen met meer dan 500 werknemers wordt bedrijfsgezondheidszorg verleend, terwijl dat in ondernemingen met $50-100$ werknemers slechts in $10 \%$ het geval is. In ondernemingen met minder dan 50 werknemers kan nauwelijks gesproken worden van bedrijfsgezondheidszorg. Van alle industriële ondernemingen telt $94 \%$ minder dan 100 werknemers, terwijl die ondernemingen

292 TK 1977-1978, 14.497, nr. 4 (Voorlopig Verslag), p. 31.

293 MvA, t.a.p. p. 42 en 43.

294 J.K.M. Gevers, SMA, 1986, t.a.p. p. 418.

295 Nederlands Instituut voor Preventieve Gezondheidszorg. NIPG/TNO, De bedriffsarts over zijn werk, Leiden 1985, p. 1 en 2. 
circa $33 \%$ van het total aantal werkmemers in de industrie omvatten. ${ }^{296}$ Hoe functioneert nu de bedrijfsgezondheidszorg in de praktijk? Aan de hand van twee specifieke onderzoeken, elk vanuit een ander perspectief, zal ik er iets over zeggen.

Het eerste onderzoek tracht vooral een antwoord te geven op de vragen wellke contacten werknemers hebben met de bgd en hoe deze contacten worden ervaren, en welk beeld werknemers hebben over de zin en de betekenis van de bgd en har activiteiten in het algemeen ${ }^{297}$ De contacten van werknemers met de bgd en hun beoordeling daarvan zijn beschreven rondom de volgende bgdactiviteiten: spreekuur, verzuimbegeleiding, periodiek geneeskundig onderzoek, ongevallenbehandeling en werkplekbezoek. Behalve bij concrete verrichtingen als ongevallenbehandeling en geneeskundig onderzoek was het oordeel van de werknemers ten aanzien van de activiteiten van de bedrijfsarts niet zonder meer positief. Dat heeft met name te maken met de onduidelijkheid over de wijze waarop de werknemers menen dat de bedrijfsarts de belangen van onderneming en individu tegen elkaar afweegt. Dit veroorzaakt gevoelens van onzekerheid en kwetsbaarheid, waardoor de arts minder gemakkelijk in vertrouwen wordt genomen. Dit speelt vooral een rol bij de verzuimbegelleiding ('Ziektewetcontrole').

Hoewel het beeld en de verwachting van werknemers over de bgd redelijk overeenstemmen met de doelstelling wan de bgd zoals die in art. 18 lid 3 van de Arbowet is geformuleerd, is het gebruik dat de werknemers van de verschillende bgd-faciliteiten maken hiermee niet in overeenstemming. Werknemers gaan gemakkelijker en vaker voor lichte en acute aandoeningen naar de bgd dan voor werkgerelateerde problemen. Dit komt omdat vaak wordt beseft dat dergelijke problemen gevolgen kunnen hebben voor de arbeidsplaats en de loopbaan in de onderneming, omdat andere personen en instanties meer vertrouwd worden in verband met een mogelijke oplossing, omdat er een verschil is in beoordeling en taxatie van werkgerelateerde gezondheidsproblemen tussen bedrijfsartsen en werknemers en omdat er onduidelijkheid is over de opstelling en verantwoordelijkheid van de bgd in deze $k$ westie, waardoor de werknemers een zekere behoedzaamheid aan de dag leggen. Op grond van deze resultaten wordt onder meer aanbevolen om tot betere samenwerking, communicatie en overlegsituaties te komen. Weliswaar wordt terecht gesteld dat de Arbowet daar goede aanknopingspunten voor biedt, maar: 'Door onduidelijkheid over de rol en verantwoordelijkheid van de bgd en een vaak verkeerde interpretatie van de onafhankelijkheid van de bgd jegens het management komt bedoelde samenwerking en overleg vaak echter niet of slechts moeizaam tot stand. '298

Deze laatste conclusie sluit aan bij het ITS-onderzoek van 1988, waarin geconstateerd wordt dat er bij de meeste ondernemingen geen of nauwelijks meer

296 Arboraad, Adviestermijnplanning uitbouw bedrijfsgezondheidszorg, Zoetermeer 1986, nr. 18, p. 22 en p. 28

297 H.N. Plomp, Werknemers en bedrijfsgezondheidsdiensten, Amsterdam 1985.

298 H.N. Plomp, t.a.p. p. 128. 
dan incidenteel contact is tussen de or of de VGW-commissie en de bgd. ${ }^{26 \%}$ Hoe denken nu de bedrijfsartsen zelf over hun functioneren? Naast een onderzoek naar het feitelijk functioneren van de bgd werd deze vraag gesteld in een ander onderzoek. ${ }^{300}$ Het eerstgenoemde onderzoek betrof case-studies in drie representatief geachte ondernemingen. In dit onderzoek stond een enquête onder in principe alle bedrijfsartsen centraal. Hieruit is gebleken dat de bedrijfsarts de meeste tijd spendeert aan individuele contacten op het spreekuur. Vervolgens besteedt hij relatief veel tijd aan het ziekteverzuimspreekuur, het werkplekbezoek, de aanstellingskeuringen en het algemeen en gericht periodiek onderzoek. Pas op de tiende plaats komt het gericht werkplekonderzoek. De meeste bedrijfsartsen geven gebrek aan tijd op als oorzaak voor de geringe contacten met het arbeidsmilieu. De betrokkenheid van de bedrijfsarts bij het bevorderen van de arbeidsomstandigheden staat niet alleen onder druk vanwege zijn omvangrijke takenpakket, maar ook door de opkomst van allerlei andere deskundigen, waardoor de situatie zou kunnen ontstaan dat hij in het arbeidsomstandighedenbeleid na verloop van tijd nog slechts een marginale plaats inneemt. Maar ook wegens een toenemende vraag om verzekeringsgeneeskundige taken in verband met de controle en de begeleiding van arbeidsongeschikte werknemers te vervullen, is de kans groot dat hij zijn preventieve taken steeds minder op verantwoorde wijze kan vervullen. Regelmatig blijken werkgevers in dit verband de kosten-baten-verhouding ten aanzien van de bedrijfsgezondheidszorg aan de orde te stellen. Toch is uit het ITS-onderzoek 1988 gebleken dat directies - voorzover ze al een mening op dit punt hebbenin het algemeen redelijk tevreden zijn over de bgd. Sommige directies vinden de meer structureel gerichte activiteiten echter bedreigend. ${ }^{301}$

Zelf ervaren de bedrijfsartsen dat hun functioneren in het algemeen een balans is van gunstige en ongunstige kanten aan het werk. De gunstige zijn vooral de zelfstandigheid en het interessante en afwisselende werk. De ongunstige met name de overbelasting en de gebrekkige organisatie van de dienst. Het saldo is positief, omdat de grote meerderheid zelf aangeeft 'goed of redelijk met zijn werk te zitten". Wat meer specifiek is ongeveer de helft van de bedrijfsartsen tevreden over de contacten met de or, bijna tweederde over die met de directie. Directies krijgen meer adviezen dan ondernemingsraden. Deze beleidsadviezen geven de bedrijfsarts echter weinig voldoening. De oorzaken van het gebrek aan succes op dit punt worden echter buiten zichzelf gezocht. Van de bedrijfsartsen die geen adviezen aan de or geven, is de helft tevreden over hun relatie met de or. (Een relatie die er dus volgens het ITSonderzoek nauwelijks zou zijn).

De conclusie uit het bovenstaande lijkt mij toch niet rooskleurig. Enerzijds wordt geconstateerd dat de bedrijfsarts zich te veel met individuele contacten bezighoudt, in relatie tot zijn algemene preventieve taak op het gebied van de arbeidsomstandigheden, terwijl hij niet altijd een voldoende mate van ver-

299 TTS-onderzoek 1988 , t.a.p. p. 58.

300 Zie noot 295. 
trouwen heeft bij de werknemer bij deze individuele contacten, met name niet bij verzuimcontrole of verzuimbegeleiding. Anderzijds lijken werkgevers juist deze contacten aan te moedigen, omdat de bedrijfsarts moet laten zien wat zijn aanwezigheid voor de onderneming waard is. De bgd wordt dan beoordeeld op de effecten die worden bereikt bij het terugdringen van de kosten van het ziekteverzuim. Op deze manier blijft er steeds minder ruimte over voor sámenwerking en overleg met de werknemers waardoor de vertrouwensrelatie kan worden gecreëerd waar de Arbowet nu juist van uitgaat.

Enigszins in tegenstelling tot deze wat sombere conclusie staan de resultaten van een onderzoek van de Industriebond FNV. ${ }^{302}$ Dit onderzoek is echter methodisch van een veel beperktere strekking dan de hiervoor genoemde. Het ging om een enquête die kaderleden van de bond uit 250 ondernemingen met in totaal 150.000 werknemers hebben ingevuld. Slechts $40 \%$ van deze ondernemingen had wettelijk verplichte bedrijfsgezondheidszorg. Daar staat echter tegenover dat de enquête gehouden is twee jaar nadat de Arbowet gedeeltelijk - maar dus inclusief de bepalingen inzake de bgd - in werking was getreden. In het algemeen werd door de vakbondskaderleden een gunstige ontwikkeling gesignaleerd in de verhouding tussen de bgd en de werknemers en met name de or. Zo had in $62 \%$ van de ondernemingen de or een aktiviteitenverslag van de bedrijfsarts ontvangen en werd dit verslag in $76 \%$ van de gevallen positief beoordeeld. Voor het overige is uit het gepubliceerde onderzoek niet erg veel op te maken inzake de feitelijke werkwijze van de bedrijfsartsen en de waardering daarvoor.

\subsection{De veiligheidsdienst en de veiligheidskundige}

De regeling van de veiligheidsdienst en de veiligheidskundige in art. 19 Arbowet lijkt zowel ten opzichte van de instelling, de erkenning en de werkingssfeer als van de doelstelling, de taken en de positie van de deskundige op die van de bgd in art. 18. Nadere invulling op een aantal punten is ook in art. 19 overgelaten aan een AMvB. Art. 19 is per 1 januari 1988 in werking getreden. De $A M v B$ bevattende de verplichtstelling en de eisen waaraan de dienst moet voldoen, is echter nog niet per die datum in het Staatsblad gekomen. ${ }^{303}$ Dit komt door onenigheid in de Arboraad over de inhoud van de AMvB. Vast staat al wel dat de verplichtstelling - net als die van de bgd - betrekking zal hebben op industriële bedrijven en stuwadoorsbedrijven met 500 of meer werknemers. Een overgangsregeling zal het mogelijk maken dat bedoelde bedrijven geleidelijk op de nieuwe situatie zullen kunnen inspelen.

301. TS-onderzock 1988 , t.a.p. p. 57

302 Industriebond FNV, Vakbondskaderleden beoordelen de Arbeidsomstandighedenwet, Amsterdinan 1985.

303 Brief wan de stadssecretaris van Sociale Zaken en Werkgelegenheid aan de voorzter wan de Tweede Kamer, TK 1987-1988, 20.200, hfdst. XV, nr. 13 . 
Belangrijke geschilpunten in de Arboraad zijn de volgende. ${ }^{304}$ De staatssecretaris is van plan om in verband met het specifieke karakter van de bouwnijverheid veiligheidszorg voor deze bedrijfstak niet verplicht te stellen, maar daarover eerst nadere studie te laten verrichten. Ook ligt het niet in de bedoeling om sociale werkplaatsen en loodverwerkende bedrijven tot veiligheidszorg te verplichten. De werknemers zijn het daar niet mee eens. Ze zijn van mening dat de gevaren in de bouw voldoende bekend zijn om ook deze bedrijfstak tot veiligheidszorg te verplichten. Hetzelfde geldt in hun opvatting ten aanzien van sociale werkplaatsen en loodverwerkende bedrijven. De werkgevers onderschrijven de opvatting van de staatssecretaris.

Volgens zijn advies pleit de Arboraad ervoor om de aan veiligheidsdiensten te stellen nadere eisen waar mogelijk en haalbaar globaal te formuleren, ten einde het bedrijfsleven voldoende speelruimte te geven. Over een verdere concretisering van deze globale voorschriften in ministeriële regelingen en publikatiebladen verschillen partijen van mening. Werknemers vinden dat een verdere invulling en nadere uitwerking er, daar waar dat verantwoord mogelijk is, zo spoedig mogelijk dient te komen. De werkgevers vinden daarentegen dat op termijn bezien zou moeten worden of, en zo ja waar, een dergelijke behoefte aan verdere uitwerking bestaat. In de toekomst zouden aan de hand van praktijkervaringen zonodig aanvullende regelingen kunnen worden getroffen.

Een belangrijke aan veiligheidsdiensten te stellen eis is die betreffende de minimale personeelsbezetting. De staatssecretaris stelt een 'minimum-bemanningsnorm' voor van één veiligheidsdeskundige op vierduizend werknemers. De werknemers in de raad achten een dergelijke norm absoluut onvoldoende en pleiten voor een norm van één op vijftienhonderd. De werkgevers wijzen een algemene getalsmatige benadering vooralsnog af. $\mathrm{Zij}$ vinden dat in het kader van de erkenning, per bedrijf, afhankelijk van de specifieke eigen situatie, moet worden bekeken wat de minimale personeelsbezetting zou moeten zijn.

Evenals ik dat deed ten aanzien van de geschilpunten tussen werkgevers en werknemers omtrent de bgd (paragraaf 4.2.1.), deel ik het standpunt van de werknemers. Tegenover de vrijblijvendheid ten aanzien van de veiligheidszorg die de werkgevers wensen - met als alibi méér onderzoek - staat het belang van veiligheid en gezondheid. In beginsel dient dit laatste de doorslag te geven.

Ondanks het feit dat art. 19 pas in 1988 in werking is getreden, zijn in veel, vooral grotere ondernemingen, veiligheidsdiensten of beter: veiligheidsfunctionarissen, aanwezig. Volgens een in 1984 gepubliceerd globaal onderzoek door de Arbeidsinspectie was in het voorafgaande jaar in ongeveer $80 \%$ van de vestigingen van ondernemingen met meer dan 500 werknemers die beschik-

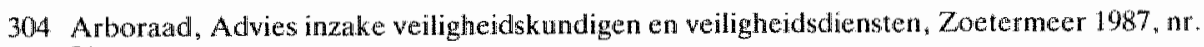
31. 
ken over bedrijfsgezondheidszorg ook veiligheidszorg aanwezig. ${ }^{305}$ Uit een in 1986 gepubliceerd onderzoek van het Veiligheidsinstituut bleek dat in tenminste $9 \%$ van de 500 -plus ondernemingen in het geheel geen veiligheidsfunctionaris werkzaam was. In de ondernemingen waar dat wèl het geval was, was de kwantitatieve bezetting als volgt: in $26 \%$ was een functionaris part-time werkzaam, in $19 \%$ een full-time functionaris, in $17 \%$ meer functionarissen en in de overige ondernemingen meer personen verbonden aan een veiligheidsdienst. 306

Over de kwaliteit van de geboden veiligheidszorg valt echter nog nauwelijks iets te zeggen, omdat daar weinig gegevens over voorhanden zijn. Wel is de Arboraad gebleken dat de actuele bedrijfsveiligheidszorg een 'grote mate van differentiatie en diepgang vertoont'.$^{307}$ Dit beeld wordt zowel door het onderzoek van het Veiligheidsinstituut (1986) als dat van het ITS (1988) bevestigd. 308

De Arboraad meent dat het (toekomstige) aanwijzings- en erkenningsbeleid zeker in het begin moet stoelen op de gegroeide praktijk en dat dus de zeer goed uitgeruste en hoog-kwalitatief bemande veiligheidsdiensten zoals met name grote ondernemingen die soms kennen, niet als norm kunnen dienen. Het betekent volgens de Arboraad onder meer dat gedurende een overgangsfase alle veiligheidsdiensten die tot een aangewezen categorie behoren, ongeacht de opleiding van het hoofd, zullen moeten worden erkend.

In tegenstelling tot de situatie met betrekking tot de bgd spreekt de wet niet alleen van een veiligheidsdienst, maar ook van een veiligheidskundige. De MvT motiveert dat als volgt: 'Voor de minder grote bedrijven, waarvoor de instandhouding van een goed uitgeruste en bemande veiligheidsdienst bezwaarlijk zou kunnen zijn, voorziet het ontwerp in de mogelijkheid te volstaan met de aanstelling van een veiligheidsfunctionaris. ${ }^{309}$ Tussen de bepalingen enerzijds ten aanzien van de veiligheidsdienst en anderzijds ten aanzien van de veiligheidskundige bestaan verschillen. De dienst moet voldoende zijn uitgerust en bemand (art. 19 lid 5); een dergelijke bepaling geldt niet voor de solitaire veiligheidskundige. Idem ten aanzien van de erkenning (art. 22). Aan de verplichting om een dienst te hebben kan ook worden voldaan door aansluiting bij een gezamenlijke dienst, terwij] het niet nakomen van de verplichting strafrechtelijk is gesanctioneerd. Beide bepalingen golden niet ten aanzien van cle veiligheidskundige. Deze laatste verschillen ontstonden pas in de laatste fase van de behandeling van het wetsontwerp door de aanneming van een amendement dat vooral beoogde om andere zaken te regelen, met name de

305 Dit onderzock is gepubliceerd als bijlage 7 bij: Arboraad betreffende de deskundige diemsten, deel 1. Bedrijfsgezondheids- en bedrijfsveiligheidsdiensten, Zoetermeer 1984, nr. 4.

306 G.I.H.M. Bayens, B. I. Tappèl, Bedrijfsveiligheidszorg in Nederland, Het Veiligheidsinstituut, Ansterdan 1986.

307 Arboraad, 1984 , nr. 4, t.a.p. p. 14

308 Onderzoek Veiligheidsinstituut, 1986, t.a.p. p. 36; ITS-onderzoek 1988, t.a.p. p. 66.

309 MvT, t.a.p. p. 15. 
Arbodienst. ${ }^{310}$ Hieruit concludeerde de Arboraad terecht dat deze verschillen onbedoeld waren ${ }^{311}$ : er valt immers geen redelijk argument aan te voeren waarom juist deze bepalingen niet voor de veiligheidskundige zouden gelden, terwijl deze wèl verplicht $\mathrm{kan}$ worden gesteld. $\mathrm{Bij}$ de dereguleringswetswijziging is dit verschil per 1 januari 1988 dan ook ongedaan gemaakt. ${ }^{312}$

Een verschil betreft ook nu nog de verplichting om voor de or een jaarverslag te maken: deze geldt wel voor de veiligheidsdienst en niet voor de veiligheidskundige. Omdat echter de laatste wèl verplichtingen heeft ten opzichte van de or zoals informatie, hulp en bijstand geven, behoeft dit voor de praktijk weinig bezwaarlijk te zijn.

De werknemersleden in de Arboraad waren van mening dat de bepalingen ten aanzien van de veiligheidskundige òf niet gebruikt zouden moeten worden òf uit de wet zouden moeten worden geschrapt. Indien een volledige dienst voor bepaalde ondernemingen immers een te zware belasting zou vormen, kan altijd nog aansluiting worden gezocht bij een gezamenlijke dienst. Bovendien zou een veiligheidsdienst ook kunnen bestaan uit één gekwalificeerde veiligheidskundige. Het gaat er immers om dat de veiligheidszorg voldoet aan bepaalde eisen van kwaliteit, organisatie, en dergelijke en dat deze erkenning behoeft, zodat er een zekere garantie is dat de wettelijke taken naar behoren worden uitgevoerd. Dit standpunt werd ook door de beroepsvereniging gehuldigd. ${ }^{313}$

De werkgeversleden wilden de wettelijke structuur in dit opzicht onaangetast laten. Volgens hen wordt in de visie van de werknemersleden te veel uitgegaan van (nog vrijwel niet bestaande) gezamenlijke diensten en wordt te weinig rekening gehouden met de behoefte aan differentiatie van de zorg. De werkgeversleden refereerden hierbij uitdrukkelijk aan de beoogde nauwe aansluiting op de praktijk. In zijn praktische uitwerking zijn deze verschillen van inzicht echter niet zo groot, omdat evenals de werknemers, de werkgevers een wetswijziging bepleitten die ertoe zou moeten leiden dat ook het niet voldoen aan de verplichting tot het hebben van een veiligheidskundige strafrechtelijke consequenties zou moeten hebben, dat aansluiting bij een gezamenlijke dienst mogelijk zou moeten worden en dat ook de individuele veiligheidskundige zou moeten worden erkend. Alleen een wetswijziging ter bereiking van dit laatste is per 1 januari 1988 dus niet gerealiseerd.

De taken van de veiligheidsdienst en de veiligheidskundige hebben tot doel de bevordering van de veiligheid en de hygiëne van het arbeidsmilieu. Te dien einde verstrekken zij adviezen en verlenen zij bijstand aan de werkgever, de werknemers en de or c.q. de Arbocommissie. Oorspronkelijk ontbrak hierbij de verplichting die de bgd wèl al vanaf de totstandkoming van de Arbowet

310 TK 1979-1980, 14.497, nr. 163 (nader gewijzigd amendement van B. Bakker en Toussaint; tweede herdruk).

311 Arborad, 1984 , nr. 4, ta.p. p. 17.

312 TK 1986-1987, 19.824 , nr. 5 (MvA), p. 16.

313 Nederlandse veremiging voor veiligheidskunde, Nota de positie van de Veiligheidsdienst, 1986. 
had, nl. het nauw samenwerken met de werkgever en de werknemers(vertegenwoordiging). Waar ook uit de parlementaire behandeling geen argument gehaald kon worden om dit verschil te rechtvaardigen, is het terecht niet gehandhaafd: per 1 januari 1988 moet ook de veiligheidsdienst nauw samenwerken met de overige partijen in de onderneming. Uit het oorspronkelijke art. 19 lid 5 kon opgemaakt worden dat niet alleen het hoofd van een veiligheidsdienst, maar ook het veiligheidskundige personeel, in tegenstelling tot de overeenkomstige regeling in art. 18 lid 5 directe toegang zou moeten hebben tot de hoogste leiding. 'Van departementale zijde' had de Arboraad al vernomen dat het nooit de bedoeling was geweest om alle veiligheidskundigen werkzaam in een veiligheidsdienst het recht te geven van toegang tot de hoogste leiding. Los van de vraag of het departement nu wel de aangewezen instantie is om duidelijk te maken wat in een wet wordt bedoeld, zeker als de betreffende passage al in een wroeg stadium van de parlementaire behandeling zo is geformuleerd, was het zowel bezien vanuit het praktisch functioneren als vanuit de overeenkomstige regeling voor de bgd redelijk om deze mogelijkheid ongedaan te maken. Ook dit is bij de dereguleringswetswijziging per 1 januari 1988 gebeurd.

Ten aanzien van de bevoegdheid van de veiligheidsdienst c.q. veiligheidskundige wil ik nog wijzen op een bevoegdheid die zij wettelijk niet hebben. Dat betreft de mogelijkheid om bindende veiligheidsmaatregelen op te leggen of zelfs om bij gebleken noodzaak de productie te stoppen. Hoewel het hier om een taakopvatting gaat waarvoor in de praktijk wel gepleit wordt, is dit door de minister in de toelichting bij het wetsontwerp, naar mijn mening terecht, afgewezen. ${ }^{315}$ De betreffende zienswijze zou immers binnen de onderneming tot verwarring kunnen leiden omtrent de bestaande verantwoordelijkheid en aansprakelijkheid. Deze dienen te (blijven) berusten bij de hoogste leiding en eventueel bij de daartoe aangewezen lijnfunctionarissen. In zijn MvA herhaalde de minister dit standpunt, maar voegde er (onnodig) aan toe dat de werkgever wèl dergelijke bevoegdheden aan zijn veilligheidskundige kan toekennen, al blijft hij in laatste instantie verantwoordelijk voor het verlenen van die bevoegdheid en voor het toezicht op het gebruik ervan. ${ }^{316}$

\subsection{De Arbodienst}

Er bestaat uiteraard een nauwe relatie tussen veiligheidszorg en gezondheidszorg: veiligheid immers is mede van invloed op de gezondheid van de werknemers. Om die reden is al door de SER in zijn advies over het ontwerp Arbowet gepleit voor een gecoördineerde behandeling van veiligheids- en gezondheidsvraagstukken, ook op het institutionele vlak. Volgens de SER betekende dit 
dat indien voor ondernemingen zowel een bgd als een veiligheidsdienst verplicht was, de mogelijkheid zou moeten bestaan om aan deze verplichting te voldoen door én dienst voor veiligheid en gezondheid in te stellen. ${ }^{317}$ In het oorspronkelijke wetsontwerp werd in art. 17 deze mogelijkheid inderdaad geopend, nà de bepalingen over de bgd en de veiligheidsdienst c.q. veiligheidskundige (oorspronkelijk de artikelen 15 en 16). Tijdens de drie jaar durende parlementaire behandeling in de Tweede Kamer heeft het vraagstuk van de geïntegreerde dienst voortdurend aandacht gevraagd. Een belangrijk punt daarbij was ook het al dan niet intern zijn van een dergelijke dienst. Uiteindelijk werd door amendering art. 17 over de Arbodienst in de wet opgenomen, waarbij als uitgangspunt de interne dienst werd geïntroduceerd. ${ }^{318}$

Deze Arbodienst zou omvattender moeten zijn dan de combinatie van de bgd en de veiligheidsdienst: ook welzijnsdeskundigen zouden moeten worden opgenomen. Doelstelling en takenpakket werden uiteindelijk een combinatie van de doelstelling en de taken van de bgd en de veiligheidsdienst met een algemene toevoeging over het welzijn in verband met de arbeid. De Arbodienst werd bovendien als eerste mogelijkheid in de wet opgenomen om duidelijk te maken dat de gecombineerde dienst niet meer een alternatief was voor de afzonderlijke diensten, maar dat de voorkeur uitging naar een geïntegreerde dienst. Afzonderlijke diensten waren tijdelijk en hadden niet de voorkeur. Minister Albeda was terughoudender: “Ik wijs erop dat de Arbodiensten in mijn ogen een toekomstperspectief zijn, te meer ondat twee van de drie componenten van de Arbodienst (veiligheid en welzijn) eigenlijk nog van de grond moeten komen. Een belangrijk feit vind ik voorts dat de sociale partners en de verenigingen van deskundigen zich in het geheel nog niet hebben kunnen uitlaten over deze zaak. Kort samengevat wil ik de Kamer erop wijzen dat aanneming van het amendement niet veel meer gevolgen zal kunnen hebben dan het in de wet zichtbaar maken van een perspectief dat nog wel even van ons af ligt. ${ }^{319}$ Iets later gaf de minister toe dat hij aanvaarding van het betreffende amendement ook niet direct als 'een catastrofe' beschouwde, waarna het amendement werd aangenomen. ${ }^{320}$ De sociale partners bleken later overigens niet onverdeeld gelukkig met het kamerinitiatief en wensten in geen geval een snelle invoering. ${ }^{321}$

Toch kan ten aanzien van de Arbodienst in elk geval geconstateerd worden dat de regeling woor zover het gaat om de interdisciplinaire aanpak méér overeenkomt met het ILO-verdrag van 1985 inzake de bgd dan de regeling van de bgd in art. 18. 'Het komt er op neer dat art. 17 meer omvat dan het verdrag eist, nl.

317 SER-adwies, 1976 , nr. 18, t.a.p. p. 5.

318 Het eerste amendement terzake was van de PwdA-leden B. Bakker en Toussant en droeg nr. 67. Nadien is het verscheidene malen gewijzigd en 'gesubamendeerd'. Zie bijvoorbeeld de nrs. 133, 146. Over nr. 163 werd uiteindelijk gestemd.

319 Handelingen TK 1979-1980, 13 mei 1980, p. 4681.

320 Handelingen t.a.p. p. 4682.

32.1 VAR, Voorlopige Arbeidsraad is tegen stimuleringsbeleid Arbodiensten, persbericht 25 november 1982. Zie woorts P.L. Spanjersberg, Het visioen van de Arbodienst in: Inzicht in de Arbowet, Deventer 1983, p. 47-71. 
een volledige integratie van bgd, veiligheidskundige zorg en welzijnszorg; handhaving van de verplichte oprichting van Arbodiensten is dan ook niet nodig om aan het verdrag te voldoen. Art. 18 biedt echter te weinig, omdat voor andere disciplines dan artsen en welzijnsdeskundigen geen gelijkwaardige plaats is ingeruimd en de leiding a priori is voorbehouden aan een medicus. ${ }^{.322}$ Mede ook in het licht van dit laatste was het verwonderlijk dat het kabinet naar aanleiding van de dereguleringsvoorstellen van de commissie Geelhoed besloot om de verplichting tot het oprichten van of het aansluiten bij een Arbodienst te laten vervallen, 'onder handhaving overigens van de in dit artikel vervatte materiële taken' ${ }^{323}$ Dit is nòg verwonderlijker als bedacht wordt dat niet lang daarvóór het ministerie van Sociale Zaken en Werkgelegenheid, na een gunstig advies van de VAR, besloten had om een onderzoek te subsidiëren naar de vorming van een Arbodienst door uitbreiding van een al bestaande bgd. ${ }^{324}$ In 1986 werd pas het resultaat gepubliceerd, dus nà het kabinetsbesluit inzake de deregulering. ${ }^{325}$ De belangrijkste conclusie van het onderzoek luidt dat door de grote samenhang tussen de zorg voor veiligheid, gezondheid en welzijn er grote voordelen aan verbonden zijn deze te verenigen in één Arbodienst. De voordelen hebben zowel betrekking op de kwaliteit van de zorg als op het vermijden van takafstemmingsproblemen en dupliceringen.

Bij de behandeling van de dereguleringsvoorstellen in de Tweede Kamer werd vervolgens sterk aangedrongen op handhaving van de Arbodienst, vooral vanuit het perspectief van integratiemogelijkheid van de functies veiligheid, gezondheid en welzijn. De staatssecretaris achtte het 'in principe mogelijk om in art. 20 aan te geven dat de werkgever aan zijn verplichting tot coördinatie tussen de bedrijfsgezondheidsdienst, de veiligheidsdienst of veiligheidsdeskundige en de uitoefening van zijn welzijnstaken (artikel 23, onderdeel c, onder $3^{\circ}$ ) zou kunnen voldoen door oprichting van een Arbodienst'. ${ }^{326}$. Dit standpunt werd neergelegd in een amendement dat vervolgens werd aangenomen. ${ }^{327}$ Vanaf 1 januari 1988 staat de Arbodienst nu dus genoemd in art. 20, het artikel dat voor het overige handelt over de aansluiting bij, of oprichting van een gezamenlijke dienst (verschillende werkgevers) en een gecombineerde dienst (verschillende deskundige diensten).

322 J.K.M. Gevers, SMA, 1986, t.a.p. p. 416.

323 Brief van de minister van Justitie, TK 1983-1984, 17.391, ar. 45, p. 2.

324 VAR, Advies inzake de notal 'Onderzoekswoorstel experiment arbeidsomstandigheden', 1981, nr. 1; ministerie van Sociale Zaken en Werkgelegenheid, Brief van 2 november 1982 aan de VAR (DGA, nr. 236).

325 Ministerie van Sociale Zaken en Werkgelegenheid, Op weg naar een Arbodienst, Den Haag 1986.

326 TK 1986-1987, 19.824 , nr. 8 (Nota n.a.v. het eindverslag), p. 7.

327 TK 1986-1987, 19.824, nr. 18 (Amendement van de Leeuw en Leijnse). 


\subsection{Arbo-instituten}

Als het ware in de slipstream van de Arbodienst werd in de Arbowet in het huidige art. 21 het fenomeen van het Arbo-instituut geïntroduceerd. Vóor de plenaire behandeling was er nog nooit over gesproken en tijdens deze behandeling buitengewoon summier. Het amendement van PvdA en CDA werd door de PvdA woordvoerder toegelicht met de opmerking dat bet een nieuw element betrof 'waaraan wij zelf nog even zullen moeten wennen. De tijd zal leren, in welke mate en op welke wijze deze gedachte gestalte zal krijgen'. ${ }^{328}$ Wetgeving als de allerindividueelste expressie van de allerindividueelste emotie. De minister was zowel welwillend als afwachtend. 'Wanneer ik eerder al uiteen heb gezet dat Arbodiensten een zaak voor de toekomst zijn, geldt dit zeker voor deze service-instituten, maar ik wacht de discussie in tweede termijn af. ${ }^{329}$ Het moet een teleurstellende ervaring voor de minister geworden zijn. De discussie daarna beperkte zich tot de mededeling van een CDA-afgevaardigde dat in het betreffende amendement 'een drukfoutje" voorkwam. ${ }^{334}$ Zonder nadere discussie is vervolgens het amendement aangenomen. Lit de woorden van de minister blijkt al de bedoeling van een Arbo-instituut. Het is vooral bedoeld als een service-instituut dat onderzoek verricht en aan de aangesloten ondernemingen voorlichting en informatie verschaft. Verplicht tot aansluiting kunnen worden bedrijven of inrichtingen die een bgd of veiligheidsdienst c.q. veiligheidskundige moeten hebben en tot een bij AMvB aangewezen categorie behoren. Inmiddels heeft het kabinet naar aanleiding van de bevindingen van de commissie Geelhoed besloten om te bezien of de verplichting tot aansluiting bij een Arbo-instituut moet worden gehandhaafd en om het advies van de Arboraad over de oprichting van een centraal instituut af te wachten. ${ }^{331}$

Dit advies is in september 1986 vastgesteld en stelt niet voor om een nieuw instituut in het leven te roepen, doch om te komen tot samenwerking van een aantal instellingen die werkzaam zijn op het terrein van de arbeidsomstandigheden. Hiertoe zou een nieuw orgaan in het leven dienen te worden geroepen onder de naam: 'Overlegorgaan dienstverlening arbeidsomstandigheden'. ${ }^{332}$ Vervolgens is art. 21 in de Arbowet gehandhaafd.

328 Handelingen t.a.p. p. 4670 .

329 Handelingen t.a.p. p. 4682

330 Handelingen t.a.p. p. 4682 .

331 Zie noot 323 .

332 In eerste aanleg zou vooral de samenwerking bevorderd moeten worden tussen enerzijds de Stichting coördinatie en commumicatie met betrekking tot gegevens voor onderzoek inzake ziekteverzuim (CCOZ) en het Veiligheidsinstitunt, en anderzijds die Afdeling bedriffsveiligheid en de sectie verzuimadvisering wan de afdeling statistiek en onderzoek wan het Gemeenschappelijk Administratiekantoor (GAK).

Arboraad, Advies inzake Overlegorgaan dienstverlening arbeidsomstandigheden, Zoetermeer 1986.

De fusie tussen het Veiligheidsinstituut en het CCOZ is in 1987 tot stand gekomen: Het nieuwe instituut heet: het Nederlands Instituut voor Arbeidsomstandigheden (NIA) en is in maart 1988 officieel geopend. 


\section{De arbeidsinspectie}

\subsection{Inleiding}

De ambtenaren van de Arbeidsinspectie zijn belast met de handhaving van het bij of krachtens de meeste wetten op het gebied van de arbeidsomstandigheden bepaalde, en met de medewerking aan de uitvoering daarvan (voor de Arbowet: art. 32) ${ }^{333}$ Het begrip 'de Arbeidsinspectie' wordt op verschillende manieren gebruikt. Soms wordt gedoeld op het gehele apparaat, dus het Directoraat-Generaal van de Arbeid (DGA) en de districten, soms alleen op de 10 districten of alleen op het DGA, en soms alleen op het districtshoofd of op een enkele ambtenaar al dan niet met een specifieke taak.

In het algemeen zal ik ook van de Arbeidspinspectie spreken tenzij dat begripsmatig verwarring wekt, bijvoorbeeld in het geval van een bevoegdheid die exclusief is toegekend aan een persoon in een specifieke functie zoals het districtshoofd.(Maar ook in dat geval zijn in de praktijk veel bevoegdheden gedelegeerd aan andere ambtenaren en worden werkafspraken gemaakt over de praktische uitoefening van bevoegdheden). Voor de nauwe relatie tussen geschiedenis en uitbouw van de arbeidsbeschermende wetgeving en de Arbeidsinspectie moge ik verwijzen naar het vorige hoofdstuk. In deze paragraaf zullen achtereenvolgens aan de orde komen de taken en de organisatie van de Arbeidsinspectie, het beleid, de werkwijze en de instrumenten en enkele overige bevoegdheden en verplichtingen. Tenslotte zal enige aandacht geschonken worden aan het functioneren van de Arbeidsinspectie in de praktijk.

\subsection{De taken en de organisatie}

Het zgn. 'Organisatiebesluit' waarvan de laatste versie dateert uit 1982 , regelt in paragraaf 4 ' $V$ an de districtshoofden der Arbeidsinspectie' de taken van het districtshoofd. Zij verschillen nauwelijks van die in het oorspronkelijke besluit van $1920 .{ }^{334}$ De taken worden niet alleen op de schouders van het districtshoofd gelegd: een aantal kan ook worden uitgevoerd door de andere ambtenaren. In dat geval draagt het districtshoofd daarvoor de zorg en oefent hij het nodige toezicht uit. De belangrijkste taken, vermeld in de artikelen 11 en 12 , zijn de volgende:

333 Daarnaast verricht de Arbeidsinspectie nog wat 'branche-vreemde' activiteiten, die echter zoveel mogelijk worden afgestoten, zoals bijwoorbeeld gebeurd is met het overlleg met de directeur van het $G A B$ inzake de toestemming tot beëindiging van een arbeidsverhouding en het daaraan vooralgaand horen wan de in aanmerking komende organisatie van werkgevers en werkmemers (art. 6 lid 4 B.B.A.). Hierover: J. van Drongelen, De rol van de Arbeidsinspectie bij ontslagzaken, Blinde vlekken in het sociaal recht, (Frenkel-bundel), Deventer 1986, p. $100-112$.

334 Beschikking van de minister van Sociale Zaken en Werkgelegenheid d.d. 3 augustus 1982 (Stc. 156). Deze beschikking vervangt het $\mathrm{KB}$ d.d. 23 augustus 1920 ( $\mathrm{S}$. 720), dat bij $\mathrm{KB}$ van 15 november $1982(S .674)$ werd ingetrokken. 
- de handhaving en de medewerking aan de uitvoering van wettelijke voorschriften, alsmede het opsporen van overtredingen daarvan, een en ander onder de zorg en het toezicht van het districtshoofd;

- het desgevraagd adviseren en informatie verstrekken aan de minister en de Directeur-Generaal van de Arbeid;

- het zich op de hoogte houden van de arbeidstoestanden in het district en van de gebeurtenissen die van belang zijn voor de kennis der arbeidsverhoudingen;

- het instellen van onderzoekingen en het verzamelen van gegevens, al dan niet opgedragen door de directeur-generaal;

- het jaarlijks aan de laatstgenoemde verslag uitbrengen over de werkzaamheden;

- het bezoeken van plaatsen die aan het toezicht van het districtshoofd zijn onderworpen;

- het voldoen aan de opdracht van de directeur-generaal tot het bezoeken van bepaalde plaatsen en tot het uitoefenen van toezicht op de naleving van bepaalde wettelijke voorschriften.

Volgens art. 15 kunnen de districtshoofden daarnaast aan de minister en de directeur-generaal ongevraagd voorstellen doen.

In twee artikelen wordt bovendien bepaald wat niet tot het taakgebied van de Arbeidsinspectie hoort. Volgens art. 6 dienen de ambtenaren weliswaar te proberen om zo veél mogelijk overeenstemming te bevorderen tussen de eisen der wetgeving en de belangen van alle bij de arbeid betrokken personen, maar zij dienen zich te onthouden van inmenging in geschillen tussen werkgevers en werknemers, tenzij zij hiertoe door de minister zijn gemachtigd. Het is een wat vreemde bepaling. De opdracht in het eerste gedeelte van de volzin lijkt me overbodig (ôf de wet is duidelijk en dan kan er door haar handhavers niet mee gemarchandeerd worden òf er is ruimte voor overleg en dan geldt de bepaling vanzelfsprekend), het verbod in het tweede gedeelte van de volzin heeft zijn betekenis in het bijzonder verloren sinds de Arbowet uitdrukkelijk de scheidsrechterfunctie in de onderneming opdraagt aan de Arbeidsinspectie, vooral op een verzoek daartoe van een van de betrokken partijen in een conflict.

Volgens art. 14 dienen de districtshoofden zich te onthouden van het geven van algemene voorschriften bij wijze van reglementen, instructies of circulaires. Hoewel het niet uitgesloten is dat het districtshoofd in de praktijk wel degelijk voorschriften geeft met een algemene strekking, is waarschijnlijk bedoeld dat hij niet op de stoel van de wetgever moet gaan zitten of dat hij niet moet handelen in strijd 'met het belang van de eenheid in de uitoefening van de dienst', zoals dat in art. 19 wordt genoemd.

Hoewel het bovengenoemde takenpakket in de officiële formulering sinds 1920 nauwelijks is veranderd, is dat in de praktijk toch wel het geval. Vooral de Arbowet heeft voor de Arbeidsinspectie op dat gebied gevolgen gehad, waarvan een van de meest belangrijke is de taak om te overleggen met de werkgevers en de werknemers(vertegenwoordiging). Vooral het overleg met de laatste groepering was niet altijd vanzelfsprekend. Veel kritiek van met 
name de vakbeweging kwam erop neer, dat de Arbeidsinspectie zich te weinig aantrok van klachten van werknemers, en zelfs met de werkgever onder één hoedje speelde. ${ }^{335}$ Dat de Arbeidsinspectie méér contacten had met de werkgever, vloeide overigens ook voort uit de structuur van de oude veiligheidswetgeving, waarin immers voor wat betreft de naleving de werkgever centraal stond en waarin er geen regeling was voor het betrekken van de werknemers bij de veiligheidsvraagstukken. ${ }^{336}$ Dat neemt echter niet weg dat al in een Aanbeveling van de ILO van 1923 (nr. 20) werd bepaald dat werknemers en hun vertegenwoordiging in de gelegenheid moesten worden gesteld om vrijelijk te klagen bij en te overleggen met de Arbeidsinspectie.

Onder de Arbowet is veel meer sprake van een evenwichtige benadering van elk der partijen. Blijkbaar moeten de werkgevers daar nog aan wennen. Nog voor de inwerkingtreding van de Arbowet schreven al enkele werkgeversvertegenwoordigers in 1981, na vastgesteld te hebben dat een evenwichtige benadering in een driehoeksverhouding altijd moeilijk is: 'Wij krijgen de indruk dat in sommige districten van de Arbeidsinspectie door het enthousiasme om in te spelen op de nieuwe wet de balans nu al uit evenwicht is geraakt., ${ }^{337}$ Nadien heb ik wan deze 'indruk' nergens enige bevestiging gevonden.

Sinds 1909 is er een centrale dienst van de Arbeidsinspectie die organisatorisch deel uitmaakt van het Directoraat-Generaal van de Arbeid. Aan het hoofd van de dienst staat een directeur-generaal (art. 76a lid 2 Arbeidswet). Ten behoeve van de Arbeidsinspectie is Nederland ingedeeld in tien districten. ${ }^{338}$ De districtshoofden van het derde en vijfde district zijn tevens hoofd van resp. de eerste en tweede Inspectie van de Havenarbeid (Rotterdam en Amsterdam). Onder het districtshoofd werken enkele hoofd-inspecteurs (meestal ingenieurs) met een beleidsmatige facettaak: veiligheid, gezondheid resp. sociaal arbeidsbeleid. Samen met een hoofd algemeen en intern beleid vormen zij het districtsmanagement. In alle districten is een arts gedetacheerd vanuit de centrale medische afdeling. In de districten werken personen in de binnendienst (staf en administratie) en in de buitendienst (bezoek, onderzoek, inspectie en controle). Deze buitendienst-ambtenaren zijn zowel technici en controleurs die zich vooral bezighouden met het toezicht op en het meewerken aan de arbeidsomstandighedenwetgeving, als personen wier werkzaamheden zich vooral afspelen in de sfeer van de Arbeidswet en de Rijtijdenwet. Daarnaast zijn er per district meestal twee inspectrices die met name werkzaam zijn

335 Vgl. bijwoorbeeld FNV, Commentaar ontwerp Arbeidsonstandighedenwet, brief aan de vaste commissie voor Sociale Zaken van de Tweede Kamer der Staten-Generaal, Amsterdam, 8 september 1977, p. 3.; Industriebond FNV, Arbeidsomstandighedenwet en Industriebond FNV, Amsterdam, september 1979, p. 31-36; J. Bloemarts, Op weg naar een driepartijenmodel voor het sociaal beleid in de onderneming?, SMA, 1978, p. 597.

$336 \mathrm{Vgl}$. in dit verband ook: MvA, t.a.p. p. 20.

337 C. de Meester (secretaris VNO), H.J.A. van de Kamp (secretaris NCW), Arbowet en medezeggenschap, Voer woor procedurevreters of basis woor samenwerking?, Gids personeelsbeleid arbeidsvraagstukken sociale verzekering, 26 mei 1981 (nr. 24), p. 27-33.

338 Beschikking van de staatssecretaris van Sociale Zaken en Werkgelegenheid d.d. 6 december 1982 (Stc. 247). Deze beschikking vervangt het $\mathrm{KB}$ van 30 december 1933 (S. 807), dat bij KB van 15 november $1982(5.674)$ werd ingetrokken. 
op basis van de Arbeidswet, en dan vooral met het oog op arbeid verricht door jeugdigen, het Verplegingsbesluit en, meer in het algemeen, betrokken zijn bij het sociaal beleid in de onderneming. Hiernaast bestaan er nog andere functies, waarvan de meeste evenmin bij of krachtens een wettelijke regeling zijn vastgesteld, maar die in de praktijk zijn gegroeid. Hoewel de samenstelling per district niet altijd dezelfde is, zijn de overeenkomsten groter dan de verschillen. ${ }^{339}$

In december 1986 werkten er bij de Arbeidsinspectie in totaal 788 personen, van wie 314 bij de centrale dienst en de overigen in de districten. Van deze laatste groep werkten er 281 in de buitendienst. ${ }^{340}$

In Nederland zijn de medewerkers van de Arbeidsinspectie ambtenaren. Hiermee is in beginsel de onafhankelijke opstelling verzekerd die geëist wordt in het betreffende ILO-verdag. ${ }^{341}$ Later werd het ambtenaar-zijn als vanzelfsprekende voorwaarde voor de onafhankelijkheid doorbroken. In het verdrag van 1969 (nr. 129) werd uitdrukkelijk de mogelijkheid opengehouden dat ook vertegenwoordigers van werknemersorganisaties de taken van de Arbeidsinspectie zouden kunnen uitvoeren, mits uiteraard hun onafhankelijkheid maar voldoende verzekerd was. In Nederland is daar geen gebruik van gemaakt. (De, althans in theorie, vanzelfsprekende relatie tussen het ambtenaarsschap en onafhankelijkheid gaat trouwens sinds de Arbowet ook van toepassing is op ambtenaren, in die zin nog slechts gedeeltelijk op).

Mede naar aanleiding van de zeer kritische conclusies van een extern onderzoeksbureau is binnen de Arbeidsinspectie in 1977 een organisatieproject gestart. ${ }^{342}$ Dit zgn. Project Ontwikkeling Arbeidsinspectie (POA) was gericht op het verbeteren van het functioneren van de dienst in al zijn aspecten zoals taken, werkwijze, structuur, overleg, besluitvorming, planning etc. (Op de kritiek op de Arbeidsinspectie en de reactie daarop kom ik in paragraaf 5.5. uitvoeriger terug). In 1985 werd POA formeel afgesloten, nadat de nieuwe directiestructuur van de centrale dienst gereed was: naast de directeur-generaal is er een afzonderlijke directie voor het algemeen en intern beleid, voor veilligheid, voor gezondheid, voor sociaal arbeidsbeleid en voor het stoomwezen gekomen. De resterende beleidsontwikkelende en invoerende taken uit het POA-project werden van de projectwerkgroepen overgedragen aan de staande organisatie.

$339 \mathrm{Er}$ bestaat cen zgn. functie-informatieformulier, waarin alle functies zijn opgenomen die binnen de Arbeidsinspectie zouden kunnen bestaan. De inhoud van deze functies word omschreven op grond van praktijkvoorbeelden. Vgl. A.W. Sluiter, m.m.v. F.P.H. Dijksterhuis en H. Timmerman, De Arbeidsinspectie: doelstelling, taken en werkwijze, Groningen 1984, (uitg. Kriminologisch Institunt RUG), p. 28-29 en bijlage IV (p. 108), watrin deze functies worden genoemd.

340 Jaarverslag Directoraat-Generaal van de Arbeid over 1986, Voorburg 1987, p. 27-28. De cijfers zijn in aantallen personen, zowel de full-time als de part-time bezetting per 31 december 1986 . Niet meegeteld zijn de districtshoolden en de directie van de centrale dienst. Wèl meegeteld zijn de personem werkzaam bij de Inspectie van de Havenarbeid en bij de Arboraad.

341 Art. 6 van ILO-verdrag, nr. 81, 1947.

342 Adviesgroep Mens en Organisatie, De Arbeidsinspectie in ontwikkeling, Amsterdam 1977. 
Een belangrijke verandering zal nog de districtsherindeling zijn (van tien naar acht districten èn grenscorrecties), waardoor onder meer de aantalien arbeidsorganisaties die aan het toezicht zijn onderworpen, meer vergelijkbaar worden. In het kader van een verdere planmatige ontwikkeling is het "werkplanArbo-91' opgesteld, op grond waarvan ter bevordering van doelmatig en doeltreffend optreden o.a. methoden en technieken worden ontwikkeld voor een (landelijk en geintegreerd) samenhangende bedrijvenbenadering. In 1988 is hier een begin mee gemaakt. ${ }^{343}$

Al in zijn MvA bij het ontwerp Arbowet heeft de toenmalige minister gezegd dat in verband met de invoering van de Arbowet uitbreiding van de Arbeidsinspectie met ongeveer 200 personen noodzakelijk was. ${ }^{344} \mathrm{Hij}$ voerde daar drie argumenten voor aan: de intensivering van de contacten met de werknemers, het betreden van nieuwe terreinen (waarschijnlijk doelde de bewindsman op de meer op overleg en sociaal ondernemingsbeleid gerichte taken) en het landelijk overleg in de Arboraad. Haaks daarop kwam echter het kabinetsbesluit om in de periode 1983-1986 de personeelsbezetting van de departementen jaarlijks met $2 \%$ te verminderen. Binnen het departement is vervolgens besloten om door middel van het afstoten van taken voor de gehele periode $15 \%$ personeelscapaciteit vrij te maken, enerzijds om te voldoen aan de $8 \%$ capaciteitsreductie en anderzijds om zodoende ruimte te scheppen voor nieuw beleid, waaronder dat ten behoeve van de Arbowet. ${ }^{345}$ Eind 1986 is deze operatie afgerond zonder gedwongen ontslagen en zonder her- of overplaatsingen. ${ }^{346}$

\subsection{Beleid, werkwijze en instrumenten}

De Arbeidsinspectie is een (voorlopig nog) in tien districten gedeconcentreerde rijksdienst. ${ }^{347}$ Dit betekent een grote mate van beleidsvrijheid voor elk districtshoofd als gedeconcentreerd ambt. In de praktijk leidt dit tot verschillen in taakopvatting en werkwijze. Zo is bijvoorbeeld uit een onderzoek gebleken dat in het district Groningen relatief beduidend meer aanwijzingen en eisen worden gegeven naar aanleiding van het Veiligheidsbesluit Fabrieken of Werkplaatsen dan landelijk het geval is. ${ }^{348}$ Daarnaast is er binnen elk district nog een grote mate van beleidsvrijheid bij de afzonderlijke ambtenaren. Dit

343 TK 1987.1988, 20.200, hfdst. XV nr. 2 (MvT bij de begroting van Sociale Zaken en Werkgelegenheid), p. 56.

344 MvA, t.a.p. p. 22

345 In het verwerpelijke Haagse mandarijnen-jargon heet dit een herallocatic-operatie". Zie Jaluerslag Arbeidsinspectie 1983 , ta.p. p. 9.

346 Jaarverslag Directoraat-Generaal van de Arbeid over 1986, p. 30.

$347 \mathrm{Vgl}$. F. A.M. Stroink, Het leerstuk der deconcentratie, Den Haag 1978. In deze dissertatie wordt de Arbeidsinspectie regelmatig als voorbeeld gebruikt, ter illustratie van diverse aspecten van gedeconcentreerde ambten.

348 A.W. Sluiter, t.a.p. p. 89. 
geldt zowel voor de selectie van arbeidsorganisaties als voor het uitvoeringsproces op de werkplek. ${ }^{3.49}$

De minister kan voor concrete beslissingen van gedeconcentreerde ambten politiek niet verantwoordelijk worden gesteld, noch kan hij in het algemeen voorschrijven hoe het districtshoofd in concreto gebruik moet maken van zijn bevoegdheden die hij direct aan de wet ontleent. ${ }^{350}$ Teneinde toch een zekere beleidseenheid te verzekeren bestaat er een aantal mogelijkheden, waarvan enkele bovendien aan de minister de gelegenheid geven om invloed uit te oefenen op het gevoerde en te voeren algemeen beleid, waarvoor hij uiteraard wèl politiek aanspreekbaar is ${ }^{351}$

In de eerste plaats zijn er de vergaderingen van de Directeur-Generaal van de Arbeid met alle districtshoofden. Deze vergaderingen dienen volgens art. 19 van het Organisatiebesluit ten minste vier maal per jaar te worden gehouden. In de praktijk gebeurt dit gemiddeld een maal per maand. Door het informele karakter vormen deze vergaderingen een snel en flexibel beleidsinstrument dat in twee richtingen werkt: oplegging van beleid aan de districten en voeding voor nieuw beleid 'naar boven'. In de tweede plaats kan de minister invloed uitoefenen op het beleid en de eenheid daarvan, doordat hij ten aanzien van de meeste (rechts)beslissingen van de Arbeidsinspectie als beroepsinstantie fungeert (vgl. art. 42 Arbowet). In de derde plaats kan een minister door zijn benoemingsbeleid een zekere invloed uitoefenen. In de vierde plaats dient hier het voor de praktijk uiterst belangrijke beleidsinstrument van de publikatiebladen (de zgn. P-bladen) te worden genoemd. Dit zijn publikaties van de Arbeidsinspectie, meestal tot stand gekomen in overleg met deskundigen en/ of het bedrijfsleven, die (delen van) wetteksten bevatten en waarin wordt uitgelegd op welke manier daar het beste aan voldaan kan worden. Bovendien staan er vaak aanbevelingen in die los staan van wettelijke bepalingen. Noch de aanwijzingen die betrekking hebben op de naleving van bepaalde artikelen, noch de aanwijzingen die niet gebaseerd zijn op wetsartikelen zijn echter bindend. De Arbeidsinspectie bezit immers in casu geen regelgevende bevoegdheid. ${ }^{35 z}$ Toch zijn deze P-bladen, ondanks het ontbreken van een wettelijke status ook juridisch wel degelijk relevant. De strafrechter zal rekening houden met het bepaalde in de P-bladen - al is overtreding van deze norm als zodanig niet strafbaar. Dit zal hij doen zowel in het geval de norm in het P-blad is gevolgd (in dat geval mag de werkgever er immers vanuit gaan voldaan te hebben aan de wettelijke bepalingen terzake) als in het geval dat dat niet is gebeurd. Ook bij een schadevergoedingsactie tegen de werkgever kan het al dan niet opvolgen van de aanwijzingen in de P-bladen in civilibus een rol spe-

349 J.C.M.M. Siemons, Bedrijfsinspecteurs van de Arbeidsinspectie: 'Jonely hunters' in val- en knelgevaar, Enschede 1986, m.n. p. 42-60.

350 Er bestaat uiteraard een politieke ministeriele verantwoordelijkheid in die zin dat de minister verantwordelijk is voor het door hem gevoerde beleid dat (mede) de basis vormt woor de concrette beslissing. Vgl. ook F.A.M. Stroink, t.a.p. p. 147 .

351 Over deze mogelijkheden: L. Bleumer-wan der Klein, F. Hent, Theorie en praktijk van de beleidsvorming door de Arbeidsinspectie, Ars Aequi, 1978, p. 377-387.

352 F.A.M. Stroink, t.a.p. p. 125. 
len. Het handelen in strijd met de normen in een P-blad kan bovendien direct strafbaar worden indien de Arbeidsinspectie een eis of een aanwijzing afgeeft die in feite het bevel inhoudt om een of meer van de in de P-bladen aanbevolen normen na te leven.

De functie van de P-bladen is illustratief voor de werkwijze van de Arbeidsinspectie: voorlichting en advies hebben in het algemeen de voorkeur boven formeel bestuurlijk - al dan niet politioneel - optreden. Ook het informeel overleg en het instrument van de overreding nemen in dit kader een belangrijke plaats in. Vooral ten aanzien van de grote ondernemingen bestaat er vaak "een netwerk van coöperatieve, informele en betrekkelijk duurzame relaties", die de wetshandhaving soepel doen verlopen. ${ }^{35.3}$ Dit betekent overigens niet dat de 'shadow of the law' gemist kan worden: het 'formeel spelen' dreigt altijd op de achtergrond indien de norm van bereidwilligheid verlaten wordt. Dit geldt overigens ook omgekeerd, 'een overheid die zich opeens bureaucratischformeel gaat gedragen, kan het succes van zijn missie wel vergeten'. ${ }^{354}$ Op verschillende manieren kan de Arbeidsinspectie in contact komen met een onderneming. In de eerste plaats is dat via al dan niet te voren aangekondigde bezoeken. Deze bezoeken kunnen bijvoorbeeld dienen ter controle, ter gerichte opsporing of plaatsvinden in het kader van een onderzoek na een bedrijfsongeval. Om deze bezoeken kan ook worden gevraagd. Dit kan een informeel verzoek zijn, bijvoorbeeld in het kader van een adviesaanvraag, of een formeel verzoek.

Formeel is onder meer het verzoek om een onderzoek in te stellen ex art. 32 lid 6 Arbowet. Dit verzoek kan gedaan worden door de or, de Arbocommissie of bij ontbreken van beide colleges, door een meerderheid van de belanghebbende werknemers, of door de vakvereniging die als zodanig in die onderneming of bedrijfstak werkzaam is. Aan een dergelijk verzoek dient de Arbeidsinspectie 'zo spoedig mogelijk' gehoor te geven. Deze bepaling is via amendering in een laat stadium in de wet gekomen. ${ }^{355}$ In de openbare commissievergadering maakte de minister vooral bezwaar tegen het amendement in verband met de takverzwaring die bij aanneming voor de Arbeidsinspectie zou kunnen optreden, al vond hij het 'op zichzelf een aantrekkelijke gedachte'. ${ }^{356}$ Vervolgens is zonder nadere discussie een iets gewijzigd amendement vrijwel zonder tegenstemmen aangenomen. ${ }^{357}$ Het bijzondere van deze bepaling is niet zozeer dat werknemers(vertegenwoordigingen) een dergelijk beroep kunnen doen op de Arbeidsinspectie, maar dat deze laatste zo spoedig mogelijk gehoor moet geven aan dat verzoek èn dat het verzoek ook gedaan kan worden door de vakvereniging. (Art. 32 lid 6 zal overigens pas in de laatste fase in werking treden).

$353 \mathrm{Vgl}$. A.J. Hoekema, Het vertrouwensbeginsel en de spanning tussen formele bewoegdheid en materiële effectiviteit van het overheidshandelen, R.M. Themis, 1984, p. 550-574, m.n. p. 555 en 556 .

354 A.J. Hoekema, t.a.p. p. 567

355 TK 1979-1980, 14.497, nr. 66 (amendement Moor, Toussaint, Hartmeyer).

356 Handelingen TK 1979-1980, OCV 12 maart 1980 , p. 1369.

357 Slechts de Boerenpartij stemde tegen het amendement nr. 156. 
Een zeer belangrijk formeel verzoek is het zgn. verzoek om wetstoepassing ex art. 40 Arbowet, dat per 1 januari 1983 in werking is getreden. Al in het betreffende SER-advies werd aangedrongen op de mogelijkheid dat betrokkenen in de onderneming een zelfstandig recht zouden moeten hebben om een zaak aanhangig te maken bij de Arbeidsinspectie. De regeling is als volgt: Indien tussen de werkgever en werknemers meningsverschil bestaat omtrent de naleving van een of meer van de bij of krachtens de Arbowet gestelde regels, dan wel omtrent de aanwezigheid van ernstig gevaar voor personen, dan kunnen de werkgever alsmede de or c.q. de Arbocommissie of bij het ontbreken van beide colleges een meerderheid van belanghebbende werknemers of de in de onderneming of bedrijfstak werkzame vakorganisatie aan het districtshoofd verzoeken om toepassing te geven aan art. 35 (het geven van een aanwijzing), art. 36 (het geven van een eis tot naleving) of art. 37 (het geven van een bevel tot stillegging van het werk). Niet de werkgever maar wel de overige zojuist genoemden kunnen bovendien een verzoek richten tot de Directeur-Generaal van de Arbeid, waarin zij vragen om toepassing te geven aan art. 5 lid 2 (het geven van een aanwijzing inzake het verplicht hebben van een arbeidsveiligheidsrapport), art. 18 lid 2 (idem inzake een bgd) en art. 19 lid 2 (idem inzake een veiligheidsdienst of een veiligheidskundige). Oorspronkelijk voelde de minister er niets voor om ook aan de werknemersverenigingen deze bevoegdheid toe te kennen, (hoewel de SER vond dat dit recht 'uiteraard' ook aan haar toekwam), maar uiteindelijk zwichtte de minister voor de druk van vakbeweging en Kamer. ${ }^{358} \mathrm{Bij}$ zijn beslissing woog zwaar de overweging dat juist in een onderneming zonder or, dus de kleine ondernemingen, de werknemers onder druk kunnen komen te staan bij het nemen van een beslissing om al dan niet een verzoek tot wetstoepassing in te dienen. ${ }^{359}$

Het verzoek moet schriftelijk en gedagtekend worden ingediend, en met redenen zijn omkleed. Betrokkenen moeten zo snel mogelijk een afschrift van het verzoek zenden aan de wederpartij. Het districtshoofd (of de directeur-generaal) beslist op zijn beurt ook zo spoedig mogelijk. Hij kan dit echter pas doen na een onderzoek waarbij de verzoeker en zijn wederpartij in de gelegenheid zijn gesteld om hun mening kenbaar te maken. Uiteraard kan tijdens dit onderzoek alsnog een compromis worden bereikt - de Arbeidsinspectie zal daar ook naar streven. Daarnaast kan het districtshoofd, indien het onderzoek daartoe aanleiding geeft, gebruik maken van andere hem ten dienste staande (wettelijke) rechtsmiddelen zoals het (doen) opmaken van een procesverbaal. Het verzoek kan natuurlijk ook worden afgewezen. Dit dient schriftelijk, gedagtekend en genotiveerd te gebeuren, aan alle betrokken partijen. Volgens art. 42 lid 4 kunnen die belanghebbenden die ook het verzoek kunnen indienen binnen 30 dagen een bezwaarschrift indienen bij de minister van Sociale Zaken en Werkgelegenheid. De minister wint eerst het advies in van de (com-

358 SER-advies, t.a.p. p. 18

359 Nota n.a.v. het eindwerslag, t.a.p. p. 44 en 45. 
missie bezwaarschriften van de) Arboraad, die alvorens te adviseren de partijen in de gelegenheid stelt te worden gehoord.

In de MvT bij de oorspronkelijke tekst van art. 40 (toen art. 36) wees de minister er met nadruk op dat het altijd al had vrijgestaan aan iedere werknemer en aan iedere belanghebbende groep of organisatie om een verzoekschrift tot de Arbeidsinspectie te richten ${ }^{360}$ Dit recht vloeit immers voort uit het grondwettelijk gegarandeerde petitierecht (toen art. 8 Grondwet; nu art. 5). Derhalve, zo meende de minister, heeft een regeling op dit punt slechts zin indien zij de belanghebbende méér te bieden heeft dan reeds uit de bestaande wetgeving en praktijk voortvloeit. Dit meerdere bestaat dan hieruit dat de klager een wettelijke beroepsmogelijkheid heeft ingeval de reactie van de Arbeidsinspectie hem geen genoegdoening zou verschaffen.

In vergelijking met het door de minister aangehaalde klachtrecht zijn er echter meer verschillen. In de eerste plaats dient er bij een verzoek om wetstoepassing éérst overleg te zijn geweest tussen de partijen: er moet immers een meningsverschil geconstateerd zijn. Dit behoeft bij een klacht niet het geval te zijn. In de tweede plaats kan een verzoek om wetstoepassing in tegenstelling tot het indienen van een klacht nooit rechtstreeks door een individuele werknemer gebeuren. In de derde plaats is het verzoek om wetstoepassing met een aantal formeel-procedurele regels omkleed. Een klacht kan informeel worden ingediend. In de vierde plaats dient de Arbeidsinspectie zo spoedig mogelijk op het verzoek tot wetstoepassing te beslissen en de beslissing aan alle betrokkenen mede te delen. Op een klacht behoeft geen wettelijk gegarandeerde reactie te volgen. (Zie hierover ook paragraaf 2.4. van hoofdstuk IV).

Het verzoek om wetstoepassing kan in de praktijk een belangrijke wettelijke bevoegdheid voor met name de werknemersvertegenwoordiging betekenen. Het gaat immers om een zelfstandig uit te oefenen initiatiefrecht waardoor een beslissing van de Arbeidsinspectie wordt uitgelokt, die van invloed kan zijn op (aspecten van) het sociaal beleid in de onderneming. Dit geldt vooral ten aanzien van de alanwijzingsbevoegdheid die betrekking heeft op de welzijnsbepalingen van art. 3 Arbowet. Een aanwijzing van het districtshoofd strekkende tot naleving c.q. uitleg van art. 3 onder $g$ en $h$ (over de verplichting van de werkgever respectievelijk om er voor te zorgen dat de arbeid bijdraagt tot de vakbekwaamheid van de werknemer, dat het werk zo ingericht wordt dat de werknemer zo zelfstandig mogelijk kan werken, contacten heeft met collega's, op de hoogte is van doel en resultaat van het werk en om lopende band werk e.d. zoveel mogelijk te vermijden) en art. 13 (de verplichting tot samenwerking tussen werkgever en werknemers) kan zelfs alleen gegeven worden nadat daartoe een verzoek om wetstoepassing is ingediend.

Naar mijn smaak zijn het belang van deze bevoegdheid en de consequenties die de uitoefening ervan kan hebben tijdens de parlementaire behandeling in de Tweede Kamer wat onderbelicht gebleven. In de Eerste Kamer echter zei de VVD woordvoerder dat zijn fractie meende dat de overheid geen grotere

360 MvT, t.a.p. p. 54. 
bevoegdheid dient te krijgen dan zij voor de uitoefening van haar taak werkelijk nodig heeft. 'De mogelijkheid tot het geven van aanwijzingen aan individuele bedrijven betreffende het welzijn in verband met de arbeid is met dit principe in strijd. ${ }^{* 31}$ Dit ongewenste dirigisme zou nog in de hand kunnen worden gewerkt, doordat de or of de terzake bevoegde Commissie te snel een verzoek om wetstoepassing zou kunnen doen. De minister verzekerde echter dat het gebruik van art. 40 gezien werd als een laatste mogelijkheid om een geschil te beslechten, nadat de werkgever en werknemer zich tot het uiterste hadden ingespannen om er zelf uit te komen ${ }^{362}$ Het is echter de vraag of het zich 'tot het uiterste' inspannen in een aantal situaties wel zo voor de hand ligt, indien het conflict wellicht in een eerder stadium door tussenkomst van de Arbeidsinspectie beëindigd kan worden.

In het voorafgaande zijn de belangrijkste (formele) instrumenten van de Arbeidsinspectie inmiddels genoemd: de eis, de stillegging van het werk, het proces-verbaal en de aanwijzing. De aanwijzing noem ik het laatst, omdat dit instrument sinds de Arbowet het enige nieuwe in het rijtje is.

De bevoegdheid om een eis te stellen kende de Veiligheidswet al toe aan het districtshoofd. Ingevolge art. 36 Arbowet kan het districtshoofd (of een andere daartoe door de minister aangewezen ambtenaar) een eis stellen betreffende de wijze waarop een of meer regels gesteld krachtens art. 2 of art. 24 moeten worden nageleefd. Art. 2 maakt het mogelijk dat al dan niet van de Arbowet afwijkende regells worden gesteld in verband met de bevordering van de veiligheid, de gezondheid en het welzijn in de sectoren onderwijs, vervoer, overheid en justitie. Ingevolge art. 24 kunnen bij AMvB nadere voorschriften worden uitgevaardigd ten aanzien van een limitatieve reeks van specifieke onderwerpen. Art. 24 biedt derhalve de basis voor het grote antal min of meer gedetailleerde normeringen vooral op het gebied van de veiligheid en gezondheid, zoals die bijvoorbeeld zijn neergelegd in het-ruim 200 artikelen tellende - Veiligheidsbesluit fabrieken of werkplaatsen (VFW). De eis is gemotiveerd, schriftelijk en bevat de termijn waarbinnen eraan moet zijn voldaan. Dit laatste kan betekenen dat ook onmiddellijk aan de eis voldaan moet kunnen worden, $\mathrm{nl}$. indien de termijn op nul wordt gesteld. ${ }^{363} \mathrm{Zij}$ wordt ter kennis gebracht aan alle betrokkenen binnen de onderneming. De - strafrechtelijk gesanctioneerde - verplichting tot nakoming rust in elk geval op de werkgever, maar ook op de werknemers voorzover zulks bij de eis is bepaald. Aan de eis behoeft niet te worden voldaan zolang de bezwaarschrifttermijn ( 30 dagen) niet is verstreken en - na een ingediende bezwaarschrift - zolang niet daarop is beslist. Indien echter het districtshoofd meent dat naleving van de eis in verband met gevaar voor de veiligheid of de gezondheid redelijkerwijs geen uitstel kan lijden, kan hij bepalen dat geen schorsende werking wordt verleend. De werkgever kan vervolgens aan de President van de Rechtbank

361 Handelingen Eerste Kamer, 4 nowember 1980, p. 65.

362 Handelingen, t.a.p. p. 73. Overigens werd het ontwerp Arbowet in de Eerste Kamer zonder stemming aangenomen.

363 TK $1979-1980,14.497$, nr 13 (derde Nota van wijzigingen), p. 9. 
verzoeken om alsnog schorsende werking te verlenen. De President geeft, na het horen van alle betrokkenen, vervolgens een gemotiveerde beslissing waartegen slechts cassatie in het belang der wet open staat. De belangrijkste wijzigingen in de regeling ten opzichte van die in de Veiligheidswet zijn de verplichting om de wederpartij alle relevante informatie te geven en de mogelijkheid om geen schorsende werking te verlenen.

Een fors instrument voor de Arbeidsinspectie vormt de mogelijkheid om het werk stil te leggen. Ook deze mogelijkheid bestond al in de Veiligheidswet (art. 26 bis). In 1951 is de bepaling ingevoegd mede ter voldoening aan een overeenkomstige regeling in het ILO-verdrag nr. 8 van 1947 (art. 13 lid 2 sub b). Achterliggende gedlachte is de mogelijkheid die de Arbeidsinspectie moet hebben om, ook zonder medewerking van de werkgever, onmiddellijk te kunnen optreden in geval van ernstig gevaar voor de gezondheid. Het bevel van het districtshoofd wordt ook wel 'parate executie' genoemd ${ }^{364}$ Art. 37 Arbowet bepaalt nu dat het districtshoofd van de Arbeidsinspectie (of een andere daartoe door de minister aangewezen ambtenaar of een onder hun gezag werkzame en daartoe gemachtigde ambtenaar), kan bevelen, zowel mondeling als schriftelijk, dat personen niet mogen blijven in door hem aangewezen plaatsen, of dat bepaalde werkzaamheden moeten worden gestaakt dan wel niet mogen worden begonnen, indien hij van oordeel is dat een en ander gevaar oplevert voor mensen. In tegenstelling tot de regeling in de Veiligheidswet kan niet alleen het staken van het werk worden bevolen, maar ook het beginnen daarmee. Terecht stelt de MvT hierover: 'De behoefte hieraan kan zich in de praktijk voordoen: men denke aan de situatie waarin het districtshoofd op basis van het hem ingevolge art. 6 (nu art. 5, AG) toegezonden veiligheidsrapport tot de overtuiging komt dat door het inwerkingbrengen van een bepaalde installatie of produktieprocédé ernstig gevaar voor de werknemers kan ontstaan. Gesteld voorts dat een controlerend ambtenaar constateert dat werknemers op het punt staan reparaties te gaan verrichten in het ruim van een tankschip, terwijl een sterk vermoeden of misschien zelfs zekerheid bestaat dat dit ruim niet of onvoldoende gasvrij is gemaakt: de ambtenaar zal in dit geval bevoegd dienen te zijn het betreden van het ruim te verbieden. ${ }^{36.5}$ Desnoods kan politiehulp worden ingeroepen om te zorgen dat het bevell wordt uitgevoerd; verder kan het districtshoofd de nodige bijkomende maatregelen treffen zoals het verzegelen van werktuigen, toestellen en gereedschappen. Het bevel geldt niet langer dan gedurende zeven dagen, tenzij het is bekrachtigd door de President van de Rechtbank. ${ }^{360}$ Het verzoek hiertoe

364 Een dergelijke bevoegdheid van het districtshoofd werd tegelijk in de Arbeidswet mogelijk gemaakt. Een belangrijk verschil tussen de Veiligheidswet en de Arbeidswet was echter hierin gelegen dat sinds 1971 (Wijzigingswet van 25 maart 1971. S. 225) van de bevoegdheid zoals omschreven in de Veiligheidswet óók gebruik kon worden gemaakt indien de gevaarlijke toestand geen gevolg was van het niet naleven van het bij of krachtens de Veiligheidswet bepaalde.

365 MvT, t.a.p. p. 53

$366 \mathrm{Vg}$. bijvoorbeeld Beschikking President Rb Breda 5 november 1976, gepubliceend in de Veuligheid, 1978, p. 336 en eveneens in: J.J. van Dodeweerd, J. Struik, uitspraken veiligheidswetgeving, Deventer 1979 , p. 49 . 
moet binnen drie dagen worden ingediend door de ambtenaar die het bevel gaf. De President beslist, na het horen van alle betrokkenen, binnen drie dagen, tenzij hij meer tijd nodig heeft. De termijn van zeven dagen wordt dan dienovereenkomstig verlengd. Tegen de beslissing van de President staat alleen cassatie in het belang der wet open. Bij weigering van de bekrachtiging kan de President tevens het bevel buiten werking stellen.

Het instrument met het meest repressieve karakter is dat tot het opmaken van een proces-verbaal. Hiervan wordt in het algemeen slechts gebruik gemaakt als andere middelen hebben gefaald. In de praktijk wordt de beslissing over het al dan niet opmaken van een proces-verbaal meestal genomen door het districtshoofd in overleg met de controlerend ambtenaar. Dit kan doordat de ambtenaar een bezoekrapport opmaakt met alle relevante gegevens, zodat achteraf altijd nog het proces-verbaal kan worden opgemaakt, mede afhankelijk van het oordeel van het districtshoofd. Indien proces-verbaal wordt opgemaakt, kan de Officier van Justitie afzien van vervolging "op gronden aan het algemeen belang ontleend'. (Het opportuniteitsbeginsel van art. 167 lid 2 Wetboek van Strafvordering). Bij het Openbaar Ministerie (OM) blijkt nog wel eens onbegrip te bestaan ten aanzien van de werkwijze van de Arbeidsinspectie. Voor de laatste heeft het seponeringsbeleid van het OM vaak een willekeurig karakter. Het komt ook wel voor dat het districtshoofd nadrukkelijk om vervolging vraagt in gevallen waarin hij vindt dat de Officier van Justitie op grond van een onjuiste waardering van de zaak wil seponeren. ${ }^{367}$

De aanwijzing is een nieuw instrument voor de Arbeidsinspectie. Hoewel uit het algemeen gedeelte van de MvT viel op te maken dat de aanwijzing vooral bedoeld was om de (vele) algemene voorschriften te concretiseren of om de vraag te beantwoorden of iets al dan niet in redellijkheid kan worden gevergd, bleek uit het oorspronkelijke wetsartikel en de toelichting erop, dat de procedure in beginsel kon worden toegepast met betrekking tot alle bij of krachtens het ontwerp Arbowet vastgestelde voorschriften. ${ }^{368}$ Terecht is daartegen aangevoerd dat het gevaar dan groot is dat deze algemene inzetbaarheid ertoe kan leiden dat het instrument gehanteerd gaat worden als milde variant van de al bestaande eis tot naleving. Met name werd door kamerleden benadrukt dat het instrument ook geen alternatief mocht vormen voor concrete minimum voorschriften ${ }^{369}$ In de MvA bleek de minister althans gedeeltelijk gevoelig voor deze kritiek. Het ontwerp werd aangepast in die zin dat zowel ten aanzien van de betrokken wetsartikelen als ten aanzien van de uitvoeringsmaatregelen nu is aangegeven wanneer een eis kan worden toegepast en wanneer een aanwijzing kan worden gegeven. Als algemeen criterium geldt dat de eis wordt toegepast wanneer de normen al zo concreet zijn, dat de wijze van naleving geen punt van discussie behoeft te zijn. "Voor de meer algemeen gestelde normen, waar meer ruimte kan worden gegeven ten aanzien van de wijze, 
waarop zij moeten worden nageleefd, zie ik een zekere marge voor overleg. $\mathbb{k k}$ onderken hierbij twee categorieën, namelijk normen waarbij de gedlachten reeds meer zijn uitgekristalliseerd en normen, waarmede nieuwe ontwikkelingen in beweging worden gezet. Met het oog hierop zou ik een verschill willen maken terzake van het optreden van de Arbeidsinspectie, dat bij de eerste categorie meer actief zal moeten zijn dan bij de tweede, ten aanzien waarvan ik het initiatief bij werkgever en werknemers zelf zou willen leggen, waarbij hun, indien zij de overheid willen inschakelen, het instrument van het verzoek tot wetstoepassing ter beschikking staat. Gelet op het vorenstaande zal bij de eerste categorie de Arbeidsinspectie zelf het initiatief kunnen nemen voor het in gang zetten van de procedure. In artikel 32, negende lid (nu: art. 35 lid 6, AG) is een opsomming gegeven van de eerstbedoelde wetsartikelen. De tweede categorie is vermeld in artikel 32, tiende lid (nu: art. 35 lid 7, AG). ${ }^{370}$ Indien nu het districtshoofd van mening is dat een of meer van de in art. 35 lid 6 genoemde bepalingen niet of niet in voldoende mate, of op onjuiste wijze, worden nageleefd, dan is hij bevoegd om de werkgever terzake een aanwijzing te geven. In de gevallen genoemd in art. 35 lid 7 (dat zijn de voorschriften van art. 3 onder $g$ en h van art. 13; zie hierboven) mag hij niet overgaan tot het geven van een aanwijzing dan nadat hem hiertoe een verzoek tot wetstoepassing is gedaan ex art. 40 . In de aanwijzing moet gemotiveerd zijn aangegeven op welke punten de wettelijke bepalingen niet, onvoldoende of onjuist zijn nageleefd en welke maatregelen nodig zijn om aan de wet te voldoen. De aanwijzing wordt ter kennis gebracht van alle partijen. Zij bevat de termijn binnen welke eraan moet zijn voldaan. Zij kan niet alleen tot de werkgever, maar ook tot de werknemers worden gericht, voorzover de aanwijzing betrekking heeft op een verplichting die bij of krachtens de Arbowet aan werknemers is opgelegd. Is de aanwijzing eenmaal gegeven, dan is zij net zo verplichtend en strafrechtelijk gesanctioneerd als de eis.

Twee belangrijke verschillen met de eis zijn dat voordat de aanwijzing wordt gegeven, de partijen bij het meningsverschil in de gelegenheid moeten worden gesteld om hun mening terzake te geven en dat aan de aanwijzing nooit behoeft te worden voldaan zolang er nog een bezwaarschrift tegen kan worden ingediend of zolang op zo'n bezwaarschrift nog niet is beslist. ${ }^{371}$

\subsection{Enkele andere bevoegdheden en verplichtingen}

Om haar taak optimaal te kunnen uitoefenen staat aan de Arbeidsinspectie nog een aantal bevoegdheden ter beschikking. Tevens dient zij zich aan enkele verplichtingen te houden.

370 MvA, ta.p. p. 23

371 Van art. 35 lid 6 is nog slechts een gedeelte (per 1 januari 1983 en per 1 januari 1988) in werking getreden, en van lid 7 alleen onderdeel $b$ dat verwijst naar art. 13. Dit hangt onder meer samen met de problemen inzake de afgrenzing van bepalingen in de WOR en in de Arbowet. Zie hierower uitwoeriger paragraaf 3.4. van dit thoofdstuk. 
Belangrijke bevoegdheden hangen samen met de politionele taak van de Arbeidsinspectie. De Arbowet noemt in art. 32 lid 3 de bevoegdheid om alle bedrijven, inrichtingen en andere plaatsen, met uitzondering van woningen, te betreden. De opsporingsambtenaren kunnen daar alle handelingen en onderzoekingen verrichten die zij noodzakelijk achten zoals bijvoorbeeld het verrichten van beproevingen en metingen, het nemen van monsters of het meenemen van voorwerpen voor nader onderzoek. Daarnaast kunnen zij te allen tijde terzake van een ongeval een onderzoek instellen (art. 32 lid 4). Omdat overtredingen van de Arbowet zijn aangemerkt als economisch delict is een groot aantal opsporingsbevoegdheden geregeld in de WED; bij ministerieel Besluit zijn de ambtenaren van de Arbeidsinspectie aangewezen als opsporingsambtenaar in de zin van art. 17 lid 1 onder $2^{\circ}$ van de WED..$^{372}$

De ambtenaren van de Arbeidsinspectie hebben de bevoegdheid om van de werkgever en de werknemers te eisen dat aan hen alle verlangde gegevens en inlichtingen worden verstrekt met betrekking tot het bij of krachtens de Arbowet bepaalde. Desverlangd moeten deze gegevens schriftelijk en binnen een bepaalde termijn worden verstrekt (art. 33 lid 1). Bovendien moet aan de ambtenaren de gelegenheid en de hulp worden geboden welke zij redelijkerwijze kunnen verlangen (art. 33 lid 2). De strafrechtelijk gesanctioneerde verplichting om gegevens te verstrekken en gelegenheid en hulp te bieden rust niet alleen op de werkgever en de werknemers, maar ook op anderen die genoemd zijn in de artikelen 27 en 28 . Dit zijn zelfstandig werkenden en eigenaren en beheerders van werktuigen, machines e. $d$. Het kan immers, bijvoorbeeld in het kader van een bedrijfsongeval, nodig zijn dat de opsporingsambtenaar onderzoek verricht aan een werktuig dat door een andere onderneming is vervaardigd en waarbij werktekeningen of soortgelijke werktuigen nodig zijn. ${ }^{373}$

De vraag heeft zich voorgedaan of het bepaalde in art. 33 lid 1 niet in strijd is met het beginsel dat een verdachte niet behoeft mee te werken aan zijn eigen strafproces en dus niet tot antwoorden is verplicht (art. 29 Wetboek van Strafvordering). Al in 1931 oordeelde de HR hieromtrent dat het recht van de verdachte om te zwijgen, de verplichting om te spreken (toen nog in de Veiligheidswet en nu in de Arbowet) opheft. ${ }^{374}$ Het is de plicht van de opsporingsambtenaar om degene die hij als verdachte beschouwt mede te delen dat hij niet tot antwoorden is verplicht. ${ }^{375}$

Twee belangrijke verplichtingen voor de Arbeidsinspectie zijn elkaars spiegelbeeld: openbaarheid en geheimhouding. In het voorafgaande is de verplichting tot bekendmaking en openbaarheid al diverse malen ter sprake gekomen, met name wanneer het ging om het bekendmaken van beslissingen niet alleen

372 Besluit aanwijzing opsporingsambtenaren Arbeidsomstandighedenwet, Besluit van de minister van Justitie d.d. 17 december 1982 (Stcr. 247).

373 MvT, t.a.p. p. 49

374 HR 27 juni 1931 , NJ 1931, 1602 (m.nt. W.P.).

375 In de MvA heeft de minister deze gang van zaken desgevraagd nog eens uitgelegd. MvA, t.a.p. p. 75 . 
aan de vragende partij, maar ook aan de wederpartij. Ook indien er ongevraagd beslissingen, rapporten e.d. geproduceerd worden, dienen deze in het algemeen aan alle partijen in de onderneming te worden kenbaar gemaakt. Expliciet is deze verplichting opgenomen in art. 32 lid 5 inzake het rapport dat is opgesteld naar aanleiding van een opsporingsonderzoek, al dan niet na een bedrijfsongeval. De bepaling is overigens pas opgenomen in de Arbowet bij de vierde Nota van wijzigingen naar aanleiding van een daartoe strekkend amendement. ${ }^{376} \mathrm{De}$ bepaling kan in de praktijk van belang zijn voor slachtoffers van bedrijfsongevallen die schadevergoeding claimen en daartoe in het kader van de in beginsel op hen drukkende bewijslast, moeten kunnen beschikken over relevante gegevens. (Zie hierover paragraaf 2.4. van dit hoofdstuk en met name 2.4.3.).

In art. 34 is de geheimhoudingsplicht van de Arbeidsinspectie geregeld. De regeling bevat twee belangrijke componenten. In de eerste plaats het geheimhouden wan zaken- en bedrijfsgeheimen en in de tweede plaats het geheimhouden van namen van klagers en aangevers. De beperking van de geheimhoudingsplicht tot zaken-en bedrijfsgeheimen is overgenomen uit de Veiligheidswet 1934, die met het oog hierop in 1977 is gewijzigd. ${ }^{377}$ Tot 1977 gold een zeer ruime plicht tot geheimhouding, $\mathrm{nl}$. van 'hetgeen hun in plaatsen waar zij krachtens de wettelijke bepalingen binnentreden omtrent het daar uitgeoefend wordende bedrijf is bekend geworden'. Deze formulering was praktisch ongewijzigd uit de Veiligheidswet 1895 overgenomen. Door de nieuwe formulering werd tevens voldaan aan art. 15 van het ILO-verdrag nr. 81. In de MvT bij het ontwerp Arbowet herhaalde de minister wat bij de wijziging in 1977 door de toenmalige bewindsman werd gezegd over zaken- en bedrijfsgeheimen. ${ }^{378} \mathrm{Bij} z$ zakengeheimen gaat het om geheimen die de financieel-economische positie van de onderneming betreffen en om commerciële geheimen. Bij bedrijfsgeheimen kan worden gedacht aan technische vindingen, waarvan de onderneming door eigen onderzoek kennis heeft gek regen. Hiermee werd dus een enge begrenzing gegeven aan de geheimhoudingsplicht. Indien een ambtenaar van de Arbeidsinspectie optreedt als getuige in een civiel-rechtelijk of strafrechtelijk proces, kan hij wel mededelingen doen over bijvoorbeeld het gebruik van een voor de gezondheid schadelijke stof, maar niet indien hij daarmee een bedrijfsgeheim bekend maakt. De geheimhoudingsplicht - in de vorm van een verschoningsrecht - geldt in beginsel ook ten aanzien van de rechter. Deze laatste beslist uiteindelijk over de grenzen van het begrip bedrijfsgeheim en dus van het verschoningsrecht. ${ }^{379}$ De geheimhoudingsverplichting ten aanzien van zaken- en bedrijfsgeheimen in het arbeidsveilig-

376 TK 1979-1980, 14.497, nr. 138 (vierde Nota van wijzigingen), p. 4; amendement van Moor c.s., t.a.p. nr. 66.

377 Wet van 23 november 1977 (S. 689).

378 MvT, t.a.p. p. 75 .

379 Nota naar aanleiding van het eindverslag, t.a.p. p. 43. In deze nota werd het begrip bedrijfsgeheim nog verder geexpliciteerd in de zin dat het gaat om gegevens die van belang zijn in de concurrentiestrijd en waarvoor 'de bedrijfsspionage' zich interesseert. 
heidsrapport geldt niet alleen voor de Arbeidsinspectie, maar ook voor alle andere instanties die hiervan kennis kunnen nemen (art. 34 lid 3 jo art. 5 lid 9). De geheimhoudingsbepalingen zijn zo geformuleerd dat daarvan afwijkende voorschriften al dan niet vastgelegd in de Arbowet, hiervoor in de plaats treden. Dit is onder meer van belang voor de informatieplicht van de Arbeidsinspectie jegens de werknemers(vertegenwoordiging) ex art. 14 lid 10 . In verband hiermee is in art. 34 lid 4 eenzelfde geheimhoudingsplicht terzake van zaken- en bedrijfsgeheimen opgelegd aan leden van de Arbocommissie. (Voor leden van de or bestond al een - overigens ruimere - geheimhoudingsplicht ex art. 20 WOR). In de MvA meende de minister terecht dat er tussen de Arbeidsinspectie en de Arbocommissie (dus ook de or) geen geheimhoudingsschot dient te zi.jn. In dat verband wees hij op de volgende samenhangen: 'Art. 31 (nu: art. 34, AG) legt aan de ambtenaren van de Arbeidsinspectie geheimhouding op ten aanzien van zaken- en bedrijfsgeheimen, 'voor zover deze geheimhouding niet in strijd is met de bepalingen van deze of een andere wet". Deze uitzondering geeft 0 .a. voorrang aan de informatieplicht, vervat in art. 12, zevende lid (nu: art. 14 lid 10, AG). Dezelfde clausule aan het slot van het vierde lid van art. 31 (nu: art. 34, AG) geeft voorrang o.a. aan de verplichting tot het geven van inlichtingen aan de ambtenaren van de Arbeidsinspectie, welke ingevolge art. 30 (nu: art. 33, AG) rust op de leden van de commissie als werknemers.'

Naast de Arbowet heeft de Arbeidsinspectie op het punt van openbaarheid en geheimhouding ook nog te maken met de Wet openbaarheid van bestuur (WOB) en het Algemeen Rijksambtenarenreglement (ARAR).

De WOB legt geen verplichting op individuele ambtenaren om informatie te verschaffen. Daar is de minister voor verantwoordelijk. In de praktijk zal de beslissing over het verstrekken van informatie genomen worden door de districtshoofden. Van belang zijn hierbij de weigeringsgronden van art. 4 WOB, waarbij onder meer wordt genoemd als absolute grond bedrijfs- en fabricagegegevens die vertrouwelijk aan de overheid zijn medegedeeld (art. 4 onder c) en als afwegingsgrond tegen openbaarheid de belangen die gemoeid zijn met opsporing en vervolging van strafbare feiten (art. 4 onder f) en met inspectie, controle en toezicht door of vanwege overheidsorganen (art. 4 onder $\mathrm{i}$ ).

Volgens art. 59 lid 1 ARAR zijn ambtenaren verplicht tot geheimhouding van hetgeen hun in hun ambt ter kennis is gekomen, voorzover die verplichting 'uit de aard der zaak' volgt. De betekenis hiervan is beperkt nu de inhoud van 'uit de aard der zaak" wordt opgevuld door Arbowet en WOB. Volgens art. 59 lid 2 ARAR bestaat de geheimhoudingsplicht niet ten opzichte van de hiërarchisch hogere. Deze laatste kan de geheimhoudingsplicht van zijn lagere geheel of gedeeltelijk opheffen, ook ten opzichte van derden.

In art. 34 lid 2 Arbowet is bepaald dat de ambtenaren van de Arbeidsinspectie verplicht zijn tot geheimhouding van de namen van de personen door wie een klacht is ingediend of door wie aangifte is gedaan van een overtreding van de wettelijke voorschriften. Dit geldt niet ten opzichte van de hiërarchisch meerdere of indien de betrokkene schriftelijk heeft verklaard geen bezwaar te heb- 
ben tegen mededeling van zijn naam. De tekst is dezelfde als die van art. 34 lid 2 Veiligheidswet. Deze is in 1967 (eindelijk) gewijzigd conform art. 15 van ILO-verdrag nr. 8 (1947). In de praktijk zou deze bepaling, waaruit indirect ook een recht tot klagen kan worden gedestilleerd, nog los van het petitierecht in art. 5 Grondwet, een belangrijke bescherming kunnen betekenen voor de werknemers. ${ }^{380}$ Het is echter de vraag of het in dezelfde praktijk altijd wel mogelijk is om de namen van de klagers geheim te houden - zeker in de kleinere onderneming. Met name de vakbeweging heeft de Arbeidsinspectie regelmatig een onvoldoende alert optreden verweten bij klachten van werknemers. ${ }^{381}$ De laatste jaren lijkt deze klacht te verminderen. ${ }^{382}$ In het volgende hoofdstuk kom ik uitgebreider terug op het klachtrecht bij de Arbeidsinspectie.

Inmiddels is in 1987 een wetsvoorstel ingediend tot wijziging van onder meer de geheimhoudingsbepalingen in art. 34 Arbowet. ${ }^{363}$ Aanleiding voor dit wijzigingsvoorstel vormt het feit dat de vigerende geheimhoudingsbepalingen het niet toelaten om bij $\mathrm{AMvB}$ te bepalen dat de Arbeidsinspectie gegevens die zaken- of bedrijfsgeheimen bevatten aan met name genoemde personen of commissies toezendt of kan toezenden. Concreet deed dit probleem zich voor bij de voorbereiding van de AMvB ter bescherming van werknemers bij het uitvoeren van recombinant-DNA-bewerkingen. Het ligt in de bedoeling dat de Arbeidsinspectie bij de uitvoering van dit besluit wordt geadviseerd door een commissie van deskundigen. Art. 34 lid 1 laat dus echter niet toe dat de Arbeidsinspectie vertrouwelijke gegevens met betrekking tot een recombinant-DNA-bewerking aan de commissie toezendt. Om toezending aan de commissie mogelijk te maken en haar leden aan een geheimhoudingsplicht te binden moet art. 34 Arbowet gewijzigd worden. Er komt dan een in beginsel algemene geheimhoudingsplicht voor ieder die over vertrouwelijke gegevens beschikt 'behoudens voor zover enig wettelijk voorschrift hem tot bekendmaking verplicht of uit zijn taak bij de uitwoering van deze wet de noodzaak tot bekendmaking voortvloeit. ${ }^{384}$ Oorspronkelijk zonder enige adstructie zou volgens het wetsvoorstel ook lid 2 van art. 34 (de geheimhoudsplicht van namen van klagers en aangevers) dienen te vervallen. De minister meende echter in de MvA (p. 3) dat de plicht tot geheimhouding van de namen van klagers ook in art. 59 ARAR besloten ligt. Waar het kennelijk de bedoeling is dat de bescherming van de bron van de klachten gegarandeerd blijft, valt het niet goed in te zien waarom deze intentie niet blijvend geformuleerd kan worden in

$380 \mathrm{Vgl}$ J. Struik, Enkele opmerkingen over de formalisering van het klachtrecht voor de inclividuele werknemer, SMA, 1973, p. 594-597.

381 Vgl. J. Bloemarts, SMA, 1978 , ta. p. p. 597.

$382 \mathrm{Vgl}$. bijvoorbeeld de resultaten van dle enquête wan de industriebond FNV (1985), waarin gesproken wordt van ervaringen die als 'belangrijk positiever' worden gekwalificeerd. Zie hierover noot 108; ook: E. Buringh, Beter Werk, FNV handboek, Amsterdam 1983, p. 243.

383 TK 1986-1987, 19.934, nrs. 1-2.

384 Tegelijkertijd worden ook de geheimhoudingsbepalingen in andere arbeidsbeschermende wetten veranderd, zodat er op dit terrẹin harmonisatie plaats vindt. TK 1986-1987, 19.934, nr. $3(\mathrm{Mv} T)$, p. 1.3 . 
de Arbowet. Bovendien zou de consequentie van het zich geheel verlaten op art. 59 ARAR zijn dat opheffing van de voorgeschreven geheimhouding ook zou kunnen plaatsvinden na mondelinge toestemming, terwijl de Arbowet schriftelijke toestemming van de betrokkene vereist. Ter vermijding van misverstanden - en daarmee ter bescherming van de klagende werknemers blijft deze laatste regeling naar mijn smaak verre de voorkeur verdienen.

\subsection{Enkele opmerkingen over de Arbeidsinspectie en de praktijk}

In het voorafgaande is aan een aantal kanten van het praktisch functioneren van de Arbeidsinspectie al aandacht besteed. Hieronder zal ik onder meer iets zeggen over (reacties op) dat functioneren en het antwoord van de Arbeidsinspectie daarop.

Tot het einde van de jaren zestig, begin zeventig kon de Arbeidsinspectie haar taak betrekkelijk ongestoord uitoefenen. Toch was er inmiddels een steeds grotere kloof gegroeid tussen de taakuitvoering in de praktijk en de snelle technische, maar vooral ook maatschappelijke ontwikkelingen. Met name van de kant van de vakbeweging kwam vanaf die tijd belangrijke kritiek. ${ }^{385}$ Bloemarts gaf deze kritiek in 1978 in grote lijnen als volgt weer. ${ }^{386}$ In de eerste plaats werd de personeelsbezetting van de dienst verre van voldoende geacht voor een adequate uitvoering van inspectie en controle op de naleving van de regels. In de tweede plaats kwam de primaire taak van de Arbeidsinspectie steeds meer in de verdrukking door allerlei nieuwe werkzaamheden waarmee zij werd belast zonder voldoende begeleidende maatregelen in de personele sfeer. (Hierbij kon bijvoorbeeld gedacht worden aan de belangrijke rol van de Arbeidsinspectie bij de uitvoering van de subsidieregeling arbeidsplaatsenverbetering). In de derde plaats werd de communicatie van de Arbeidsinspectie met de werknemers en hun vertegenwoordigers als gebrekkig beschouwd en werd door haar wijze van optreden twijfel opgeroepen over de effectiviteit van de controle. Daaraan zou onder meer debet zijn: de geheimhoudingsregels en hun interpretatie; het feit dat de contacten beperkt bleven of uitsluitend liepen via leiding en staffunctionarissen; een onvoldoende alert optreden bij klachten van werknemers; de wel eens bestaande neiging om het accent van controle op en afdwinging van naleving van de voorschriften te verleggen naar vormen van min of meer vrijblijvend advies, leidend tot een ongewenst geachte vertrouwelijkheid tussen controleur en werkgever.

Een aantal van de eerste reacties van de Arbeidsinspectie leek karakteristiek voor de inmiddels gegroeide discrepantie tussen haar taakuitvoering en -op-

$385 \mathrm{Vgl}$. bijvoorbeeld $\mathrm{A}$. de Bruin, Humanisering van de arbeid door de vakbeweging sterker naar voren gebracht; inleiding weiligheidsdagen 1977, De Veiligheid, 1977, p. 267-269; Federatie Nederlandse vakbeweging, Commentaar ontwerp Arbeidsomstandighedenwet; brief aan de vaste Commissie voor Sociale Zaken van de Tweede Kamer der Staten-Generant, Amsterdam, 8 september 1977 , p. 3.

386 II. Bloemarts, SMA, 1978, t.a.p. p. 597-598. 
vatting en de wensen uit de maatschappij. Deze reacties werden gekenmerkt door ontkenning van de kritiek, afweer en het aanbrengen van cosmetica. Zo publiceerde de Arbeidsinspectie in 1976 een brochure waarin alleen maar een zeer positief beeld van de dienst werd geschetst, terwijl met geen woord werd ingegaan op de kritiek. ${ }^{387}$ In 1978 moest de Burlet constateren dat inzake het vraagstuk van het al dan niet afgeven van informatie er bij de Arbeidsinspectie een notitie bestond getiteld 'openheid'. Deze bleek echter te vertrouwelijk om er gebruik van te kunnen maken. ${ }^{388}$ En nog in 1980 schreef een districtshoofd een artikel ter gelegenheid van het 90 -jarig bestaan van de Arbeidsinspectie waarin een overwegend rooskleurig beeld werd gegeven en de kritiek vooral werd afgedaan met het verwijt dat de critici slecht geinformeerd waren. ${ }^{389}$ Gelukkig bleef het daar niet bij. In 1976 werd aan een extern organisatiebureau de opdracht gegewen om een onderzoek in te stellen naar de organisatie en de werk wijze van de dienst. In 1977 verschenen de resultaten in het rapport: 'De Arbeidsinspectie in ontwikkeling'. ${ }^{390}$ In het rapport werd aan de critici voor een groot gedeelte gelijk gegeven. Een kenmerkend citaat: 'De Arbeidsinspectie heeft zich ontwikkeld tot een dienst die zich kenmerkt door een uitstekende technische know-how, die ook naar onze mening door de technologische ontwikkeling op dit moment eerder versterking dan verzwakking behoeft; maar tevens tot een dienst die de ontwikkelingen op sociaal-wetenschappelijk gebied en andere terreinen van het sociaal beleid dan het veiligheidsaspect, onvoldoende heeft gevolgd. ${ }^{331}$ Het rapport achtte zowel de organisatiestructuur, het informatieproces, het personeelsbeleid, de personeelsbezetting en de werkwijze voor verbetering vatbaar. Op basis van dit rapport zijn binnen de Arbeidsinspectie vijf projectwerkgroepen aan de slag gegaan om voorstellen te ontwikkelen over de doelstelling en de taken, het werkterrein, de werkwijze, het personeel en de organisatie en de informatievoorziening. (POA, zie ook paragraaf 5.2.). De opzet en verdere uitvoering werden vastgelegd in een projectplan. Het gehele project zou in de pas moeten lopen met de fasegewijze invoering van de Arbowet. Tijdens de parlementaire behandeling van het ontwerp Arbowet, schetste de minister voor wat betreft de werkwijze en interne organisatie de volgende grondtrekken (waaruit tevens afgeleid kon worden waar het nog aan ontbrak): stimuleren van samenwerking tussen werkgever en werknemers op het niveau van de arbeidsorganisatie; intensiveren van de contacten met werkgevers en werknemers en hun vertegenwoordigers in de overlegorganen van de onderneming; verdieping en verbreding van specifieke deskundigheid binnen de dienst; verbeterde samenwerkingsvormen binnen en tussen de disciplines die binnen de dienst werkzaam zijn; uitbouw van de integratie tussen de beleidsvoorbereiding en de beleids-

387 Arbeidsinspectie, mens en werk; de Arbeidsinspectie is er goed voor, Den Haag 1976.

388 H.M. de Burlet, Gezondheid en veiligheid op de werkplek, Leiden 1978, p. 81.

389 J.J. van Dodeweerd, De Arbeidsinspectie bestaat 90 jaar, SMA, 1980, p. 378-385. Zie ook mijn reactie hierop in SMA, 1980, p. 737-741 en van Dodeweerds naschrift, t.a.p. p. 741-742.

390 Mens en organisatie, De Arbeidsinspectie in ontwikkeling. Hoofdpunten uit een vooronderzoek, Ansterdam 1977.

391 Mens en organisatie, t.a.p. p. 20. 
uitvoering; afstemming van de centrale en decentrale organisatie op de problematiek van het werkterrein. Ten aanzien van de werving, selectie, opleiding en vorming onderstreepte de minister volledig de opmerking van kamerleden dat niet alleen gelet moest worden op de objectieve technische kundigheid, maar vooral ook op gemotiveerdheid om als overheidsdienaar te werken aan arbeidsbescherming en arbeidsontplooiing. ${ }^{392}$

Behalve de ontwikkelingen die voortvloeien uit het project ontwikkeling Arbeidsinspectie is ook de Arbowet een belangrijke bron voor een nieuwe taakopvatting van de arbeidsinspectie gebleken. Ik noem als voorbeeld de informatieplicht ten aanzien van de werknemersvertegenwoordiging, het recht voor leden van de werknemersvertegenwoordiging om de Arbeidsinspectie te vergezellen bij bezoeken aan de onderneming en om vertrouwelijk met de betrokken ambtenaren van gedachten te wisselen, de mogelijkheid dat ook de vakvereniging onder enkele voorwaarden een verzoek tot wetstoepassing kan doen en de plicht om onderzoeksrapporten openbaar te maken.

Dat de Arbeidsinspectie zowel het ontwikkelingsproject als de Arbowet serieus neemt, blijkt onder meer uit de implementering van de voorstellen van de projectgroepen, uit de talloze interne voorlichtings- en scholingsbijeenkomsten en uit de bezoeken ('relatie-opbouw-gesprekken') die in de jaren 1983 en 1984 zijn gebracht aan ondernemingen met 100 of meer werknemers, waar een or functioneert. ${ }^{393}$ Doel van deze gesprekken was het verhelderen van taak en positie van werkgever, or en deskundige diensten in relatie tot de Arbeidsinspectie en het maken van afspraken over procedures voor de uitvoering van de wettelijke bepalingen voor zover de or daarbij taken en bevoegdheden heeft. In totaal zijin in 1983 en 1984 gesprekken gevoerd met circa 1650 ondernemingsraden. Dit betreft $70 \%$ van het oorspronkelijk geplande aantal ${ }^{394}$ Over het resultaat was de Arbeidsinspectie tevreden, althans volgens de staatssecretaris en waarschijnlijk dus volgens de ambtelijke top. ${ }^{395}$ Uit het ITSonderzoek 1988 blijkt echter dat tweederde deel van de ondervraagde arbeidsinspecteurs teleurgesteld is over de gesprekken. 'Matheid', 'mosterd na de maaltijd', 'magere inbreng or', 'geringe belangstelling' zijn de termen die in dat verband werden gebruikt. ${ }^{396}$

Overigens lijkt de kritiek op de dienst belangrijk minder te zijn. Een kritiek die, hoewel begrijpelijk en vaak terecht, op een aantal punten toch gerelativeerd dient te worden. Dit hangt samen met een aantal feitelijke gegevenhe-

392 Nota naar aanleiding van het eindverslag, t.a.p. p. 6-7.

393 Over de voortgang van het Projekt ontwikkeling Arbeidsinspectie tot de afslunting zie de bij brief van 9 juli 1985 aan de Tweede Kamer aangeboden interimrapportage, TK 1984-1985, 18.600 , hfdst. XV, nr. 103.

394 Een deel van de geplande introductiegesprekken heeft dus niet plaatsgevonden. In ongeveer gelijke mate is daarvoor als oorzaak aangegeven: reorganisatie en/of bedrijfssluiting , geen or meer of wel een or maar minder dan 100 werknemers, geen medewerking van de onderneming, doelstelling van het gesprek werd op andere wijze verwezenlijkt. Voortgangsnotitie betreffende de Arbeidsomstandighedenwet over de periode 1984 tot medio 1985, 7 november 1985 , Den Haag, p. 34.

395 Voortgangsnotitie, t.a.p. p. 4.

396 TTS-onderzoek 1988 , t.a.p. p. 32. 
den waar de Arbeidsinspectie zelf weinig aan kan doen. In de eerste plaats is de taak van de dienst een dualistische; hiermee is het problematische karakter ervan voor een deel gegeven. Enerzijds advisering en anderzijds inspectie en controle schept verschillende verwachtingen bij werkgevers en werknemers. In dit verband vallen ook de vakverenigingen niet vrij te pleiten van een zekere inconsistentie in hun opvattingen, waar aan de ene kant gepleit wordt voor een weinig 'ambtenaarachtig' optreden, geen regelzifterij en aan de andere kant voor een uitputtend gebruik maken van de in de wet gegeven politionele bevoegdheden en instrumenten. In de tweede plaats legde de traditionele veiligheidswetgeving de handhaving ervan eenzijdig op de Arbeidsinspectie (naast uiteraard de 'gewone politie'), die dat moest doen met een volstrekt ontoereikend apparaat, terwijl steeds weer nieuwe taken erbij opgelegd werden. In de derde plaats vormde het vervolgings- en straftoemetingsbeleid geen stimulans. Vaak werd op voor de Arbeidsinspectie onduidelijke gronden geseponeerd en als het al tot straffen kwam, waren deze laag, zelfs gelet op de beperkte mogelijkheden van de Veiligheidswet en in elk geval in geen verhouding tot het voordeel dat ondernemingen bij overtreding van de voorschriften konden halen. In de vierde plaats was er een overschatting van de mogelijkheden van de Arbeidsinspectie op het punt van de controle en de handhaving. Zelfs als bijvoorbeeld via stringente controle - alle wettelijke regels worden nageleefd, is er nog geen enkele garantie dat veilig en gezond zal worden gewerkt. Daar komt meer voor kijken en dan met name een actieve betrokkenheid van de werknemers zelf. "In de praktijk is gebleken dat medebeheer en participatie van werknemers in de veiligheidsbevordering veel grotere betekenis hebben dan wetten en voorschriften. ${ }^{397}$ Het is duidelijk dat voor deze laatste notie in de Arbowet aanzienlijk meer ruimte is dan onder de Veiligheidswet.

Is de Arbowet nu ook praktisch van grote invloed gebleken op de relatie Arbeidsinspectie-onderneming? Uit het ITS-onderzoek 1988 is gebleken maar dat was eigenlijk al bekend uit onder meer voortgangsrapportages en de jaarverslagen - dat aanwijzingen en verzoeken om wetstoepassing in de praktijk hoogst zelden voorkomen. Hierdoor valt voor een deel de basis voor een adviserende en stimulerende taak weg. Het is in dit licht begrijpelijk dat ongeveer tweederde van de onderzochte ondernemingen zegt weinig of niets te merken van een andere werkwijze van de Arbeidsinspectie. Bij ongeveer eenderde deel van de ondernemingen wordt opgemerkt dat de Arbeidsinspectie wel adviezen geeft over zaken betreffende met name veiligheid en gezondheid. Het gaat dan bijna altijd om vragen vanuit de veiligheidsfunctionaris of vanuit de afdeling personeelszaken. Vragen vanuit de directie of de or komen zelden voor.

Volgens een meerderheid van de inspecteurs heeft de invoering van de Arbo-

$397 \mathrm{P}$, wan Zuuren, Stromingen in de arbeidsveiligheid; samenvattingen pleaaire voordracliten ge Wereldveiligheidscongres 1980 , De Veiligheid, 1980, p. 313.

In de rechtssociologische literatuur is herhaaldelijk gewezen op het belang wan handhaving door de betrokkenen zelf. Vgl. bijwoorbeeld A.A.G. Peters, Recht als project, Ars Aequi, 1979, p. $881-893$. 
wet niet of nauwelijks geleid tot een ander of beter beleid bij de ondernemingen, of tot maatregelen ter verbetering wan de arbeidsomstandigheden. Volgens veel Arbeidsinspecties bevordert de gefaseerde invoering wan de wet ook niet een soepele en effectieve werking. ${ }^{398}$

Tot slot dient nogmaals benadrukt te worden dat ook ten aanzien van het oordeel van de Arbeidinspectie over de Arbowet de grote onderlinge verschillen tussen de inspecties en de ambtenaren in acht moeten worden genomen, waarbij uiteraard persoonlijke belevenissen en voorkeuren een belangrijke rol spelen. "Illustratief voor het verschil in beleving van de Arbowet is dat in de constatering 'er is weinig veranderd in vergelijking met de Veiligheidswet, bij de ene arbeidsinspecteur teleurstelling doorklinkt en bij de andere opluchting.' 399

\section{Werkgevers- en werknemersorganisaties}

\subsection{Inleiding}

Werkgevers- en werknemersorganisaties zi.jn op verschillende manieren betrokken bij de humanisering van de arbeid in de onderneming. Met name de vakbeweging is zich vanaf het begin van de jaren zeventig in toenemende mate voor dit onderwerp gaan interesseren, met als onbetwiste koploper de toenmalige Industriebond NVV. ${ }^{400}$ Katalysator bij de activiteiten, inmiddels ook van werkgeverszijde, vormde (het proces van totstandkoming van) de Arbowet. In de eerste plaats waren de sociale partners erbij betrokken via hun deelnemersschap in de SER, die moest adviseren over de nieuwe wetgeving. ${ }^{401}$ In de tweede plaats hebben de betrokken organisaties in afzonderlijke brieven aan de Tweede Kamer op verschillende momenten invloed trachten uit te oefenen op de uiteindelijke inhoud van de Arbowet ${ }^{402}$ In een aantal gevallen is deze invloed ook aanwijsbaar. In de derde plaats gaven en geven de organisa-

398 ITS-onderzoek 1988, t.a.p. p. $85 \%$

399 ITS-onderzoek 1988 , t.a.p. p. 92.

400 Naast rapporten en aanbevelingen inzake specifieke onderwerpen zoals over de gevaren wan chemische stoffen (1976), wan metaaldampen- en stof (1976), en van lawat (1977), publiceerde de Industriebond bok algemene beleidsprogramma's inzake humanisering van de arbeid: Beleidsprogramma veiligheid en gezondheid, Amsterdam 1977 en Sociaal beleid en humanisering, Amsterdam 1977.

401 SER, Advies inzake de vernieuwing van de wetgeving betreffende de gezondheid en de veiligheid bij de arbeid, Den Haag 1976 , nr. 18.

402 Bijwoorbeeld: FNV, Commentaar ontwerp Arbeidsomstandighedenwet, brief alan de vaste Commissie voor Sociale Zaken van de Tweede Kamer der Staten-Generaal 8 september 1977; Raad van bestuur in arbeidszaken, Commentaar wetsontwerp 14.497: Arbeidsomstandighedenwet, brief aan de vaste Commissie voor Sociale Zaken van de Tweede Kamer der Staten-Generaal, d.d. 19 september 1.977.

(Los van de FNV reageerde de Industriebond met een opstelling die vooral afweek van het FNV-standpunt inzake de medezeggenschap, waarover de Industriebond terughoudender was: Veilig is anders, Amsterdam 1976. Deze opstelling droeg de bond ook uit in: Het wetsontwerp ondernemingsraden gezien vanuit de Industriebond, Nunspeet 1977). 
ties in brochures en soms in uitgebreide commentaren op de Arbowet, voorlichting aan hun leden met aanbevelingen hoe in concrete omstandigheden gebruik kan of moet worden gemaakt van de wet. ${ }^{403}$ Soms bevatten deze producten ook feitelijk onderzoeksmateriaal en geven zij bepaalde opvattingen inzake de humanisering van de arbeid, die niet direct gekoppeld zijn aan de Arbowet. Dit laatste doet vooral de vakbeweging. ${ }^{404}$ In de vierde plaats zijn de werknemers- en werkgeversorganisaties vertegenwoordigd in de (commissies van de) Arboraad, het belangrijkste overleg-en adviesorgaan op het gebied van de arbeidsomstandigheden, dat is ingesteld ingevolge art. 43 Arbowet. ${ }^{405}$ Daarnaast voorziet de Arbowet nog in een samenwerkingsorgaan op regionaal niveau: de districtscommissie ex art. 45 . In de vijfde plaats hebben (alleen) de vakorganisaties ingevolge de artt. 32, 40 en 42 Arbowet nog een aantal specifieke bevoegdheden, waarvan alleen gebruik gemaakt kan worden bij ontstentenis van een de werknemers vertegenwoordigend orgaan binnen de onderneming.

Naast deze activiteiten en mogelijkheden die alle direct of indirect voortvloeien uit de Arbowet, kunnen de sociale partners, los van de Arbowet, via de door hen afgesloten collectieve arbeidsovereenkomsten (CAO) directe invloed uitoefenen op de humanisering van de arbeid in de ondernemingen.

Hieronder zal ik achtereenvolgens aandacht schenken aan de twee in de Arbowet genoemde activiteiten van resp. de sociale partners beiden (in de Arboraad en de districtscommissie) en van één van hen, $\mathrm{nl}$. de vakbeweging (bij het plaatsvervangend kunnen uitoefenen van enkele bevoegdheden). Bij dit laatste zal ook de rol van de vakbeweging in het algemeen in de onderneming kort aan de orde komen. Tot slot zal de rol van de CAO bij de arbeidsomstandigheden aan de orde komen, waarbij onder meer de resultaten vermeld worden van een eigen onderzoek terzake.

\subsection{De Arboraad en de (districts) commissies}

In zijn adviesaanvraag aan de SER in 1975 opperde de minister de wenselijkheid van een geïstitutionaliseerde vorm van samenwerking op het gebied van de arbeidsomstandigheden tussen de overheid en het belanghebbende be-

403 Uitgebreid voorbeeld van de kant van de werkgevers: Raad van de centrale ondernemingsorganisaties, Arbowet, hoofdlijnen en toelichting, 1983, met als aanwalling: Arbowet stand van zaken per 1 juni 1985; van de kant van de werknemers: FNV, Een wet voor beter werk, toelichting op de Arbeidsomstandighedenwet, Amsterdam 1983.

404 Bijvoorbeeld: FNV, Beter werk, discussienota over de arbeidsomstandigheden en in het bijzonder de gezondheid en veiligheid in het werk, Amsterdam 1980 en FNV, Beleidsnota humanisering van de arbeid, feiten en meningen, 1983.

405 Anders dan bij de SER, ten aanzien waarvan de Kroon bepaalt welke "algemeen erkende centrale en andere representatieve organisaties van ondernemers' en welke 'algemeen erkende centrale organisaties van werknemers" leden mogen benoemen (art. 4 Wet op de bedrijfsorganisatie), worden ten aanzien van de werkgevers- en werknemersorganisaties die leden in de Arboraad aanwijzen geen eisen gesteld omtrent erkenning en/of representativiteit (art. 4 Arbowet). 
drijfsleven. Nadat al in 1959 een dergelijk orgaan was ingesteld ten behoeve van de bedrijfsgeneeskundige zorg, het College van bijstand en advies voor de bedrijtsgeneeskunde, zou op deze ingeslagen weg voortgegaan moeten worden door een advieslichaam in het leven te roepen ter bevordering van de bedrijfsveiligheid, dat in belangrijke mate werkzaam zou moeten zijn in het uitvoerende vlak. ${ }^{406}$ De SER betuigde zijn instemming met de instelling van een dergelijk orgaan en benadrukte de noodzaak van een gecoördineerde en geïntegreerde beleidsaanpak van de veiligheids- en de gezondheidsproblematiek. Bijzondere aandacht zou geschonken moeten worden aan de relatie met de SER ${ }^{407}$ In de MvT was de minister nog van mening dat het nieuwe orgaan, dat toen de naam Arbeidsraad kreeg, zich zelfstandig zou moeten ontwikkelen, los van het College van bijstand en advies voor de bedrijfsgeneeskunde. Dit laatste adviesorgaan oefende immers al meer dan 15 jaren zijn taak bevredigend uit, terwijl met de behandeling van specifieke veiligheidsvraagstukken door een orgaan op centraal niveau nog geen ervaring was opgedaan. Na verloop van tijd zou de minister willen bezien of het alsnog aanbeveling zou verdienen om over te gaan tot een institutionele organisatie. 4 is

De argumentatie van de minister was niet sterk. ${ }^{409}$ Ook in de vaste kamercommissie voor Sociale Zaken werden bezwaren naar voren gebracht die vooral hierop neerkwamen dat het instellen van een Arbeidsraad naast het College, met een geheel eigen taak voor beide, aan een gecoördineerde behandeling van veiligheids-, gezondheids- en welzijnsaspecten in de weg zou staan, althans deze zou bemoeilijken. ${ }^{410}$ In zijn MvA oordeelde de minister de bezwaren reëel. Om die reden, en daarin bovendien gesterkt door de opvatting van de centrale werkgevers- en werknemersorganisaties, wijzigde hij zijn standpunt. De Arbeidsraad werd een centraal advies- en overlegorgaan voor de minister waarbinnen een aantal organisaties als commissies van de raad zou functioneren. Hierbij dacht de minister behalve aan het College van bijstand en advies voor de bedrijfsgeneeskunde ook aan de MAC-commissie (MAC = maximaal aanvaarde concentratie) en de Adviescommissie Asbestbesluit. Over de relatie met de SER was de minister minder duidelijk ten aanzien van de interpretatie van het begrip 'welzijn' meende hij dat geen competentiekwesties tussen Arbeidsraad en SER zouden behoeven te ontstaan. Wel zou

406 Brief aan de minister van Sociale Zaken en Werkgelegenheid van 19 juni 1975 aan de SER, opgenomen als bijlage I bij SER-advies 1976 , nr. 18 , t.a.p. p. II 3 en 4 inet College van bijstand en advies voor de bedrijfsgeneeskunde is ingesteld bij Wet van 19 februari 1959 ( $\mathrm{S}$. $56 \%$.

407 SER-advies, tha.p. p. 18.

408 MvT, t.a.p. p. 19.

409 Zou de minister wellicht geschrokken zijn van de brief van het College van bijstand en advies voor de bedrijfsgeneeskunde? Hierin deelde het onder meer mede "onoverkomelijke bezwaren' te hebben over de 'volstrekte onduidelijkheid' inzake begrippen als veiligheid, gezondheidszorg e.d. Het zou "absoluut noodzakelijk" zijn om deze begrippen te definiëren, opdat de samenwerking wan de verschillende disciplines en de albakening van hun taken nader zou kunnen worden geexpliciteerd. Brief van het College d.d. 21 november 1975 , bijlage. V bij het SER-advies t.a.p. p. V/1.

410 Voorlopig verslag, t.a.p. p. 33 en 34 . 
voor doublures moeten worden gewaakt. Overigens was het niet de bedoeling dat het bepaalde in de Arbowet afbreuk zou doen aan de SER, wiens positie immers afdoende geregeld is in de Wet op de Bedrijfsorganisatie, met name in art. 41. ${ }^{411}$ Tijdens de plenaire behandeling in de Tweede Kamer benadrukte de minister nog eens dat van overlappingen tussen de werkzaamheden van de SER en de Arboraad geen sprake zal zijn, omdat de bepalingen (in de handelingen staat 'betalingen') van de Wet op de bedrijfsorganisatie en de Arbowet duidelijk zijn. ${ }^{412}$ Hoewel de minister er niet enthousiast over was - en evenmin de voorzitter van de toenmalige Voorlopige Arbeidsraad - is door aanneming van een amendement terzake de naam Arbeidsraad gewijzigd in Arboraad. Nadat in afwachting van de inwerkingtreding van de eerste fase van de Arbowet in 1980 de Voorlopige Arbeidsraad (VAR) was geïnstalleerd, is deze in 1983 definitief omgezet in Arboraad.

De Arboraad is (art. 43 lid 2) samengesteld uit gelijke aantallen vertegenwoordigers van werkgevers- en werknemersorganisaties. De ministers van Sociale Zaken en Werkgelegenheid, van Volkshuisvesting, Ruimtelijke Ordening en Milieubeheer en van Binnenlandse Zaken worden in de Arboraad vertegenwoordigd door de respectievelijke directeuren-generaal. Daarnaast benoemt de minister van Sociale Zaken en Werkgelegenheid een aantal andere ambtenaren, met dien verstande dat het aantal ambtelijke leden (inclusief de persoon die benoemd is als vertegenwoordiger van de lagere overheden) tesamen niet groter is dan eenderde van het totaal aantal leden. De overheidsvertegenwoordigers hebben (anders dan de oorspronkelijke bedoeling was) geen stemrecht. ${ }^{413}$ De onafhankelijke voorzitter is wel lid, maar heeft evenmin stemrecht. In art. 43 de leden 4 en 5 worden de taken van de Arboraad vermeld. De raad pleegt overleg omtrent de totstandkoming en uitvoering van algemeen verbindende voorschriften ter uitvoering van de Arbowet en de daarmee verband houdende aangelegenheden; hij brengt desgewenst advies uit over de bovengenoemde aangelegenheden aan de minister; hij doet de minister voorstellen en adviseert hem in het kader van de bevordering van de veiligheid, de gezondheid en het welzijn bij de arbeid; hij adviseert de minister over de bezwaarschriften die bij hem op basis van art. 42 Arbowet worden ingediend. (Hiertoe is een aparte commissie bezwaarschriften ingesteld). De, meer op het

411 MvA, t.a.p. p. 45.

412 Handelingen TK, t.a.p. p. 4683. De minister ventileerde zijn geringe enthousiasme mede naar aanleiding van een amendement van D'66 (nr. 145) waarin SER en Arboraad werden verplicht om een gemeenschappelijk overlegorgaan in te stellen, teneinde de onderlinge coördinatie te bevorderen. Terecht sprak de minister in dit verband van een 'duidelijke vorm van overorganisatie'. Het amendement werd verworpen.

413 Dit is ook niet veranderd met de invoering van de Arbowet voor de overheid per 1 juni 1985. Denkbaar zou immers zijn om vanaf die datum aan de overheidswertegenwoordigers eenzelfde positie te geven als die de vertegenwoordigers van de particuliere werkgevers in de Arboraad hebben. De Arboraad wees zelfs een tussenoplossing af waarbij aan de overheidswertegenwoordigers het recht zou worden gegeven om een overheidsstandpunt in cen advies van de Arboraad te laten vastleggen.

Arboraad, Standpunt van de Arboraad inzake de positie van de overheid als werkgever in de Arboraad en zijn commissies en werkgroepen, Zoetermeer 1986. 
niveau van de afzonderlijke onderneming gerichte, taak om "in ieder geval' desgevraagd bijstand en advies te verlenen aan werkgevers, ondernemingsraden, Arbocommissies en deskundige diensten in lid 6 is per 1 januari 1988 (dereguleringswetswijziging) vervallen. Dit laatste geldt ook voor enkele andere specifieke activiteiten van de Arboraad, liggend op het vlak van de deskundigheid in de onderneming. Zij werden genoemd in art. 43 de leden 7,8 en 9. Op basis daarvan konden de aanstelling van bedrijfsartsen, veiligheidskundigen en deskundigen op het gebied van het welzijn, onder nader te stellen regels, worden gebonden aan de goedkeuring van de Arboraad. Het erkennen of intrekken van een erkenning van een deskundige dienst kon de minister pas nadat eerst de Arboraad in de gelegenheid moest zijn gesteld om advies uit te brengen. De Directeur-Generaal van de Arbeid tenslotte kon geen aanwijzing geven tot het instellen van een deskundige dienst zonder dat de raad in de gelegenheid moet zijn gesteld om te adviseren.

De Arboraad zelf meende, zeer voorstelbaar, dat de betrokkenheid bij individuele aangelegenheden als omschreven in art. 43 leden $6 \mathrm{t} / \mathrm{m} 9$ diende te worden beëindigd. Wèl wilde de raad als adviserende instantie betrokken kunnen worden bij een eventueel vaststellen van criteria die van toepassing zouden moeten zijn bij het nemen van beslissingen ten aanzien van individuele zaken. De staatssecretaris kon zich hiermee verenigen. ${ }^{414}$

De leden en de plaatsvervangende leden van de Arboraad en van de commissies van de Arboraad hebben eenzelfde geheimhoudingsplicht als de leden van de Arbocommissie en de ambtenaren van de Arbeidsinspectie (art. 43 lid 6).

Gezien de taakstelling van de Arboraad en de samenstelling ervan ligt het voor de hand dat hij invloed kan uitoefenen op de arbeidsomstandigheden in de onderneming. Dit zal zeker het geval zijn bij unanieme besluitvorming. Geconstateerd kan echter worden dat dat - trouwens geheel in de lijn wan wat bijvoorbeeld ook in de SER gebeurt - steeds vaker niet het geval is. Zeker naarmate meer concrete belangen in het geding zijn, wordt de unanimiteit minder. Dit is bijvoorbeeld duidelijk te zien ten aanzien van de belangrijkste werkzaamheden van de Arboraad tot nu toe: de advisering over de gefaseerde inwerkingtreding van de Arbowet en de uitleg van bepalingen die in aanmerking komen voor inwerktreding. ${ }^{415}$ Het beeld dat hieruit naar voren komt, is de overheersende wens van werkgeverszijde om de verdere invoering en invulling van de Arbowet zoveel mogelijk te minimaliseren en te temporiseren, terwijl van werknemerszijde wordt aangedrongen op een zo spoedig mogelijke onverkorte invoering van met name die artikelen die het karakter van de wet voor een groot deel bepalen, zoals art. 3 (welzijnsartikel) en art. 4 lid 4

414 TK 1986-1987, 19.824, nr. 8 (Mota naar aanleiding van het Eindverstag), p. 2.

415 Zie VAR, Advies inzake de eerste fase wan de invoering van de Arbeidsomstandighedenwet, Zoetermeer 1982, nr. 2; Arboraad, Advies inzake de tweede en volgendle fasen wan invoering van de Arbeidsomstandighedenwet, Zoetermeer 1985 , nr. 9. Voor een overzicht van adviezen, nota's e.d. van de A rboraad zie de jaarverslagen van de raad. Het eerste verscheen over het jaar 1983. 
(zeggenschapsbepaling). Het kabinet lijkt in het algemeen te kiezen voor een middenweg. ${ }^{416}$

In het kader van het Project reorganisatie rijksdienst heeft het kabinet de aanbevelingen van de Projectgroep externe advisering ten aanzien van de Arboraad overgenomen. Deze behelzen het verzoek aan de Arboraad om in 1987 een zelf-evaluatie aan te bieden, waarin in elk geval aandacht besteed moet worden aan de relatie met de SER, de positie van de overheid in de raad, de relatie tussen overlegfunctie en adviesfunctie en het zelfstandig voortbestaan van adviesorganen naast de Arboraad. Daarnaast zou aan het einde van de invoeringsperiode van de Arbowet uitdrukkelijk de wenselijkheid van het voortbestaan van de Arboraad moeten worden overwogen, mede in relatie tot de activiteiten van de SER. ${ }^{417}$

De Arboraad reageerde met een 'Standpunt van de Arboraad over taken en organisatiestructuur van de Arboraad' en een daarop aansluitende brief aan de minister van Sociale Zaken en Werkgelegenheid van maart $1987 .{ }^{418} \mathrm{De}$ Arboraad schreef onder meer dat de heroverweging van het zelfstandig voortbestaan van de Arboraad omstreeks 1991 'thans uiteraard nog niet aan de orde' is. Bovendien was de Arboraad (mèt de staatssecretaris) van mening dat de positie van de Arboraad ten opzichte van de SER voor de duur van de invoeringsperiode van de Arbowet was vastgelegd: De SER wordt op het terrein van de arbeidsomstandigheden hoofdzakelijk ingeschakeld als er sprake is van beleidsvoornemens met een grensverleggend karakter, alsmede wanneer zulke voornemens belangrijke sociaal-economische consequenties hebben. De Arboraad richt zich bij zijn advisering met betrekking tot arbeidsomstandigheden meer in het bijzonder op de invoering en de nadere uitvoering van de Arbowet. In de praktijk blijkt volgens de Arboraad tussen beide raden een goede takkverdeling en samenwerking te bestaan.

De Arboraad gaat vervolgens nog in op de combinatie van advies- en overlegorgaan (geen onjuiste combinatie), op de rol van de overheid (zie noot 413), en het zelfstandig voortbestaan van adviesorganen naast de Arboraad (deze organen worden commissies van de Arboraad).

Hoewel het natuurlijk nooit kwaad kan om het voortbestaan van eenmaal ingestelde organen ter discussie te stellen, lijkt het koppelen van de desbetreffende vraag ten aanzien van de Arboraad aan de invoeringsperiode van de Arbowet toch op een te enge visie te berusten over de taken van de Arboraad. Deze zijn immers ruimer dan alleen die met betrekking tot de advisering over de gefaseerde inwerkingtreding van de Arbowet. Bovendien zal in de loop der tijd veel specialistische kennis en ervaring zijn opgebouwd, waarvan het jam-

416 Bijvoorbeeld in de MvT bij de begroting voor Sociale Zaken en Werkgelegenheid 1986-1987. TK 1986-1987, hoofdstuk XV, nr. 2, p. 18-21. Deze tendens was al eerder merkbaar zoals in het kabinetsstandpunt ten aanzien van de dereguleringsvoorstellen, TK 1983-1984, 17.931, nir. 45 .

417 In haar brief van 10 mei 1985 heeft de toenmalige staatssecretaris Kappeyne van de Cappello de wens te kennen gegeven om omstreeks 1 maart 1987 deze zelf-ewalluatie van de Arboraad te ontvangen (brief aan Arboraad, kenmerk DSA/Si/85/4776A).

418 Brief van 3 maart 1987 , kenmerk R-1259. 
mer zou zijn indien die verloren zou gaan, of althans minder toegankelijk zou worden. Dit zou zich bijvoorbeeld kunnen wreken bij de taak van de raad om partijen te horen bij gelegenheid van een ingediend bezwaarschrift en vervolgens de minister daarover te adviseren.

Zoals de samenwerking tussen overheid en bedrijfsleven op landelijk niveau plaatsvindt in de Arboraad, zo is voor het regionale overleg tussen deze partners in art. 45 Arbowet de districtscommissie in het leven geroepen. Volgens de MvT werd gedacht aan de situatie waarin het op regionaal niveau georganiseerde bedrijfsleven "de behoefte gevoelt tot het formaliseren van het overleg met het districtshoofd dat in de praktijk reeds thans in verschillende districten min of meer regellmatig plaatsvindt' ${ }^{419}$ Geheel in de lijn hiermee was de instelling van districtscommissies niet verplichtend geformuleerd. Later is via amendering de mogelijkheid tor instelling veranderd in een verplichting. ${ }^{420}$ Wel staat het de minister vrij om per district (van de Arbeidsinspectie) een of meer commissies in te stellen. De minister is eveneens vrij in het regelen van de samenstelling, en zo nodig, van de taak en werkwijze, met dien verstande dat in de commissie in elk geval zitting hebben het districtshoofd van de Arbeidsinspectie en een gelijk aantal werkgevers- en werknemersvertegenwoordigers. Als taakstelling noemt art. 45 lid 3-vanzelfsprekend - het overleg zo vaak als daartoe een aanleiding bestaat over aangelegenheden van veiligheid, gezondheid en welzijn in verband met de arbeid en meer in het bijzonder betreffende de uitvoering van het bij of krachtens de Arbowet bepaalde. Art. 45 is niet in werking getreden en als het aan het kabinet ligt zal dat ook nooit gebeuren, omdat het de aanbeveling van de commissie Geelhoed heeft overgenomen om het artikel in beginsel te doen vervalien. Wel zal nog rekening worden gehouden met de uitkomsten van het beraad over functionele decentralisatie van taken binnen het departement van Sociale Zaken en Werkgelegenheid. ${ }^{421}$ Dat is dan ook de reden dat art. 45 (nog) niet per 1 januari 1988 is vervallen.

Het schrappen van deze bepaling lijkt mij geen ramp. Waarschijnlijk is er geen behoefte aan bij de sociale partners en, mocht die er wèl zijn, dan is de Arbowet niet nodig om een en ander te reguleren. ${ }^{422}$ Bovendien: de praktische betekenis van een dergelijk overleg moet ook daarom gerelativeerd worden, omdat districtshoofden nu eenmaal niet autonoom de wet naar hun hand, of naar die van de sociale partners kunnen zetten.

419 MvT, t.a.p. p. 58 .

420 TK 1979-1980, 14.497, nr. 24 (amendement Weyers, B. Bakker), Overigens waren noch het bedrijfsleven nòch de mimister enthousiast over deze verplichtstelling. Handelingen TK, t.a.p. p. 1457.

421 TK $1983-1984,17.931, \mathrm{nr}, 45, \mathrm{p} .2$.

422 Vgl. de conclusie van de werkgroep ter voorbereiding van het Eindbericht van de commissie Geelhoed, TK 1983-1984, 17.931, nr. 9, p. 171 . Zie ook noot 420 . 


\subsection{De werknemersorganisaties in de onderneming}

Vanaf het einde van de jaren zestig bestaat er een groeiende aandacht van de vakorganisaties voor het beleid in het algemeen van afzonderlijke ondernemingen. Vanaf die tijd worden er ook in de CAO afspraken gemaakt over de activiteiten van de bond in de onderneming, meestal in de vorm van het verlenen van bepaalde faciliteiten voor dit werk door de werkgever. ${ }^{423}$ Deze toegenomen aandacht van de bond voor de afzonderlijke onderneming geldt vooral ook het sociaal beleid met als belangrijk onderdeel daarvan de humanisering van de arbeid. ${ }^{424}$ Ook de MvT bij het in 1981 ingediende wetsontwerp inzake het vakbondswerk in de onderneming noemde als eerste overweging bij de keuze voor een wettelijke vorziening de toegenomen aandacht voor de kwaliteit van de arbeid en voor de participatie- en ontplooiingsmogelijkheden binnen de specifieke arbeidssituatie. 'Een meer ondernemingsgewijze belangenbehartiging door de vakbonden kan naast de genoemde medezeggenschapsontwikkelingen naar mijn oordeel een belangrijk aanvullend instrument vormen."425 In het wetsontwerp wordt het vakbondswerk inhoudelijk niet geregeld, maar verschaft het een algemene basiswoorziening, volgens welke iedere werkgever in beginsel verplicht wordt om faciliteiten ten behoeve van het vakbondswerk te verstrekken. De verplichting tot het geven van de faciliteiten, over de aard en omvang waarvan de werkgever overleg zou moeten plegen met de daarom verzoekende vakbond, geldt alleen ten opzichte van de vakbond die drie procent of meer, maar tenminste 10 werknemers in de onderneming onder haar leden telt. Bovendien worden in het wetsontwerp regels gesteld ter bescherming van de vakbondswerker tegen benadeling en ontslag. Het wetsontwerp is mede gebaseerd op het ILO-verdrag nr. 135 (Trb. 1971, 207).

Drie jaar later, in 1984, werd echter besloten om het uitbrengen van de MvA twee jaar op te schorten. Dit was conform het voorstel van de commissie Geelhoed. Belangrijkste argument was dat het een zaak betrof van de sociale partners en derhalve in eerste instantie via de $\mathrm{CAO}$ diende te worden geregeld. En zowel de commissie Geelhoed als de minister waren in dit opzicht positief over het zelfregulerend vermogen van de sociale partners. ${ }^{426}$ Dit bleek echter te optimistisch. Al in 1985 moest de minister constateren dat de Stichting van de Arbeid niet in staat was gebleken om tot een eenstemmige aanbeveling te komen om de verdere totstandkoming van afspraken in CAO's betreffende het vakbondswerk in de onderneming krachtig te bevorderen. Hoewel de mi-

423 Zie over (het ontstaan van) het zgn. bedrijvenwerk in de onderneming: J.P. Windmuller, $C$. de Galan, A F. van Zweeden, Arbeidsverhoudingen in Nederland, Utrecht/Antwerpen 1983 (vierde druk), p. 378.382; G.E. van Vliet, Bedrijvenwerk als vorm wan belangenbehartiging, Alphen a/d Rijn 1979

424 Zie noten 400 en 404.

425 TK 1980.1981, 16.703, nr. 3, p. 6. Over het wetsontwerp: F. Koning, Het Wetsontwerp Vakbondswerk in de onderneming. Een momentopname uit onze arbeidsverhoudingen, SMA, 1981 , p. 435-439.

426 Eindbericht commissie Geelhoed, t.a.p. p. 178-180. 
nister dit 'bijzonder teleurstellend' achtte, liet hij aan de Stichting van de Ar* beid weten niet terug te zullen komen op zijn besluit om eind 1986 te beslissen over de voortzetting van de parlementaire behandeling van het ingediende wetsontwerp. ${ }^{427}$ In de MvT bij zijn begroting 1988 deelde de minister echter opnieuw droogjes mee: 'Over faciliteiten en rechtsbescherming voor vakbondswerk in de onderneming wordt overleg gevoerd in de Stichting van de Arbeid. In verband daarmee heb ik mijn beslissing over de voortzetting van de behandeling van het wetsontwerp Vakbondswerk in de onderneming (16703) nog aangehouden. 428

Naast de meer indirecte bemoeienis van de vakbond met de arbeidsomstandigheden in de afzonderlijke onderneming via de CAO (zie hieronder) en de educatieve activiteiten (documentatiemateriaal, cursussen, het FNV-centrum voor ondersteuning van ondernemingsraden e.d.) verdient een bijzondere activiteit hier vermeld te worden. Dat is het vakbondswerk in de vorm van werknemersonderzoek naar de arbeidsomstandigheden in de eigen onderneming. De grote hoeveelheid checklisten die met name door de vakbonden zijn geconcipieerd ten behoeve van de leden die op onderzoek gaan, en de resultaten die (soms) geboekt worden, maken het aannemelijk dat het eigen werknemersonderzoek in de toekomst nog wel zal toenemen. ${ }^{42 y}$ (Overigens heeft dit onderzoek, verricht door vakbondsleden, geen juridische basis in de Arbowet. Art. 14 lid 10 onder c geeft wel aan de Arbocommissie - en dus ook aan de or - het recht om in werktijd en met behoud van loon voldoende tijd en gelegenheid te krijgen 'voor kennisneming van de arbeidsomstandigheden in het bedrijf of dle inrichting').

In 1985 verscheen de omvangrijke studie van Buitelaar en Vreeman over vakbondswerk en kwaliteit van de arbeid. ${ }^{430}$ Zij beschrijven achttien voorbeelden van werknemersonderzoek in de Nederlandse industrie. Hoewel het duidelijk wordt dat de onderzoekende werknemers vaak grote problemen hebben te overwinnen (gebrek aan kennis, tegenwerking van het management), dat doelstellingen tijdens het onderzoek kunnen verschuiven (van bijvoorbeeld het inventariseren van knelpunten naar het concreet zoeken van oplossingen), en dat het zeer lastig is om algemene conclusies te trekken op basis van deze achttien case-studies is de slotconclusie overwegend positief. Een citaat: 'Het geheel overziend kunnen we stellen dat er met name op het terrein van de arbeidsomstandigheder (cursivering van de auteurs, AG) verbeteringen tot stand zijn gebracht. Soms kleine en soms zeer grote. Bedacht moet worden dat ook kleine verbeteringen voor de werknemers van grote betekenis kunnen zijn. Niet zichtbaar in het overzicht zijn al die voorstellen die op de programma's van ondernemingsraden en commissies VGW zijn gebracht. Door het onderzoek is vaak een inhoudelijke basis gelegd, die binnen de Arbowet ver-

427 TK 1985-1986, 19.200, hoofdstuk XV, nr. 2, p. 35-36.

428 TK 1987-1988, 20.200, hoofdstuk XV, nr. 2, p. 17.

429 V. Chr. Vrooland, Arbeid en gezondheid in de jaren tachtig, Amsterdam 1984, p. 49.

$430 \mathrm{~W}$. Buitelaar, R. Vreeman, Vakbondswerk en kwaliteit van de arbeid, Voorbeelden van werknemersonderzoek in de Nederlandse industrie, Nijmegen, 1985. 
der zal worden uitgewerkt. Ook voor de kadergroep is een werknemersonderzoek vaak pas een begin. Zeker wanneer er veel kaderleden actief bij betrokken zijn geweest, is een stap vooruit gezet in de kwalitatieve verdieping van het vakbondswerk in het bedrijf. ${ }^{\text {"431 }}$ Onmiskenbaar kan werknemersonderzoek naar de arbeidsomstandigheden in de onderneming een belangrijke positieve rol vervullen. Werknemers raken betrokken bij de problematiek en alleen al het inventariseren van de knelpunten is een voorwaarde voor verdere, eventueel juridische, stappen. Een laatste citaat: "Werknemersonderzoek moet worden geplaatst in de traditie van de syndicale onderstroom in de Nederlandse vakbeweging, het bevat een aanklacht tegen ongezonde, onzekere en dekwalificerende arbeidssituaties en roept op basis daarvan op tot een verbetering van de kwaliteit van de arbeid. ${ }^{2432}$

In het licht van het belang ervan - en niet alleen ten aanzien van de arbeidsomstandigheden - verdient het vakbondswerk in de onderneming gestimuleerd te worden. Hiertoe zou in elk geval de parlementaire behandeling van het wetsontwerp vakbondswerk in de onderneming moeten worden voortgezet. Het argument voor de ijskast vormde het alternatief van de CAO. Dit is ook de minister heeft dat moeten constateren - mislukt; en er is geen enkele aanleiding om te verwachten dat de Stichting van de Arbeid in de nabije toekomst wel unaniem zal adviseren om indringende bepalingen terzake in de $\mathrm{CAO}$ te bevorderen. Wettelijk gegarandeerde faciliteiten voor vakbondswerkers in de onderneming kunnen bovendien van belang zijn bij werknemersonderzoeken, bij het behartigen van de belangen van juist diegenen die een meer marginale rol in de onderneming vervullen (deeltijdwerkers e.d.) en bij het verlenen van steun aan de (vakbondsleden van de) or, in de praktijk een van de belangrijkste functies van de vakbondsactiviteiten in de onderneming. ${ }^{433}$ Het is trouwens zeer de vraag of bij het definitief afvoeren van het wetsontwerp Nederland niet in strijd handelt met ILO-verdrag nr. 135 dat bepaalt dat aan werknemersvertegenwoordigers faciliteiten en rechtsbescherming moet worden geboden. In ondernemingen met meer dan 35 werknemers wordt hieraan voldaan door de WOR. In de kleine ondernemingen waar geen ondernemingsraadsregeling geldt, echter niet.

In het oorspronkelijke ontwerp voor de Arbowet werden de werknemersorganisaties slechts genoemd bij de samenstelling van de Arboraad en de districtscommissies. Op aandrang van de vakorganisaties en een meerderheid van de Tweede Kamer stemde de minister in met de uitbreiding in de Arbowet dat bij het ontbreken van een or c.q. een Arbocommissie, het verzoek om wetstoepassing ex art. 40 ook kan worden gedaan door een 'vereniging van werknemers, die krachtens haar statuten ten doel heeft de belangen van haar leden als werknemers te behartigen en als zodanig in de betrokken onderneming of bedrijfstak werkzaam is en in het bezit is van volledige rechtsbevoegdheid'.

431 W. Buitelaar, $\mathbb{R}$. Vreeman, t.a.p. p. 546.

432 W. Buitelaar, R. Vreeman, t.a.p. p. 554.

433 G.E. wan Vliet, t.a.p. p. 543. 
(Zie over het verzoek om wetstoepassing hierboven paragraaf 5.3.). Oorspronkelijk voelde de minister hier niets voor. Dat viel inzoverre te billijken, dat de primaire overlegstructuur in de Arbowet gebaseerd is op enerzijds de werkgever en anderzijds de or c.q. Arbocommissie. Maar met name in de kleinere ondernemingen is er geen or. Dit geldt soms ook in de grotere, waar er weliswaar een behoort te zijn, maar er feitelijk geen is. Juist in die ondernemingen kunnen individuele werknemers onder druk komen te staan bij het nemen van een beslissing om een verzoek tot wetstoepassing te doen - wat ook in de oorspronkelijke tekst al mogelijk was indien het namelijk ging om 'een meerderheid van de belanghebbende werknemers'. Derhalve zou ook aan de vakbond die leden heeft onder de werknemers, eenzelfde recht gegeven moeten worden als de or, de Arbocommissie of een meerderheid van de belanghebbende werknemers terzake heeft. ${ }^{434}$

In de MvA wees de minister deze suggestie van de hand: '.. zal de situatie dat geen commissie aanwezig is zich slechts bij de zeer kleine ondernemingen kunnen voordoen. Aan het toekennen van het recht om wetstoepassing te vragen aan de werknemersorganisaties bestaat naar mijn mening dan ook in die ondernemingen geen behoefte. ${ }^{435}$ Een onlogische conclusie. Terecht is de minister er op teruggekomen. ${ }^{436}$ De wijziging betreft een aanvulling: het blijft ook de meerderheid van de belanghebbende werknemers, bij ontstentenis van een or of Arbocommissie, mogelijk om een verzoek tot wetstoepassing te doen. Als uitvloeisel van deze wijziging in art. 40 is art. 42 in gelijke zin gewijzigd: een vakorganisatie kan, onder dezelfde voorwaarden, een bezwaarschrift indienen bij de minister. Zij kan dat echter niet - en dat geldt ook voor de meerderheid van de belanghebbende werknemers - indien het een eis betreft van het districtshoofd om aanvullende gegevens en voorzieningen in het arbeidsveiligheidsrapport en om technische en organisatorische voorzieningen te treffen teneinde gevolgen van een bedrijfsramp zoveel mogelijk te beperken (art. 5 leden 10 en 11).

In een nog later stadium van de parlementaire behandeling is aan de vakbond, wederom onder dezelfde woorwaarden, het recht toegekend om aan de Arbeidsinspectie te vragen een onderzoek in te stellen (zie hierover eveneens paragraaf 5.3.).

Het feit dat de vakbond plaatsvervangende rechten heeft voor de or, zonder dat de vakbondsleden de wettelijk gegarandeerde bescherming genieten die or-leden wèl hebben, vormt naar mijn smaak nog een extra argument voor een spoedige invoering van een Wet vakbondswerk in de onderneming.

434 Zie ook de brief van de FNV aan de vaste Commissie voor Sociale Zaken, t.a.p. p. 3-4.

435 MvA, t.a.p. p. 79.

436 Nota naar aanleiding van het Eindverslag, t.a.p. p. 45. 


\subsection{De rol van de $C A O$}

\subsubsection{Inleiding}

In het vorige hoofdstuk (paragraaf 8.5.) is gewezen op de toename van het aantal CAO-bepalingen op het gebied van de humanisering van de arbeid, samenvallend met de groeiende belangstelling van vooral de vakbeweging voor dit onderwerp. Ook van de kant van de overheid werd sinds circa 1975 een steeds grotere nadruk gelegd op de eigen verantwoordelijkheid van de sociale partners voor het sociaal beleid in de onderneming. (Zie paragraaf 8.1. van het vorige hoofdstuk). De trend werd in het begin van de jaren tachtig voortgezet door de aanbeveling van de Stichting van de Arbeid om de kwaliteit van de arbeid als onderwerp van het CAO-overleg op te voeren. ${ }^{437}$ En in 1981 schreef de Wetenschappelijk raad voor het regeringsbeleid in Vernieuwingen in het arbeidsbestel: 'Het zou wenselijk zijn indien in CAO's aandacht aan de kwaliteit van de arbeid zou worden besteed, ${ }^{938}$

Blijkbaar vinden ook de in de onderneming actieve leden van de Industriebond FNV dat de CAO een belangrijke rol kan spelen, naast en in aanvulling op de Arbowet. Volgens de resultaten van een hierboven al ter sprake gekomen, in 1985 gepubliceerde enquête, meende $70 \%$ van de vakbondskaderleden dat het wenselijk zou zijn om in de CAO bepalingen op te nemen op het gebied van de veiligheid, de gezondheid en het welzijn bij de arbeid. ${ }^{439} \mathrm{Als}$ belangrijke argumenten voor dit standpunt werd aangevoerd dat CAO-bepalingen terzake een extra steun in de rug kunnen betekenen voor de or en de commissie VGW, dat de gehele uitvoering van de Arbowet te lang op zich laat wachten, dat de bedrijfsspecifieke problemen op deze manier beter opgelost kunnen worden en dat de naleving van de $\mathrm{CAO}$ beter is te controleren dan de naleving van de Arbowet.

De belangrijkste voordelen lijken ook mij te liggen in de mogelijkheid om méér dan wetgeving vermag, specifieke regelingen vast te stellen voor een bepaalde bedrijfstak of een bepaalde onderneming. Daarnaast kan altijd geprobeerd worden om in een $\mathrm{CAO}$ aanvullende regels te stellen, bijvoorbeeld omdat het niet gellukt is via wetgeving. Zo raadt de FNV aan om in de CAO op te nemen dat or-commissies VGW verplicht moeten worden ingesteld. ${ }^{440}$ $\mathrm{Bij}$ het argument van de voorstanders dat de naleving van de $\mathrm{CAO}$ beter is te controleren dan de naleving van de Arbowet zet ik echter vraagtekens. Ten aanzien van zowel de bepalingen van de Arbowet als van de CAO: op dit punt heeft de or toch een gelijke taak? Bij de Arbowet speelt bovendien nog de

437 Stichting wan de arbeid, Aambewellingen en afspraken woor overleg over werkgelegenheid en arbeidsmarkt, Den Haag, maart 1981.

438 Wetenschappelijke raad voor het regeringsbeleid, Vernieuwingen in het arbeidsbestel, Den Haag 1981, nr. 21, p. 161.

439 Industriebond FNV, Vakbondskaderleden beoordelen de arbeidsomstandighedenwet, Amsterdam, april 1985, p. 8.

440 Belleidsgroep onderzoek FNV, Beter werk, Amsterdam, oktober 1980, p. 78. 
Arbeidsinspectie een belangrijke rol. En als het gaat om de kenbaarheid en de eenduidigheid van de bepalingen en de praktische betekenis ervan lijkt het me toe dat de CAO in elk geval niet helderder is dan de Arbowet. Wèl is het zo dat algemeen wordt aangenomen dat een direct beroep van de (individuele) werknemer op CAO-bepalingen met betrekking tot arbeidsomstandigheden, voor zover die althans individualiseerbare rechten scheppen, mogelijk is. (Het gaat daarbij dus om bepalingen die wel de individueel-rechtelijke verhouding tussen de werkgever en de werknemer regelen, maar niet direct betrekking hebben op de tussen hun geldende arbeidsvoorwaarden). ${ }^{441}$

Er zijn ook nadelen aan een regeling bij $\mathrm{CAO}$ verbonden. Een belangrijk nadeel is dat de inhoud telkens opnieuw afhankelijk is van de fluctuerende krachtsverhoudingen tussen de partijen, waardoor verschillen kunnen ontstaan tussen de diverse bedrijfstakken en ondernemingen. Bovendien zou een regeling bij $\mathrm{CAO}$ wellicht als een substituut kunnen worden gezien voor een wettelijke regeling. Ten aanzien van de Arbowet en dan vooral in het kader van de gefaseerde invoering en van de dereguleringsoperatie is daar ook wel over gespeculeerd. ${ }^{442}$ Gezien het belang van de in het geding zijnde waarden mag dat in elk geval nooit gebeuren. In de CAO dient het altijd te gaan om een bevestiging van de wettelijke bepalingen, wat psychologisch van belang kan zijn, en om een uitwerking en uitbreiding, nooit om een vervanging. 'Legislation can rarely do more than establish a 'floor', it is however a floor on which all can stand, all those who work and whose political vote may influence legislation even if they are too poorly organised to lift themselves to a higher level. ${ }^{, 443}$ Hoe is het nu gesteld met de inhoud en de frequentie van vórkomen van CAO-bepalingen op het gebied van de humanisering van de arbeid? In 1977 is door het toenmalige Loonbureau een onderzoek gedaan naar bepalingen betreffende de veiligheid, de gezondheid, de hygiëne en het milieu, waarbij de zuiver op geld waardeerbare bepalingen buiten beschouwing zijn gelaten. In het vorige hoofdstuk is hier al aandacht aan besteed. Tot 1986 is er terzake geen onderzoek meer geweest. Dit was de aanleiding om opnieuw zelf een dergelijk onderzoek te verrichten naar in 1986 bij de Dienst Collectieve Arbeidsvoorwaarden geregistreerde CAO's. Vervolgens verscheen in 1987 een nieuw onderzoek van de Dienst Collectieve Arbeidsvoorwaarden (DCA). Dit onderzoek bevestigt in grote lijnen de resultaten van het eigen onderzoek, dat ik hieronder zal beschrijven.

441 Fase meent dat, mocht aan het directe individuele worderingsrecht getwiffeld worden, veclat een vordering geconstrueerd via een derdenbeding mogelijk is. Wordt ook daaraan get wijfeld, dan zou een beroep op art. $1638 \mathrm{z}$ BW nog uitkomst kunnen bieden, W.J.P.M. Fase, CAO-recht, Alphen a/d Rijn 1982, p. 61.

442 Zie het interview met het CDA Tweede Kamerlid Weijers onder de titel: Arbobeleid inbrengen in CAO-onderhandelingen, in Maandblad voor arbeidsomstandigheden, 1986, p. 361363 en - mede als reactie - het interview met het FNV-lid van de Arboraad Schmitz: Arbozaken in CAO regelen is een miskleun, Maandblad voor arbeidsomstandigheden, 1986, p. $553-555$.

443 O. Kahn-Freund, Labour and the law, Londen 1977, p. 43. 


\subsubsection{Onderzoek naar CAO-bepalingen ${ }^{444}$}

Mijn onderzoek is evenals dat van het Loonbureau in 1977 kwalitatief en kwantitatief van aard. Het is enerzijds enger, doch anderzijds ruimer van opzet dan dat van 1977. Het is enger in die zin, dat het alleen betrekking heeft op CAO's waaronder tenminste tienduizend werknemers vallen. Het onderzoek van het Loonbureau had betrekking op alle bedrijfstak-CAO's. Bovendien bevatte het bepalingen omtrent het milieu en de arbeidstijden.

Het is andlerzijds ruimer van opzet, omdat dit onderzoek niet alleen betrekking heeft op bedrijfstak-CAO's, maar ook op ondernemings-CAO's (voor zover geldend voor tienduizend of meer werknemers). Het betreft in totaal vijftig bedrijfstak-CAO's en tien ondernemings-CAO's. Bovendien wordt er uitgegaan van de ruimere definitie van het arbeidsomstandighedenrecht zoals in hoofdstuk I geformuleerd. Het gaat dus niet alleen om de veiligheid, de gezondheid en de hygiëne, maar ook om de zeggenschapsaspecten (zoals in de WOR en in de Arbowet geregeld) en aspecten van verantwoordelijkheid, ontplooiing en creativiteit van de werknemers: de zogenaamde welzijnsaspecten. In het kader van deze (ruimere) definitie zijn de CAO-bepalingen op de volgende onderwerpen onderzocht:

- de onderwerpen die in de Arbowet geregeld zijn. Veiligheid, gezondheid en welzijn van de werknemers staan hierin centraal.

- regelingen over werkoverleg met betrekking tot de veiligheid, gezondheid en het welzijn. Dit onderwerp is behalve in de Arbowet ook in de Wet op de Ondernemingsraden (WOR) geregeld.

- interne klachtenprocedures voor het geval dat zich een bedrijfsongeval voordoet c.q. voor het geval dat cao-bepalingen op het gebied van de veiligheid, gezondheid en het welzijn niet in acht worden genomen c.q. ter bevordering van de bestaande arbeidsomstandigheden.

- interne regelingen met betrekking tot bedrijfsongevallen (wordt bijvoorbeeld na een bedrijfsongeval de werknemer schadeloos gesteld?)

- het afsluiten van een verzekering voor bedrijfsongevallen.

Om een vergelijking te kunnen maken tussen 1977 en 1986 geef ik hieronder eerst de resultaten uit 1977 .

Van de 184 in 1977 bij het toenmalige Loonbureau geregistreerde bedrijfstakcontracten (2.014.000 werknemers) waren in 107 (1.500.500 werknemers) bepalingen opgenomen inzake veiligheid, gezondheid, hygiëne en milieu. Dit houdt in dat voor circa $75 \%$ van de werknemers onder een bedrijfstak-CAO een bepaling was opgenomen inzake veiligheid enz.

De bepalingen hadden betrekking op de volgende onderwerpen:

444 Graag wil ik hier de onderzoek-assistent mr. P. Maessen bedanken die een belangrijke bijdrage heeft geleverd aan dit onderzoek. 
soort bepaling

aantal be-

aantal werkne- \% van het to-

drijfstak-

mers

taal aantal

CAO's met

werknemers

betreffende

bepalingen

1. Algemeen:

- algemene verplichtin-

27

558.000

28

gen van de werkgever

- algemene verplichtin- 53

672.900

33

gen van de werknemer

2. Aanbeveling t.a.v.:

- opstellen van een vei- 1

255.000

ligheidsprogramma

- veiligheidsopleiding

2

255.900

13

- taken van de or

255.000

13

- instellen van een veilig- 1

255.000

13

heidscommissie

- samenwerking met een 1

255.000

13

bedrijfsgeneeskundige dienst

3. Overleg en signaleren:

- het bespreken van de 28

790.238

39

te nemen maatregelen

met werknemers/or

- het bespreken van het

54.800

verplichtstellen van

medisch onderzoek

met or

- het aanmelden van on- 10

455.000

23

veilige situaties

4. Specifieke maatregelen:

- verstrekken van veilig- 14

715.900

36

heidsmiddelen

- geneeskundig onder- 38

423.300

21

zoek

- werkkleding 27

- verbodsbepaling voor 13

529.000

26

jeugdigen

339.400

17

- arbeidstijd incl. rusttijd 6

34.200 
5. Overige maatregelen:

- schuil- en schaftgele- 19

481.900 genheid

- bemanningssterkte

- wachthouder

17.200

- rookverbod

36.000

2

- alcoholverbod

40.000

- slaapdiensten

Van de zestig in 1986 onderzochte CAO's (2.167.912 werknemers) bevatten er zesenvijftig ( 2.022 .312 werknemers) bepalingen op het terrein van de veiligheid, de gezondheid en het welzijn. Dit houdt in dat voor ruim $93 \%$ van het totaal aantal werknemers onder de zestig CAO's een bepaling is opgenomen inzake arbeidsomstandigheden.

In het onderstaande volgt een overzicht van de soorten bepalingen die er in de in 1986 onderzochte CAO's voorkomen, met vermelding van het aantal werknemers dat eronder valt.

$\begin{array}{ll}\text { soort bepaling } & \begin{array}{l}\text { antal } C A O ' s \text { aantal werkne- \% van het to- } \\ \text { met betreffen- mers }\end{array} \\ \text { de bepalingen } & \text { taal antal } \\ & \text { werknemers }\end{array}$

1. Verplichtingen:

A. verplichtingen van de werkgever:

- het nemen van maatre- 23

791.484

36,5

gelen in het belang van

de veiligheid/gezond-

heid/het welzijn

- het afsluiten van een ongevallenverzekering/

356.000

16,4

uitkering bij overlijden of ongeval

- samenwerking met een bedrijfsgeneeskundige dienst

- het verstrekken van in- $\mathbb{1 5}$ formatie

- een goede introductie t.b.v. de werknemer

- het opstellen van een sociaal jaarverslag c.q. het verstrekken van feitelijke gegevens

$160.000 \quad 7,4$


m.b.t. het sociaal be- 15

leid in de onderneming

- het opstellen van een 1

Arbo-beleidsplan

B. verplichtingen van de werknemer:

- het verlenen van mede- 14 werking aan een medisch onderzoek

- het inachtnemen van 20 de veiligheid voor het bedrijf, voor zichzelf en voor anderen
855.677

160.000

689.653

31,8

714.874

33

2. Aanbeveling t.a.v.:

- het opstellen van een 7

341.874

15,8 veiligheidsprogramma

c.q. het nemen van maatregelen ter bevordering van de arbeidsomstandigheden

- veiligheidsopleiding 179.597

- taken van de or 179.597 8,3

- instelling van een 221.500 10,2 arbeidsomstandighedencommissie

- samenwerking met een 10

283.092

13,1 bedrijfsgeneeskundige dienst/geneeskundig onderzoek

- introductie/informatie

- het te voeren sociaal beleid

3. Overleg en signaleren:

- het bespreken van de 710.789 32,8 te nemen maatregelen met werknemers/or

- aanmelden van onveili- 13 ge situaties

- bespreken van het ver- 1 plichtstellen van medisch onderzoek met de or

$192.000 \quad 8,9$

$819.754 \quad 37,8$


4. Specifieke maatregelien:

- verstrekken van veilig- 15

heidsmiddelen/ver-

bandtrommels enz.

- geneeskundig onder- 18

1.059 .369

48,9

zoek

- werkkleding 17

- verbodsbepaling voor 2

588.771

27,2

jeugdigen

- verbodsbepaling voor 1

187.500

8,6 ouderen

- bewakingsdienst

179.597

8,3

14.000

0,6

5. Overige maatregelen:

- schuil- en schaftgelegenheid

- rookverbod c.q. -rege- 4 ling

- alcoholverbod 3

- etiketteringssysteem 2

6. Klachtenregeling op het 3 gebied van de arbeidsomstandigheden

Bij veel bepalingen is het niet onmiddellijk duidelijk of het normatieve bepalingen betreft, met andere woorden of de betreffende bepaling bedoeld is om in de individuele arbeidsovereenkomst door te werken. Soms is dit ook minder problematisch. Zo is de CAO-verplichting voor de werkgever om aan zijn werknemers beschermingsmiddelen te verstrekken zodanig concreet opgesteld, dat daarvan aangenomen mag worden, dat deze bedoeld is om in de individuele arbeidsovereenkomst door te werken. De werknemer kan naleving daarvan vorderen op basis van zijn arbeidsovereenkomst.

Opmerkelijk is, dat geen enkele van de onderzochte CAO's een regeling kent voor het geval dat zich een bedrijfsongeval voordoet. Wel zijn er drie CAO's (229.097 werknemers of $10,6 \%$ van het totaal aantal werknemers) die een klachtenregeling kennen op het gebied van de arbeidsomstandigheden:

- De CAO voor de Metaalindustrie (179.597 werknemers): ter bevordering van de veiligheid, de gezondheid en de hygiëne zal de werkgever in samenwerking met de or regelingen opstellen. Deze regelingen zullen in ieder geval bevatten de wijze van indienen en behandelen van klachten (art. IX4 van de $\mathrm{CAO}$ ). De regeling van de $k$ lachtenprocedure is dus niet in de $\mathrm{CAO}$ te vinden, doch wordt overgelaten aan de samenwerking tussen de werkgever en de or. Van een 'inhoudelijke regeling' in de betekenis van art. 27 lid 3 WOR is geen sprake, zodat de instemmingsverplichting krachtens lid 1 blijft bestaan. 
Art. X8 van de CAO kent bovendien een bemiddelingsprocedure: bij een klacht van een werknemer/groep werknemers inzake de arbeidsverhouding kan deze, alsmede de betrokken werkgever de klacht voorleggen aan de Bemiddelingsinstantie voor de Metaalindustrie.

- De CAO voor het schilders- en afwerkingsbedrijf (27.500 werknemers): deze kent de mogelijkheid van instelling van commissies, die belast zijn met de bevordering van de naleving van de wettelijke regelingen ten aanzien van de veiligheid en hygiëne, en het voorkomen van of bemiddelen bij geschillen.

- De CAO voor de Tuinbouw (22.000 werknemers): voor zover in een bedrijf geen or is ingesteld en er bovendien 25 of meer werknemers werkzaam zijn, zal de werkgever een Commissie van Vertrouwen instellen. Deze commissie heeft onder meer als taak het doen van voorstellen ter verbetering van arbeidsomstandigheden, het bespreken met de werkgever van het sociale beleid, het houden van toezicht op naleving van CAO-bepalingen, en het bespreken met de werkgever en de werknemers van individuele of collectieve klachten of geschillen c.q. de bijlegging van deze geschillen (art. 59 van de $\mathrm{CAO}$ ).

Ook een regeling betreffende een spontane schadeloosstelling van de werknemer voor het geval hem een bedrijfsongeval overkomt, ontbreekt in de onderzochte CAO's. De enige uitzondering daarop is de CAO voor het KLMgrondpersoneel (12.000 werknemers). Deze kent een regeling krachtens welke uitkering kan plaatsvinden in het geval van overlijden of blijvende invaliditeit van de werknemer als gevolg van een vliegongeval of molest.

Wel is in een aantal CAO's de verplichting voor de werkgever opgenomen om ten behoeve van zijn werknemers een collectieve ongevallenverzekering af te sluiten (te weten 8 CAO's geldend voor 344.000 werknemers). Krachtens deze verzekering kan er dan uitkering plaatsvinden in het geval van overlijden of invaliditeit van de werknemer als gevolg van een bedrijfsongeval.

In 18 CAO's (710.789 werknemers) is de verplichting voor de werkgever opgenomen om de te nemen maatregelen inzake de veiligheid, de gezondheid en het welzin te bespreken met de werknemers of de or.

Evenals voor het rapport van 1977 ujikt ook hier te gelden dat deze verplichting een uitvloeisel is van art. 27 lid 1, onder e WOR (in 1977 onder d), warain het instemmingsrecht van de or is geregeld. De onderzochte CAO*s onthouden Zich echter van een inhoudelijke regeling. Zie bijwoorbeeld art. IX4 van de CAO voor de Metaalindustrie (179.597 werknemers): ter bevordering van de veiligheid, de gezondheid en de hygiene zal de werkgever in samenwerking met de or regelingen opstellen. In de CAO zelf wordt dus niets geregetd; de nadere uitwerking wordt aan het overleg overgelaten. De instemmingsverplichting ex art. 27 lid 1 onder $e$ WOR, blift gelden.

Er waren vier $\mathrm{CAO}$ 's die helemal geen relevante bepalingen bevatten, te weten de CAO voor het kappersbedriff (16.600 werknemers), de CAO voor de Nederlandse Spoorwegen (27.000 werknemers), de CAO voor de uitzendkrachten in de kantoor-en administratieve sector (17.000 werknemers) en als 
laatste de Detailhandelwerordening secundaire arbeidsvoorwaarden $(85.000$ werknemers). Gezamenlijk vormen zij circa $7 \%$ van het totaal aantal werknemers van de onderzochte CAO's.

Bij de overige bepalingen valt toch in meer of mindere mate, direct of indirect, de invloed van de Arbowet te bespeuren:

- CAO-bepalingen betreffende het geneeskundig onderzoek (geldend voor 1.059 .369 werknemers; dit is bijna $50 \%$ van het totaal aantal werknemers). Vergelijk art. 25 Arbowet.

- CAO-bepalingen betreffende de informatieverplichting van de werkgever met betrekking tot de veiligheid en de gezondheid (373.392 werknemers); vergelijk art. 6 lid 1 Arbowet.

- CAO-bepalingen betreffende algemene verplichtingen van de werkgever (791.484 werknemers); vergelijk art. 3 Arbowet (nog niet in werking getreden.

- CAO-bepalingen betreffende de algemene verplichtingen van de werknemer ( 714.874 werknemers); vergelijk art. 12 Arbowet.

- CAO-bepalingen betreffende het verstrekken van veiligheidsmiddelen (683.889 werknemers); vergelijk art. 3 onder a Arbowet.

- De CAO voor de Tuinbouw (20.000 werknemers) bevat in art. 59 een bepaling, waarin de mogelijkheid tot instelling van een "Commissie van Vertrouwen' geregeld wordt. De taak van deze commissie, te weten het doen van voorstellen ter verbetering van de arbeidsomstandigheden, vertoont overeenkomst met de regeling van de Arbodienst in art. 20 c.q. die van de Veiligheidsdienst in art. 19 Arbowet.

De nadruk op de meer immateriële aspecten van het sociaal beleid was veel minder terug te vinden in de CAO's van 1977. Deze regelden vooral de materiële aspecten van het sociaal beleid, zoals aanstelling en ontslag, beloning, promotie, veiligheid en hygiëne etc. Over het bellang van het welzijn in verband met de arbeid werd nauwelijks gerept. Dit is in de in 1986 geldende CAO's anders. In de CAO voor het Bankbedrijf bijvoorbeeld, wordt gesproken over de bevordering van voldoening in het werk, van creativiteit en van verantwoordelijkheidsgevoel (93.000 werknemers). (Vgl.art. 3 onder g Arbowet). In de CAO voor het bouwbedrijf ( 160.000 werknemers) is bijvoorbeeld artikel 47 te vinden dat de werkgever verplicht om een Arbo-beleidsplan op te stellen. Vergelijk art. 4 lid 3 Arbowet dat de verplichting regelt voor aangewezen werkgevers om het beleid ten aanzien van veiligheid, gezondheid en welzijn in een schriftelijk plan vast te leggen. De bepaling is niet in werking getreden en over het tijdstip waarop dat wel zou moeten gebeuren, bestond onenigheid in de Arboraad. Ten aanzien van (de inhoud van) het sociaal jaarverslag is de overeenkomst met art. 10 Arbowet opvallend. 


\subsubsection{Enkele conclusies}

Een vergelijking van dit onderzoek met dat van 1977 is moeilijk om de volgende redenen:

- Het onderzoek in 1977 had betrekking op alle bij het Loonbureau geregistreerde bedrijfstak-CAO's. Dit onderzoek daarentegen betrof 'slechts' zestig CAO's waaronder minstens tienduizend werknemers vallen.

- Enerzijds is het huidige onderzoek enger van aard (bepalingen betreffende de arbeidstijden en het milieu zijn niet opgenomen), anderzijds ruimer van aard (klachtenregeling, bedrijfsongevallenregeling, Arbowet-onderwerpen, collectieve ongevallenverzekering zijn onderwerpen die wel zijn opgenomen).

In het licht van het voorafgaande kan wel gesteld worden dat het aantal bepalingen betreffende de veiligheid, gezondheid en het welzijn is toegenomen.

Wanneer men het onderzoek van 1,977 en dat van nu alleen met elkaar vergelijkt met betrekking tot de onderwerpen die zij gemeen hebben, dan valt een behoorlijke stijging waar te nemen van het aantal relevante $\mathrm{CAO}$-bepalingen. In 1977 viel $75 \%$ van het totaal aantal werknemers in de bedrijfstakken onder de werking van één of meer CAO-bepalingen inzake de veiligheid, gezondheid en de hygiëne. In 1986 waren dat er ruim $93 \%$. In 1977 bevatte 107 van de 184 CAO's relevante bepalingen (dat is ongeveer $58 \%$ van het totaal aantal CAO's); nu zijn er dat 56 van de 60 (dat is ca. 93\%).

Natuurlijk moet men deze aanzienlijke procentuele stijging van het aantal CAO's met relevante bepalingen en de procentuele stijging van de daaronder vallende werknemers relativeren, omdat het laatste onderzoek betrekking had op een beperkter aantal CAO's.

Toch kan naar mijn mening een duidelijk accentverschil in de onderwerpen van relevante $\mathrm{CAO}$-bepalingen geregistreerd worden. In het onderzoek van 1977 was het aantal bepalingen betreffende verplichtingen voor de werkgever aanzienlijk kleiner dan dat voor de werknemer. In 1986 lijkt meer sprake te zijn van een eerlijke verdeling van het aantal verplichtingen over de werkgever en de werknemers.

Dit wordt wellicht verklaard door de invloed die de Arbowet sinds 1980 op de inhoud van de CAO's uitoefent. In de Arbowet gaat het om het bevorderen van de humanisering van de arbeid, waarbij de werknemers niet langer meer object van zorg zijn, maar zelfstandige dragers van rechten en plichten: de zorg voor goede arbeidsomstandigheden is een kwestie geworden van samenwerking tussen werkgever en werknemers. Niet één partij, doch beide partijen zijn verantwoordelijk voor de veiligheid, de gezondheid en het welzijn. Dit heeft tot gevolg, dat de verplichtingen meer verspreid zijn over beide partijen dan vroeger. De samenwerking tussen werkgever en werknemers leidt ook tot meer overleg op allerlei niveaus. Het aantal bepalingen met de verplichting tot overlleg en het verstrekken van informatie is dan ook beduidend.

Het is bovendien opmerkelijk, dat in de in 1986 onderzochte CAO's regelmatig (aspecten van) de humanisering van de arbeid met zoveel woorden wordt 
vermeld in diverse (obligatoire) bepalingen. (Bijvoorbeeld in de CAO's van Hoogovens, KLM-grondpersoneel, Philips-bedrijven). In all die CAO's wordt gesproken over het bevorderen van de kwaliteit van de arbeid, de vakbekwaamheid en het verantwoordelijkheidsgevoel van de werknemer of de voldoening in en door het werk. Behalve in de bedrijfstak-CAO's van verzekerings-en bankbedrijven is in zes ondernemings-CAO's het bevorderen van het welzijn van de werknemers bovendien uitdrukkelijk tot doelstelling verklaard (246.064 werknemers).

Het in 1987 gepubliceerde onderzoek van de DCA bevestigde in grote lijnen deze conclusies. ${ }^{445}$ Precies valt dat niet te zeggen, omdat een iets afwijkende onderzoeksopzet werd gehanteerd: alleen bedrijfstak-CAO's zijn onderzocht (van toepassing op 10.000 of meer werknemers) en bepalingen inzake klachtenregelingen over arbeidsomstandigheden, ongevallenverzekeringen, sociale jaarverslagen/plannen zijn niet bij het onderzoek betrokken. Maar ook uit dit onderzoek kan geconcludeerd worden, dat er ten opzichte van 1976 een toename is van het aantal arbeidsomstandighedenbepalingen. De invoering van de Arbowet heeft dus niet geresulteerd in een afname van dergelijke bepalingen in een $\mathrm{CAO}$. In veel gevallen zijn bepalingen over een bepaald onderwerp letterlijk of met kleine wijzigingen gehandhaafd ten opzichte van 1976 . In andere gevallen evenwel zijn afspraken over een bepaald onderwerp in de CAO's 1985/1986 veel verder uitgevoerd dan in de CAO's 1975/1976 het geval was. Voor wat betreft de inhoud van de bepalingen gaat het voor een deel om bepalingen waarin werkgevers in algemene zin verplichtingen hebben op het gebied van de arbeidsomstandigheden, voor een ander deel betreft het afspraken over meer specifieke onderwerpen (zie hiervoor het eigen onderzoek). In het algemeen kan geconcludeerd worden dat de 'nieuwe' bepalingen in de $\mathrm{CAO}$ goeddeels ontleend zijn aan c.q. geïnspireerd zijn door de Arbowet. Soms bevatten zij uitwerkingen voor een specifieke ondernemingssituatie, soms bevatten zij regelingen die in de Arbowet nog niet in werking zijn getreden, maar zelden hebben zij een substantiële meerwaarde. Ten opzichte van de vigerende wetgeving blijkt de $\mathrm{CAO}$ toch vooral trendvolger te zijn. ${ }^{446} \mathrm{Dit}$ moet te denken geven bij degenen die menen dat ook vernieuwingen in de onderneming die méér beogen dan economisch rendement, in de eerste plaats of zelfs alleen van de bedrijfsgenoten zelf dienen te komen.

445 Dienst Collectieve Arbeidswoorwaarden (ministerie van Sociale Zaken en Werkgelegenheid), Arbeidsomstandigheden in CAO's (reeks: Studies van CAO's), Den Haag 1987.

446 "Ten opzichte van dit onderwerp kan dus bepaald niet van "volggedrag" van de wetgever worden gesproken. Het omgekeerde is hier het geval. Het pleidooi van Fase voor een terugtredbenadering van de wetgever ten aanzien van bijwoorbeeld arbeidswetgeving in enge zin en medezeggenschapswetgeving lijkt me om die reden dan ook niet op te kunnen gaan. W.J.P.M. Fase, Collectief arbeidsrecht na vijftig jaar, Vijftig jatar sociaal recht in Leiden, (red. M.G. Rood), Deventer 1986, p. 25. 


\section{De werknemer}

\section{Algemene inleiding}

In het vorige hoofdstuk is de positie van de (individuele) werknemer al regelmatig ter sprake gekomen, maar altijd gerelateerd aan rechten, bevoegdheden en plichten van andere actoren. Dat betekent niet dat de positie van de werknemer van minder belang zou zijn. Integendeel, de regelingen die besproken zijn hebben juist alle meer of minder expliciet tot doel het creëren en handhaven van humane arbeidsomstandigheden voor de werknemers. Maar dat zegt nog weinig over de mogelijkheden, in termen van rechten, bevoegdheden en de handhaving en controle ervan, die de werknemer zèlf ter beschikking staan. Anders geformuleerd: in hoeverre is het in de adviesaanvraag aan de SER inzake het ontwerp Arbowet geformuleerde uitgangspunt dat de werknemer niet meer vrijwel uitsluitend als object van beschermende overheidsmaatregelen wordt gezien, maar dat zijn actieve betrokkenheid in de voorgestelde nieuwe wetgeving tot uitdrukking moet komen ook juridisch vertaald, anders dan via gecollectiveerde medezeggenschapsstructuren ${ }^{1}$ En hoe staat het op dit punt met andere regelingen? In dit hoofdstuk zal eerst de positie van de individuele werknemer in de Arbowet onderzocht worden. In het volgende gedeelte van dit hoofdstuk zullen enkele andere relevante regelingen en mogelijkheden waardoor de juridische positie van de werknemer bij de humanisering van zijn arbeid wordt gemarkeerd, de revue passeren. Aandacht zal worden besteed aan de mogelijkheden die het BW biedt, de WOR, de CAO en een wettelijk geregeld klachtrecht (nu nog ius constituendum).

1 Volgens de adviesaanvraag betekent actieve betrokkenheid "allereerst" dat aan werknemers een belangrijke mate van inspraak moet worden toegekend waarbij verwezen wordt nastr de WOR. Daarnaast 'mag worden verwacht' dat werknemers zich bewust zijn van hun verantwoordelijkheid om mee te werken aan de gestelde overheidsregels. Vervolgens wordt geconcludeerd dat dit samenwerkingspatroon 'in een zekere mate' in de nieuwe wet zal moeten worden geïnstitutionaliseerd. SER. Advies inzake vernieuwing van de wetgeving betreffende de gezondheid en de veiligheid bij de arbeid, Den Haag, $1976, \mathrm{nr}$. 18 , bijlage 1, p. 2-3. De onduidelijkheid en dubbelzinnigheid die uit het bovenstaande blijkt, niet alleen tussen de medezeggenschapsregelingen in de WOR en de Arbowet, maar ook tussen persoonlijke verantwoordelijk heid en collectieve bevoegdheidstoekenning is nooit uit de Arbowet verdwenen. Vgl, bijvoorbeeld de adviesaanwraag en het advies van de SER inzake de samenloop van bepalingen in de WOR en de Arbowet (1986, nr. 6). 
Het ligt woor de hand dat ter bepaling van deze positie regelmatig terug gegrepen zal worden op de bevindingen uit het vorige hoofdstuk.

\section{De werknemer in de Arbowet}

\subsection{Inleiding}

In de Arbowet zou het paternalisme ten aanzien van de (individuele) werknemer waarvan de Veiligheidswet 1934 nog was doordrongen, plaats moeten maken voor het beeld van de geëmancipeerde werknemer als zelfstandige drager van rechten en bevoegdheden en een daaraan gerelateerde verantwoordelijkheid en aansprakelijkheid. Desondanks komt de individuele werknemer in de Arbowet niet uitgesproken aan bod. Dat komt omdat de meeste rechten en bevoegdheden voor werknemers toegekend zijn aan een of meer hen vertegenwoordigende collectiviteiten. Dit geldt ook voor de juridische actiemogelijkheden. Zelfs ten aanzien van de bevoegdheden die de individuele werknemer wèl heeft, ligt de handhaving primair bij het hem vertegenwoordigende orgaan - met als belangrijkste uitzondering de bevoegdheid om onder omstandigheden het werk te onderbreken zoals dat geregeld is in art. 38 .

Voor deze constructie zijn ook goede redenen aan te voeren. Op deze manier kan immers worden aangesloten bij de bestaande medezeggenschapsstructuur en de reële mogelijkheden in vooral de grotere ondernemingen. Bovendien zijn dle problemen over arbeidsomstandigheden vaak geen louter individuele problemen. Tenslotte is de macht van een collectiviteit nu eenmaal groter, en daarmee de beïnvloedingsmogelijkheden, dan van een individu. Ik heb deze redenen in het eerste hoofdstuk genoemd.

Toch blijft de individuele werknemer in de Arbowet ook niet helemaal in de kou staan: er is hem zowel een aantal rechten en bevoegdheden toegekend, hoewel vaak niet rechtstreeks zo geformuleerd, als een aantal verplichtingen. De meeste rechten zijn afgeleid van in de wet met zoveel woorden geformuleerde verplichtingen van de andere actoren, met name de werkgever. De belangrijkste rechten die hieronder aan de orde zullen komen, zijn het recht op informatie, op voorlichting en op onderricht, het recht op werkonderbreking en het recht tot klagen bij de Arbeidsinspectie. Vervolgens zullen andere mogelijkheden op basis van de Arbowet onderzocht worden, waarbij een onderscheid gemaakt dient te worden tussen ondernemingen met en zonder een or. In het laatste geval kunnen de belanghebbende werknemers of een meerderheid van hen een rol spelen. Daarna zal aandacht worden besteed aan de verplichtingen van de individuele werknemer in de Arbowet. 


\subsection{Informatie, voorlichting en onderricht}

Het algemene recht op informatie en de meer specifieke rechten op voorlichting en onderricht zijn voor elke werknemer van wezenlijk belang. Het gatat immers om zijn persoonlijke veiligheid en gezondheid die in het geding zijn. Wil hij in dit verband invloed kunnen uitoefenen in welke vorm dan ook, dan is kennis over zijn arbeidsomstandigheden in de meest ruime zin van grote betekenis. De Arbowet gaat bovendien uit van een zekere gelijkwaardigheid van werkgever en werknemers waar het gaat om hun betrokkenheid en verantwoordelijkheid bij de arbeidsomstandigheden in de onderneming. Zij zijn zelfs verplicht om op dit punt samen te werken. Reële samenwerking veronderstelt tenminste een zo veel mogelijk gelijk kennisniveau. Dit geldt te meer omdat de individuele werknemer in een aantal gevallen ook strafrechtelijk aansprakelijk gesteld kan worden wegens overtreding van het gestelde bij of krachtens de Arbowet.

Tot deze wet gold een informatierecht eigenlijk alleen voor vertegenwoordigingen van werknemers. ${ }^{2}$ (Wèl zou een individueel recht terzake direct of indirect ontleend kunnen worden aan het arbeidsovereenkomstenrecht, zie hieronder).

Ook in de Arbowet zijn rechten op informatie, op voorlichting en op onderricht niet met zoveel woorden geformuleerd. Maar uit de tekst en de intentie ervan kunnen ze wel worden afgeleid. Ten aanzien van het recht op informatie van de werknemer van de kant van de werkgever meende de minister desgevraagd dat dit recht voortvloeit uit het bepaalde in art. 13, waarin aan werkgever en werknemers de verplichting is opgelegd om samen te werken in het behartigen van de zorg voor veiligheid, gezondheid en wellzijn. ${ }^{3}$ (Zie over art. 13 ook het vorige hoofdstuk, paragraaf 2.2.8.). Met de uitkomst van deze interpretatie kan ik vrede hebben in zoverre dat de minister op deze wijze te kennen geeft dat hij een recht op informatie voor de werknemer van belang acht. Maar bij de interpretatie zelf kunnen vraagtekens geplaatst worden: immers het direct affeiden van een juridisch verankerd informatierecht voor de individuele werkmemer uit een overlegverplichting voor de werkgever en zijn werknemers ligt toch niet onmiddellijk voor de hand. Dit is naar mijn smaak te meer het geval, nu in het daarop volgende artikel 14, ter bevordering van de in art. 13 bedoelde samenwerking Arbocommissies worden geïntroduceerd aan wie de werkgever verplicht is de nodige inlichtingen te verschaffen. Volgens art. 15 geldt dit ook ten aanzien van de or. De individuele werknemer komt in de Arbowet bij de specifieke invulling van art. 13 niet in het stuk voor.

Een recht op informatie kan ook, en beter, afgeleid worden uit de verplichting van de werkgever in art. 6 om aan zijn werknemers de benodigde voorlichting

2 Zie bijvoorbeeld de dissertatie van G.J.W. Arendsen de Wolff: Over de informatieplicht wan de onderneming, met als veelzeggende ondertitel: Beschouwingen orntrent informatieverstrekking en geheimhouding in de betrekkingen tussen de onderneming en de werknemersvertegenwoordigers, Deventer, 1976.

3 Nota naar aanleiding van het eindverslag, t.a.p. p. 25. 
en onderricht te geven. (Voor een bespreking van deze werkgeversverplichting zie het vorige hoofdstuk, paragraaf 2.2.5.). Dat dat mogelijk is, vond de minister ook. Acht pagina's nadat hij in de Nota naar aanleiding van het eindverslag de hierboven gememoreerde opmerking maakte dat het recht op informatie voortvloeide uit art. 13 waarin de samenwerkingsverplichting staat, stelde hij "dat de in art. 6 vervatte verplichting van de werkgever om aan de werknemers informatie te geven juridisch het recht op informatie bevat' ${ }^{4}$

Langs twee verschillende wegen kan dus voor de werknemers een informatierecht geconstrueerd worden. Ten aanzien van de laatste weg moet opgemerkt worden dat het recht voor de werknemer weliswaar duidelijker uit de wettekst blijkt, maar dat het gaat om specifieke vormen van informatie, nl. voorlichting en onderricht die bovendien direct gerelateerd zijn aan de eigen taken en werkzaamheden. Voorts zijn de momenten waarop deze activiteiten dienen plaats te vinden in de tekst van art. 6 enigszins geobjectiveerd: 'zo dikwijls als dit in verband met de veiligheid ... noodzakelijk is ...' en 'zo dikwijls de daarmee opgedane ervaring of gewijzigde werkmethoden of werkomstandigheden daartoe aanleiding geven .... Uit de tekst van art. 6 blijkt dus weliswaar dat het de bedoeling is dat gewaarborgd wordt dat de werkgever op eigen initiatief voorlichting en onderricht geeft, maar het (subjectieve) oordeel van de werknemer over de wenselijkheid, de noodzaak of het tijdstip is juridisch niet relevant. De wetgever bepaalt bovendien in art. 12 onder d dat de werknemer verplicht is mede te werken aan het voor hem door de werkgever georganiseerde onderricht. Blijkt hier toch niet uit dat de werknemer in elk geval op dit punt nog vooral gezien wordt als object van zorg, meer dan als drager van een subjectief recht? Waarom niet een algemeen informatierecht voor elke werknemer klip en klaar in de Arbowet geformuleerd?

Maar ook als er van uit wordt gegaan dat de Arbowet nu al aan de werknemer dat recht op informatie jegens de werkgever geeft, blijft de vraag hoe hij dit dan geldend kan maken of, anders gezegd, wat hij kan doen indien de werkgever hem de gewenste informatie niet of onvoldoende verschaft. Overtreding door de werkgever van art. 6 vormt weliswaar een economisch delict (art. 57), maar daar heeft de werknemer weinig aan. De Arbeidsinspectie kan ook een aanwijzing geven bij het in onvoldoende mate of op onjuiste wijze naleven van art. 6. Zij kan dat zowel gevraagd als ongevraagd doen. In beide gevallen heeft de individuele werknemer geen zelfstandig actierecht. Het zgn. verzoek om wetstoepassing kan immers in beginsel alleen gedaan worden door de or of de Arbocommissie. Pas als die er niet zijn, kan het gedaan worden door een meerderheid van de belanghebbende werknemers of door een in de onderneming werkzame vakbond. Nooit door een individuele werknemer. (Zie over het verzoek tot wetstoepassing hoofdstuk III, paragraaf 5.3.). Natuurlijk kan hij zich wel tot de Arbeidsinspectie wenden met een klacht over de informatieverstrekking door de werkgever, maar dat behoeft geen consequenties te hebben, omdat de Arbeidsinspectie ten aanzien van het klachtrecht volgens de

4 Nota naar aanleiding van het eindverslag, t.a.p. p. 33. 
Arbowet alleen de algemene plicht heeft om de namen van klagers geheim te houden (art.34 lid 2).

Ten aanzien van art. 13 geldt iets dergelijks. Alleen is de individuele werknemer hier nòg meer afhankelijk van de bereidwilligheid van de werkgever en de hem vertegenwoordigende organen in de onderneming: overtreding van art. 13 is niet strafbaar en een aanwijzing terzake kan door de Arbeidsinspectie alleen gegeven worden nadat hiertoe een verzoek om wetstoepassing is gedaan. Het optreden naar aanleiding van een klacht van een werknemer of op eigen initiatief behoort ten aanzien van art. 13 niet tot de mogelijkheden (art. 40 lid 1).

Samenvattend: een recht op informatie van de werknemer jegens zijn werkgever over de arbeidsomstandigheden in de onderneming staat niet met zoveel woorden in de Arbowet. Weliswaar kan een dergelijk recht afgeleid worden uit de artt. 6 en 13, maar ten aanzien van beide artikelen is deze interpretatie niet vanzelfsprekend; in elk geval kan niet gesproken worden van een stevig juridisch verankerd subjectief recht op informatie, gekoppeld aan een zelfstandige juridische actiemogelijkheid voor de individuele werknemer, althans op basis van de Arbowet.

\subsection{Werkonderbreking}

In art. 38 is een ondubbelzinnige bevoegdheid voor elke individuele werknemer geformuleerd: het onder bepaalde voorwaarden en omstandigheden kunnen onderbreken van het werk. Zonder dat in de adviesaanvraag inzake het ontwerp Arbowet deze kwestie aan de orde was gesteld, signaleerde de SER in zijn advies dat zich in een onderneming omstandigheden kunnen voordoen waarin (verdere) uitvoering van opgedragen werkzaamheden in redelijkheid niet van de betrokken werknemer(s) kan worden gevergd wegens een dreigend acuut gevaar. Werkweigering achtte de SER alsdan gerechtvaardigd, zonder dat de werknemer nadelige gevolgen van zijn initiatief zal ondervinden. ${ }^{5} \mathrm{Bij}$ deze - op zich niet zo opzienbarende - mededeling liet de SER het verder.

In zijn MvT erkende ook de minister dat het nooit geheel kan worden uitgesloten dat zich in een onderneming plotseling een acute bedreiging voordoet van de veiligheid of de gezondheid. In een dergelijke situatie zouden de betrokken werknemers echter de leiding dienen te waarschuwen om daarna, zo mogelijk in gezamenlijk overleg, een beslissing te nemen over eventuele maatregelen. Ten aanzien van de situatie dat geen overeenstemming kan worden bereikt en de werknemers besluiten op eigen verantwoordelijkheid de opgedragen werkzaamheden te staken, meent de minister mèt de SER dat zich inderdaad omstandigheden kunnen voordoen waarin de uitvoering van de opgedragen werkzaamheden in redelijkheid niet van een werknemer kan worden gevergd 
wegens een dringend acuut gevaar voor hemzelf of voor zijn mede-werknemers. De minister meent dat dit in het burgerlijk recht ligt opgesloten. ${ }^{6} \mathrm{Hij}$ licht dit standpunt niet toe, maar neemt het wel terecht in. Hoewel in het BW geen uitdrukkelijke bepaling is te vinden waarin een dergelijke vorm van 'eigen richting' is toegestaan, kan een dergelijke bevoegdheid er wel uit worden afgeleid. Niet voor niets noemt art. $1639 \mathrm{q} \mathrm{BW}$ als dringende reden voor beëindiging van de dienstbetrekking door de werknemer in het algemeen 'zodanige omstandigheden, die ten gevolge hebben, dat van de arbeider redelijkerwijze niet kan gevergd worden de dienstbetrekking te laten voortduren'; vervolgens noemt lid 2 onder 9 , onder meer, als zodanige dringende reden ernstige gevaren voor leven en gezondheid waarvan bij de indiensttreding nog niet was gebleken. Kennelijk acht de wetgever het bestaan van gevaren voor de gezondheid reden om niet door te gaan of te beginnen met het werk. Het onder die omstandigheden wèl werken wordt terecht niet redelijk geacht. Zou overigens een goede werkgever volgens art. $1638 \mathrm{z}$ zich anders behoren te gedragen?

De jurisprudentie over dit onderwerp is schaars en casuïstisch, maar een principiële afwijzing van een dergelijke bevoegdheid van werknemers is niet te vinden. ${ }^{7}$

Een algemeen criterium is door de HR in 1966 gegeven ten aanzien van het niet voldoen door de werknemer aan een redelijk bevel van de werkgever in de zin van art. $1639 \mathrm{q}$ lid 2 onder $10 .^{8}$ Zelfs indien de werknemer 'steekhoudende bezwaren' heeft, dan nog mag hij daaraan slechts gehoor geven indien daarbij met het belang van de werkgever in redelijke mate rekening wordt gehouden. Het gaat dus om een afweging tussen het belang dat de werkgever heeft bij voortzetting van de arbeid en het belang van de werknemer om ermee te stoppen. Met dit arrest voor ogen komt Duk tot de volgende conclusie ten aanzien van werkweigering die zijn grond vindt in de omstandigheden waaronder het werk verricht moet worden. 'Afgezien daarvan dat van de werknemer niet verlangd zal mogen worden zich aan serieuze gevaren voor leven of gezondheid bloot te stellen, zal daarom voor dit soort gevallen geen algemener regel geformuleerd kunnen worden dan deze dat de werkgever goede gronden zal moeten hebben om werk onder omstandigheden die ongebruikelijk slecht zijn, te mogen verlangen. ${ }^{*}$

Dit standpunt (en dat van de HR) lijkt niet juist. Nog afgezien van de onlogica die er naar mijn smaak te bespeuren valt tussen het eerste en het tweede gedeelte van het citaat, dient er geen ruimte te zijn voor een dergellijke rechtvaardiging door de werkgever of voor een belangenafweging achteraf door de rechter. De wetgever heeft immers, blijkens het hierboven al genoemde art.

6 MWT, t.a.p. p. 15 .

$7 \mathrm{Ktg}$. Eindhoven, 19 juni 1953, NJ 1953, 510, Ktg. Haarlen, 2 oktober 1972, Praktijkgids, 1973 , nr. 802; vgl. ook: J Mannoury, Ontslagrecht en Arbeidswet ... en ceterum censeo, SMA. 1958, p. $532-539$.

8 HIR 24 juni 1966 , NJ $1966,457$.

9 R.A.A. Duk, Redelijk bevel en dringende reden, SMA, 1976, p. 93. 
$1639 \mathrm{q}$ lid 2 onder 9 , de in het geding zijnde belangen al afgewogen en aan leven en gezondheid van de werknemer voorrang gegeven. Dit neemt uiteraard niet weg dat de werknemer zorgvulldig dient op te treden: hij dient zich te gedragen als een 'goed arbeider' volgens art. $1639 \mathrm{~d} \mathrm{BW}$. Dit betekent onder meer dat hij de werkgever tijdig en gemotiveerd in kennis moet stellen van zijn weigering, zodat de laatste (nog) de mogelijkheid heeft om de omstandigheden te veranderen. ${ }^{10}$

In 1984 oordeelde de HR ten aanzien van een schilder die werk op een hoge staalconstructie weigerde, omdat hij dit werk in verband met een handicap aan zijn knie te risicovol vond, dat een werkweigering slechts dan een reden tot ontslag oplevert wanneer de werkgever uitvoering van de opdracht in redelijkheid van de werknemer kan vergen. In dit geval zou het aankomen op de vraag of de ingeroepen handicap inderdaad een beletsel voor de uitvoering van de opdracht vormde. ${ }^{\text {II }}$

Het antwoord op de vraag of de weigering van de kant van de werknemer in verband met gevaar voor zijn gezondheid redelijk kan worden geacht, lijkt ook mij het enige criterium. Bij die afweging behoren de belangen van de werkgever ondergeschikt te zijn. (De HR overweegt verder nog dat de verzwijging door de werknemer van zijn handicap bij het aangaan van de dienstbetrekking, juist omdat de werkgever wegens die handicap niet alle overeengekomen werkzaamheden van de werknemer kan vergen, in beginsel wel een (zelfstandige) dringende reden voor ontslag kan opleveren. Op dit laatste had de werkgever zijn ontslaggrond' echter niet gebaseerd).

In ieder geval kan geconstateerd worden dat het onder bepaalde omstandigheden kunnen neerleggen van het werk c.q. weigeren van opdrachten in beginsel rechtens geoorloofd is.

Toch is met name door de vakbeweging aangedrongen op een nadere wettelijke regeling van deze bevoegdheid. ${ }^{12}$ Als argument werd de zwakke positie van de werknemer aangevoerd, die ertoe zou kunnen leiden dat hij uit vrees voor ontslag of anderszins benadeling van zijn positie objectief gezien onaanvaardbare risico's zou nemen, eventueel zelfs handelen in strijd met een direct tot hem gericht verbod. 'De sociale en procesrechtelijke positie van waaruit de werknemer een eenmaal op staande voet verleend ontslag zou moeten aanvechten, maakt hem veelal uiterst terughoudend waar het er op aan komt zijn

$10 \mathrm{VgI}$ HR 8 juni 1962, NJ 1963, 526. In dit arrest werd een dringende reden woor ontslag aarigenomen, hoewel het bevel tot overwerk in strijd was met de bepalingen van de Arbeidswet, omdat de werknemer zijn weigering niet zo tijdig ter kennis wan de werkgever had gebracht dat nog de nodige voorzieningen konden worden getroffen met het oog op die weigering. Vgl in dit verband ook HR 6 april 1979, NJ 1979, 492, waarin gesteld wordt dat het weigeren on langer te werken dan de Arbeidswet toestaat op zichzelf geen dringende reden voor ontslag oplevert. Voor een belangenafweging lijkt de HR hier geen ruimte te laten.

11 HR 2 november 1984, NJ 1985, 192.

12 FNV, Commentaar ontwerp Arbeidsomstandighedenwet, brief aan de vaste commissie voor sociale zaken van de Tweede Kamer der Staten-Generaal Amsterdam, 8 september 1977, p. 8-9. Eveneens: J. Bloemarts, Op weg naar een drie-partijen-model voor het sociaal beleid in de onderneming?', SMA, 1978, p. 596-597. 
rechten te doen gelden. ${ }^{13}$ Voorgesteld werd om werkweigering c.q. onderbreking toe te staan voor het geval dat de werkgever de voorgeschreven persoonlijke beschermingsmiddelen niet ter beschikking stelt, op machines e.d. de voorgeschreven beveiligingsmiddelen ontbreken, de werkgever een eis van de Arbeidsinspectie niet naleeft en de voorgeschreven afzuiginstrumenten ontbreken. Daarnaast werd voorgesteld om een algemene bevoegdheid aan de werknemer toe te kennen om het werk te weigeren indien hij in redelijkheid kan aannemen dat voor de veiligheid of gezondheid van hemzelf of van anderen een onmiddellijk gevaar dreigt, tenzij het uitdrukkelijk tot zijn taak behoort maatregelen te treffen om het gevaar te keren. In deze situatie zou de bewijslast omgekeerd dienen te worden: niet de werknemer zou moeten aantonen dat het gegeven bevel onredelijk was, resp. dat hij in redelijkheid mocht aannemen dat serieuze gevaren voor de gezondheid aanwezig waren, maar de werkgever zou moeten bewijzen dat de werknemer niet in redelijkheid kon aannemen dat onmiddellijk gevaar dreigde. Bovendien zou de eventuele schadeplichtigheid van de werknemer beperkt moeten worden. Zonder deze omkering van de bewijslast en beperking van de aansprakelijkheid zou het risico van het neerleggen van het werk voor de werknemer zo groot zijn, dat deze daar ook in gerechtvaardigde gevallen niet toe zou durven overgaan.

Nadat ook van de kant van de kamer druk was uitgeoefend om een dergelijke bevoegdheid expliciet wettelijk te regelen is de minister overstag gegaan. Zonder enig enthousiasme overigens en met vrijwel geheel voorbij gaan aan de argumenten van de vakbeweging. In de Nota naar aanleiding van het eindverslag motiveert de minister de toevoeging van het huidige art. 38 slechts met de mededeling dat men er niet absoluut van uit kan gaan dat het leidinggevend personeel steeds voldoende deskundig en zorgvuldig is, dat een werkgever altijd voldoende zorg heeft voor de veiligheid en dat er zich gevaarlijke situaties kunnen voordoen terwijl de werkgever noch een leidinggevende aanwezig is. ${ }^{14}$ En enige maanden na de ontvangst van de bovengenoemde nota deelt de minister in de openbare commissievergadering mee: 'Het artikel is niet zozeer ingegeven door een gebleken behoefte en evenmin zijn er praktijkgevallen waaruit de noodzaak blijkt. Bij een aantal fracties leefde echter een verlangen in deze richting.' 15 '

Nu is het uiteraard niet gemakkelijk om een gebleken behoefte of een blijkbare noodzaak ten aanzien van een juridische voorziening aan te tonen indien wegens het ontbreken van een dergelijke voorziening nu juist geen activiteiten worden ontplooid die zo'n voorziening zouden rechtvaardigen. Desondanks had de minister toch wel kunnen wijzen op een arrest van de HR gewezen circa een jaar voor zijn bovengeciteerde mededelingen in de openbare commissievergadering. ${ }^{16}$

Het ging in dit arrest om een havenwerker die opdracht kreeg om zich, beladen

13 Bloemarts, t.a.p. p. 596.

14 Nota naar aanleiding wan het eindverslag, t.a.p. p. 13.

15 Handelingen TK 1979-1980, OCV 36, 9 maart 1980, p. 1455.

16 HR 9 februari 1979, NJ 1979, 629 (m.nt. F.H.J.M.). 
met enkele forse werktuigen, vanaf een ponton aan boord van een schip te begeven om dit te lassen. Tussen ponton en schip (circa drie meter) was geen loopplank aanwezig, maar een roeibootje. De werknemer, die niet kon zwemmen, weigerde op deze manier aan boord te gaan, waarna hij op staande voet werd ontslagen. De havenwerker riep de nietigheid van het ontslag in en beriep zich daarbij op art. 6 van het Veiligheidsbesluit Binnenvaart (VBB), waarin voor deze gevallen een veilige loopplank of iets dergelijks wordt geëist. De feitenrechter oordeelde dat art. 6 VBB niet voor deze situatie geschreven was. (Het ging vooral om de interpretatie van het "langszij meren"). In aanmerking nemende dat de havenwerker geholpen kon worden en een normaal postuur had, behoefde de overbrugging volgens de Rechtbank voor een valide havenwerker geen ernstige moeilijkheden op te leveren zodat de weigering van de opdracht om op deze wijze aan boord te gaan een voldoende dringende reden voor ontslag opleverde. De HR meende dat het oordeel van de Rechtbank dat art. 6 VBB niet voor de onderhavige situatie was geschreven, niet blijk gaf van een onjuiste rechtsopvatting. Terecht meende annotator Mijnssen dat in het licht van de bedoeling van art. $6 \mathrm{VBB}$ deze uitleg te beperkt is. ${ }^{17}$ Voor mij lijdt het geen twijfel dat een beroep van de werknemer op art. 38 Arbowet tot een andere uitkomst geleid zou hebben. ${ }^{18} \mathrm{Ik}$ zal dat nu laten zien aan de hand van de bestanddelen van het artikel en de uitvoerige toelichting erop in de Nota naar aanleiding van het eindverslag. ${ }^{19}$

Elke individuele werknemer is bevoegd om het werk te onderbreken en de onderbreking voort te zetten, indien en zolang naar zijn redelijk oordeel gevaar voor personen alls bedoeld in art. 37 lid 1 aanwezig is en naar zijn redelijk oordeel het gevaar zo onmiddellijk dreigt dat de Arbeidsinspectie niet tijdig kan optreden. Art. 37 lid 1 doelt op de bevoegdheid van de Arbeidsinspectie om het werk stil te leggen in een situatie waarin het verblijf van personen op een bepaalde plaats dan wel het voortzetten of het aanvangen van bepaalde werkzaamheden ernstig gevaar oplevert voor personen. (Zie voor deze bevoegdheid van de Arbeidsinspectie hoofdstuk III, paragraaf 5.4.). Uit de verwijzing naar art. 37 lid 1 blijkt dat het gevaar ernstig moet zijn. Wanneer dat zo is, is niet altijd even duidelijk, maar het ligt voor de hand dat daar in elk geval sprake van zal zijn bij een reële kans op ongeval of letsel. Het gevaar moet ook zò onmiddellijk dreigen dat er geen tijd meer is om de Arbeidsinspectie in te schakelen. Is daar wel voldoende tijd woor dan moet aan deze de beslissing worden gelaten, bijvoorbeeld om toepassing te geven aan art. 37. Het maakt geen verschil of het gevaar voortvloeit uit het niet naleven van de arbeidsomstandighedenwetgeving dan wel uit een andere oorzaak.

17 Zoook: I.J. van Dodeweerd, Een vreend ontslag langs de waterkant, SMA, 1980, p. 734-736. Van Dodeweerd wijst er ook op dat de opvatting van de Rechtbank dat art. 6 VBB niet woor de situatie die in casu aan de orde is, is geschreven onterecht is. Hij verwijst datarvoor nat de MvT bij onder meer art. 6 , waruit blijkt dat het artikel nauw aansluit bij de conventie nr. 325 wan de ILO, voor ons land in 1934 in werking getreden. De conventie latat een interpretatic zoals die door de Rechtbank is gegeven, niet toe.

18 Zo ook: M.M. Olbers, Opdracht in strijd met de wet, SMA, 1984, p. 150-166, m.n. p. 166; H. . van Zwam, Veranderingen in het arbeidsomstandighedenrecht, Deventer 1983, p. 71.

19 Nota naar a anleiding van het eindverslag, t.a.p. p. 12-16. 
Vervolgens bepaalt art. 38 uitdrukkelijk dat de werknemer voor de duur van de werkonderbreking zijn aanspraak op het vastgestelde loon behoudt. Terecht vermeldt de toelichting dat werknemers bij stillegging van het werk op bevel van de Arbeidsinspectie recht hebben op doorbetaling van het Ioon. Dit vloeit voort uit art. $1638 \mathrm{~d}$ BW: de gedwongen werkonderbreking wegens gevaar ligt in de risicosfeer van de werkgever. Om nu alle twijfel uit te slluiten over de vraag of art. 1638d ook het geval omvat waarin een werknemer, menend dat onmiddellijk dreigend gevaar aanwezig is, zelf besluit het werk te onderbreken, is de bovenbedoelde bepaling opgenomen. Uiteraard handelen werknemers, indien zij van hun wettelijke bevoegdheid om het werk neer te leggen, gebruik maken in beginsel rechtmatig: zij behoeven eventuele schade niet te vergoeden. Komt het toch tot een procedure over doorbetaling van het loon of schadevergoeding, bijvoorbeeld omdat men meent dat die algemene zorgvuldigheidsnorm is geschonden, waaraan de nieuwe bepalingen geen afbreuk doen, dan kan de vraag aan de orde komen of de werknemer terecht op grond van de feitelijke situatie de aanwezigheid van onmiddellijk dreigend gevaar heeft aangenomen.

In dit verband geeft het derde onderdeel van art. 38 een regel van (civielrechtelijk) bewijsrecht. Degene die beweert dat de werknemer de aanwezigheid van het onmiddellijk dreigend gevaar op grond van de feiten waarop hij zich beroept, niet naar zijn redelijk oordeel mocht aannemen, moet dit bewijzen. Dit betekent dat de betrokken werknemer alleen behoeft aan te tonen dat de verschijnselen die hij als een teken van gevaar heeft opgevat, zich ook werkelijk hebben voorgedaan. Dit blijkt uit de zinsnede 'op grond van de feiten waarop hij zich beroept'. Met feiten is bedoeld datgene dat de werknemer met de zintuigen heeft waargenomen. Indien het echter gaat om de interpretatie van de verschijnselen, met andere woorden om het antwoord op de vraag of deze verschijnselen acuut gevaar opleverden, dan wordt de bewijslast omgekeerd ten gunste van de werknemer. Niet hij moet dan bewijzen dat hij de verschijnselen juist interpreteerde, maar degene die beweert dat hij ten onrechte op grond van die feiten het werk heeft neergelegd. In dit verband is de zinsnede: 'naar zijn redelijk oordeel' van belang. Hiermee wordt verwezen naar het vermogen dat bij de werknemer op grond van zijn opleiding, ervaring en gegeven voorlichting mag worden verondersteld, om in korte tijd verschijnselen te beoordelen. De werknemer moet daarbij ook de ruimte worden gegund voor beoordelingsfouten die een deskundige zouden worden verweten. De omkering van de bewijslast houdt dus in dat degene die de redelijkheid van het oordeel van de werknemer bestrijdt, moet bewijzen dat het reeds voor mensen met de kennis en ervaring van de betrokken werknemer onredelijk was de situatie zo te beoordelen als hij deed. De minister: "Het wil mij voorkomen dat de boven beschreven bewijslastverdeling enerzijds de werknemers voldoende ruimte biedt voor beoordelingsfouten en anderzijds een waarborg bevat tegen misbruik. ${ }^{20}$ Dat is juist.

20 Nota naar aanleiding wan het eindverslag, t.a.p. p. 15. 
Een vierde regel in art. 38 betreft de verplichting van de werknemer om zijn werkonderbreking 'terstond' te melden aan zijn werkgever, onderscheidenlijk aan de bij de arbeid betrokken leidinggevende persoon, indien deze er nog niet van op de hoogte waren. De melding dient plaats te vinden bij de werkgever indien deze een natuurlijk persoon is en de werkzaamheden zelf leidt en bij degene die de leiding heeft in de andere gevallen, dat is dus wanneer de werkgever een rechtspersoon is, of een natuurijk persoon die niet zelf de leiding bij de betrokken arbeid heeft. Deze meldingsplicht is op zich niet bijzonder. Op grond van art. 12 onder e heeft elke werknemer al de plicht om de door hem opgemerkte gevaren voor de veiligheid of de gezondheid terstond te melden aan de werkgever of aan de leidinggevende. Een dergelijke verplichting kan ook gedestilleerd worden uit het 'goede arbeiderschap' van art. $1639 \mathrm{~d}$ BW. Bovendien wordt in de toelichting nog gewezen op de mogelijkheid dat bij het achterwege laten van de melding door de betrokken werknemer aan hem, in verband met de doorbetaling van het loon, verweten zou kunnen worden dat de werkonderbreking langer heeft geduurd dan nodig was. Waarschijnlijk wordt hiermee gedoeld op de consequentie van art. 1638d: de werknemer is verplicht zijn bereidheid te tonen om de bedongen arbeid te verrichten. Bij een werkonderbreking toont hij die bereidheid door de werkgever zo spoedig mogelijk in staat te stellen om maatregelen te treffen waardoor het werk hervat kan worden. ${ }^{21}$ Met Olbers ben ik van mening dat het in de opzet van de regeling niet past dat bij het niet-melden van de werkonderbreking het recht vervalt; wèl dat geen loon wordt betaald over de periode dat de werknemer verwijtbaar verzuimd heeft de onderbreking te melden. ${ }^{22}$

Het laatste element van art. 38 behelst de rol van de Arbeidsinspectie. Indien de werkonderbreking ter kennis wordt gebracht van de Arbeidsinspectie, dan geeft deze hetzij het bevel af tot stillegging van het werk volgens art. 37 eerste of tweede lid, hetzij een verklaring dat het werk kan worden hervat zonodig onder het stellen van een eis. Door deze beschikking eindigt de bevoegdheid van de werknemer de werkonderbreking voort te zetten. Deze bepaling begint met 'indien'. Er is dus geen verplichting om de Arbeidsinspectie te waarschuwen. Volgens de toelichting omdat de werkonderbreking veelal intern zal worden opgelost, doordat de betrokken leiding ermee instemt, of door het wijken van het gevaar. Wordt de werkonderbreking echter ter kennis van de Arbeidsinspectie gebracht - en blijkens de tekst is ieder hiertoe bevoegd - dan mòet deze er zich ook mee bemoeien door te verklaren dat het werk wel of niet kan worden hervat. Uit het oogpunt van registratie en daarmee van bekendheid met acuut gevaarlijke situaties in een onderneming, of beter: van bekendheid met de subjectieve percepties van werknemers over de veiligheid in hun onderneming, is het jammer dat er geen meldingsplicht bij de Arbeidsinspectie bestaat. Zelfs behoeft een overzicht van werkonderbrekingen niet in het jaarverslag ex art. 10 te staan (weer wèl het overzicht van de door de werknemers ingevolge art. 12 onder e gemelde gevaren).

21. Vgl, ook HR 8 juni 1962, NJ 1963, 526.

22 M.M. Olbers, t.a.p. p. 160. 
Het belangrijkste nieuwe element in de regeling van art. 38 ten faveure van de individuele werknemer is in de eerste plaats natuurlijk de omkering van de bewijslast. De werknemer behoeft slechts feiten en omstandigheden aan te voeren die hem geleid hebben tot de conclusie dat hij het werk zou moeten neerleggen. Op de werkgever rust de verplichting om te bewijzen dat er op basis van deze feiten geen onmiddellijk dreigend gevaar aanwezig was. In de tweede plaats, en nauw samenhangende met het bovenstaande, is de norm op grond waarvan van de bevoegdheid gebruik gemaakt mag worden een gesubjectiveerde. Het gaat om de subjectieve inschatting van de werknemer waarbij deze - mede afhankelijk van zijn ervaring, genoten voorlichting e.d. - de ruimte wordt gegund om beoordelingsfouten te maken. De betekenis hiervan zal vooral zijn dat de werknemer minder angst behoeft te hebben voor een juridische tegenactie van de werkgever, waarbij met name gedacht kan worden aan ontslag op staande voet wegens dringende reden op grond van art. $1639 \mathrm{p}$ lid 3 onder $10 \mathrm{BW} .^{23}$

Terugkerend naar de havenwerker in HR 9-2-1979 kan gesteld worden dat bij een beroep op art. 38 de afloop anders zou zijn geweest. In de eerste plaats zou het VBB en dus de interpretatie ervan geen rol hebben behoeven te spelen. De bevoegdheid om het werk neer te leggen ex art. 38 waaronder ook is begrepen de bevoegdheid om te weigeren er mee aan te vangen, is niet afhankelijk van een overtreding door de werkgever van een wettelijk voorschrift. In de tweede plaats zou de werkgever moeten bewijzen dat de situatie niet gevaarlijk was en dat de werknemer dat redelijkerwijze had kunnen weten. In de derde plaats leidt de gesubjectiveerde norm van wat als acuut gevaarlijk beschouwd wordt ertoe dat de rechter slechts marginaal kan toetsen. In het onderhavige geval werd na een interpretatie van art. 6 VBB door de feitenrechter een geobjectiveerd oordeel uitgesproken over de gevaarssituatie en werd het gedrag van de werknemer, die zelf diende te bewijzen dat hij terecht het werk weigerde, integraal getoetst. ${ }^{24}$

Hoewel de regeling van art. 38 dus ongetwijfeld onder omstandigheden soelaas kan bieden aan de werknemer die geconfronteerd wordt met een acuut dreigend gevaar voor zijn gezondheid, blijft er nog een belangrijke vraag onbeantwoord. Wat zijn de mogelijkheden voor de werknemer indien de veiligheidsvoorschriften worden overtreden maar het gevaar niet acuut is? De minister zegt dan dat deze situatie ter beoordeling kan worden voorgelegd aan de Arbeidsinspectie via het verzoek om wetstoepassing. In een dergelijk geval mag de werknemer 'dus', nog steeds volgens de minister, het werk niet weigeren. ${ }^{25}$ Hierbij verzuimt hij echter te vermelden dat het verzoek om wetstoepassing alleen gedaan kan worden door de werkgever of door de Arbocommissie, de or of bij het ontbreken van beide laatste, een meerderheid van de belanghebbende werknemers of de in de onderneming werkzame vakbond. Niet

$23 \mathrm{Vgl}$. A.J.H. van Lynden, De individuele werknemer in het arbeidsomstandighedenrecht, SMA, 1984, p. 499 .

24 Zie noot 18 .

25 Nota naar aanleiding van het eindverslag, t.a.p. p. 14 
door de individuele werknemer. Hij moet dus een van de genoemde groeperingen (òf zijn werkgever) zo ver zien te krijgen dat zij een beroep doen op de Arbeidsinspectie. Maar wat indien dat niet lukt? Olbers meent dat ook in een dergelijk geval de werknemer een beroep kan doen op het recht op werkweigering van art. 38 in verband met een naar zijn redelijk oordeel onmiddellijk dreigend, ernstig gevaar. Immers, zo luidt zijn redenering, is er sprake van arbeid in strijd met de veiligheidswetgeving 'dan zal toch niet gesteld kunnen worden dat de arbeider naar zijn redelijk oordeel geen ernstig gevaar nocht aannemen, nu de wetgever in zijn normstelling toch een geobjectiveerd oordeel heeft uitgesproken over het gevaar verbonden aan het werken zonder inachtneming van de gestelde voorschriften'. ${ }^{26}$ Deze interpretatie zou bovendien recht doen aan de wensen terzake van werkweigering zoalls die geformuleerd waren door de FNV en Bloemarts en die ik hiervoor weergegeven heb. Ook mij lijkt deze ruime interpretatie van art. 38 redelijk, zeker indien de bevoegdheid dan nog beperkt wordt tot de situatie dat de werknemer door overtreding van de veiligheidsvoorschriften de kans loopt om min of meer direct in zijn gezondheid te worden geschaad, bijvoorbeeld indien hem niet de wettelijk voorgeschreven beschermingsmiddelen zijn verschaft. Indien zijn belang er slechts in verwijderde zin bij betrokken is of het hem vooral om het algemene belang van handhaving van de wettelijke voorschriften gaat, dan lijkt een werkweigering niet redelijk te zijn. ${ }^{27}$

Voor de wetgever lijkt dit standpunt echter allerminst redelijk te zijn. Niet alleen wees de minister zoals ik hierboven al schreef deze interpretatie ondubbelzinnig af, ook een nadien ingediend amendement met als doel de opvatting van de FNV op dit punt in de wettekst op te nemen, werd door de Kamer verworpen. ${ }^{28}$ Wijst men mèt de Kamer deze extensieve interpretatie van art. 38 af, dan behoeft dit natuurlijk niet te betekenen dat de werknemer zich zonder meer zou moeten neerleggen bij de weigering van zijn werkgever om de veilligheidsvoorschriften na te leven. In een dergelijk geval kan de werknemer nog altijd wegens de kennelijke onredelijkheid ervan weigeren om een opdracht uit te voeren. Terecht wordt ook door Olbers aangenomen dat het immers niet de bedoeling is dat art. 38 het algemene arbeidsovereenkomstenrecht doorbreekt, zoals bijvoorbeeld art. $1639 \mathrm{~b} \mathrm{BW}$, waarin staat dat de werknemer zich dient te houden aan de door de werkgever gegeven voorschriften echter wèl binnen de perken van de wet, verordening, overeenkomst of reglement gegeven. ${ }^{29}$ Echter: de nadelen van een beroep op het arbeidsovereenkomstenrecht zijn tevens de nieuwe voordelen van art. 38 Arbowet. Bij toepassing van het laatste immers rust de bewijslast op de werkgever en wordt slechts marginaal getoetst.

Hoewel ook ik het betreur dat de opvattingen van de FNV niet integraal in art.

26 M.M. Olbers, t.a.p. p. 161

27 Voor dit standpunt eveneens: A.J.C.M. Geers en J.K.M. Gevers, Arbeidsomstandighedenrecht, Deventer 1979, p. 153

28 TK 1979-1980, 14.497, nr. 118 (amendement van Moor c.s.).

29 M.M. Olbers, t.a.p. p. 162. 
38 zijn opgenomen, verdient de regeling omtrent het kunnen neerleggen van het werk als logisch sluitstuk van de Arbowet waardering. Zij doorbreekt de grote nadruk op de collectivistische bevoegdhedentoedeling in de Arbowet en (her)geeft aan werknemers, met juridische rugdekking, een reële mogelijkheid, méér dan in het burgerlijk recht in elk geval, tot het gebruik maken van een 'authentiek protestmiddel'. ${ }^{30}$

Hoe vaak in de praktijk gebruik wordt gemaakt van het instrument is onbekend. Wèl is het aantal gevallen bekend waarin de Arbeidsinspectie wordt ingeschakeld. Het betrof in de jaren 1984, 1985 en 1986 respectievelijk twee-, zes- en eenmaal. ${ }^{31}$ Maar omdat het inschakelen van de Arbeidsinspectie volgens art. 38 niet verplicht is, kunnen deze aantallen hooguit als indicatie beschouwd worden. In elk geval zou het tè gemakkelijk zijn om uit dit geringe aantal te concluderen, dat kennelijk het overleg tussen werkgever en werknemers prima verloopt, of dat er kennelijk weinig acuut gevaarlijke situaties voorkomen. ${ }^{32} \mathrm{Mij}$ is voorts slechts één procedure bekend terzake van een ontslagzaak waarbij een beroep op art. 38 is gedaan. Deze zaak wordt in het laatste hoofdstuk behandeld.

\subsection{Klagen bij de Arbeidsinspectie}

In deze paragraaf gaat het om de bevoegdheid van de individuele werknemer om te klagen bij de Arbeidsinspectie, niet om het algemene klachtrecht binnen de onderneming. Dit interne klachtrecht komt in het vervolg van het hoofdstuk afzonderlijk aan de orde. In paragraaf 5.4. van het vorige hoofdstuk is het klachtrecht bij de Arbeidsinspectie al kort besproken in verband met de geheimhoudingsplicht van de namen van de klagers in art. 34 lid 2 Arbowet, waarvan de formulering op haar beurt ontleend is aan het ILO-verdrag mr. 8 van 1947. Ook in dit geval is een dergelijke bevoegdheid dus niet met zoveel woorden geformuleerd, maar kan zij, voor wat betreft de Arbowet, worden afgeleid uit de verplichting van een ander.

Een algemeen petitierecht is wel ondubbelzinnig in art. 5 van de Grondwet geformuleerd: "Ieder heeft het recht verzoeken schriftelijk bij het bevoegd gezag in te dienen.' Een klacht zal in dit verband vaak beschouwd kunnen worden als een specifiek verzoek. Is het betreffende overheidsorgaan, in casu de Arbeidsinspectie, nu ook verplicht om tot behandeling van de klacht en/of beantwoording ervan over te gaan? Uiteraard is het antwoord op deze vraag doorslaggevend voor de praktische betekenis van deze bevoegdheid voor de

30 De term is afkomstig van A.A.G. Peters, Recht als project, Ars Aequi, 1979, p. 254. Hij gebruikt de term naar aanleiding van een vergelijkbare bevoegdheid in de Noorse en $Z$ weedse Arbeidsveiligheidswetgeving.

31 Ministerie van Sociale Zaken en Werkgelegenheid, Jaarverslag Directoraat-Generaal van de Arbeid over 1986, Voorburg 1987, p. 126.

32. Aldus ook uit de praktijk de inspecteur van de Arbeidsinspectie P.J. Huyzendveld, De Arbeidsinspectic en de toepassing van de Arbowet, lezing op het Arbo-congres 1986, gepubliceerd in Arbo '86, Congreslezingen, Amsterdam, RAl, april 1986, p. 7-8 
individuele werknemer. Hij kan immers, anders dan de or, de Arbocommissie of bij het ontbreken van deze, een meerderheid van de belanghebbende werknemers of de vakbond geen verzoek tot wetstoepassing doen ex art. 40, op grond waarvan de Arbeidsinspectie gehouden is om een onderzoek in te stellen waarbij alle betrokkenen worden gehoord waarna zo spoedig mogelijk op het verzoek wordt beslist (zie over de verschillen tussen het klachtrecht en het verzoek om wetstoepassing paragraaf 5.3. van het vorige hoofdstuk).

Hoewel het petitierecht oorspronkelijk slechts beoogde om de verzoeker te vrijwaren van strafrechtelijke vervolging is er de in de praktijk gegroeide verplichting bijgekomen dat een ingekomen petitie bekeken en behandeld wordt. Van Maarseveen: 'Weliswaar gaan de juridische verplichtingen niet zover dat ook antwoord moet worden gegeven op een binnengekomen petitie, maar het is politieke en ambtelijke praktijk om met name klachtpetities eerst te beantwoorden met een bericht van ontvangst en daarna zo mogelijk ook met een inhoudelijk antwoord. Dat gebeurt niet met alle petities, maar alle petities worden wel volgens een bepaalde procedure, die van orgaan tot orgaan kan verschillen, behandeld. ${ }^{33}$ Volgens Van Maarseveen is ongelezen terzijde leggen ongrondwettig en in strijd met de beginselen van behoordelijk bestuur. Hoewel de behandelingsplicht dus wordt aangenomen, geldt dit minder sterk ten aanzien van de beantwoordingsplicht. ${ }^{34}$ Toch lijkt ook mij dat een beantwoordingsplicht zonder meer dient te worden aangenomen: evenzeer als dat geldt ten aanzien van het onbehandeld laten is er bij het onbeantwoord laten sprake van strijdigheid met de beginselen van behoorlijk bestuur. Dit lijkt ook afgeleid te kunnen worden uit de parlementaire behandeling van de Grondwetsherziening 1983. Hoewel een wettelijke antwoordplicht is afgewezen, werd in de MvT gezegd: "... dat zich reeds in belangrijke mate de bestuurspraktijk heeft gevormd dat verzoeken van burgers worden beantwoord; deze bestuurspraktijk zou zich aldus kunnen ontwikkelen, dat ook de behandeling en beantwoording van verzoekschriften beheerst wordt door de algemene beginselen van behoorlijk bestuur. ${ }^{35}$ En tijdens de behandeling in de Tweede Kamer meende de minister van Binnenlandse Zaken dat beantwoording vanzelf spreekt. "Daarom ben ik het met de Raad van State eens dat het vanzelf spreekt dat men een verzoekschrift, dat ook maar de schijn van redelijkheid heeft, beantwoordt, maar dat het ook mogelijk moet zijn om niet of niet langer te antwoorden. ${ }^{36}$

33. H. van Maarseveen, Petitierecht, Grondrechten, commentaar op hoofdstuk I van de herziene grondwet, (Jeukens-bundel), Nijmegen 1982, p. 140.

34 Van Zwam (Veranderingen in het arbeidsomstandighedenrecht, t.a.p. p. 56) en van Lynden (De individuele werknemer in het arbeidsomstandighedenrecht, t a.p. p. 499) vermelden dat in de praktijk 'meer en meer' een recht op antwoord als keerzijde van het petitierecht wordt aangenomen. Zij beroepen zich daarbij op Burkens die echter, in navolging van een eerdero publicatie van van Maarseveen, eveneens uitdrukkelijk de behandeling van een verzoek als grondnorm stelt, om daarna nog enkele andere normen te noemen zoals "de wijze van beantwoording'. M.C.B. Burkens, Beperking van grondrechten, Deventer 1971, p. 92 , noot 2

35 TK 1975-1976, 1.3.872, nr. 3 (Mv'T), p. 28 (deel 1a).

36 Handelingen TK 1976-1977, p. 456 (deel la). 
Maar wat nu indien de klager met het antwoord ontevreden is of, ondanks de aangenomen plicht ertoe, er geen antwoord komt? Staat er dan een beroepsmogelijkheid open voor de klager? In zijn toelichting op de regeling van het verzoek om wetstoepassing aan de Arbeidsinspectie schreef de minister dat de méérwaarde van dit verzoek vergeleken met het individuele klachtrecht hierin bestond dat voorzien werd in een wettelijke beroepsregeling. De minister ging er dus vanuit dat op een klacht geen beroep mogelijk is. ${ }^{37}$ Helemaal juist is dit niet. Indien ook overigens voldaan wordt aan de eisen die daartoe gesteld zijn, dan is het in beginsel mogelijk om na een schriftelijk antwoord van de Arbeidsinspectie, of bij het niet geven van een antwoord een procedure te starten op grond van de Wet administratieve rechtspraak overheidsbeschikkingen. ${ }^{38}$ Voorts bestaat soms de mogelijkheid, bijvoorbeeld indien er geklaagd wordt over overtreding van de veiligheidswoorschriften waarop niet, of niet adequaat gereageerd wordt, om het Openbaar Ministerie te verzoeken om aan de Arbeidsinspectie een bevel tot een opsporingsonderzoek te geven.

Het belang van een beroepsmogelijkheid hangt ook samen met het volgende. Het is niet onmogelijk dat de Arbeidsinspectie in de praktijk klagers meer dan vóór de inwerkingtreding van de Arbowet zal doorverwijzen naar de or. Dit laatste orgaan is immers in de Arbowet primair aangewezen om namens de werknemers de contacten met de Arbeidsinspectie te onderhouden en ook overigens de zorg voor goede arbeidsomstandigheden in de onderneming te behartigen. Niet voor niets heeft de Arbeidsinspectie in 1983 en 1984 met bijna alle ondernemingsraden van ondernemingen met meer dan 100 werknemers zogenaamde 'rellatie-opbouw-gesprekken' gevoerd. (Zie hierover hoofdstuk III, paragraaf 5.5.). Het is bij zo'n doorverwijzing natuurlijk zeer de vraag of de werknemer dat wil - hij wendde zich immers tot de Arbeidsinspectie en niet tot de or - en vervolgens of de or zo serieus in de klacht geïnteresseerd is dat hij het risico wil lopen onenigheid met de werkgever te creëren waarna een verzoek om wetstoepassing ingediend zou kumnen worden. ${ }^{39}$ Zelfs zou zich de situatie kunnen voordoen dat de or, om hem moverende redenen, bijvoorbeeld met het oog op een goede verstandhouding met de werkgever, er de voorkeur aan geeft dat de Arbeidsinspectie stappen onderneemt op grond van een klacht van een individuele werknemer, die uiteraard ook or-lid kan zijn. Naar mijn smaak mag het in elk geval niet zo zijn dat het toekennen van een collectief recht (het verzoek om wetstoepassing), in de praktijk zou kunnen betekenen dat daardoor een individueel, grondwettelijk recht verschraalt.

Voor zover dat op te maken valt uit de jaarverslagen van de Arbeidsinspectie lijkt het er overigens nog niet op dat sinds de inwerkingtreding van art. 40 Arbowet per 1 januari 1983 het beeld ten aanzien van de indiening van klachten sterk is gewijzigd. In 1980, 1981 en 1982 werden door werknemers respectievelijk 666, 488 en 294 klachten ingediend. In 1983, 1984, 1985 en 1986 waren

$37 \mathrm{Mvr}$, t.a.p. p. 54.

$38 \mathrm{Vgl}$. H. van Maarseveen, t.a.p. p. 145 .

39 Over deze problematiek eveneens: H.J. van Zwam, Veranderingen in het arbeidsomstandig. hedenrecht, t.a.p. p. 61 en A.J.H. van Lynden, t.a.p. p. 502. 
deze aantallen $405,491,521$ en 382 . In alle zeven jaren werden door de vakvereniging circa 70 klachten per jaar ingediend. Circa $30 \%$ wan het totale aantal klachten (dus ook ingediend door de werkgevers, anderen dan werknemers of vakvereniging of anoniem) werd in elk van de zeven jaren gegrond bevonden en circa $25 \%$ ten dele gegrond. Het aantal processen-verbaal, opgemaakt terzake van wederom het totale aantal ingediende klachten was en is laag: zowel in de drie jaren voorafgaande aan de invoering van de Arbowet, als in de eerste vier jaar daarna gemiddeld $23.4 i$

\subsection{Enkele andere bepalingen}

\subsubsection{Beleid en grondbeginselen}

Naast het recht van de individuele werknemer op informatie, op werkonderbreking en op klagen bij de Arbeidsinspectie komt zijn positie in de Arbowet nog een aantal malen ter sprake. In de eerste plats dienen, wellicht voor de hand liggend, maar daarom niet minder belangrijk, genoemd te worden de in hoofdstuk III, paragraaf 2.2.1. besproken artikelen 3 en 4. Art. 4 behelst de algemene opdracht aan de werkgever om zijn ondernemingsbeleid mede te richten op een zo groot mogelijke veiligheid, een zo goed mogelijke bescherming van de gezondheid en het bevorderen van het welzijn van de werknemer. Met deze formulering is tevens de belangrijkste doelstelling van de Arbowet gegeven. Art. 3 bevat een aantal principes die aan de zorg voor veiligheid, gezondheid en welzijn ten grondslag liggen en die de werkgever bij het voeren van zijn in art. 4 bedoelde beleid als richtsnoer dient te hanteren. Vooral de verplichting in art. $3 \mathrm{om}$ 'welzijnsmaatregelen' te treffen is gericht op de individuele werknemers. Ik noem hier nog eens de vier groepen van verplichtingen waar het daarbij om gaat. In de eerste plaats de aanpassing van de arbeidssituatie en -taak aan de eigenschappen van de werknemer. Het is duidelijk dat dit ergonomische principe 'fitting the job to the worker' bij uitstek geschreven is voor de individuele werknemer. Het betekent ook dat het mogelijk moet zijn om taken tijdelijk te wijzigen. Zo zal een werkgever op grond van dit uitgangspunt in het algemeen rekening moeten houden met de verminderde weerstand van moslimwerkers tijdens de vastenperiode. ${ }^{41}$ In de tweede plaats het scheppen van ruimte voor de werknemer om het werk naar eigen inzicht te verrichten. Er dient dus een zekere keuzevrijheid voor de werknemer te be-

40. Deze klachten behoeven niet per se betrekking te hebben op de arbeidsomstandighedenwetgeving. Zil handelen volgens de Arbeidsinspecte "over de naleving van de verschillende wetten en besluiten (met uitzondering van klachten die betrekking hebben op het Buitengewoon Beshut Arbeidsverhoudingen, 1945)'. Vgl. de Jaarverslagen over 1982 warin gegevens $z i j n$ opgenomen over 1980, 1981 en 1982, over 1985 warin gegevens te winden zijn over 1983, 1984 en 1985, en over 1986, respectievelijk p. 183 (tabel 32), p. 138 (tabel 25) en p. 124 (tabel 26 ).

41 Vgl. de Nota naar aralleiding van het eindverslag, t.a.p. p. 32 . 
staan bij de uitwoering van zijn taak. Op grond hiervan dient lopende band werk zoveel mogelijk te worden vermeden. In de derde plaats het scheppen van ruimte voor de werknemer om contacten met andere werknemers te kunnen onderhouden. Hoewel de grens niet altijd even scherp is te trekken gaat het zowel om functionele als om sociale contacten. In de vierde plaats het geven van informatie over doel en resultaten van de arbeid. Deze laatste verplichting hangt samen met het hierboven beschreven informatierecht dat voortvloeit uit art. 6. Dit laatste is echter ruimer.

De werkgever is in het algemeen slechts gehouden aan deze verplichtingen te voldoen voor zover dit redelijkerwijs van hem kan worden gevergd. Met deze laatste zin is de relativering gegeven van deze verplichtingen - en daarmee tevens van de mate waarin de werknemer er een recht aan kan ontlenen. "De wijze waarop en de mate waarin deze grondbeginselen het beleid kunnen beïnvloeden en dus in concrete maatregelen ter uitvoering van dit beleid in een bepaalde onderneming kunnen worden gerealiseerd, hangt van verschillende factoren af en kan in de wet dan ook niet als een sterk geformuleerde verplichting worden opgenomen. ${ }^{42}$ Desondanks kon ik in het vorige hoofdstuk concluderen dat het zeker niet de bedoeling is dat de werkgever all te gemakkelijk met een beroep op de redelijkheid onder zijn verplichtingen op dit punt uit zou kunnen komen.

Kan nu de individuele werknemer een beroep doen op deze specifiek voor hem geschreven voorschriften? Zoals al vaker het geval is geweest in dit hoofdstuk moet het antwoord luiden: ja natuurlijk, omdat in beginsel iedereen, altijd en overal een beroep op kan doen. Maar als het gaat om directe juridische actiemogelijkheden op grond van de Arbowet dient het antwoord vooral ontkennend te zijn. Weliswaar dienen werkgever en werknemers ex art. 13 samen te werken in het behartigen van de zorg voor de veiligheid, de gezondheid en het welzijn, maar het in dit kader te voeren overleg met, en advisering aan de werkgever vindt plaats met de or of de Arbocommissie (art. 14 lid 5). Deze laatste organen hebben ook het instemmingsrecht terzake van elk door de werkgever voorgenomen besluit met betrekking tot de vaststelling, wijziging of intrekking van een regeling op het gebied van de veiligheid, de gezondheid of het welzijn in verband met de arbeid (art. 14 lid 6 Arbowet en art. 27 lid 1 onder e WOR; in art. 14 lid 6 Arbowet is art. 27 lid 3 WOR - het vervallen van het instemmingsrecht indien de betreffende materie al inhoudelijk in de CAO is geregeld - van overeenkomstige toepassing verklaard).

Een betere mogelijkheid biedt art. 4 lid 4: de werkgever moet over zijn ondernemingsbeleid voor zover dat van aanwijsbare invloed kan zijn op de veiligheid, de gezondheid en het welzijn vooraf overleg plegen met de or of de Arbocommissie of, bij het ontbreken van beide colleges, met de belanghebbende werknemers. (Op dit laatste begrip kom ik hieronder terug). Maar het blijft bij overleg waarbij de gewenste welzijnsverplichtingen slechts van toe-

42 MvT, t.a.p.p. 10. 
passing zijn voor zover dit redelijkerwijs van de werkgever kan worden gevergd.

Ook de Arbeidsinspectie zal in dit opzicht voor de individuele werknemer geen vanzelfsprekende bondgenoot zijn. Het is de officiële beleidslijn dat de Arbeidsinspectie zich bij het proces van inhoud geven aan de welzijnsbepalingen van art. 3 terughoudend zal opstellen en geen actief, controlerend inspectiebeleid zal voeren ${ }^{43} \mathrm{Het}$ accent zal in eerste instantie vooral liggen op een informerende en stimulerende rol. Dit betekent in de praktijk dat de Arbeidsinspectie ongevraagd nauwelijks gebruik zal maken van haar wettelijke instrumenten: de aanwijzingsbevoegdheid, al dan niet gevolgd door een procesverbaal. Ten aanzien van twee specifieke welzijnsbepalingen màg de Arbeidsinspectie trouwens niet eens op eigen initiatief een aanwijzing geven (art. 3 onder $g$ en $h$, jo art. 35 lid 7). Daarom formeel gevraagd zal de Arbeidsinspectie, indien althans blijkt dat men er binnen de onderneming niet uitkomt, wel in actie moeten komen. Maar, zoals bekend, een dergelijk formeel verzoek ex art. $40 \mathrm{kan}$ alleen worden gedaan door hetzij de werkgever, hetzij een de werknemers vertegenwoordigende collectiviteit. De individuele werknemer heeft geen been om op te staan indien de daartoe bevoegden niet van zins zijn een dergelijk verzoek in te dienen.

Blijft over het klachtrecht bij de Arbeidsinspectie. Gezien het beleid van terughoudendheid zal de dienst zich weinig enthousiast tonen om de klagende werknemer terwille te zijn, zolang geen officieel verzoek is ingediend volgens art. 40. Juist waar het gaat om bepalingen waarvan de wet benadrukt dat zij gestalte moeten krijgen via het daartoe geïnstitutionaliseerde overleg in de onderneming, zal de Arbeidsinspectie immers geneigd zijn om de individuele werknemer te verwijzen naar zijn or. Wellicht dat van de Arbeidsinspectie méér verwacht mag worden indien de welzijnsverplichtingen nader zijn uitgewerkt in uitvoeringsbesluiten ex art. $24 .{ }^{44}$ Voor zover zulks bij die regelingen is bepaald, kan de Arbeidsinspectie bijvoorbeeld direct een eis stellen betreffende de wijze van naleving (art. 36 lid 1). In het licht van de filosofie van terughoudendheid van de kant van de overheid ten aanzien van de wijze waarop binnen de onderneming het sociaal beleid in het algemeen gestalte krijgt en de aarzelingen ten aanzien van van buiten opgelegde welzijnsbepalingen in het bijzonder, verwacht $i k$ echter niet dat binnen afzienbare tijd concrete regels zullen worden gesteld bij of krachtens $A M v B$ terzake van het welzijn in verband met de arbeid ex art. 24 .

Ook hier dient de conclusie dus weer te luiden dat belangrijke bepalingen in de Arbowet weliswaar geschreven zijn ten behoeve van het welzijn van de individuele werknemer, maar dat hij er volgens diezelfde wet geen directe rechten

43 Directoraat-Generaal van de Arbeid, Nota De inhoud van het welzijnsbegrip in artikel 3 van de Arbowet*, Voorburg, juni 1986, p. 23.

44 De in art. 24 lid 1 bedoelde regelingen beben bijworbeeld betrekking op communicatiemogelijkheden van werknemers die geïsoleerde arbeid verrichten (art. 24 lid 2 onder y), op informatieverschaffing inzake doel en result aat van de arbeid, alsmede de ergonomische aspecten van de arbeid en de overige arbeidsomstandigheden (art. 24 lid 3 onder a en b). 
aan kan ontlenen, nóch dat hij voldoende juridische instrumenten in handen heeft om de naleving van de bepalingen te vorderen. ${ }^{45}$

\subsubsection{De deskundigen}

De deskundige diensten hebben eveneens een aantal taken die direct gericht zijn op de individuele werknemers. Voor wat betreft een aantal taken van de bedrijfsarts is dit vanzelfsprekend: aanstellingskeuringen, periodieke onderzoeken, bedrijfsspreekuren zijn naar hun aard individueel gericht. Het gaat hier echter nauwelijks om rechten die de individuele werknemer aan dit takenpakket kan ontlenen. Soms zullen deze activiteiten ten aanzien van de werknemer trouwens het karakter hebben van een verplichting. Afhankelijk van een AMvB (die er nog niet is) is het ondergaan van een geneeskundig onderzoek volgens art. 25 voor de werknemers ook een wettelijke verplichting. Dichter in de buurt van een recht voor werknemers als spiegelbeeld van een verplichting voor de deskundigen is de verplichting van de laatsten om te adviseren aan, onderscheidenlijk nauw samen te werken met en bijstand te verlenen niet alleen aan de or en de Arbocommissie, maar ook aan de werknemers.

Twee opmerkingen hierbij. In de eerste plaats staat niet in de wet dat de verplichting zich alleen uitstrekt tot de werknemers indien een or of een Arbocommissie ontbreken. In de tweede plaats wordt gesproken over de werknemers in het meervoud. Dit betekent echter niet dat het dus om collectiviteiten van werknemers zou gaan. Die kent de Arbowet in de vorm van de or, de Arbocommissie of (een meerderheid van) de belanghebbende werknemers. Deze groeperingen worden niet bedoeld. Ook de individuele werknemer kan uit deze verplichting een recht op hulp afleiden. Deze verplichting is geformuleerd zowel voor de bgd (art. 18 lid 3 ) als voor de veiligheidsdienst c.q. veiligheidskundige (art. 19 lid 3).

Voldoet de deskundige niet atan deze verplichtingen dan zal het echter buitengewoon lastig zijn om dat op basis van de Arbowet af te dwingen. Dit geldt niet alleen voor de individuele werknemer, maar ook voor de or. De Arbeidsinspectie kan namelijk terzake van het niet nakomen van deze verplichting geen aanwijzing geven. Wel kan de Arbeidsinspectie zich indirect bemoeien met het werk van de deskundigen. Dan dient een beroep gedaan te worden op de verplichting in art. 23 onder $c$ van de werkgever om zodanige maatregelen te nemen en de werkzaamheden zodanig in te richten dat de deskundige diensten (en ook de overlegorganen) hun taken op de juiste wijze kunnen vervullen. Ten aanzien van deze verplichting kan de Arbeidsinspectie wél ongevraagd en gevraagd een aanwijzing geven. Maar, wederom, het verzoek hiertoe kan niet gedaan worden door de individuele werknemer. En dan nog, wat zou de praktische betekenis van een dergelijke aanwijzing zijn? Het is wel-

$45 \mathrm{Vgl}$. echter de toepassing van art. 3 in een civielrechtelijke procedure door de President Rb Breda, 9 december 1985, KG 1985, nr. 2314 (hoofdstuk III, paragraaf 2.4.1.). 
iswaar voorstelbaar, hoewel niet echt woor de hand liggend, dat de Arbeidsinspectie aan de werkgever opdraagt om zulke maatregelen te nemen dat de deskundigen hun diensten ook slijten aan de werknemers, maar bij weigering of boycotten door de deskundigen is de Arbeidsinspectie uitgepraat. Dan is weer het woord aan de werkgever die wellicht een ontslagprocedure kan overwegen - maar dat heeft dan behalve de ontslagbescherming weinig meer van doen met de mogelijkheden van de Arbowet. Eventueel zou de erkenning van een deskundige dienst bij duidelijk disfunctioneren kunnen worden ingetrokken (art. 22 lid 4). Maar de individuele werknemer zal daar toch niet zoveel aan hebben - hooguit zou de dreiging met dergelijke maatregelen de deskundigen beter kunnen laten functioneren. Het wapen van de dreiging lijkt mij voor de individuele werknemer echter zelden effectief. Van een hard, juridisch afdwingbaar recht op hulp van de deskundigen is derhalve ook hier weer geen sprake, moet de conclusie zijn.

\subsection{Belanghebbende werknemers}

De toedeling van rechten, bevoegdheden en actiemogelijkheden aan vertegenwoordigingen van werknemers roept de vraag op hoe werknemers die niet over een dergelijke vertegenwoordiging beschikken zich in dit opzicht toch van een (enigszins) gelijke positie verzekerd weten. De vraag speelt uiteraard vooral in ondernemingen met minder dan 35 werknemers waar immers geen or verplicht is gesteld. (Het criterium van 35 werknemers is volgens de WOR overigens niet zo absoluut. Het gaat om 35 werknemers die tenminste eenderde van de normale arbeidstijd werken. Dit betekent dat het in werkelijkheid ook om ondernemingen kan gaan met meer werknemers. Kortheidshalve zal ik spreken over het 35-regime). ${ }^{46}$ Maar zij is evenzeer van belang ten aanzien van die ondernemingen waarin weliswaar een or behoort te zijn, maar er feitelijk geen is. Indien in een onderneming geen or is, kunnen bij AMvB voor categorieën van bedrijven en inrichtingen, behorend tot zo'n onderneming, een of meer Arbocommissies worden ingesteld op grond van art. 14 leden 1 en 2. Eenzelfde bevoegdheid heeft het districtshoofd ten aanzien van een afzonderlijk bedrijf of inrichting (art. 14 lid 3). In beginsel komen alle bevoegdheden, rechten en handhavingsmogelijkheden die de or heeft op het gebied van de arbeidsomstandigheden ook toe aan de Arbocommissie (zie hoofdstuk III, paragraaf 3.3.1.).

De vraag of nader kon worden aangegeven vanaf welk minimum aantal werknemers de verplichting om een Arbocommissie te hebben zou gaan gelden, kon de minister tijdens de parlementaire behandeling van de Arbowet nog niet

46 In ondernemingen watar in de regel tussen de 10 en 35 personen meer dan een derde van de normale arbeidstijd werkzaam zijin, moeten deze volgens art. 35 b lid 5 wan de WOR wel door de ondernemer in de gelegenheid worden gesteld om advies uit te brengen onder meer over elk voorgenomen besluit dat kan leiden tot een belangrijke verandering van de arbeidsomstandig. heden van tenminste een vierde van de in de onderneming werkzame personen - behoudens een inhoudelijke regeling terzake in de $\mathrm{CAO}$. (Zie ook paragraaf 5 ). 
exact beantwoorden. In elk geval zou dat aantal per bedrijfstak kunnen verschillen. Maar eigenlijk vond de minister dat het in dit soort (kleinere) ondernemingen eerder gezocht moest worden 'in het betrekken van alle werknemers bij de vraagstukken van veiligheid, gezondheid en welzijn, dan in het aanstellen van vertegenwoordigers'45. Deze laatste opmerking is al een indicatie, naast het argument van werkgeverszijde dat op de kleinere ondernemingen weer een zware verplichting zal komen te liggen, dat zelfs nadat art. 14 in werking is getreden (pas in de laatste fase), in weinig ondernemingen Arbocommissies verplicht zullen worden gesteld. ${ }^{48}$

Voor die ondernemingen waar nu zowel een or als een Arbocommissie ontbreken - dat laatste is dus nog overal het geval en dat zal in de toekomst waarschijnlijk niet of nauwelijks veranderen - heeft de Arbowet in een aantall gevallen als substituut de begrippen de belanghebbende werknemers of in een kleiner aantal gevallen de meerderheid van de belanghebbende werknemers geintroduceerd. ${ }^{49}$ De rechten van de belanghebbende werknemers zijn in twee categorieën in te delen: het recht op informatie en het recht om geconsulteerd te worden.

Het informatierecht wordt vooral geconcretiseerd in een informatieplicht van de werkgever. Hij dient zonder dat daartoe is verzocht onder meer informatie te verstrekken over de inhoud van een aantal beschikkingen van de DirecteurGeneraal van de Arbeid, van het districtshoofd (aanwijzingen, eisen, stillegging van het werk), van de minister en van de President van de Rechtbank die betrekking hebben op het afzonderlijke bedrijf of de inrichting. Daarnaast dient de werkgever de adviezen van de deskundige diensten aan de belanghebbende werknemers mede te delen.

De Arbeidsinspectie zelf meent volgens een ambtelijke nota, dat, uitgaande van het beginsel van gelijke informatie van de partners, de werknemers (bedoeld zal zijn in elk geval de belanghebbende werknemers), ook in kennis worden gesteld van de inhoud van de niet-officiële beslissingen van de Arbeidsinspectie. ${ }^{50}$ De voor de informatie verantwoordelijke werkgever zou

47 Nota naar aanleiding van het eindverslag, t.a.p. p. 12.

48 Het argument van een te zware verplichting woor kleineme ondernemingen werd door de workgevers al eerder aangevoend toen het ging om de verplichtstelling van een or voor ondernemingen met minder dan 100 werknemers en meer dan 35 (Wet van 22 mei 1981, S. 416). Deze verplichting werd verwolgens in de Voorlopige Arbeidsraad aangevoerd als argument om gedurende de eerste twee jaren na inwerking treding van art. 40 de daaringeregelde bevoegdheid van de vakorganisaties om ook ex verzoek tot wetstoepassing te kunnen doen, op te schorten. Voorlopige Arbeidsraad (VAR), Advies inzake de cerste fase wan invoering van de Arbeidsonstandighedenwet. Zoetermeer 1982 , nr. 2, p. 28 .

49 Terecht wijst de VAR op het verschil tussen de gehanteerde begrippen 'bedrijf of inrichting" (de Arbowet) en 'onderneming' (WOR). Een onderneming kan verscheidene bedrijven of inrichtingen omvatten. Een or vertegenwoordigt alle werknemers van de betrokken onderneming; cen Arbocommissie de werknemers van het betrokken bedrijf of de betrokken inrichling. Voor zover in dit latste geval niet alle werknemers van de ondernening vertegenwoprdigd worden, is er voor de niet door de Arbocommissic vertegenwoordigde werknemers ruimte voor de belanghebbende werknemers. VAR-advies, 1982, nr. 2, t.a.p. p. 24.

50 Zie de ambtelijke nota "De relatie met werknemers van kleine arbeidsorganisaties" bij brief van 24 september 1982 angeboden aan de VAR. D. 5. De nota is opgenomen in: Arboraad, reactie op de ambtelijke nota, Zoetermeer 1984; nr. 1. 
hierop moeten worden gewezen. De Arboraad meent dat, hoewel dit 'als regel' inderdaad zou moeten gebeuren, de desbetreffende nota op dit punt te stringent is geredigeerd. Hij vindt bovendien dat het uitgangspunt niet voortvloeit uit de Arbowet. ${ }^{51}$

De Arboraad moge gelijk hebben in de opvatting dat een wettelijk geformuleerde informatieplicht voor de werkgever op dit punt niet bestaat, onmiskenbaar vloeit uit de strekking van de Arbowet wel degelijk een beginsel van gelijke informatie voort, al kan dit recht dan juridisch moeilijk hard gemaakt worden (zie paragraaf 2.2. van dit hoofdstuk). Wel is het informatierecht van de werknemer ten opzichte van dat van de or in deze zin minder dat de orleden terzake van zaken-en bedrijfsgeheimen een geheimhoudingsplicht hebben. De Arbeidsinspectie heeft eveneens een geheimhoudingsplicht waardoor zij informatie die als zaken- of bedrijfsgeheim kan worden beschouwd, moet onthouden aan werknemers die niet tevens lid zijn van de or.

Niet via de werkgever, maar rechtstreeks, dienen de belanghebbende werknemers geïnformeerd te worden inzake een eis door de medisch adviseur van de Arbeidsinspectie of het districtshoofd in het kader van een verplicht geneeskundig onderzoek (art. 25 leden 4, 5 en 9) en door de minister via een afschrift van een beschikking inzake een bezwaarschrift (art. 42 lid 10).

De belanghebbende werknemers kunnen hun recht om geconsulteerd te worden uitoefenen terzake van voorgenomen individuele aanwijzingen door de Directeur-Generaal van de Arbeid, aanwijzingen en beschikkingen door het districtshoofd, beslissingen door de President van de Rechtbank en adviezen van de Arboraad aan de minister met betrekking tot ingediende bezwaarschriften. Volgens art. 4 lid 4 dient de werkgever omtrent het ondernemingsbeleid, voor zover dat van aanwijsbare invloed kan zijn op de veiligheid, de gezondheid en het welzijn van de werknemers, vooraf overleg te plegen met de belanghebbende werknemers.

Wie moeten nu beschouwd worden als belanghebbende werknemers? De wetsgeschiedenis verschaft hierover geen opheldering. Het is echter duidelijk dat het altijd gaat om die werknemers die direct invloed ondervinden van de (voorgenomen) maatregel, of er direct mee te maken hebben. Wie dat dan zijn zal van geval tot geval verschillen. Gaat het bijwoorbeeld om een eis tot naleving, dan zijn alleen die werknemers belanghebbend, die werkzaam zijn in de situatie waarop de eis betrekking heeft. Gaat het om overleg vooraf over het ondernemingsbeleid terzake van de arbeidsomstandigheden, dan zijn alle werknemers belanghebbend op wie dat beleid invloed kan uitoefenen. De Arbeidsinspectie heeft terecht in twee ambtelijke nota's het gevaar gesignaleerd, dat het begrip belanghebbende wellicht te eng zal worden opgevat. Derhalve meent zij dat in de gevallen waarin een verschil van interpretatie kan worden verwacht, nauwkeuriger moet worden aangegeven om welke (categorieën van) werknemers het gaat. ${ }^{52}$

51 Reactic op de ambtelijke nota, nr. 1, t.a.p. p. 7.

52. Ambtelijke nota De relatie met werknemers van kleine arbeidsorganisaties, ta.p. p. 4 en de nota Werkwijze Arbeidsinspectie naar bedrijven zonder or, bij brief van 27 september 1983 
In een aantal gevallen zijn, bij het ontbreken van een or of een Arbocommissie, niet de belanghebbende werknemers remplaçant, maar een meerderheid van hen. In alle gevallen gaat het om de bevoegdheid om zelf een initiatief te nemen: het verzoek aan de Arbeidsinspectie om een onderzoek in te stellen (art. 32 lid 6), het verzoek aan de Arbeidsinspectie om wetstoepassing (art. 40 lid 1) en de bevoegdheid om een bezwaarschrift in te dienen bij de minister (art. 42 lid 7). In al deze gevallen komt die bevoegdheid eveneens in beginsel toe aan de in de onderneming als zodanig werkzame vakorganisatie (zie hoofdstuk III, paragraaf 6.3.)..$^{53}$

Desgevraagd antwoordde de minister de problemen bij het bepalen van de meerderheid van de belanghebbende werknemers (in het desbetreffende antwoord is het woord 'belanghebbende' ten onrechte weggelaten) niet zo groot te achten: het gaat immers om kleine ondernemingen zonder or of Arbocommissie.${ }^{54}$ Dat is weliswaar juist, maar ook in de grotere ondernemingen waar feitelijk geen or is, kan het probleem aan de orde zijn. Het uitgangspunt dat de Arbeidsinspectie - terecht - hanteert, is dat het verzoek in beginsel is ingediend door een meerderheid van de belanghebbende werknemers. Tijdens het (verplicht) horen van de werknemers wordt dan wel duidelijk of het inderdaad een meerderheid betreft. Daarbij wordt er van uitgegaan dat de groep werknemers die voorstander is van het verzoekschrift/bezwaarschrift groter dient te zijn dan de som van de tegenstemmers en onthouders. Bij twijfel kan aan de ondertekenaar van het verzoekschrift/bezwaarschrift eventueel nog gevraagd worden om een door de voorstanders ondertekende machtiging over te leggen ${ }^{55}$ Hierbij moet overigens wel bedacht worden dat het begrip werknemers in de zin van de Arbowet (art . 1) méér omvat dan personen die op arbeidsovereenkomst werkzaam zijn. Het betreft bijvoorbeeld ook ingeleende krachten, stagiaires en uitzendkrachten.

De constructie dat bij het ontbreken van institutionele vormen van medezeggenschap (een meerderheid van) de belanghebbende werknemers bepaalde bevoegdheden kunnen uitoefenen, is ongetwijfeld een belangwekkende. Dit geldt vooral voor het kunnen inschakelen van de Arbeidsinspectie via het verzoek om wetstoepassing en de mogelijkheid om vervolgens van de uitspraak in beroep te kunnen gaan. Het betekent immers dat een meerderheid van de belanghebbende werknemers wier veiligheid, gezondheid of welzijn worden bedreigd, zich rechtstreeks tot de Arbeidsinspectie kunnen wenden die vervolgens verplicht is om een uitspraak te doen. Het valt zelfs te verdedigen dat in ondernemingen waar geen or (of Arbocommissie) werkzaam is, de werknemers onder omstandigheden soms nog beter af kunnen zijn, namelijk indien de or, ten aanzien van problemen die bepaalde werknemers hebben op

aangeboden aan de Arboraad, p. 5. Ook deze nota is opgenomen in de in noot 50 genoemde publicatic van de Arboraad.

53 Op deze regel is én uitzondering: belanghebbende werknemers, nóch de vakorganisatie kunnen een bezwaarschrift indienen tegen een eis van het districtshoofd inzake een arbeidsweiligheidsrapport (art. 42 lid 7 , jo art. 5 leden 10 en 11).

54 Nota naar aanleiding van het eindverslag, t.a.p. p. 45 .

55 Bijlage II bij de nota Werkwijze Arbeidsinspectie naar bedrijven zonder or (zie ook noot 50 ). 
het gebied van de arbeidsomstandigheden, zich niet belanghebbend opstelt en zich dus ook niet tot de Arbeidsinspectie zal wenden.

In de praktijk zal dat overigens niet altijd meevallen: er moet immers wèl een meerderheid gevonden worden en dat zou nog wel eens knap lastig kunnen zijn. Daarnaast is de positie van de belanghebbende werknemers in een aantal opzichten feitelijk en juridisch zwakker dan die van de or of de Arbocommissie. Het zal veelal gaan om de kleinere ondernemingen waarin de relatie werkgever-werknemer een nauwere is dan in de grotere ondernemingen waarin de or als een soort buffer dienst kan doen. Angst voor verstoorde relaties zal dan ook sneller een rol spelen. Belanghebbende werknemers missen bovendien niet alleen een aantal bevoegdheden en faciliteiten die de or wèl heeft, zoals bijvoorbeeld het instemmingsrecht, het recht op beraad en raadpleging en het mogen vergezellen van de Arbeidsinspectie, maar ook hebben zij niet de ontslagbescherming van de or-leden.

Dit alles kan er in de praktijk toe leiden, dat het instituut van de belanghebbende werknemers niet die betekenis krijgt die het in theorie zou kunnen hebben. Dat zou - alhoewel begrijpelijk - ook daarom te betreuren zijn, omdat het juist in de kleinere ondernemingen vaak minder goed gesteld is met de arbeidsomstandigheden. Het zijn overigens ook die ondernemingen die in het algemeen de minste contacten hebben met de Arbeidsinspectie en waarin de minste bekendheid is met de Arbowet. ${ }^{56}$ Deze laatste factoren spelen uiteraard weer een rol bij het te verwachten geringe gebruik van de mogelijkheden die een meerderheid van de belanghebbende werknemers heeft. Mede afhankelijk van de organisatiegraad zou dan de vakorganisatie een rol kunnen spelen. ${ }^{57}$ Maar ook zij kan pas een verzoek tot wetstoepassing doen na een geconstateerd meningsverschil tussen werkgever en werknemers. Bovendien moeten ook in dat geval de belanghebbende werknemers door de Arbeidsinspectie worden gehoord, waardoor het in een kleine onderneming niet gemakkelijk zal zijn de anonimiteit te handhaven: wellicht eveneens een feitelijke belemmering om de vakorganisatie in te schakelen.

$56 \mathrm{Vgl}$ J.H.T.H. Andriessen e.a., K.leine Bedrijven en Arbeidsomstandighedenbeleid, cen verkennend onderzoek in enkele bedrijfstakken, Instituut voor sociast-wetenschappelijk onderzoek, Tilburg, december 1985. De Arboraad benadrukte in zijn reactie op de ambtelijke nota inzake de relatie van de Arbeidsinspectie met werknemers van kleine arbeidsorganisaties, dat de achterblijvende zorg van de Arbeidsinspectie voor de arbeidsomstandigheden in de kleine arbeidsorganisaties voor de dienst in haar beleid een punt van aanhoudende en bijzondere aandacht dient te blijven, t.a.p. p. 13. Het ITS-onderzoek 1988 bevestigt het beeld dat de activiteiten wan de Arbeidsinspectie vooral gericht zijn op de grotere ondernemingen; t.a.p. p. 128.

57 Het toekennen van de bevoegdheid an de vakorganisatie om een verzoek tot wetstoepassing te doen is immers in de Arbowet toegevoegd vanuit de overweging dat individuele werknemers onder een zodanige druk kunnen staan dat een meerderheidsbesluit voor de uitoefening van de toegekende bevoegdheden niet tot stand komt, hoewel claar aanleiding toe zou zijn. Nota naar aanleiding van het eindverslag, t.a.p. p. 45 


\subsection{Verplichtingen}

In de Veiligheidswet 1934 was, onder meer in art. 7 lid 6, vastgelegd dat de werknemers bepaalde bij AMvB gestelde voorschriften of een ter uitvoering van die voorschriften gestelde eis van het districtshoofd moesten naleven, voor zover zij redelijkerwijs geacht konden worden met dat voorschrift of die eis bekend te zijn. ${ }^{58}$ Die bekendheid was doorgaans slechts aanwezig indien en voor zover de werkgever daarop gerichte inlichtingen had verstrekt. In de opzet van de Veiligheidswet was deze aansprakelijkheidsstelling van de werknemer begrijpelijk: over voorlichting en onderricht liet deze wet zich niet uit en evenmin was er sprake van enige betrokkenheid van de werknemer bij de kwaliteit van zijn arbeidsomstandigheden. De aspiraties van de Arbowet zijn andere: deze wet voorziet in verplichte voorlichting en onderricht aan de werknemers en tracht hun mede een stem te geven bij het bepalen van het beleid op het arbeidsomstandighedenterrein en geeft aan hun vertegenwoordigers bepaalde bevoegdheden en rechten. 'Onder deze omstandigheden mag van hen worden verwacht dat zij zich ook van hun verantwoordelijkheid bewust zijn en dat zij in dit verband bereid zijn ook een aantal verplichtingen en de daaruit voortvloeiende aansprakelijkheid te aanvaarden, al is deze uiteraard van veel beperkter omvang dan die van de werkgever. ${ }^{5 y}$

Dit uitgangspunt heeft met name gestalte gekregen in art. 12. De inhoud van de (hoofd) bepaling komt hierop neer dat elke werknemer, onverminderd hetgeen elders bij of krachtens de Arbowet is bepaald, verplicht is in verband met de arbeid de nodige voorzichtigheid en zorgvuldigheid in acht te nemen ter vermijding van gevaren voor de veiligheid of de gezondheid van hemzelf of van anderen, dan wel met het oog op het welzijn. Vervolgens wordt onder a tot en met een aantal, op de algemene zorgvuldigheidsplicht gebaseerde, nadere verplichtingen omschreven.

In zijn advies over de inwerkingtreding van art. 6 is door de Arboraad nadrukkelijk gewezen op de onderlinge samenhang tussen de in art. 6 opgenomen werkgeversverplichting om voorlichting en onderricht te verzorgen en de verplichtingen met de daaraan gekoppelde aansprakelijkheidsstelling van de werknemer in art. 12. ${ }^{\infty}$ Volgens de Arboraad zou art. 12 dan ook tegelijk met art. 6 in werking moeten treden. Dit is per 1 juni 1985 inderdaad gebeurd.

De woorden 'of anderen' in de hoofdverplichting slaan niet alleen op de bescherming van de collega-werknemers, maar ook op niet-werknemers (bezoekers) of werknemers van andere bedrijven die met hen te maken krijgen. ${ }^{61} \mathrm{Het}$

58 Art. 7 Veiligheidswet bevat de juridische grondslag voor de bij AMvB te geven woorschriften voor het veilig en gezond werken in fabrieken en werkplaatsen. Het is te vergelijken met bet overigens veel ruimere - art. 24 Arbowet. Het Veiligheidsbeslluit Fabrieken of Werkplaatsen was op art. 7 Veiligheidswet en is thans op art. 24 Arbowet gebaseerd. Zie werder voor de strafbaarstelling van werknemers onder de Veiligheidswet 1934, hoofdstuk II, paragraaf 6.1.

59 MvT, t.a.p. p. 12 .

60 Arboraad, Advies inzake de wijze van inwerkingtreding van art. 6 van de Arbowet, Zoetermeer, 21 april 1983 .

61 MvT, t.a.p. p. 28 
is in wezen dezelfde beschermingsverplichting ten aanzien van derden die ook de werkgever opgedragen krijgt in art. 11 (zie hierover paragraaf 2.2.7. van hoofdstuk III).

Onder a wordt bepaald dat de werknemers verplicht zijn om machines, toestellen, werktuigen, gevaarlijke stoffen, transportmiddelen en andere hulpmiddelen op de juiste wijze te gebruiken. Deze verplichting is niet geheel nieuw. Soortgelijke verplichtingen bestonden al in de oorspronkelijk op de Veiligheidswet gebaseerde Veilligheidsbesluiten. Zij staan daar nog steeds in en de naleving ervan is onder de Arbowet verplicht gesteld krachtens art. 26 lid 1. Overtreding van onderdeel a is ex art. 57 direct strafbaar gesteld.

Onderdeel b verplicht de werknemers om de hen ingevolge de Arbowet ter beschikking gestelde persoonlijke beschermingsmiddelen op de juiste wijze te gebruiken en deze na gebruik op de daartoe bestemde plaatsen op te bergen. ${ }^{62}$ Echter: "een en ander voor zover niet krachtens deze wet is bepaald dat werknemers niet verplicht zijn beschermingsmiddelen als vorenbedoeld te gebruiken'. Deze laatste zinsnede is bij (eerste) Nota van wijzigingen toegevoegd. Volgens de toelichting is het immers denkbaar dat wel de werkgever kan worden verplicht tot ter beschikkingstelling, zonder dat het tevens voor de hand ligt de werknemers te verplichten deze middelen ook te gebruiken, bijvoorbeeld indien de kans op schade zo gering is dat een verplichting voor de werknemer niet gerechtvaardigd is, maar toch het risico van dien aard is dat de werknemers de gelegenheid moet worden geboden zich ook tegen dit geringe risico te beschermen. ${ }^{63} \mathrm{De}$ in deze bepaling bedoelde (straf)wettelijke verplichting strekt zich alleen uit ten aanzien van de ingevolge de Arbowet ter beschikking gestelde persoonlijke beschermingsmiddelen. Een verdergaande juridische verplichting ten aanzien van het gebruik van persoonlijke beschermingsmiddelen kan derhalve slechts gebaseerd zijn op een civielrechtelijke regeling bijvoorbeeld in een $\mathrm{CAO}$, een arbeidsovereenkomst of een reglement. (Bij overtreding waarvan overigens óók een sanctie kan volgen in de vorm van een boete).

Onder $\mathrm{c}$ worden de werknemers verplicht om aangebrachte beveiligingen niet te veranderen of buiten noodzaak weg te halen en deze op de juiste wijze te gebruiken. In deze bepaling wordt niet, zoals ten anzien van beschermingsmiddelen, vermeld: 'ingevolge deze wet'. Dat betekent dat de werknemer, strafrechtelijk gesanctioneerd, verplicht is de beveiligingen niet te veranderen e.d, óók als deze niet wettelijk zouden zijn voorgeschreven. 'Buiten noodzaak' ziet vooral op de situatie dat bijvoorbeeld tijdens schoonmaakwerkzaamheden een beveiliging tijdelijk moet worden weggehaald of veranderd. De onderdelen b en $c$ zijn vooral daarom van belang, omdat in de praktijk blijkt, althans volgens de MvT, dat het gebruik van persoonlijke bescher-

62. Impliciet kunnen werknemers ook verplicht worden tot het nìet dragen van bepaalde kledingstukken indien deze bijvoorbeeld niet in overeenstemming zijn met het bepaalde in art. $173 \mathrm{a}$ onder $d$ van het Veiligheidsbesluit voor Fabrieken of Werkplaatsen ower "doelmatige nauwsluitende kleding of hoofdbedekking".

63 TK 1978-1979, 14.497, $\mathrm{m}_{\mathrm{n}} 6$ (eerste Nota van wijzigingen), p. 20. 
mingsmiddelen en van op werktuigen aangebrachte beveiligingen nogal eens op weerstand stuit bij de werknemers, hetzij door onverschilligheid, hetzij door gemakzucht omdat het gebruik van deze middelen tijd en moeite kan kosten $^{64}$

Wat de woorden 'op de juiste wijze', die voorkomen onder $a$, b en $c$, in de praktijk betekenen, kan op verschillende manieren bepaald worden. In ellk geval lijken van belang te zijn de beschermingsdoelstelling van de Arbowet, zoals die onder meer ook naar voren komt in de algemene norm waarmee art. 12 begint, maar uiteraard ook de meer concrete bepalingen in de Veiligheidsbesluiten, de voorschriften en instructies van de werkgever, de fabrikanten en de publicatiebladen van de Arbeidsinspectie. (Over de P-bladen: hoofdstuk III, paragraaf 5.3.).

De bepaling onder $\mathrm{d}$ verplicht de werknemers om mee te werken aan het voor hen georganiseerde onderricht, zoals dat bedoeld is in de artt. 6,7 en 8, waarin de verplichting voor de werkgever geregeld is om voorlichting, onderricht en begeleiding (voor jeugdige werknemers door de mentor) te geven. (Zie hierover hoofdstuk III, paragraat 2.2.5.). De verplichting van de werknemers en de daarmee samenhangende strafrechtelijke aansprakelijkheid zal dus pas effect kunnen hebben afhankelijk van de mate waarin door de werkgever praktische uitvoering is gegeven aan de artt. 6 e.v.

Tenslotte wordt onder e aan de werknemer de verplichting opgelegd om de door hem opgemerkte gevaren voor de veiligheid of de gezondheid terstond ter kennis te brengen aan de werkgever of degene, die namens de werkgever ter plaatse met de leiding is belast. Ingevolge art. 10 onder $f$ moet de werkgever een overzicht van de ingevolge art. 12 onder e gemelde gevaren opnemen in het jaarverslag. ${ }^{65}$

Tijdens de behandeling van het wetsontwerp is erop gewezen dat naleving van de verplichting ex art. 12 e bezwaarlijk zou kunnen zijn vanwege de sociale controle tussen de werknemers onderling. Daarom werd gevraagd of de melding niet ook zou kunnen worden gedaan aan de veiligheidsdienst of de bedrijfsgezondheidsdienst. De minister vond echter dat de melding bij die personen zou moeten geschieden die bevoegd en/of verplicht zijn om in voorkomende gevallen terstond die matregelen te treffen die de gesignaleerde gevaren kunnen afwenden ${ }^{66}$ Later voegde hij daaraan toe, dat de wet aan genoemde wens bovendien in voldoende mate voorziet door de in art. 23 onder b genoemde verplichting voor de werkgever om er voor te zorgen dat de deskundige diensten op de juiste wijze hun taak kunnen vervullen. ${ }^{67}$ Dat moge allemaal waar zijn, maar deze overwegingen vormen toch geen argument tegen het wettelijk toestaan van de melding mede aan de deskundigen? Het signaleren en oplossen van problemen behoort immers tot hun taken, terwijl ze boven-

64 MvT" t.a.p. p. 28.

65 Onderdeel $f$ van art. 10 is, na bespreking in de openbare commissievergadering pas ingevoegd bij de vierde Nota van wijzigingen, TK 1979-1980, 14.497, nr. 138, p. 2.

66 MvA, t.a.p. p. 65.

67 Nota naar aanleiding van het eindverslag, t.a.p. p. 35. 
dien verplicht zijn om te adviseren en aanbevelingen te verstrekken aan de werkgever, zodat deze laatste ook op die manier op de hoogte kan worden gebracht.

Overtreding van de bepaling onder $\mathrm{e}$ is, evenals de hoofdnorm van art. 12 , maar in tegenstelling tot de bepalingen onder a tot en met $d$, niet direct strafbaar gesteld. Dit is conform de wens van de SER op dit gebied die dit overigens niet motiveerde ${ }^{68}$ Dit gebeurde evenmin in de MvT waarin de wens van de SER werd overgenomen. ${ }^{6}$ In de MvA werd slechts droogjes opgemerkt dat het ontbreken van een strafrechtelijke sanctionering ten aanzien van meer voorschriften het geval is..$^{70}$

Wellicht dat hierbij toch een rol heeft gespeeld de overweging dat het onder omstandigheden voor de werknemer, met name veroorzaakt door de genoemde sociale controle, niet gemakkelijk zal zijn om naar zijn werkgever te stappen. Bovendien zou geredeneerd kunnen worden dat, anders dan de bepalingen onder a tot en met $d$, niet-naleving van de verplichting onder e wellicht minder ernstige repercussies zou kunnen hebben voor de veiligheid en gezondheid van de werknemer zelf en anderen. In dat licht bezien is het ontbreken van een directe strafbaarstelling begrijpelijk. Indirect kan de strafbaarstelling overigens wèl een rol spelen, namelijk indien de Arbeidsinspectie een aanwijzing tot naleving met betrekking tot deze bepaling aan de werknemer heeft gegeven. Niet naleving van de verplichting die hieruit voortvloeit, kan wel leiden tot vervolging en bestraffing. Desgevraagd zei de minister dat een aanwijzing gegeven zou kunnen worden bijvoorbeeld bij een gevaarsituatie die zich kan herhalen en dus in een aanwijzing kan worden omschreven. De aanwijzing zou dan aan de werknemer kunnen worden gegeven die in voorafgaande gevaarsituaties niet overeenkomstig art. 12 onder e heeft gereageerd. ${ }^{71}$ Het lijkt mij een wat theoretische mogelijkheid. Indien de gevaarsituatie echt regelmatig voorkomt, dan zal die toch ook wel anderszins bij de leiding bekend raken? Mocht dat niet zo zijn of wordt er niets aan gedaan en de Arbeidsinspectie ontdekt dit, dan lijkt het toch meér voor de hand te liggen daar wat aan te doen door de werkgever op te dragen maatregelen te treffen dan door aan de werknemer opdracht te geven een en ander te melden?

Tijdens de behandeling van het wetsontwerp is door kamerleden gesuggereerd om art. 12 zó te redigeren dat alleen opzet of grove onachtzaamheid van de werknemer een strafbaar feit zou opleveren. De kamerleden beriepen zich hierbij op de woorden van de toenmalige minister in de Eerste Kamer bij de behandeling van art. $1638 \times \mathrm{BW}$, namelijk dat 'van niemand, allerminst van de arbeider, bij de dagelijkse verrichtingen van zijn arbeid, een voortdurende, nimmer talende waakzaamheid redelijkerwijze kan worden gevergd en dagelijkse omgang zelfs met gevaarlijke werktuigen onvermijdelijk en van natu-

68 SER-advies, t.a.p. p. 21

69 MvT, t.a.p. p. 28.

70 MvA, t.a.p. p. 28.

71 MwA t.a.p. p. 28. 
re een zekere mate van zorgeloosheid, van schuld doet ontstaan ${ }^{72}$ De minister wees de suggestie af. ${ }^{73}$ Naar zijn oordeel heeft art. 12 leden a tot en met d het oog op situaties waarbij niet naleving van de voorschriften ernstige gevolgen kan hebben voor de veiligheid en de gezondheid van de werknemers en van anderen. Hierbij past niet een norm die beperkt is tot opzet of grove onachtzaamheid: ook een geringe mate van onachtzaamheid kan al ernstige consequenties hebben.

Niet naleving vormt een overtreding. Anders dan bij misdrijven maken psychische elementen als opzet en schuld bij overtredingen als regel geen deel uit. van de delictsomschrijving. Dat behoeft dus ook niet te worden bewezen. De werknemer die handelt in strijd met art. 12 a tot en met $d$ zal dus alleen al op grond van dat handelen kunnen worden veroordeeld, echter wel met dien verstande dat de rechter hem bij gebleken afwezigheid van (alle) schuld (AVAS) van rechtsvervolging zal ontslaan.

Tenslotte zullen in gevaarlijke situaties opzettelijk of door grove onachtzaamheid begane gedragingen, als zij leiden tot de dood of zwaar lichamelijk letsel van een collega wan de werknemer, veelal vallen onder bijvoorbeeld de misdrijven dood door schuld of zwaar lichamelijk letsel door schuld. Volgens de minister bestaat ook daarom geen behoefte aan de invoering van het opzet of grove schuld vereiste.

Ten aanzien van het argument dat ontleend werd aan de behandeling van art. 1638x BW in de Eerste Kamer, wees de minister er naar mijn mening terecht op dat het destijds ging om medeschuld in civielrechtelijke zin van de werknemers. De opmerking wilde verklaren waarom in het tweede lid van art. $1638 \mathrm{x}$ $B W$ de regering niet zover heeft willen gaan om de werkgever de mogelijkheid te bieden zich reeds van zijn verplichting de werknemer schadeloos te stellen te bevrijden door te bewijzen dat de werknemer lichte schuld had. Bij art. 12 gaat het echter om strafrechtelijk gesanctioneerde normen die aan de werknemer direct een bepaald gedrag voorschrijven met het oog op zijn veiligheid en gezondheid en die van anderen.

Hierboven heb ik er al op gewezen dat onder de Veiligheidswet de werknemer zich kon vrijpleiten van strafrechtelijke repercussies door een beroep te doen op de wettelijke clausule dat hij redelijkerwijze geacht kon worden niet bekend te zijn met het voorschrift dat overtreden zou zijn. De Arbowet kent deze disculpatiegrond niet. Met name Bloemarts en de FNV hebben ernstig bezwaar gemaakt tegen het niet meer opnemen hiervan. ${ }^{74}$ De verplichting voor de werkgever om te zorgen voor voorlichting en onderricht kan volgens hen niet voldoende grond opleveren voor het schrappen van de bekendheidsclausule. Het adagium immers 'ieder wordt geacht de wet te kennen', zo luidt hun redenering, moet voor de werknemer uitzondering lijden op het terrein van de door talloze, noodzakelijkerwijze veelal gedetailleerde, voorschriften

72 Voorlopig verslag, t.a.p. p. 18. Zie voor de parlementaire behandeling van art. $1638 \times$ hoofdstuk II, paragraaf 4.3 .

73 MvA, t.a.p. p. 27.

74 Bloemarts, SMA, ta.p. p. 595. 
gekenmerkte veiligheidswetgeving. De verplichting voor de werkgever tot het geven van voorlichting en onderricht garandeert bovendien niet dat het in de praktijk ook altijd in voldoende mate zal gebeuren. Hoewel de minister dit ook wel inziet, meent hij - evenals ten aanzien van het niet meer opnemen van de disculpatiegronden van art. 29 lid 2 Veiligheidswet voor de bestuurders en leidinggevenden - dat ook hier het beginsel van gebleken afwezigheid van (alle) schuld soelaas kan bieden. ${ }^{75} \mathrm{Ik}$ meen dat de minister in dit opzicht gelijk heeft en dat de bekendheidsclausule als het ware besloten ligt in de AVAS formulering.

In elk geval lijkt het niet onwaarschijnlijk dat door de ruime formulering van de verplichtingen voor de werknemer in art. 12 de kans zal toenemen dat hij strafrechtelijk aansprakelijk wordt gesteld - eventueel samen met de werkgever terzake van eenzelfde feit. Tijdens de parlementaire behandeling spraken kamerleden de vrees uit dat, indien lichte fouten al tot een strafrechtelijke veroordeling zouden kunnen leiden, de gelaedeerde werknemer vanwege die veroordeling in een burgerlijk geding ex art. 1638x BW mogelijk grove schuld zou kunnen worden verweten, waardoor de werkgever zich zou kunnen disculperen en geen of mindere schadevergoeding zou behoeven te betalen aan die werknemer. ${ }^{76}$ De minister deelde die vrees niet. ${ }^{77}$ Hij verwees naar art. 1955 BW dat niet verder gaat dan te bepalen dat een vonnis, waarbij iemand wegens enig feit tot straf is veroordeeld, in een burgerlijk geschil behoudens tegenbewijs, als bewijs van dat feit wordt aangenomen. Met andere woorden: een strafrechtelijke veroordeling zegt nog niets over de civielrechtelijke schuld. Weliswaar geeft de tekst van art. $1955 \mathrm{BW}$ de minister gelijk, maar dat neemt niet weg dat door de - ook door de rechtspraak aangenomen - nauwe verwevenheid van de publiekrechtelijke en civielrechtelijke normen op dit gebied een strafrechtelijke veroordeling van de werknemer de positie van de werkgever in een civiel geding zal versterken - en die van de werknemer evenredig zal verzwakken.

Ten aanzien van de verplichting van art. 12 onder e (de verplichte melding van gevaren aan de werkgever) die niet direct strafrechtelijk gesanctioneerd is, doet zich een soortgelijke vraag voor. Hoe is de positie van een werknemer, die deze verplichting niet heeft nageleefd, in een jegens de werkgever aangespannen procedure tot schadevergoeding wegens een bedrijfsongeval veroorzaakt door een gevaar, dat hij ten onrechte niet gemeld heeft bij de werkgever? Sinds HR 9-1-1987 zal dat de positie van de werknemer die procedeert ex art. $1638 \mathrm{x}$ niet verslechteren: immers eigen schuld - behoudens grove schuld - is niet van invloed op de hoogte van de toe te kennen schadevergoeding. (Zie hoofdstuk III, paragraaf 2.4.2.). Indien de vordering gebaseerd is op art. $1401 \mathrm{BW}$ zal de mate van schuld wel meetellen bij de vaststelling van de hoogte van de schadevergoeding. (Hierbij dient overigens nog bedacht te worden dat,

76 Voorlopig verslag, t.a.p. p. 22.

77 MvA, t.a.p. p. 32 . 
ook zonder het bestaan van art. 12 onder e aan een werknemer, die geen melding maakt van de gevaren die hij signaleert en er ook anderszins niets aan doet, het verwijt zou kunnen worden gemaakt dat hij zich niet gedraagt als een goede werknemer (art. 1639d BW) en dat hij derhalve (mede) schuld heeft aan een hem overkomen bedrijfsongeval).

De Arbeidsinspectie kan niet alleen terzake van de naleving van art. 12 onder e een aanwijzing geven, zij kan dat ook bij de andere voorschriften van art. 12 , die dus tevens direct strafbaar zijn gesteld. Volgens de minister zijn deze voorschriften concreet genoeg voor een bewijsvoering door het O.M., terwijl zij zich tevens lenen voor een nadere concretisering in een aanwijzing ${ }^{78}$ Geheel duidelijk is deze constructie niet: immers de aanwijzing heeft vooral als achtergrond dat eerst in overleg tussen Arbeidsinspectie en werkgever en werknemers geprobeerd wordt om tot een bevredigende oplossing voor bepaalde werksituaties te komen. Dit valt toch niet altijd te rijmen met de mogelijkheid van een directe strafdreiging, zonder overleg vooraf, ten aanzien van dezelfde situaties.

In elk geval kan de Arbeidsinspectie ten aanzien van de naleving van art. 12 leden a tot en met $d$ nu kiezen: (eerst) een aanwijzing geven of direct een proces-verbaal opmaken. Dit laatste dient naar mijn smaak een ultimum remedium te zijn. Het gaat immers niet alleen om een aantal verplichtingen die volstrekt nieuw zijn voor de werknemers, maar voor het kunnen voldoen er aan zijn zij bovendien in hoge mate afhankelijk van activiteiten van de werkgever, zoals het geven van voorlichting en onderricht en het ter beschikking stellen van beschermingsmiddelen. Eerst zal dus bekeken moeten worden of en in hoeverre de werkgever aan zijn verplichtingen heeft voldaan. Pas indien die vraag in voldoende mate bevestigend is beantwoord, kan de afweging plaats vinden of een proces-verbaal op zijn plaats is of een aanwijzing. De ernst van de geconstateerde overtreding, de consequenties ervan voor de veiligheid en de gezondheid van de werknemers en anderen en de mate van verwijtbaarheid van de werknemer, waarbij zijn afhankelijke positie cruciaal is, zullen hierbij een rol moeten spelen.

Naast de algemene verplichtingen van art. 12 zijn in de Arbowet nog enkele andere in algemene zin geformuleerde verplichtingen van de werknemer opgenomen, die strafrechtelijk gesanctioneerd zijn. De belangrijkste betreffen de verplichting tot naleving van de voorschriften of verboden die bij of $\mathrm{krach}$ tens AMvB's worden gesteld ter bescherming van de gezondheid, de veiligheid en de bevordering van het welzijn bij de arbeid (de zgn. Veiligheidsbesluiten) voor zover en op de wijze als bij ieder van deze maatregelen is bepaald en de verplichting om de eisen en aanwijzingen van de Arbeidsinspectie na te leven voor zover deze betrekking hebben op verplichtingen die bij of krachtens de Arbowet aan de werknemers is opgelegd (resp. art. 26 lid 1 jo, art. 24 en de artt. 35 lid 4 en 36 lid 5). Deze verplichtingen bestonden voor wat betreft de Veiligheidsbesluiten en de eisen ook al onder de Veiligheidswet 1934.

78 MvA, t.a.p. p. 28. 


\section{De werknemer in het BW}

\subsection{Inteiding}

De juridische en feitelijke positie van de individuele werknemer wordt uiteraard ook genormeerd door de rechten en plichten die voortvloeien uit de arbeidsovereenkomst tussen hem en zijn werkgever. De praktische betekenis van de arbeidsovereenkomst voor de arbeidsomstandigheden van de werknemer is echter betrekkelijk. Deze betrekkelijkheid beperkt zich overigens niet tot het onderwerp arbeidsomstandigheden alléen. ${ }^{79}$

In de eerste plaats wordt de vrijheid van partijen om inhoud te geven aan de arbeidsovereenkomst verregaand beperkt door wettelijke regelingen. Met name betreft dit de (geheel of gedeeltelijke dwingend-rechtelijke) regeling van de arbeidsovereenkomst in het $\mathrm{BW}$ en de verwante regelgeving zoals die bijwoorbeeld te vinden is in het B.B.A. of de Wet minimumloon en minimumvakantiebijslag. De beperkingen die door deze wettelijke regelingen direct aan de inhoud van de arbeidsovereenkomst gesteld worden, strekken in het algemeen wèl ter bescherming van de werknemer. Niet direct de inhoud beïnvloedend, maar wel mede het rechtskader bepalend waarbinnen de arbeidsovereenkomst kan worden aangegaan en worden toegepast, dient hier uiteraard de publiekrechtelijke arbeidsomstandighedenwetgeving vermeld te worden.

In de tweede plaats wordt de inhoud van de arbeidsovereenkomst veelal beheerst door de CAO. De uitermate belangrijke directe doorwerking van de (normatieve) CAO-bepalingen in de arbeidsovereenkomst is overigens ook weer gefundeerd op wettelijke regelingen: de Wet op de collectieve arbeidsovereenkomst van 1927 en de Wet op het algemeen verbindend en onverbindend verklaren van bepalingen van collectieve arbeidsovereenkomsten van 1937.

In de derde plaats is de betekenis van de arbeidsovereenkomst in die zin betrekkelijk dat, naast de zekere mate van onvrijheid die door wet en CAO aan de partijen wordt opgelegd, de werkgever een grote mate van vrijheid behoudt om naar eigen goeddunken de gang van zaken in de onderneming te bepalen met name op het 'brede terrein van de dagelijkse ordening van de arbeid, de feitelijke omstandigheden op de arbeidsplaats en de werkruimte, het materiaal waarmede wordt gewerkt, het werktempo, de indeling in ploegendiensten, werkfaciliteiten, enz. ${ }^{80}$ De rechtsgrond voor deze vrijheid vloeit rechtstreeks voort uit de aan de arbeidsovereenkomst inherente gezagspositie van de werkgever - een positie die anderzijds weer beperkt wordt door de algemene normen van de goede trouw en het goede werkgeverschap (artt. 1375 en

$79 \mathrm{Vgl}$. ook SER, Advies inzake het klachtrecht van individuele werknemers, Den Haag 1981, nr. 14, p. 9

80 SER-adwies, 1981 , nr. 14, t.a.p. p. 12. 
$1638 z \mathrm{BW}){ }^{81}$ Binnen de vigerende beperkingen heeft de werknemer zich echter te houden aan de door de werkgever uitgevaardigde voorschriften (art. $1639 \mathrm{~b} \mathrm{BW})$.

Hierboven is al aandacht geschonken aan de betekenis van de Arbowet voor de individuele werknemer. In paragraaf 4 van dit hoofdstuk zal de betekenis van de CAO voor de individuele werknemer aan de orde komen. De belangrijkste bepalingen betreffende de arbeidsomstandigheden in de regeling van de arbeidsovereenkomst in het BW volgen hieronder.

\subsection{Enkele bepalingen uit het $B W$ in relatie tor de arbeidsomstandigheden}

Terwijl in de Arbowet sterk de nadruk wordt gelegd op de rol van collectiviteiten van werknemers en de individuele werknemer juridisch gezien een betrekkelijk marginale positie inneemt, geldt het omgekeerde voor de regeling van de arbeidsovereenkomst in het BW: uitgangspunt is de positie van de individuele werknemer, een positie die onder bepaalde voorwaarden echter mede bepaald kan worden door de invloed van een collectiviteit van werknemers, met name door de mogelijkheid dat van sommige bepalingen afgeweken kan worden bij CAO.

Slechts weinig artikelen in het BW handelen echter expliciet over veiligheid, gezondheid en welzijn bij de arbeid. Dat is ook begrijpelijk, omdat dit onderwerp bij uitstek zijn regeling vindt in de publiekrechtelijke wetgeving.

Ook in het BW moeten de rechten van de werknemers vooral afgeleid worden van de civielrechtelijke verplichtingen op dit gebied van de werkgever. De meest uitgesproken verplichting voor de werkgever is geformuleerd in art. $1638 \mathrm{x}$. Omdat dit artikel in het vorige hoofdstuk al uitvoerig aan de orde is geweest, wordt het hier niet verder behandeld.

Art. 1639 q lid 2 onder 9 noemt met zoveel woorden onder meer ernstige gevaren voor leven en gezondheid, die bij het voortduren van de dienstbetrekking voor de werknemer zouden ontstaan, als dringende reden voor de werknemer om de dienstbetrekking onverwijld te mogen beëindigen (art. 1639o lid 1). Het is een voorbeeld van de algemene regel in art. $1639 \mathrm{q}$ lid 1 en in die zin niet meer dan een vuistregel voor de werknemer. Van dit concrete voorbeeld in de wet wordt door de werknemer in het kader van het beëindigen van de dienstbetrekking waarschijnlijk weinig gebruik gemaakt, voor zover dat althans uit de gepubliceerde jurisprudentie is op te maken.

De meest algemeen geformuleerde verplichting voor de werkgever is te vinden

81 Vgl. bijwoorbeeld Ktg. Middelburg, 26 mei 1986, Praktijkgids 1987, nr. 2630. De kantonrechter erkende de in beginsel aanwezige beleidsvrijheid van de werkgever bij de indeling van werknemers in functiegroepen en toetste derhalve binnen deze beleidsruimte marginaal: 'Toetsing van een door de werkgever genomen besluit door de rechter kan dan ook slechts in zoverre geschieden, dat de rechter slechts mag beoordelen of de werkgever gegeven diens beleidswrijheid enerzijds en gegeven de grenzen daarwan zoals die woortv loeien uit de in acht te nemen goede trouw, de verplichting zich als goed werkgever te gedragen en de inhoud van het functiewaarderingssysteem, in redelijkheid tot het genomen besluit had kunnen komen.' 
in art. 1638z: hij is verplicht al hetgeen te doen en na te laten wat een goed werkgever in gelijke omstandigheden behoort te doen en na te laten. ${ }^{82}$ Juist omdat deze verplichting zo algemeen geformuleerd is, kan er gebruik van worden gemaakt, en lijkt er in de praktijk ook meer gebruik van te worden gemaakt, in die gevallen waarin wet en overeenkomst geen uitkomst bieden of de publiekrechtelijke beschermingsnormen te kort schieten. Enkele voorbeelden op het gebied van de arbeidsomstandigheden.

Het lijkt mij toe dat de werkgever op grond van art. $1638 \mathrm{z}$ verplicht is om zijn werknemer desgevraagd alle relevante informatie te verstrekken over (de gevaren die verbonden zijn aan) zijn arbeidsomstandigheden. Tot deze informatieplicht behoort eveneens een motiveringsplicht ten aanzien van zijn activiteiten op dit gebied, zeker indien deze er niet toe strekken voor de betreffende situatie de hoogst bereikbare graad van veiligheid en gezondheid te bereiken. Uit deze verplichting voor de werkgever op grond van art. $1638 \mathrm{z}$ zou dus, net zoals ten aanzien van de werkgeversverplichting ex art. 6 Arbowet, een voor elke individuele werknemer geldend informatierecht kunnen worden afgeleid. Dit is des te belangrijker nu ik bij de bespreking van de rechten van de individuele werknemer in de Arbowet moest concluderen dat van een stevig juridisch verankerd subjectief recht op informatie op basis van die wet, vooral door het ontbreken van directe juridische actiemogelijkheden voor de individuele werknemer, niet gesproken kan worden. Op basis van het $\mathrm{BW}$ heeft de individuele werknemer wèl een directe actiemogelijkheid bij schending van art. $1638 \mathrm{z}$ door de werkgever. Bij de interpretatie van het artikel zou dan de Arbowet als lex specialis ingezet kunnen worden.

Naar mijn mening kan een werknemer zich ook beroepen op de verplichting van een werkgever om zich in die hoedanigheid goed te gedragen om te bewerkstelligen dat voor zijn situatie de indicatieve normeringen, zoals die met name geformuleerd zijn in art. 3 van de Arbowet, concreet worden toegepast. Ik denk dan bijvoorbeeld aan de bepaling die een aanpassing verlangt van de arbeidssituatie en -taak aan de eigenschappen van de individuele werknemer. In dit opzicht zou een parallel getrokken kunnen worden met de redenering in het arrest van de HR van 8-11-1985 (van Haaren-Cehave). ${ }^{83}$ Hierin interpreteerde de HR onder meer artikel $1638 \mathrm{z}$ door er de rechtsregel uit te destilleren dat de werkgever in beginsel verplicht is om zijn blijvend arbeidsongeschikte werknemer arbeid te laten verrichten, die voor zijn krachten en bekwaamheden is berekend en die hem met het oog op zijn opleiding en arbeidsverleden kan worden opgedragen, tenzij de werkgever kan stellen en bewijzen dat zulks redelijkerwijze niet van hem verlangd kan worden. ${ }^{84}$ Waar het mij nu in dit

82 Zie noot 114 in hoofdstuk III.

83 HR 8 november 1985, NJ 1986, 309 (m.nt. PAS).

84 Hesseling meent zelfs dat de HR - volgens hem ten onrechte - met de formulering van deze rechtsregel als plaatsvervangend wetgever heeft gefunctioneerd. W. Hesseling, Nieuwe rechtsregels; aanwulling van art. $1638 \mathrm{~d}$ en $1638 \mathrm{z}$ BW door de Hoge Raad, Praktijkgids, 1985 , p. 653. Dit laatste lijkt me echter niet het geval te zijn: de HR gaf slechts een interpretatie van art. $1638 \mathrm{z}$ waar het artikel zelf alle ruimte toe biedt en overigens in de lijn ligt van een eerder pleidooi van Rood ter handhaving van het artikel, omdat het de mogelijkheid biedt de sociale" en culturele ontwikkelingen harmonisch te volgen. Zie noot 114 van het vorige hoofdstuk. 
verband om gaat, zijn de argumenten van de HR. Hij beroept zich namelijk op de 'huidige rechtsopvattingen' zoals die onder meer tot uiting komen in $\mathrm{CAO}$ bepalingen op dit gebied en de brede instemming, die het wetsontwerp arbeid gehandicapte werknemers (WAGW) in de Tweede Kamer had ondervonden. Welnu, waar de HR 'huidige rechtsopvattingen' bij de interpretatie van art. $1638 \mathrm{z}$ met name concludeert uit $\mathrm{CAO}$-bepalingen en de recente parlementaire instemming met een wetsontwerp, geldt een overeenkomstige redenering zeker ten aanzien van gewenste humane arbeidsomstandigheden voor werknemers. Bij de behandeling wan de Arbowet immers, die qua doelstelling, inhoud en procedurele effectueringsmogelijkheden toch een zekere overeenkomst vertoont met de WAGW, kon minister Albeda spreken van "de opvallende eensgezindheid' van de Tweede Kamer en mede geïnspireerd door deze wet is het aantal CAO-bepalingen op dit punt toegenomen. ${ }^{85}$

Art. 1638z kan ook een rol spelen bij het tegengaan van on-welzijn bevorderende maatregelen die niet zo duidelijk uit de Arbowet zijn te halen, zoals het Hof 's Hertogenbosch in 1986 deed. ${ }^{86}$ Een werkgever had op vaste punten in de bedrijfsruimten camera's bevestigd om via monitoren een volledig, gelijktijdig overzicht te hebben over al die ruimten. Degenen die zich in de ruimten bevonden, konden zelfs niet ontdekken of deze camera's al dan niet in werking waren. Volgens het Hof worden de werknemers door de aanwezigheid van de camera's bij voortduring blootgesteld aan een mogelijk langdurige en gerichte observatie waarop zij geen enkele invloed hebben. Een dergelijke werksituatie blijft verre ten achter bij wat uit een oogpunt van normalle menselijke bejegening aanvaardbaar is. Van een noodzaak voor het controlesysteem was niet gebleken. De werkgever handelde derhalve in strijd met art. $1638 \mathrm{z}$ BW.

Deze civielrechtelijke mogelijkheid voor de individuele werknemer om op basis van art. $1638 \mathrm{z}$ zijn welzijin bij de arbeid te bevorderen, wint ook hier aan betekenis, omdat ik - gelijk ik dat deed ten aanzien van het recht op informatie - eerder concludeerde dat de formulering van de grondbeginselen voor het arbeidsomstandighedenbeleid in art. 3 van de Arbowet op zich geen direct juridisch geldend te maken recht voor de werknemer oplevert. Daar komt ten aanzien van art. 3 bovendien bij dat het nog niet in werking is getreden. Dit laatste was overigens voor de President van de Rechtbank in Breda in 1985 geen beletsel om op grond van art. 3 van de Arbowet een werkgever te veroordelen om een werkneemster onder dezelfde omstandigheden als vór haar (ten onrechte gegeven) ontslag te laten werken ${ }^{87}$ Mij lijkt echter dat hier nu bij uitstek (ook) art. 1638z van toepassing kon zijn.

De kantonrechter te Gorinchem verwees in 1986 in het kader van het verzoek tot ontbinding van de arbeidsovereenkomst (art. 1639w) evenmin expliciet

85 De minister sprak toen eveneens van teen van de belangrijkste stukken wetgeving van ma de oorlog" - en ook uit deze uitspraak valt toch af te leiden dat deze wet spoorde met vigerende rechtsopvattingen. Handelingen TK 1979-1980, p. 4673.

86 Hof "s Hertogenbosch, 2 jull 1986, NJ 1987, 451 .

87 President Rb Breda, 9 december 1985, KG 1986, 28. 
naar art. 1638 z, maar wel naar de WAGW. ${ }^{88}$ Het ging om het volgende: De werkgever wilde automatiseren, waardoor de betrokken werknemer als gevolg van een visuele handicap niet meer in de nieuwe geautomatiseerde opzet volwaardig zou kunnen functioneren. Nadat de kantonrechter zich had laten voorlichten door enkele deskundigen, beschikte hij tot afwijzing van het verzoek: 'Omdat er binnen de ondernemingen van verzoekster, zelfs na de doorgevoerde automatiseringen, zij het met enige welwillendheid en vindingrijkheid, nog werkzaamheden zijn te vinden die voor van Dam, zelfs met zijn handicap, als passend zijn te beschouwen, zijn de omstandigheden van partijen nog niet zodanig gewijzigd dat er reden is de arbeidsovereenkomst te ontbinden.' De kantonrechter meende dat daartoe niet te snel kon worden besloten, mede vanwege een aantal feiten en omstandigheden zoals het lange dienstverband, de geringe kans op ander werk voor betrokkene, het aanbod om alle passende arbeid te willen verrichten en de verantwoordelijkheid van de werkgever de arbeidsplaats van de gehandicapte werknemer zoveel mogelijk te verzekeren zoals 'recentelijk ook door de wetgeving is bevestigd". Nu is er natuurlijk ook verschil tussen de WAGW en de Arbowet. De eerste wet beoogt immers vooral om gehandicapte werknemers in het arbeidsproces deel te laten nemen onder meer door de werkgever te verplichten het werk zoveel mogelijk aan te passen aan de mogelijkheden van de gehandicapte werknemer. Bij de Arbowet gaat het niet zozeer om het verschaffen en het behoud van werk aan een bepaalde groep werknemers, maar om het bevorderen van humane arbeidsomstandigheden voor alle zittende werknemers. Toch neemt dit niet weg dat de tendens om art. 1638z, en daarmee dus de individuele rechtsverhouding tussen werkgever en werknemers, mede in te vullen aan de hand van aan het publiekrecht ontleende normen, met een verwijzing naar de Arbowet ook van betekenis kan zijn voor de niet gehandicapte werknemer, wiens arbeidsomstandigheden bijvoorbeeld geschaad worden door veranderingen in de arbeidsorganisatie.

Blijkens een uitspraak van de kantonrechter Rotterdam in 1984 zou art. $1638 \mathrm{z}$ ook ingezet kunnen worden indien art. $1638 \mathrm{x}$ geen soelaas biedt. ${ }^{89}$ Volgens de kantonrechter lag een bedrijfsongeval als in casu voor de werkgever niet zó voor de hand, dat een regeimatig toezicht en regelmatig gegeven waarschuwingen voor mogelijke gevaren van hem redelijkerwijze te vergen zijn. Hij concludeert dat de werkgever heeft voldaan aan zijn verplichting om het gebruikte materiaal zo te onderhouden en omtrent het verrichten van de arbeid zodanige regelingen te treffen en zodanige aanwijzingen te verstrekken, dat de werknemer tegen gevaren zover is beschermd als redelijkerwijze in verband met de aard van de arbeid gevergd kan worden. De kantonrechter overweegt bovendien nog dat ook de werknemer niet heeft gesteld dat de werkgever in strijd met de veiligheidswetgeving heeft gehandeld. Dat de vordering van de

88 Ktg. Gorinchem, 21 juli 1986. Praktijkgids, 1987, 2627; over deze beschikking: H.T. van Staveren, De wet arbeid gehandicapte werknemers en de Hoge Raad: invloed op de $1639 \mathrm{x} \mathrm{BW}$. procedure, Praktijkgids, 1987, p. 57-66.

89 Ktg. Rotterdam, 10-1-1984, Praktijkgids, 1985, 2314, zie ook hoofdstuk III, paragraaf 2.4.1 
werknemer dus niet op art. $1638 \mathrm{x}$ kon worden gebaseerd, bracht volgens de kantonrechter echter niet mee dat deze vordering zonder meer moet worden afgewezen. Een arbeidsovereenkomst verbindt de werkgever namelijk ook tot alles wat door gebruik of billijkheid wordt gevorderd (vgl. artt. 1375 en $1638 \mathrm{z}$ ). Op grond hiervan kan de werknemer, die tijdens zijn werkzaamheden door toedoen van zijn werkgever schade opliep, alsook indien hij schade ondervond zelfs zonder toedoen of nalatigheid van zijn werkgever, onder bepaalde omstandigheden in beginsel een recht op een tegemoetkoming ter zake van ondervonden schade krijgen.

Volgens de kantonrechter zullen zulke omstandigheden zich met name kunnen voordoen indien de werknemer ten gevolge van de uitvoering van zijn werk in relatie tot de mate van zijn schuld zó onevenredig veel nadeel ondervindt, dat ook al valt zijn werkgever niet of nauwelijks iets te verwijten, het alsdan niet toekennen wan een redelijke tegemoetkoming aan de werknemer in strijd met een goed werkgeverschap te achten is. Voorwaarde hiervoor is in ieder geval dat niet is gebleken van grove of aanzienlijke schuld of nalatigheid van de werknemer, omdat deze in dat geval zijn eigen schade en - indien de werkgever tengevolge van zijn gedraging ook schade heeft ondervonden ook die van zijn werkgever dient te dragen en/of vergoeden (art. 1637w). Nu in het onderhavige geval niet is gebleken van grove schuld, maar slechts van enige onzorgvuldigheid aan de zijde van de werknemer, en van zijn werkgever hooguit gezegd kan worden dat hij er goed aan had gedaan om iets meer toezicht te houden, dan wel de werknemer te waarschuwen voor het gevaar van de onderhavige werkwijze, zal de wel zeer aanzienlijke schade die deze opliep, voor een deel ook door zijn werkgever in het kader van een redelijke tegemoetkoming moeten worden vergoed. (Het ging bij dit bedrijfsongeval om het verlies van een rechteroog. Het maximaal te vorderen smartegeld werd door de kantonrechter getaxeerd op $\mathrm{f} 40.000,--$. Op grond van voornoemde overwegingen oordeelde hij het billijk dat de werkgever hiervan een vierde deel draagt).

Tot slot dient hier vermeld te worden dat art. $1638 \mathrm{z}$ de juridische basis verschaft op grond waarvan de werkgever gehouden is op een fatsoenlijke manier te reageren op klachten van zijn werknemer over de arbeidsomstandigheden, zonder dat deze laatste door het indienen van zijn klacht benadeeld wordt in zijn positie in de onderneming. ${ }^{90}$ Deze basis is temeer van belang zolang het voorgestelde wettelijke klachtrecht in de onderneming niet is ingevoerd. Ik kom hier uitvoeriger op terug.

90 SER-advies 1981, tr. 14 , t.a.p. p. 7. Hoewel ook Bakels ten aanzien wath het klachtrecht verwijst naar art. $1638 \mathrm{z}$, meent hij dat het wenselijk en mogelijk is om, anders dan gesuggereerd wordt in de adviesaanvraag aan de SER en het advies ter zake, via een concretisering in het BW van de ongeschreven, vage billijkheidsnormen die uit art. $1638 \mathrm{z}$ kunnen worden afgeleid, het individueel klachtrecht een hechtere basis te verschaffen. H.L. Bakels, Het individueel klachtrecht, de goede werkgever en het collectief overleg. SMA, 1981, p. 302-310, m.n. 309. 
De werknemer krijgt in thet BW ook verplichtingen opgelegd. Zij zijn beduidend minder in aantal dan de verplichtingen voor de werkgever en zijn algemeen geformuleerd. Geen ervan heeft expliciet betrekking op de arbeidsomstandigheden. Art. 1639b verplicht de werknemer zich te houden aan de voorschriften die de werkgever hem geeft "omtrent het verrichten van de arbeid' en 'welke strekken ter bevordering van de goede orde in de onderneming', een en ander binnen de perken van wet en overeenkomst. Het artikel illustreert de gezagsverhouding die er in het kader van de arbeidsovereenkomst (art. 1637a) bestaat tussen de werkgever en zijn werknemer. Voorschriften op het gebied van de arbeidsomstandigheden vallen in beginsel onder de werkingssfeer van art. $1639 \mathrm{~b}$. De gegeven voorschriften moeten uiteraard redelijk zijn. Hoewel het vaak niet eenvoudig zal zijn om vast te stellen wat in concrete situaties redelijk is, zal de opdracht van een werkgever aan een werknemer om ander dan het oorspronkelijk overeengekomen werk te verrichten, dat een verslechtering van zijn arbeidsomstandigheden betekent, om die reden in het algemeen niet redelijk zijn. Voorschriften, die gegeven worden in strijd met de vigerende regelingen op het gebied van de arbeidsomstandigheden behoeven in beginsel niet nageleefd te worden, zeker niet indien de werkgever - na gewezen te zijn op het onregelmatige van het voorschrift in casupersisteert. ${ }^{91}$ Het weigeren om een dergelijke opdracht uit te voeren of het stoppen met de werkzaamheden - ook als die geen acuut gevaar opleveren voor de veiligheid of gezondheid - is onder die omstandigheden terecht en vormt, zoals hierboven (in paragraaf 2.3.) al is betoogd, een nog steeds noodzakelijke aanvulling op het recht om het werk neer te leggen op grond van art. 38 Arbowet.

Indien de werkgever een voorschrift wenst uit te vaardigen dat beschouwd kan worden als een regeling op het gebied van de veiligheid, de gezondheid of het welzijn in verband met de arbeid, dan heeft de or een instemmingsrecht volgens art. 27 lid 1 onder e van de WOR, tenzij het onderwerp al inhoudelijk in de CAO is geregeld (zie hoofdstuk III, paragraaf 3.2.1.).

Het goede werkgevers-artikel $1638 \mathrm{z}$ heeft een analoge regeling ten aanzien van de werknemer: volgens art. $1639 \mathrm{~d}$ is de werknemer verplicht al datgene te doen en na te laten wat een goede werknemer in gelijke omstandigheden behoort te doen en na te laten. ${ }^{92}$ Ten aanzien van de arbeidsomstandigheden is deze algemene en globaal geformuleerde civielrechtelijke verplichting van de werknemer terug te vinden in art. 12 van de Arbowet, waarin - eveneens in algemene termen - de verplichting voor de werknemers is opgenomen om in verband met de arbeid de nodige zorgvuldigheid in acht te nemen ter vermijding van gevaren voor de veiligheid of de gezondheid van hen zelf of van anderen, dan wel met het oog op hun welzijn. Deze algemene norm is uitgewerkt in een aantal meer concrete verplichtingen, die naar mijn mening voor

$91 \mathrm{Vgl}$. ook HR 6 aprill 1979, NJ1979, 492: een opdracht tot overwerk in strijd met de Arbeidswet mag een werknemer in beginsel weigeren.

92 Zie noot $114 \mathrm{in} \mathrm{hoofdstuk} \mathrm{III.}$ 
een groot deel evenzeer reeds op grond wan art. $1639 \mathrm{~d}$ behoren tot datgene waartoe een goede werknemer gehouden is, zoals het melden van opgemerkte gevaren voor de veiligheid en gezondheid. (Zie voor art. 12 Arbowet paragraaf 2.7. van dit hoofdstuk). Bij het niet nakomen van zijn verplichtingen ex art. $1639 \mathrm{~d}$ pleegt de werknemer wanprestatie en dit laatste kan de verplichting doen ontstaan om de daardoor veroorzaakte schade te vergoeden - los uiteraard van de mogelijkheid dat de werknemer terzake van eenzelfde gedraging ook strafrechtelijk aansprakelijk gesteld kan worden op grond van de Arbowet. Met de civielrechtelijke procedure zal het echter niet zo'n vaart lopen: nadat de HR in 1959 al had uitgemaakt dat de aard van de arbeidsovereenkomst kan meebrengen dat een werkgever de gevolgen moet dragen van geringe fouten, die de werknemer bij de verrichting van zijn werkzaamheden begaat, oordeelde de HR in 1983 dat een werknemer terzake van door hem toegebrachte schade eerst aansprakelijk is indien hem terzake, alle omstandigheden van het geval in aanmerking nemend, een ernstig verwijt valt te maken. ${ }^{9.3}$

Het in ernstige mate en verwijtbaar niet nakomen van zijn verplichtingen kan voor de werknemer bovendien ontslag op staande voet betekenen. Ten aanzien van de arbeidsomstandigheden noemt art. $1639 \mathrm{p}$ lid 2 onder 8 in dit verband als een mogelijk dringende reden hiervoor de omstandigheid dat de werknemer opzettelijk, of ondanks waarschuwing roekeloos, zichzelf of anderen aan ernstig gevaar blootstelt. Dit gedrag is in het algemeen ernstiger dan de overtreding van de globale norm van art. $1639 \mathrm{~d}$ : maar de mogelijke sanctie is navenant. Artikel 1639d vormt ten slotte volgens de HR de juridische basis voor de verplichting van de werknemer om zijn werkgever te informeren over een voorgenomen werkweigering in verband met het niet nakomen van wettelijke bepalingen door de werkgever opdat deze voorzieningen kan treffen met het oog op die weigering. ${ }^{94}$

In de Wet op de arbeidsovereenkomst komen dus, met uitzondering van art. $1638 x$, nauwelijks bepalingen voor die expliciet betrekking hebben op de arbeidsomstandigheden van de werknemers. Voor zover de werknemers rechten kunnen ontlenen aan deze bepalingen, wederom met als uitzondering art. $1638 \mathrm{x}$, moeten deze vooral worden afgeleid uit de algemeen geformuleerde verplichting voor de werkgever om zich als goede werkgever te gedragen. In die zin is er sprake van zowel overlapping van, als aanvulling op de normen van de publiekrechtelijke arbeidsomstandighedenwetgeving.

Voor wat betreft de handhaving van deze rechten is de werknemer aangewezen op de burgerlijke rechter, evenals hij dat is ten aanzien van de bepalingen in zijn arbeidsovereenkomst. In de praktijk blijkt dit voor de werknemer echter geen vanzelfsprekende exercitie te zijn. Dit hangt samen met de oorzaken die ten grondslag liggen aan het feit dat de rechter door werknemers in het 
algemeen nauwelijks geadieerd wordt tijdens en in verband met hun dienstbetrekking.

Nog afgezien van de juridische problemen, zoals de bewijslast, spelen angst voor verstoorde relaties met de werkgever, psychische druk en dergelijke een belangrijke rol. Bakels spreekt over de gang naar de rechter zelfs van een 'oorlogsverklaring'. ${ }^{95}$ Pas bij ernstige geschillen komt het tot een gerechtelijke procedure, maar dan staat ook meestal het voortbestaan van de arbeidsovereenkomst op het spel. Daar komt nog iets bij. In de inleiding van deze paragraaf is al gesteld dat de werkgever nu eenmaal bevoegd is om allerhande beleidsbeslissingen te nemen, ook op het gebied van de arbeidsomstandigheden, die de werknemer wellicht niet alle even welgevallig zullen zijn. Terecht komt de SER in dit verband tot de volgende slotsom: 'Een gerechtelijke procedure komt hier praktisch nimmer in aanmerking, zulks niet alleen omdat dit middel onpraktisch en onhanteerbaar is, maar ook omdat de rechter geen uitkomst zal kunnen bieden: immers, zolang een werkgever beslissingen neemt die binnen de (redelijkheids)grenzen van zijn (beleids)vrijheid liggen, zal de rechter die beslissingen intact moeten laten. ${ }^{396}$

De conclusie die uit het voorafgaande kan worden getrokken, moet naar mijn mening luiden dat zowel de wettelijke bepalingen ten aanzien van de arbeidsovereenkomst, als de inhoud wan de arbeidsovereenkomst weliswaar ruimte bieden voor in beginsel afdwingbare rechten voor de werknemer, maar dat de praktische realisering van deze rechten te onzeker is dan dat de publiekrechtelijk te handhaven bepalingen op dit punt gemist zouden kunnen worden, hoe problematisch ook die handhaving moge zijn. Wel lijkt er een tendens bespeurbaar (zie ook hoofdstuk III, paragraaf 2.4.6.) dat steeds meer werknemers bereid zijn om de hulp van de rechter in te roepen, waarschijnlijk mede onder invloed van een toenemende erkenning door de rechter van een recht op humane arbeid, al dan niet (mede) gebaseerd op publiekrechtelijke normen.

\section{De werknemer in de $\mathrm{CAO}$}

Eerder heb ik, uit eigen onderzoek van 1986, geconstateerd dat het aantal bepalingen in CAO's terzake van veiligheid, gezondheid en welzijn bij de arbeid sinds 1977 , het jaar van het onderzoek van het toenmalige Loonbureau naar deze bepalingen, is toegenomen (zie hoofdstuk III, paragraaf 6.4.2.). Dit is waarschijnlijk mede gebeurd onder invloed van (het proces van totstandkomen van) de Arbowet. Inhoudelijk verschillen deze nieuwe bepalingen van die van 1977 , die vooral op algemene en organisatorische zaken gericht waren, met name door drie onderling samenhangende kenmerken: een eerlijker verdeling van rechten en plichten over werkgever en werknemers, méér aandacht voor de immateriële aspecten van de humanisering van de arbeid en een toena-

95 H.L. Bakels, SMA, 1981 , t.a.p. p. 309.

96 SER-advies 1981 , nr. 14 , t.a.p. p. 12; vgl. ook noot 81 
me wan overleg- en informatiebepalingen. Overigens blijken ook de bepalingen in de recente CAO's in het algemeen niet veel verder te gaan dan in de Arbowet is bepaald. Om wat voor soort bepalingen gaat het nu gerelateerd aan hun rechtstreekse invloed op de positie van de individuele werknemer? Het grootste aantal bepalingen in de door mij onderzochte CAO's geldend voor 1986, geeft concrete en individualiseerbare rechten en plichten aan werknemers die tamelijk vanzelfsprekend en weinig spectaculair zijn, en bovendien meestal al voorkomen in de bestaande arbeidsomstandighedenwetgeving. Ik noem er een aantal. (De onderstaande resultaten stemmen grotendeels overeen met het onderzoek van de Dienst Collectieve Arbeidswoorwaarden van 1987). ${ }^{97}$

In 17 wan de onderzochte CAO's is het recht op werkkleding vastgelegd. Dit betreft 588.771 werknemers, dat is $27 \%$ van het totaal onder de onderzochte CAO's vallende werknemers. Hoewel het recht op werkkleding niet als zodanig in wettelijke regels is geformuleerd, heeft de werkgever wel de verplichting om er voor te zorgen dat bij bepaalde gevaarlijke werksituaties de werknemer aangepaste kleding draagt (vgl. bijvoorbeeld art. 173a Veiligheidsbesluit Fabrieken of Werkplaatsen, VBF).

Volgens 15 CAO's hebben werknemers recht op bepaalde veiligheidsmiddelen en eerste hulpvoorzieningen, zoals verbandtrommels. Het gaat om 683.889 werknemers, dat is $31,5 \%$ van het totale aantal (vgl. bijvoorbeeld de artt. $172 \mathrm{j}$ en 174 van het VBF en de artt. 76a, b en 67 van het Landbouw Veiligheidsbesluit, LVB).

De CAO voor het bouwbedrijf geeft aan de werknemers het recht op kennisneming van het Arbo-beleidsplan. Deze CAO geldt voor 160.000 werknemers, of $7,5 \%$ van het totaal (vgl. art. 4 lid 5 van de Arbowet).

In 5 CAO's is voor 274.100 werknemers, $13 \%$ van het totaal, het recht neergelegd op inzage van het sociaal jaarverslag (vgl. art. $31 \mathrm{~b}$ WOR en art. 10 lid 4 Arbowet).

De verplichting voor werknemers om zich te onderwerpen aan een medische keuring en/of een psychologisch onderzoek is vastgelegd in 14 CAO's, geldend voor 689.653 werknemers, $31,8 \%$ van het totaal (vgl. art. 25 Arbowet).

In 20 CAO's, geldend voor 714.874 werknemers, $33 \%$ van het totale aantal, is de verplichting voor de werknemers opgenomen om de eigen veiligheid en die van anderen in acht te nemen en de veiligheidsvoorschriften na te leven (vgl. art. 12 Arbowet).

De verplichting voor de werknemers om onveilige situaties te melden bij de werkgever (de leiding van de betreffende afdeling) is te vinden in $13 \mathrm{CAO}$ 's, geldend voor 490.489 werknemers, $22,5 \%$ van het totalle aantal (vgl. art. 12 onder e Arbowet).

97 Ministerie van Sociale Zaken en Werkgelegenheid (Dienst Collectieve Arbeidswoorwalarden), Arbeidsomstandigheden in CAO's, Den Haag 1987; zie over dit onderzoek ook hoofdstuk III, paragrat 6.4.2. 
Al eerder heb ik gewezen op het belang van het recht op informatie over de arbeidsomstandigheden in de onderneming. In 15 CAO's is een dergelijk recht toegekend, geldend voor 373.392 werkmemers, dat is $17 \%$ van het totaal aantal werknemers (vgl. art. 6 Arbowet, waar dit recht als een plicht voor de werkgever is geformuleerd).

Een ander belangrijk recht voor de individuele werknemer vormt het recht om het werk neer te leggen c.q. dit te weigeren. Het is interessant dat in dit geval de CAO-bepalingen in een aantal gevallen verder gaan dan art. 38 Arbowet. Het recht tot werkonderbreking wordt namelijk veelal ook erkend in de situatie dat de veiligheidsvoorschriften niet in acht worden genomen..$^{98}$ In totaal gaat het om 13 CAO's, geldend voor 593.497 werknemers, $27,5 \%$ van het totaal. Volgens 11 CAO's daarvan kan de werknemer niet worden verplicht tot het verrichten van werkzaamheden indien niet aan de wettelijke en/of bedrijfsvoorschriften omtrent de veiligheid is voldaan:

Electriciteitsbedrijven

Metaalindustrie

Metaalnijverheid (8 CAO's)

Suikerverwerkende industrie totaall
10.000 werknemers 179.597 werknemers 209.800 werknemers 14.000 werknemers $\overline{413.397}$ werknemers (11 CAO's; 19\%)

Daarnaast vermeldt de CAO voor het bouwbedrijf (160.000 werknemers, $7,5 \%$ ) dat het werk geweigerd mag worden wegens het ontbreken van veiligheidshelmen en de CAO voor de textielindustrie (20.100 werknemers, $1 \%$ ) dat bij dreigend acuut gevaar het werk mag worden opgeschort en dat de werknemer de plicht heeft de chef te waarschuwen die vervolgens zal bepalen of de situatie van dien aard is dat, alvorens de werkzaamheden hervat mogen worden, de nodige voorzieningen dienen te worden getroffen.

CAO's bevatten, naast bepalingen die direct individualiseerbare rechten en plichten creëren, ook (diagonale) bepalingen die de werkgever verplichtingen opleggen die indirect van betekenis zijn voor de individuele werknemer.

Voorbeelden daarvan zijn de verplichting om op een bepaalde manier een klachtenregeling ten aanzien van de arbeidsomstandigheden in het leven te roepen (drie CAO's, geldend voor 229.097 werknemers, 10,6\%) of het recht op werkplek-onderzoek door speciale functionarissen binnen de onderneming, zoals de CAO voor het bouwbedrijf die kent (160.000 werknemers, $7,5 \%)$.

Ook voor de $\mathrm{CAO}$-bepalingen geldt dat de praktische betekenis ervan voor de individuele werknemer voor een groot gedeelte bepaald wordt door het antwoord op de vraag hoe de bepalingen gehandhaafd kunnen worden. Van nor-

98 In de CAO voor de Autobusdienstondernemingen is expliciet een mogelike consequentie opgenomen wan het zich voordoen van een ommiddellijk dreigend gevar: alsden heeft de werknemer het recht om de uitvoering van een veilligheidsvoorschrift op te schorten of daarvan af te wijken. Deze $\mathrm{CAO}$ geldt voor 13.000 werknemers, $0,5 \%$ van het totaal. 
matieve bepalingen, die immers automatisch deel uitmaken van de arbeidsovereenkomst (artt. 12 en 13 WCAO), kan de individuele georganiseerde werknemer, rechtstreeks nakoming vorderen voor de rechter op basis van zijn arbeidsovereenkomst.

Ook ten aanzien van de ongeorganiseerde werknemers heeft de (gebonden) werkgever de plicht om op basis van art. 14 WCAO de CAO-bepalingen na te komen, tenzij de CAO anders bepaalt. De ongeorganiseerde werknemers behouden van hun kant echter het recht om met de werkgever af te spreken af te wijken van de normatieve $\mathrm{CAO}$-bepalingen. Indien zij dit doen, is er een rechtsgeldige arbeidsovereenkomst tot stand gekomen en daarvan kan elke niet gebonden individuele werknemer weer nakoming vragen. Hij kan echter geen nakoming van de verplichting ex art. 14 WCAO vorderen.

Voor de praktijk maakt het weinig uit. In de eerste plaats zijn vrijwel alle onderzochte CAO's voor de betreffende bedrijfstak verbindend verklaard. Dit betekent dat de desbetreffende normatieve èn diagonale bepalingen automatisch en dwingend doorwerken in de arbeidsovereenkomst tussen alle werkgevers en werknemers in de bedrijfstak, georganiseerd of niet. In de tweede plaats is het gebruikelijk dat de werkgever de ongeorganiseerde werknemers net zo behandelt als de georganiseerde: het is het meest praktische, de werkgever weet vaak ook niet of een werknemer georganiseerd is of niet en op deze wijze zal, althans op dit punt, geen onrust in de onderneming ontstaan. In de praktijk wordt door de georganiseerde werknemers daar in het algemeen geen bezwaar tegen gemaakt, zodat aangenomen wordt dat de CAO-bepalingen met stilzwijgende instemming onderdeel zijn gaan uitmaken van de arbeidsovereenkomst. Vaak wordt in de arbeidsovereenkomst de toepasselijkheid van de CAO zelfs uitdrukkelijk vastgelegd.

Een probleem terzake van de handhaving door de werknemer zelf zou nog gevormd kunnen worden door bepalingen die weliswaar betrekking hebben op de individueelrechtelijke verhouding tussen werkgever en werknemer, maar geen arbeidsvoorwaarden inhouden, zodat de artt. 12,13 en 14 van WCAO niet van toepassing zouden zijn. Fase, die uitdrukkelijk hierbij melding maakt van de categorie CAO-bepalingen met betrekking tot de arbeidsomstandigheden, meent dat, voor zover er individualiseerbare rechten worden geschapen, de werknemer een direct beroep kan doen op deze CAObepalingen. ${ }^{99}$ Dit is naar mijn mening juist en volgens de bedoelingen van de bepalingen. Het onderscheid tussen arbeidsvoorwaardenbepalingen en arbeidsomstandighedenbepalingen is trouwens niet altijd even scherp te maken. Wat bijvoorbeeld te denken van de CAO-bepalingen waarin aan de werknemer recht wordt gegeven op de verstrekking van veiligheidskleding door de werkgever?

In elk geval: in het algemeen bestaat er voor de individuele werknemer de mogelijkheid om zijn aan de CAO ontleende individualiseerbare rechten op

$99 \mathrm{Bij}$ twijfel is dan nog altijd een vordering via een derdenbeding mogelijk of een beroep op art. $1638 z$ BW. W.J.P.M. Fase, CAO-recht, Alphen a/d Rijn 1982, p. 59-61. 
het gebied van de arbeidsomstandigheden voor de rechter af te dwingen. Hier moet onmiddellijk aan toegevoegd worden dat de juridische en praktische problemen die in de voorgaande paragraaf kort geschetst zijn, uiteraard ook hier een rol spelen.

Ten aanzien van de CAO-bepalingen is er in vergelijking met de actiemogelijkheden op grond van de bepalingen in het $\mathrm{BW}$ en/of de arbeidsovereenkomst (althans voor zover het gaat om bepalingen die niet ontleend zijn aan een $\mathrm{CAO}$ ) nog wel een andere mogelijkheid. Dat is de handhaving van de bepalingen door de contracterende organisaties zelf. Voor de werknemer dus de vakbond, die bij de rechter op grond van eventuele wanprestatie nakoming van de CAO (of eventueel schadevergoeding) kan vorderen (artt. 9 lid 2, 15 en 16 WCAO). In de praktijk moet daar echter niet al te veel van verwacht worden: 'Slechts in principiele zaken, of wanneer het optreden van de vakvereniging duidelijk efficiènter is dan het procederen van de arbeider op eigen naam, zal de vakorganisatie soms tot het instellen van een rechtsvordering overgaan. '"1n0

Geconcludeerd kan worden dat individuele werknemers zowel kwantitatief als kwalitatief niet veel méér rechten op het gebied van de arbeidsomstandigheden aan de CAO kunnen ontlenen dan zij al hebben op grond van wet en overeenkomst. Uitzonderingen worden onder meer gevormd door het bestaan van een geïnstitutionaliseerde klachtenregeling, door het toekennen van rechten op informatie en door een ruimere mogelijkheid om het werk neer te leggen dan art. 38 Arbowet toelaat. Zij gelden echter voor een (kleine) minderheid. Ook de handhavingsmogelijkheden van de betreffende CAO-bepalingen zijn niet beduidend beter.

\section{De werknemer in de WOR}

In tegenstelling tot de Arbowet, het $\mathrm{BW}$, de arbeidsovereenkomst of de $\mathrm{CAO}$ vormt de WOR geen directe rechtsbron voor de positie van de individuele werknemer op het gebied van de arbeidsomstandigheden. Overigens rekent de or het in het algemeen ook niet tot zijn taak om individuele problemen van werknemers te behandelen. ${ }^{101}$ (Dit wordt natuurlijk anders als blijkt dat het probleem een collectieve strekking heeft - en dat zal met betrekking tot de arbeidsomstandigheden nogal eens het geval kunnen zijn). Illustratief hiervoor is dat uit recent onderzoek (1986) is gebleken dat (slechts) 1.5\% van de ondernemingsraden een spreekuur kent voor individuele personeelsleden. ${ }^{102}$ Hoewel deze taakuitvoering in het licht van de doelstelling van de WOR te

100 H.L. Bakels, Kluwer, Schets van het Nederlands Arbeidsrecht, Deventer 1987 (achtste druk), p. 171 .

101 Vgl. SER-advies 1981 , nr. 14, t.a.p. p. 14

102 I.C. Looise, J.Z. Heijink, De or en zijn bevoegdheden, Nijmegen, 1986, p. 113. Op de betreffende vraag heeft $10 \%$ van de geinterwiewde or-voorzitters en or-leden geen antwoord gegeven. In theorie zou het in de tekst genoemde percentage dus ook $5 \%$ of $25 \%$ kunnen zijn. (Over dit onderzoek noot 109 van hoofdstuk III). 
billijken is, zou het wellicht een van de oorzaken kunnen zijn van de soms onverschillige, of zelfs negatieve, houding van werknemers tegenover 'hun' or. ${ }^{103}$ Uit het bovengenoemde onderzoek blijkt dan ook dat de totale invloed van de achterban op het or-werk door slechts $12 \%$ van de or-voorzitters en $13 \%$ van de or-leden als krachtig wordt ervaren, terwijl $86 \%$ (resp. $83 \%$ ) daarentegen van mening is, dat de or weinig of geen impulsen uit de achterban krijgt. ${ }^{104}$ Dit beeld wordt door een ander onderzoek (1987) bevestigd. Uit de resultaten van dit onderzoek blijkt dat $74 \%$ van de ondervraagde or-leden veronderstelt dat de werknemers weinig tot geen belangstelling hebben woor het or-werk. ${ }^{105}$ Dat is betreurenswaardig, omdat aan de or een zeer belangrijke taak is toegedacht in het vorm geven van het arbeidsomstandighedenbeleid in de onderneming, terwijl dit beleid nu juist de individuele werknemer zeer direct raakt.

Maar - los van een aantal feitelijke gegevens - hoe staat het met de juridische mogelijkheden voor de werknemer om invloed te kunnen uitoefenen op de or op basis van de WOR? In de eerste plaats moet natuurlijk genoemd worden het recht om de or te kiezen en om erin gekozen te worden. Actief kiesrecht hebben personen die gedurende ten minste zes maanden in de onderneming werkzaam zijn geweest en passief kiesrecht die dat gedurende ten minste een jaar zijn geweest (art. 6 leden 2 en 3 WOR). Ten aanzien van een onderneming waarin in de regel minder dan 100 personen werken en waarvoor een or is ingesteld, geldt zowel voor het actieve als het passieve kiesrecht dat de werknemers ten minste een jaar in de onderneming werkzaam zijn geweest en dat zij gedurende ten minste een derde van de normale arbeidstijd in de onderneming werken (art. 35a lid 1 onder c). Iedere kiesgerechtigde werknemer kan, na verplichte bemiddeling door de bedrijfscommissie, bij de kantonrechter de naleving vorderen van het in de WOR bepaalde inzake het instellen van een or (art. 36). De ondernemer dient ervoor te zorgen dat werknemers die op een kandidatenlijst staan of gestaan hebben, die lid zijn of geweest zijn van de or of van een or-commissie, niet daardoor benadeeld worden in hun positie binnen de onderneming (art. 21 lid 1). Naast de or kan iedere werknemer van deze bepaling de naleving vorderen bij de kantonrechter (art. 36 lid 3). Bovendien geldt voor leden van de or en de commissies een ontslagverbod, waarop echter enkele titzonderingen bestaan (art. 21 lid 2 en lid 5). Voor werknemers die

103 Het probleem achterban-or is al langer in de wooral niet juridische literatuur beschreven. Vgl. M. Mulder, Omgaan met macht, Amsterdam 1978 (tweede druk), m.n. p. 193-197 en Het werk van de ondernemingsraad in de jaren tachtig, - moeilijkheden en mogelijkheden -, De zellstandige ondernemingsraad, Leiden/Antwerpen, p. 15-16.

104 J.C. Looise, J.Z. Heijink, t.a.p. p. 113.

105 J. Acampo, P.E.J. Kunst, J. Soeters, A. Woltmeijer, Or-lidmaatschap, loopbaan van en vertoop, Rijksuniversiteit Limburg en CNV, Utrecht/Mastricht, juni 1987, p. 41. Het ging: in dit onderzoek om gegevens over het verloop van or-leden en de inhoud van het or-lidmaatschap op het dagelijks functioneren. Er werden 286 zittende en 239 ex-or-leden, afkomstig uit 54 ondernemingsraden benaderd voor het invullen wan een vragenlijst. Er kwam een respons. van $78 \%$. Aparte vragenlijsten werden verstuurd aan de voorzitter en/of secretarissen van de deelnemende ondememingsraden. Van de 54 verstuurde vragenlijsten werden er 52 terugontvangen. 
anderszins bij de or betrokken zijn (geweest), geldt een ontslagbescherming (art. 21 lid 3). Vermelding verdient in dit verband de in het voorjaar van 1987 verschenen 'Aanbevelingen over de rechtspositie van or-leden' van de SER. Dit model 'sociaal-statuut' draagt echter een algemeen en weinig concreet karakter, bedoeld als het is voor alle or-plichtige organisaties.

Hoewel in beginsel dus elke werknemer tot or-lid kan worden gekozen, en in die hoedanigheid ook bescherming geniet, blijken er in de praktijk nogal wat eisen gesteld te worden aan een effectief participeren in een geinstitutionaliseerd overlegorgaan als de or, eisen waarvan wellicht een zekere prohibitieve werking kan uitgaan. Het gaat daarbij onder meer om opleiding, acceptatie door andere werknemers, deskundigheid en de bereidheid om buiten werktijd tijd in het overleg te steken. ${ }^{106}$ Dit speelt uiteraard een grotere rol naarmate de positie in de or geprononceerder is. Zo blijkt het functieniveau van or-voorzitters over het algemeen hoger te liggen dan dat van de overige or-leden, die vooral $(65 \%)$ een uitvoerende of een ondersteunende functie vervullen. Uit hetzelfde onderzoek blijkt de lengte van het dienstverband van de or-leden in hun onderneming op gemiddeld 14 jaar te liggen en voor de voorzitters op gemiddeld 16 jaar: werknemers dus die al geruime tijd in vaste dienst zijn. In vergelijking met de organisatiegraad van het totale personeel van de onderzochte ondernemingen is die van or-leden zeer hoog: de geschatte organisatiegraad-exacte gegevens ontbreken veelal - bedraagt $30 \%$, tegen $67 \%$ voor de or-leden. ${ }^{107}$

Ik geef deze onderzoeksresultaten hier weer, omdat het erop lijkt dat structureel in de or groepen werknemers misschien wel vertegenwoordigd, maar in elk geval niet zelf aanwezig zijn. En het lijkt niet onwaarschijnlijk dat het ook deze werknemers zijn, wier arbeidsomstandigheden het meest problematisch zijn, en wier positie in de onderneming het meest kwetsbaar is.

Een andere manier om niet-or-leden zeer direct te betrekken bij het or-werk op het gebied van de arbeidsomstandigheden is het lidmaatschap, bijvoorbeeld namens een afdeling of werkeenheid, van de commissie VGW. In het algemeen is dit een $\mathrm{zgn}$. vaste commissie, ingesteld krachtens art. 15 lid 1 WOR. In het vorige hoofdstuk heb ik deze commissie aan de orde gesteld. In een dergelijke commissie kunnen ook niet-or-leder deelnemen - mits de orleden een meerderheid in de (vaste) commissie behouden. Uit een onderzoek uit 1983 van het GBIO is echter gebleken dat ook op deze manier betrekkelijk weinig werknemers direct betrokken zijn bij het arbeidsomstandighedenwerk van de or en zijn commissie(s). In de door de or ingestelde (in totaal 135) commissies in de onderzochte 100 plus ondernemingen zaten in $75 \%$ van de commissies geen vertegenwoordigers van afdelingen in de onderneming, in $17 \%$ slechts 1 of 2 vertegenwoordigers van afdelingen en in $8 \% 3$ à 9 vertegenwoordigers. In $95 \%$ van de gevallen zaten er geen vakbondskaderleden (niet-

106 A. Koopman-Iwema, Macht, motiwatie, medezeggenschap, een studie naar partícipaticf gcdrag van leden van overlegorganen in industriële bedrijven, Nijmegen 1980 .

107 J.C. Looise, J.Z. Heijink, t.a.p. p. 106-109. 
or-leden) in de commissie. De werkgever participeerde in de commissie in $12 \%$ van de gevallen en een of meer personeelsfunctionarissen in $24 \%$. Voorts zaten er in $20 \%$ van de gevallen een veiligheidskundige en in $10 \%$ een vertegenwoordiging van de bgd in. ${ }^{108}$

Het ITS-onderzoek (1988) geeft als resultaat dat van de onderzochte VGWcommissies van de or de helft alleen uit or-leden bestaat en de andere helft voor het grootste deel. De overige VGW-commissies (een derde van het totale aantal onderzochte commissies) bestonden voor het grootste deel uit niet-orleden, met name functionarissen van de onderneming. Maar deze laatste commissies zijn geen commissies van de or en missen ook de op de WOR en de Arbowet gebaseerde bevoegdheden van een vaste or-commissie. ${ }^{109} \mathrm{Het}$ lijkt er dus op dat ook via dit kanaal een directe betrokkenheid van 'gewone' werknemers die geen or-lid zijn, moeizaam of nauwelijks gerealiseerd wordt.

Kan nu de individuele werknemer anders dan te kiezen voor of zich te laten kiezen in de or, juridisch bewerkstelligen dat dit orgaan gehoor geeft aan zijn vragen en problemen op het gebied van de arbeidsomstandigheden? De WOR voorziet niet in individuele actiemogelijkheden voor de werknemer in zaken die liggen op het gebied van de taakuitoefening door de or - maar dit betekent niet dat ze er in de praktijk ook niet kunnen zijn. In zijn reglement dient de or zijn werkwijze te regelen (art. 14 lid 1). Dit zou kunnen betekenen dat de or regelingen stelt over de wijze waarop de niet-or-leden in de onderneming betrokken kunnen worden bij het arbeidsomstandighedenwerk van de or, bijvoorbeeld door de bepaling dat onderwerpen op dat gebied ook door hen op de agenda kunnen worden geplaatst, dat zij dan ook het woord kunnen voeren in de or-vergadering of dat regelmatig contact met hen wordt onderhouden, bijvoorbeeld in de vorm van enquêtes, waarvan de resultaten dan zowel intern als in de overlegvergadering met de werkgever kunnen worden besproken. ${ }^{10}$ Gegevens over het feitelijk voorkomen van dergelijke regelingen ontbreken mij echter. Het blijft in elk geval louter een zaak van de or of hij vindt dat iets dergelijks nodig is: juridisch kan de individuele werknemer daar niets aan doen.

In theorie kan hij dat wel indien de or handelt in strijd met zijn in de WOR neergelegde rechtsplicht. In dit verband kan art. 28 lid 1 genoemd worden, waarin de or de taak krijgt opgedragen om zoveel als in zijn vermogen ligt de naleving te bevorderen van, onder meer, de voorschriften ter bescherming van de veiligheid en de gezondheid van de in de onderneming werkzame personen (zie over deze bepaling hoofdstuk III, paragraaf 3.2.2.). Indien de or nu, desgevraagd door een werknemer, weigert om deze verplichting na te komen, dan

108 In het onderzoek ging het in $76 \%$ om een vaste commissie wan de or. GBIO, or-cursussen onderzocht, Arbo-scholing en -vorming in ontwikkeling, 's Gravenhage, december 1983, p. 13.

109 ITS-onderzoek 1988 , t.a.p. p. 33.

110 Het woorbeeld-reglement van de SER schenkt hier nauwelijks aandacht aan. Dat is jammer, temeer ook omdat het bijna gecanoniseerde uitlegboekje over de WOR. Inzicht van het ministerie van Sociale Zaken en Werkgelegenheid 'sterk aanbeveelt" om het voorbeeldreglement van de SER te volgen (Inzichi, 1987, vijfde druk p. 28). 
is het denkbaar dat deze werknemer nakoming en eventueel schadevergoeding vordert bij de civiele rechter wegens onrechtmatig gedrag van de or zeker bij (dreigende) schadetoebrenging. De mogelijkheid blijft echter theoretisch. Het is immers in het algemeen al moeilijk voorstelbaar dat een werknemer tegen zijn or gaat procederen en daar komt in dit geval bij dat het zeer lastig zal zijn de rechter ervan te overtuigen dat de or niet zoveel als in zijn vermogen ligt, deze taak heeft vervuld; bovendien ligt het natuurlijk veel meer voor de hand om de werkgever terzake aan te spreken: hij is immers de eerst verantwoordelijke èn aansprakelijke voor het arbeidsomstandighedenbeleid in de onderneming. ${ }^{111}$

In de WOR wordt wel de betrokkenheid van niet-or-leden bij de arbeidsomstandigheden in ondernemingen met minder dan 100 werknemers expliciet benadrukt. Voor de kleinere ondernemingen ligt dat natuurlijk ook meer voor de hand. Het gaat om de volgende bepalingen. Ten aanzien van een onderneming waarin in de regel minder dan 100 personen werkzaam zijn en waarvoor een or is ingesteld, geldt volgens art. 35a lid 1 onder $\mathrm{g}$ WOR de verplichting voor de ondernemer om advies te vragen aan de or over een besluit als genoemd in art. 25 WOR slechts indien en voor zover het betrokken besluit kan leiden tot een belangrijke verandering van - onder meer - de arbeidsomstandigheden van ten minste een vierde van de in de onderneming werkzame personen. Op deze manier is in elk geval ten aanzien van de kleinere ondernemingen getracht enige invulling te geven aan het, toch in veel gevallen multiinterpretabele begrip 'belangrijk' in art. 25 .

In ondernemingen met in de regel ten minste 10 werknemers maar met minder dan 35 , die meer dan een derde van de normale tijd werken en waarvoor geen or is ingesteld, is de ondernemer verplicht om deze werknemers ten minste tweemaal per jaar in de gelegenheid te stellen met hem te vergaderen. Dit is hij ook indien ten minste een vierde van de werknemers hierom met redenen omkleed verzoekt (art. 35 b lid 1). De ondernemer dient de werknemers tijdens zo"n vergadering in de gelegenheid te stellen advies uit te brengen over elk door hem voorgenomen besluit dat kan leiden tot - onder meer - een belangrijke verandering van de arbeidsomstandigheden van tenminste een vierde van de werknemers, tenzij de betrokken aangelegenheid inhoudelijk al in de toepasselijke CAO is geregeld (art. 35b lid 5). In beginsel is hier dus sprake van een individueel adviesrecht inzake arbeidsomstandigheden voor elke werknemer. ledere werknemer en de vakbond kunnen van het bovenstaande bovendien naleving vorderen bij de kantonrechter (art. 36a).

Afgezien van deze laatste bevoegdheden kan geconcludeerd worden dat de individuele werknemer in de WOR juridisch nauwelijks een rol speelt - ook niet ten aanzien van de arbeidsomstandigheden. Dit betekent dat de welwillendheid van de or in de praktijk doorslaggevend zal zijn voor het antwoord op de vraag hoe het gesteld is met de positie en de invloed van de individuele 
werknemer op het door de or op basis van de WOR te voeren arbeidsomstandighedenbeleid.

De betrokkenheid c.q. de invloed van werknemers op de or lijkt in elk geval manifest te zijn indien de vakbond sterk vertegenwoordigd is in de onderneming en (daarmee) in de or. Zo heeft onderzoek van Buitelaar en Vreeman uitgewezen dat, wanneer resultaten van onderzoek naar arbeidsomstandigheden door werknemers in de or komen, het van de positie van de Industriebond FNV in de or afhangt of behandeling leidt tot een programma van aanpak. Indien de fractie van de Industriebond de meerderheid heeft, is de kans hierop het grootst - hoewel ook geen $100 \% .12$.

De or kan bovendien een juridische basis leggen voor participatie van werknemers bij het door hem te voeren arbeidsomstandighedenbeleid door bepalingen terzake op te nemen in zijn reglement, waarbij uitdrukkelijk ook gedacht moet worden aan de samenstelling wan de commissie VGW.

Individuele werknemers zijn echter vrijwel machteloos wanneer het gaat om het juridisch kunnen afdwingen van participatie bij of controle van het door de or te voeren of gevoerde beleid. In het licht van de structuur en de strekking van de WOR is dat begrijpelijk. In het licht van de strekking van de Arbowet is dat te betreuren.

\section{De werknemer en het klachtrecht}

Tijdens de behandeling van de Arbowet in de Tweede Kamer deelde de minister desgevraagd mee dat hij geen aanleiding zag om "thans in dit wetsontwerp de werknemers een individueel klachtrecht toe te kennen nu deze zaak nog in discussie is bij de SER'. ${ }^{113}$ De (van de D'66 fractie afkomstige) vraag werd vooral gesteld met het oog op de kleinere ondernemingen waarin geen or werkzaam is en waarin de individuele werknemer (dus) een geformaliseerde en rechtens vastgelegde mogelijkheid zou moeten hebben om zijn stem te doen horen. ${ }^{114}$

Ook om een andere reden zou opneming van een dergelijk recht in de Arbowet, vooruitlopend op, of eventueel nog los van, een algemene wettelijke regeling terzake, nog zo gek niet zijn. Uit een onderzoek van 1975 was namelijk gebleken dat er onder werknemers betrekkelijk veel onvrede bestond over zaken met betrekking tot de veiligheid en de gezondheid (vooral stof, warmte en gelluid) en dat die onvrede ook relatief vaak werd omgezet in klachten. ${ }^{115}$

112 W. Buitelaar, R. Vreeman, Vakbondswerk en kwaliteit van de arbeid, Nijmegen 1985, p. 544.

113 TK 1979-1980, 14.497, nr. 11 (Nota nat aanleiding van het Eindverslag), p. 25.

114 Vgl. TK 1978-1979, 14.497, nr. 9 (Eindverslag), p. 20.

115 H.P.W. Schmitx, G. Laenen en H.A.J. Koekenbier, Onvrede en klanchten van werknemers; een studie naar het ontstaan, de opvang en de oplossing wan klachten van werknemers teli behoeve van het beleid, Utrecht, Stichting Wetenschappelijk onderzoek vakcentrales Nijmegen, Instituut voor toegepaste sociologie, 1975, m.n. p. 18.

Het onderzoek strekte zich uit over 93 ondernemingen, waarwan er 59 meer diepgaand onderzocht werden. 
Aanleiding voor dit onderzoek (dat voorafgegaan werd door een verkennende studie op dit terrein in opdracht van de SER) was de Aanbeveling betreffende het onderzoek van klachten van de ILO van 1967. ${ }^{116}$ Volgens art. 2 van de Aanbeveling dient iedere werknemer die, individueel of gezamenlijk met andere werknemers meent reden tot klagen te hebben, het recht te hebben om deze klacht naar voren te brengen zonder dat daaruit voor hem (of hen) enig nadeel uit voortvloeit en om deze klacht te laten onderzoeken volgens een 'passende procedure'.

Zowel de Aanbeveling als het bovengenoemde onderzoek hebben ertoe geleid dat de minister in 1977 advies heeft gevraagd aan de SER over een wettelijke regeling inzake het klachtrecht van individuele werknemers. ${ }^{17}$ Het advies waarop de minister in de aanhef van deze paragraaf doelde, verscheen in 1981. ${ }^{118}$ De SER adviseerde unaniem om het klachtrecht wettelijk vast te leggen. Anders dan het voorstel in de adviesaanvraag pleitte de SER echter niet voor een gedetailleerd uitgewerkte regeling, maar voor een korte, globale wet. Aan de sociale partners zou vervolgens overgelaten moeten worden om een op maat gesneden regeling te treffen. De volgende drie materiële beginselen zouden aan de wet ten grondslag moeten liggen. In de eerste plaats dient uitdrukkelijk het recht erkend te worden van iedere werknemer om te klagen over hem persoonlijk betreffende aangelegenheden die verband houden met zijn arbeidsovereenkomst zonder dat hij om die reden in zijn positie wordt benadeeld. In de tweede plaats dient het recht te worden erkend van de betreffende werknemer om, op een schriftelijk ingediende klacht, een schriftelijke en gemotiveerde beslissing te krijgen van zijn werkgever. In de derde plaats moet die werknemer het recht krijgen om zich bij de indiening en verdere behandeling van de klacht te laten bijstaan door een collega-werknemer die optreedt als erkend klachtenbegeleider en om die reden evenmin in zijn positie benadeeld mag worden. De werknemer behoudt uiteindelijk het recht om zich op de rechter te beroepen.

De SER was eveneens unaniem overtuigd van het nut van de invoering door werkgevers van deugdelijk opgezette klachtenreglementen. Deze kunnen door de werkgever worden vastgesteld met, als die er is, instemming van de or (art. 27 lid 1 onder k), dan wel worden vastgesteld bij CAO.

De SER was echter verdeeld over de wenselijkheid dat aan werkgevers ook de wettelijke opdracht gegeven zou worden om in een reglement het klachtrecht nader uit te werken op een aantal in de wet te noemen onderwerpen. Een minderheid van de SER, bestaande uit de CNV-leden en een aantal kroonleden, pleitte vóór een dergelijke opdracht tot regelgeving, althans voor werkgevers die ingevolge de WOR een or moeten instellen. Volgens deze minder-

116 Aanbeveling nr. 130, Tractatenblad 1969, nr. 174.

117 De Aanbeveling vraagt in art. 1 niet per se om een wettelijke regeling. Realisatie kan behalve door middel wan nationale wetten en voorschriften ook door collectieve arbeidsovereenkomsten, ondernemingsreglementen, scheidsrechtelijke uitspraken, of op iedere andere wijze, die overeenkomstig het nationalal gebruik passend lijkt.

118 SER, Advies inzake het kłachtrecht van individuele werknemers, Den Haag, 1981, nr. 14. De adviesaanvraag is als bijlage opgenomen. 
heid zou geregeld moeten worden de wijze van klagen, de klachtenopvang, de klachtenbegeleiding, de klachteninstantie bij beroepsprocedures, het informatierecht en de geheimhouding. De meerderheid van de SER (bestaande uit ondernemersleden, de FNV en een aantal kroonleden) was tegen opneming in de wet van deze opdracht aan werkgevers. Op de argumenten van voor-en tegenstanders kom ik hieronder terug.

In november 1984 deelde de minister in een brief aan de Tweede Kamer over de standpuntbepaling ten aanzien van een ander SER-advies, namelijk over het sociaal beleid in de onderneming, mee dat hij voornemens was overeenkomstig het SER-advies terzake een wetsvoorstel in te dienen inhoudende een globale regeling van het klachtrecht met als kern de drie in het SER-advies genoemde beginselen. ${ }^{119}$ Hoewel het voorgenomen wetsontwerp niet is gesneuveld tengevolge van de dereguleringsoperatie, blijkt er ook niet erg veel haast mee gemaakt te worden: elf jaar na de adviesaanvraag aan de SER is er nog steeds geen wetsontwerp bij de Tweede Kamer ingediend, terwijl er overigens geen enkele aanwijzing is dat een dergelijke regeling voor werknemers van minder betekenis zou zijn geworden. ${ }^{120}$

Indien er nu een wetswoorstel komt conform het advies van de SER, waar het toch nog wel naar uitziet, hoe dient dat dan beoordleeld te worden in het licht van de te verwachten praktische betekenis voor de klachten van werknemers over hun arbeidsomstandigheden?

Het feit dat in principe gekozen is voor een wettelijke regeling en bijvoorbeeld niet voor een onverplichte regeling bij CAO - een mogelijkheid die de ILOAanbeveling uitdrukkelijk biedt - is toe te juichen: het onderwerp is tè belangrijk om het alleen aan de sociale partners over te laten.

Juist daarom is het teleurstellend dat een meerderheid van de SER opteert voor een globale regeling zonder dat een voor iedere onderneming (minimaal) verplichte uitwerking van een reglement wordt voorgeschreven. ${ }^{121}$ De argumenten voor deze minimale opzet zijn globaal tweeërlei. Een wet met een minder globale regeling zal zekere inhoudelijke grenzen moeten aangeven over de wijze waarop werkgevers vorm en inhoud dienen te geven aan elk van de genoemde onderwerpen in het reglement. Dit zou ertoe kunnen leiden dat weliswaar een reglement tot stand komt volgens de wens van de wetgever

119 TK $1984-1985,18.711$, nr, 1, p. 8.

120 In de toelichiting op de begroting van Sociale Zaken en Werkgelegenheid voor het dienstjaar 1986-1987 werd aangekondigd dat het kabinet 'op korte termijn' een definitief standpunt zou bepalen over een wetswoorstel inzake het klachtrecht van individuele werknemers. TKK 1986$1987,19.700$, hoofdstuk XV, mr. 2, p. 37. In de toelichting voor het dienstjaar 1987-1988 staat: "Dezer dagen zal een afronding plaatsvinden van de beraadslagingen over de indiening van een wetsvoorstel inzake Klachtrecht van individuele werknemers, aan de hand van het terzake ontvangen advies van de Raad van State. TK 1987-1988, 20.200, hoofdstuk II, nr. 2 , p. 19. In mei 1988 was echter nog steeds geen wetsontwerp bij de Tweede Kamer ingediend.

121 Ook in de meeste literatuur over dit onderwerp is dit standpunt gevolgd. VIg. H.L. Bakels, SMA, 1981, t.a.p. p. 302-310 (zie ook noot 90); F. Koning, het SER-advies inzake het klachtrecht van individuele werknemers, SMA, 1981, p. 843-848;P.F. van der Heijden, Een eerlijk proces in het sociaal recht?, Deventer 1984, p. 151 en eerder in OR-informatie, november 1981, p. 17. 
maar ten aanzien waarvan niet verzekerd is dat het weerklank vindt bij de werkgever enlof zijn werknemers. Daarnaast zou een dergelijke wettelijke regeling problemen kunnen oproepen op het punt van de verzekering van naleving van de opdracht. Gedoeld wordt hierbij op de positie van de bedrijfscommissie die geroepen kan zijn om het reglement vast te stellen indien de werkgever er niet in slaagt om het vast te stellen volgens de vereisten van de wet en/of dat het de instemming van de or niet verkrijgt (art. 27 lid 1 onder $k$ WOR). Deze taak zou voor de bedrijfscommissie te zwaar en te moeilijk zijn. De beide argumenten zijn niet overtuigend. In de eerste plaats lijkt het erop dat de opdracht tot regelgeving ten onrechte gelijkgesteld wordt met het bepalen van inhoudelijke normen. Wèl worden zekere minima gesteld, maar het is van tweeën één: of de wetgever ziet het belang in van de regeling van een aantal onderwerpen in het reglement en geeft daarvoor dan ook aanwijzingen die gevolgd moeten worden, ook als sommige belanghebbenden het daar niet mee eens zijn, of men laat het al dan niet instellen van het reglement en de inhoud ervan over aan de werkgever die dan de vrijheid heeft om te komen tot slechts een minimale, symbolische uitwerking. In het laatste geval moet ook niet hoog opgegeven worden over het grote belang van het onderwerp. Hoewel consensus tussen de werkgever en de werknemers in de onderneming van groot gewicht is, mag dat niet het leidend beginsel zijn voor een wetgever die constateert dat fundamentele waarden in het geding zijn die in de praktijk onvoldoende tot hun recht komen. In dit licht zijn ook de (technische, juridische) problemen die gesignaleerd worden ten aanzien van het optreden van de bedrijfscommissie weliswaar niet irrelevant, maar onvoldoende zwaar om om die reden geen wettelijke opdracht tot regelgeving te verstrekken. In de praktijk zal het met die problemen waarschijnlijk ook wel meevallen: in de eerste plaats is een dergelijke bevoegdheid voor de bedrijfscommissie niet helemaal nieuw (vgl. de artt. 18 lid 3, 22 lid 2, 23a lid 5 en 31 lid 1 WOR) en in de tweede plaats zal het aantal ter bindende beslissing voor te leggen reglementen niet zo groot zijn, juist omdat de wet de onderwerpen al noemt, en de invulling aan minimum normen is gebonden. 122

Ik ben het derhalve eens met de minderheid in de SER dat een wet die niet erg veel verder gaat dan de erkenning van het klachtrecht te weinig reële betekenis heeft en vermoedelijk niet in betekenende mate zal bijdragen aan de oplossing van het probleem dat werknemers er dikwijls niet toe komen om hun gevoelens van onvrede in klachten te uiten of op hun klachten geen behoorlijk antwoord krijgen. Indien de werkgever op het punt van invoering en inhoud van een klachtenreglement wrijheid van beslissing wordt gelaten, bestaat de kans dat juist ondernemingen war een klachtenreglement het meest nodig is, daar-

122 De positie van de bedrijfscommissie zal trouwens, indien het SER-advies van 1986 over vereen woudiging van de WOR door de wetgever wordt gevolgd, geheel anders van kavakter worden: meer bemiddelend en adviserend dan beslissend. Dat laatste zou met name de kantonrechter moeten doen.

SER, Advies inzake vereenvoudiging van de Wet op de ondernemingsraden, Den Haag 1986 , nr. 14. 
van verstoken zullen blijven. Bovendien behoeft de vrijheid om over de inhoud van het reglement overleg te voeren tussen de werkgever enerzijds en de werknemers (via de vakbond of de or) anderzijds niet aangetast te worden zolang de wet, die aangeeft welke onderwerpen geregeld moeten worden, daarmee niet ook inhoudelijk concrete en gedetailleerde aanwijzingen bevat. Bovengenoemde opvatting vindt ook steun in de resultaten van een onderzoek dat het Sociologisch Instituut van de Rijksuniversiteit te Leiden in de jaren 1980-1981 uitvoerde over de mate van effectiviteit van een klachtenregeling. ${ }^{123}$ Hieruit bleek dat het effectief gebruik van een klachtenregeling afhankelijk is van voorwaarden die in de regeling zelf, in de bedrijfsstructuur en in het bedrijfsklimaat gelegen zijn. Een belangrijke conclusie luidde dat de aanwezigheid van een erkend en vastgelegd recht tot klagen in de onderneming op zich zelf een onvoldoende voorwaarde is voor klachtoplossing, of zelfs maar voor het gebruik maken van de geboden regeling. Daarnaast signaleren de onderzoekers de 'wonderlijke paradox' dat enerzijds, indien de bedrijfsvoorwaarden als ongunstig worden beoordeeld, de noodzaak van de regeling wordt onderstreept, terwijl anderzijds deze zelfde bedrijfsvoorwaarden fungeren als een belangrijke reden waarom de regeling minder goed aan haar doelstel.ling beantwoordt. ${ }^{124} \mathrm{Al}$ vind ik deze paradox nu niet zó verwonderlijk, de constatering blijft natuurlijk van belang en vormt een reden te meer voor ondersteuning van het minderheidsstandpunt van de SER: enerzijds de wettelijke dwang dàt belangrijke condities in het reglement terecht komen en anderzijds voldoende vrijheid om over de concrete inhoud te kunnen onderhandelen en consensus te verkrijgen in elke afzonderlijke onderneming.

De pleitbezorgers in de SER van de wettelijke opdracht tot regelgeving meenden dat de volgende onderwerpen in het reglement zouden moeten voorkomen: de wijze van klagen, de klachtenopvang, de klachtenbegeleiding, de klachteninstantie, het informatierecht en de geheimhouding. Zij zijn voor de hand liggend. In elk geval lijkt het mij van belang dat het begrip klacht niet al te eng wordt gedefinieerd en geïnterpreteerd en dat ditzelfde geldt voor de wijze waarop de klacht geventileerd wordt. De eis om dat schriftelijk te doen bijvoorbeeld is, zeker in eerste instantie, onnodig drempelverhogend. Degenen die in eerste instantie belast zijn met het in ontvangst nemen van de klacht, dienen de bevoegdheid en de instructies te hebben om effectief en soepel te kunnen opereren. ${ }^{125}$ De klachtenbegeleider dient vrij gekozen te kunnen worden zowel in als buiten de collega-werknemers. Indien het een collega betreft, dient hij voldoende tijd te krijgen voor zijn begeleiding en mag hij door zijn werkzaamheden niet in zijn positie in de onderneming worden geschaad.

Van groot belang is de samenstelling van een (beroeps)instantie waar de on-

123 E.A. Mante-Meijer, J.J.G.J. wan Helvert, Individueel klachtrecht, Het SER-advies getoetst aan de sociale werkelijkheid, SMA, 1982, p. 101-120. Het onderzoek strekte zich uit over vier Nederlandse ondernemingen (een groot bankbedrijf, een verzekeringsbedrijf, een multinational en een groot productiebedrijf) met in totaal 125.375 werknemers.

124 E.A. Mante-Meijer, J.J.G.J. van Helvert, t.a.p. p. 119.

$125 \mathrm{Vgl}$ K. lest, Behandeling van klachten, OR-informatie, juni 1985, p. 23. 
opgeloste klachten uiteindelijk terechtkomen. Er dient een garantie voor onafhankelijkheid te bestaan, of het nu gaat om een louter adviserende bevoegdheid aan de werkgever of om een, namens de werkgever beslissende bevoegdheid. ${ }^{126}$ Een in beginsel tripartite samenstelling lijkt aanbevelenswaardig: een vertegenwoordiging van de werknemers en van de werkgever en een onafhankelijke deskundige.

Voor deze laatste figuur is wel eens gedacht aan de Arbeidsinspectie. ${ }^{127}$ De suggestie ben ik later niet meer tegengekomen. Dat lijkt me terecht. Immers, weliswaar zijn de ambtenaren van de Arbeidsinspectie als het goed is in het algemeen redelijk op de hoogte van de toestand in de ondernemingen in hun district en zijn zij daarnaast onafhankelijk, daar staat tegenover dat deze voorgestelde nieuwe functie zich slecht verhoudt met een aantal (wettelijke) bevoegdheden, zoals met name het geven van een formele eis of een aanwijzing al dan niet na een (anonieme) klacht. Materieel zou hun mening in een beroepsinstantie kunnen neerkomen op een eis of aanwijzing, zonder dat daartoe de voorgeschreven proceclure is gevolgd of dat er een beroep op de minister openstaat. Zeker indien de klachteninstantie beslissingsbevoegdheid heeft namens de werkgever, zou de positie van de Arbeidsinspectie in een dergelijke instantie buitengewoon onduidelijk kunnen worden.

Maar voor een onafhankelijke deskundige behoeft niet per se buiten de onderneming gezocht te worden: gedacht zou ook kunnen worden aan de bedrijfsarts of de veiligheidskundige, die immers een door de Arbowet gegarandeerde onafhankelijke positie in de onderneming innemen. Bovendien zou het mogelijk moeten zijn, bijvoorbeeld omdat het zoeken naar een onafhankelijke deskundige te moeilijk is, of te zwaar in relatie tot de klacht, dat de vertegenwoordiging van de werkgever en van de werknemers tezamen besluiten om zonder zo iemand te werken.

Naast de bovengenoemde aspecten formuleren de opstellers van het Leidse onderzoeksrapport nog enkele andere voorwaarden die van belang zijn voor het functioneren van de klachtenregeling als een effectief instrument voor het oplossen van individuele onvrede. De belangrijkste zijn: een goede voorlichting en (herhaalde) informatie, een bevredigende uitleg van genomen beslissingen naar de klager, gepaard aan een goede rapportage naar de werknemersvertegenwoordiging op ondernemingsniveau, een feedback-mechanisme als onderdeel van de adviesbevoegdheid van de beroepsinstantie, en initiatieven tot nazorg voor de klager en de aangeklaagde. ${ }^{128} \mathrm{Zij}$ lijken mij inderdaad van belang voor het praktisch goed functioneren van een klachtenprocedure.

Tot slot nog iets over de rol van de or. De wettelijke opdracht tot regelgeving die de minderheid van de SER voorstaat zou alleen moeten gelden voor ondernemingen waarin krachtens de WOR een or werkzaam is. Het belangrijkste

126 Volgens van der Heijden is er alleen ten aanzien warn de eerstgenoemde bevoegdheid sprake van zuivere klachtspraak. P.F. van der Heijden, t.a.p. p. 151.

$127 \mathrm{~J}$. Struik, Enkele opmerkingen over de formalisering van het klachtrecht voor de individuele werknemers, SMA, 1973, p. 597.

128 E.A. Mante-Meijer, J J.G.J. van Helvert, t.a.p. p. 119. 
argument hiervoor is praktisch. Op deze manier kan betrekkelijk eenvoudig worden aangehaakt bij de bestaande wettelijke voorzieningen in de WOR. Kennelijk wordt dan (naast het instemmingsrecht van art. 27 WOR) met name gedoeld op de mogelijkheid om de naleving van de verplichte regelgeving in de onderneming af te dwingen via art. 36 WOR. ${ }^{129}$

Op dit punt ben ik het met de minderheid in de SER niet eens. Het zou betekenen dat een meerderheid van de ondernemingen geen opdacht zou krijgen om een klachtenreglement met daarin een aantal voorgeschreven onderwerpen te vervaardigen. Op het belang van een dergelijke opdracht heb ik boven al gewezen. Weliswaar is het juist dat het systeem van de WOR aantrekkelijke aanknopingspunten biedt voor een klachtenregeling en de handhaving ervan, maar dat mag niet betekenen dat in de kleinere ondernemingen, waarin bovendien vaak nog meer aanleiding tot klagen lijkt te bestaan, een dergelijke regeling onverplicht wordt. Wellicht dat voor die ondernemingen aangesloten kan worden bij het systeem van de Arbowet waarin de rol van de or ten aanzien van een aantal vitale onderwerpen overgenomen kan worden door (een meerderheid van) de belanghebbende werknemers of de in de onderneming werkzame vakbond. De vordering tot naleving ten aanzien van het hebben van een rechtsgeldig klachtenreglement kan natuurlijk in beginsel ook gegeven worden aan elke individuele werknemer.

Concluderend kan gesteld worden dat voordelen van de introductie van een klachtenprocedure in de onderneming onder meer zijn dat de problemen binnen de onderneming opgelost kunnen worden zonder dat de individuele werknemer meteen naar de gewone rechter behoeft te stappen. De barrières die hij daarbij kan aantreffen, zijn hierboven genoemd. Bovendien is hij niet afhankelijk van de hem vertegenwoordigende organen die, met name ook op het gebied van de arbeidsomstandigheden, in het algemeen het juridische actiemonopolie bezitten. Het wettelijk erkennen van een individueel klachtrecht voor werknemers is derhalve zinvol. Het SER-advies dient op dit punt positief gewaardeerd te worden. Minder waardering kan worden opgebracht voor het voorgestelde vrijblijvende karakter van de implementatie van deze erkenning. Teneinde het klachtrecht niet slechts tot een symbolisch recht te laten verworden, is het een belangrijke voorwaarde dat de wet aan de werkgevers de verplichting oplegt om een klachtenreglement op te stellen waarin tenminste een aantal onderwerpen geregeld zijn. Hoewel ik besef dat met een dergelijke opdracht alleen, het klachtrecht niet onmiddellijk een effectief instrument zal zijn (uiteraard zijn er nog talloze andere, per onderneming verschillende feitelijke factoren van belang, zoals het ondernemingsklimaat, de medezeggen-

129 Koning pleit er bovendien voor om de opdracht tot regelgeving, als dat dan per se zou moeten, niet te richten tot de werkgever, maar tot de or via een uitbreiding van art. 28 WOR. Hierin zou dan ook moeten staan dat de or moet bevorderen dat er een klachtenregeling komt.

Dit lijkt mij niet juist. In de eerste plats moet de werkgever als goed werkgever er als eerst verantwoordelijke en juridisch aansprakelijke voor zorgen dat een dergelijke regeling er komt en in de tweede plaats is "bevorderen" nog altijd iets anders dan dwingend voorschrijven. F. Koning, SMA, 1981, t.a.p. p. 848. 
schapsregelingen en dergelijke), kan het wel een belangrijk element of wellicht sluitstuk vormen om ook op het gebied van de arbeidsomstandigheden te kunnen komen tot een verbetering van de positie van de individuele werknemer. In schril contrast met het ook door de SER geaccepteerde belang hiervan, staat overigens de traagheid waarmee achtereenvolgende kabinetten sinds het SER-advies met initiatieven tot wetgeving komen. 


\section{Enkele concluderende beschouwingen}

\section{Inleiding}

In de voorafgaande hoofdstukken is een beeld geschetst van het recht met betrekking tot de humanisering van de arbeid, de ontwikkeling daarvan en de positie daarin van vooral de werknemer. Een beschrijving van de rol van de andere betrokkenen was hierbij een belangrijk hulpmiddel. In dit hoofdstuk zal ik op grond van mijn bevindingen een aantal conclusies trekken en er enkele beschouwingen aan vast knopen om op die manier een antwoord te formuleren op de in het inleidende hoofdstuk geformuleerde vragen. Sommige conclusies zijn meer of minder expliciet in het voorafgaande al voor het voetlicht gekomen.

\section{Ontwikkeling in beleid en wetgeving}

Gebleken is dat de ontwikkeling van dit rechtsgebied vooral gemarkeerd wordt door veranderingen en aanpassingen van de bestaande publiekrechtelijke wetgeving en het tot stand komen van geheel nieuwe, méér dan bijvoorbeeld door de inhoud van $\mathrm{CAO}$ en/of jurisprudentie, hoewel de laatste ten aanzien van de ontwikkeling van het civiele recht zeker van betekenis is. Waar wetgeving vooral de expressie is van het beleid van de overheid (en sociale wetgeving van het sociale beleid van de overheid), is getracht een korte en globale analyse te geven van dit beleid vanaf het begin van de jaren zeventig onder meer aan de hand van de toelichtingen bij de begrotingen van het Ministerie van Sociale Zaken en Werkgelegenheid over de jaren 1973-1983. Belangrijkste legislatieve producten in deze periode op het gebied van de medezeggenschap en de arbeidsomstandigheden waren respectievelijk de veranderingen in de WOR van 1979 en de Arbowet van 1980.

Het in die periode uitgedragen beleid kan met enkele onderling samenhangende karakteristieken als volgt beschreven worden.

Nadat in de periode ná 1919 vooral doorgeborduurd wordt op het patroon van bescherming van werknemers door een steeds groeiender complex van gedetailleerde regelingen die beogen de gevaren voor de veiligheid en de gezond- 
heid te keren, gaat de overheid vanaf de jaren zeventig zich actief bemoeien, niet zozeer met het bestrijden van het 'on-welzijn', maar met het bevorderen van het welzijn bij de arbeid van de werknemers." Dit beleid past geheel in de sociaal-culturele ontwikkelingen van die jaren en beperkt zich dan ook niet tot het gebied van de arbeidsomstandigheden, maar heeft een veel ruimer bereik. Deze uitbreiding van de overheidszorg zou men, in de woorden van Schuyt, kunnen karakteriseren als "een lijn die loopt van het garanderen van een materieel minimum naar het de facto bewerkstelligen van een optimum, zowel in materieel als in immaterieel opzicht, de bekende individuele ontplooiing". Passend hierbij is ook dat deze individuele ontplooiing als belangrijkste determinant van de humanisering bij de arbeid, oorspronkelijk als doel in zich zelf, als zelfstandige intrinsieke waarde wordt geintroduceerd. Pas in de tweede helft van de jaren zeventig - het ontwerp Arbowet is inmiddels ingediend treedt er mede onder druk van de economische crisis, een zekere omslag op: de formulering in ideële termen van het humaniseringsconcept wordt bijgesteld door een instrumentalisering ervan, waardoor het mede gewaardeerd wordt als bijdrage aan de economische groei en de terugdringing van het ziekteverzuim. ${ }^{3}$ Een, althans voorlopig, laatste stap op de weg naar een correctie uit economische overwegingen van de welzijnsdoelstelling in de Arbowet en tevens resultaat van de dereguleringsoperatie vormt de wetswijziging waardoor het begrip welzijn in de wet gelimiteerd en geconcretiseerd wordt. ${ }^{4} \mathrm{De}$ vereisten in het oorspronkelijke art. 3 lid 1 onder $i$ dat de arbeid zou moeten bijdragen tot zelfontplooiing van de werknemer en een vermeerdering van zijn vakbekwaamheid, zijn als onderdeel van deze operatie geschrapt als zijnde 'te ambitieuze elementen'. 5

Parallel aan deze ontwikkeling wordt de terughoudende rol van de overheid meer benadrukt en daarmee de zelfwerkzaamheid van de sociale partners in het bedrijfsleven. De oorspronkelijke pretentie van de actief zorgende overheid óok ten aanzien van het welzijn van de werknemers bij hun werk, uit het begin van de jaren zeventig, lijkt te zijn stukgelopen op de realiteit van de jaren tachtig, waarin humanisering van de arbeid niet meer louter als doel in zich zelf, maar ook, en misschien zelfs vooral, als instrument ter bereiking van andere, vooral economische doelstellingen wordt gezien. In dat licht kan gesteld worden dat de Arbowet in elk geval op onderdelen de neerslag vormt van een denken over de rol van de arbeid en de betrokkenen hierbij dat inmiddels

1 Zie woor exen concluderende beschouwing over de periode wór 1919 Hooldstuk II, paragraal 5 .

2 C.J.M. Schuyt, De fragmentering van bestuur en beleid in de verzorgingsstaat in: Verzorgingsstaat: de samenlewing alls weeshuis, Alphen a/d Rijn 1984, p. 227 (oorspronkellik verschenen in Mens en Maatschappij, december 1979).

3 Vgl ook H.G. de Gier, Voor alle zekerheid, social beleid in matschappelijk perspectief, Den Haag 1987, p. 115. Volgens de Gier is het streven nat humanisering vande arbeid zelfs een valn de peilers van het door de overheid gevoende volumebeleid, t.a.p. p. 114.

4 Wet van 26 november 1987 , houdende wijziging van de Arbeidsomstandighedenwet en van de Wet op de gevaarlijke werktuigen met betrekking tot deregulering en enige andere onderwerpen (S. 1987,535$)$.

5 TK 1986-1987, 19.824, пг. 3, (MvT), p. 5. 
weer verlaten schijnt te zijn. Een weerspiegeling van deze omslag in het denken, vooral van de kant van de overheid en wan de werkgevers, vormen de discussies in de Arboraad over de betekenis en de fasering van de inwerkingtreding van de nog niet inwerking getreden artikelen van de wet en als resultaat daarvan de op belangrijke punten vaak sterk verdeelde adviezen ${ }^{6}$

In elk geval is het resultaat van zo'n 100 -jarige rechtsontwikkeling op dit gebied een betrekkelijk ingewikkeld complex van regelingen, zowel met een publiekrechtelijk als een civielrechtelijk karakter, die naast en soms overlappend voorkomen, daterend uit verschillende perioden en - mede daardoor ongelijk in uitgangspunten, definities en operationalisering. Ook de Arbowet is, mede door het geharrewar over wetswijzigingen als gevolg van de deregulering en de samenloop met de WOR en door de onzekerheid over de betekenis van sommige bepalingen en de verdere fasering van de inwerkingtreding, niet het monument van helderheid waarop oorspronkelijk werd gerekend.

\section{De betrokkenen}

Een nader beeld van de inhoud van dit rechtsgebied is verkregen door een onderzoek naar de - vooral juridische - positie die de betrokkenen in en buiten de onderneming innemen. De Arbowet is hierbij de belangrijkste rechtsbron, hoewel de rechten en plichten van met name werkgever en werknemers en hun onderlinge relatie, mede genormeerd worden door bijvoorbeeld het $\mathrm{BW}$ en de CAO.

Gebleken is dat in elk geval twee actoren door de Arbowet een juridische versterking hebben gekregen van hun positie in de onderneming: de or en de deskundige diensten. De eerste vooral doordat hij, aansluitend bij de WOR, bevestigd wordt in zijn positie van formeel belangrijkste orgaan op het gebied van medezeggenschap van werknemers, wat nog eens geaccentueerd wordt door de toekenning van een aantal nieuwe bevoegdheden en faciliteiten; de tweede door een aanscherping van de onafhankelijke positie die zij dienen in te nemen, eveneens geschraagd door de toekenning van enkele nieuwe bevoegdheden, maar ook van nieuwe plichten (samenwerken en hulp verlenen aan de werknemers) en van een ontslagbescherming. De vernieuwde juridische positie van beide berust op het uitgangspunt van de Arbowet dat het arbeidsomstandighedenbeleid in de eerste plaats in de onderneming zelf gevormd dient te worden door een versterking van de interne deskundigheid en het overleg tussen de or en de werkgever.

De laatstgenoemde heeft in de Arbowet vooral een aantal verplichtingen erbij gekregen, naast de 'oude' civielrechtelijke verplichtingen, die hij uiteraard bleef behouden. Maar hier moet wel bij aangetekend worden dat zijn opdrach-

6 Zie bijvoorbeeld het Advies inzake de tweede en volgende fasen van invoering van de Arbeids. omstandighedenwet, Arboraad 1985, nr. 9 of het Advies inzake veiligheidskundigen en veiligheidsdiensten, Arboraald 1987, nr. 31. 
ten minder verplichtend zijn naarmate zij méér betrekking hebben op de nieuwe welzijnsaspecten. Strafrechtelijk gesanctioneerde verplichtingen heeft de werkgever op het gebied van de concrete normstellingen zoals die vooral te vinden zijn in de op de Arbowet gebaseerde Veiligheidsbesluiten (maar die had hij al), in de eisen en aanwijzingen van de Arbeidsinspectie (alleen de laatste zijn nieuw) en op het gebied van organisatorische maatregelen, zoals het instellen van een bgd, het uitbrengen van een arbeidsveiligheidsrapport of een jaarverslag (gedeeltelijk nieuw). De opdrachten tot het creëren van, en het voeren van overleg over het arbeidsomstandighedenbeleid of de opdrachten zoals die geformuleerd zijn in het welzijnsartikel bij uitstek, art. 3 (de toetsstenen van het beleid) zijn in het algemeen veel minder concreet en (daarom) minder direct verplichtend. Het zijn ook juist deze laatste bepalingen ten aanzien waarvan de Arbeidsinspectie een terughoudend controle- en opsporingsbeleid zal voeren - passend bij de filosofie van de Arbowet.

In de juridische positie van de Arbeidsinspectie zijn eigenlijk nauwelijks wijzigingen gekomen ten aanzien van haar rechten, bevoegdheden en plichten; het belangrijkste nieuwe instrument, de aanwijzing, sluit aan op de al langer gegroeide praktijk dat de ambtenaren vooral proberen eerst de vigerende regelingen (al dan niet wettelijke) uit te leggen, toegesneden op de concrete situatie, alvorens naar zwaardere middelen te grijpen. De veranderingen liggen dan ook eerder in de sfeer van het uitvoeringsbeleid dan in die van het strikt juridische en, zoals ik hierboven al schreef, ook deze veranderingen zijn betrekkelijk, omdat het optreden van de Arbeidsinspectie in de praktijk al langer meer gericht was op advies en overreding dan op controle en politionele taken. De belangrijkste verandering die de Arbowet voor de Arbeidsinspectie heeft betekend, is warschijnlijk het - veelal wettelijk verplichte - contact en overleg met de werknemers en dan met name natuurlijk de or of zijn remplaçant en, hiermee verband houdend, het verzoek om wetstoepassing.

De positie van de werknemers- en werkgeversorganisaties ten aanzien van de humanisering van de arbeid heeft eveneens in de eerste plaats een juridische basis in de Arbowet. Op centraal niveau zijn zij participanten in het belangrijkste adwiesorgaan op het gebied van de arbeidsomstandigheden, de Arboraad. Op ondernemingsniveau kan de werknemersorganisatie onder bepaalde voorwaarden de rol overnemen van de or bij diens afwezigheid. Het is de vraag of deze laatste bevoegdheid in de praktijk van veel betekenis zal zijn. Zij kan immers alleen uitgeoefend worden in ondernemingen waar geen or (of Arbocommissie, maar dat is verre toekomstmuziek) is, en waar het bovendien dan óók kan door een meerderheid van de belanghebbende werknemers. Terwijl daarnaast de vakbeweging in het algemeen al niet te veel vaste voet in veel ondernemingen en een aantal bedrijfstakken heeft (een eis om op basis van de Arbowet te kunnen optreden), geldt dat vooral woor de ondernemingen waar geen or is, dus veelal de kleinere.

Belangrijker zou de rol van de sociale partners kunnen zijn door het opnemen van humaniseringsbepalingen in de $\mathrm{CAO}$ die verder gaan dan de wettelijke regels. Gebleken is echter dat daar nog nauwelijks sprake van is. 
De vakorganisatie kan, zonder juridische basis, ook nog een rol spelen in het kader van het werknemersonderzoek naar de arbeidsomstandigheden in een onderneming. De kansen op verwerking van de onderzoeksresultaten in het ondernemingsbeleid lijken het meest reëel wanneer de or zich daar, met gebruikmaking van zijn wettelijke bevoegdheden, achter stelt.

Hoe is het tot slot gesteld met de juridische positie van de werknemer zelf wiens welzijn bij de arbeid uiteindelijk het doel is van de regelingen ter zake? Gebleken is dat de rechten die hij op basis van de Arbowet, gerelateerd aan de overige betrokkenen, heeft, met gradatie- en nuanceverschillen, niet direct, ongeclausuleerd zijn toegekend, noch dat hij directe juridische actiemogelijkheden heeft om de daadwerkelijke uitoefening.ervan te realiseren: recht op informatie van de werkgever (afgeleid van de artikelen 6 en 13), recht op veilig, gezond en plezierig werken afhankelijk van de werkgever (art. 3), recht op klagen bij de Arbeidsinspectie (afgeleid van art. 34 en art. 5 Grondwet) en recht op hulp van de deskundigen in de onderneming (artikelen $18 \mathrm{t} / \mathrm{m} 20$ ). Het recht om het werk neer te leggen (art. 38) vormt nog het meest ondubbelzinnig toegekende subjectieve recht voor de individuele werknemer, hoewel het ook niet onvoorwaardelijk uitgeoefend kan worden.

Als het ware tussen de positie van de individuele werknemer en de or in wordt een interessante constructie in de Arbowet gevormd door de mogelijkheid dat de belanghebbende werknemers - of in sommige gevallen een meerderheid van hen - de rol kunnen overnemen van de or. Ik heb echter tevens aangetoond dat deze mogelijkheid in de praktijk aan betekenis verliest, omdat de positie van deze werknemers in een aantal opzichten zowel feitelijk als juridisch zwakker is dan die van de or.

Mogen de rechten van de werknemer dan niet altijd even helder en voor wat hun handhaving betreft even hard in de Arbowet geformuleerd staan, dit geldt omgekeerd wèl voor een aantal nieuwe verplichtingen op grond van art. 12, waarvan overtreding direct strafbaar is gesteld. Met name omdat de werknemers voor het kunnen vervullen van de in dat artikel geformuleerde plichten in hoge mate afhankelijk zijn van activiteiten van de werkgever, dient een strafrechtelijke vervolging als een ultimum remedium beschouwd te worden.

De constatering dat de juridische positie van de individuele werknemer in de Arbowet niet opvallend uit de verf komt en dat hij als expliciete adressant van de bepalingen er nauwelijks in voorkomt, valt wellicht te verklaren uit het karakter (niet uit het doel!) van de Arbowet: zij is sterk gericht op organisatorische en institutionele voorzieningen, en vooral aansluitend op de bestaande collectivistische medezeggenschapsstructuur.

In het BW ligt de zaak echter anders. Daar wordt bij uitstek de individueelrechtelijke relatie tussen de werkgever en de werknemer geregeld. Op het gebied van de humanisering van de arbeid zijn er echter - in kwantitatieve zin - weinig artikelen die van betekenis zijn. De belangrijkste zijn in de eerste plaats het specifieke art. $1638 \mathrm{x}$ en in de tweede plaats het veel algemenere artikel $1638 z$. Ten aanzien van de handhaving van deze, uit de in de artikelen geformuleerde verplichtingen voor de werkgever voortvloeiende, rechten bij 
de burgerlijke rechter heb ik echter geconstateerd dat er ook hier weer veelal juridische en feitelijke barrières bestaan. Tevens heb ik echter aangegeven dat de mogelijkheden op dit punt beter lijken te worden, onder meer onder invloed van de publiekrechtelijke normen in de Arbowet. Evenals in de Arbowet heeft de werknemer in het BW ook plichten opgelegd gekregen. Zij zijn echter beduidend minder in aantal en niet specifiek geschreven voor het gebied van humanisering van de arbeid.

Als laatste directe rechtsbron voor de positie van de individuele werknemer is aandacht geschonken aan de CAO. Gebleken is dat de inhoud hiervan in het algemeen geen beduidende méérwaarde betekent ten opzichte van de bestaande wettelijke regelingen - ook niet op het gebied van de handhaving. Volledigheidshalve heb ik ook onderzocht of de individuele werknemer zelf een actieve rol zou kunnen spelen bij het door de or op basis van de WOR te voeren arbeidsomstandighedenbeleid. Ik constateerde dat indien de or dat wilde daar de (juridische) mogelijkheden voor aanwezig waren, maar dat het juridisch kunnen afdwingen van participatie bij of controle van het door de or op dat terrein te voeren of gevoerde beleid vrijwel onmogelijk was.

Tot slot kreeg het individuele klachtrecht, hoewel al wel voorkomend in sommige CAO's maar nog (steeds) ius constituendum, enige aandacht. Geconciudeerd werd dat onder bepaalde voorwaarden een dergelijk wettelijk vastgelegd recht een belangrijke bijdrage zou kunnen leveren aan een verbetering van de positie van de individuele werknemer, ook ten aanzien van zijn arbeidsomstandigheden. Deze voorwaarden zouden betrekking moeten hebben op de wettelijke opdracht tot een zekere uitwerking en operationalisering van het toegekende klachtrecht. Een meerderheid in de SER, zoals het er naar uitziet gevolgd door het kabinet, will deze voorwaarden echter niet in een wettelijke regeling opgenomen zien.

\section{De positie van de werknemer nader beschouwd}

Het feit dat op basis van de bestaande regelingen te zamen niet zonder meer gesproken kan worden van een recht van elke individuele werknemer op humane arbeidsomstandigheden, betekent natuurlijk niet dat die regelingen daar geen bijdrage aan zouden leveren. Alleen: er is een duidelijk onderscheid tussen de in die regelingen vastgelegde zorgplicht die anderen, en met name de werkgevers, hebben op dat gebied en de toekenning van eigen rechten en daaraan gekoppelde juridische actiemogelijkheden. Geconstateerd moet worden dat deze zorgplicht - ook weer in de nieuwe Arbowet - nog steeds de dominante juridische vormgeving is ten aanzien van de humanisering van de arbeid als doelstelling van overheidsbeleid. Dit betekent dat de individuele werknemer bij de verbetering van zijn arbeidsomstandigheden zowel juridisch als feitelijk in hoge mate afhankelijk is van de bereidwilligheid van de werkgever, en in mindere mate van andere betrokkenen, of van de machtsverhoudin- 
gen die op een gegeven moment bestaan tussen werkgever en werknemers. Des te belangrijker is derhalve de rol van de Arbeidsinspectie en de onafhankelijke rechter die bij een eventueel conflict te hulp kunnen worden geroepen. Zo beschouwd is er een grotere continuiteit in het arbeidsomstandighedenrecht te constateren dan - met name door de invoering van de Arbowet - wel eens wordt gesuggereerd, niet in de laatste plaats door de wetgever zelf.

Dit geldt vooral voor de relatie werkgever-werknemer, gekenmerkt als die wordt door feitelijke machtsongelijkheid die slechts in beperkte mate met juridische middelen gecorrigeerd blijkt te kunnen worden. ${ }^{7}$ Hekkelman wijst er in zijn Amsterdamse oratie op dlat het gegeven van de hiërarchisch gestructureerde onderneming, gekenmerkt door aan de ene kant gezag en bevelsbevoegdheid en aan de andere kant onderschikking en gehoorzaamheidsplicht, in samenhang met het maatschappelijk gegeven van de economische afhankelijkheid van de werknemers, een struikelblok vormt voor de gelding van het recht binnen de ondernemingen, voor een beheersing van deze machtsorde door het recht. Hierdoor ontstaat ook een kwetsbaarheid van de individuele werknemer en moet zijn optreden wanneer dat gericht is op handhaving van een rechtsregeling waardoor het ondernemingsbestuur gebonden is, als een waagstuk gelden - als hij tenminste zijn positie en toekomstperspectieven binnen de onderneming wil behouden. ${ }^{8}$ Of, kernachtig door Hekkelman geformuleerd: 'De positie van de werknemer in de onderneming wordt immers ook nog in belangrijke mate niet door het recht, maar door de werking van macht en onmacht bepaald."

En enkele jaren later meende $F$, van der Ven in zijn Tilburgse afscheidscollege, sprekend over de aard van de arbeidsovereenkomst, dat ook de collectieve onderhandelingen in wezen toch steeds weer uitliepen op 'het tegen betaling door de werknemers aanvaarden van de van ouds bestaande machtsverhouding, welke het de werkgever mogelijk maakt de arbeidsverrichting op zijn persoonlijk belang te oriënteren'. ${ }^{10}$

Meer specifiek ten aanzien van de arbeidsomstandigheden luidde één van de conclusies van een recente en uitvoerige studie naar de rol van het werknemersonderzoek in de Nederlandse industrie naar de kwaliteit van de arbeid: 'Vooral werd duidelijk dat de 'quality of working life' zich voltrekt in de con" text van de vigerende machtsverhoudingen (cursivering van de onderzoekers) in een bedrijf....'."

Maar ook als niet wordt uitgegaan van de factor macht als bepalend beginsel

7 Hierover in het algemeen: Kahn-Freud, Some reflections on law and power, Labour and the law, Londen 1983 (third edition), p. 12-28. Vgl. voorts Taco van Peijpe, Macht en arbeidsrecht, Ars Aequi, 1985, p. 78-85, m.n. p. 79 .

$8 \mathrm{G}$. Hekkelman, Tekorten van het arbeidsrecht, (Oratie), Amsterdam 1967, Arbeidsrechtelijke geschriften 1962-1977, samenst. H.L. Bakels, Dewenter/Alphen a/d Rijn 1977, p. 77-102.

9 G. Hekkelman, t.a.p. p. 92.

10 F.J.H.M. van der Ven, Over dle aard der arbeidsovereenkomst, (Afscheidscollege Katholieke Hogeschool Tilburg), Alphen a/d Rijn 1972, Arbeidsrechtelijke geschriften, t.a.p. p. 24.

11 W. Buitelaar en R. Vreeman, Vakbondswerk en kwaliteit van de arbeid, Nijmegen 1985, p. 558. 
voor het interne functioneren van de onderneming en de daarmee samenhangende relatief ondergeschikte positie van zowel het recht als van de werknemer die het van dat recht juist moet hebben, dan kan in elk geval toch geconstateerd worden, en ik zeg het nu maar voorzichtig, dat de belangen van de werkgever en van de werknemer niet altijd even parallel lopen. Bakels stelt dat het alleen maar van realiteitszin getuigd om dat te erkennen - zeker voor wat betreft het dagelijkse leven in de onderneming. Disharmonie is nu eenmaal inherent aan iedere onderneming. Het benadrukken van de harmoniegedachte is volgens hem zelfs niet zonder gevaren, omdat daardoor de mogelijkheden om tot het oplossen van conflicten te komen gebaseerd zijn op een onvruchtbare, illusoire benadering van de bestaande industriële verhoudingen. ${ }^{12}$

$\mathrm{Nu}$ behoeft dit natuurlijk niet te betekenen dat samenwerking tussen werkgever en werknemers tot de onmogelijkheden behoort, maar het betekent wèl dat het op zijn zachtst gezegd van naïviteit getuigt om, zoals de belangrijkste CDA-woordvoerder deed tijdens de parlementaire behandeling van de Arbowet, op te merken dat de 'verhouding tussen werkgever en werknemers (...) gevoed (wordt) door vermeende en opgefokte klassetegenstellingen" en dat daarom de verplichte samenwerking in de Arbowet een goede zaak zou zijn. ${ }^{13}$ Even naïef zou het overigens zijn om de ongelijke machtsverhoudingen of de divergerende belangen die er tussen werkgever en werknemers bestaan te beschouwen als de alleen zalig makende verklaring voor het feitelijk reilen en zeilen in de onderneming. Dat is ongetwijfeld te schematisch, te zwart-wit en te weinig recht doende aan de gecompliceerde werkelijkheid waarin allerlei andere factoren een mede-bepalende rol spelen. J.J.M. van der Ven spreekt in dit verband kortheidshalve 'zij het onnauwkeurig' over drie instanties die in het algemeen de macht hebben op het terrein van het arbeidsleven: kapitaal, arbeid en overheid. Daaruit volgt volgens hem al dat er sprake is van een uiterst ingewikkeld en bovendien beweeglijk netwerk van macht ${ }^{14}$ Op het niveau van de onderneming zijn het met name de producten van de overheid in de vorm van allerlei - niet altijd wettelijke - regelingen die een rol spelen bij dit ingewikkelde netwerk.

Ten aanzien van de humanisering van de arbeid heb ik, behalve aan de or, ook uitvoerig aandacht geschonken aan de deskundigen die, gesteund en geinspireerd door hun wettelijk genormeerde positie, invloed (kunnen) hebben op de machtscultuur binnen de onderneming. In de Arbowet hebben zij bevoegdheden en faciliteiten gekregen die hen bij de uitoefening van hun taken een zekere onafhankelijkheid van de werkgever garanderen. Maar dit betekent niet automatisch dat zij in de praktijk de machtsverhoudingen in de onderneming ten aanzien van de humanisering van de arbeid zullen beinvloeden of

12 H.L. Bakels, De leiding van de onderneming en de belangen van de werknemers, Vrijheid en recht, ('s Jacobs-bundel), Zwolle 1975, p. 27-38, m.n. p. 29.

13 Kamerlid S. Weijers, Handelingen TK 1979-1980, 13 mei 1980, p. 4684.

14 J.J.M. van der Ven, Recht en macht, Aspecten van Arbeidsrecht, Jubileumbundel Vereniging voor arbeidsrecht 1946-1971, Alphen a/d Rijn, p. 82. 
corrigeren in het voordeel van de werknemers, nòch dat deze laatsten dat via hen kunnen bewerkstelligen.

De bedrijfsartsen (ik beperk me nu tot deze deskundigen in de onderneming, omdat zij al veel لlanger een wettelijke status hebben en derhalve over hun functioneren het meest bekend is en de hun regarderende artikelen in de Arbowet per 1 januari 1983 in werking zijn getreden) hebben onder meer als expliciet in die wet geformuleerde taak het verschaffen van hulp, bijstand en advies aan de individuele werknemers en het samenwerken met hen. Gebleken is echter dat de contacten van cle bedrijfsarts met de individuele werknemer vooral bestaan in enkele van oudsher geaccepteerde, en ook al in de Veiligheidswet genoemde taken als aanstellingskeuringen, periodieke onderzoeken en ziektewetcontroles. Het zijn vooral medische handelingen die de werknemer in de praktijk zo goed als verplicht moet ondergaan. Mede hierdoor en de ermee samenhangende traditionele oriëntatie op de belangen van de werkgever is het vertrouwen wan de werknemers in hun bedrijfsarts nog niet altijd even groot. En dat vertrouwen is een noodzakelijke basis voor de relatie die de Arbowet introduceert tussen bedrijfsarts en werknemer, en die beoogt de werknemer minder athankelijk te doen zijn van zijn werkgever op het punt van de deskundigheid van de bedrijfsarts. Gebleken is daarnaast dat de werknemer nauwelijks juridische instrumenten tot zijn beschikking heeft om de bedrijfsarts zijn verplichtingen te doen nakomen. In dit verband lijkt een beroep op de werkgever nog de meeste kans te maken. Aan de beoordeling van de positie van de werknemer in zijn relatie tot de bedrijfsarts wordt in elk geval geen onrecht gedaan alls geconstateerd wordt dat zij er toch in veel gevallen vooral een lijkt te zijn van feitelijke en juridische afhankelijkheid. De juridische mogelijkheden om de machtswerhoudingen bij te stellen ten behoeve van de arbeidsomstandigheden van de werknemer zijn er, maar de praktische realisatie ervan ligt in de handen van de bedrijfsarts zelf en in die van degene ten koste van wie in het algemeen een dergelijke bijstelling zal plaatsvinden: de werkgever.

Gebleken is dat veel van wat hierboven gezegd is over de relatie tussen de werknemer en de bedrijfsarts ook gezegd kan worden over cle relatie tussen de werknemer en de or. Ook hier is het sleutelwoord weer afhankelijkheid. Maar er is daarnaast sprake van een extra probleem, veroorzaakt door de in menig opzicht dualistische positie van de or en zijn leden. Zij zijn ten opzichte van de werkgever zowel (juridisch) afhankelijke werknemers als (juridisch) gelijkwaardige overlegpartners, terwijl zij daarmee samenhangend zowel de belangen van de werknemers als die van de onderneming zullen trachten te dienen. Bovendien is zeggenschap voor de or in het kader van de humanisering van de arbeid zowel doel als instrument. Dit maakt een goede juridische en feitelijke relatie tussen de or en 'zijn' werknemers extra belangrijk. Geconstateerd moest echter worden dat die relatie niet zonder problemen is. Dat betekent dat de or weliswaar een factor van betekenis kan zijn bij een reductie van de in beginsel bij de werkgever geconcentreerde macht ten behoeve van de werknemers, mar dat dat niet vanzelfsprekend is. Ook juridisch niet, omdat de me- 
dezeggenschapswetgeving de zeggenschapsverhoudingen zoals die in de overige wetgeving zijn neergelegd, met als leidend vertrekpunt nog steeds art. 1637a BW, uiteindelijk niet aantast. ${ }^{15}$ Het lijkt me dan ook reeel te spreken van een spanning die er kan bestaan tussen enerzijds de belangen van de werknemer met name op het terrein van zijn individueel welzijn bij de arbeid en anderzijds de collectieve belangen waar de or het oog op gericht houdt, terwijl bovendien de werknemer voor de realisering van zijn individuele belangen op basis van de Arbowet grotendeels afhankelijk is van diezelfde or.

Voor de werknemer betekent dit dat er naast de afhankelijkheid van de werkgever een nieuwe bij is gekomen, maar nu een ten opzichte van het hem juist formeel vertegenwoordigende orgaan. De sterke kanten van een or zijn de wettelijk toegekende bevoegdheden, rechten, faciliteiten en handhavingsmiddelen. Maar, juist mede daardoor veroorzaakt, heeft de or ook zwakke kanten zoals het traditionele achterban-probleem, het formele karakter, de ingewikkelde en tijdrovende procedures, de detaillistische aanpak en het moeizame proces van interne eenheid. Hierdoor ook kunnen problemen die in beginsel dicht bij de werknemers, bij de werkvloer, liggen (onnodig) geformaliseerd en gebureaucratiseerd worden. (Een effectief functionerend werkoverleg zou hier trouwens soelaas kunnen bieden). De door mij vermelde onderzoeken naar het beleid van de or op het gebied van humanisering van de arbeid sinds de inwerkingtreding van de Arbowet hebben dit beeld (nog) niet wezenlijk aangetast. Daar komt nog bij dat door de grote nadruk die de Arbowet legt op de positie van de or, hij voor de andere betrokkenen in hun relatie tot de individuele werknemer als alibi kan gaan dienen. Werkgever, cleskundigen, zelfs de vakorganisatie maar ook de or zelf kunnen zich beroepen op de wettelijk vastgelegde overleg- en zeggenschapsstructuur en de individuele werknemer daarnaar verwijzen wanneer hij zich tot hen wendt. De Arbeidsinspectie heeft deze opvatting voor een goed deel in haar uitvoeringsbeleid geïncorporeerd. Zo bezien zijn werknemers in een onderneming zonder or soms wellicht nog beter af.

Ik vind het opvallend dat aan deze problematiek, wellicht met recente uitzonderingen voor de problematiek van de slinkende aanhang bij de vakbeweging in het CAO-recht, in de juridische literatuur nog betrekkelijk weinig aandacht is geschonken, hoewel het samengaan van individualisme en collectivisme en de ermee samenhangende potentiële spanning in hoge mate een kenmerk is van het gehele terrein van het sociaal recht. ${ }^{16}$ Ook de nieuwe juridische belangstelling voor het arbeidsomstandighedenrecht, en met name de Arbowet waarin immers een individuele doelstelling als welzijn bij de arbeid samengaat met een collectivistisch instrumentarium, heeft natuelijks geresulteerd in beschouwingen over de problemen die dit samengaan in de praktijk zou kunnen

15 Zie voor een - mislukte - poging om deze juridische constellatie te doorbreken het eindrapport van de reeks Experimenten Medezeggenschap van COB/SER: Medezeggenschap, besluitvorming en organisatie, Den Haag 1985 , m.n. p. 216-220.

16 Vgl. bijvoorbeeld W.J.P.M. Fase, Arbeidsrecht in: Nederlands reclat in kort bestek, Deventer 1983, p. 295. 
oproepen ${ }^{17}$ Dit zelfde kan gezegd worden van de wetgever. Alleen de fractie van D'66 noemde het, tijdens de parlementaire behandeling van de Arbowet, met een beroep op de machtsongelijkheid ongewenst dat binnen het raam van de wet atan de individuele werknemers geen andere middelen ter beschikking zouden staan om conflicten tussen werkgever en werknemer op te lossen dan alleen door tussenkomst van de or of de Arbocommissie of de meerderheid van de werknemers. ${ }^{18}$ De minister volstond in zijn antwoord met te verwijzen naar de (toen nog bij de SER aanhangige) adviesaanvraag inzake het individuele klachtrecht. ${ }^{19}$

Toch meen ik dat de bovenbedoelde spanning in de praktijk wel eens problemen op zou kunnen leveren. Wanneer immers aan mensen door de wetgever idealen als bereikbaar worden voorgehouden, terwijl de realisatie ervan goeddeels in handen is van anderen die menen dat niet dezelfde waarden prioriteit moeten hebben, dan werkt dat - in letterlijke zin - niet bevorderlijk, zeker niet als die anderen het orgaan vormen dat geacht wordt namens hen op te treden. Dat zou wel eens kunnen leiden tot het in stand houden of zelfs bevorderen van een houding van individuele werknemers, vooral van hen die traditioneel niet tot de 'medezeggenschapselite' behoren, ten opzichte van de (nieuwe) wettelijke regelingen die door J.J.M. van der Ven al enkele decennia geleden (maar dan ten opzichte van de Arbeidswet 1919) gekenschetst werd als 'onverschilligheid, zelfs weerstand' ${ }^{20}$ Deze houding kan in de hand worden gewerkt door een sociaal-economisch klimaat waarin het hebben van werk meer wordt benadrukt dan de kwaliteit ervan. Nu zou geredeneerd kunnen worden dat, mits het werk voldoet aan enkele minimale normen op het gebied van de veiligheid en de gezondheid, dat ook niet erg is. Maar daarmee wordt toch voorbijgegaan - nog los van de economische betekenis - aan de grote intrinsieke waarde die de humanisering van de arbeid heeft woor elke werknemer en aan het schrille contrast met de in de Arbowet gepropageerde voorstelling van actief bij hun arbeidsomstandigheden betrokken werknemers.

Het bovenstaande moet wel gerelativeerd worden - en niet alleen omdat ik een meedogenloze oplossing voor het dilemma individuatisme-collectivisme, anders dan door aanpassingen en aanvullingen zoals bijvoorbeeld door de introductie van het klachtrecht, niet zie. Al eerder heb ik geschreven dat een collectieve belangenbehartiging, zeker in termen van machtsuitoefening, onmiskenbare voordelen biedt. Bovendien zijn veel problemen op het gebied van de veiligheid en de gezondheid bij het werk niet louter individuele problemen, maar hebben zij een collectief karakter en zijn tot op zekere hoogte objectiveerbaar. Dit betekent dat het probleem zich vooral zal kunnen voor-

17 Als uitzonderingen noem ik H.J. van Zwam, Veranderingen in het arbeidsomstandighedentrecht, Deventer 1983, m.n. p. 61 en A.H.J. van Lynden, De indiwiduele werknemer in het arbeidsomstandighedenrecht, SMA, 1984, p. 496-505.

18 TK 1977-1978, 14.497, nr. 4 (VV), p. 55.

19 TK 1978-1979, 14.497, nir. 5 (MvA), p. 79.

20 J.J.M. van der Ven, Rechtssociologische aantekeningen bij de Arbeidswet 1919, SMA, 1958, p. 297. 
doen als het niet gaat om betrekkelijk harde en meetbare veiligheids- en gezondheidsaspecten, maar om het meer immateriële, individueel bepaalde welzijnsaspect. Ten aanzien van dit laatste aspect ontbreekt ook nog een andere juridische rechtvaardiging die, los van de bovenstaande argumenten, kan worden aangevoerd ter verdediging van de collectieve uitoefening van bevoegdheden. Ten aanzien van problemen van veiligheid en gezondheid in enge zin wordt de collectieve belangenbehartiging immers nog aangevuld met een individueel juridisch protestmiddel, nl. het uiteindelijke recht van iedere individuele werknemer om bij dreigend en acuut gevaar op basis van art. 38 Arbowet het werk neer te leggen. De wettelijke machtiging tot deze vorm van eigenrichting is ten aanzien van bijvoorbeeld een inbreuk op het zoveel mogelijk kunnen verrichten van het werk naar eigen inzicht (art. 3 onder g) niet wel denkbaar.

In het licht van het bovenstaande is het dus, zoals ik in het begin van deze paragraaf al schreef, uiterst belangrijk of, bij wie en op welke manier de individuele werknemer bij eventuele conflicten binnen de onderneming 'neutrale' externe steun kan zoeken. Twee instanties van buiten de onderneming zijn in dit verband van belang: het overheidstoezicht in de vorm van de Arbeidsinspectie en de onafhankelijke rechter (beide met hun eigen beroepsmogelijkheid).

Het eerste probleem voor de individuele werknemer ten opzichte van de Arbeidsinspectie is de toegang tot deze instantie. Bij conflicten over de arbeidsomstandigheden met de or, de deskundigen, de werkgever of anderen in de onderneming bestaat er voor hem geen legale basis voor het inroepen van interventie door de Arbeidsinspectie (uiteraard wèl voor de interventie zèlf!), anders dan door gebruikmaking van het algemene klachtrecht. Alleen ten aanzien van een conflict met de werkgever kan op basis van art. 40 Arbowet een formeel verzoek om wetstoepassing ingediend worden, maar dan moet de werknemer zijn or of bij het ontbreken daarvan een meerderheid van de belanghebbende werknemers of de vakorganisatie daarvoor wel weten te mobiliseren. Lukt dat niet, dan blijft ook hier alleen het klachtrecht bij de Arbeidsinspectie over, dat, zo is gebleken, in termen van ondersteunende procedureregels en beroepsmogelijkheden juridisch nauwelijks houvast biedt. Maar stel nu dat de individuele werknemer de Arbeidsinspectie voor zijn zaak heeft weten te interesseren. Dan doemt onmiddellijk het tweede probleem op: de feitelijke opstelling van de ambtenaren.

Hoewel gebleken is dat zij bij hun uitvoeringspraktijk een grote mate van beleidsvrijheid hebben, zijn zij wèl gebonden aan de onder meer op basis van de Arbowet op centraal ambtelijk niveau vastgestelde uitgangspunten. Een daarvan is de praktische vertaling van de in de Arbowet neergelegde medezeggenschapsstructuur. Dat wil zeggen dat de Arbeidsinspectie zich voor wat betreft problemen van werknemers vooral zal richten op het daartoe wettelijk aangewezen orgaan: de or of zijn remplaçant. Die moet dan vervolgens in overleg met de werkgever voor een oplossing zorgen. De Arbeidsinspectie zal de werknemer in het algemeen dan ook daar naar verwijzen of zich in elk geval 
bij zijn optreden in de eerste plaats op hem richten. De vicieuze cirkel die dan kan ontstaan - de or wil geen gebruik maken van het verzoek om wetstoepassing aan de Arbeidsinspectie die op haar beurt de werknemer weer verwijst naar de or - kan in het kader van de Arbowet door de werknemer niet met juridische middelen doorbroken worden.

Daar komt bovendien nog bij dat uit een analyse van de uitvoering van de Arbowet en haar nadere regelgeving is gebleken dat voor de ambtenaren de contacten met, en de beinvloeding door de werkgever (of vaak personen of instanties namens hem) dominant zijn. Dat is ook niet zo gek: het is de werkgever die vanuit zijn positie de beslissingen van de Arbeidsinspectie moet omzetten in concrete acties waarvoor hij ook de machtsmiddelen tot zijn beschikking heeft. Hoewel de Arbeidsinspectie ongetwijfeld een cruciale rol kan spelen -en in de praktijk ook speelt - in de verbetering van de arbeidsomstandigheden van de werknemers, gebeurt dat vooral op eigen initiatief, of op initiatief van andere betrokkenen, en minder vaak via een directe actie van een individuele werknemer. Zowel het vigerende recht als de uitvoeringspraktijk zijn hier debet aan. In die zin moet een beroep van de individuele werknemer op de Arbeidsinspectie om steun in zijn afhankelijke positie, toch vooral gekwalificeerd worden als een onderneming waarvan de honorering onzeker is. De andere instantie buiten de onderneming die juridische machtsmiddelen kan aanwenden ter werandering van de situatie binnen de onderneming is de civiele rechter. Er zijn nogal wat verschillen met de Arbeidsinspectie. Van belang hierbij zijn onder meer de toegang, de onafhankelijkheid en de lijdelijkheid. In tegenstelling tot de Arbeidsinspectie is de rechter gehouden om een uitspraak te doen bij een (te verwachten) schending van het recht, maar hij kan dat niet dan nadat er door een belanghebbende om is gevraagd - in het kader van deze paragraaf de individuele werknemer. De rechter kan zich daarbij onafhankelijk van de overheid opstellen. Met name de toegangsmogelijkheden en de grote mate van vrijheid die de rechter heeft, zowel ten aanzien van zijn uitspraak en het terrein waarop die uitspraak betrekking heeft, als ten aanzien van alle bij het conflict betrokkenen, kunnen het voor de individuele werknemer die elders nul op het rekest heeft gekregen, juridisch atantrek kelijk maken om de hulp van de rechter in te roepen. De werknemer zou zelfs, indien hij meent dat de Arbeidsinspectie haar wettelijke taak niet is nagekomen waardoor hij in zijn belangen is geschaad, op grond van schending van haar rechtsplicht eventueel in kort geding van de rechter kunnen eisen dat de Arbeidsinspectie (in casu zal de Staat der Nederlanden worden gedaagd) alsnog de gevraagde acties onderneemt of nalaat, of dat aan de werknemer een schadevergoeding wordt toegekend - al zal de rechter in zo'n geval waarschijnlijk toch vooral marginaal toetsen in verband met het freies Ermessen van de overheid.

Maar in de praktijk zal vooral de werkgever de gedaagde zijn. Als het zover komt, dan heeft de eisende werknemer echter al de in het vorige hoofdstuk aangegeven barrières, die vooral samenhangen met zijn juridisch en feitelijk afhankelijke positie, genomen. 
Hoewel deze feitelijke barrières zullen blijven bestaan, lijkt er toch een tendens in de rechtspraak te zijn waardoor zij voor een deel juridisch gecompenseerd worden. De indruk bestaat immers dat de rechtspraak, ook, onder inwloed van (recente) publiekrechtelijke normen op dit terrein, het beroep van werknemers op humane arbeidsomstandigheden steeds vaker honoreert - al gebeurt dit vaak indirect, bijvoorbeeld in een ontslagzaak of een verzoek tot ontbinding van de arbeidsovereenkomst (zie voor een uitgewerkt voorbeeld de volgende paragraaf). Het ziet er naar uit, gelet op de ontwikkeling in rechtspraak en wetgeving, dat deze tendens zich voortzet. Dit zou betekenen dat voor de individuele werknemer, die zich gedwongen voelt (of gedwongen wordt) om externe steun te zoeken voor een verbetering van zijn arbeidsomstandigheden, de gang naar de civiele rechter nog het meeste perspectief biedt.

Voor de individuele werknemer zou een groot belang van de Arbowet, in het kader van het rechtens kunnen afdwingen van humane arbeidsomstandigheden, derhalve wel eens gelegen kunnen zijn in de omstandigheid, dat de civiele rechter de normen uit deze wet kan gebruiken, en ook gebruikt, ter honorering van de claim op humane arbeidsomstandigheden die diezelfde wet biedt aan de werknemer, zonder hem echter daarbij de mogelijkheden te geven om die claim zelfstandig te realiseren.

\section{Intermezzo uit de praktijk}

Op 17 juni 1987 wees de Amsterdamse Rechtbank een voor het onderwerp van dit boek belangwekkend (niet gepubliceerd) vonnis. ${ }^{21}$ De inhoud ervan maakte mij nieuwsgierig naar de achtergronden. Ik heb daarom de uitvoerige procesdossiers en andere stukken doorgenomen, en enkele betrokkenen, waaronder de hoofdpersoon, geinterviewd. Deze laatste was een werknemer in een grote onderneming die zich inspande voor de verbetering van de arbeidsomstandigheden. Het (zijn) verhaal vormt in verschillende opzichten een illustratie uit de praktijk van wat ik eerder in dit boek heb geschreven over de positie van de individuele werknemer bij de humanisering van de arbeid en de rol van het recht hierbij. Hieronder volgt het verhaal met daarna mijn commentaar.

\subsection{De woorgeschiedenis}

In 1957 treedt de dan 18-jarige $G$., met een vooropleiding als chemisch analist, in dienst van de onderneming N. In 1972 gaat hij in het research-centrum werken. In datzelfde jaar verhuist het centrum naar een nieuw gebouw. Vanaf 1981 begint zich in toenemende mate stankoverlast te manifesteren in het cen-

21 Rechtbank Amsterdam, 17 juni 1987, rolnummer H 86.1509. 
trum, waar dan circa 100 mensen werken. (In de gehele onderneming zijn dan zo'n 1000 mensen werkzaam). De stankoverlast veroorzaakt onder meer klachten over hoofdpijn, oogirritaties en sufheid en is vooral te wijten aan het systeem van klimaatbeheersing in het gebouw. In de "Interne mededelingen voor het personeel' schenkt de VGW-commissie - geen commissie van de or in de zin van art. 15 WOR, maar een zgn. gemengde commissie zonder wettelijke basis (zie hierover hoofdstuk III, paragraaf 3.3.1.) - aandacht aan de problematiek. Naar aanleiding van de klachten, vooral ook van $G$. afkomstig, stelt de eigen technische dienst een onderzoek in dat resulteert in het besluit om een onafhankelijke en beter geëquipeerde instantie nader onderzoek te laten verrichten. Eveneens naar aanleiding van de klachten stelt de regionale bgd, waar de onderneming bij is aangesloten, een onderzoek in met als conclusie in maart 1982 dat het aantal klachten 'vrij groot is' en dat het 'gezien de mogelijke samenhang in de oorzaak misschien aan te bevelen is een ter zake kundige onderzoeksinstantie in de arm te nemen'. Deze onafhankelijke instantie brengt in oktober 1982 een rapport uit waarin een groot aantal aanbevelingen is opgenomen ter verbetering van het werkklimaat en (dus) ter voorkoming van verdere klachten. Op basis van dit rapport en een nieuw rapport van september 1983 van dezelfde instantie wordt een aantal maatregelen genomen. Deze maatregelen blijken echter niet voldoende om de klimatologische problemen geheel op te lossen; een opiniepeiling onder het personeel van eind 1984, de zgn. 'Arbo-enquête' wijst uit dat medewerkers op het research-centrum klachten blijven houden. Hiermee wordt ook een bulletin van de Industriebond FNV uit april 1984 bevestigd.

G. laat zich bij dit alles niet onbetuigd. Hij spreekt en schrijft over de problemen met zijn afdelingschef, met de directie en met collega's. Daarnaast benadert hij een aantal malen de Arbeidsinspectie. Deze laatste spreekt in een brief aan G. over 'persoonlijke overgevoeligheid' bij hem, verlaat zich met betrekking tot de problemen vooral op mededelingen van de bedrijfsleiding (verricht dus zelf geen onderzoek), en ziet overigens geen aanleiding om in te grijpen. Zij motiveert haar terughoudende opstelling schriftelijk met het argument dat het in de geest van de Arbowet besloten ligt, dat werkgever en werknemers in onderling overleg de problemen tot een oplossing trachten te brengen. De voornaamste bijdrage van de bedrijfsarts van de regionale bgd vormt het advies aan $G$. om in verband met zijn klachten minder te gaan werken.

De enige relevante instanties tot wie $G$. zich formeel nooit heeft gewend zijn de or (wel sprak hij 'informeel' met leden ervan) en de vakbond waarvan G. ook geen lid is. Volgens hem laten deze instanties zich toch vooral "democratisch de mond snoeren'.

De bezorgdheid van $\mathrm{G}$. wordt niet in het minst gevoed door het feit dat hij betrekkelijk vaak last heeft van allerlei ziekteverschijnselen die van toxicologische aard zijn, waardoor hij zich regelmatig ziek moet melden. Naarmate G. langer thuis is, nemen de klachten af. Als hij daarna weer aan het werk gaat, komen de klachten na enkele dagen terug. De ziekteverschijnselen van G. zijn door de onderneming overigens nooit betwist. 
G. blijft met grote hardnekkigheid de verantwoordelijke personen in de onderneming attenderen op de klimatologische omstandigheden in het centrum. Het laatst doet hij dat in een gesprek in juli 1985 met de algemeen directeur, het hoofd van de veiligheids- en milieudienst en zijn afdelingschef. In dit gesprek wordt van de zijde van de onderneming gewezen op datgene wat al verbeterd is, terwijl tevens wordt geconstateerd dat er nog steeds problemen bestaan, waarvan men (nog) niet weet hoe die aan te pakken. Concrete toezeggingen worden niet gedaan, maar op de problematiek zou worden teruggekomen.

Samenvattend is de situatie in de zomer van 1985 deze dat de onderneming weliswaar aandacht heeft geschonken aan de klimaatbeheersing in het research-centrum en ook verschillende maatregelen heeft getroffen, maar dat de problemen nog niet alle zijn opgelost, òf omdat de onderneming geen reële mogelijkheden daartoe ziet òf ondat sommige wel reële mogelijkheden te duur worden geacht. De klachten van $G$. (en van anderen) blijven.

In verband met zijn inmiddels bekende ziekteverschijnselen meldt $\mathrm{G}$. zich op 5 september 1985 weer ziek. Op 30 september wordt $G$. door de controlerend arts van de onderneming (een zgn. 'eigen risicodrager' in de zin van de Ziektewet) in overleg met de huisarts arbeidsgeschikt verklaard. Op dezelfde dag wordt G. telefonisch door de personeelsafdeling medegedeeld dat hij op 1 oktober op het werk wordt verwacht. G. stelt zich echter op het standpunt dat hij niet kan worden verplicht om de overeengekomen arbeid te verrichten uit vrees voor schade aan zijn gezondheid en een terugkeer c.q. verergering van zijn klachten. Hij beroept zich op art. 38 Arbowet (onder omstandigheden geoorloofde werkonderbreking; zie hoofdstuk IV, paragraaf 2.3.). Na een nieuwe schriftelijke sommatie van de onderneming wordt $G$. op 2 oktober op staande voet wegens herhaalde werkweigering ontslagen. Op 4 oktober roept G. schriftelijk de nietigheid van het ontslag in en herhaalt dat zijn werkweigering gerechtvaardigd was op grond van het bepaalde in art. 38 Arbowet en zijn nog steeds bestaande arbeidsongeschiktheid. Tevens vraagt hij aan het GAK terzake van de hersteldverklaring een voor beroep vatbare beslissing. Tot zover de feitelijke gang van zaken, die aanleiding heeft gegeven tot verschillende procedures.

\subsection{De procedures}

Op 22 oktober 1985 verzoekt $G$. aan de kantonrechter om de onderneming te veroordelen tot doorbetaling van loon; op 30 oktober dient de onderneming een verzoek ex art. 1639 $\mathrm{wW}$ in tot ontbinding van de arbeidsovereenkomst voor zover vereist. $\mathrm{Bij}$ (niet gepubliceerde) beschikking van 11 december 1985 wordt dit laatste verzoek afgewezen. ${ }^{22}$

De kantonrechter overweegt hierbij samengevat onder meer dat G. ruim 28 
jaar bij $\mathrm{N}$. heeft gewerkt in een verantwoordelijke functie, terwijl op de kwalliteit van zijn werk nooit aanmerkingen zijn gemaakt; dat $\mathrm{G}$. geen gemakkelijk mens is en dat hij een 'kruistocht' heeft ondernomen om verbeteringen in de arbeidsomstandigheden te bewerkstelligen op de afdeling waar hij werkzaam was, welke verbeteringen ook inderdaad zijn aangebracht, hoewel volgens het oordeel van $\mathrm{G}$. nog onvoldoende; dat het duidelijk is dat het voor $\mathrm{G}$. ongewenst moet worden geacht om op zijn vroegere afdeling terug te keren omdat zijn klachten dan ongetwijfeld spoedig zullen terugkeren; dat desgevraagd tijdens de mondelinge behandeling namens $N$. is medegedeeld dat herplaatsing van $G$. uiterst moeilijk zou zijn, maar dat van een volstrekte onmogelijkheid de kantonrechter vooralsnog niet is gebleken; dat aan $\mathrm{G}$. deze laatste mogelijkheid ook niet is geboden; dat door de kantonrechter een voorstel is gedaan om de conflicten tussen de partijen op te lossen welk voorstel door $\mathrm{N}$. is getorpedeerd door een voor $\mathrm{G}$. volstrekt onaanvaardbaar bedrag alls schadeloosstelling aan te bieden.

Daarbij overweegt de kantonrechter dat hij er nog geenszins van overtuigd is dat het ontslag op staande voet rechtsgeldig zal worden geacht. Voorshands meent de kantonrechter dat $\mathrm{N}$. mogelijk niet voldoende zorgvuldig te werk is gegaan, omdat niet nader is onderzocht of $\mathrm{G}$. ter zake van zijn werkweigering een zo ernstig verwijt kan worden gemaakt dat ontslag op staande voet de enige weg was die $\mathrm{N}$. had kunnen bewandelen.

Bij (niet gepubliceerd) vonnis van 26 maart 1986 oordeelt dezelfde kantonrechter vervolgens het ontslag op staande voet nietig en wordt de loonvordering van $\mathrm{G}$. toegewezen. ${ }^{23}$

De kantonrechter verwijst voor de motivering van zijn vonnis naar zijn hierboven weergegeven gemotiveerde beschikking inzake de 1639 w-zaak. Maar hij voegt daaraan onder meer nog het volgende toe. Wanneer een arts een patiënt arbeidsgeschikt verklaart, wil dat nog niet zeggen: voor iedere vorm van arbeid, hetgeen in het onderhavige geval betekent, dat $\mathrm{G}$. weer wel bij $\mathrm{N}_{\text {. }}$ aan de slag kon gaam, maar niet zonder meer in zijn oude functie op dezelfde werkplek die bij hem immers herhaaldelijk ziekteverschijnselen veroorzalakte. N., die dit wist, had dus niet zonder meer kunnen eisen dat G. zijn vorige arbeid zou hervatten, maar eerst, door bijvoorbeeld een toxicoloog, moeten laten vaststellen of $G$. na de bekende voorgeschiedenis zonder medische problemen zijn arbeid op de research-afdeling zou kunnen hervatten. Volgens de kantonrechter heeft $\mathrm{N}$. dus onverantwoordelijk gehandeld door zonder zo'n onderzoek $\mathrm{G}$. op staande voet te ontslaan en niet eerst na te gaan of voor $\mathrm{G}$. bijzondere omstandigheden golden die zijn weigering gerechtvaardigd kon doen zijn. Bovendien is de kantonrechter op geen enkele wijze gebleken dat $\mathrm{N}$. zich voldoende heeft ingespannen om $\mathrm{G}$. elders in de onderneming te plaatsen zodat de magistraat zich niet kan onttrekken aan de gedachte dat deze weg door N. is gekozen om de 'lastpost' G. zo snel mogelijk kwijt te raken, terwijl 
N. al 28 jaar lang op het door $G$. verrichte, verantwoordelijke werk geen enkelle aanmerking heeft gemaakt.

Van dit vonnis gaat $\mathrm{N}$. in hoger beroep bij de Rechtbank Amsterdam. (Inmiddels heeft de Raad van Beroep bij beschikking van 23 april 1986 het beroep van $G$. inzake de weigering van het bestuur van de bedrijfsvereniging om $G$. geen uitkering krachtens de Ziektewet te verschaffen ongegrond verklaard). Voor de Rechtbank voert N. een aantal grieven aan waarvan de eerste zes alle neerkomen op de vraag of $\mathrm{G}$. op 2 oktober 1985 al dan niet terecht op staande voet door N. werd ontslagen. Bij vonnis van 17 juni 1987 overweegt de Rechtbank na vaststelling van de hierboven gememoreerde feitelijke omstandigheden, hieromtrent onder meer het volgende.

Naar het oordeel van de Rechtbank mocht $G_{\text {. }}$ in het afwegingsproces waarvoor hij stond - niet verschijnen op zijn werkplek na arbeidsgeschikt te zijn verklaard enerzijds tegenover te gaan werken in een meer dan alleen naar subjectieve opvatting ongezonde klimatologische omgeving - kiezen voor een zo zwaarwegend belang als zijn eigen gezondheid. Gelet op de aard van zijn klachten, waarvan niet aannemelijk is geworden dat zij een andere oorzaak hadden dan de omstandigheden waaronder hij werkzaam was in het researchcentrum was de vrees van $G$. dat, indien hij weer terug zou keren op zijn afdeling, hij zich binnen korte tijd weer opnieuw ziek zou moeten melden, gegrond. De Rechtbank neemt daarbij in aanmerking dat G. als individuele werknemer nauwelijks in staat was zelf zijn werkomstandigheden zodanig te wijzigen dat zijn ziekteverzuim zou verminderen. Hij kaartte de klimatologische omstandigheden wel voortdurend bij daartoe geëigende personen aan. maar dit leidde niet tot een afdoende oplossing van dit probleem.

De vraag of onder de omstandigheden van het geval waarbij $G$. terecht voor zijn eigen gezondheid koos, het ontslag op staande voet gerechtvaardigd was, moet dus volgens de Rechtbank ontkennend worden beantwoord. Een dergelijke maatregel was niet het geëigende middel om te reageren op de problemen waarmee niet alleen $\mathrm{G}$. maar het bedrijf als geheel kampte -getuige de opiniepeilingen en het ter gelegenheid van het pleidooi door $\mathrm{N}$. niet betwiste gegeven, dat $N$. sinds 1987 bezig was het gehele ventilatiesysteem en afvoersysteem te verbeteren. Dit geldt volgens de Rechtbank temeer nu het ontslag op staande voet gericht was tegen een werknemer die reeds 28 jaar in dienst was en het niet onwaarschijnlijk is dat diens gevoeligheid voor de werkomstandigheden mede door dat lange dienstverband is ontstaan, dan wel vergroot is.

Een volgende, subsidiaire grief - want pas aan de orde als de Rechtbank N. niet zou volgen in haar stelling dat het gegeven ontslag op staande voet gerechtvaardigd was - stelt de vraag aan de orde of $\mathrm{G}$. zijn aanspraak op doorbetaling van loon kan laten gelden, hoewel hij zich voor de overeengekomen arbeid niet beschikbaar heeft gehouden, noch behoudt. Volgens de Rechtbank moet deze vraag bevestigend worden beantwoord indien de omstandigheden waaronder G. zijn werk niet hervatte voor risico van N. komen. De Rechtbank overweegt hieromtrent het volgende.

Vast staat dat het research-centrum dat in 1972 naar een nieuw gebouw was 
verhuisd, zonder noemenswaardige problemen tien jaar heeft gefunctioneerd. Vanaf 1982 komen er klachten. Het is echter onbetwist dat N. niet alle aanbevelingen die met name door externe deskundigen zijn gedaan, heeft opgevolgd. De Arbo-enquête toont aan dat $\mathrm{G}$. niet alleen stond in zijn klachtem: Vervolgens herhaalt de Rechtbank nog eens zijn overweging dat bij deze stand van zaken verder moet worden bedacht dat $G$. wel steeds stappen ondernam om de problemen onder de aandacht te brengen van hen die direct verantwoordelijk waren voor de genoemde klimatologische werkomstandigheden doch dat daarin voor $\mathrm{G}$. geen duidelijk merkbare verbetering optrad. De Rechtbank komt dan tot de conclusie dat onder deze omstandigheden, in ieder geval voor het grootste deel in de risicosfeer van N. liggende omstandigheden - veranderende werkomstandigheden gedurende het werkverband van $\mathrm{G}$. waarop $\mathrm{G}$. zelf geen directe invloed kon uitoefenen - de werkgever, dus N., gehouden is het loon aan de werknemer $G$. te betalen .

De grieven die zich richten tegen de weigering van de kantonrechter om de loonvordering te matigen en tegen de vaststelling van de verhoging met $50 \%$ van het overeengekomen loon worden vervolgens eveneens door de Rechtbank verworpen op basis van bovenstaande overwegingen.

Hoewel het mij vooral gaat om het vonnis van de Rechtbank, dient hier ter complementering van het verhaall wel vermeld te worden dat het gelijk dat $\mathrm{G}$. kreeg inmiddels overschaduwd was door de uitkomst van weer een andere procedure: op 26 februari 1987, dus tijdens de procedure voor de Rechtbank, één dag voor de zitting en nog geen vier maanden vóór het vonnis, geeft de directeur $\mathrm{GAB}$ toestemming aan $\mathrm{N}$. om de arbeidsverhouding voor zover vereist met $\mathrm{G}$. te beëindigen. De directeur $\mathrm{GAB}$ overweegt dat $\mathrm{G}$. als gevolg van ervaringen in het verleden en angst voor nieuwe klachten zich niet meer beschikbaar stelt om de bedongen arbeid te verrichten. Bij onderzoek door de Arbeidsinspectic werd volgens de directeur GAB een opmerkelijke verontreiniging van de binnenlucht niet vastgesteld. De directeur overweegt vervolgens dat als mogelijke oorzaak van de door $\mathrm{G}$. ondervonden hinder door de Arbeidsinspectie wordt genoemd: 'een persoonlijke overgevoeligheid voor bepaalde chemische stoffen in geringe concentratie'. Na een verwijzing naar de bevestiging van de Raad van Beroep dat $G$. geschikt werd geacht om de bedongen arbeid te verrichten, concludeerde de directeur GAB vervolgens dat 'gelet op de hiervoor omschreven omstandigheden' een voortzetting van de arbeidsverhouding niet meer in het belang van de partijen wordt geacht. Het verzoek van $N$. aan de directeur GAB werd gedaan in oktober 1986, bijna een jaar nadat $N$. bij de kantonrechter de kous op de kop heeft gekregen bij haar ontbindingsverzoek ex art. 1639w BW voor zover vereist.

\subsection{Commentaar}

a. Het beeld dat uit het geschetste feitencomplex naar voren komt, is dat van een werknemer die, ook volgens de onderneming, bijna 30 jaar prima werk 
heeft geleverd en die vooral de laatste jaren, mede veroorzaakt door zijn eigen ziekteverschijnselen, een groeiende, maar kennelijk gefundeerde bezorgdheid heeft getoond voor de gezondheid van zichzelf en zijn collega's. Deze bezorgdheid uitte zich door het actief zoeken naar oplossingen van de problemen op de werkplek door zelf voorstellen te doen voor verbetering en door het voortdurend aankaarten van problemen bij de mensen en instanties die er volgens hem wat aan zouden kunnen doen. De reacties waren in het algemeen, om overigens uiteenlopende redenen, terughoudend. Wèl werd $\mathrm{G}$. door sommigen in de onderneming gezien als een Don Quichotte die zijn soms eenzame strijd streed tegen windmolens - wat wellicht mede een verklaring kan vormen voor deze reacties.

Maar dit mag uiteraard geen rechtvaardigingsgrond zijn, zeker niet na 1 januari 1983 toen de Arbowet gedeeltelijk in werking trad. En dat is eigenlijk het eerste dat opvalt: op die wet is in het hele verhaal nauwelijks expliciet een beroep gedaan. Twee uitzonderingen moeten genoemd worden. In de eerste plaats verklaart de Arbeidsinspectie haar terughoudende opstelling met een beroep 'op de geest van de Arbowet' en in de tweede plaats het beroep op art. 38 van G. - echter pas na zijn hersteldverklaring, en als grond voor zijn weigering om het werk te hervatten.

De bgd voert in opdracht van N. een onderzoek uit met als belangrijkste conclusie dat nader onderzoek geboden is; de bedrijfsarts wiens wettelijk verplichte taak onder meer bestaat uit adviseren aan, nauw samenwerken met en bijstand verlenen aan de werknemers (los van het feit dat hij ook ten opzichte van de or die taken heeft, art. 18 lid 3 Arbowet), beperkt zich vooral tot het advies aan $\mathrm{G}$. om korter te werken.

De or heeft zijn taken op het gebied van de arbeidsomstandigheden overgedragen aan een VGW-commissie zonder wettelijke status en bevoegdheden, maar wendt zich ook zelf niet (na geconstateerde onenigheid met de werkgever), tot de Arbeidsinspectie met een verzoek om wetstoepassing (art. 40), waardoor de dienst haar terughoudende opstelling zou moeten laten varen. De VGW-commissie is tamelijk actief (organiseert bijvoorbeeld, weliswaar op initiatief van de directie, een Arbo-enquête), maar kan geen enkel (juridisch) machtsmiddel in stelling brengen.

De veiligheids- en milieudienst functioneert nog vooral in de lijn van de directie - wat geoorloofd is, omdat in tegenstelling tot art. 18 art. 19 over de veiligheidsdienst nog niet in werking was getreden.

De vakbonden, en dan gaat het in dit geval vooral om de Industriebonden van FNV en CNV doen weinig meer dan signaleren - kunnen ook niet veel meer doen. Juridisch op basis van de Arbowet niet, omdat er een or is en buiten-juridisch nauwelijks, omdat de organisatiegraad laag is. (Ten opzichte van $G$. is de houding al helemaal niet erg welwillend, omdat hij ostentatief geen lid is - maar ook als dat wèl zo zou zijn, zou dat in de praktijk waarschijnlijk weinig hebben uitgemaakt).

In de (ondernemings-) CAO hebben de vakbondspartijen wel een aantal bepalingen opgenomen weten te krijgen over de veiligheid, maar het be- 
treft vooral parafraseringen van enkele bepalingen uit de Arbowet en van art. $1638 \mathrm{x}$ BW. Een uitzondering vormt wellicht de ondubbelzinnige erkenning door de werkgever van 'het recht van de werknemer op een vellige arbeidsplaats". Maar een beroep op de CAO waaraan ook G. krachtens arbeidsovereenkomst gebonden is, komt in het verhaal evenmin voor.

De opstelling van de werkgever wordt vooral gekenmerkt door welwillend luisteren, vooruit schuiven door nieuwe adviezen en onderzoeken te vragen en door het met mondjesmaat aanbrengen van verbeteringen. Beperkte financiële middelen vormen een gebraikelijk alibi. Bovendien - en dat zal in de juridische procedures terecht wan belang blijken te zijn-getroost de werkgever zich geen enkele moeite om $G$., waar immers aan zijn signalen voor een gezondere werkplek onvoldoende tegemoet wordt gekomen, elders in de onderneming actief te doen zijn.

G. zelf tenslotte is de levende illustratie van mijn betoog dat de individuele werknemer bij zijn pogingen on zijn arbeidsomstandigheden te verbeteren, zowel juridisch als feitelijk in hoge mate afhankelijk is van anderen binnen de onderneming en vooral van de werkgever. Juridisch zou G. wellicht nog geholpen zijn met een, met de waarborgen die ik in het vorige hoofdstuk noemde toegeruste, klachtenprocedure. Die kent de onderneming echter niet. Hoewel mede door zijn toedoen verbeteringen zijn bereikt, zou het resultaat door (een gecombineerde) inzet van vooral de bedrijfsarts, de or en Arbeidsinspectie die zich elk kunnen beroepen op wettelijke bevoegdheden die de individuele werknemer mist, stukken beter geweest kunnen zijn. Dit is des te schrijnender, omdat het hier gaat om een werknemer aan wiens actieve inzet voor betere arbeidsomstandigheden niet getwijfeld kan worden, maar die tegelijk de bestaande (machts-) verhoudingen niet effectief kon doorbreken. Uiteindelijk is de burgerlijke rechter hem te hulp gekomen - maar dan in procedures waarin de hoofdzaak eigenlijk een andere was. Hieronder ga ik op een aantal saillante punten in de diverse uitspraken nader in.

b. G. heeft zich bij zijn weigering om het werk te hervatten beroepen op art. 38 Arbowet. Hoewel dit beroep door partijen werd herhaald, respectievelijk bestreden zowel bij de kantonrechter als de Rechtbank, hebben deze colleges er geen aandacht aan geschonken. Dat is jammer, want het antwoord op de vraag of het beroep van $G$. op art. 38 terecht was, is van belang voor de interpretatie en praktische betekenis van het artikel.

Ik meen dat het beroep niet terecht was. Men zou natuurlijk kunnen redeneren, zoals $\mathrm{G}$. deed, dat een terugkeer naar het research-centrum onder de daar heersende omstandigheden niet meer verantwoord was en dat hij derhalve mocht menen dat er voor zijn gezondheid van een onmiddellijk dreigend gevaar sprake was. G. zou in redelijkheid tot dit subjectieve oordeel kunnen komen, omdat hij immers alleen maar hoeft aan te tonen dat de verschijnselen die hij als een teken van gevaar opvatte zich ook werkelijk voordeden (zie hoofdstuk IV, paragraaf 2.2.). Welnu, G. heeft 
niet nagelaten bij voortduring te verwijzen naar de klimaatbeheersingsproblematiek op de werkplek als gevolg waarvan hij telkens klachten had en ziek thuis moest blijven.

Maar met deze redenering wordt toch voorbijgegaan aan de strenge eisen die de wetgever zeer nadrukkelijk en uitgebreid gemotiveerd heeft gesteld bij de toepassing van het zware middel van het onderbreken van het werk. In de eerste plaats spreekt het artikel van de bevoegdheid om het werk te onderbreken bij dreigend en acuut gevaar. Dit betekent naar mijn mening dat de werknemer ook inderdaad aan het werk moet zijn c.q. op het werk aanwezig moet zijn. Een beoordeling vanuit het huis van de werknemer is kennelijk niet bedoeld. In de tweede plaats moet het gevaar zo onmiddellijk dreigen dat het optreden van de Arbeidsinspectie niet kan worden afgewacht. In dit geval had G. wel degelijk de gelegenheid om (vanuit zijn huis) de Arbeidsinspectie in te schakelen - het feit dat hij (veel) eerder van dezelfde dienst de kous op de kop heeft gekregen is geen argument om, ook gezien de tijdsduur, dit niet opnieuw te proberen. Er was voor G. geen reden om met het inschakelen te wachten tot het moment dat hij weer arbeidsgeschikt was verklaard. In de derde plaats kunnen er vraagtekens geplaatst worden bij G.'s optreden ten aanzien van de verplichting op grond van art. 38 om de werkonderbreking 'terstond' te melden. G. deed dit immers voor het eerst in het telefoongesprek waarin hem gesommeerd werd weer aan het werk te gaan.

Ook de combinatie van een beroep op arbeidsongeschiktheid en art. 38 ligt niet onmiddellijk voor de hand. Bij een beroep op dit laatste immers stelt de werknemer dat hij wèl geschikt is voor de overeengekomen arbeid, maar dat hij, in afwachting van het eventuele optreden van de Arbeidsinspectie zijn werk onderbreekt wegens een onmiddellijk dreigend gevaar. Helemaal duidelijk is deze scheiding overigens ook weer niet, omdat het beroep op het een, althans in casu, onlosmakelijk met het beroep op het andere is verbonden. Maar, ook in aanmerking nemend dat aan juridische leken in beginsel 'the benefit of the doubt' moet worden gegeven en dat juist in dit soort gevallen een interpretatie naar de geest van het artikel geboden is, lijkt het mij, alles afwegend toch niet dat in enige uitspraak het beroep van $\mathrm{G}$. op art. 38 terecht had kunnen worden geoordeeld.

c. Toch heeft G. zowel in eerste instantie als in hoger beroep gelijk gekregen. Volgens beide instanties blijken er namelijk zware verplichtingen te rusten op de schouders van de werkgever N., die hij onvoldoende heeft weten te realiseren. Een belangrijke omstandigheid hierbij wordt gevormd door het feit dat de werknemer ruim 28 jaar in dienst is. De lengte van het dienstverband blijkt art. 1638z BW (de goede werkgever) als het ware evenredig op te rekken.

Meer specifiek speelde het voor de kantonrechter een belangrijke rol dat aan $G$. niet de mogelijkheid was aangeboden om op een andere afdeling werkzaam te zijn. Hiermee lijkt de kantonrechter - mijns inziens terecht- 
niet de vraag centraal te stellen of het in casu ging om de redelijkheid van een opdracht tot het verrichten van (de overeengekomen) arbeid, maar om de vraag of $G$. in verband met zijn (terugkerende) arbeidsongeschiktheid door de heersende arbeidsomstandigheden mocht weigeren zijn werk te hervatten. Bij het antwoord op deze laatste vraag trekt de kantonrechter kennelijk - het blijkt niet met zoveel woorden uit het vonnis - een parallel met het arrest van Haaren-CEHAVE inzake de verplichting van de werkgever tot inpassing van een gedeeltelijk arbeidsongeschikte werknemer in de arbeidsorganisatie. ${ }^{24} \mathrm{Nu}$ is die parallel ook niet zo gek. G. werd immers niet meer in staat geacht om de bedongen arbeid op zijn voormalige werkplek te verrichten, terwijl $\mathbf{N}$. geen enkele poging heeft gedaan om hem op een andere manier in het bedrijf in te passen. Welnu, in het bovengenoemde arrest heeft de HR beslist dat een werknemer, die niet meer in staat is de bedongen arbeid te verrichten, van zijn werkgever kan verlangen, dat deze hem passende arbeid laat verrichten, welke hij voor zover mogelijk heeft gespecificeerd, tenzij dit wan de werkgever niet valt te vergen. Stelt de werkgever zonder deugdelijke gronden een werknemer daartoe niet in staat, dan behoudt de werknemer zijn recht op loon en handelt hij niet in strijd met art. $1638 \mathrm{~d} \mathrm{BW}$.

Wanneer de criteria van dit arrest in verband worden gebracht met deze casus, dan lijkt de kantonrechter er deze uitbreiding c.q. interpretatie aan te geven dat de arbeidsgeschiktheidsverklaring hier betekent dat $G$. in beginsel wèl geschikt is om de bedongen arbeid te verrichten, alleen niet op dle werkplek waar hij dat altijd heeft gedaan.

Bovendien lijkt de kantonrechter ten aanzien van het aantonen dat er geen andere geschikte werkplek is in de onderneming, hogere eisen te stellen aan $N$. dan an het specificeren van $G$. voor welke arbeid hij dan wèl geschikt zou zijn. ${ }^{25}$ Een belangrijk argument voor deze opstelling lijkt - terecht - te zijn dat $G$. al zo lang zijn werk naar tevredenheid heeft uitgevoerd.

d. De Rechtbank gaat niet expliciet in op bovenaangehaald standpunt van de kantonrechter, hoewel én der grieven er zich tegen richtte, maar is het er kennelijk mee eens, getuige onder meer de zinsnede dat 'een dergelijke maatregel' (het ontslag op staande voet) 'niet het geëigende middel was om te reageren op de problemen ...'.

Zeer belangwekkend is de overweging van de Rechtbank dat $G$. in zijn afwegingsproces om al dan niet te gaan werken mocht kiezen "voor een zo zwaarwegend belang als zijn eigen gezondheid', die bedreigd zou worden door de omstandigheden op de werkplek. Dat dit geen vrijbrief vormt voor elke werknemer om te weigeren het werk na een arbeidsgeschiktheids-

24 HIR 8 november 1985 , NJ 1986,309 , m.n. PAS.

25 Toch dient deze specificatie-eis serieus genomen te worden; vgl. bijvoorbeeld $\mathrm{Ktg}$. Eindhoven, 2 mei 1985, Praktijkgids, 1985, nr. 2345; Ktg. Rotterdam, 30 juni 1986, Praktijkgids, 1986 , nr. 2580. 
verklaring te hervatten - of doorredenerend het werk na een dergelijke afweging neer te leggen waardoor een soort recht zou ontstaan als in art. 38 Arbowet is verwoord - moge blijken uit twee andere bijkomende overwegingen. In de eerste plaats moet de werkplek meer dan alleen naar subjectieve opvatting ongezond makend zijn, en in de tweede plaats moet de werknemer zelf niet in staat zijn de omstandigheden te verbeteren, hoewel hij dit wèl probeert. Dit laatste vormt een invulling van de algemene zorgvuldigheidsnorm waaraan een goede werknemer (art. 1639d BW) zich heeft te houden, en die bij een afweging van de belangen van de werkgever en de werknemer dus een rol speelt. Het lijkt bovendien op de plicht van de werknemer, die door de HR in 1962 werd aangenomen, om de werkgever tijdig en gemotiveerd in kennis te stellen van zijn weigering zodat deze laatste (nog) de mogelijkheid heeft om de omstandigheden te verbeteren. ${ }^{26}$ Het is nog van belang om hier op te merken dat er kennelijk geen sprake was van overtreding van de veiligheidsvoorschriften (dan zou de weigering van de werknemer veel sneller acceptabel zijn) en dat dat wellicht er toe heeft bijgedragen dat de Rechtbank geen aandacht heeft gegeven aan de bepalingen van de Arbowet waar hij het vergeefse pogen van $\mathrm{G}$. aan de orde stelt. Denkbaar was bijvoorbeeld geweest dat de Rechtbank van een goede werknemer had gevraagd dat hij zich tot de or zou wenden, die immers volgens de Arbowet het orgaan is dat namens de medewerkers de arbeidsomstandigheden behartigt ten opzichte van degenen die daar invloed op kunnen uitoefenen (zie uitvoeriger over de civielrechtelijke aspecten van deze materie hoofdstuk IV, de paragrafen 2.3. en 3.2.).

e. Interessant en belangrijk is ook de opvatting van de Rechtbank dat G. zijn aanspraak op doorbetaling van loon kan laten gelden, hoewel hij zich niet voor de overeengekomen arbeid beschikbaar houdt, omdat de omstandigheden waaronder $\mathrm{G}$. zijn werk niet hervatte voor risico van $\mathrm{N}$. komen. Ruim een jaar voor dit vonnis immers had de HR uitgemaakt (de Rechtbank verwijst er overigens niet naar) dat de lawaaidoofheid die een werknemer verhinderde om de bedongen arbeid te verrichten voor diens risico behoorde te komen, behoudens bijzondere omstandigheden. ${ }^{27}$ Het ging in dat geval om een onderneming waarin het lawaai onlosmakelijk verbonden was met het werk, ook al bij het in dienst treden van de werknemer. Volgens het oordeel van de Rechtbank is er in de door mij beschreven casus kennelijk sprake van de door de HR genoemde bijzondere feitelijke omstandigheden: veranderende werkomstandigheden gedurende het dienstverband van $G$. waarop $G$. zelf geen directe invloed kon uitoefenen, hoewel hij dit wel probeerde, terwijl van de kant van de werkgever vanwege met name financiële consequenties niet die maatregelen werden genomen die de arbeidsomstandigheden substanticel hadden kunnen verbeteren. On- 
der deze omstandigheden ligt de verhindering van de werknemer dus in de risicosfeer van de werkgever zodat art. $1638 \mathrm{~d} \mathrm{BW}$ van toepassing is.

Het is annotator Stein bij bovengenoemd arrest niet duidelijk 'wat dat voor ziekte kan zijn die in de risicosfeer van de werkgever is gelegen'. Het gaat er echter niet zozeer om welke ziekte het betreft maar, zoals de Rechtbank terecht aanneemt, of er omstandigheden in de onderneming zijn die ziekmakend zijn, die optreden nádat de werknemer in dienst is getreden, waarop hij geen invloed kan uitoefenen en die - ten onrechte - onvoldoende aangepakt worden door de werkgever: dan zijn de gevolgen van die omstandigheden voor zijn risico.

f. De mening van de controlerend geneesheer en van de Raad van Beroep inzake de arbeids(on)geschik theid laat de zelfstandige bevoegdheid van de rechter om hier een oordeel over te vellen onverlet. ${ }^{28}$ Dat blijkt ook hier. De Rechtbank acht G. ongeschikt om het werk te hervatten, althans oordeelt de vrees van $G$. dat hij zich na terugkeer op de werkplek opnieuwen daardoor - ziek zal moeten melden gegrond. De Rechtbank sluit hiermee aan op een recent door de HR gewezen arrest. ${ }^{29}$ Het cassatiemiddel hield in dat de werkweigering van een werknemer alleen dan met werkverzuim wegens arbeidsongeschiktheid van die werknemer kan worden gelijkgesteld, indien de werknemer op grond van een desbetreffende verklaring van de door hem geraadpleegde arts, dat deze hem niet tot werken in staat acht, meende en te goeder trouw mocht menen arbeidsongeschikt te zijn. De HR meent echter dat deze opvatting in haar algemeenheid geen steun vindt in het recht. Kennelijk kunnen er dus nog meer redenen zijn dan de verklaring van een arts, waaronder een werknemer te goeder trouw mag menen arbeidsongeschikt te zijn. Welnu, in casu mocht $G$. menen nog arbeidsongeschikt te zijn, omdat 1) zijn klachten nog bestonden en 2) - en dat is de belangrijkste reden - de ervaring had geleerd dat hij zich spoedig weer net zo ziek zou voelen als toen hij in september 1985 arbeidsongeschikt werd. Naarmate $G$. langer in de onderneming $N$. verbleef, verergerden zijn klachten en naarmate hij langer thuis was, namen zij af. Een vicieuze cirkel dus.

g. Uiteindelijk heeft de directeur van het GAB aan $N$, toestemming gegeven om de arbeidsverhouding met $\mathrm{G}$. te beëindigen. Ten onrechte, lijkt me. In de eerste plaats rijst de vraag, terecht door de raadsman van $G$. gesteld, of de directeur nog wel aan een inhoudelijke toetsing kon toekomen. Wordt er niet een oneigenlijk gebruik gemaakt van de mogelijkheid om door opzegging een einde te maken aan het dienstverband? In casu wordt de mogelijkheid tot het verkrijgen van een voorwaardelijke ontslagvergunning immers als laatste redmiddel gebruikt nadat de werkgever eerst ongelijk heeft

28 HR 6 jumi 1975. NJ 1975, 484; HR 13 jamuani 1978 , NJ 1978, 433.

29 IIR 19 december 1986, NJ $1987,297$. 
gekregen bij de kantonrechter in het kader van een ontbindingsverzoek ex art. 1639 w voor zover vereist. Dat verzoek wordt bovendien ingediend een jaar na de uitspraak van de kantonrechter en zonder dat er nieuwe feiten op tafel zijn gekomen, behalve dan wellicht de wens van $\mathrm{N}$. om een einde te maken aan de onzekerheid over de vraag of de arbeidsovereenkomst is geëindigd, waarbij gewezen wordt op de vermoedelijke lange duur van de procedure bij de Rechtbank (en mogelijk bij de Hoge Raad).

Daar komt dan nog bij dat $\mathrm{N}$. zelf weinig haast leek te hebben: pas vijf maanden na het vonnis van de kantonrechter maakte $\mathrm{N}$. haar grieven kenbaar.

Hoe dit ook zij: met de constatering dat $\mathrm{G}$. zich niet meer beschikbaar stelt om de bedongen arbeid te verrichten en een beroep op de mening van de Arbeidsinspectie en de beschikking van de Raad van Beroep, daarbij in acht nemend de - volgens het voor de onderneming geldend sociale plante treffen afvloeiingsregeling gaat de directeur $\mathrm{GAB}$ akkoord met het verzoek van $\mathbb{N}$.

Het is dan toch wel zeer opvallend dat de directeur volstrekt anders oordeelt dan de kantonrechter. Met name over de (on)mogelijkheden van $\mathrm{N}$. om $\mathrm{G}$. ander werk te verschaffen wordt geen woord gerept.

De zeer restrictieve interpretatie van het begrip 'bedongen arbeid' lijkt bovendien in strijd te zijn met de strekking van HR 8-11-1985 (van HaarenCEHAVE) en de mede daarop gebaseerde circulaire van de DirecteurGeneraal van de Arbeidsvoorziening aan alle directeuren van de Gewestelijke Arbeidsbureaus. ${ }^{30}$ Hierin valt te lezen dat een actieve opstelling c.q. toetsing van de directeur wordt geëist voor het geval dat een werknemer tot het verrichten van de bedongen arbeid blijvend ongeschikt is geworden en hij zich bereid heeft verklaard ander, passend werk te gaan verrichten. Letterlijk staat in de circulaire: 'Door de HR uitspraak ligt het nu immers meer voor de hand om een ontslagvergunning te weigeren indien ander passend werk redelijkerwijs beschikbaar is .... ${ }^{31}$

Van een actief onderzoek ter zake is echter geen sprake geweest en, nog los van de bovengenoemde circulaire, dat mocht in het licht van de uitkomsten bij de kantonrechter wel verwacht worden.

Het zoet van het - terechte - gelijk bij de Rechtbank werd door deze uitspraak well zeer bitter gekruid.

\section{Humanisering en recht}

\subsection{Inleiding}

De conclusie die uit het voorafgaande onder meer getrokken kan worden,

30 Circulaire inzake ontslagbeleid ex art. $6 \mathrm{BBA}$ bij arbeids(on)geschiktheid, 9 december 1986 , Kenmerk A.rbo/Jura-B/TA86/19638.

31 Circulaire, t.a. p. p. 11. 
luidt dat het nieuwe recht betreffende de humanisering van de arbeid zoals dat met name is neergelegd in de Arbowet weliswaar nieuwe beloften inhoudt als het gaat om doelstellingen, maar in zijn juridische en praktische uitwerking toch nog veelal aansluit bij de meer traditionele concepten, terwijl de indivíduele werknemer voor de realisering van de doelstellingen bij conflictsituaties afhankelijk blijft van externe machten. Daarbij moet het nieuwe recht wel onderscheiden worden van het "oude' recht dat ook nog, overgenomen uit de Veiligheidswet, in de Arbowet is opgenomen of althans op basis daarvan is vastgesteld en dat vooral (concrete) regelingen bevat over de bescherming tegen gevaren voor de fysische veiligheid en gezondheid. De invloed, de realisering en de handhaving van die laatste groep regels in de onderneming is in het algemeen veel duidelijker.

'But the law can make only a modest contribution to the standard of living of the population. On some matters it is crucial. Safety at work is an obvious example, though even here we must see its limitations. ${ }^{32}$

Betekent dit nu dat humanisering zich eigenlijk niet leent voor effectieve juridisering via wettelijke maatregelen? Met inachtneming van de notie dat het recht in het algemeen slechts een bescheiden bijdrage kan leveren, zeker indien het beoogt bestaande feitelijke ongelijkheden juridisch te compenseren, moet het antwoord toch niet zonder meer bevestigend luiden.

Alleen lijkt er wel aan een aantal voorwaarden voldaan te moeten worden, wil recht, dat verandering in de bestaande verhoudingen beoogt, in de praktijk worden gerealiseerd. Dit is het complexe vraagstuk van de effectiviteit van recht en dan met name van wetgeving.

\subsection{Effectiviteit van de Arbowet}

Hieronder zal ik trachten vooral aan de hand van enkele, mijns inziens elkaar voortreffelijk aanvullende publicaties van de (rechts-)sociologen Peters en Schuyt iets meer te zeggen over de effectiviteit van de Arbowet. Beide auteurs trachten de condities te formuleren onder welke een wet effectief zal kunnen zijn. Effectiviteit is allerminst een eénduidig begrip. ${ }^{33}$ Onder effectiviteit versta ik in de eerste plaats de mate waarin doel en uitgangspunten van de wet door de (overige) inhoud van de wet zelf worden of kunnen worden bereikt. In de tweede plaats het antwoord op de vraag of de doelstelling van de wetgever wellicht ook gehaald wordt of kan worden zonder dat de regels in de wet zelf daartoe direct aanleiding geven en in de derde plaats of de wet wellicht ook niet-beoogde consequenties heeft. ${ }^{34}$

32 Kahn-Freud, t.a.p. p. 13.

33 Vgl, woor deze problematiek toegespitst op medezeggenschapswetgeving: W.H.J. Reynaerts, Wet en bedrijfsdemocratisering, Beleid en maatschappij, 1977, p. 208-215; B. Geersing, Ondernemingsrecht en effectiviteit. Ars Aequi, 1981, p. 14-19.

$34 \mathrm{~J}$. Griffith onderscheidt directe effectiviteit (gedraagt de adressant zich volgens de norm? indirecte (wat komt er van de doelstielling terecht?), onafhankelijke (zijn er andere sociale gevolgen op cen geheel ander terrein?) en onbedoelde (zijn er onvoorziene neveneffecten?) in: Is law important?, (Groningse oratie), Deventer 1978 . 
Ook Peters gaat er van uit dat nieuw recht dat gecreëerd wordt om de positie van bepaalde categorieën van personen te verbeteren, moet worden doorgezet tegen dominante maatschappelijke verwachtingspatronen en belangenconstellaties in. " Zo'n wet (Peters doelt hier als voorbeeld op de WOR, maar elders noemt hij ook de arbeidsveilligheidswetgeving) moet operatief worden in een hiërarchische gezagscontext, waarin de ondernemer 'als tegenpartij' over onnoemelijk veel voordelen beschikt, waaronder met name het uit die gezagscontext voortvloeiende morele overwicht, marar ook de mogelijkheden om de wet te interpreteren, te ontwikkelen of te neutraliseren, kortom te gaan aanwenden in het eigen belang. ${ }^{36}$

Dit soort recht vereist dus een extra krachtsinspanning: het moet als het ware nog daadwerkelijk veroverd worden, het moet vooral beschouwd worden als een project. 'Van de groepen en individuen die dit project willen realiseren wordt, juist anders dan in geval van het meeste recht waarmee zij te maken hebben, geen conformisme, maar non-conformisme gevraagd. Zij moeten tegen het in hun situatie heersende verwachtingspatroon ingaan. Hoewel het nieuwe recht vóór hen is, is het niet vàn hen. En de kans is groot dat het in beslag genomen wordt door de tegenpartij. ${ }^{37}$

Dit veroveringsproces van rechten dat uiteraard voor individuen lastiger zal zijin dan voor groepen, kan bevorderd worden door "effectieve programmering'. Als dat achterwege wordt gelaten, kan zelfs gesproken worden van een collectieve exercitie in kwade trouw. Onder effectieve programmering verstaat Peters, zeer beknopt samengevat, het volgende. Een wet die nieuwe rechten creëert voor zwakkere afhankelijke groepen dient expliciet gericht te zijn op het overkomen, neutraliseren en compenseren van obstakels, dwangmechanismen en morele nadelen die voor de doelgroep van de wet uit de context voortvloeien. Dit is de 'afstemming op de context'. Vervolgens, en met het bovenstaande samenhangend, moet gesproken kunnen worden van 'instrumentering naar de doelgroep'. Hierbij is van groot belang in de eerste plaats een eenvoudige, heldere vormgeving waarin de rechten kort en puntig zijn geformuleerd, en in de tweede plaats een gemakkelijke rechtsgang, gekenmerkt zowel door het ontbreken van overbodige obstakels, als door de mogelijkheid van self-help en het leggen van de bewijslast bij de gevestigde, sterkere, status quo partij. Tenslotte dienen ook de officiële instanties die met geschillen over betekenis of reikwijdte van dit recht te maken krijgen, zich ondubbelzinnig te engageren in het waarmaken van dit recht. Dat vereist een interpretatie in het licht van de doelstelling van de regeling waardoor die tevens nader wordì geëxpliciteerd en geïnstrumenteerd.

Waar Peters vooral een beroep doet op het actieve gedrag van de rechtsconsument aan wie nieuwe rechten worden toegekend waarbij factoren die direct of indirect met de regelingen samenhangen een barrière-slechtende werking 
kunnen hebben, richt Schuijt zich vooral op het laatste. ${ }^{38}$ Hij heeft een soort analysemodel ontworpen met behulp waarvan de effectiviteit, en dan vooral de effectiviteit in de eerste door mij genoemde betekenis van een wet kan worden getoetst. Aan dit model ligt zijn hypothese van de differentiële effectiviteit van rechten en plichten ten grondslag. Het komt hierop neer. De verdeling van de meest waardevolle dingen in het leven (bezit, kennis, lichamelijk welzijn, plezierig en gezond werk) is niet voor alle groepen van de bevolking gelijk. Deze ongelijkheid is niet toevallig, maar is als regel overeenkomstig de machtsverhoudingen in de maatschappij. Een functie van het recht is nu om die machtsverhoudingen te reguleren en wel zo dat niet alleen de factor macht de ontplooiingskansen van mensen bepaalt. Het recht doet dat door aan verschillende leden van de samenleving uiteenlopende rechten en plichten toe te kennen: daarbij ligt de nadruk op het toekennen wan rechten aan de zwakkere; afhankelijke partij.

Toch wil dit nog niet zeggen dat als er sprake is van (her)verdelend recht de beoogde gevolgen in de praktijk gerealiseerd worden. Volgens diverse onderzoekingen blijkt er een discrepantie te bestaan tussen het recht in theorie en in praktijk. Deze discrepantie heeft een bepaald patroon: naarmate iemand hoger op de sociale, economische etc. ladder staat, is de kans groter dat hij effectief weerstand kan bieden aan de hem opgelegde verplichtingen, terwijl hij zijn rechten optimaal weet te benutten. Omgekeerd geldt voor de zwakkere dat het moeilijk is om zijn rechten te realiseren, terwijl hij uitputtend aan zijn verplichtingen herinnerd wordt. Met andere woorden: de effectiviteit van het recht wordt voor een groot deel bepaald door de mate van sociale ongelijkheid die in een samenleving aanwezig is. Of het nu gaat om rechten of plichten: de machtspositie van degene tot wie ze zijn gericht, is van groot belang.

Van belang zijn natuurlijk ook, maar wellicht in mindere mate doorslaggevend, de volgende drie factoren: de inhoud van de rechtsregels, de instrumenten (ondersteunende regels) waarmee ze kunnen worden afgedwongen door de betrokkenen en de toepassing door de officiële uitvoeringsinstanties.

Voor wat betreft de eerste factor, de inhoud, is het van grote betekenis hoe bepaalde bedoelingen geformuleerd worden. Zo makt het bijvoorbeeld verschil of er ten aanzien van het werkoverleg geschreven wordt dat het 'bevorderd' moet worden (art. 28 WOR) of dat het verplicht is voorgeschreven (art. 16 Arbowet) ${ }^{39}$ Een ander aspect van de inhoud is de manier waarop de rechten en plichten zijn geformuleerd. Dat kan vaag en diffuus zijn, maar ook concreet en niets ter interpretatie overlatend. Schuyt formuleert hierover als algemene werkhypothese, dat de plichten voor de minder machtigen vaker specifiek zijn geformuleerd, hun rechten daarentegen vaker diffuus en algemeen. En het omgekeerde: de rechten van de machtigste groepen zijn vaker specifiek geformuleerd, hun plichten diffuus en algemeen. ${ }^{40}$

38 C.M.M. Schuyt, Rechtvaardigheid en effectiviteit in de verdeling van de levenskansen, Universitaire Pers, Rotterdam 1973.

39 Zie voor een aantal andere verschillen tussen het werkoverleg in de wOR en in de Arbowet hoofdstuk III, paragraaf 3.5 .

40 Schuyt, t.a.p. p. 20. 
De uiteindelijke formulering heeft natuurlijk een voorgeschiedenis. Schuyt noemt dat de transformatie van sociale claims in juridische claims. Wetgeving is nu eenmaal óók een proces van botsende en concurrerende belangen. Overeenstemming over de uiteindelijke tekst is moeilijker naarmate de directe betrokkenheid van de partijen groter is en de belangen tastbaarder. De tekst die eruit rolt, is dan ook vaak een bloedeloos compromis, vlees noch vis, vaag en multi-interpretabel. De effectiviteit van zo'n regeling zal ook in de praktijk geringer zijn dan wanneer het gaat om een heldere, duidelijke regeling. ${ }^{41}$

De tweede belangrijke factor voor het vraagstuk van de effectiviteit van rechten en plichten is de aanwezigheid van instrumentele, ondersteunende regels. Het gaat hierbij met name om het antwoord op de vraag of er een effectieve juridische procedure is, met behulp waarvan men de toegekende rechten ook kan afdwingen. Schuyt: 'Bij de interferentie met bijvoorbeeld het recht op eigendom heeft de eigenaar een zeer grote kans om zijn rechten de facto te effectueren en indringers te weren, dit in tegenstelling tot bijw. iemand die in het net van de sociale wetgeving verstrikt raakt, terwijl hij voor zijn primaire bestaan van dit stuk wetgeving afhankelijk is. In het privaatrecht vindt een opeenstapeling van rechten plaats die elkaar ondersteunen ... Deze cumulatieve verwevenheid van rechten is een belangrijke eigenschap van het recht. Het recht heeft kennelijk een zelfde vermogen - een soort multiplier effect - als twee andere belangrijke schaarse goederen, $\mathrm{nl}$. geld en kennis. ${ }^{42}$

Vanouds zeer belangrijk is de derde factor: de manier waarop organisaties ter handhaving of realisering van rechten en plichten functioneren. Hierbij is niet alleen van belang de rechterlijke macht, de politie, de advocatuur en het openbaar bestuur, maar ook en vooral de specifieke organen die belast zijn met de uitvoering van bepaalde wetten, zoals de Arbeidsinspectie. Voor dit soort organisaties bestaat veel aandacht. Schuyt: 'Die aandacht is terecht, omdat het interne functioneren van dergelijke organisaties een belangrijke invloed zal hebben op de manier waarop de sociale claims en de rechten en plichten gerealiseerd worden. In deze organisaties is ook veel kans op 'ruis", het sociale proces waarin de oorspronkelijke doeleinden van het recht of van bepaalde regels langzaam en valk ongemerkt verschuiven, verdwijnen of zelfs tot tegengestelde resultaten leiden. Machtsverhoudingen binnen de organisatie - denk hierbij bijv. aan de overheidsburocratieën - zullen een duurzame druk uitoefenen op de door de regels van het recht voorgeschreven manieren van machtsuitoefening., 43

Uiteindelijk komt Schuyt uitgaande van het bovenstaande tot veertien zowel juridische, als sociaal-culturele factoren die zelf weer uit talloze variabelen zijn opgebouwd, waarvan de effectiviteit van het recht theoretisch afhankelijk is.

41 Een dergelijke compromis-wet wordt ook wel symboolwet genoemd. Aalders bijvoorbeeld heef volgens het axioma dat symboolwetten ineffectef zijn getrach de ineffectiviteit van de Hinderwet a an te tonen. M.V.C. Aalders, Industrie, milieu en wetgeving, de Hinderwet tussen symboliek en effectiviteit. Amsterdam, 1980.

42 Schuyt, t.a.p. p. 22.

43 Schuyt, t.a. p. p. 22. 
Samenvattend lijkt het mij dat in elk geval de volgende factoren van betekenis zijn: de inhoud en vormgeving van de bepalingen (1), de rellatie tussen materiële bepalingen en ondersteunende (procedure)regels (2), de uitvoerings- en handhavingsvoorzieningen (3), de sociaal-culturele infrastructuur binnen de onderneming en daarbuiten (4), en tot slot de opstelling van de rechtsconsumenten zelf (5).

Het belangrijkste doel van de Arbowet is de bevordering van de humanisering van de arbeid van de werknemers. In welke mate kan de inhoud van de wet nu bijdragen aan deze doelstelling, gelet op de vijf bovengenoemde factoren? I $\mathrm{k}$ zal bij de beantwoording van deze vraag vooral het oog gericht houden op de werknemer als zwakkere partij voor wie de doelstelling immers geschreven is, en die dus primair belang heeft bij de realisering ervan.

\subsubsection{Inhoud en vormgeving}

Al eerder heb ik geconstateerd dat in de Arbowet geen ondubbelzinnig recht op humane arbeidsomstandigheden voor de werknemer is geformuleerd. Voor zover van zo'n algemeen recht gesproken kan worden, is het afgeleid uit de algemene verplichtingen van de werkgever zoals die met name te vinden zijn in de artikelen 3 en 4 . Het is dan opvallend dat de door de werkgever te hanteren grondbeginselen bij het te voeren beleid in art. 3 meestal vergezeld gaan van de mededeling dat de verplichting geldt, tenzij dit redelijkerwijze niet kan worden gevergd. Ten aanzien van de algemene verplichtingen van de werknemer in art. 12 is een dergelijk voorbehoud echter niet opgenomen. $\mathrm{Nu}$ spreekt het vanzelf dat de bovengrens van wat verplicht gesteld kan worden, of dat nu gaat om een zorgplicht of een naleefplicht, gevormd wordt door wat redelijkerwijze mogelijk is voor de adressant, en in die zin is een dergelijke formulering altijd overbodig. Dit neemt niet weg dat het verschil opvallend is, vooral in het licht van Schuyts hypothese dat de machtigen nogal eens onder hun verplichtingen uitkomen.

Ook andere rechten voor de individuele werknemer die een bijdrage kunnen leveren aan de humanisering van zijn arbeid moeten afgeleid worden - en soms is dat juridisch niet eens zo gemakkelijk, bijvoorbeeld ten aanzien van het klachtrecht of het informatierecht - uit verplichtingen die anderen hebben. (Een uitzondering moet gemaakt worden voor het recht om het werk neer te leggen). Het gaat bovendien vaak om globale normen en opdrachten tot nadere regelgeving die er evenmin toe zullen leiden dat de werknemers hum daaruit voortvloeiende rechten, evenals trouwens hun plichten, als het ware zo uit het hoofd kunnen leren.

Daar komt bij dat het de bedoeling is om ook in de op de Arbowet gebaseerde AMvB's meér dan voorheen de nadruk te leggen op algemeen omschreven doelstellingen in plaats van op gedetailleerde normen. ${ }^{44}$ Binnen de onderneming zelf moeten dan, eventueel met behulp van de Arbeidsinspectie, de doel-

44 MvT, t.a.p. p. 6. 
stellingen in concrete maatregelen omgezet worden. Hoewel doelstellingsvoorschriften en globale normen niet per definitie afgewezen behoeven te worden is het toch de vraag of, wanneer het gaat om bescherming tegen gevaren voor de gezondheid en veiligheid, niet de voorkeur moet worden gegeven voor zover mogelijk aan concrete normen. ${ }^{45}$ In bewijsrechtelijk opzicht kunnen concrete en helder geformuleerde normen bovendien van belang zijn bij de strafrechtelijk gesanctioneerde niet-naleving van de bepalingen. Ten aanzien van de Wet gelijk loon voor vrouwen en mannen bijvoorbeeld werd de vaagheid van de norm 'gelijke beloning voor gelijkwaardige arbeid' als argument gehanteerd om een strafsanctie achterwege te laten. ${ }^{46}$

Niet zozeer globaal als wel vrijblijvend zijn de artikelen die aangeven dat iets pas moet als dat bij nadere regelgeving wordt bepaald zonder dat die nadere regelgeving verplicht is. Voor de werknemersparticipatie bij de arbeidsomstandigheden is een dergelijke formulering van belang ten aanzien van de instelling van een Arbocommissie ex art. 14. In de praktijk kan dit ertoe leiden dat zowel in de kleinere ondernemingen (waar geen or is) als in de grotere (waar er wel een is) het geïnstitutionaliseerde overleg over arbeidsomstandigheden met de werkgever achterwege blijft. In de kleinere zal dat het geval zijn als de onderneming niet wordt aangewezen voor verplichte instelling van een Arbocommissie en in de grotere als de or onwillig is om zich in het overleg met de werkgever te bemoeien met de arbeidsomstandigheden, terwijl zijn loutere aanwezigheid het volgens art. 14 onmogelijk maakt om een Arbocommissie in te stellen.

Eveneens teleurstellend voor de participatiemogelijkheden van werknemers die geen lid zijn van de or is de onduidelijke, vrijblijvende en veel vragen open latende redactie van art. 16 waarin het verplichte werkoverleg is geregeld. In dit artikel wordt zelfs niet de mogelijkheid geopend van nadere regelgeving. Vaak ook is de opdracht wel duidelijk en concreet, maar wordt over de uitwerking weinig of niets bepaald, anders dan dat de minister regels kàn stellen. Een voorbeeld van dit laatste. Art. 6 verplicht de werkgever er voor te zorgen dat een werknemer bij zijn indiensttreding en voorts zo dikwijls als dit in verband met de arbeidsomstandigheden noodzakelijk is, doeltreffend wordt ingelicht over de aard van de aan de arbeid verbonden gevaren, alsmede over de maatregelen die erop gericht zijn deze gevaren te voorkomen of te beperken. Deze verplichting laat op zich weinig te raden over. Echter, over vragen als hòe dat dient te gebeuren, schriftelijk of mondeling, wie het moet doen, of het individueel moet of groepsgewijs kan, daar laat het artikel zich niet over uit. Een aantal verplichtingen voor de werkgever is ook ondubbelzinnig en helder in de wet geformuleerd, al wordt soms de mogelijkheid tot nadere regelgeving geopend; het valt echter op dat het dan vaak verplichtingen betreft waar de werknemer slechts indirect wat aan heeft. Als voorbeelden noem ik de verplichting om een arbeidsveiligheidsrapport, een jaarplan of een jaarverslag te

$45 \mathrm{Vgl}$. ook het SER-advies inzake het ontwerp Arbowet, t.a.p. p. 17.

$46 \mathrm{Vgl}$. A.M.Th. Bots "De wetgever in het arbeidsrecht, Macht en onmacht van de wetgever, Deventer 1978 , p. 151 . 
maken (resp. de artikelen 5,4 en 10) of om ongevallen en beroepsziekten te melden en te registreren (art. 9).

Wat ik hierboven schreef over specifiek op de werknemers toegesneden rechten, geldt in mindere mate voor de hen vertegenwoordigende organen. Zo zijn de meeste bevoegdheden, rechten en faciliteiten voor de or zonder meer duidelijk. Wel dient in dit verband de gebrekkige aansluiting bij de WOR geregistreerd te worden, waardoor het bijvoorbeeld niet duidelijk is hoe de relatie ligt tussen de faciliteitenregeling in de Arbowet en de WOR en tot welke beroepsinstantie de or zich kan wenden. (Zoals ik heb vermeld, wordt deze gebrekkige aansluiting echter gerepareerd).

Terugziende op de inhoud en de vorm van de meeste bepalingen moet geconstateerd worden dat de vertaling van de sociale claim op humane arbeid in juridische termen niet heeft plaatsgevonden in specifieke, wettelijke rechten voor de werknemers (wèl voor hun vertegenwoordigers), maar in soms concrete, en soms nogal vage en diffuus geformuleerde verplichtingen voor andere betrokkenen.

\subsubsection{Materiële en hulpregels}

De aanwezigheid van procedurele hulpregels op basis waarvan de betrokkenen zelf op een eenvoudige manier hun rechten kunnen handhaven, is van belang voor de praktische realisering van die rechten. Een gemakkelijke rechtsgang zou moeten voldoen aan drie voorwaarden. Er zouden geen obstakels mogen zijn voor de gang naar de rechter (dat kan ook de Arbeidsinspectie zijn) zoals bijvoorbeeld door een verplicht voorgeschreven eerdere gang naar andere instanties (Peters: verplichte bemiddeling betekent ontkenning van het recht op een juridisch geschil. Het kan een effectief middel zijn om mensen van hun rechten af te houden), mogelijkheden tot self-help of eigenrichting in geval van inbreuk op rechten zouden moeten worden ingebouwd en het bewijs moet ten laste komen van de status quo en van de daarin gevestigde sterkere partij.

Er is in de Arbowet één bepaling die tegemoet komt aan deze voorwaarden: het recht van elke individuele werknemer om het werk neer te leggen in art. 38. Maar daar staat tegenover dat het ook alleen maar mogelijk is in noodsituaties, waarbij er sprake moet zijn van ernstig gevaar voor personen dat zo onmiddellijk dreigt dat de Arbeidsinspectie niet tijdig kan optreden. Voor het overige is er op basis van de Arbowet geen sprake van een gemakkelijke rechtsgang voor de individuele werknemer en dat correspondeert met de kwaliteit en kwantiteit van de hem toegekende rechten.

Voor de or, of voor de met hem gelijkgestelde organen of groeperingen, ligt de zaak anders. Onder weinig formele voorwaarden kan de or immers bij onenigheid met de werkgever (die dan trouwens hetzelfde kan) een beroep doen op de Arbeidsinspectie om de wet toe te passen (art. 40). Van de uitspraak van de Arbeidsinspectie is weer, eveneens betrekkelijk informeel te realiseren, beroep mogelijk bij de minister. Dit lijkt voorlopig een procedurele voorziening 
te zijn die snel, vrijwel kosteloos, eenvoudig en zonder hoge drempel benut kan worden.

Indien het voorstel wet wordt om op de geschillen over de faciliteiten voor de or in de Arbowet die óók in de WOR staan, exclusief de WOR-procedure van toepassing te verklaren, dan zou dat volgens datzelfde voorstel betekenen dat de kantonrechter beslist ná voorafgaande bemiddeling door de bedrijfscommissie. Volgens Peters zou dat laatste een barrière zijn die de werknemers van het halen van hun recht kan afhouden. Dat ben ik niet met hem eens. Ik meen veeleer dat juist de informele procedure bij de bedrijfscommissie, die bovendien deels nog is samengesteld uit een vertegenwoordiging vanuit werknemerskringen, wel eens het welkome opstapje zou kunnen zijn naar de "echte' rechter, naar wie men minder snel durft te gaan. Daar komt nog bij dat het de vraag is of het wel zo verstandig is om bij een permanente arbeidsrelatie onmiddellijk de gang naar de rechter te maken. Een verstoring van die relatie zou de werknemer wel eens verder van huis kunnen brengen.

Voor de or lijken samenvattend de procedurele regelingen te voldoen, de individuele werknemer staat weer vrijwel met lege handen - althans op basis van de Arbowet; uiteraard blijft zijn toegang tot de civiele rechter onverlet.

\subsubsection{Uitvoerings- en handhavingsvoorzieningen}

Het belang voor de effectiviteit van een wet van de met de uitvoering en handhaving belaste instantie is evident. Dit belang is des te groter als het om een wet gaat die nieuwe doelstellingen en uitgangspunten formuleert die moeten worden waar gemaakt in een context waarin dat niet altijd even vanzelfsprekend is. De Arbowet is zo'n wet. Zij richt zich op de onderneming en met haar uitvoering en handhaving is vooral de Arbeidsinspectie belast. Juist wanneer de bepalingen die gestalte moeten geven aan de doelstelling en de uitgangspunten zelf in vorm en inhoud niet altijd even helder zijn, is een interpretatie ervan in het licht van doelstelling noodzakelijk. Dergelijke uitspraken hebben een demonstratie-effect. Eventuele scepsis bij de nieuwe rechthebbenden kan er door verminderd worden. Dit betekent dat de Arbeidsinspectie voor werknemers gemakkelijk bereikbaar moet zijn en dat zij zich niet te snel moet terugtrekken op formele stellingen. Een werknemer die klaagt moet dus in beginsel niet teruggewezen worden naar zijn or, omdat dat het door de Arbowet gepriviligeerde orgaan is voor de bemoeienis van werknemers met de arbeidsomstandigheden.

Een voorbeeld van hoe het niet moet, vormt de volgende casus. ${ }^{47}$ In augustus 1986 dient de VGW-commissie van een gemeentelijk bedrijf een verzoek om wetstoepassing in bij het districtshoofd (art. 40 Arbowet). Deze VGW-commissie is een commissie van de medezeggenschapscommissie. De voorzitter en secretaris van de medezeggenschapscommissie paraferen het verzoek voor gezien. Deze medezeggenschapscommissie is volgens de gemeentelijke verorde-

47 Gepubliceerd in Arbobulletin, 1987, p. 27-28 
ning te beschouwen als het overlegorgaan dat vergelijkbaar is met de or in de Arbowet (vgl. art. 2 van het Arbobesluit burgerlijke openbare dienst). Het verzoek aan het districtshoofd houdt in dat de medezeggenschapscommissie in de praktijk onvoldoende faciliteiten heeft om de taken van de Arbowet te kunnen realiseren omdat de directeur van het gemeentelijk bedrijf de nodige bevoegdheden ontbeert en omdat de implementatie van de Arbowet door het gemeentebestuur wordt gestagneerd.

In oktober 1986 verklaart het districtshoofd het verzoek niet ontvankelijk, omdat de commissie VGW van de medezeggenschapscommissie geen bevoegdheden gedelegeerd heeft gekregen en dus niet bevoegd zou zijn tot het indienen van een verzoek om wetstoepassing. Daarnaast acht het districtshoofd zich niet bevoegd om een uitspraak te doen over de bevoegdheden van de directeur die geregeld zija in de bovengenoemde verordening en vindt thij dat de regeling van de faciliteiten op zich voldoet aan hetgeen in de Arbowet c.s. daaromtrent is vereist. De medezeggenschapscommissie gaat in beroep bij de staatssecretaris (art. 42). Op het bezwaarschrift heeft de staatssecretaris op 25 mei 1988 (bijna twee jaar na het verzoek om wetstoepassing!) beslist. In zijn beslissing sluit de staatssecretaris zich aan bij het advies van de bezwaarschriftencommissie van de Arboraad (art. 42 lid 9), die circa een jaar daarvóór all zijn advies had gegeven. ${ }^{48}$

Deze commissie is van oordeel dat het verzoek om wetstoepassing geacht moet worden te zijn ingediend door de - daartoe bevoegde - medezeggenschapscommissie. Het bezwaar tegen de niet ontvankelijkheidsverklaring door het districtshoofd wordt op dit punt dus gegrond verklaard. Ondat echter in het verzoek om wetstoepassing niet aangegeven was van welke artikelen de toepassing werd verzocht, terwijl dit ook later niet is gebeurd, acht ook de commissie het verzoek niet ontvankelijk. Voorts meent zij dat ten aanzien van appelantes faciliteiten en de wijze waarop het overleg met de werkgever wordt gevoerd door de Arbeidsinspectie geen eis kan worden gesteld of een aanwijzing kan worden gegeven.

Hoewel de staatssecretaris dus niet van het advies is afgeweken was dat ten aanzien van een gedeelte van het advies echter wèl te hopen. Dat geldt niet voor het gedeelte waarin het verzoek om wetstoepassing wel degelijk geacht moet worden te zijn ingediend door het bevoegde medezeggenschapsorgaan. De oorspronkelijke beslissing van het districtshoofd valt ook niet goed te begrijpen: als immers duidelijk is dat de VGW-commissie kennelijk handelt in opdracht van de medezeggenschapscommissie en dat de gemeentelijke verordening dat toestaat (en dat is het geval), dan gaat het niet aan om het verzoek niet ontvankelijk te verklaren op grond van het argument dat de commissie in het algemeen geen bevoegdheden gedelegeerd heeft gekregen. Bovendien had het districtshoofd in zijn overweging kunnen betrekken de mening van de minister en het parlement, dat de verschillen tussen ambtenaren en

48 Arboraad, BZ 023/29, 22 juni 1987. De beslissing van de staatssecretaris is gedateerd op 25 mei 1988, kenmerk Win-k/SoZa-256/HB. 
particuliere werknemers onder meer op het gebied van de medezeggenschapsstructuren er in geen geval toe mogen leiden dat de positie van de ambtenaren om die reden ten aanzien van het bepaalde in de Arbowet een slechtere zou mogen zijn..$^{49}$ Hier was dus van de kant van het districtshoofd sprake van een onnodige formalistische opstelling en van onwil of onmacht om te interpreteren in het licht van de doelstelling van de wet.

Vervolgens oordeelt de bezwaarschriftencommissie echter dat het verzoek niet ontvankelijk is, omdat niet is aangegeven van welke artikelen de wetstoepassing wordt verzocht en dat bovendien ten aanzien van het gevraagde geen eis of aanwijzing kan worden gegeven. Ook dit lijkt mij een té formalistische opstelling: het is toch niet zo moeilijk en in elk geval niet verboden om het verzoek (ambtshalve) juridisch te kwalificeren door de van toepassing zijnde artikelen te noemen en vervolgens na te gaan of een eis of een aanwijzing mogelijk is? Zo lijkt bijvoorbeeld ten aanzien van het probleem over de wijze waarop het overleg met de werkgever wordt gevoerd, art. 13 van toepassing te zijn, op grond van welk artikel een aanwijzing kan worden gegeven. Ook bij het oordeel dat het districtshoofd geen uitspraak kan doen over de bevoegdheidstoedeling aan de directeur, omdat dat geregeld is in de verordening, kunnen vraagtekens gezet worden. Het al dan niet toekennen van bevoegdheden aan de directeur heeft immers een directe relatie met de vraag wie werkgever is in de zin van de Arbowet en deswege aansprakelijk kan worden gesteld.

Hoewel het vanzelfsprekend is dat door officiële uitvoeringsinstanties zorgvuldig de formele regelingen in acht moeten worden genomen, juist omdat zij vaak geschreven zijn ten behoeve van de rechthebbenden, dienen zij wel, indien die ruimte er is, met het oog op dezelfde belangen geïnterpreteerd te worden.

Een uitvoeringspraktijk die minder de doelstellingen van de wet dan wel de status quo begunstigt, kan worden versterkt door een overheidsbeleid dat enerzijds een terughoudende opstelling van de Arbeidsinspectie voorstaat, maar anderzijds de noodzaak benadrukt van toenemende advisering, stimulering en overleg door de dienst binnen de onderneming. Dat laatste, zo wordt gesteld, is arbeidsintensief en uitbreiding met gekwalificeerde mensen is derhalve geboden. Alleen: dat gebeurt niet of nauwelijks. Zo kan vrijwel elk optreden of niet-optreden van de Arbeidsinspectie gerechtvaardigd worden met het - begrijpelijke - alibi dat de Arbowet weliswaar nieuwe en uitdagende taken voor de ambtenaren meebrengt, maar dat helaas de middelen ontbreken om tot een verantwoorde uitvoering over te gaan. Het argument van de terughoudende overheid kan ook gebruikt worden om het ontbreken van een directe strafrechtelijke controle te verklaren, hoewel daar waarschijnlijk,

49 De minister: 'Ik wil ... gaarne toezeggen, dat deze afwijkende regelen er nimmer toe zullen leiden, dat de arbeidsomstandigheden van het overheidspersoneel ongunstiger worden dan die van personem werkzaam in het particuliere bedrijfsleven.' MvA, t.. a.p. p. 54. 
nauw mee samenhangend, evenzeer debet aan zal zijn de moeilijke verenigbaarheid van vage normen met concrete strafsancties. ${ }^{50}$

Ongetwijfeld zal de effectiviteit van de Arbowet voor een groot deel in de praktijk afhangen van het optreden van de Arbeidsinspectie. Geconstateerd moet echter worden dat niet alle condities in dat opzicht even gunstig zijn.

\subsubsection{Het economisch en sociaal-culturele klimaat}

Het economisch en sociaal-culturele klimaat is van belang zowel voor de totstandkoming en de inhoud van een wet als voor haar effectiviteit. Er is al op gewezen dat de Arbowet én van die wetten is die in het begin van de zeventiger jaren op stapel is gezet en die nu in fasen van de helling komt in een sterk veranderd sociaal-cultureel klimaat. In het begin van de jaren zeventig immers scoorden 'zachte' begrippen als medezeggenschap, welzijn, humanisering, ontplooiing en dergelijke, net zoals in andere westerse landen, in het algemeen hoog. Het was het klimal waarin een wet als de Arbowet geintroduceerd kon worden. Niet voor niets werd zij met betrekkelijk weinig essentiële wijzigingen in de Tweede Kamer unaniem aangenomen. De tijden veranderden echter snel. Vanaf het begin van de jaren tachtig zijn het de 'harde' sleutelwoorden als markteconomie, technologische vernieuwing, flexibilisering, deregulering, efficiency, terugtredende overheid die de toon aangeven. Vergeleken met zo'n vijftien jaar geleden is het aantal werklozen ruimschoots verdubbeld en zijn de matschappelijke en economische condities en vooruitzichten onvergelijkbaar. Onder invloed hiervan zijn de arbeidsverhoudingen en de situatie op de arbeidsmarkt grondig veranderd.

Binnen de onderneming is dit alles uiteraard niet zonder effect gebleven. Vooral de technologische ontwikkelingen spelen een zeer belangrijke rol. ${ }^{5 n}$ Die ontwikkelingen zelf lijken echter vrijwel geheel door de werkgevers gedicteerd te worden. werknemers komen in dit stuk nauwelijks voor. Illustratief hiervoor is het in 1987 verschenen SER-advies inzake het technologische aandachtsgebiedenbeleid. Terwijl de raad constateert dat invoering van (onder meer) nieuwe technologieën 'noodzakelijkerwijze met name op het niveau van de onderneming' vorm moet worden gegeven, wordt ten aanzien van de werknemers een stuk minder imperatief geformuleerd dat informatie aan en raadpleging van werknemers zowel de kwaliteit van de besluitvorming kan verbeteren, als de acceptatie van veranderingen en vernieuwingsgezindheid bevorderen. Vervolgens wordr toch enigszins gratuit medegedeeld dat de

so Het verschijnsel van een overheid die, ondanks tegengestelde woonemens, nog steeds rijkelijk met regels strooit, doch terughoudend is met de handhaving ervan wordt ook well werklaard met de noodzaak om compromissen te sluiten. Een bekend voorbeeld wormt de Noorse wet op het huishoudelijk personed. Zie hiervoor V. Aubert, Enkele sociale functies wan wet. geving in: Bram Peper en Cees Schuyt, Proeven van rechtssociologie uit het werk van Vilhelm Aubert, Rotterdam 1971 , p. $46-74$, m.n. p. 61 .

51 De FNV in 1987: "Waarschijnlijk is de technologische ontwikkeling wel de scharnier walar alle veranderingen in de ondernemingen - en ook daarbuiten - om draaien.' FNV-nota Werken in 2000, Ansterdam, 18 augustus 1987, p. 19. 
daarvoor in aanmerking komende vertegenwoordigers van de werknemers een centrale rol kunnen vervullen bij het vernieuwingsproces. ${ }^{52}$

Het lijkt mij eerder dat zij een centrale rol mòeten vervullen bij het proces van technologische ontwikkelingen. Zowel de kwantiteit als de kwaliteit van de arbeidsplaatsen zal er door worden beïnloed en deze beïnvloeding zal voor de werknemers niet altijd even positief uitvallen: nieuwe technieken zijn in het algemeen arbeidsbesparend, terwijl ze daarnaast belangrijke functieveranderingen kunnen veroorzaken waardoor bijvoorbeeld contacten met machines de plaats innemen van die met collega's. Derhalve zal reeds op juridische gronden betrokkenheid van de werknemers op grond van met name de WOR en/of de Arbowet vaak geboden zijn.

In juli 1987 verscheen de notitie van de minister van Sociale Zaken en Werkgelegenheid over de sociale aspecten van technologische vernieuwing. ${ }^{53}$ Hoewel in deze notitie de zinvolheid van betrokkenheid van werknemers wordt benadrukt - samengevat om drie redenen: de acceptatie van het systeem door de werknemers, de bij hen opgeslagen kennis en ervaring en de mogelijke veranderingen van de werkinhoud - ademt de notitie voor het overige de geest van de tijd, namelijk een terughoudende overheid die de gewenste betrokkenheid van de werknemers niet dwingend wil voorschrijven. Het zijn de sociale partners binnen de onderneming die de door de overheid beleden filosofieën moeten realiseren. 'Goede relaties tussen de uitvoerende werknemers en management zijn daarom essentieel', merkt de minister vroom op.

Technologische ontwikkelingen en de veranderde arbeidsmarktsituatie zijn ook oorzaken voor de zogenaamde flexibilisering van en binnen de onderneming: de arbeidsorganisatie zelf wordt flexibel zodat producten en diensten kunnen worden aangeboden die direct kunnen voorzien in snel veranderende behoeften, en manieren om dat te bereiken zijn bijvoorbeeld het werken met flexibele arbeidsrelaties zoals afroepcontractanten en uitzendkrachten en het manipuleren met werktijden en functie-invullingen. Het is duidelijk dat een flexibiliseringsbeleid dat louter gevoerd wordt uit het oogpunt van efficiency en bedrijfseconomische overwegingen, tegelijkertijd weinig ruimte laat voor een verantwoord sociaal beleid.

Ook de (getalsmatig en inhoudelijk) verzwakte vakbeweging lijkt geen kans te zien dit proces - waarbij ook nog genoemd kan worden de wens van werkgevers tot decentralisatie van het arbeidsvoorwaardenoverleg - een halt toe te roepen.

Bovendien is het een ideologisch uitgangspunt van de overheid om terug te treden, opdat zoveel mogelijk het vrije marktmechanisme zijn zegenrijke werk kan verrichten. De facto betekent dat een keuze voor de sterkste partij in het sociaal-economische veld. ${ }^{54} \mathrm{Om}$ het in het (economische) lleven verder niet al te moeilijk te maken moet er gedereguleerd worden.

52. SER. Advies teclinologische aandachtsgebiedenbeleid, Den Hag 1987, n., 10, m.n. p. 44

53 Sociale aspecten wan technologische wernieuwing, notitie van de minuster wan Socialte Zaken en Werkgelegenheid, TK 1986-1987, 20.037, nir. 2 .

54 Vgl. FNV nota Werken in 2000, t.a.p. p. 12. 
Het ligt voor de hand dat het klimaat dat ik hier zeer kort en schematisch schets, niet gunstig is voor de effectiviteit van de Arbowet. Bovendien zou het er, denk ik, nu toe leiden dat een Arbowet, hoe weinig zij ook fundamenteel zal (en kan) veranderen in de bestaande verhoudingen, niet meer tot stand zou kunnen komen. Het is waarschijnlijk alleen te danken aan het feit dat de wet betrekkelijk kort geleden kamerbreed werd aangenomen door parlementariërs die veelal nog deel uitmaken van de volksvertegenwoordiging of inmiddels van het kabinet, dat zij betrekkelijk ongeschonden door de dereguleringsoperatie is gekomen - al waren de oorspronkelijke aanbevelingen veellzeggend en illustratief voor het veranderde klimaat.

Zo meende de Commissie deregulering in verband met de economische ontwikkeling (Commissie van der Grinten) dat de doelstelling welzijn maar geheel uit de Arbowet geschrapt zou moeten worden, zodat alleen de beleidsterreinen veiligheid en gezondheid nog door de wet zouden worden bestreken, net als de oude Veiligheidswet dus. Hoewel de Commissie vermindering en vereenvoudiging van overheidsregelingen (Commissie Geelhoed) zover niet wilde gaan, legde zij wel een onmiskenbare relatie tussen de economische ontwikkelingen en de mate waarin aan een begrip als welzijn behoefte zou bestaan. Deze commissie concludeerde dat met het begrip welzijn een positieve streefnorm ("derhalve vaag en wijd') in de Arbowet geintroduceerd werd en meent vervolgens: 'Vage wettelijke streefnormen kunnen alras tot een caoutchouc-artikel verworden, in economisch goede tijden onderhavig aan inflatie en in (daarop volgende) economisch slechte tijden (in beperkte mate) aan deflatie. Juist een geïnfleerd welzijnsbegrip brengt de zowel door de Commissie deregullering in verband met de economische ontwikkeling als de door de werkgroep gevreesde overmaat aan externe en interne beleidslasten met zich mee, die in economisch slechte tijden moeilijk terug te brengen is. ${ }^{55}$

Nog los van het feit dat het begrip welzijn helemaal niet zo vaag is als de commissie doet voorkomen, geconcretiseerd als het immers is na een uitgebreide parlementaire discussie bij de totstandkoming van de Arbowet door het invoegen van een aantal nieuwe bepalingen in art. 3 , is de strekking van de opmerkingen van de commissie duidelijk: het primaat ligt bij de economische ontwikkelingen en in dat licht bezien is welzijn bij de arbeid toch vooral een mooi weer begrip.

Een andere illustratie van de veranderde sfeer is de verdere fasering van de inwerkingtreding van de Arbowet: keer op keer loopt deze vertraging op, vooral door de strubbelingen tussen werkgevers en werknemers in de Arboraad. De posities liggen vast en zijn voor de hand liggend. De werkgevers hebben geen enkele moeite met uitstel, vertraging en een zo eng mogelijke interpretatie van de bepalingen, de werknemers trachten te redden wat er te reddlen valt, waarbij ook zij worstelen met enerzijds de eisen van een zo hoog

55 Eindbericht van de commissie vermindering en vereenvoudiging van overheidsregelingen TK $1983-1984,17.931$, wr. 9, p. 173. 
mogelijk economisch rendement in de onderneming en anderzijds die van een menswaardig, sociaal beleid.

Hetzelfde sociaal-economische klimaat dat naar mijn mening niet gunstig is voor de effectiviteit van de Arbowet, bevordert overigens wèl een ontwikkeling die in haar effecten gelijkenis kan vertonen met uitgangspunten en wenselijkheden in de Arbowet. Ik doel hiermee op werkstructureringsexperimenten, werkoverleg, MANS en dergelijke. Deze (vaak experimentele) projecten functioneren echter niet primair met het oog op het welzijn bij de arbeid als zelfstandige doelstelling van het ondernemingsbeleid, maar als instrumenten die van betekenis zijn voor de overlevingskansen van de onderneming. ${ }^{56} \mathrm{Op}$ zich behoeft tegen deze ontwikkelingen geen bezwaar te worden gemaakt, zeker niet als de werknemers daadwerkelijk invloed erop kunnen uitoefenen, maar wel moet beseft worden dat het hier slechts om instrumenten gaat die vervangen worden zodra de (bedrijfseconomische) doelstelling ook op een andere, goedkopere, betere manier bereikt kan worden - bijwoorbeeld door automatisering. En dat is ook het grote verschil met doeistelling, inhoud en strekking van de Arbowet, wier effectiviteit onder sterke druk staat van andere dan juridische ontwikkelingen.

\subsubsection{De rechtsconsument/werknemer}

Nieuwe rechten - en vooral nieuwe rechten die niet vanzelfsprekend zijn moeten worden opgeëist, gehandhaafd en waar mogelijk creatief uitgebreid. In een aantal gevallen lijkt non-conformisme geboden, wil er in de praktijk conform de bedoelingen van de Arbowet gehandeld worden. Dit legt een zware claim op de werknemers. Stilzitten kan immers een normatieve werking hebben waardoor zich een verwachtingsprobleem van niet-gebruik vestigt. Het ligt voor de hand dat dit 'veroveringsproces' voor individuele werknemers moeilijker is dan voor collectieven, zoals de or. De zwakke formulering van de rechten, het vrijwel ontbreken van een sterke procedurele ondersteuning, de terughoudende opstelling van de Arbeidsinspectie en het sociaal-economische klimaat vormen even zoveel belemmerende factoren. Toch zal bijvoorbeeld van het recht om onder omstandigheden het werk te kunnen neerleggen ook gebruik moeten worden gemaakt om duidelijkheid te verkrijgen over de grenzen van de toepasbaarheid en om het recht als zodanig in de praktijk gevestigd en verankerd te krijgen. Iets dergelijks geldt ook voor de informatierechten: als er geen beroep op wordt gedaan, lijken ze niet nodig te zijn wat weer als argument gebruikt kan worden om toch vooral, in wetgeving en praktijk, geen duidelijker geformuleerde en/of verderstrekkende informatierechten met daaraan gekoppelde handhavingsmogelijkheden toe te kennen.

$56 \mathrm{Vgl}$. ook Wetenschappelijke raad woor het regeringsbeleid, Vernieuwingen in het arbeidsbestel, Den Haag 1981, nr. 21, p. 122. In die zin meent de commissie Geelhoed ten onrechte dat zelfontplooing, werken volgens eigen inzicht e.d. elementen uit de Arbowet zijn die dienen te vervallen, omdat zij naast te ambitieus 'onvoldoende bij de ondernemingspraktijk' zouden aansluiten. Eindbericht, t.a.p. p. 174. 
Met name kan ook gedacht worden aan de noodzakelijke inzet van or en vakbeweging om de vooral op de individuele werknemer gerichte algemeen geformuleerde zorgverplichtingen in art. 3, "voor zover zulks redelijkerwijze" van de werkgever kan worden gevergd te vertalen in directe op het welzijn tijdens het dagelijkse werk gerichte concrete maatregelen. Dit is des te belangrijker nu bij de invoering en toepassing van nieuwe technologieën de kwaliteit van de arbeid naar de achtergrond dreigt te verdwijnen. De welzijns-criteria zoals die in de Arbowet zijn geformuleerd, zijn in beginsel bruikbaar om te komen tot sociale innovatie bij technologische vernieuwing. ${ }^{57}$ Maar de wet moet dan wel op die manier gehanteerd worden.

De or kan hierbij een belangrijke rol spelen: enerzijds door zelf het voorbeeld te geven van een dergelijk actief gedrag en anderzijds door het ondersteunen van individuele werknemers die hun rechten trachten te realiseren. Hetzelfde geldt voor de vakbeweging, ook al lijkt haar invloed tanende te zijn. Juist individuele werknemers zullen het vaak moeten hebben van haar ondersteuning, zeker als de or onwillig is of zoals in de kleine ondernemingen, ontbreekt. Niet voor niets is het recht van de vakvereniging om een verzoek om wetstoepassing in te dienen (art. 40) gebaseerd op de overweging 'dat juist in kleinere ondernemingen de individuele werknemers onder druk kunnen komen te staan bij het nemen van hun beslissing om al dan niet een verzoek om wetstoepassing in te dienen'. ${ }^{58}$

\subsubsection{Betekenis Arbowet en CAO}

Op grond van de bovenstaande bespreking van een aantal factoren die bepalend zijn voor de effectiviteit van de Arbowet, kan het oordeel over die effectiviteit - dus het antwoord op de vraag in hoeverre de weltelijke doelstelling humanisering van de arbeid gerealiseerd wordt of kan worden met name door het instrument van de wet zelf - toch niet alleen rooskleurig zijn. Dit oordeel wordt versterkt door de sociaal-economische ontwikkelingen, die in het algemeen weinig ruimte laten voor werknemers om zich actief in te zetten teneinde het recht op humanisering van de arbeid daadwerkelijk te realiseren. Het gevaar bestaat hierdoor dat met name de vernieuwende doelstelling en uitgangspunten in de Arbowet in het kader van de wet zelf vooralsnog niet veel meer zullen betekenen dan een ideologisch, retorisch programma en dat voor de praktijk de wet primair zal fungeren als instrument ter bevestiging van de status quo.

Maar ook als de Arbowet haar doelstelling niet, of niet helemaal haalt, zijn er nog wel enkele andere, niet direct beoogde effecten te constateren, die wel degelijk een bijdrage kunnen leveren aan de erkenning en realisering van het recht op een humane arbeidsplaats voor de werknemer. Ik denk hierbij aan de maatschappelijk en juridische uitstraling die bepaalde ideeën die tot een wet- 
telijke status zijn verheven, kunnen hebben. Zo heb ik bijwoorbeeld vermeld dat de civiele rechter in zijn uitspraken soms rekening houdt met het bepaalde in de Arbowet. CAO-partijen sluiten collectieve overeenkomsten af warin steeds meer bepalingen, letterlijk of naar de geest, wit de Arbowet worden overgenomen, hetzij om het belang ervan voor een bepaalde onderneming of bedrijfstak te benadrukken, hetzij omdat de bepaling in de wet nog niet in werking is getreden. ${ }^{59}$ Het feit dat in de periode 1983-1984 een regeling op het gebied van de veiligheid, de gezondheid en het welzijn bij de arbeid op eén na het meest voorkomende instemmingsonderwerp voor de or was op basis van de WOR (art. 27 lid 1 onder e) heeft ongetwijfeld een relatie met de (gedeeltelijke) invoering van de Arbowet in 1982.

Er kunnen echter ook niet beoogde effecten ontstaan die minder prettig uitpakken voor werknemers - en juist deze zullen eerst ontstaan indien de wet wèl 'werkt'. Zo moet bijwoorbeeld volgens art. 3 monotone arbeid zoveel mogelijk worden vermeden. Dit kan door werkherstructurering. Uit onderzoek is echter gebleken dat dit kan leiden tot arbeidsbesparing en dus tot werkloosheid. ${ }^{61}$ Het streven naar humanisering van de arbeid door te voldoen aan art. 3 Arbowet kan dus in zijn effecten ook negatief zijn voor werknemers. Op een ander belangrijk voorbeeld he $\mathrm{ik}$ reeds verscheidene malen gewezen: de afhankelijkheid van de werknemer die in strijd is met de gedachten aan zelfstandigheid, ontplooiing e.d.

Betekent dit alles nu dat de Arbowet eigenlijk overbodig is? Dat humanisering van de arbeid eigenlijk niet met een dergelijke publiekrechtelijke regeling kan worden 'afgedwongen'? Vaak hebben degenen die dergelijke vragen stellen het antwoord al bij de hand. Inderdaad, luidt dat antwoord dan, beter ware het geweest om niet met deze Arbowet te beginnen. De Veiligheidswet voorzag al in de minimum-normering, nodig om veilig en gezond te kunnen werken, de WOR bood al medezeggenschap óók op het gebied van de veiligheid en de gezondheid en de werknemer kon altijd nog een beroep doen op zijn werkgever om zich als zodanig goed te gedragen volgens het BW. Moet er dan zonodig toch meer geregeld worden, dan maar via de CAO. Indien blijkt dat daar tot nu toe op dit gebied weinig spectaculairs in staat, dan vinden de sociale partners dat blijkbaar niet nodig.

Hoewel ik me in het bovenstaande ook niet al te optimistisch heb getoond over de effectiviteit van de Arbowet en ook uitdrukkelijk heb gewezen op de mogelijkheden van andere (wettelijke) regelingen, meen ik dat met name CAObepalingen niet, zoals tegenwoordig nog al eens bepleit wordt, de plaats kunnen innemen van wettelijke bepalingen op het gebied van de humanisering van de arbeid. Bovendien kan een aantal oorzaken voor de te verwachten niet optimale effectiviteit, bijvoorbeeld die gelegen zijn in de formulering van de tekst van de bepalingen en de handhaving ervan, worden weggenomen. Na-

59 Dienst Collectieve Arbeidsvoorwaarden, ministerie van Sociale Zaken en Werkgelegenheid, Arbeidsomstandigheden in CAO's, Den Haag 1987, p. 16.

60 J.C. Looise, J.Z. Heijink, De or en zijn bevoegdheden, Nijmegen 1986, p. 47

61 H.G. de Gier, t.a.p. 143. 
tuurlijk heeft een CAO enkele voordelen boven een wet: ik noem met name de mogelijkheden om zoals dat tegenwoordig heet "flexibel te kunnen inspelen' op de concrete situaties in afzonderlijke ondernemingen en bedrijfstakken, het gegeven dat bij consensus tussen de saciale partners regelingen waarschijnlijk effectiever zullen werken en de zelfstandige (juridische) actiemogelijkheden van de vakbond. Daarnaast wordt op deze manier recht gedaan aan de tegenwoordige filosofie van de overheid dat de staat moet terugtreden zodat de verantwoordelijkheid komt te liggen waar zij zou thuishoren.

Vooral met het laatste argument ben ik het echter niet eens. Juist als het gaat om belangrijke waarden als veiligheid, gezondheid en welzijn bij de arbeid, gaat het niet aan om de verantwoordelijkheid voor garanties op dat punt over te laten aan de sociale partners. Hoewel er waarschijnlijk wel een zekere consensus zal bestaan tussen de sociale partners over het feit dat arbeid de gezondheid in beginsel niet mag bedreigen, zal het afhangen van de (toevallige) machtsverhoudingen in ondernemingen en/of bedrijfstakken en de stand van zaken van de conjunctuur hoe en op welk niveau die consensus - telkens weer tijdelijk! - gestalte zal krijgen. Bovendien kunnen regelingen bij CAO een wezenlijke ongelijkheid tussen bedrijfstakken en ondernemingen veroorzaken, terwijl niet alle werknemers, ondanks de Wet op het algemeen verbindend en onverbindend verklaren van bepalingen van collectieve arbeidsovereenkomsten, onder de werking van een CAO vallen. Pogingen om bijvoorbeeld het klachtrecht in de ondernemingen of het vakbondswerk in de onderneming via CAO's te regelen, zodat wettelijke maatregelen niet nodig zouden zijn, zijn trouwens ook teleurstellend verlopen.

Wetgeving blijft derhalve noodzakelijk, maar zeker ook gezien de defecten die kleven aan de Arbowet, kán de CAO een belangrijke aanvullende rol spelen. Uit onderzoek is echter gebleken dat zij dat thans nog niet op uitgebreide schaal - althans op het gebied van de humanisering van de arbeid doet.

\section{Slotconclusie}

De vraag of een verbetering van de positie van de werknemer op het gebied van de humanisering van de arbeid door het recht, maar vooral door wetgeving, kan worden afgedwongen, moet in beginsel positief worden beantwoord. Tegelijkertijd moet echter geconcludeerd worden dat publiekrechtelijke wetgeving zoals de Arbowet zich kennelijk beter leent voor de vaststelling van bepaalde minimale eisen op het gebied van de veiligheid en de gezondheid en voor het creëren van organisatorische voorwaarden zoals collectief overleg (en daarin zit ook een onmiskenbare waarde van de wet!), dan voor het garanderen van individuele aanspraken op humane arbeidsomstandigheden.

Voor zover er sprake is van een garantie moet die vooral komen van de zorgplicht van de werkgever. Op zich behoeft deze constructie de juridische positie van de werknemer niet zwak te maken, maar dan moeten die plichten wel 
ondubbelzinnig en concreet geformuleerd worden, terwijl de rechtshandhaving ervan verzekerd is. Dat is echter niet altijd het geval. Juist daarom is het van belang dat de individuele werknemer over eigen juridische actiemogelijkheden beschikt. En daar zit juist het probleem: gebleken is dat daar op basis van de Arbowet niet of nauwelijks van gesproken kan worden. Voor het praktisch inhoud geven aan de juridische normen is hij vooral afhankelijk van de werkgever, en voor het afdwingen ervan vooral van de or. Het blijkt dat de werknemer voor zijn juridische actiemogelijkheden dan toch vooral zijn heil moet zoeken bij de civiele rechter.

De Arbowet kan dan ook niet los worden gezien van het civiele recht. Het lijkt mij toe dat de juridische positie van de werknemer op het gebied van de arbeidsomstandigheden nog te vaak alleen bezien wordt in het licht van de publiekrechtelijke arbeidsomstandighedenwetgeving en dan met name de Arbowet. Het civiele recht speelt vaak pas een rol nadat bijvoorbeeld een bedrijfsongeval heeft plaatsgevonden. Dat is jammer, omdat daardoor eerdere juridische actiemogelijkheden voor de werknemer onbenut blijven. Wellicht zou een beroep op $1638 \mathrm{x}$ BW ook minder voor behoeven te komen als in een eerder stadium de civiele rechter zou zijn ingeschakeld ter verbetering van de individuele arbeidsomstandigheden. De civiele rechter lijkt immers bij uitstek in staat om nieuwe rechtsbeginselen daadwerkelijk gestalte te geven en uit te bouwen. De wetgever hoeft daarbij niet per se het nakijken te hebben: de in de Arbowet neergelegde normen kunnen een bellangrijk richtsnoer vormen voor de civiele rechter, zoals dat bijvoorbeeld ook het geval is ten aanzien van de WAGW. In deze optiek vervult de Arbowet behalve als draagster van (minimale) normeringen op het gebied van veiligheid, gezondheid en welzijn, nog een andere (misschien vooral symbolische) functie: zij positiveert belangrijke maatschappelijke denkbeelden over de betekenis van de arbeid en de arbeidsomstandigheden, die, doordat ze een wettelijke status hebben gekregen, gemakkelijker een toetsingskader kunnen vormen voor de civiele rechter. Ook in dit licht was en is het gehannes over de inwerkingtreding enerzijds en de wetswijziging van het beginselartikel 3 van de Arbowet, waarbij de elementen als 'ontplooiing' en 'vermeerdering van de vakbekwaamheid' als doelstellingen werden geschrapt anderzijds, verwerpelijk. Dit geldt temeer, omdat dit artikel een belangrijke rol kan vervullen met betrekking tot de positie van de werknemer in het kader van nieuwe technologieën.

Enkele relativerende opmerkingen over de betekenis van het recht voor de humanisering van de arbeid van de werknemer wil ik hier nog maken. In de eerste plaats, ik schreef er al over maar wil het nogmaals benadrukken, is het eerder de structuur van de machtsverhoudingen in en rond de onderneming die de grenzen stelt dan het recht. Dat valt niet door wetgeving alleen te veranderen. ${ }^{62}$ In de tweede plaats hangt de betekenis van juridische constructies - ook dat schreef ik eerder - sterk af van de mate waarin er binnen de onder-

$62 \mathrm{Vgl}$. hierover ten aanzien wan veranderingen in de bestaande medezeggenschapsstatutem ook COB/SER, Medezeggenschap, besluitworming en organisatic, Den Haag 1985, m.n. p. 219. 
neming met name door de werknemer zelf gebruik van wordt gemaakt, of moet worden gemaakt. In sommige ondernemingen waarin wordt gewerkt met geavanceerde technologieën, met een hoog kennisniveau bij de werknemers en waarin nauwelijks meer sprake is van een duidelijke hiërarchie, zal het recht met betrekking tot medezeggenschap en humanisering van de arbeid waarschijnlijk geen belangrijke rol (hoeven te) spelen. Juist door de opkomst van dit soort ondernemingen dreigt er echter een toenemende kloof tussen de verschillende ondernemingen te ontstaan onder meer voor wat betreft de arbeidswoorwaarden en de arbeidsomstandigheden. Ook nu is er al een fors onderscheid tussen de verschillende bedrijfssectoren: in bijvoorbeeld schoonmaakbedrijven, de bouw, het vervoer en slecht renderende industrietakken lijken de arbeidsomstandigheden in het algemeen beduidend slechter dan in bijvoorbeeld de grote chemische industrieën en het bank- en verzekeringswezen. ${ }^{63}$ In de eerstgenoemde sectoren zal het op humanisering gerichte recht belangrijker zijn zonder dat deze constatering overigens iets zegt over de implementatie ervan.

Maar zoals 'de' onderneming niet bestaat, bestaat ook 'de' werknemer niet. Ook hier valt een kloof te constateren tussen enerzijds goed opgeleide werknemers in vaste dienst en werkzaam in de bedrijfstakken van de toekomst (high tech, informatica) en anderzijds de groeiende groep werknemers al dan niet met allerlei vormen van flexibele arbeidsovereenkomsten, werkzaam in traditionele, hiërarchische, soms marginale ondernemingen, wier arbeidsomstandigheden door en in de onderneming slecht of niet geregeld zijn. Het zijn vooral jongeren, vrouwen, ongeschoolde en buitenlandse werknemers die op dergelijke banen aangewezen zijn. Het zijn ook deze werknemers die zonder hulp nauwelijks toegang hebben tot de besluitvormingscircuits, of kunnen opkomen voor de eigen rechten. Die hulp kan bijvoorbeeld gegeven worden door de vakbeweging, de Arbeidsinspectie en de rechter. Maar het is van belang dat zij zich op hun beurt kunnen beroepen op wetgeving zoals de Arbowet die zowel concrete (minimum)normen dwingend voorschrijft als algemene rechtsbeginselen vastlegt. Juist voor de zwakkere groepen werknemers is zij een onvervangbare bondgenoot. "In de strijd tussen het sterke en het zwakke is het de vrijheid die verdrukt, en de wet die bevrijdt. ${ }^{\text {is }}$

63. F.J.H. wan Dijk, T.F. Meijman, Arbeid en gezondheid, Een programma woor onderzoek, onderwijs en dienstverlening. Amsterdam 1987, p. 69.

64 De Franse Dominicaner monnik Lacordaire, geciteerd in de Nota van Franssen, Roethof en van Thijn inzake de opneming van individuele werknemersrechten bij de sociale grondreclhten in de Grondwet, TK 1975-1976, 13.873, nr. 5-6, p. 21 . 


\section{Summary \\ Law and Humanization of Labour}

This is a book about humanization of labour and the law. More specifically the book will deal with the (legal) position of the employee. Although humanization of labour has for a long time been seen as a purpose of labour law, new interest for this concept was established by the approval, in 1980, of the "Arbeidsomstandighedenwet' (Labour Circumstances Act, to be compared with the Health and Safety at Work Act), hereafter referred to as Arbo-Act. It is in this Act that humanization of labour is explicitly put forward as a purpose to be achieved through the Act. This purpose, however, should be realized within a certain context, namely that of the company, of dissimilar interests and of traditional power relationships. This means, for instance, that employees under the Arbo-Act are no longer seen as objects of care, but as independent subjects of rights and duties. But this also implies that this independence is only a relative one; not only because the employer still has a primary position in the developing of a policy on labour circumstances, but also because many of the rights and powers created on behalf of the employees have been granted to collectives representing the employees. Therefore these rights and powers will have to be exercised and maintained through the existing collective structure of consultation and decision-making within the company. Essential in this respect is the role of the 'ondernemingsraad' (works council). It can be argued that dealing with problems collectively has great advantages for the employees, for instance with respect to the pursuit of power and influence. But doesn't this also imply that for the individual employee a new dependence has been created, namely the dependence upon the collective which represents him or her. The foregoing presents a source of tension, within which the problem which is central to this thesis is stated; partly this will be done in the form of a hypothesis. Central to this thesis is a research into the legal developments with respect to humanization of labour of the employee, as well as into the legal and practical meaning which these developments have for the employee. The relevant law in this respect cannot only be found in the Arbo-Act, but will also have to be derived from other important sources of law. To ask what the meaning of this field of law is, is to ask to what extent it does justice to the values - stated as its intrinsic and social-ethical purpose - which form the substance of the humanization of labour on behalf of the employees. Follow- 
ing this line of thought it is important not only to put forward claims, but also, and more particularly, to establish an effective implementation of legal provisions which neutralize the factors which constitute an impediment to the achievement of the purpose mentioned above.

Furthermore in Chapter I a definition will be given of some notions which frequently recur in this book, followed by a description of the structure of the book.

In Chapter II a description will be given of the historical developments of the law of labour circumstances from the nineteenth century onwards, and more particularly of the effects of industrialization and economic growth in this respect. The passive role of the government, urged by the appalling circumstances in which many employees lived and worked, and by the activities of various pressure groups and individuals pursuing various goals, changed into an active one; active in the sense that the government started interfering with the relationship between employer and employee, a relationship which until then had been unregulated.

The year of the approval of the Labour Act (1919), which has been valid until today, in more than one way represents the end of an era: principal issues have been settled, such as the need for legislative intervention by the government, and the acknowledgement of the need for control of the application of the law. Public law guarantees for employees are no longer restricted to women and children. The framework for a new era is outlined. The period between 1919 and about 1975 is characterized by a gradual extension of legislation on the protection of labour; great changes in the general policy on the subject do, however, not take place in this period. Changes in policy do, however, occur from 1975 onwards. This process will be illustrated and analysed by reference to the Explanatory Papers to the Budgetary Laws of Ministry of Social Affairs and Employment for the years 1973 to 1983. In the first half of the seventies the need for a greater participation and development of employees is emphasized. This results in some important legislation: the 'Wet op de ondernemingsraden 1979' (the Works Council Act, hereafter referred to as OR-Act) and the ArboAct 1980. From now on most emphasis is laid upon the need for a more restrained position of the government. The pretence of an active, caring government, is beached upon the reality of the eighties, during which humanization is no longer seen as a purpose in itself, but more and more as an instrument to achieve other, mainly economic, goals. This tendency is heavily supported by the employers. The deliberate minimization of rulemaking and the stepwise implementation of the Arbo-Act represent some good examples of this changing attitude.

To give a good picture of the position of the employee with regard to the humanization of labour, Chapter III describes the field of countervailing legal forces in which this position is settled. This is done by a description of the role which other important actors play in this field. Attention will be given to the role of the employer, the works council and the specialists in the company. Furthermore the role of the unions of employers and of employees and the 
Labour Inspection, which operate outside the company, will be discussed. From the Arbo-Act it appears that the employer mainly has general or more specific duties, but that his most important right, the power to make internal regulations, is self-evident. It is the encroachments upon this power which have to be formulated explicitly.

Then the role of the employer in the OR-Act is examined. The legal obligation to establish a works council and to consult with it about labour circumstances is discussed. In spite of the considerable differences between companies, it appears from various studies that the contacts between the employer and the works council about labour circumstances are not only to be described as negative.

The position of the employer is also regulated in private law. The most important statutory provision in this respect is article $1638 \mathrm{x}$ of the Civil Code, which obliges the employer to provide good labour conditions. If he refrains from doing so and if this causes the employee to have an accident, then, in principle, the employer will be liable for damages. Considerable attention is given to the legal questions and answers which are connected with this article. Some remarks about the application of article $1638 \mathrm{x}$ in the present time and about expectations for the future in this respect conclude this paragraph. Research shows that more and more employees appeal to article $1638 \mathrm{x}$; over the last ten years the number of employees who apply for legal aid has doubled. However, this has not lead to an increase of the number of $1638 \mathrm{x}$-cases before the "kantonrechter' (to be compared with the county court judge). It is to be expected, however, that in the future more employees will appeal to the judge. Relevant in this respect are both the growing assertiveness of employees and recent caselaw advantageous to employees, which last can be explained by the incorporation of the public law rule of the Arbo-Act (rules with an administrative law character) in civil procedure, and by new legislation, in particular article 7.10.4.2 of the New Civil Code. The role of the works council, on the basis of powers and institutions granted in the OR-Act and the Arbo-Act, is discussed. In connection with this the unintended coincidence of some provisions of these Acts is discussed, as well as the most desirable legal solution to this problem. A separate paragraph is devoted to the legal and practical meaning of labour consultation as regulated - in terms which are too discretionary - in the ORAct as well as in the Arbo-Act. Finally from various studies the conclusion is drawn that the works council makes (too) little use of the Arbo-Act. The main legal result to which the interest in the Arbo-Act has lead seems to have been an increase in the use of the institutions of the OR-Act. The position of the specialists in the company is illustrated, mainly by discussing the company health service and the position of the company physician. The conclusion is drawn that the company physician has acquired a firmly established independent position, but also that he is still too occupied with individual contacts whilst he doesn't always enjoy the trust of the employee in these contacts instead of with his general preventative task. Furthermore, attention will be given in this paragraph to the Safety Service, the Specialists on Safety, the 
Arbo-service and the Arbo-institute.

The Labour Inspection Service is concerned with the enforcement of legislation on labour conditions. Its tasks, powers, policy and ways of working are discussed extensively, followed by discussion of the criticism which it has attracted, particularly from the unions. Furthermore, attention is given to the way in which the Labour Inspection Service has reacted to this criticism. Although it seems that criticism is now abating, research shows that, in spite of the obligations which arise from the Arbo-Act in this respect, the majority of companies appear to have noticed little change in the ways of proceeding of the service.

In various ways, unions of employers and employees are involved in the humanization of labour. At a national level they participate in advisory bodies particularly in the Arbo Council - and in the concluding of collective agreements. A separate role within the company is attributed to the employees' union which, in the absence of the works council, can replace the latter in the exercise of a number of powers.

A discussion about the results of research into the quantity and quality of collective agreement provisions concerning labour circumstances conclude this paragraph. The conclusion is drawn that in the past ten years there has been an increase of such provisions, probably under the influence of the ArboAct. The two main substantive differences between the new provisions and their predecessor are: the greater attention which is given to questions of welfare in labour, and the increase in the number of provisions concerned with consultation and information. It should be noted, however, that these new provisions have mainly been derived from the Arbo-Act; new substantial changes are scarce.

Chapter IV deals entirely with the employee. His or her legal position is researched according to the possibilities for the employee to realize the humanization of his or her labour in the way that this has been expressed by the numerous regulations, i.e. the rights, powers and possibilities for legal actions in the field. The conclusion is drawn that the Arbo-Act contains hardly any provisions exercisable by the individual employee. In sofar as he or she has any rights, these rights nearly always have to be derived from the obligations of others, in particular the obligations of the employer. The most distinct right of the employee is the right to interrupt work under specific conditions. Ample attention is given to the legal implications of this right. In spite of the criticism that can be expressed against this provision, it is argued that the provision represents a genuine means of protest and that as a logical conclusion of the Arbo-Act it deserves appreciation.

In the paragraph concerned with the position of the individual employee under the Arbo-Act, attention is given to: the right to information and education; the right to complain to the Labour Inspection Service; the possibilities to influence the employers" policy about labour circumstances; and the relationship with the specialists in the company. In respect of all the provisions of the ArboAct which are discussed, it is concluded that the provisions are written on 
behalf of the employee, but that it is equally true that the employee can hardly claim any directly enforcable rights. This is followed by a discussion of the position of (the majority of) interested employees. According to the ArboAct, the interested employees have specific powers of there is no works council or Arbo-committee, which is comparable with the works council. It is considered important that, in the absence of institutionalized forms of participation, (a majority of) interested employees have specific powers. Another conclusion which is drawn in this respect, however, is that, in a number of ways, their position is inferior to that or the Arbo-committee.

The paragraph dealing with the position of the employee under the Arbo-Act ends with a discussion of the employee's obligations. The present Arbo-Act imposes more obligations upon the employee than did its predecessor. It is debated whether this increase is justified, considering the dependence of the employee upon the activities, particularly, of the employer.

The position of the employee is also regulated by the rights and obligations which flow from the contract of employment. This contract, however, is governed by the Civil Code and by the relevant collective labour agreement provisions. With respect to the regulations in the Civil Code ample attention is given to article $1638 \mathrm{z}$, the 'good-employer-article'. It is argued that this article is particularly suitable to improve the position of the employee in the field of conditions of employment. This is because the employee can take direct legal action if article $1638 \mathrm{z}$ is violated; in such cases the Arbo-Act could be applied as 'lex specialis'. There are some indications in case law in this direction. Apart from the Civil Code the collective agreement is, in many cases, decisive for the contents of the employment contract. The earlier mentioned study into the quantity and quality of collective agreement provisions shows that such rights and duties of the employee which are concrete and which can apply to him as an individual, are, generally spoken, self-evident and hardly spectacular.

To complete the picture, the position of the employee, as it appears in the ORAct, is studied. The conclusion is drawn that, when it comes to the legal enforcement of participation in establishment of the policy on labour circumstances by the works council, individual employees are almost powerless. The same is true for the legally enforceable control of the policy of the works council. But, in respect of the structure and the purpose of the OR-Act, this is understandable.

The end of Chapter IV is about the employee's right of complaint within the company. It is argued that a statutory right of complaint is an important factor in the endeavour to improve the position of the employee with respect to the humanization of labour. 'The advice of the 'Sociaal Economische Raad' (Social Economic Council) on this point is extensively discussed and found to be insufficient. The striking inertia of consecutive governments in the drafting of legislation on this subject glaringly contrasts with its importance.

Some concluding considerations form the substance of Chapter V. First, the development in policy and legislation and the role of the persons involved in the humanization of labour are described. Then attention is focussed upon the 
position of the employee. The importance of the actual power-relationships in the company are indicated, as well as the dependent position of the employee within the company. It remains difficult to provide legal compensation for this factual inequality. Two external institutions could play an important role in this respect: the Labour Inspection Service and the courts. It appears that the Labour Inspection Service is not an ally that can be taken for granted. This is due to the existing law as well as to the way it is actually applied by the Service. The courts present a better opportunity. In the end the conclusion is drawn that the great importance of the Arbo-Act for the employee is that the courts could - and already appear to be doing so - apply provisions from this Act in order to grant a claim for humane labour circumstances; the same humane circumstances as the Arbo-Act purports to grant to the employee without, however, supplying the legal means to bring this claim individually and independently.

The chapter explains the factual backgrounds, legal implications and legal proceedings of a recent case which illustrates the relatively powerless position of the employee who strives for improvement of his conditions of employment. Humanization and the law is the subject of the paragraph mainly concerned with the effectivity of the Arbo-Act. Criteria derived from a number of theories of sociology and the law are used to assess this effectivity. These criteria are: the contents and structure of the Act; the rellationship between substantive and procedural rules; the provisions for implementation and maintenance of the Act; the economic and socio-cultural climate; and the attitude of the employee in pursuing legal actions.

The conclusion is drawn that the question whether an improvement of the employee's position with regard to the humanization of labour can be accomplished through the Arbo-Act, has, in principle, to be answered affirmatively. At the same time, however, it should be noted that this Act is more suitable for the fixing of minimum demands in the field of health and safety and for the establishment of organizational conditions - such as collective consultation than for the giving of guarantees for individual claims to humane labour circumstances. This is emphasized by socio-economic developments: generally speaking few opportunities remain for the employee to be actively engaged in a true realization of the right to humanization of labour. This is another reason why the legal position of the employee with respect to labour circumstances must not only be judged in the light of legislation on labour circumstances of a public law character, and the Arbo-Act in particular; mistakenly the application of private law is largely ignored in this field. Most of all, it is the courts which are capable of creating and developing new principles of law. The legislator does not necessarily have to be excluded; the rules laid down in the ArboAct could be an important guideline for the courts. From this point of view the function of the Arbo-Act is not limited to its guarantees for a minimum of health and safety; it performs another function which perhaps can be characterized as symbolic: it incorporates certain important social views about the meaning of labour and labour circumstances into the existing law. Due to the 
fact that these social views have acquired legal status the courts are more likely to use them as a basis for their judgements. This function is too important to be taken over by the collective agreement. Consensus between employer and employee about the fact that employment should not present a threat to the health and safety of the employee is to be expected. But the way in which this consensus will be reached and the extent to which it will be reached - whereby the level of consensus will always be temporary - is dependent upon the power-relationships within the companies, and the state of the economy. It is for this reason that legislation remains an irreplaceable ally for the more marginal groups in society and, particularly, the employees in the companies. 



\section{Lijst van geraadpleegde literatuur}

(niet opgenomen zijn de geraadpleegde parlementaire stukken)

- Aalders M.V.C., Industrie, milieu en wetgeving, de Hinderwet tussen symboliek en effectiviteit, Amsterdam, 1980.

- Acampo J., Kunst P.E.J., Soeters J., Woltmeijer A., Or- lidmaatschap, Joopbaan en verloop, Rijksuniversiteit Limburg en CNV, Utrecht/Maastricht, 1987.

- Adviesgroep Mens en Organisatie, De Arbeidsinspectie in ontwikkeling, Amsterdam, 1977.

- Andriessen J.H.T.H. e.a., Kleine bedrijven en Arbeidsomstandighedenbeleid, een verkennend onderzoek in enkele bedrijfstakken, Instituut voor sociaal-wetenschappelijk onderzoek, Tilburg, 1985.

- Arbeidsinspectie, Mens en werk; de Arbeidsinspectie is er goed voor, Den Haag, 1976.

- Arbeidsinspectie, Jaarverslag Arbeidsinspectie 1982, 1983, 1984, 1985, 1986.

- Arboraad, Advies inzake de wijze van inwerkingtreding van art. 6 van de Arbowet, Zoetermeer, 1983

- Arboraad, Reactie op de ambtelijke nota 'Beleidswoering in het kader van de Arbeidsomstandighedenwet' (artikel 4), Zoetermeer, 1983.

- Arboraad, Nota De relatie met werknemers van kleine arbeidsorganisaties, Zoetermeer, 1984.

- Arboraad, Advies betreffende deskundige diensten, deel 1, Bedrijfsgezondheidsdiensten en Bedrijfsveiligheidsdiensten, Zoetermeer, 1984.

- Arboraad, Advies inzake de tweede en volgende fasen van invoering van de Arbeidsomstandighedenwet, Zoetermeer, 1985.

- Arboraad, Advies termijnplanning uitbouw bedrijfsgezondheidszorg, Zoetermeer, 1986.

- Arboraad, Advies inzake overlegorgaan dienstverlening arbeidsomstandigheden, Zoetermeer, 1986.

- Arboraad, Standpunt van de Arboraad inzake de positie van de overheid als werkgever in de Arboraad en zijn commissies en werkgroepen, Zoetermeer 1986.

- Arboraad, Advies inzake besluiten risico's zware ongevallen en de wijziging van het besluit verplichtstelling arbeidsveiligheidsrapport, Zoetermeer, 1987.

- Arboraad, Commentaar op de nota: Evaluatie le fase AVR (Arbeidsveiligheidsrapport) en aanpassing van de AVR-regeling, Zoetermeer 1987.

- Arboraad, Advies inzake art. 30 van de Arbeidsomstandighedenwet, Zoetermeer. 1987 
- Arboraad, Advies inzake art. 31 van de Arbeidsomstandighedenwet, Zoetermeer, 1987

- Arboraad, Advies incake invoering volgende fasen Arbowet, Zoetermeer, 1987

- Arboraad, Advies inzake veiligheidskundigen en veligheidsdiensten, Zoetermeer, 1987

- Arendsen de Wolff G.J.W., Over de informatieplicht van de onderneming; Beschouwingen omtrent informatieverstrekking en geheimhouding in de betrekkingen tussen de onderneming en de werknemersvertegenwoordigers, Deventer, 1976.

- Arnold J.G.M., Arbeidsomstandighedenwet en strafbaarheid van overtreding van veiligheidsbesluiten, SMA 1985, p. 594.

- Atherley S., Booth R., Kelley M., Workers` involvement in occupational health and safety in Britain, International Labour Review 1975, p. 470.

- Aubert V., Enkele sociale functies van wetgeving, in: B. Peper, C. Schuyt, Proeven van rechtssociologie uit het werk van Vilhelm Aubert, Rotterdam, 1971, p. 46.

- Bakels H.L., De leiding van de onderneming en de belangen van de werknemers, in: Vrijheid en Recht ('s Jacob-bundel), Zwolle, 1975, p. 27.

- Bakels H.L., Het individueel klachtrecht, de goede werkgever en het collectief overleg, SMA, 1981, p. 302.

- Bakels H.L., Opheikens L., Schets van het Nederlands arbeidsrecht, Deventer, 1982, (6e druk), Dewenter 1986 (7e druk).

- Bakels H.L., Schets van het Nederlands arbeidsrecht, Deventer, 1987 (8e druk).

- Banda P.H., Het recht op onaantastbaarheid van het menselijk lichaam, in: Grondrechten, Commentaar op hoofdstuk $\mathbb{1}$ van de herziene Grondwet (Jeukens-bundel), Nijmegen, 1982 , p. 249.

- Bayens G.I.H.M., Tappèl B.J., Bedrijfsweiligheidszorg in Nederland, het Veiligheidsinstituut, Amsterdam 1986.

- Bayens Guido, Arbo-jaarverslagen nader bekeken, Maandblad voor arbeidsomstandigheden, 1988, p. 91.

- Beenhakker H.F., De Arbeidswet 1919, haar grondslag, inhoud en betekenis, SMA, 1969, p. 643 .

- Beenhakker H.F., De betekenis van de Wet op de Bedrijfsgeneeskunde voor de volksgezondheid, Tijdschrift voor Sociale Geneeskunde, 1971, p. 763.

- Bles A. E., De Wet op de Arbeidsovereenkomst, Den Haag, 1907-1909, deel 1, deel III.

- Bleumer- van der Klein L., Hent F., Theorie en praktijk van de beleidsworming door de Arbeidsinspectie, Ars Aequi, 1978, p. 377.

- Bloemarts J., Op weg naar een drie-partijen-model voor het sociaal belleid in de onderneming?, SMA, 1978 , p. 590.

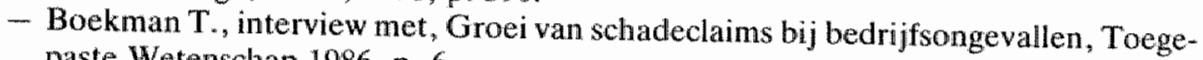
paste Wetenschap 1986, p. 6.

- Bots A.M.Th., De wetgever in het arbeidsrecht, in: Macht en onmacht van de wetgever, Deventer, 1978 , p. 145.

- Bots L., Wie van de twee is de aansprakelijke werkgever bedoeld in artikel $1638 \mathrm{x}$ BW?, in: Blinde vlekken in het sociaal recht (Frenkel-bundel), Deventer, 1986, p. 162.

- Brouwer E., Melding en registratie van beroepsziekten, Verslag Workshop beroepsziekten, Interfacultaire werkgroep Arbeid en gezondheid, Coronel Laboratorium, Amsterdam, 1987, p. 11 
- Brouwer Elly/Willems Han, Hoe staan werkgevers tegenover een verplichte melding van beroepsziekten?, Maandblad voor arbeidsomstandigheden, 1987, p. 100.

- Brugmans I.J., Paardenkracht en mensenmacht, sociaal-economische geschiedenis van Nederland 1795-1940, Den Haag, 1961.

- Brugmans I.J., De arbeidende klasse in Nederland in de negentiende eeuw 18131870, Utrecht/Antwerpen, 1975 (10e druk).

- Brugmans I.J., Standen en klassen in Nederland gedurende de negentiende eeuw, Economische ontwikkeling en sociale emancipatie, samengesteld door Geurts P.A.M. en Messing F.A.M., Den Haag, 1977, p. 110.

- Bruin A. de, Humanisering van de arbeid door de vakbeweging sterker naar voren gebracht, inleiding veiligheidsdagen 1977, De Veiligheid, 1977, p. 267.

- Buitelaar W., Vreeman R., Vakbondswerk en kwaliteit van de arbeid, Voorbeelden van werknemersonderzoek in de Nederlandse industrie, Nijmegen, 1985.

- Buiting Th.J., Economische criminaliteit, in: Recht, macht en manipulatie (red. C. Kelk e.a.), Utrecht/Antwerpen, 1976, p. 281.

- Burger G.C.E., De ontwikkeling van de arbeids- en bedrijfsgeneeskunde, Leiden, 1974.

- Buringh E., Beter Werk, FNV handboek, Amsterdam, 1983.

- Burkens M.C.B., Beperking van grondrechten, Deventer, 1971.

- Burlet H.M. de, Gezondheid en veiligheid op de werkplek, NIPG, Leiden, 1978.

- Bijll Nachenius H.J. de, Artikel 27, Wet op de ondernemingsraden, Alphen a/d Rijn, 1983.

- Camminga J.J., lets over de taak van de controleurs van den Arbeid, in: Gedenkboek 1909-1934, Groningen/Den Haag/Batavia, 1934, p. 59.

- $\mathrm{CCOZ}$, Het werkt anders, een overzicht van maatregelen tegen veel voorkomende problemen met de kwaliteit van arbeidsplaatsen in de industrie, Voorburg, 1986.

- C.J.D., Ingezonden brief Overtreding der Arbeidswet en reactie van de redactie, Sociaal Weekblad, 1898, p. 299.

- Clausing B., Aansprakelijkheid van werkgever en derden, in het bijzonder tegen de ongevalsgetroffenen in de Ongevallenwet 1921 en in het ontwerp WAO, SMA, 1964 , p. 406.

- COB/SER, Eindrapport van de reeks experimenten medezeggenschap: Medezeggenschap, besluitvorming en organisatie, Den Haag, 1985.

- College van bijstand en advies voor de bedrijfsgeneeskunde, De toekomst van de bedrijfsgezondheidszorg, Den Haag, 1979.

- Dienst Collectieve Arbeidsvoorwaarden, Arbeidsomstandigheden in CAO's, Den Haag, 1987.

- Dienst Collectieve Arbeidsvoorwaarden, Onderzoek OR-bevoegdheden in CAO's, Den Haag, 1988.

- Dijk F.J.H. van, Meijman T.F., Arbeid en gezondheid, een programma voor onderzoek, onderwijs en dienstverlening, Amsterdam, 1987.

- Directoraat-Generaal wan de Arbeid, Adviesaanvraag aan de VAR inzake de inwerkingtreding van art. 10, Voorburg, 1982.

- Directoraat-Generaal van de Arbeid, Nota toelichting op art. 11 van de Arbowet, Voorburg, 1982.

- Directoraat-Generaal van de Arbeid, Nota artikel 6 Arbowet, Voorburg, 1982.

- Directoraat-Generaal van de Arbeid, Brief aan de VAR inzake toelichting op art. 11 


\section{LISTT VAN GERAADPLEEGDE LITERATUUR}

van de Arbowet, Voorburg, 1982.

- Directoraat-Generaal van de Arbeid, Brief aan de VAR inzake de inwerkingtreding van art. 6, Voorburg, 1982.

- Directoraat-Generaal van de Arbeid, Voortgangsnotitie betreffende de Arbowet over 1983, Voorburg, 1984.

- Directoraat-Generaal van de Arbeid, Het uitwoeringsbeleid met betrekking tot het vergezelrecht, Voorburg, 1985.

- Directoraat-Generaal van de Arbeid, Voortgangsnotitie betreffende de Arbowet over de periode januari 1985 tot medio 1985, Voorburg, 1985.

- Directoraat-Generaal van de Arbeid, Nota De inhoud van het welzijnsbegrip in artikel 3 wan de Arbowet, Voorburg, 1986.

- Dodeweerd J.J, van, Daderschap en strafbaarstelling in enkele sociale wetten, SMA 1963 , p. 414.

- Dodeweerd J.J. van, Recente ontwikkeling der strafbaarstelling in enkele sociale wetten, SMA, 1973, p. 85.

- Dodeweerd J.J. van, Het stelsel van aansprakelijkheid volgens de Arbeidsomstandighedenwet, SMA, 1977, p. 764.

- Dodeweerd J.J. van, Over je eigen ongeval kun je altijd het nodige te weten komen!, De Veiligheid, 1977 , p. 45

- Dodeweerd J.J. van, De Arbeidsinspectie bestaat 90 jaar, SMA, 1980, p. 378.

- Dodeweerd J.J. van, Een vreemd ontslag langs de waterkant, SMA, 1980, p. 734.

- Dodeweerd J.J. van, Struik J., Uitspraken veiligheidswetgeving, Deventer, 1979.

- Dorrestein Th.H.J., Hernieuwde belangstelling voor art. 1638x, NJB, 1972, p. 1141.

- Drongelen $\mathbf{J}$, van, De rol van de Arbeidsinspectie bij ontslagzaken, in: Blinde vlekken in het sociaal recht (Frenkel-bundel), Deventer, 1986, p. 100.

- Duijn J.J. van, Macro-economische gevolgen van deregulering, Beleid en Maatschappij, 1982, p. 213.

- Duk R.A.A., Redellijk bevel en dringende reden, SMA, 1976, p. 93.

- Duk/Fase/v.d. Heijden/Masschaupt, De ondernemingsraad, (losbladig), Dewenter.

- E.G. Bureau van de Statistiek der Europese Gemeenschappen, Arbeidsvoorwaardlen in de landen van de Gemeenschap 1975-1977.

- Esveld N.E.H. van, De ontplooiing van het individu in het arbeidsrecht, Amsterdam, 1946.

- Esveld N.E.H. van, Arbeidsrecht en gerechtigheid, rede, Rotterdam 1953, in: Van sociale politiek naar sociaal recht, Alphen a/d Rijn, 1966, p. 305.

- Esveld N.E.H. van, Vrijheid en dwang in het arbeidsrecht, SMA, 1975, p. 286.

- Fase W.J.P.M., CAO-recht, Alphen a/d Rijn, 1982.

- Fase W.J.P.M., Arbeidsrecht, in: Nederlands recht in kort bestek, Deventer, 1983, p. 295.

- Fase W.J.P.M., Collectief arbeidsrecht na vijftig jaar, in: Vijftig jaar sociaal recht in Leiden (red. M.G. Rood), Deventer, 1986, p. 25.

- Fillet L.J., Gedeelde smart, halve smart?, SMA, 1984, p. 350.

- Fillet L.J., Geen dikke bult bij eigen schuld ex art. 1638x BW, SMA, 1987, p. 170.

- Fischer E.J., Fabriqueurs en fabrikanten, Utrecht, 1983.

- FNV, Commentaar ontwerp Arbeidsomstandighedenwet, brief aan de vaste commissie voor Sociale Zaken van de Tweede Kamer der Staten-Generaal, Amsterdam, 1977. 
- FNV (beleidsgroep onderzoek), Beter werk, Amsterdam, 1980.

- FNV, Belleidsnota humanisering van de arbeid, feiten en meningen, Amsterdam, 1983.

- FNV, Nota Werken in 2000, Amsterdam, 1987.

- Fruytier B., Het einde van de humanisering?, Tijdschrift voor arbeidsvraagstukken, 1986 , p. 57.

- Galan C. de, Humanisering van de arbeid: betekenis, opbrengsten en kosten, in: Arbeid, nu en in de toekomst, Nijkerk, 1982, p. 43.

- GBIO, OR-cursussen onderzocht, Arboscholing en -vorming in ontwikkeling, Den Hagg, 1983.

- Geers A.J.C.M., De inwerkingtreding van de Arbeidsomstandighedenwet, NJB, 1983, p. 83 .

- Geers A., Veilig en wel, Alphen a/d Rijn, 1985 (tweede herziene druk).

- Geers A.J.C.M., Gevers J.K.M., Bedrijfsarts en werknemer, Ars Aequi, 1976 (themanummer Gezondheidsrecht), p. 612.

- Geers A.J.C.M., Gevers J.K.M., Schadeloosstelling van slachtoffers van bedrijfsongevallen en beroepsziekten, NJB, 1977, p. 951.

- Geers A.J.C.M., Gevers J.K.M., Arbeidsomstandighedenrecht, Deventer, 1979.

- Geersing B., Ondernemingsraden, Alphen a/d Rijn, 1979.

- Geersing B., Ondernemingsrecht en effectiviteit, Ars Aequi, 1981, p. 14.

- Geersing, van der Heijden, Rechtspraak medezeggenschapsrecht 1982, Deventer, 1983.

- Geudeker Th.C., Een kwart eeuw “Centrale Dienst”, in: Gedenkboek 1909-1934, Groningen/Den Haag/Batavia, 1934, p. 74.

- Gevers J.K.M., Zeggenschap van werknemers inzake gezondheid en veiligheid in bedrijven. De rechtsontwikkeling in de lidstaten van de Europese Gemeenschap, Deventer, 1982.

- Gevers J.K.M. , De nieuwe ILO-normen inzake de bedrijfsgezondheidszorg, SMA, 1986 , p. 414.

- Giele Jacques, Nawerk bij de heruitgave van de arbeidsenquête van 1887, Een kwaad leven, deel 3, Nijmegen, 1981.

- Gier H.G. de, Making work more human, een beschouwing over betekenis en achtergronden van het wetsontwerp arbeidsomstandigheden, Beleid en maatschappij, 1978 , p. 263.

- Gier H.G. de, Making work more human, welzijn en overleg in het gewijzigde Wetsontwerp arbeidsomstandigheden, Beleid en maatschappij, 1980, p. 101.

- Gier H.G. de, Voor alle zekerheid, sociaal beleid in maatschappelijk perspectief, Den $\mathbb{H a a g}, 1987$.

- Gisolf R.C., De goede werkgever, in: Arbeid in kort geding (Borgerhoff Mulderbundel), Deventer, 1983, p. 33.

- Griffith J., Is law important?, (oratie Groningen), Deventer, 1978.

- Grinten W.C.L. van der, De goede werkgever en de goede arbeider, in: Hedendaags Arbeidsrecht (Levenbach-bundel), Alphen a/d Rijn, 1966, p. 134.

- Grinten W.C.L. van der, Arbeidsovereenkomstenrecht, Alphen a/d Rijn, 1987 (13e en $14 \mathrm{e}$ druk).

- Haren I. van, Medezeggenschap van werknemers in bedrijven en instellingen, Deventer, 1985. 
- Harmsen Ger, Reinalda Rob, Woor de bevrijding van de arbeid, Nijmegen, 1975.

- Heijden P.F. van der, Een eerlijk proces in het sociaal recht?, Deventer, 1984.

- Heijden P.F. van der, Rechtspraak De ondernemingsraad (behorende bij De Ondernemingsraad, losbl. Deventer) 1971-1984 I t/m 1987 I, Deventer.

- Heijenrijk H., Arbeidsinspectie, Sociaal Weekblad, 1896, p. 278.

- Hekkelman G. Tekorten van het arbeidsrecht, (oratie), Amsterdam, 1967, in: Arbeidsrechtelijke geschriften 1962-1977, Deventer/Alphen a/d Rijn, 1977, p. 77.

- Hesseling W., Nieuwe rechtsregels: aanvulling van art. 1638d en $1638 \mathrm{z}$ BW door de Hoge Rand, Praktijkgids, 1985, p. 653.

- Heuvel G. van den, Industrieel burgerschap als uitnodiging, Deventer, 1983.

- Hoekema A.J. Rechtssociologische aantekeningen bij het schadevergoedingsrecht, in: Schade lijden en schade dragen, Zwolle, 1980, p. 175.

- Hoekema A.J., Het vertrouwensbeginsel en de spanning tussen formele bevoegdheid en materiële effectiviteit van het overheidshandelen, R.M. Themis, 1984, p. 550 .

- Hofstee E.W., Arbeid op de tweesprong, in: Arbeid op de tweesprong, opstellen uitgegeven t.g.v. het 75-jarig bestaan der Arbeidsinspectie, Den Haag, 1965, p. 95.

- Hövels B, Nas P., Ondernemingsraden en medezeggenschap, Alphen a/d Rijn, 1976.

- H.S., Over kinderarbeid en Arbeidswet, Sociaal Weekblad, 1898, p. 256, 264, 272.

- Huysmans R. e.a. (red), Gezondheidszorg in Nederland, Nijmegen, 1973.

- Huyzenveld P.J., De Arbeidsinspectie en de toepassing van de Arbowet, Arbo '86, Congreslezingen, Amsterdam, RAI, 1986.

- lest $K$., Onderzoeken die onder het instemmingsrecht vallen; Waar moet je op letten bij een klachtenregeling, OR-informatie, 1985, p. 20.

- IJsselsteyn H.A., Vijfentwintig jaren Arbeidsinspectie, 1890-1915 (overdruk uit het centraal verslag der Arbeidsinspectie over 1915), Den Haag.

- ILO, Publications on occupational safety and health, (jaarlijkse uitgave).

- Industriebond FNV, Veilig is anders, Amsterdam, 1976.

- Industriebond FNV, Het wetsontwerp ondernemingsraden gezien vanuit de Industriebond, Nunspeet, 1977.

- Industriebond FNV, Beleidsprogramma veiligheid en gezondheid, Amsterdam, 1977.

- Industriebond FNV, Sociaal beleid en humanisering, Amsterdam, 1977.

- Industriebond FNV, Arbeidsomstandighedenwet en Industriebond FNV, Amsterdam, 1979.

- Industriebond FNV, Vakbondskaderleden beoordelen de Arbeidsomstandighedenwet, Amsterdam, 1985.

- Jaspers A.Ph.C.M., Betekenis en functie van de arbeidsovereenkomst in haar maatschappelijke context, SMA, 1982, p. 531.

- Joekes A.M., De internationale arbeidswetgeving 1919-1925, in: A.L. Scholtens e.a., Het Departement wan de Arbeid, Handel en Nijverheid onder minister Aalberse 1918-1925, Alphen a/d Rijn, 1926, p. 263.

- Jong J.H. de, Nieuwe ontwikkelingen in de Arbeidsomstandighedenwetgeving en de Arbeidsveiligheidswetgeving in de bouw, Bouwrecht, 1977, p. 694.

- Jong, T. de, Walravens A.H.C.M., Zeggenschap en humanisering, in: Humanisering van de arbeid, Assen, 1980, p. 108. 
- Jongbloed T., Civielrechtelijke verhoudingen rond uitzendarbeid, Ars Aequi, 1982. p. 43 .

- Jonge J.A. de, De industrialisatie in Nederland tussen 1850 en 1914, Amsterdam, 1968, (Sun-reprint, Nijmegen, 1976).

- Kahn-Freud, Some reflections on law and power, Labour and the law, London., 1983, (third edition), p. 1.

- Kapteyn P.J.G., VerLoren van Themaat P., Inleiding tot het recht van de Europese Gemeenschappen, Deventer, 1984.

- Kerdijk A., Noodige medewerking, Sociaal Weekblad, 1896, p. 241.

- Kleer P.J. de, Werkoverleg hoeft geen fopspeen te zijn, Alphen a/d Rijn, 1980.

- Koning F., Omtrent de ondernemingsraad deel I en II, SMA, 1975, resp. p. 85 en p. 174.

- Koning F., Het Wetsontwerp vakbondswerk in de onderneming. Een momentopname uit onze arbeidsverthoudingen, SMA, 1981, p. 435.

- Koning F., Het SER-advies inzake het klachtrecht van individuele werknemers, SMA, 1981, p. 848 .

- Koning F., Art. 27 WOR: Een bron van mogelijke spanningen in het arbeidsvoorwaardenoverleg, in: Blinde vlekken in het sociaal recht (Frenkel-bundel), Deventer, 1986, p. 252.

- Koopman-Iwema A., Macht, motivatie, medezeggenschap, een studie naar participatief gedrag van leden van overlegorganen in industriële bedrijven, Nijmegen, 1980.

- Koopman-Iwema A., Wiegersma S., Sociale arbeidspsychologie, Haarlem, 1985 , (2e druk).

- Koopmans T., De begrippen werkman, arbeider en werknemer, Alphen a/d Rijn, 1962.

- Korstjens H.A., Het alandeel van de werknemers in de veiligheidszorg, De Veiligheid, 1934, p. 74.

- Kraan D.J., Deregulering: een begripsbepaling, Beleid en Maatschappij, 1982, p. 177.

- Kronenberg, Riet, Werknemersrechten: een discussienota, Socialisme en Democratie, 1975 , p. 258.

- Kuiper A.D., Beursbericht, SMA, 1957, p. 236.

- Kuiper J.P., Melding van beroepsziekten, probleem van een probleem, Medisch Contact, 1971, p. 1151.

- Kuiper J.P., Een gezondheidskundige kijk op de mens-arbeid relatie, in: Humanisering van de arbeid, Assen, 1980, p. 201.

- Kuipers J.H., Beleidsvoering door werkoverleg, Alphen a/d Rijn/Brussel 1975.

- Lakeman P., Hoe representatief is het evaluatie-onderzoek 'De or en zijn bevoegdheden'?, Or-informatie, 1986, p. 22.

- Lange F.G.M., de, Looise J.C. Ondernemingsraden, bestuurders en besluitworming, Nijmegen, 1987.

- Leede L.J.M. de, Asser-Kamphuisen, Bijzondere overeenkomsten III, Zwolle, 1983.

- Levenbach M.G., Het nieuwe arbeidsrecht, in: Arbeidsrecht; een bundel opstellen, Alphen a/d Rijn, 1951, p. 13.

- Levenbach M.G., Nederlands bestuursrecht III, Alphen a/d Rijn, 1964. 
- Lijphart A., The pollitics of accommodation, Berkley, 1968.

- Looise J.C., Heijink J.L., De or en zijn bevoegdheden, ITS, Nijmegen, 1986.

- Loonbureau, Veiligheid, gezondheid, hygiëne en milieu; bepalingen terzake voorkomend in de collectieve arbeidsovereenkomsten voor bedrijfstakken, Den Haag, 1977.

- Lynden A.J.H., van, De individuele werknemer in het arbeidsomstandighedenrecht, SMA, 1984, p. 496.

- Maarseveen H. van, Petitierecht, in: Grondrechten, commentaar op hoofdstuk 1 van de herziene Grondwet (Jeukens-bundel), Nijmegen, 1982, p. 140.

- Mannoury J., Ontslagrecht en Arbeidswet. . en ceterum censeo, SMA, 1958, p. 532.

- Mannoury J., Honderd jaar na de Kinderwet van 1874, SMA, 1974, p. 353.

- Mante-Meijer E.A., Helvert J.J.G.J. van, Individueel klachtrecht, Het SER-advies getoetst aan de sociale werkelijkheid , SMA, 1982, p. 101.

- Meester C. de, Ontwerp Arbeidsomstandigheden laat veel ter invulling over, de werkgeversvisic, SMA, 1978, p. 1978.

- Meester C. de, Kamp H.J.A. van de, Arbowet en medezeggenschap, voer woor procedurevreters of basis woor samenwerking?, Gids personeelsbeleid arbeidsvraagstukken socialle verzekering, 1981 , p. 27.

- Meester $\mathbb{I}$. de, Kamp H. van de, Het spanningsveld tussen Arbowet en Wet OR, SMA, 1982, p. 726.

- Meurs P.L., Heeft de or de toekomst?, Men O, Tijdschrift voor organisatiekunde en sociaal beleid, 1984, p. 499.

- Ministerie van Sociale Zaken en Werkgelegenheid, Bedrijfsarts en ziektecontrole, Verslagen en rapporten, Den Haag, 1972.

- Ministerie van Sociale Zaken en Werkgelegentheid, Adviesaanvraag aan de SER van 19 juni 1975 inzake de vernieuwing van de wetgeving betreffende de gezondheid en de veiligheild bij de arbeid.

- Ministerie van Sociale Zaken en Werkgelegenheid, Subsidieregeling 1977 arbeidsplaatsenverbetering; tekst, toelichting en bijlagen, Den Haag, 1977.

- Ministerie van Sociale Zaken en Werkgelegenheid, Adviesaanvraag van 18 juni 1981 aan de SER inzake het voorkomen en beperken van overmatig geluid in fabrieken of werkplaatsen.

- Ministerie van Sociale Zaken en Werkgelegenheid, Brief wan 16 september 1982 aan de VAR inzake de inwerkingtreding eerste fase (DGA, nr. 242 763).

- Ministerie van Sociale Zaken en Werkgelegenheid, Brief van 7 oktober 1982 aan de VAR, kenmerk nr. 240221 AAZ.

- Ministerie van Sociale Zaken en Werkgelegenheid, Resultaten enquête ondernemingsraden, Den Haag, 1985.

- Ministerie van Sociale Zaken en Werkgelegenheid, Op weg naar een Arbodienst, Den Haag, 1986.

- Ministerie van Sociale Zaken en Werkgelegenheid, Inzicht, Den Haag, 1987, 5e druk.

- Mok S., Arbeidsrecht en individu, Sociaal Maandblad, 1948, p. 17.

- Molenaar A.N., Arbeidsrecht I, Zwolle, 1953.

- Molenaar A.N., Arbeidsrecht II, Zwolle, 1958.

- Molenaar A.N., Bronnen van het arbeidsrecht, openbare les, Leiden, 1927, in: Van. sociale politiek naar sociaal recht, Alphen a/d Rijn, 1966, p. 3.

- Mulder M., Omgaan met macht, Amsterdam, 1978, (2e druk). 
- Naber H., Is het gezag van de werkgever overdraagbaar?, NJB, 1984, p. 106.

- Naber H., De arbeidsovereenkomst in Nederland, Deventer, 1985.

- Nederlands Institumt voor preventieve gezondheidszorg, NIPG/TNO, De bedrijfsarts over zijn werk, Leiden, 1985.

- Nederlandse Organisatiekring, Nota betreffende bouwstenen woor de nieuwe subsidieregeling voor de verbetering van arbeidsplaatsen, Utrecht, 1976.

- Nederlandse vereniging voor veiligheidskunde, Nota De positie van de veiligheidsdienst, 1986.

- Nolte H.J.A., Het strafrecht in de afzonderlijke wetten, Nijmegen, 1949.

- NVV, Arbeidersleven in Nederland; resultaten der enquêtte naar wenschelijkheid ên mogelijkheid van beperking van den arbeidsduur voor volwassenen tot 10 uren per etmaal en afschaffing, respectievelijk beperking wan nacht-en kinderarbeid, uitg. SDAP en NVV, Amsterdam, 1908.

- Olbers M.M., Opdracht in strijd met de wet, SMA, 1984, p. 150.

- Oostrum H. van, Arbeidrechtelijke en strafrechtelijke aspecten van bedrijfsongevallen, Ars Aequi, 1974, p. 139.

- Peijpe T. van, De ontwikkeling van het loonvormingstrecht, Nijmegen, 1985.

- Peijpe Taco van, Macht en arbeidsrecht, Ars Aequi, 1985, p. 78.

- Peters A.A.G., Recht als project, Ars Aequi, 1979, p. 881.

- Pijpers R.J., Hoe floreert en stagneert werkoverleg"?, Intermediair nr. 14, 1978, p. 16.

- Plomp H.N., Werknemers en bedrijfsgezondheidsdiensten, Amsterdam, 1985.

- Postma A., De mislukte pogingen tussen 1874 en 1889 tot verbetering van uitbreiding van de Kinderwet wan Houten, Deventer, 1977.

- Raad van bestuur in arbeidszaken, Commentaar wetsontwerp 14497: Arbeidsomstandighedenwet, brief van 19 september 1977 aan de vaste commissie voor Sociale Zaken van de Tweede Kamer der Staten-Generaal.

- Raad van de centrale ondernemingsorganisaties, Arbowet, hoofdlijnen en toelichting, 1983 .

- Raad van de centrale ondernemingsorganisaties, Arbowet, stand van zaken per 1 juni 1985 .

- Reijnders L. e.a., Veilig op je werk, Amsterdam, 1976.

- Reubsaet T.J.M., De Boer P.A.M., Sweere P.C.J., Tillaart H.J.M. van den, De Arbowet in uitvoering, een onderzoek naar ervaringen in de praktijk, ITS, Den Haag, 1988.

- Reynaerts W.H.J., Wet en bedrijfsdemocratisering, Beleid en maatschappij, 1977, p. 208.

- Robert M., Parmeggiani L., Fifty years of international collaboration in occupational safety and health, International Labour Review, 1969, p. 4.

- Roland Holst Henriëtte, Kapitaal en arbeid in Nederland, deel 1, Amsterdam, 1901, (Sun-reprint).

- Rood M.G., Bedrijfsdemocratie: vlag of lading?, Deventer, 1979.

- Rood M.G., Wet op de ondernemingsraden, (losbladig), Arnhem.

- Rood M.G., Rechtspraak: medezeggenschapsrecht, TVVS, 1981, p. 49.

- Rood M.G., Over vage vormen in het sociaal recht, in: Gratia Comercii (van Ovenbundel), Zwolle, 1981, p. 225. 
- Rood M.G., Over de goede werkgever en de goede werknemer, SMA, 1982, p. 498.

- Rood M.G., Over samenloop van medezeggenschapsrechten, in: Arbeid in kort geding (Borgerhoff Mulder-bundel), Deventer, 1983, p. 89.

- Rood M.G., Hoofdlijnen in het sociaal recht, NJB, 1984, p. 993.

- Roos A.J. de, De ontwikkelingen in het werk van de Arbeidsinspectie, Maatschappijbelangen, 1976, p. 453.

- Roos A.J. de, De Arbeidsomstandighedenwet, SMA, 1982, p. 308.

- Schilfgaarde P. van, Beijzelde loopkat, Ars Aequi, 1987, p. 477.

- Schmitz (FNV-lid van de Arboraad), interview met, Arbozaken in CAO regelen is een miskleun, Maandblad voor arbeidsomstandigheden, 1986, P. 553.

- Schmitz H.P.W., Lavenen G., Koekenbier.H.A.J., Onvrede en klachten van werknemers; een studie naar het ontstaan, de opvang en de oplossing van klachten van werknemers ten behoeve van het beleid, Stichting Wetenschappelijk onderzoek wakcentrales, ITS, Utrecht/Nijmegen, 1975.

- Scholtens A.L. e.a., Het Departement van Arbeid, Handel en IJverheid onder minister Aalberse 1918-1925, Alphen a/d Rijn, 1962.

- Schoordijk H.C.F., Enige aantekeningen naar aanleiding van de aansprakelijkheid wan ondernemer en arbeider voor bedrijfsongevallen na de inwerkingtreding van de WAO mede in verband met de thans geldende W.A.-verzekeringen voor bedrijven, NJB, 1967, p. 341.

- Schut G.H.A., Medezeggenschap en het gezag van de werkgever, in: Arbeidsrechtelijke geschriften, Deventer/Alphen a/d Rijn, 1977, p. 266.

- Schuyt C.J.M., Rechtvaardigheid en effectiviteit in de verdeling van de levenskansen, Universitaire Pers, Rotterdam, 1973.

- Schuyt $\mathrm{C}$ J.M., De fragmentering van bestuur en beleid in de verzorgingsstaat, in: Verzorgingsstaat: de samenleving als weeshuis, Alphen a/d Rijn, 1984, p. 227.

- SER, Advies inzake vernieuwing van de wetgeving betreffende de gezondheid en de veiligheid bij de arbeid, Den Haag, 1976, nr. 18.

- SER, Advies inzake het sociaal beleid in de onderneming, Den Haag, 1981, nr. 11.

- SER, Advies inzake geluid op de arbeidsplaats, Den Haag, 1984, nr. 1.

- SER, Advies inzake samenloop van de Wet op de ondernemingsraden en de Arbeidsomstandighedenwet, Den Haag, 1986, nr. 6.

- SER, Advies inzake vereenvoudiging van de Wet op de ondernemingsraden, Den Haag, 1986, nr, 14.

- SER, Advies technologisch aandachtsgebiedenbeleid, Den Haag, 1987, nr. 10.

- Sevenhuijsen $\mathbb{J}$., Historie van de Nederlandse arbeidsbeschermende wetgeving, Universitair onderwijs en onderzoek in Veiligheid, Delft, 1.978.

- Siemons J.C.M.M., Bedrijfsinspecteurs van de Arbeidsinspectie: 'lonely hunters' in wal en knelgevalar, Enschede, 1986.

- Sitter L.U. de, Op weg naar nieuwe fabrieken en kantoren, Deventer, 1982.

- Slagter W.J., Compendium van het ondernemingsrecht, Deventer, 1985.

- Sluiter A.W., m. m.v. Dijksterhuis F.P.H. en Timmerman H., De Arbeidsinspectie: doelstelling, taken en werkwijze, Groningen, 1984 (uitg. Kriminologisch Instituut RUG).

- Snijders A.J.C., De veiligheid van den werkman bij den arbeid, Vragen des tijds, 1894 , p. 178 .

- Sociaal en Cultureel Planbureau, Sociaal-Cultureel rapport, Den Haag, 1978.

- Sociaal en Cultureel Planbureau, Sociale en Culturele Verkenningen 1986, SCP- 
cahier 48, Rijswijk 1985.

- Spanjersberg P.L., Arbowet, ondernemingsraad en werkoverleg, SMA, 1982, p. 587.

- Spanjersberg P.L., Inzicht in de Arbowet, Deventer, 1983.

- Spanjersberg P.L., Veiligheid, gezondheid en welzijn, Instemmingsrecht, Cahiers OR-informatie, nr. 2, 1986.

- Staveren H.T. van, De wet arbeid gehandicapte werknemers en de Hoge Raad: invloed op de $1639 \mathrm{x}$ BW-procedure, Praktijkgids, 1987, p. 57.

- Stichting van de Arbeid, Aanbevelingen en afspraken voor overleg over werkgelegenheid en arbeidsmarkt, Den Haag, 1981.

- Stoop John, Geschiedenis van veiligheid en gezondheid in arbeidsomstandigheden in Nederland, Delft, 1982.

- Strien P.J. van, Wat betekent humanisering van de arbeid?, in: Humanisering van de arbeid, Assen, 1983, (2e druk).

- Stroink F.A.M., Het leerstuk der deconcentratie, Den Haag, 1978.

- Struik J., Enkele opmerkingen over de formalisering van het klachtrecht voor de individuele werknemer, SMA, 1973, p. 594.

- Tak P.J.P., Leven en laten leven, over paternalistische strafwetgeving, (rede), Zwolle, 1978.

- Tak P.J.P., De strafrechtelijke verantwoordelijkheid voor de naleving van de technische bouwvoorschriften, Bouwrecht, 1980, p. 543 .

- Tamminga Anja, Vrijk Irene, Koning Peter de, De lange weg naar schadeloosstelling, Wetenschapswinkel/Erasmusuniversiteit, Rotterdam, 1986.

- Tasman H.J., De grenzen der sociale wetgeving, Sociaal Weekblad, 1911, p. 169.

- Tijn Th. van, Het sociale leven in Nederland 1844-1875, Algemene geschiedenis der Nederlanden, deel 12, Haarlem, 1977.

- Tijn Th. van, De sociale bewegingen van 1876-1887, Het sociale leven in Nederland, Algemene geschiedenis der Nedlerlanden, deel 13, Haarlem, 1978.

- Tinga E., Verslag van de discussie over J.J.M. van der Ven's Rechtssociologische aantekeningen bij de Arbeidswet 1919, SMA, 1958, p. 626.

- Tinga E., De geschiedenis van de Arbeidswet (1874-1919), SMA, 1969, p. 617.

- Urk G.H. van, Aanstellingskeuring, ziekteverzuim en karakter der sociale geneeskunde, Medisch Contact, 1969, p. 847.

- Uyl J.M. den, Socialisme en vrije ondernemingsgewijze produktie ${ }_{\text {}}$ in: Inzicht en uitzicht, opstellen over economie en politiek, Amsterdam, 1978, p. 181.

- Valkhoff J., Een eeuw rechtsontwikkeling. De vermaatschappelijking van het $\mathrm{Ne}$ derlandse privaatrecht sinds de codificatie (1838-1938), Amsterdam, 1938.

- Veen Th.W. van, Door overmacht gedwongen, in: Recht als instrument van behoud en verandering (J.J.M. v.d. Ven-bundel), Deventer, 1972, p. 341.

- Ven F.J.H.M. van der, Over de aard der arbeidsovereenkomst, (afscheidscollege KHT), in: Arbeidsrechtelijke geschriften 1962-1977, Deventer/Alphen a/d Rijn, 1977 , p. 245.

- Ven J.J.M. wan der, Rechtssociologische aantekeningen bij de Arbeidswet 1919 , SMA, 1958, p. 290.

- Ven J.J.M. wan der, Voortgang en stillstand van het arbeidsrecht, Hedendaags Arbeidsrecht (Levenbach-bundel), Alphen a/d Rijn, 1966, p. 345. 
- Ven J.J.M. van der, Recht en macht, Aspecten van Arbeidsrecht, Jubileumbundel Vereniging voor arbeidsrecht 1946-1971, Alphen a/d Rijn, p. 82.

- Visser D., Wat kunnen ondernemingsraden verwachten van de vakbeweging? Arbeidsomstandighedenwet en ondernemingsraad, Industriebond FNV, Amsterdam, 1985.

- Vleggeert J.C., De kinderarbeid, Amsterdam, 1951.

- Vleggeert J.C., Kinderarbeid in Nederland 1500-1874, Assen, 1964.

- Vleggeert J.C., Kinderarbeid in de negentiende eeuw, Bussum, 1967.

- Vliet G.E van, Bedrijvenwerk alls vorm van belangenbehartiging, Alphen a/d Rijn, 1979.

- Vliet L. van, Preventie staat of valt met betrouwbare informatie, Maandblad voor arbeidsomstandigheden, 1987 , p. 166.

- Voorllopige A rbeidsraad, Advies inzake de eerste fase van invoering van de Arbeidsomstandighedenwet, Zoetermeer, 1982, nr. 2.

- Voorlopige Arbeidsraad, Advies inzake de inwerkingtreding van art. 10 van de Arbowet, Zoetermeer, 1982, nr. 3.

- Voorlopige Arbeidsraad, Reactie van 26 oktober 1982 op de toelichtende nota op art. 11 van de Arbowet, Zoetermeer, 1982.

- Vooys I.P. de, Arbeidsinspectie, Vragen des tijds, 1901, p. 131.

- Vries Wzn. W. de , De totstandkoming van de Ongevallenwet 1901, Deventer, 1970.

- Vrooland V.C., Arbeid en gezondheid in de jaren tachtig, Amsterdam, 1984.

- Weijel J.A., Achtergronden van sociale zekerheid, Amsterdam, 1973.

- Weijers (CDA Tweede Kamerlid), interview met, Arbobeleid inbrengen in CAOonderhandelingen, in Maandblad woor arbeidsomstandigheden, 1986, p. 361.

- Westhoff $\mathbf{J}$., Arbeidsbescherming in engeren zin, in: Scholtens A.L. e.a., Het Departement van Arbeid, Handel en Nijverheid onder minister Aalberse 1918-1925, Alphen a/d Rijn, 1926, p. 12.

- Wetenschappelijke raad voor het regeringsbeleid, Over sociale ongelijkheid; een beleidsgerichte probleemwerkenning, rapport aan de regering, Den Haag, 1977, nr. 16.

- Wetenschappelijke raad voor het regeringsbeleid, Vernieuwingen in het arbeidsbestel, Den Haag, 1981, nr. 21.

- Windmuller J.P. , Galan C. de, Zweeden A.F. van, Arbeidsverhoudingen in Neder" land, Utrecht/Antwerpen, 1983, (4e druk).

- Winkel N.C., Beginselen voor de beveiliging bij den arbeid in fabrieken, gedeelten uit een voordracht voor de afdeeling Gezondheidstechniek van het Kon. Int. v. Ingenieurs op 10 juli 1936, De Veiligheid, 1936, p. 114.

- Witte $W$. de, De organisatie van het veiligheidsoverleg in de onderneming; de histonische ontwikkeling van veiligheidscommissie bij Gist-Brocades, De Veiligheid, p. 169.

- Zuthem H.J. van, Arbeidsbeleid in de onderneming, Assen, 1967.

- Zuuren P. van, Stromingen in de arbeidsveiligheid; samenvattingen plenaire voordrachten 9e Wereldveiligheidscongres 1980 , De Veiligheid, 1980, p. 313.

- Zwam H.J. van, Veiligheidscommissies en de Wet op de Ondernemingsraden, De Veiligheid, 1976, p. 266. - Zwam H.J. van, De hiërarchische plaats van de veiligheidskundige, De Veiligheid,
1982, p. 37 . 
- Zwam H.J. van, Veranderingen in het Arbeidsomstandighedenrecht, Deventer, 1983.

- Zwam H.J. van, De gehaaste textielarbeider, SMA, 1984, p. 232. 



\section{Zakenregister}

Er wordt verwezen naar pagina's

Aanwijzingen Arbeidsinspectie 295, 298,322

Algemeen Nederlandsch WerkliedenVerbond 32

Algemeen Rijksambtenarenreglement (ARAR) 239

Ambtenaar 14

Arbeid

- het begrip 66

Arbeiders

- belangstelling voor het lot van 27

Arbeiderscommissie 54

Arbeiderscontroleurs 54

Arbeidsbeschermende wetgeving

- factoren totstandkoming eerste 63 e.v.

- effectiviteit eerste 65

Arbeidsinspectie 64, 335, 338, 344

-instelling en ontwikkeling 40 e.v., 47 e.v.

- taken (districtshoofd) 224, 225

- opbouw 226

- klachtrecht $240,270,280,282,285$

- eis 233

- stillegging van het werk 234

- proces-verbaal 235,298

- aanwijzing 235, 295, 298, 322

- verzoek om wetstoepassing 231 (zie ook: verzoek om)

- P-bladen 229, 230

- openbaarheid en geheimhouding 237

-zakengeheimen 238

- bedrijfsgeheimen 238
- praktijk 241 e.v.

Arbeidsovereenkomst $60,64,299,310$, 311

Arbeidsomstandighedenrecht

- het begrip 12, 13

Arbeidsrecht

- doelstelling 2, 3

- autonoom 3

- heteronoom 3

Arbocommissie 133, 179, 181, 208, $269,286,287,334,355$

- samenstelling 182

- taak 182

- bevoegdheden 183

- rechten en faciliteiten 183,185 e.v.

Arbodienst

- terugkeer in de wet 109

- doelstelling 221

- taken 221

-en het ILO-verdrag 1985221

Arbo-enquête $338,342,343$

Arbo-instituut

- doel 223

- taak 223

Arboraad 92, 218, 250, 289, 327, 358

- instelling en ontwikkeling 246,247

- samenstelling 248

- taken 248, 249

Arbowet

- achtergrond totstandkoming 83,85

- filosofie 4, 5

- doelstelling 9, 89, 92, 191, 328, 367

- inwerkingtreding 92, e.v. 105, e.v., 362

- belangrijkste bepalingen 90 e.v. 
- betekenis van de - en de CAO 364 e.v.

- effectiviteit 305 e.v.

- de Arbeidsinspectie en de 92

- deregulering 105 e.w., 110, 111

Arbeidswetten

- motieven eerste 2

Arbeidswet 1889

- totstandkoming 39

Arbeidswet 1911

- totstandkoming 59

Arbeidswet 1919

- totstandkoming 51,52

Arbeidsveiligheidsrapport 123,327 , 355

- evaluatie resultaten 124

Art. 1638x BW 102, 103, 148 e.v.

-in de praktijk en in de toekomst 165 e.v.

\section{Bedrijf}

- het begrip 204

Bedrijfsarts $75,211,321,338,343,344$

- taak 268,332

- relatie werknemer 332

- (waarborg) positic 209, 210

-in een gezamenlijke dienst 212

Bedrijfscommissie 319

Bedrijfsgeheimen 238

Bedrijfsgeneeskundige dienst 54,75 , 76

Bedrijfsgezondheidsdienst 203,286 , $294,327,338,343$

- doel 207

- taken 207 e.v.

- de praktijk 213 e.v.

Bedrijfsgezondheidszorg 204 e.v.

Belanghebbende werknemers 287 , 289,334

- rechten 288,289

Besluit erkenning bedrijfsgezondheidsdienst 205

Besluit nadere eisen gezamenlijke bgd 205

Besluit verplichtstelling bgd 204

Bezwaarschriftencommissie 359

Caissonwet 190555

CAO 72, 100 e.v., 329, 343, 344, 365
- bedrijfsgewijze 101

- ondernemingsgewijze 101

- regeling arbeidsomstandigheden 256 , 257

- onderzoek m.b.t. arbeidsomstandigheden $258 \mathrm{e} . \mathrm{v}$.

- conclusies onderzoek 256,266

Centrale probleemstelling 10

Civiele schadevergoedingsactie 80,150 e.p.y

Collectieve ongevallenverzekering 169 , 263

Comité ter bespreking der sociale quaestie 32

Deregulering $117,222,325,360,362$

Deskundigen 202 e.v.

Districtscommissie

- taak 251

Effectiviteit Arbowet 350 e.v.

- effectieve programmering 351

- afstemming op de context 351

- instrumentering naar de doelgroep 351

- aanwezigheid instrumentele regels 353

- differentiële effectiviteit rechten en plichten 352

- handhaving rechten en plichten 353

Eis door de Arbeidsinspectie 233

Ernstig lichamelijk letsel 130

Fabrieken

- omstandigheden 24

Flexibilisering

- van en binnen de onderneming $36 I$

GAB 342, 348, 349

GAK 339,

Geheimhoudingsplicht

- van leden or 190

- van de Arbeidsinspectie 237, 238

Gemengde commissie 184

Geneeskundig Staatstoezicht 30

Gevaar

- het begrip 132

Grote materiële schade 130 
Hooge Raad van de Arbeid $62,68,69$

Huisarbeidswet $19337 I$

Humanisering van de arbeid

- het begrip $1,11,12$

- mogelijkheden beïnvloeding door werknemer 8

- positie werkgevers- en werknemersorganisaties 327

- karakteristieken beleid t.a.v. 324, 325

Industrialisatie $17,20,29,31,63$

Informatierecht

- de werknemer 284 e.v.

Informatierechten $187,188,19 l$ e.v. 363

Instemmingsrecht

- strekking 172

- or 194

- Arbocommissie 194

- CAO 172

Internationaal Werklieden-Verbond 32

Internationale normen 103,104

- m.b.t. arbeidsomstandigheden 81 e.v.

International Labour Organization 72

Jaarplan 120,355

- inhoud 121

- functie 121,122

-instemmingsrecht 121,122

Jaarverslag 327,355

-inhoud 124

- doel 124

- wijze van naleving 126

Kinderarbeid 24, 27, 28, 31, 36

- verbod van - (in de Arbeidswet 1889) 27,40

Kinderwet Van Houten 187418

- totstandkoming 33, 34

- inhoud 33,34

- effectiviteit 34,35

- ontwikkeling 35 e.v.

- enquête naar de nalewing 37 e.v.

Klachtrecht

- bij de Arbeidsinspectie 280 e.v.

Klachtrecht individuele werknemer 344 -introductie wettelijke regeling 316 , 334

- effectiviteit 320

Leerplicht $28,34,35$

Liberale economische theorie 30

Lichamelijke integriteit

- het grondrecht op de bescherming van 6

Machtsverhoudingen

- relatie werkgever-werknemer en 330,331

Medezeggenschapsstructuur 7,9

- collectivistische 5

Medezeggenschapscommissie 358

Melding en registratie

- ongevalien en beroepsziekten 80 , 129 e.v. 356

Mentor, zie bedrijfsarts

Mijnwet 190354

Nationaal Arbeiders Sekretariaat (NAS) 49

NVV 49

Nieuwe Nederlandse Werklieden Verbond 36

Nieuwe technologieën $360,361,367$

Onafhankelijke rechter $335,336,367$

Onderneming

- het begrip 14, 15

- wijziging doelstelling 113

Ondernemingsraad (or) $326,338,347$

- functie 7,77,78

- taken 77,169

- bevoegdheden 77

- positie groeps- 195

- positie centrale 195

- recht om gehoord te worden 189

- recht om advies te geven 189

- recht op informatie $177,187,188$

- instemmingsrecht 181

- adviesrecht 181

- andere rechten en faciliteiten 178 185 e.v.

-commissie o.g.v. WOR 178

-relatie werknemer- 332

Ongeval 130 
Ongevallenwet 1901

- lotstandkoming 57,58

- rechtsgrond 58

Ongevallenwet 1921

- totstandkoming 72

Or-reglement 179,314

Overheidsinterventie

- rechtvaardiging 30

Overlegverplichtingen 195

Parate executie 74,234

Petitierecht 280,281

Phosphorluciferwet 190154

Proces-verbaal en de Arbeidsinspectie 235,298

Redelijkheidsclausule 119,149

Relatie werkgever-werknemer

- kenmerken 330,331

Samenloop Arbowet en WOR 190 e.v.

Schadlevergoeding $59,102,103$

- bewijslastverdeling 158 e.v.

- causaliteit bij 160,161

- (geringe) schuld werknemer 156

- medeschuld werknemer 155 e.v.

- grove schuld werknemer $155 \mathrm{e} v$.

- uit onrechtmatige daad 613,164, 165

- t.a.v. uitleenkrachten 162,163

Scholing en vorming 191

- van leden commissie or 193

Silicosewet 195176

Sociaal jaarversiag 177

Sociaal-Democratische Bond 37

Sociaal-Democratische Vereeniging (SDV) 37

Sociale grondrechten 104

Steenhouwerswet 191156

Stichting van de Arbeid 252,254, 245

Strafrechtelijke aansprakelijkheid

- van de werkgever 0.g.v. Arbowet

135 e.v.

- problemen door vervanging

Veiligheidswet 141

Structuur

- agrarisch-commerciële 20

- commercieel-industriële 20

Stuwadoorswet 191456

Stuwadoorswet 193171
Veiligheidsdienst 286,294

- doel 219

- inrichting 218

Veiligheidskundige $203,286,321$

- doel 218, 219

- taken 219

Veiligheids- en milieudienst 343

Veiligheidscomissie $170,179,184$

Veiligheldsrapport

- doel 87

- inhoud 87

Veiligheidswet 1895

- totstandkoming 42 e.v. 66 e.v.

- filosofie 5

- strekking 45

Veiligheidswet 1934

- filosofie 5

- taken 70

- bevoegdheden 70

- samenstelling veiligheidscommissie 70

- persoonlijke aansprakelijkheid 67 , 68,137

- aanvulling $74 \mathrm{e} . \mathrm{v}$.

Verzoek om wetstoepassing 117,231, $254,255,270,278,282,290,291$, $327,343,356,357,364$

- behandeling 231,232

VGW-commissie $170,179,180,313$, $314,338,343,357,358$

- rechten en faciliteiten $185 \mathrm{e} . \mathrm{v}$.

Welzijn 83, 90,107,108, 117, 283, $333,335,360,362$

- factoren die bijdragen tot 4,5

Werkgever

- het begrip 113

Werkgever in het $B W$

-zorgplicht $6,204,329,364,366$

- redelijk en billijk 149

- onderzoeksplicht 149

- civielrechtelijke zorgplicht 148

- aansprakelijkheid ongeval $59 \mathrm{e} . \mathrm{v}$., 150

- behoorlijke instructies 150

- relatie tot or $144 \mathrm{e} . \mathrm{v}$.

Werkgever in de Arbowet

- (strafrechtelijk gesancioneerde) verplichtingen algemeen $133 \mathrm{e.v}$, 326 e.v. 
- melding en registratieplicht 129 e.v.

- onderricht 127 e.v.

- voorlichting $127 \mathrm{e} . \mathrm{v}$.

- begeleiding 127

- ondernemingsbeleid 115

- arbeidsomstandighedenbeleid 117 , 118

Werkloosheid 23, 29, 31

Werknemer

- het begrip 13

- strafrechtelijke aansprakelijkheid 6 , 229 e.v.

- juridische actiemogelijkheden 367

- uitoefening invloed op or 312 e.v.

- verplichtingen o.g.v. BW 305 e.v.

- recht op informatie 269,284 , e.v.

- recht op voorlichting 269

- recht op onderricht 269

Werknemersonderzoek 328

Werkonderbreking

- bevoegdheid tot $335,339,344,345$, 356,363

- bewijslastverdeling 276

- melding onderbreking 277

- rol Arbeidsinspectie 277
- bij niet acuut gevaar 278,279

Werkoverleg 196 e.v.

- omschrijwing begrip 197

- verschillen WOR en Arbowet 197

Wet op de

Arbeidsongeschiktheidsverzekering

- totstandkoming 79

- rechtsgrond 79

WOR 195073

WOR 1971

- doelstelling 191

- herziening in 197983,98 e.v.

Wet op de Gevaarlijke Werktuigen 76

Wet op de openbaarheid van bestuur (WOB) 239

Wetsontwerp

- vakbondswerk in de onderneming 252 e.v.

Zakengeheimen 238

Zeggenschap

- het begrip 12

Zorgplicht werkgever $6,148,168,204$, $329,364,366$ 



\section{Jurisprudentieregister}

Er wordt verwezen naar pagina's

Hoge Raad

\begin{tabular}{|c|c|c|}
\hline $2-12-1901$ & W. 7700 & 45 \\
\hline 9. 6-1904, & W. 8076 & 45 \\
\hline 14- 2-1916, & NJ 1916,681 & 138 \\
\hline 28-1-1918, & NJ 1918,261 & 138 \\
\hline $5-2-1917$ & $\begin{array}{l}\text { vermeld bij Molenaar, IIB p. } 1380 \text {, } \\
\text { (overigens niet gepubliceerd) }\end{array}$ & 45 \\
\hline $4-\mathbb{1}-1929$ & NJ 1929,1662 & 138 \\
\hline 22- 6-1931, & NJ 1931, 1602, m.nt. W.P. & 237 \\
\hline $26-10-1931$ & NJ 1932,413 & 2 \\
\hline $24-4-1933$ & W. 12620 & 45 \\
\hline 1- 2-1949, & NJ 1949,552 & 149 \\
\hline 3- 5-1949, & NJ 1949,538, m.nt. B.V.A.R. & 88 \\
\hline $22-11-1949$ & NJ 1973,446 & 88 \\
\hline $31-1-1950$ & N.J 1950,286 , m.nt. B.V.A.R. & 137 \\
\hline 23-2-1954, & NJ 1954,378, m.nt. B.V.A.R. & 137 \\
\hline 26- 6-1959, & NJ 1959, 551, m.nt. L.E.H.R. & 306 \\
\hline 8-6-1962, & NJ 1963,526 & $273,277,306,347$ \\
\hline 1- 3-1963, & NJ 1964,12 , m.nt. J.H.B. & 133,151 \\
\hline 24- 6-1966, & NJ 1966,457 & 272 \\
\hline 29- 4-1969, & NJ 1970,46 & 137 \\
\hline $21-6-1974$ & NJ 1974,453 , m.nt. G.J.S. & 160,161 \\
\hline $21-6-1974$ & NJ 1975,17, m.nt. G.J.S. & 165 \\
\hline $6-6-1975$ & NJ 1975,484, m.nt. G.J.S. & 348 \\
\hline 13-6-1975, & NJ 1975,509, m.nt. G.J.S. & 165 \\
\hline $27-6-1975$ & NJ 1976,81 , m.nt. G.J.S. & 148 \\
\hline $27-7-1975$ & NJ 1976,81 , m.nt. G.J.S. & 155,166 \\
\hline 13- $1-1978$ & NJ 1978,433 , m.nt. P.Z. & 348 \\
\hline 14- 4-1978, & NJ 1979,245 & 149,151 \\
\hline 9- 2-1979. & NJ 1979 , 629, m.nt. F.H.J.M. & 274 \\
\hline $16-2-1979$ & NJ 1979, 453, m.nt. P.A.S. & 164 \\
\hline
\end{tabular}


6- 4-1979,

22- 6-1979,

7- 3-1980,

23- 5-1980,

25- 6-1982,

15-10-1982,

4- 2-1983,

29. 4-1983,

17- 5-1983,

10- 6-1983,

2-11-1984,

8- 2-1985,

9. 4-1985,

8-11-1985,

17-12-1985,

18- 4-1986,

19-12-1986,

9- 1-1987,

6- 3-1987,
NJ 1979, 492, m.nt. P.A.S.

NJ 1979, 535, m.nt. G.J.S.

NJ 1980,365

NJ 1980,633 , m.nt. P.A.S.

NJ 1983, 151, m.nt. P.A.S.

NJ 1984, 21 m.nt. F.H.J.M.

NJ 1983, 543, m.nt. P.A.S.

NJ 1984,19

NJ 1983, 690, m.nt. G.E.M.

NJ 1984, 20, m.nt. P.A.S.

NJ 1985,192

NJ 1986,136, m.nt. C.J.H.B.

NJ 1985, 857, m.nt. Th.W.w.V.

858, m.nt. Th.W.v.V.

859, m.nt. Th.W.v.V.

NJ 1986, 309, m.nt. P.A.S.

NJ 1986,591 , m.nt. Th.W.v.V.

NJ 1986, 763, m.nt. P.A.S.

NJ 1987, 297

NJ 1987,948 , m.nt. P.A.S.

NJ 1987,533
273,347

165

80

162

$153,159,160,166$

168

$150,151,154,155$

160

306

149

138

150

273

161

141

141

141

$168,301,346$

138

347

348

157, 167

151

209

302

138

Arnhem 11-12-1986, nr.

212/86, gepubliceerd in

NJ 1982, 243, m.nt. Ma.

mingskamer) 22-1-1981,

NJ 1987,451

Arbobulletin, 1987, p. 9

\section{Rechtbank}

Maastricht 4-11-1969,

NJ 1971,166

88,138

NJ 1973,446

88,138

Utrecht 29-5-1974,

NJ 1976,156

156

NJ 1977,532

139

De veiligheid 1978 , p. 336

234

NJ 1981,10

NJ 1980,579

159,162

Praktijkgids 1982, nr. 1821

150,159

N.J 1983,396

NJ 1984, 141, m.nt. P.J.P.T.

Praktijkgids 1988 , nr. 2806

Alkmaar 27-10-1983,

Praktijkgids 1984, nr. 2057 
Zwolle 20-6-1984,

Praktijkgids 1984, nr. 2159, m.nt.

W. Hesseling

157

150

's-Hertogenbosch 26-4-1985, Praktijkgids 1988, nr. 2805

286

Breda 9-12-1985,

KG 1985, ar. 2314

152,302
160

Breda 9-12-1985,

KG 1986,28

Alkmaar 7-8-1986,

Praktijkgids 1988, nr. 2806

Amsterdam 17-6-1987,

Breda 19-4-1988, rolnummer H 86.1509 (niet gepubliceerd)

337

nr. 4293/87 (niet gepubliceerd)

\section{Kantongerecht}

Amsterdam 27-11-1922,

Recht. Besl. Arb. ovk. XI, nr. 3 en 4

NJ 1926, p. 1358

137

Zuindbroek 23-9-1926,

NJ 1953,510

Haarlem 2-10-1972,

Praktijkgids 1973, nr. 802, m.nt. J.

Manoury

272

NJ $1976,402 \quad 151$

Tilburg 24-4-1975,

NJ 1981,167

172

NJ 1983,9

172

ROR 1971-1984, III, nr, 114

175

Bergen op Zoom

13-10-1982,

Amsterdam 2-2-1983,

Praktijkgids 1984, nr. 2050 m.nt.

W. Hesseling

nr. 213,034/2, De Veiligheid 1985,

p. 417

162,163

141

Bergen op Zoom 30-3-1983, Praktijkgids 1984, nr. 2050, m.nt.

W. Hesseling

162

Rotterdam 10-1-1984,

Praktijkgids 1985, nr. 2314

Zevenbergen 24-10-1984, nr. 02.565835/82, De Veiligheid. 1985 , p. 417

Praktijkgids 1986, nr. 2532

156

Praktijkgids 1985, nr. 2345

346

Rep.nr. 747/85 (niet gepubliceerd) 339

ROR 1986, II, nr. 35

176

Rolnummer 1930/85 (niet gepubliceerd)

340

Praktijkgids 1987, nr. 2630 300

Praktijkgids 1986 , nr. 2580

Praktijkgids 1987, nr. 2627

Praktijkgids 1987, nr. 2779

Praktijkgids 1987, nr. $2710 \quad 150$

Zutphen $25-11-1986$
Utrecht, $14-5-1987$,

De Minister c.q. staatssecretaris van Sociale Zaken en Werkgelegenheid

3-7-1981, Geersing/van der Rechtpraak medezeggenschaps-

Heijden,

recht 1981-1982, nr. 13 


\section{IURISPRUDENTIEREGISTER}

6-9-1982,

29-7-1983,

30-12-1986,

25-5-1988, Win-k/SOZA/

HB
Rechtspraak Medezeggenschapsrecht 1981-1982, nr. 26 180

Rechtspraak Medezeggenschapsrecht 1982-1983, nr. 64

Rechtspraak de ondernemingsraad (ROR), Deventer, 1986, II, nr. 34 (niet gepubliceerd) 


\section{Curriculum vitae}

De auteur is geboren op 28 oktober 1945 te Steenbergen (N.Br.).

In 1965 behaalde hij het diploma gymnasium alpha aan het Dr. Mollerlyceum te Bergen op Zoom. In 1970 behaalde hij het doctoraal examen Nederlands recht aan de universiteit van Amsterdam. Sindsdien bekleedde hij diverse ambtelijke, wetenschappelijke en politieke functies.

Vanaf 1984 is hij als universitair hoofddocent sociaal recht verbonden aan de juridische faculteit van de Rijksuniversiteit Limburg. 